Prepared in Cooperation with the Bureau of Reclamation

\title{
Rio Grande Transboundary Integrated Hydrologic Model and Water-Availability Analysis, New Mexico and Texas, United States, and Northern Chihuahua, Mexico
}

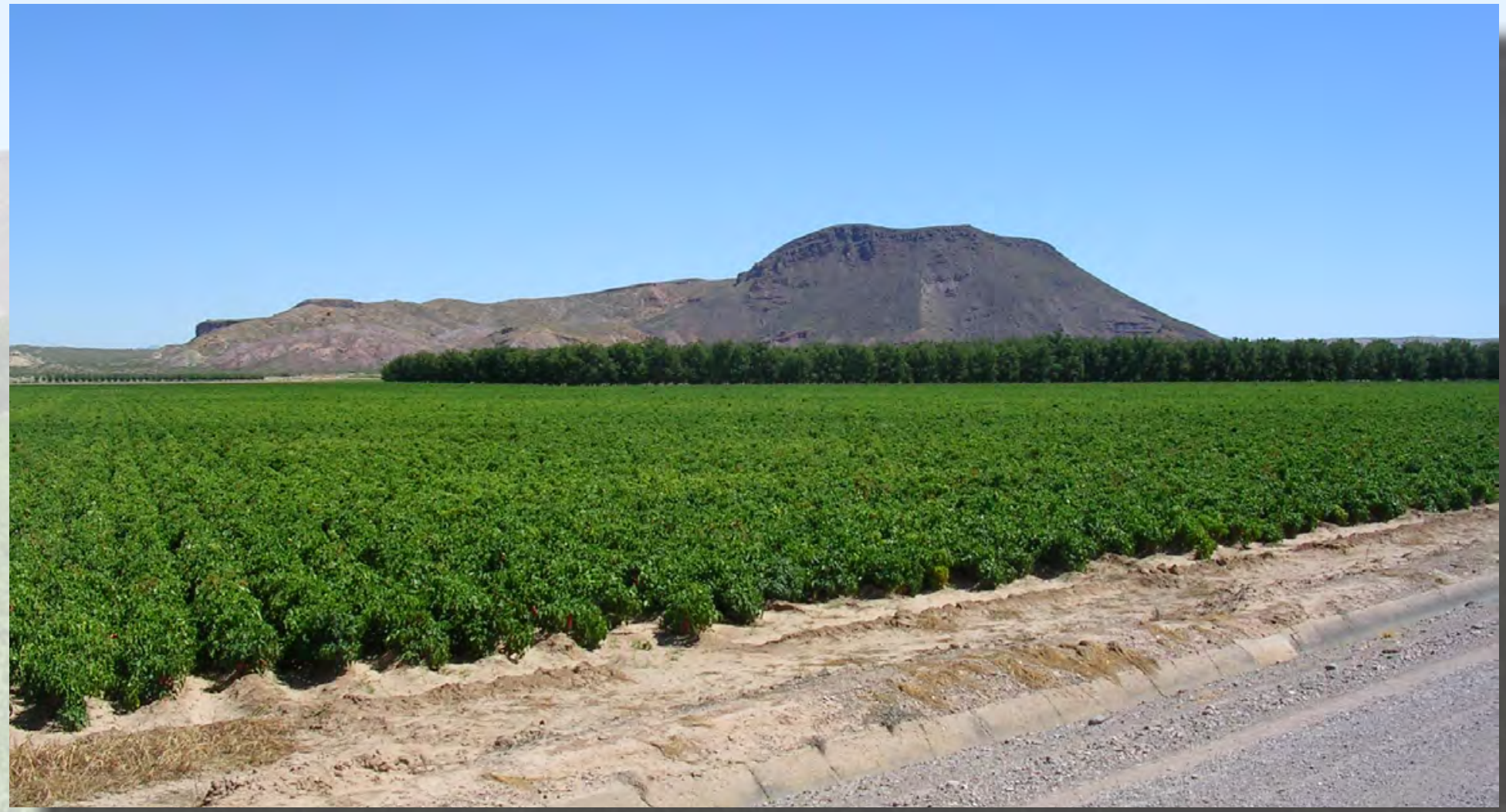

Scientific Investigations Report 2019-5120 
Front cover: View of southern Rincon Valley, with San Diego Mountain in the background and chili fields and pecan orchards in the foreground. Photograph taken by Randall T. Hanson, U.S. Geological Survey, September 15, 2004. 


\section{Rio Grande Transboundary Integrated Hydrologic Model and Water-Availability Analysis, New Mexico and Texas, United States, and Northern Chihuahua, Mexico}

By Randall T. Hanson, Andre B. Ritchie, Scott E. Boyce, Amy E. Galanter, Ian A. Ferguson, Lorraine E. Flint, Alan Flint, and Wesley R. Henson

Prepared in cooperation with the Bureau of Reclamation

Scientific Investigations Report 2019-5120 


\title{
U.S. Department of the Interior DAVID BERNHARDT, Secretary
}

\author{
U.S. Geological Survey \\ James F. Reilly II, Director
}

\section{U.S. Geological Survey, Reston, Virginia: 2019}

For more information on the USGS - the Federal source for science about the Earth, its natural and living resources, natural hazards, and the environment-visit https://www.usgs.gov or call 1-888-ASK-USGS.

For an overview of USGS information products, including maps, imagery, and publications, visit https://store.usgs.gov.

Any use of trade, firm, or product names is for descriptive purposes only and does not imply endorsement by the U.S. Government.

Although this information product, for the most part, is in the public domain, it also may contain copyrighted materials as noted in the text. Permission to reproduce copyrighted items must be secured from the copyright owner.

Suggested citation:

Hanson, R.T., Ritchie, A.B., Boyce, S.E., Galanter, A.E., Ferguson, I.A., Flint, L.E., Flint, A., and Henson, W.R., 2020, Rio Grande transboundary integrated hydrologic model and water-availability analysis, New Mexico and Texas, United States, and northern Chihuahua, Mexico: U.S. Geological Survey Scientific Investigations Report 2019-5120, 186 p., https://doi.org/10.3133/sir20195120.

Associated data for this publication:

Ritchie, A.B., Hanson, R.T., Galanter, A.E., Boyce, S.E., Damar, N.A., Shephard, Z.M., and Tillman, F.D., 2018, Digital hydrologic and geospatial data for the Rio Grande transboundary integrated hydrologic model and water-availability analysis, New Mexico and Texas, United States, and Northern Chihuahua, Mexico: U.S. Geological Survey data release, https://doi.org/10.5066/P9J9NYND. 


\section{Contents}

Abstract

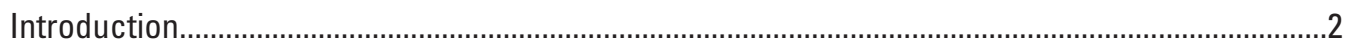

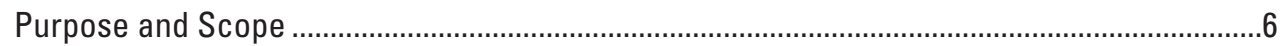

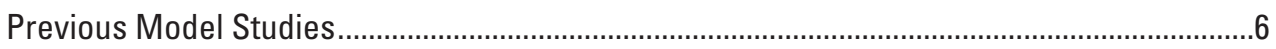

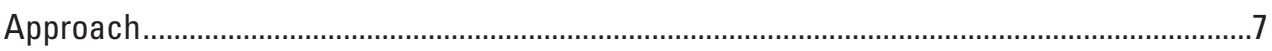

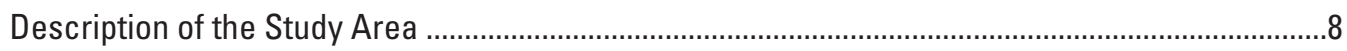

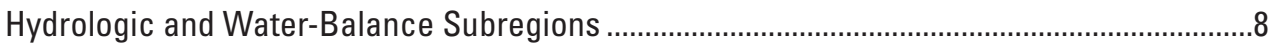

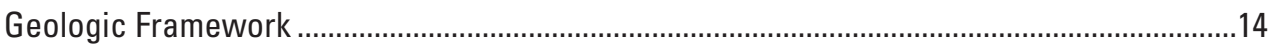

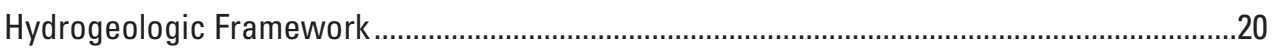

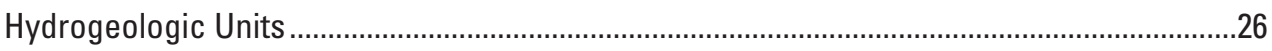

Faults, Subbasins, and Groundwater Flow System..........................................................30

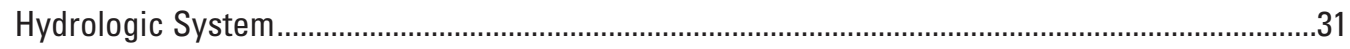

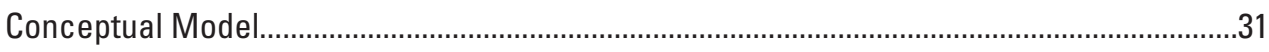

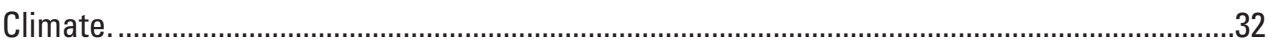

Development of Water Resources .....................................................................................

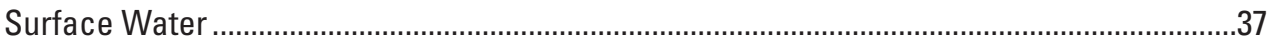

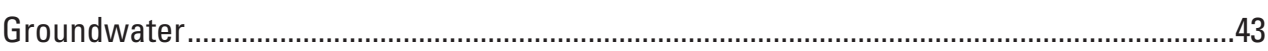

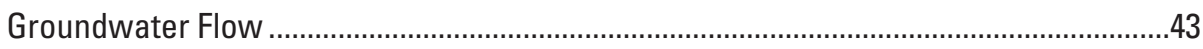

Groundwater Development for Agriculture..................................................................47

Groundwater Development for Municipal and Industrial Supply....................................51

Groundwater Development for Domestic Use ...............................................................53

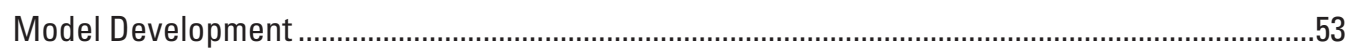

Water-Balance Model—Transboundary Rio Grande Watershed Model ...............................53

Estimation of Recharge and Runoff ............................................................................53

Calibration and Comparison to Measured Streamflows ..............................................56

Transboundary Rio Grande Watershed Model Results .................................................56

Integrated Hydrologic Model—Rio Grande Transboundary Integrated Hydrologic Model...61

Discretization—Rio Grande Transboundary Integrated Hydrologic Model............................63

Spatial Discretization and Layering ...........................................................................63

Temporal Discretization ...................................................................................................64

Groundwater Conditions_-Rio Grande Transboundary Integrated Hydrologic Model...........64

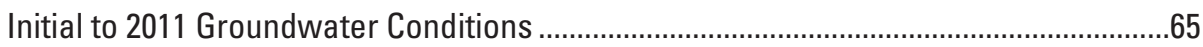

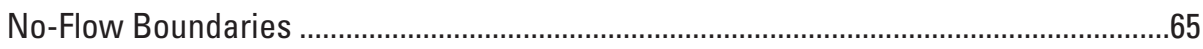

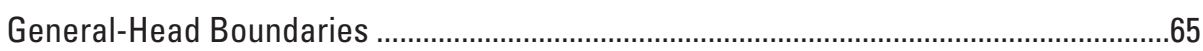

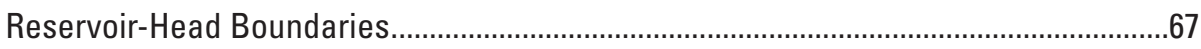

Surface-Water Network—Rio Grande Transboundary Integrated Hydrologic Model...........67

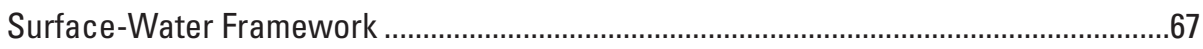

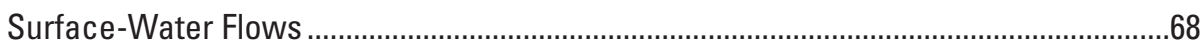

Groundwater Supply—Rio Grande Transboundary Integrated Hydrologic Model .................69

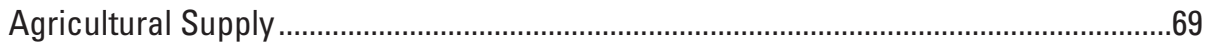

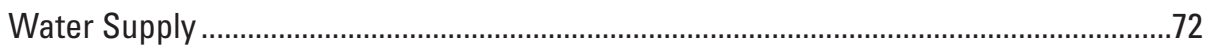


Landscape Features-Rio Grande Transboundary Integrated Hydrologic Model..................74

Total Farm Delivery Requirement ...................................................................................

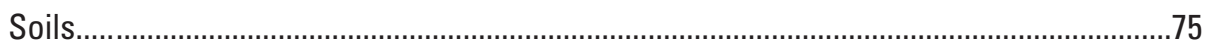

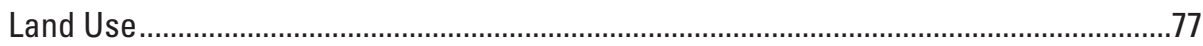

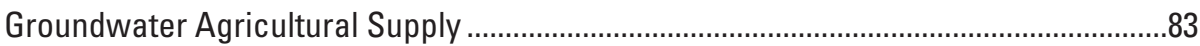

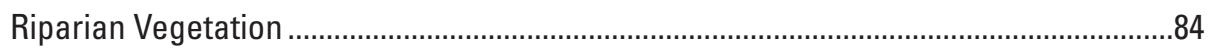

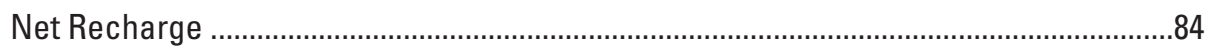

Aquifer Characteristics—Rio Grande Transboundary Integrated Hydrologic Model.............85

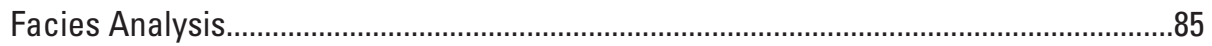

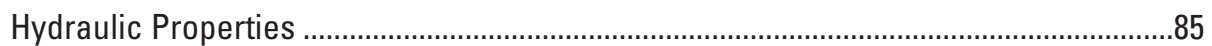

Hydraulic Conductivity.................................................................................94

Conductance of Faults and Dikes ....................................................................105

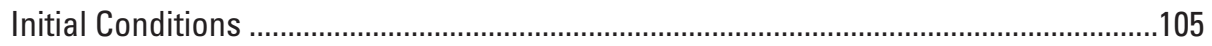

Calibration and Sensitivity—Rio Grande Transboundary Integrated Hydrologic Model...............106

Rio Grande Transboundary Integrated Hydrologic Model Parameters for Calibration ........111

Landscape-Process Parameters ...............................................................................111

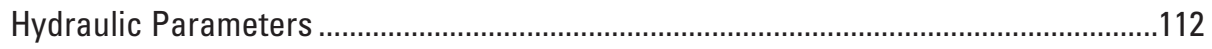

Surface-Water Network Parameters ………………….................................................113

Multiple-Aquifer Well Parameters ..............................................................................113

Underflow Boundary Parameters ..........................................................................114

Horizontal-Flow Barrier Parameters …………………...........................................114

Reservoir Parameters .................................................................................................114

Rio Grande Transboundary Integrated Hydrologic Model Observations and Results ..........115

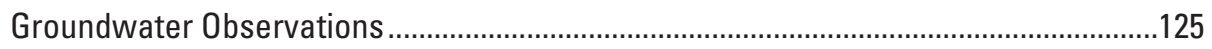

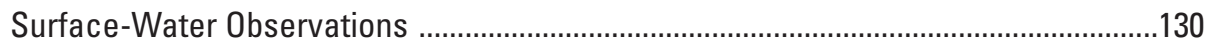

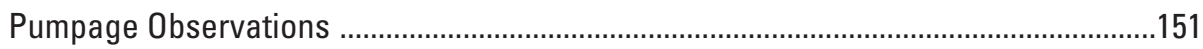

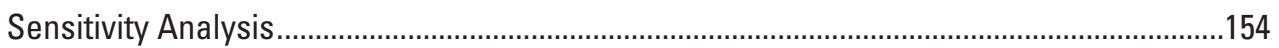

Hydrologic Flow Budgets—Rio Grande Transboundary Integrated Hydrologic Model ................156

Water-Balance Subregion Landscape-Delivery Budgets.....................................................156

Surface-Water Flow Budget ............................................................................................160

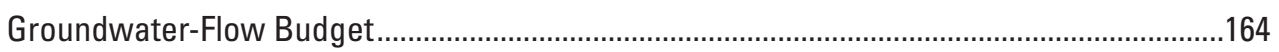

Model Limitations, Uncertainty, and Potential Improvements ......................................................170

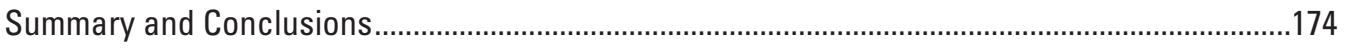

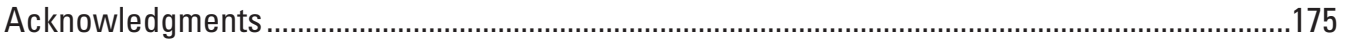

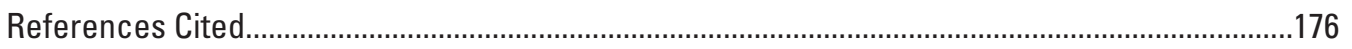




\section{Figures}

1. Maps showing areas modeled by the Rio Grande Transboundary Integrated Hydrologic model in the Transboundary Rio Grande, New Mexico, Texas, and Mexico, along with active hydrologic model grid, selected climate stations, and rivers for specific areas...

2. Maps showing Rio Grande Transboundary integrated hydrologic model (RGTIHM) hydrologic analysis subregions, related hydrologic flow barriers, and groundwater boundary flows locations used in the RGTIHM in the Transboundary Rio Grande, New Mexico, Texas, and Mexico.

3. Maps showing generalized geology of the Transboundary Rio Grande, New Mexico, Texas, and Mexico and the active and total region of the Rio Grande Transboundary Integrated Hydrologic Model...

4. Cross-sections showing hydrostratigraphic units through the three-dimensional Hydrogeologic Framework Model Rio Grande Transboundary integrated hydrologic model of the Transboundary Rio Grande, New Mexico, Texas, and Mexico.

5. Maps showing average annual values for Transboundary Rio Grande, New Mexico, Texas, and Mexico ...

6. Graphs showing annual and seasonal variability of surface-water releases at Caballo Reservoir and precipitation in the Transboundary Rio Grande

7. Graphs showing the generalized history of human development.

8. Maps showing distribution of streams with parameter groups of streamflowrouting cells and segments, parameter groups, and location of inflows and diversions of the Rio Grande transboundary integrated hydrologic model in the Transboundary Rio Grande, New Mexico, Texas, and Mexico.

9. Maps showing compilation of reported groundwater levels for the Transboundary Rio Grande, New Mexico, Texas, and Mexico.

10. Maps showing Rio Grande Transboundary Integrated Hydrologic Model well distribution in the Transboundary Rio Grande, New Mexico, Texas, and Mexico...........48

11. Graphs showing estimated groundwater pumpage in the Transboundary Rio Grande, New Mexico, Texas, and Mexico

12. Maps showing points used to estimate recharge by the Transboundary Rio Grande Watershed Model for Transboundary Lower Rio Grande, New Mexico, Texas, and Mexico.

13. Graphs showing comparisons of evapotranspiration for the Transboundary Rio Grande, New Mexico, Texas, and Mexico

14. Graph showing comparison of measured and simulated basin streamflow for the Rio Grande between Elephant Butte Dam and the narrows, using the Transboundary Rio Grande Watershed Model, New Mexico.

15. Graphs showing annual flows for selected gaged inflows for arroyos in and near the model domain of the Rio Grande Transboundary Integrated Hydrologic Model for the Transboundary Rio Grande, New Mexico, Texas, and Mexico

16. Graphs showing simulated subwatershed inflows as annual precipitation and recharge and runoff for selected ranges of water years for the active region of the Rio Grande Transboundary Integrated Hydrologic Model, the Transboundary Rio Grande, New Mexico, Texas, and Mexico.

17. Map showing model cells where reservoir leakage is simulated and parameter groups where faults and volcanic dikes are simulated as groundwater-flow barriers for the Transboundary Rio Grande, New Mexico, Texas, and Mexico. 
18. Map showing agricultural soil groups for the Rio Grande Transboundary Integrated Hydrologic Model simplified from Soil Survey Geographic Database for the Transboundary Rio Grande, New Mexico, Texas, and Mexico.

19. Map and pie chart showing land use in the Rio Grande Transboundary Integrated Hydrologic Model, New Mexico, Texas, and Mexico. .78

20. Graphs showing initial estimates of factors related to water use by land-use category in the Transboundary Rio Grande, New Mexico, Texas, and Mexico.

21. Maps showing distribution of parameter zones used for model calibration of hydraulic properties in the Transboundary Rio Grande, New Mexico, Texas, and Mexico, for the nine model layers by hydrostratigraphic unit...

22. Maps showing calibration data sites for the Rio Grande Transboundary Integrated Hydrologic Model, Transboundary Rio Grande, New Mexico, Texas, and Mexico

23. Graphs showing simulated and measured groundwater-level hydrographs for selected wells in the Transboundary Rio Grande, New Mexico, Texas, and Mexico

24. Graphs showing measured and simulated groundwater levels in wells in the Transboundary Rio Grande, New Mexico, Texas, and Mexico, from the Rio Grande Transboundary Integrated Hydrologic Model

25. Maps showing contoured measured water levels compared to simulated water levels in the Transboundary Rio Grande, New Mexico, Texas, and Mexico

26. Map showing calibration-data sites for Rio Grande streamflows and canal and drain flows for the Rio Grande Transboundary Integrated Hydrologic Model, Transboundary Rio Grande, New Mexico, Texas, and Mexico.

27. Graphs showing simulated and observed streamflow hydrographs for selected river, canal and drain gages within the Rio Grande Transboundary Integrated Hydrologic Model in the Transboundary Rio Grande, New Mexico and Texas

28. Graphs showing histogram of residuals for the Transboundary Rio Grande, New Mexico and Texas.

29. Graphs showing simulated surface-water deliveries and estimated allotment limits for selected water-balance subregions for the Transboundary Rio Grande, New Mexico and Texas, 1940-2014...

30. Graphs showing observed values compared to Rio Grande Transboundary Integrated Hydrologic Model simulated values for the Transboundary Rio Grande, New Mexico, Texas, and Mexico ..

31. Graphs showing agricultural pumpage or related land use

32. Graph showing magnitudes of the relative composite scaled sensitivity for selected parameters computed from observations at calibration points with PEST....155

33. Charts showing distribution of water-budget components of inflows and outflows for the landscape and flow system of the Rio Grande Transboundary Integrated Hydrologic Model hydrologic model, Transboundary Rio Grande, New Mexico, Texas, and Mexico.

34. Graphs showing agricultural irrigation components for the Rio Grande Transboundary region of New Mexico and Texas, 1940-2014

35. Graphs showing simulated seepage along the Rio Grande for parameter groups of the Rio Grande Transboundary Integrated Hydrologic Model for the Transboundary Rio Grande, New Mexico, Texas, and Mexico.

36. Charts showing results of simulated groundwater flow values for the hydrologicflow budget from the Rio Grande Transboundary Integrated Hydrologic Model, New Mexico, Texas and Mexico. 
37. Graphs showing simulated groundwater pumpage and recharge factors from the Rio Grande Transboundary Integrated Hydrologic Model, 1940-2014,

Transboundary Rio Grande, New Mexico, Texas, and Mexico.

38. Graph showing net flow into groups of model layers from adjacent groups of layers, Rio Grande Transboundary Integrated Hydrologic Model, 1940-2014, Transboundary Rio Grande, New Mexico, Texas, and Mexico.

\section{Tables}

1. Summary of water-balance subregions used in the Rio Grande Transboundary Integrated Hydrologic Model, Transboundary Rio Grande, New Mexico, Texas and Mexico

2. Summary of virtual land use in the Rio Grande Transboundary Integrated Hydrologic Model, Transboundary Rio Grande, New Mexico, Texas and Mexico

3. Summary of alluvial facies codes used to represent the hydrogeologic properties used in the Rio Grande Transboundary Integrated Hydrologic Model, Transboundary Rio Grande, New Mexico, Texas, and Mexico...

4. Summary of basement-rock zone codes for categories of pre-Santa Fe Group rocks used to represent the hydrogeologic properties used in the Rio Grande Transboundary Integrated Hydrologic Model, Transboundary Rio Grande, New Mexico, Texas, and Mexico

5. Summary of climate periods for the Rio Grande Transboundary Integrated Hydrologic Model, Transboundary Rio Grande, New Mexico, Texas, and Mexico

6. Scaling coefficients for estimation of streamflow for the MODFLOW "Streamflow

Routing" package from recharge and runoff maps developed by the Basin Characterization Model for ungaged basins in three geologic types for the Transboundary Rio Grande Valley, New Mexico, Texas, and Mexico.

7. Mean annual precipitation, recharge, and runoff during water years 1940-2015 as simulated by the Basin Characterization Model for dry and wet periods based on precipitation from New Mexico State University for the Transboundary Rio Grande, New Mexico, Texas, and Mexico

8. Summary of MF-OWHM2 packages and processes used to simulate the Rio Grande Transboundary Integrated Hydrologic Model of the Transboundary Rio Grande, New Mexico, Texas, and Mexico

9. Coordinates defining extent and rotation of the Rio Grande Transboundary Integrated Hydrologic Model of Transboundary Rio Grande, New Mexico, Texas, and Mexico.

10. Summary of root depths, range in monthly consumptive use values, and fractions of runoff from irrigation for land use in the Rio Grande Transboundary Integrated Hydrologic Model for the Transboundary Rio Grande, New Mexico, Texas, and Mexico.

11. Summary of fractions of transpiration and evaporation of virtual land-use categories by regions for the Transboundary Rio Grande.

12. Irrigation efficiency for virtual crops and related pumping-capacity scale factors for wells serving the regions of the Transboundary Rio Grande, New Mexico, Texas, and Mexico

13. Summary of parameter zones and related property parameter names used to calibrate horizontal hydraulic conductivity, vertical hydraulic conductivity, and aquifer specific storage in the Rio Grande Transboundary Integrated Hydrologic Model, Transboundary Rio Grande, New Mexico, Texas, and Mexico 
14. Summary of parameter values estimated for the Rio Grande Transboundary Integrated Hydrologic Model, Transboundary Rio Grande, New Mexico, Texas, and Mexico

15. Summary of surface-water channel conductivity and the "Streamflow Routing" package diversion parameters and final values, in the Rio Grande Transboundary Integrated Hydrologic Model, Transboundary Rio Grande, New Mexico, Texas, and Mexico

16. Summary of groundwater-flow budgets for selected periods in the Rio Grande Transboundary Integrated Hydrologic Model, Transboundary Rio Grande, New Mexico, Texas, and Mexico

\section{Conversion Factors}

U.S. customary units to International System of Units

\begin{tabular}{|c|c|c|}
\hline Multiply & By & To obtain \\
\hline \multicolumn{3}{|c|}{ Length } \\
\hline inch (in.) & 2.54 & centimeter $(\mathrm{cm})$ \\
\hline inch (in.) & 25.4 & millimeter $(\mathrm{mm})$ \\
\hline foot (ft) & 0.3048 & meter $(\mathrm{m})$ \\
\hline mile (mi) & 1.609 & kilometer $(\mathrm{km})$ \\
\hline \multicolumn{3}{|c|}{ Area } \\
\hline acre & 4,047 & square meter $\left(\mathrm{m}^{2}\right)$ \\
\hline acre & 0.4047 & hectare (ha) \\
\hline acre & 0.4047 & square hectometer $\left(\mathrm{hm}^{2}\right)$ \\
\hline acre & 0.004047 & square kilometer $\left(\mathrm{km}^{2}\right)$ \\
\hline square foot $\left(\mathrm{ft}^{2}\right)$ & 929.0 & square centimeter $\left(\mathrm{cm}^{2}\right)$ \\
\hline square foot $\left(\mathrm{ft}^{2}\right)$ & 0.09290 & square meter $\left(\mathrm{m}^{2}\right)$ \\
\hline section (640 acres or 1 square mile) & 259.0 & square hectometer $\left(\mathrm{hm}^{2}\right)$ \\
\hline \multicolumn{3}{|c|}{ Volume } \\
\hline acre-foot (acre-ft) & 1,233 & cubic meter $\left(\mathrm{m}^{3}\right)$ \\
\hline acre-foot (acre-ft) & 0.001233 & cubic hectometer $\left(\mathrm{hm}^{3}\right)$ \\
\hline \multicolumn{3}{|c|}{ Flow rate } \\
\hline acre-foot per day (acre-ft/d) & 0.01427 & cubic meter per second $\left(\mathrm{m}^{3} / \mathrm{s}\right)$ \\
\hline acre-foot per year (acre-ft/yr) & 1,233 & cubic meter per year $\left(\mathrm{m}^{3} / \mathrm{yr}\right)$ \\
\hline acre-foot per year (acre-ft/yr) & 0.001233 & cubic hectometer per year $\left(\mathrm{hm}^{3} / \mathrm{yr}\right)$ \\
\hline \multicolumn{3}{|c|}{ Hydraulic conductivity } \\
\hline foot per day $(\mathrm{ft} / \mathrm{d})$ & 0.3048 & meter per day $(\mathrm{m} / \mathrm{d})$ \\
\hline
\end{tabular}




\section{Datum}

Vertical coordinate information is referenced to the North American Vertical Datum of 1988 (NAVD 88).

Horizontal coordinate information is referenced to the North American Datum of 1983 (NAD 83)].

Elevation, as used in this report, refers to distance above the vertical datum.

\section{Abbreviations}

$\begin{array}{ll}\text { AET } & \text { actual evapotranspiration } \\ \text { BCM } & \text { Basin Characterization Model } \\ \text { CIR } & \text { crop irrigation requirement } \\ \text { EBID } & \text { Elephant Butte Irrigation District } \\ \text { ENSO } & \text { El Nino-Southern Oscillation } \\ \text { EPCWID1 } & \text { El Paso County Water Improvement District No. 1 } \\ \text { ET } & \text { evapotranspiration } \\ \text { ET }{ }_{h^{\prime}} \text { ET } & \text { reference evapotranspiration } \\ \text { IBWC } & \text { International Boundary and Water Commission } \\ \mathrm{K}_{\mathrm{c}} & \text { crop coefficient } \\ \mathrm{K}_{\mathrm{h}^{\prime}} \text { HK } & \text { horizontal hydraulic conductivity } \\ \mathrm{K}_{\mathrm{v}} \text {,VK } & \text { vertical hydraulic conductivity } \\ \text { LRG_2007 } & \text { Groundwater flow model of the Lower Rio Grande Basin } \\ \text { LRG_FMP 2011 } & \text { Hydrologic flow model of the Lower Rio Grande } \\ \text { LRG_USBR_EIS } & \text { Bureau of Reclamation Environmental Impact Statement hydrologic flow } \\ \text { MF-OWHM2 } & \text { model of the lower Rio Grande } \\ \text { NAMS } & \text { North American Monsoon System } \\ \text { NCDC } & \text { National Climatic Data Center } \\ \text { NMOSE } & \text { New Mexico Office of the State Engineer } \\ \text { NMSU } & \text { New Mexico State University } \\ \text { PDO } & \text { Pacific Decadal Oscillation }\end{array}$




\begin{tabular}{ll} 
PET & potential evapotranspiration \\
PEST & Parameter Estimation Program \\
Reclamation & Bureau of Reclamation \\
RGP & Rio Grande Project \\
RGTIHM & Rio Grande Transboundary Integrated Hydrologic Model \\
RGV & Rio Grande Valley \\
RMBHM & Rincon and Mesilla Basins Hydrologic Model \\
SDR & submitted drillers reports \\
SFR & streamflow routing package \\
SOSWR & sum of squared weighted residual \\
TFDR & total farm delivery requirement \\
TRG & Transboundary Rio Grande \\
TRGWM & Transboundary Rio Grande Watershed Model \\
TWDB & Texas Water Development Board \\
USGS & U.S. Geological Survey \\
WBS & water-balance subregion \\
\hline
\end{tabular}




\title{
Rio Grande Transboundary Integrated Hydrologic Model and Water-Availability Analysis, New Mexico and Texas, United States, and Northern Chihuahua, Mexico
}

\author{
By Randall T. Hanson'1, Andre B. Ritchie², Scott E. Boyce', Amy E. Galanter², Ian A. Ferguson³, Lorraine E. Flint', \\ Alan Flint ${ }^{1}$, and Wesley R. Henson ${ }^{1}$
}

\section{Abstract}

Changes in population, agricultural development and practices (including shifts to more water-intensive crops), and climate variability are increasing demands on available water resources, particularly groundwater, in one of the most productive agricultural regions in the Southwestthe Rincon and Mesilla Valley parts of Rio Grande Valley, Doña Ana and Sierra Counties, New Mexico, and El Paso County, Texas. The goal of this study was to produce an integrated hydrological simulation model to help evaluate water-management strategies, including conjunctive use of surface water and groundwater for historical conditions, and to support long-term planning for the Rio Grande Project. This report describes model construction and applications by the U.S. Geological Survey, working in cooperation and collaboration with the Bureau of Reclamation.

This model, the Rio Grande Transboundary Integrated Hydrologic Model, simulates the most important natural and human components of the hydrologic system, including selected components related to variations in climate, thereby providing a reliable assessment of surface-water and groundwater conditions and processes that can inform water users and help improve planning for future conditions and sustained operations of the Rio Grande Project (RGP) by the Bureau of Reclamation. Model development included a revision of the conceptual model of the flow system, construction of a Transboundary Rio Grande Watershed Model (TRGWM) water-balance model using the Basin Characterization Model, and construction of an

\footnotetext{
${ }^{1}$ United States Geological Survey, California Water Science Center, Sacramento, Calif.

${ }^{2}$ United States Geological Survey, New Mexico Water Science Center, Albuquerque, N. Mex.

${ }^{3}$ Bureau of Reclamation, Technical Service Center, Water Resources Planning and Operations, Denver, Colo.
}

integrated hydrologic flow model with MODFLOW-OneWater Hydrologic Flow Model version 2 (referred to as MF-OWHM2). The hydrologic models were developed for and calibrated to historical conditions of water and land use, and parameters were adjusted so that simulated values closely matched available measurements (calibration). The calibrated model was then used to assess the use and movement of water in the Rincon Valley, Mesilla Basin, and northern part of the Conejos-Médanos Basin, with the entire region referred to as the "Transboundary Rio Grande" or TRG. These tools provide a means to understand hydrologic system response to the evolution of water use in the region, its availability, and potential operational constraints of the RGP.

The conceptual model identified surface-water and groundwater inflows and outflows that included the movement and use of water both in natural and in anthropogenic systems. The groundwater-flow system is characterized by a layered geologic sedimentary sequence combined with the effects of groundwater pumping, operation of the RGP, natural runoff and recharge, and the application of irrigation water at the land surface that is captured and reused in an extensive network of canals and drains as part of the conjunctive use of water in the region.

Historical groundwater-level fluctuations followed a cyclic pattern that were aligned with climate cycles, which collectively resulted in alternating periods of wet or dry years. Periods of drought that persisted for one or more years are associated with low surface-water availability that resulted in higher rates of groundwater-level decline. Rates of groundwater-level decline also increased during periods of agricultural intensification, which necessitated increasing use of groundwater as a source of irrigation water. Agriculture in the area was initially dominated by alfalfa and cotton, but since 1970 more water-intensive pecan orchards and vegetable production have become more common. Groundwater levels substantially declined in subregions where drier climate combined with increased demand, resulting in periods of reduced streamflows. 
Most of the groundwater was recharged in the Rio Grande Valley floor, and most of the pumpage and aquifer storage depletion was in Mesilla Basin agricultural subregions. A cyclic imbalance between inflows and outflows resulted in the modeled cyclic depletion (groundwater withdrawals in excess of natural recharge) of the groundwater basin during the 75-year simulation period of 1940-2014. Changes in groundwater storage can vary considerably from year to year, depending on land use, pumpage, and climate conditions. Climatic drivers of wet and dry years can greatly affect all inflows, outflows, and water use. Although streamflow and, to a minor extent, precipitation during inter-decadal wet-year periods replenished the groundwater historically, contemporary water use and storage depletion could have reduced the effects of these major recharge events. The average net groundwater flow-rate deficit for 1953-2014 was estimated to be about 1,090 acre-feet per year.

\section{Introduction}

Changes in population, agricultural development and practices (including shifts to other longer term water-intensive crops), and climate variability are increasing demands on available water resources, particularly groundwater, in one of the most productive agricultural regions in the Southwestthe Rio Grande Valley; Doña Ana and Sierra Counties, New Mexico; and El Paso County, Texas. The goal of this study was to produce an integrated hydrological simulation model capable of simulating the quantity and movement of surfacewater and groundwater resources in the Rincon Valley and Mesilla Basin, including interactions and feedbacks between surface-water and groundwater management and use. The resulting model is intended to be used to evaluate and understand how historical and potential future stresses on the surface-water and groundwater systems affect the quantity and movement of water resources in the study area. In addition, the model can be used to evaluate alternative management strategies, including conjunctive management of surface water and groundwater, to support long-term planning and decision making for the Rio Grande Project (RGP).

The Transboundary Rio Grande (TRG) region consists of the Rincon Valley part of the Palomas Basin in New Mexico, the Mesilla Basin in New Mexico and Texas, and the northern part of the Conejos-Médanos Basin of northern Mexico (fig. 1A). This hydrologic system is characterized by conjunctive use, which is the coordinated use of surface water and groundwater (Bureau of Reclamation, 2015). The TRG region is bounded on the northwest by the Black Range; on the southwest by the East and West Potrillo Mountains; on the east by the San Andres, Organ, and Franklin Mountains; and on the south by the Sierra de Juárez and other unnamed bedrock outcrops (fig. 1A). The study area includes two generally northwest-southeast trending valleys that form the floodplain of the Rio Grande, referred to as the Rio Grande Valley in this report (RGV): the Rincon Valley between Caballo Dam and Selden Canyon and the Mesilla Valley between Radium Springs, New Mexico, and the El Paso narrows to the west of El Paso, Texas. Rincon and Mesilla Valleys are linked by Selden Canyon, a narrow valley incised into the Selden Hills uplift (Sweetkind, 2017). The Bureau of Reclamation's (Reclamation) Rio Grande Project (Bureau of Reclamation, $2016,2017)$ stores and delivers surface water for irrigation and municipal uses in the Rincon Valley, the Mesilla Valley, and the El Paso Valley south of the El Paso narrows (outside of the study area) and in the study area in the United States (fig. 1A).

Analysis of the complex relationship between the use and movement of water in the TRG region requires an integrated hydrologic model capable of tracking the three-dimensional movement and use of water in the aquifers, through the surface-water network, and across the landscape. This simulation tool can help assess the effects of use and reuse of streamflow and groundwater on hydrologic conditions and water availability in the context of changing population, land use, cropping and irrigation practices, and climate.

Increases in population in the region and transitions to crops that consume additional water have increased the demand for water in the TRG region. Urban water supply is provided by groundwater, and irrigated agriculture is supplied from surface water and groundwater. The aquifers in the TRG region historically (1940-2014) have undergone periods of storage depletion that are generally related to a combination of the changes in irrigated acreage, crop types, crop-irrigation requirements, and regional climate cycles that, in turn, dictate the amount of regional runoff transported down the Rio Grande from Colorado and northern New Mexico to the TRG region. The groundwater levels in the RGV generally rise during periods of high surface-water supply, when seepage from the Rio Grande, irrigation canals, and laterals and deep percolation from irrigated lands recharge the groundwater system and when surface-water deliveries reduce demands for groundwater pumping. By contrast, groundwater levels generally decline during periods of low surface-water supply, when reduced surface-water deliveries reduce recharge from seepage and deep percolation and when groundwater pumping is increased to meet irrigation demand. 
$\boldsymbol{A}$

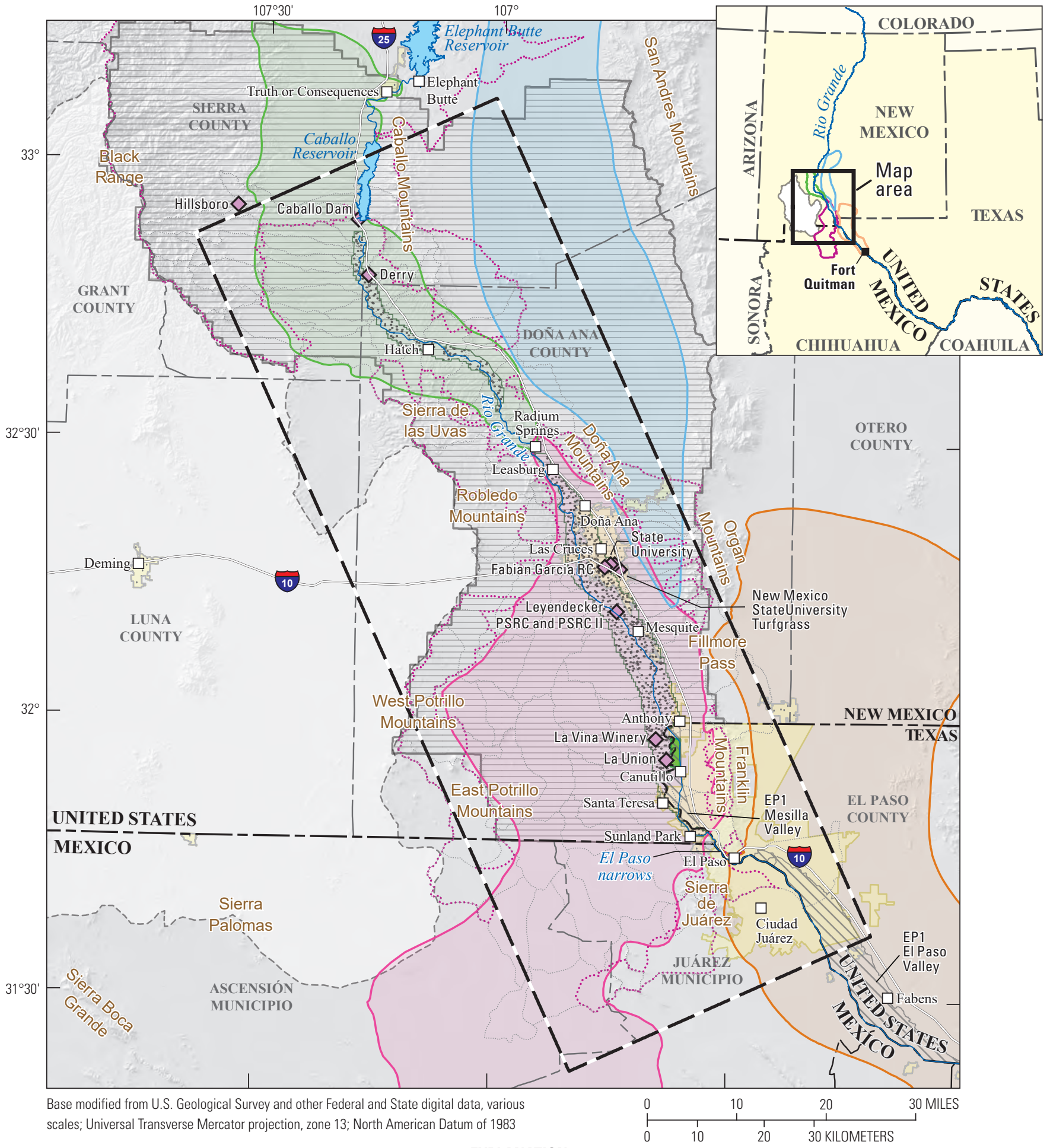

EXPLANATION

Groundwater basins

Hueco (Driscoll and Sherson, 2016)

Palomas (Driscoll and Sherson, 2016)

Jornada del Muerto (after Witcher and others, 2004)

Mimbres (Hanson and others, 1994)

Mesilla and Conejos-Médanos (after Sheng and others, 2013)
$\Gamma$ Maximum extent of Rio Grande Transboundary Integrated Hydrologic Model (RGTIHM)

Watershed Boundary Dataset 12-digit sub-watershed

Lower Rio Grande Water Master district

Elephant Butte Irrigation District (EBID)

El Paso County Water Improvement District No. 1 (EPCWID1)

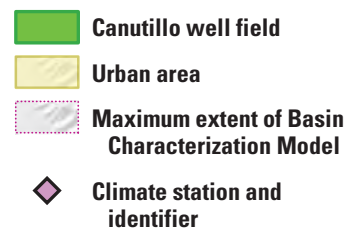

identifier

Figure 1. Areas modeled by the Rio Grande Transboundary Integrated Hydrologic model (RGTIHM) in the Transboundary Rio Grande, New Mexico, Texas, and Mexico, along with active hydrologic model grid, selected climate stations, and rivers for specific areas: $A$, the total extent of the model area, including watersheds and groundwater basins; $B$, the Rincon Valley; and $C$, the Mesilla and Conejos-Médanos Basins. 
B

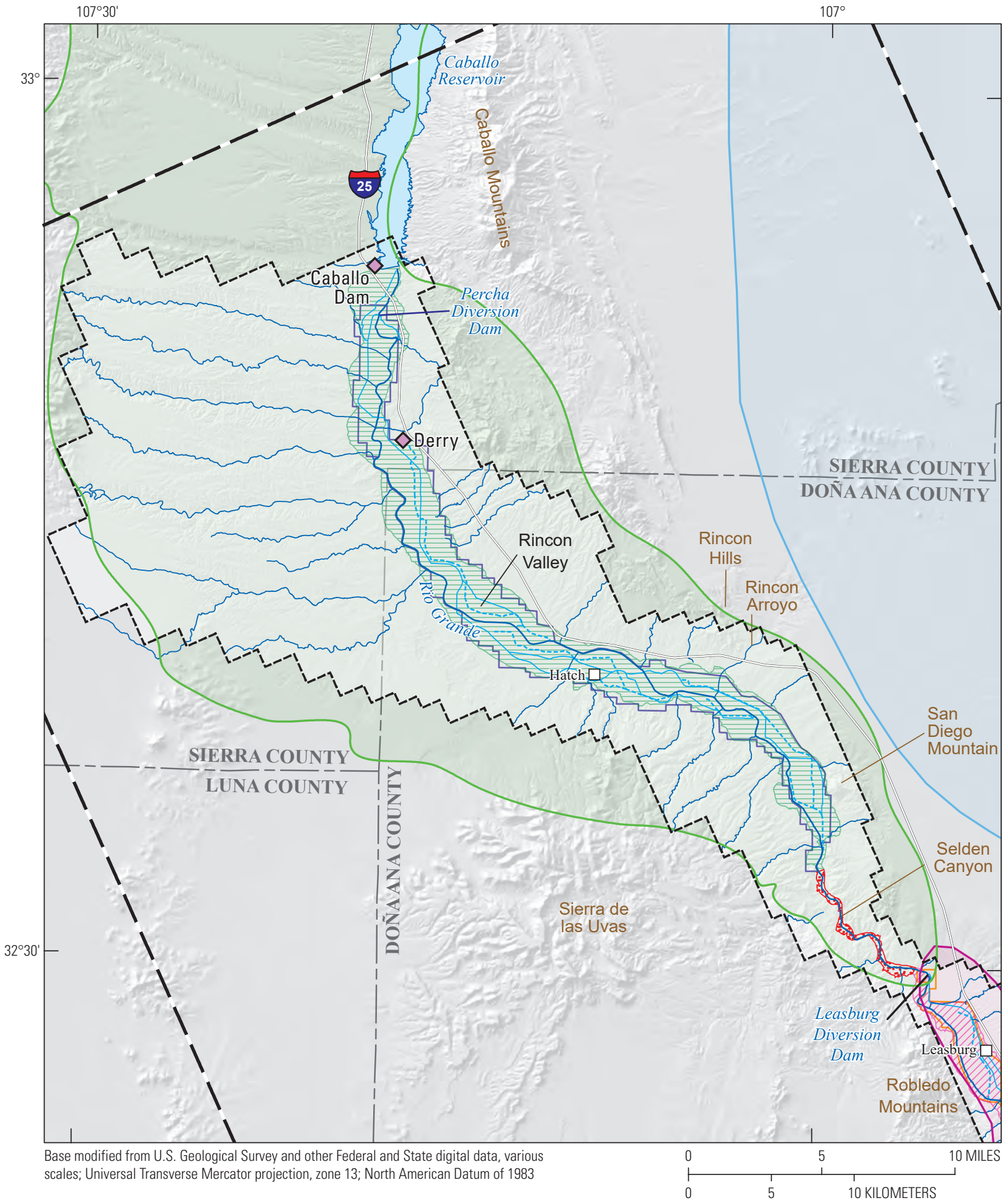

\section{Groundwater basins}

Palomas (Driscoll and Sherson, 2016)

Jornada del Muerto (after Witcher and others, 2004)

EXPLANATION

Mesilla and Conejos-Médanos (after Sheng and others, 2013
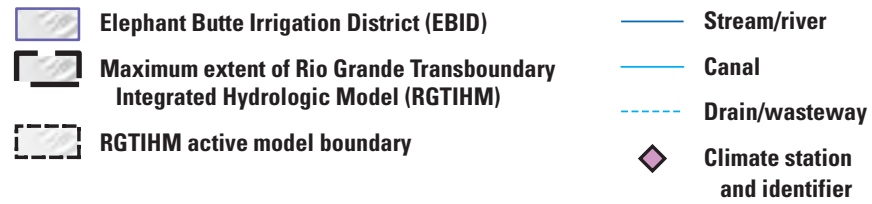

Figure 1. - Continued 
c

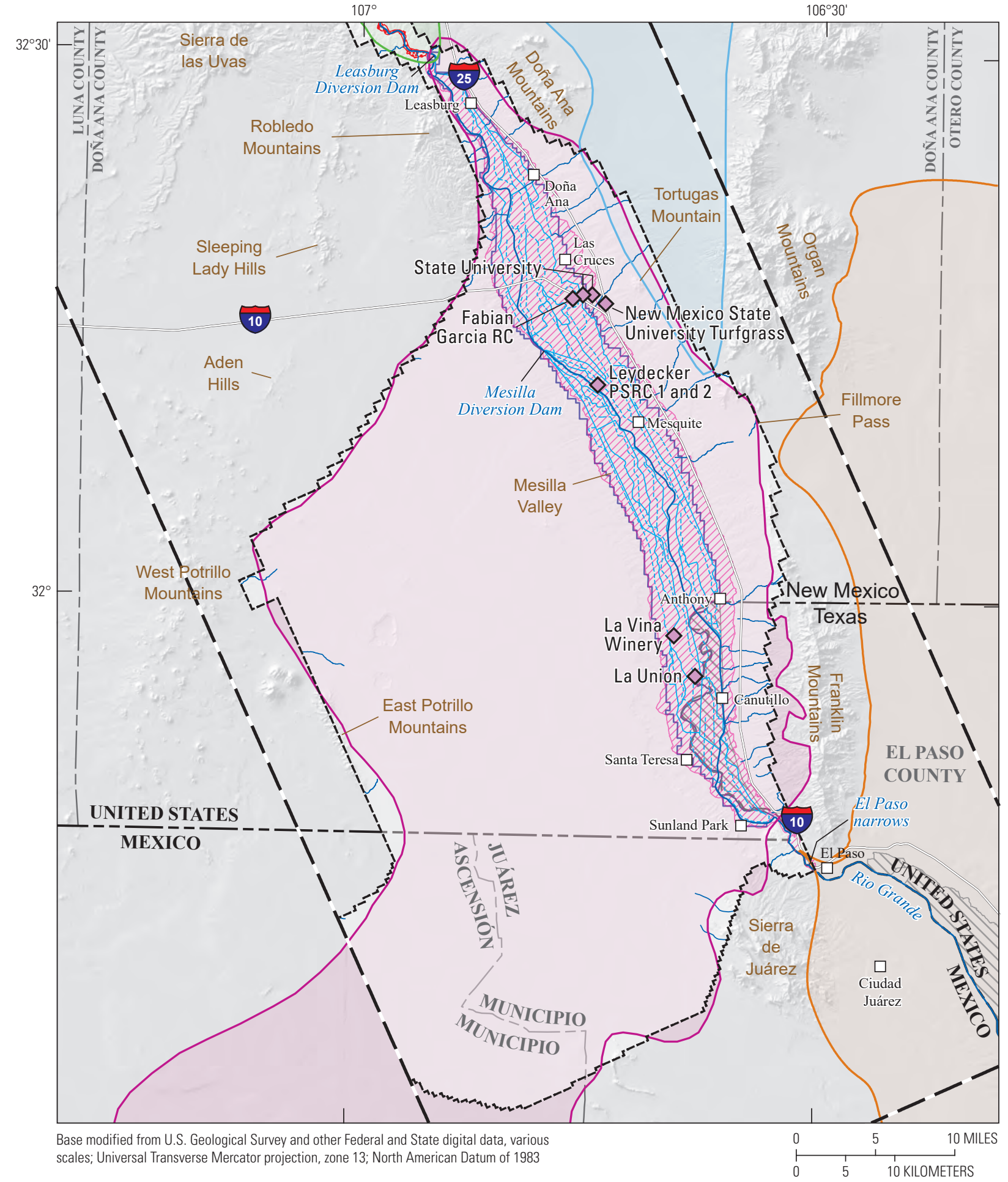

Groundwater basin

Hueco (Driscoll and Sherson, 2016)

Palomas (Driscoll and Sherson, 2016)

Jornada del Muerto (after Witcher and others, 2004)

Mesilla and Conejos-Médanos (after Sheng and others, 2013)

EXPLANATION

Rio Grande Valley

Selden Canyon

Mesilla Valley irrigation area

Elephant Butte Irrigation District (EBID)

El Paso County Water Improvement District No. 1 (EPCWID1)

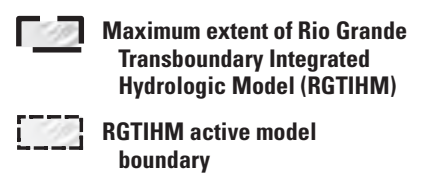

Stream/river

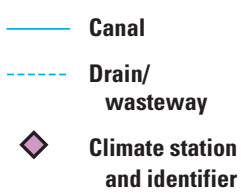

and identifier

Figure 1. - Continued 


\section{Purpose and Scope}

The purpose of the study was to develop a quantitative tool, the Rio Grande Transboundary Integrated Hydrologic Model (RGTIHM), capable of simulating the quantity and movement of surface-water and groundwater resources in the Rincon Valley and Mesilla Basin, including interactions and feedbacks between surface-water and groundwater management and use. This tool is needed to evaluate and understand how historical and potential future stresses on the surface-water and groundwater systems affect the quantity and movement of water resources in the study area. In addition, this tool can be used to evaluate alternative management strategies, including conjunctive management of surface water and groundwater, to support long-term planning and decision making for the RGP.

The RGTIHM was constructed, in cooperation with Reclamation, using a refined three-dimensional interpretation of the geology (Sweetkind, 2017), new estimates of water inflows to the system, and a refined representation of the conjunctive use and movement of water. The RGTIHM was calibrated to quantify the use and movement of water and water availability for historical conditions from 1940 to 2014. The supply-and-demand and physical model frameworks were designed to effectively capture system response at a temporal and spatial scale that is appropriate for the RGP operation and water-resource analysis to help inform regional stakeholders of potential constraints of different water-supply options for the RGP. This regional hydrologic flow model simulates groundwater and surface-water movement and uses at scales relevant to water-management decisions for interannual to interdecadal periods. In particular, the RGTIHM can be used to evaluate regional water availability; surfacewater and groundwater management and use, including the RGP surface-water operations; and alternative water-resource management strategies.

This report documents (1) an analysis and refinement of the conceptual model of the hydrologic system of the TRG, (2) the description of the hydrologic features used in the hydrologic flow models of the TRG region, (3) development and calibration of the Transboundary Rio Grande Watershed Model (TRGWM) and RGTIHM, and (4) an evaluation of historical water and land use and potential climate variability and change.

\section{Previous Model Studies}

Hydrologic models of the study area have been developed and improved as modeling tools and techniques have advanced. All of these models were developed to answer the same fundamental questions about the conjunctive use and movement of the water resources. This progression of models reflects improved simulation capabilities, need for more detailed or specific simulation of separate features, and improved data used as input and for comparison of specific model features that represent the elements of conjunctive use. These models were largely based on the sequence of U.S. Geological Survey (USGS) models called MODFLOW (McDonald and Harbaugh, 1984, 1988; Harbaugh and others, 2000; Harbaugh, 2005), which is the modular code of packages for each model feature and boundary condition. Before the use of MODFLOW, the simulation of groundwater flow in the Mesilla Basin was simulated by a quasi-threedimensional code developed by Peterson and others (1984), which used specified stages for streams and two model layers to represent the alluvial aquifers. The earliest MODFLOW model had similar features and structure (Maddock and Wright Water Engineers, 1987). This version of the MODFLOW model was expanded to four model layers (S.S. Papadopulos and Associates, Inc., 1987). The newer MODFLOW model was adapted and was used for administration of groundwater rights by the New Mexico Office of the State Engineer (NMOSE; Frenzel and others, 1992; Hamilton and Maddock, 1993). Further development to explicitly represent the simulation of diversions by some streamflow routing, two seasons per year, and to include the Rincon Valley as well as the Mesilla Basin (fig. 1A) was completed by Weedon and Maddock (1999).

A model that was more detailed than previous models, LRG_2007, was developed for the NMOSE (S.S. Papadopulos and Associates, Inc., 2007). This five-layer model extended the simulation period (1940-2004) and continued to use a 4-month non-pumping winter season and 8-month pumping agricultural season for each year. The LRG_2007 model also used the new "Streamflow Routing" (SFR) package for streams and drains, the "Riparian Evapotranspiration" (RIP-ET) package, precalculated agricultural pumpage, recharge, estimated domestic pumpage derived from population and per capita use rates, and reported municipal and industrial groundwater pumpage. Except for agricultural pumpage, groundwater pumpage was applied to wells at the actual well locations. The LRG_2007 model also was extended areally to include the Rincon Valley, Mesilla Basin, and a small part of the Conejos-Médanos Basin in northern Mexico. This model used estimated, net groundwater pumpage for agriculture based on an external spreadsheet of the pre-calculated crop-irrigation requirement (CIR) developed for the NMOSE (NMOSE-CIR). The CIRs were calculated by the modified Blaney-Criddle method (Blaney and Criddle, 1950, 1962) using annual cropping and climate data (S.S. Papadopulos and Associates, Inc., 2007). 
Building on the LRG 2007 model, increasingly more complete regional integrated hydrologic models were developed that more fully coupled the surface-water and groundwater resources with the movement and use of water across the landscape. The first integrated hydrologic model, LRG_FMP2011, was developed as part of the USGS Transboundary Aquifer Assessment Program (Hanson and others, 2013). This model included a limited implementation of the MODFLOW Farm Process (FMP; Schmid and others, 2006a, b; Schmid and Hanson, 2009; Hanson and others, $2014 b$ ) that enabled internal simulation of surface-water deliveries in a supply and demand framework; some landscape properties, such as soils, fractions of transpiration, and root depths; time-varying surface-water allotments; and the use of surface-water flows as observations. This model retained the same layering and hydraulic properties of the LRG_2007 and extended the period of simulation from 2004 through 2009. Similar to LRG_2007, the LRG_FMP2011 relied on consumptive use pre-calculated from the NMOSE-CIR, which was also extended through 2009. Additional hydrologicflow budget analyses associated with this model included an evaluation of the simulated RGP delivery performance (that is, the relationship between RGP releases from Caballo Dam and project diversions at canal headings; Hanson and others, 2013), further analysis of simulated streamflow capture, and evaluations of other aspects of the supply-and-demand components (Knight, 2015). The LRG_FMP2011 model also was used to assess the effects of elevation resolution on the simulation of evapotranspiration (Kambhammettu and others, 2012), which ultimately helped guide the spatial rediscretization implemented in the new RGTIHM described in this report.

The LRG_FMP2011 model subsequently became the basis for the Rincon and Mesilla Basins Hydrologic Model (RMBHM; Ferguson and Llewellyn, 2015). Reclamation, in collaboration with the USGS, developed the RMBHM to simulate RGP operations and corresponding surface-water and groundwater conditions in the Rincon and Mesilla Basins under a range of alternative RGP operating procedures and projected future climate scenarios. The RMBHM adopts much of the model configuration and inputs directly from the LRG FMP2011, including the use of the NMOSE-CIR as the basis for agricultural water demands; however, the RMBHM uses an updated version of MODFLOW (MODFLOW-OneWater Hydrologic Flow Model, or "MF-OWHM"; Hanson and others, 2014b) that has additional software features developed and implemented by Reclamation (Ferguson and Llewellyn, 2015). These new software features provide the capability to simulate RGP surface-water operations, including RGP storage, allocation, release, diversion, delivery, and water accounting. New features were linked to existing features of MF-OWHM, including FMP and SFR, to allow the dynamic simulation of surface-water and groundwater management and use, including the coupled use and movement of surface water and groundwater based on reservoir supply, agricultural demand, and specified RGP operating procedures. The RMBHM thus simulates interactions and feedbacks between RGP surface-water operations and groundwater recharge, incentives for groundwater pumping for supplemental irrigation, and groundwater/surface-water interactions. By contrast, previous models represented RGP operations as model inputs, which, therefore, were not capable of simulating the full range of feedbacks between changes in surface-water and groundwater management and use.

In addition to this evolution of regional model development, several subregional models were developed. These included a Farm Process version of the southern Rincon Valley (Schmid and others, 2009; Tillery and King, 2006) used to analyze subregional flows at a more detailed scale. A model used to evaluate potential streamflow capture of the underflow near the well field, Canutillo, Texas (fig. 1A), was developed for the period 1995-2002 using the Weeden and Maddock model (Talbot, 2003). This model was recently updated by Reclamation, based on features from the LRG_FMP2011 model, to help estimate capture and related compensation for potential streamflow capture of the Rio Grande by the Canutillo well field (Tom Maddock and Jake Knight, University of Arizona, written commun., 2015).

In brief, the history of model development for the TRG has spanned several decades and demonstrates the incremental improvement of hydrologic simulation tools and methods for analysis of conjunctive use. The transition from the previous models to the RGTIHM, which incorporates many new features, is described in detail in the model sections of this report and in the related geologic framework report (Sweetkind, 2017).

\section{Approach}

The RGTIHM was developed to simulate and analyze the conjunctive use and movement of surface water and groundwater throughout the TRG from March 1940 through December 2014 using an updated verison of MF-OWHM, the MODFLOW-One-Water Hydrologic Flow Model version 2 (MF-OWHM2; Boyce and others, 2020) to simulate coupled use and flows in a supply-and-demand framework of conjunctive use. The development of this model required refinement of the conceptual model, incorporation of the new geohydrologic framework (Sweetkind, 2017), and detailing of components of the related water budget, including the estimates from the surrounding watersheds. The conceptual model was updated with recently acquired information about the conceptual framework of natural and engineered features in the TRG region. These new features and information are covered in subsequent sections that describe the components of the model. Refinement of the geohydrologic framework required remapping geologic surfaces to accord with recently acquired geologic information available from wells and other investigations (Sweetkind and others, 2017; Sweetkind, 2017). 
The resulting RGTIHM includes new estimates of model layering and of surface-water and groundwater inflows and outflows and a more detailed spatial distribution of the 2016 land-use subregions than previous models for this region.

The new TRGWM valley-wide water-balance model includes estimates of runoff from the surrounding watersheds (fig. $1 A$ ) simulated by the Basin Characterization Model (BCM; Flint and Flint, 2012, Flint and others, 2010, 2012, 2013), which is a regional-scale precipitation-runoff model. Simulations from this model provided runoff estimates for all of the ungaged ephemeral streams and arroyos that form a drainage network carrying mountain-front recharge from flood flows along the boundary of the alluvial groundwater basin.

\section{Description of the Study Area}

The RGV is a rift valley that runs from southern Colorado to northern Mexico (Sweetkind, 2017), through which the Rio Grande flows and the related axial drainage of various tributaries. In the TRG area, the Rio Grande is controlled by the RGP through Elephant Butte and Caballo Reservoirs (fig. 1A). The TRG watershed downstream from Caballo Dam is a high desert watershed having a surfacewater drainage area of about 3,140 square miles $\left(\mathrm{mi}^{2}\right)$ in the United States and Mexico (fig. 1A). In the TRG, the Rio Grande flows through alluvium of Quaternary age covering about $36 \mathrm{mi}^{2}$ in the Rincon Valley and Mesilla Basin (figs. 1A, $B$ ). The Rincon Valley straddles the southern part of Sierra County and the northern part of Doña Ana County in New Mexico. The Mesilla Valley extends from north-central Doña Ana County, New Mexico, to western El Paso County, Texas. Land-surface elevations in the local watersheds containing the Rincon and Mesilla Valleys range from 3,600 feet (ft) near the El Paso narrows (fig. 1C) to greater than $9,000 \mathrm{ft}$ at the Organ Mountains, and land-surface elevations in the region of the active RGTIHM model grid range from about 3,600 to $7,500 \mathrm{ft}$ (figs. $1 B, C$ ).

The Rincon Valley part of the TRG is bounded by the Caballo Mountains, Rincon Hills, and San Diego Mountain on the east and by the Black Range and Sierra de las Uvas on the west (figs. $1 A, B$ ). The valley is fed by the Rio Grande and its tributaries, of which Rincon Arroyo is the largest in the Rincon Valley (figs. 1A, B). The Rio Grande flows south from the Rincon Valley through the structural narrows of Selden Canyon to the Mesilla Basin. The Mesilla Basin part of the TRG is bounded by the Doña Ana Mountains, Organ
Mountains, and Franklin Mountains on the east and by the Robledo Mountains, Sleeping Lady Hills, Aden Hills, and West and East Potrillo Mountains on the west (figs. 1A, C). The Rio Grande flows southeast out of the TRG through the El Paso narrows, south of which the Rio Grande forms the boundary between the United States and Mexico. Although the Rio Grande flows to the southeast, the structural Mesilla Basin, containing the regional aquifer system, extends south into Mexico, where the basin is called the Conejos-Médanos Basin. The northern part is bounded on the east by the Sierra de Juárez, various small unnamed basement-rock hills to the south, and the Sierra Palomas and the Sierra Boca Grande Mountains to the west (figs. $1 A, C$ ).

The valley has been developed mostly for agriculture since the early 1900 s, but also contains several urban centers around the cities of Las Cruces, New Mexico, and El Paso, Texas, and other small towns (fig. 1A). The RGTIHM active model region (figs. $1 B, C$ ) covers about $1,759 \mathrm{mi}^{2}$, and in 2014, about 11 percent was used for agriculture, about 84 percent was native vegetation, and about 5 percent was urban-related land use. Groundwater is the primary drinkingwater supply and is used for supplemental irrigation. As a result, the aquifer is susceptible to periodic overdraft (groundwater pumpage in excess of recharge) and related secondary effects, such as streamflow depletion when groundwater and evapotranspiration outflows (including groundwater pumpage) exceed inflows for extended periods.

\section{Hydrologic and Water-Balance Subregions}

The assessment and analysis of the use and movement of water relative to the components of the hydrologic cycle required the division of TRG into water-balance subregions (WBSs) that can be analyzed individually with respect to supply-and-demand components. Most of the zones were developed during previous modeling studies (S.S. Papadopulos and Associates, Inc., 2007; Hanson and others, 2013; Ferguson and Llewellyn, 2015) and have been extended to include more of the Conejos-Médanos Basin, Mexico, where a new well field was installed as a supplemental groundwater supply for Ciudad Juárez, Chihuahua, Mexico (figs. 1A, 2A). To simplify the analysis, the WBSs in the TRG were further grouped into six regional zones, the Rincon Valley and the Selden Canyon in New Mexico, the upper and middle Mesilla Basin in New Mexico, the lower Mesilla Basin in New Mexico and Texas, and the Conejos-Médanos Basin in northern Chihuahua, Mexico (fig. 2A). 
The LRG 2007 and LRG FMP2011 models subdivided the TRG into six agricultural units for water supply-anddemand analysis (S.S. Papadopulos and Associates, Inc., 2007; Hanson and others, 2013). The RMBHM model further subdivided these 6 agricultural units into a total of 57 hydrologic WBSs (Ferguson and Llewellyn, 2015). The 57 WBSs from RMBHM were further subdivided and refined into a total of 71 WBSs for the RGTIHM on the basis of recent land use and additional urban and native vegetation land-use categories (figs. $2 B, C$; table 1 ). This refinement of the WBSs further separated the landscape into areas that have different water sources, uses, or both. The WBSs representing agricultural-land uses rely either on a combination of surface-water and groundwater irrigation supplies or solely on groundwater (table 1). This resulted in 31 WBSs receiving both groundwater and surface water and 28 receiving only groundwater. Additional non-irrigation WBS represent the 3 urban WBSs (64-66), six native WBSs (58-63), the Rio Grande floodplain and riparian corridor (WBS 67), portion of Caballo Reservoir (WBS 70), and nonriparian floodplain portion of Rio Grande (WBS 71). The number and spatial extent of these subregions were held static for the entire historical period of simulation. They comprise a combination of private and public lands from which data can be used to estimate the water-balance components of land use, streamflow, and groundwater flow relative to the use and movement of water at the land surface. To facilitate regional water-availability analysis, these 71 subregions represented the Elephant Butte Irrigation District (EBID), the El Paso County Water Improvement District No. 1 (EPCWID1) in the Mesilla Basin, the native vegetation on the east and west sides of the Rio Grande, the urban regions, and the region in Mexico (figs. 2B, C).

Superimposed on these WBSs are cell-by-cell distributions of land use that include different categories of "virtual land use" (area-weighted average of crop types in an agricultural WBS) that represent composite "virtual crops" as virtual land use for native vegetation, urban, and agricultural uses in the RGV (described in the "Model Development" section; table 2). These units were transformed from those used in the RMBHM and were expanded to include the native vegetation, urban, and golf-course land uses.
$\boldsymbol{A}$ Groundwater basins

EXPLANATION

Hueco (Driscoll and Sherson, 2016)

Palomas (Driscoll and Sherson, 2016)

Jornada del Muerto (after Witcher and others, 2004)

Mesilla and Conejos-Médanos (after Sheng and others, 2013)

Elephant Butte Irrigation District (EBID)

El Paso County Water Improvement District No. 1 (EPCWID1)

7 Maximum extent of Rio Grande Transboundary Integrated Hydrologic Model (RGTIHM)

Horizontal flow barrier (HFB)
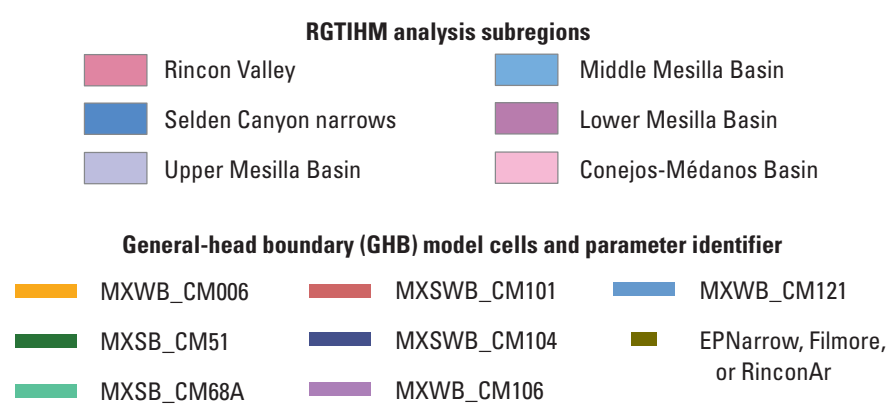

Well with groundwater level used to define time-varying GHB boundary head, Mexico
$\begin{array}{llll}\text { CM-006 } & \text { CM-068A } & \text { CM-104 } & \text { CM-121 } \\ \text { CM-051 } & \bigcirc & \text { CM-101 } & \text { CM-106 }\end{array}$

Figure 2. Rio Grande Transboundary integrated hydrologic model (RGTIHM) hydrologic analysis subregions, related hydrologic flow barriers, and groundwater boundary flows locations used in the RGTIHM in the Transboundary Rio Grande, New Mexico, Texas, and Mexico, for $A$, the Rio Grande Valley; $B$, the Rincon Valley; and $C$, the Mesilla and Conejos-Médanos Basins. 


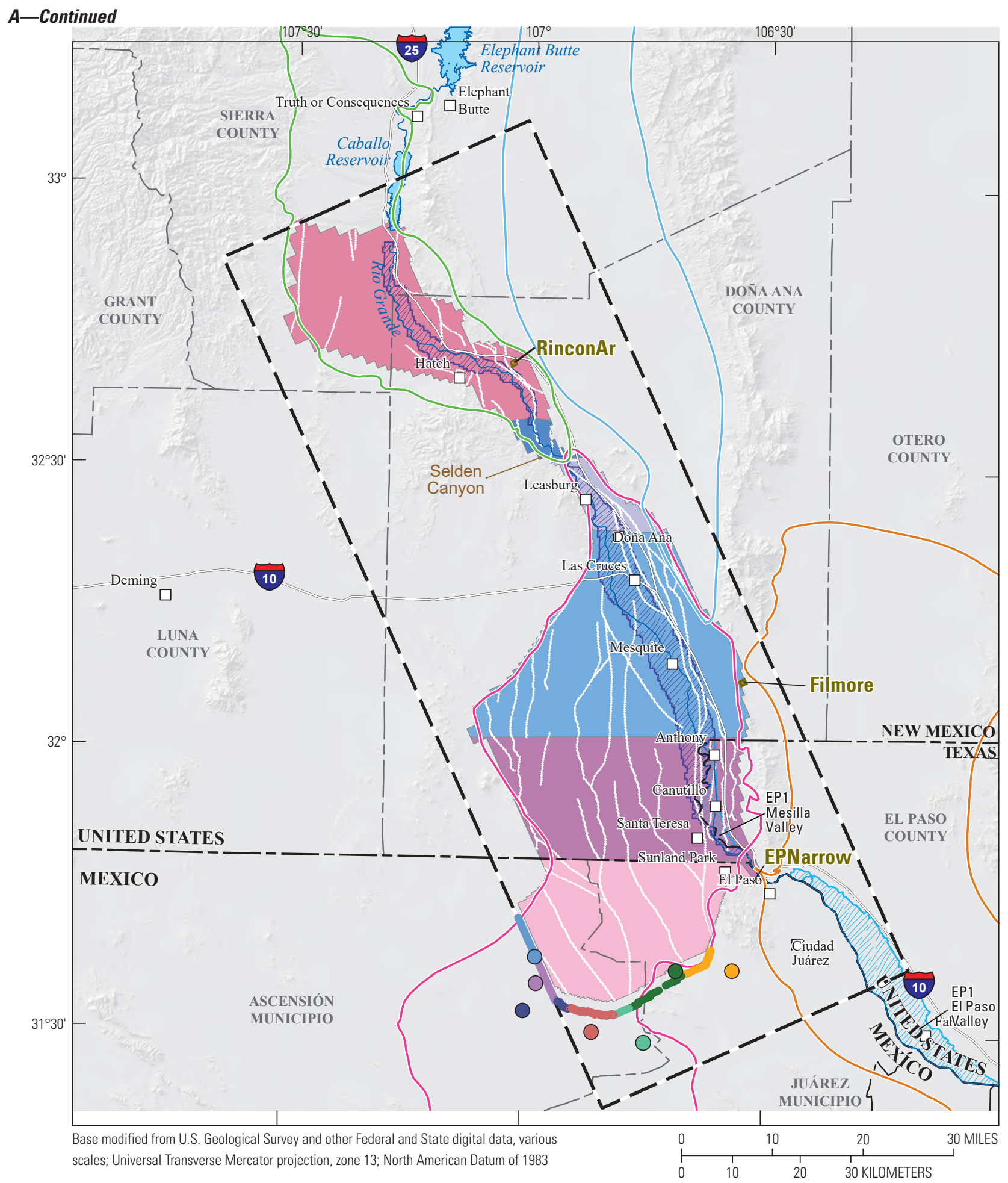

Figure 2. - Continued 


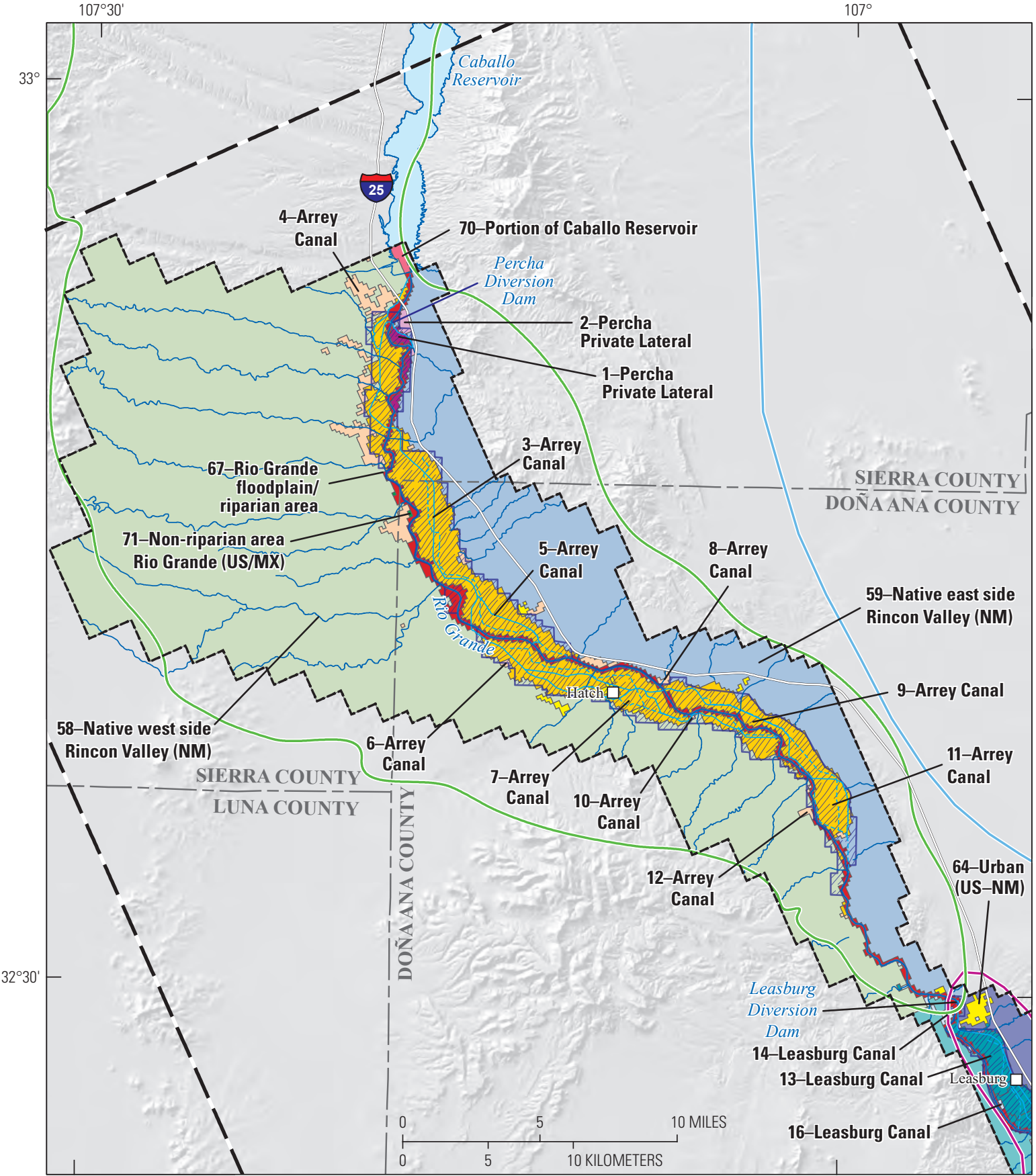

Base modified from U.S. Geological Survey and other Federal and State digital data, various scales; Universal Transverse Mercator projection, zone 13; North American Datum of 1983

EXPLANATION
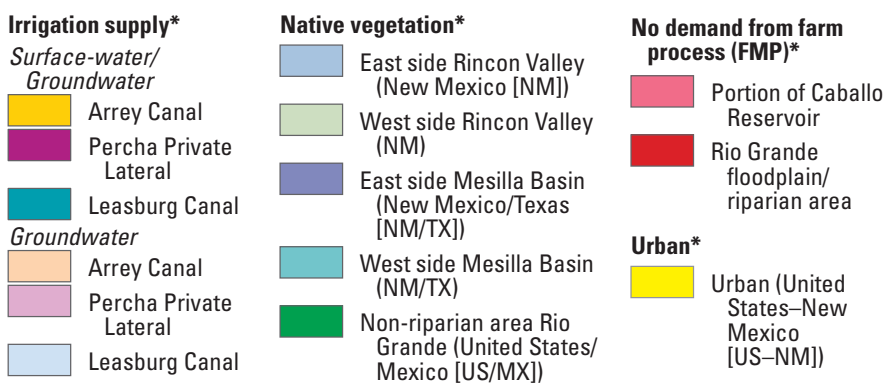

Groundwater basins

Hueco (Driscoll and Sherson, 2016

Palomas (Driscoll and Sherson, 2016)

Jornada del Muerto (after Witcher and others, 2004

Mesilla and Conejos-Médanos Basins (after Sheng and others, 2013)

Elephant Butte Irrigation District (EBID)
Maximum extent of Rio Grande Transboundary Integrated Hydrologic Model (RGTIHM)

RGTIHM active model boundary

Stream/river Canal Drain/wasteway

*Number on map is water-balance subregion name (WBS ID) (see table 1)

Figure 2. - Continued 
c

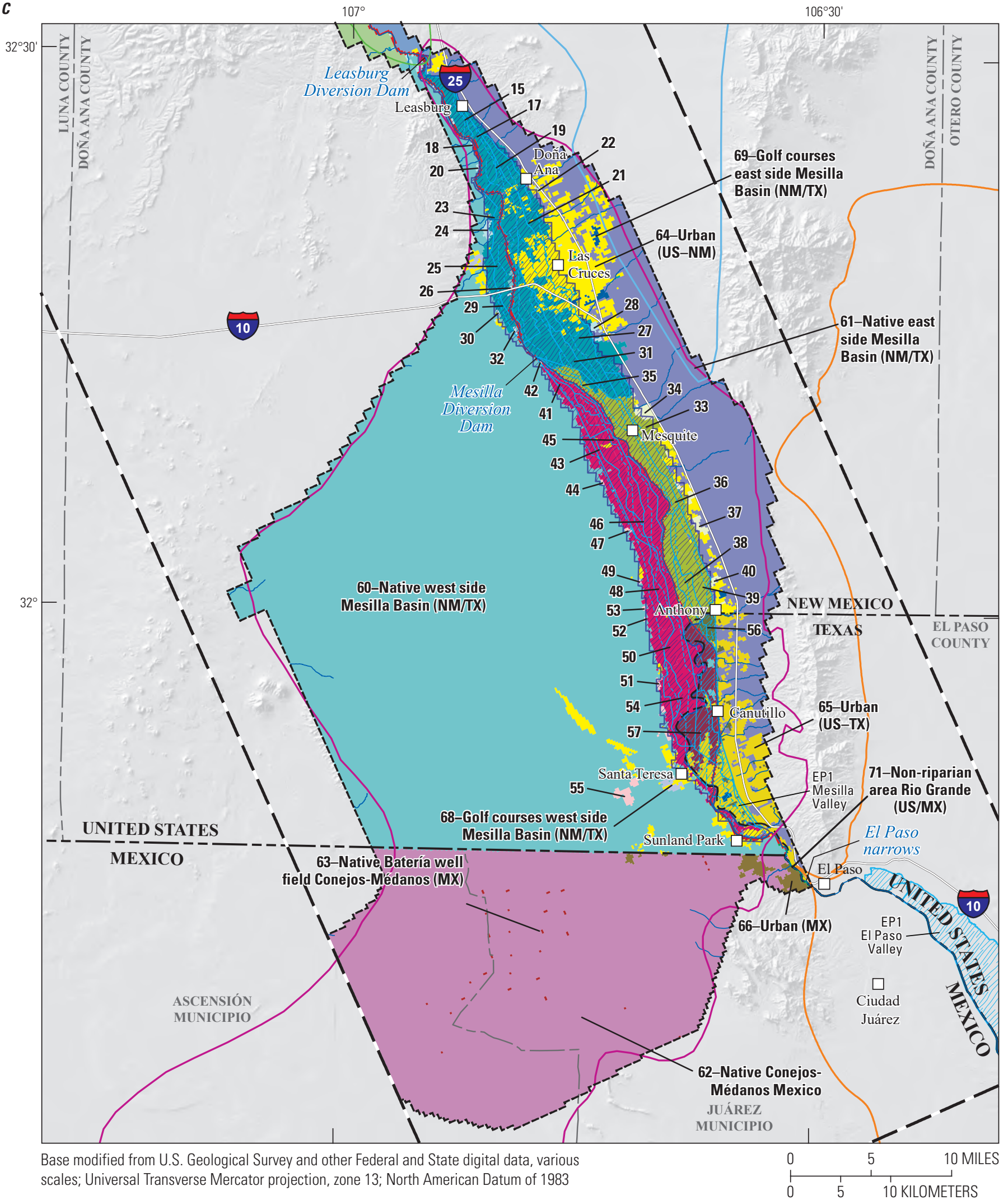

Figure 2. - Continued 


\section{C-Continued}

\section{EXPLANATION}

Source of irrigation supply*

Surface-water/Groundwater

Leasburg Canal

West side Rincon Valley (NM)

Eastside Canal (New Mexico [NM])

East side Mesilla Basin (NM/TX)

Eastside Canal (Texas [TX])

West side Mesilla Basin (NM/TX)

Westside Canal (NM)

Conejos-Médanos (Mexico [MX])

Batería well field Conejos-

Médanos (Mexico)

East side Rincon Valley (NM)

\section{Leasburg Canal}

Eastside Canal (NM)

Westside Canal (NM)

\section{Groundwater Golf courses east side Mesilla
Basin (NM/TX) \\ Golf courses west side Mesilla Basin (NM/TX)}

\section{Native vegetation*}

East side Rincon Valley (NM) West side Rincon Valley (NM)

East side Mesilla Basin (New Mexico/Texas [NM/TX])

Urban*

United States-New Mexico (US-NM)

United States-Texas (US-TX)

Mexico (MX)

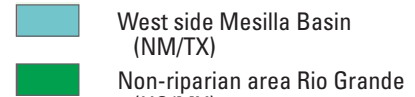
(US/MX)

Riparian ET (RIP) demand subregion with no Farm Process (FMP) demand from WBS 67*

Rio Grande/floodplain/riparian area
Groundwater basins

Hueco (Driscoll and Sherson, 2016)

Palomas (Driscoll and Sherson, 2016)

Jornada del Muerto (after Witcher and others, 2004)

Mesilla and Conejos-Médanos Basins (after Sheng and others, 2013)

Elephant Butte Irrigation District (EBID)

El Paso County Water Improvement District No. 1 (EPCWID1)

Taximum extent of Rio Grande Transboundary Integrated Hydrologic Model (RGTIHM)

RGTIHM active model boundary

Stream/river

Canal

Drain/wasteway

*Number on map is water-balance subregion (WBS ID) (see table 1)

Figure 2. - Continued

Table 1. Summary of water-balance subregions used in the Rio Grande Transboundary Integrated Hydrologic Model, Transboundary Rio Grande, New Mexico, Texas and Mexico.

[Unit Number, Irrigation units as originally defined in LRG_2007 model (S.S. Papadopulos and Associates, Inc., 2007). Abbreviations: GW, groundwater; ID, identification; NM, New Mexico; RIP, riparian; SW, surface water; TX, Texas; WBS, water-balance subregions; - , not applicable]

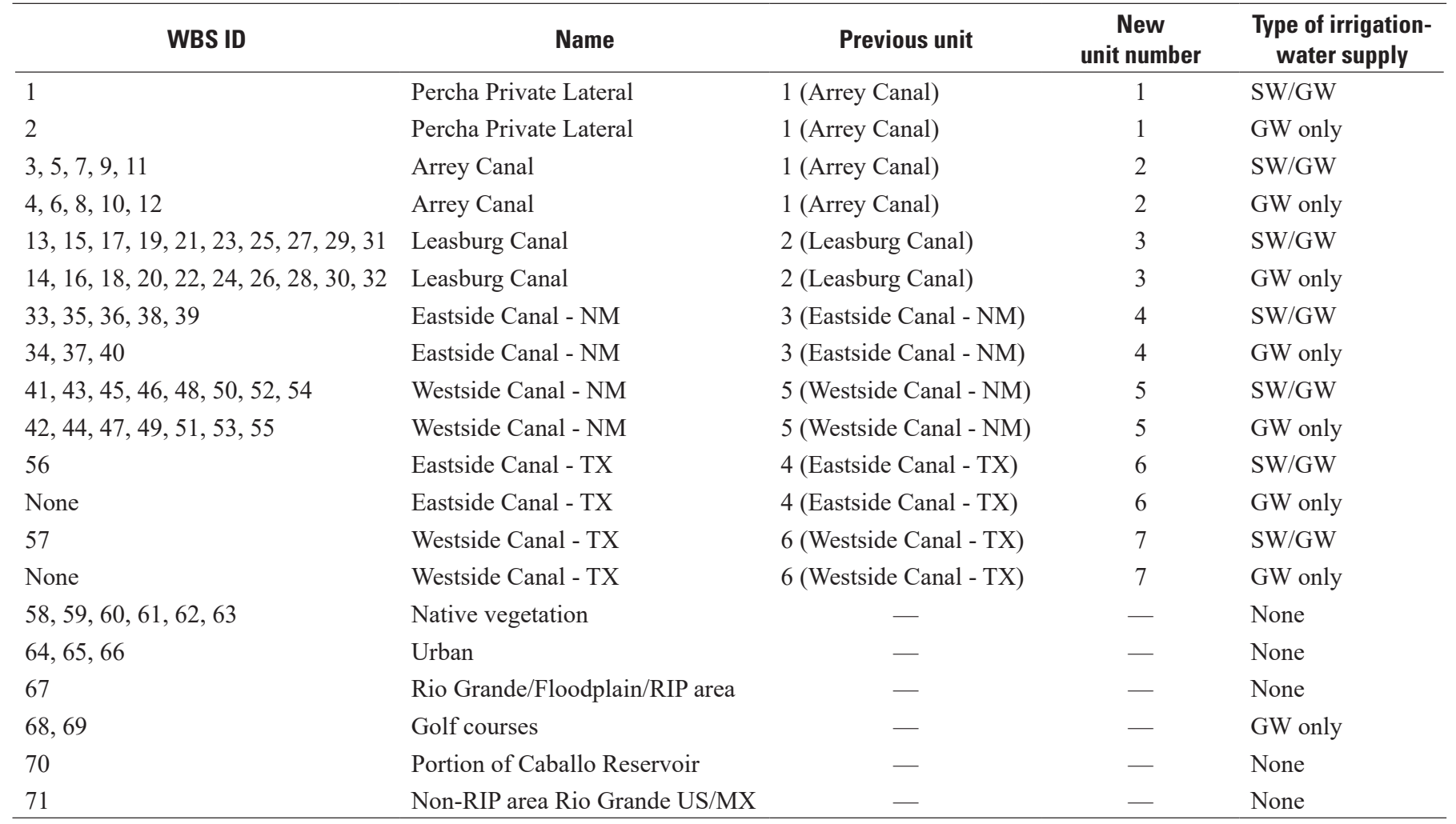


Table 2. Summary of virtual land use in the Rio Grande Transboundary Integrated Hydrologic Model, Transboundary Rio Grande, New Mexico, Texas and Mexico.

[ID, identification; NM, New Mexico; MX, Mexico; RIP, riparian; TX, Texas; WBS, water-balance subregion]

\begin{tabular}{|c|c|c|c|}
\hline $\begin{array}{l}\text { Land-use ID number } \\
\text { (virtual crops, } \\
\text { native vegetation, } \\
\text { urban, and golf } \\
\text { course) }\end{array}$ & Virtual land-use names & Relation to units and farms & $\begin{array}{c}\text { WBS ID } \\
\text { number } \\
\text { (water-balance } \\
\text { subregions) }\end{array}$ \\
\hline 1 & Unit 1 & Percha Private Lateral & 1 and 2 \\
\hline 2 & Unit 2 & Arrey Canal & 3 to 12 \\
\hline 3 & Unit 3 & Leasburg Canal & 13 to 32 \\
\hline 4 & Unit 4 & Eastside Canal (NM) & 33 to 40 \\
\hline 5 & Unit 5 & Westside Canal (NM) & 41 to 55 \\
\hline 6 & Unit 6 & Eastside Canal (TX) & 56 \\
\hline 7 & Unit 7 & Westside Canal (TX) & 57 \\
\hline 8 & $\begin{array}{l}\text { Rio Grande/Floodplain/RIP area/ } \\
\text { Caballo Reservoir }\end{array}$ & $\begin{array}{l}\text { Rio Grande/Floodplain/RIP area/Portion of Caballo } \\
\text { Reservoir }\end{array}$ & 67 and 70 \\
\hline 9 & Native Rio Grande Valley Terrace & $\begin{array}{l}\text { Native vegetation on terraces adjacent to Rio Grande } \\
\text { Valley }\end{array}$ & 58 to 61 \\
\hline 10 & Native west side Rincon Valley, NM & Native vegetation on west side of Rincon Valley, NM & 58 \\
\hline 11 & Native east side Rincon Valley, NM & Native vegetation on east side of Rincon Valley, NM & 59 \\
\hline 12 & Native west side Mesilla Basin, NM/TX & $\begin{array}{l}\text { Native vegetation on west side of Mesilla Basin, NM/ } \\
\text { TX, and Rio Grande/Floodplain not in RIP area in the } \\
\text { Rincon Valley and Mesilla Basin }\end{array}$ & 60 and 71 \\
\hline 13 & Native east side Mesilla Basin, NM/TX & Native vegetation on west side of Mesilla Basin, NM/TX & 61 \\
\hline 14 & Native Conejos-Médanos, MX & Conejos-Médanos, MX & 62 \\
\hline 15 & $\begin{array}{l}\text { Native Batería well field Conejos- } \\
\text { Médanos, MX }\end{array}$ & Conejos-Médanos, MX & 63 \\
\hline 16 & Urban landscape & Urban NM & 64 \\
\hline 17 & Urban landscape & Urban TX & 65 \\
\hline 18 & Urban landscape & Urban MX & 66 \\
\hline 19 & Golf courses west side & Mesilla Basin, NM/TX & 68 \\
\hline 20 & Golf courses east side & Mesilla Basin, NM/TX & 69 \\
\hline
\end{tabular}

\section{Geologic Framework}

Although these subregions have been studied extensively, an updated synthesis of the hydrogeologic framework analysis of the entire region was completed by Sweetkind (2017) as a companion study that synthesized these subregions into a hydrogeologic framework spanning a larger region than previously. The geology of the study region is summarized in this section to explain the relationship of the hydrogeologic framework to the model components used in the RGTIHM.

The geologic structure of the TRG region developed as a result of tectonic events from the Late Paleozoic to Mesozoic and was subsequently dissected by younger, block-faulted uplifts and grabens as part of the subsequent development of the Rio Grande Rift. The Rio Grande Rift in the TRG region is bordered on the east and west by uplifts of various older rocks that are bounded by a series of normal and strike-slip faults and on the south by the Cretaceous bedrock outcrops in the Conejos-Médanos Basin and the Sierra de Juarez, Mexico (fig. 3A). The western part of the TRG is bounded by the uplift of the East and West Potrillo Mountains, which trend parallel to the long axis of the valley (Sweetkind, 2017). The eastern edge of the valley is bounded by pre-Cambrian and Paleozoic rocks. 
$\boldsymbol{A}$

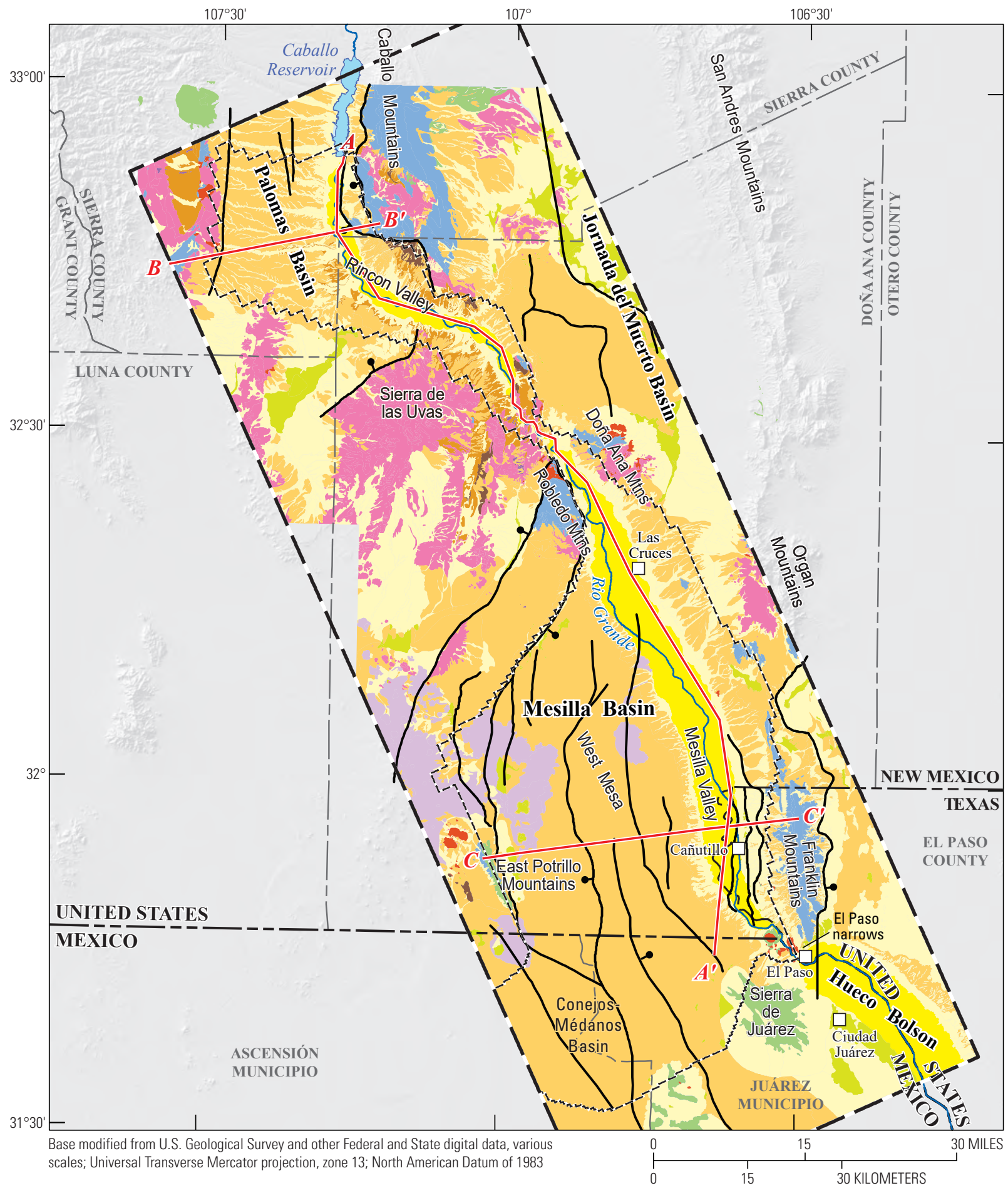

Generalized stratigraphic units (Sweetkind, 2017)

Quaternary fluvial and alluvial channel deposits Quaternary alluvial fan and piedmont deposits Quaternary basin-axis deposits Quaternary volcanic rocks Upper member Santa Fe Group (informal) Middle member Santa Fe Group (informal)

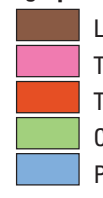

Lower member Santa Fe Group (informal) Tertiary volcanic rocks; pre-Santa Fe Group Tertiary intrusive rocks Cretaceous rocks, undivided

Paleozoic and Precambrian rocks, undivided
$\Gamma$ Maximum extent of Rio Grande Transboundary Integrated Hydrologic Model (RGTIHM)

RGTIHM active model boundary

Faults that cut offset up to the upper member of the Santa Fe Group (USF), ball and bar on downthrown side

C $C^{\prime}$ Line of section

Figure 3. Generalized geology of the Transboundary Rio Grande, New Mexico, Texas, and Mexico and the active and total region of the Rio Grande Transboundary Integrated Hydrologic Model (RGTIHM): $A$, outcrops of geologic units and major faults represented in model grid and $B$, geologic structure. 


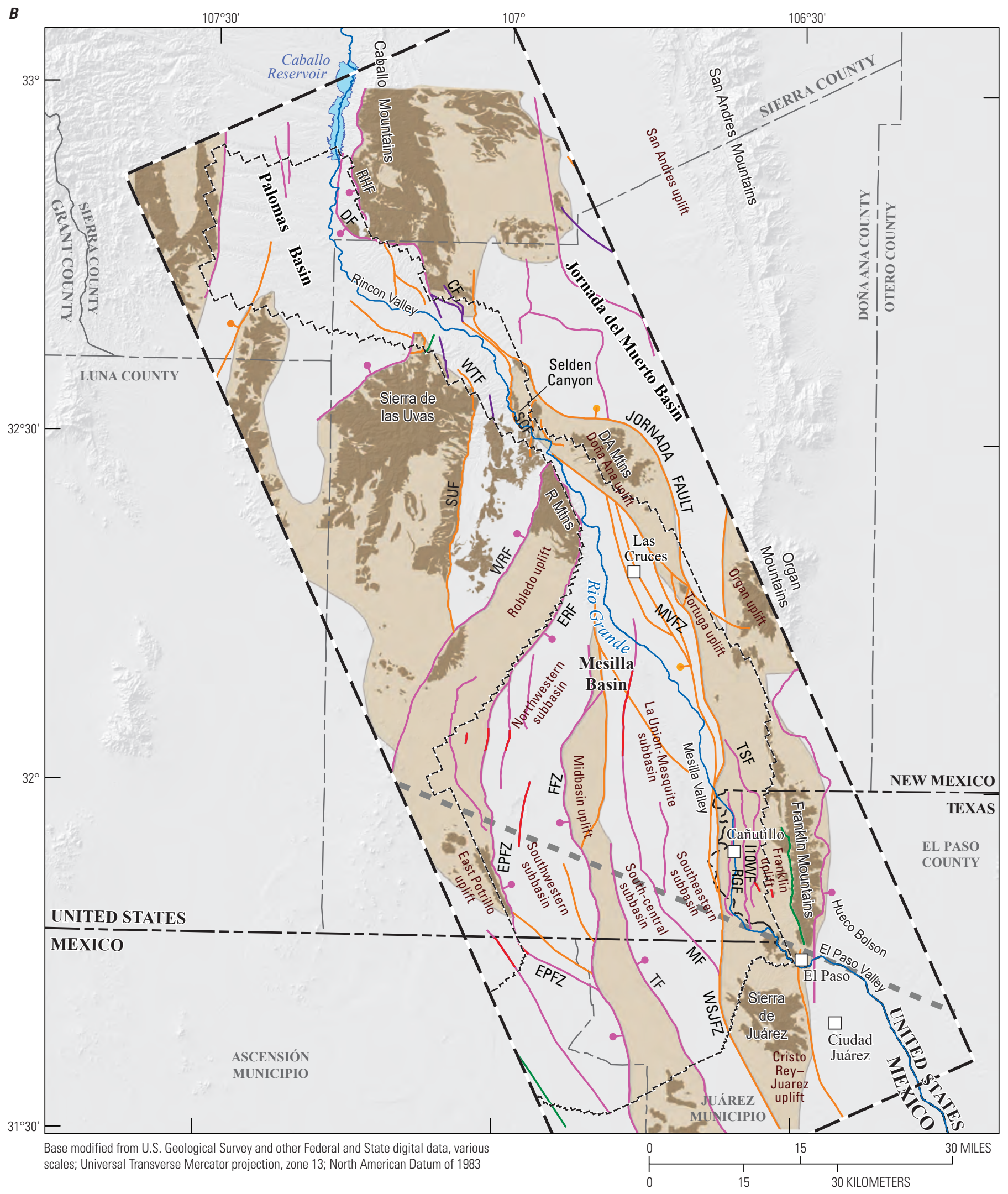

Figure 3. - Continued 


\section{B-Continued}

\section{EXPLANATION}

Outcrop of pre-Santa Fe Group rocks and intrusive rocks

Tectonic and structural units (modified from Hawley and Kennedy, 2004, Sweetkind, 2017)

Taximum extent of Rio Grande Transboundary Integrated Hydrologic Model (RGTIHM)

:- RGTIHM active model boundary

Faults - Symbolized by the youngest unit that is cut; ball and bar on down-thrown side [CF, Central fault; DF, Derry fault; EPFZ, East Potrillo fault zone; ERF, East Robledo fault; FFZ, Fitzgerald fault zone; I10WF, I-10 West fault; MF, Mastadon fault; MVFZ, Mesilla Valley fault zone; RGF, Rio Grande fault; RHF, Red Hills fault; SUF, Sierra de las Uvas fault zone; SCF, Selden Canyon fault zone; TF, Transboundary fault; TSF, Three Sisters fault; WTF, Ward Tank fault; WRF, West Robledo fault; WSJFZ, West Sierra Juarez fault zone]

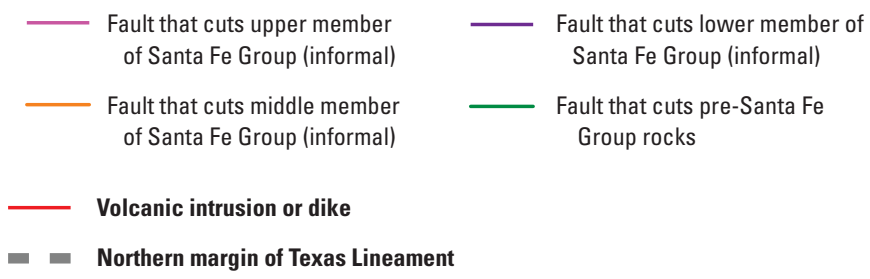

Figure 3. - Continued

The Texas Lineament represents a northern boundary for the regional structural features in the southern part of the RGV (fig. 3B). Regionally, the lineament extends northwestward from the Hueco Bolson (fig. $3 B$ ) of the Trans-Pecos region of Texas (Muehlberger, 1980), spans the southern TRG region, and includes the Mangas Trench in the adjacent Mimbres
Basin (Hanson and others, 1993; fig. 4); the lineament could represent the northern extent of Basin-and-Range deformation in this region. In the TRG region, the Texas Lineament is largely concealed by young deposits, but is interpreted to trend from the El Paso narrows, where the lineament separates the west-tilted Paleozoic rock section in the Franklin Mountains from the highly folded Cretaceous rocks exposed to the south in the Sierra de Juarez, across the TRG to the north end of the East Potrillo mountains (Sweetkind, 2017; fig. 4).

The Santa Fe Group members of Tertiary age form the alluvial aquifers that fill the valleys defined by older rocks that form the uplifted mountains bounding the study area (fig. 4). The pre-Santa Fe Group rocks are deformed and faulted, and the lower, middle, and upper hydrostratigraphic units of the Santa Fe Group also show some offsets related to faulting. The recency of these faults, shown by the youngest formations that were offset, was delineated by Sweetkind (2017; fig. 4). In addition to faulting, Cenozoic volcanic rocks from several eruptive centers also crop out in the Rio Grande Rift. Feeder dikes to some of these volcanic deposits are aligned with some of the groups of faults (Sweetkind, 2017; fig. 4). As a result of this geologic history of tectonic deformation and faulting, followed by erosion and sedimentation, the four major regions of TRG - the Rincon Valley of the Palomas groundwater basin, the Selden Canyon narrows, the Mesilla Basin, and the northern part of the Conejos-Médanos Basinhave been variously dissected into a set of uplifted regions and structural subbasins within the members of the Santa Fe Group and bedrock units (fig. 4) that underlie the more continuous Quaternary alluvium of the RGV. 


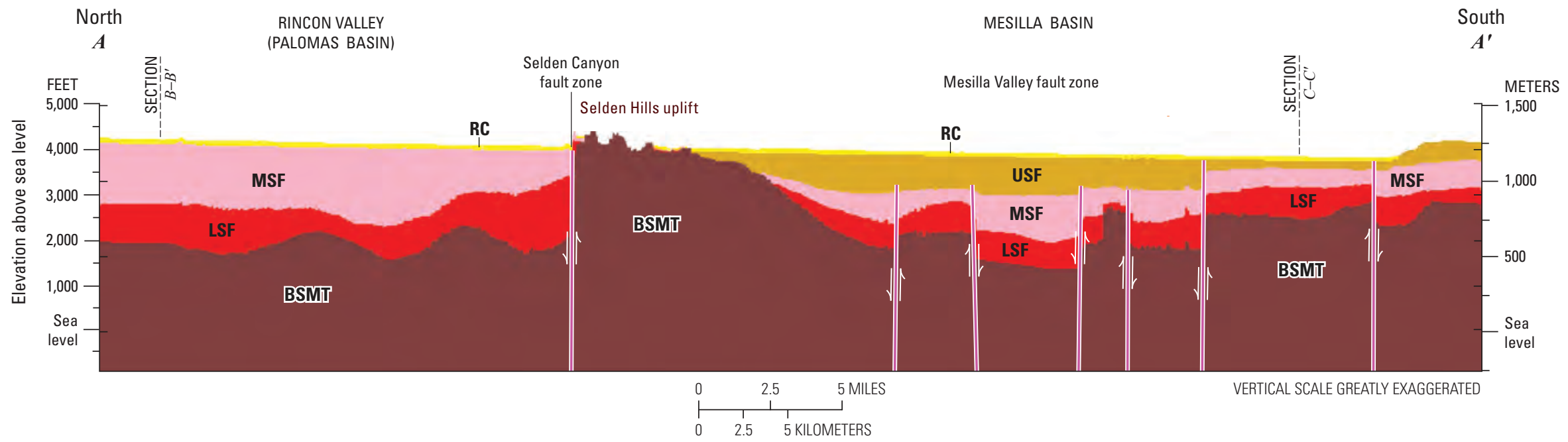

EXPLANATION

Hydrostratigraphic units (HSU)—on profile through three-dimension

Hydrogeologic Framework Model (Sweetkind, 2017)

$\square$ RC-river channel and floodplain Quaternary alluvium
USF-upper member of Santa Fe Group (informal)
MSF-middle member of Santa Fe (informal)
LSF-lower member of Santa Fe (informal)
BSMT-all pre-Santa Fe Group rocks (undivided)

- Fault that cuts upper member of Santa Fe Group (informal),

arrows denote relative sense of motion

Figure 4. Hydrostratigraphic units through the three-dimensional Hydrogeologic Framework Model Rio Grande Transboundary integrated hydrologic model (RGTIHM) of the Transboundary Rio Grande, New Mexico, Texas, and Mexico, for $A$, the axial hydrogeology (A-A'); $B$, the transverse hydrogeology of the Rincon Valley (B-B'); and $C$, the transverse hydrogeology of the Mesilla Basin (C-C'). 
$\begin{array}{cc}\text { West } & \text { East } \\ \boldsymbol{B} & \boldsymbol{B}^{\prime}\end{array}$

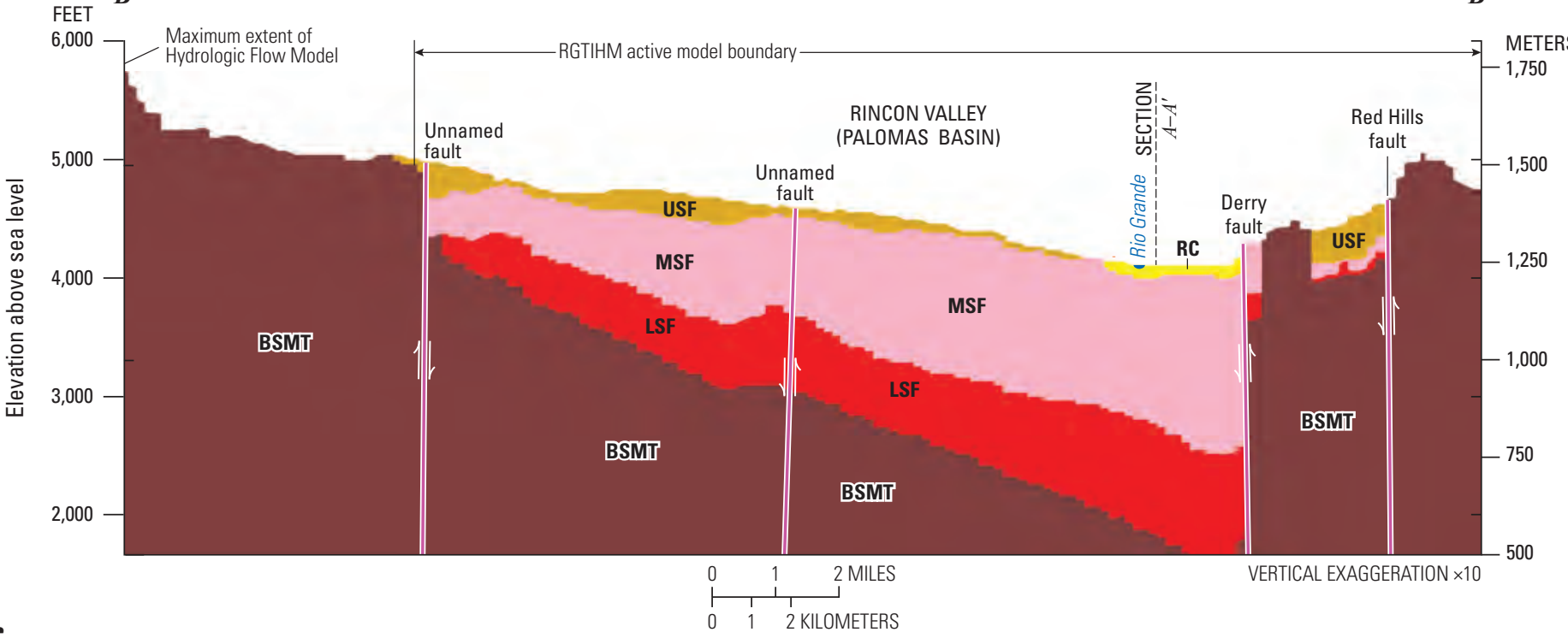

C West

BSMT

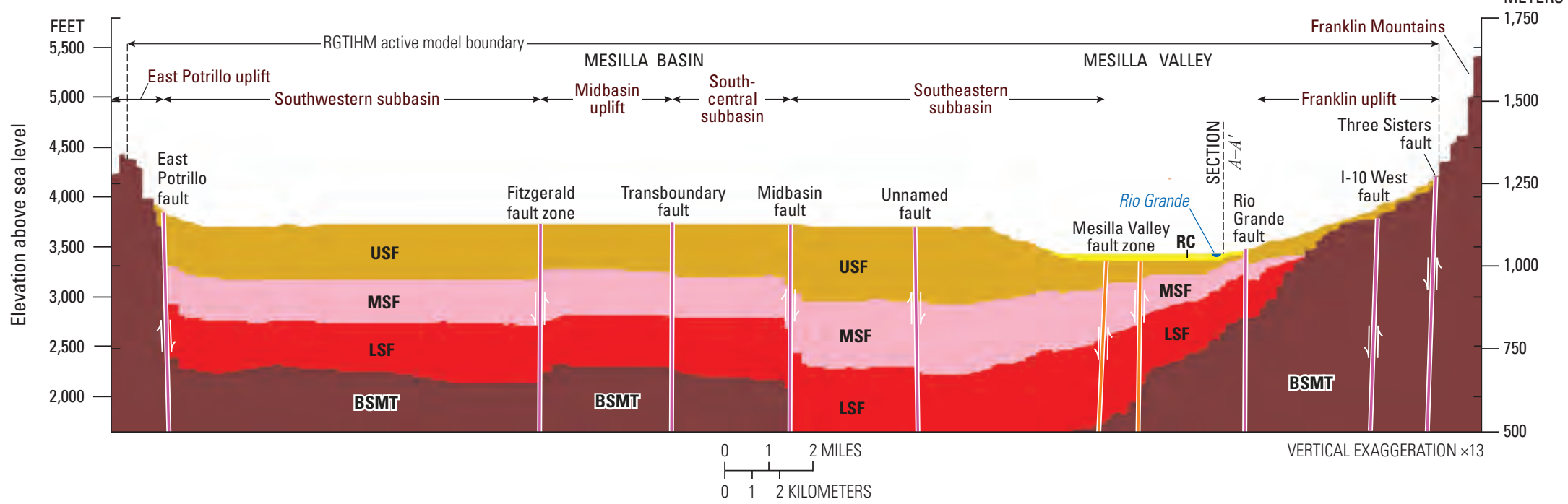

\section{EXPLANATION}

METERS

1,750

250

, 000

$-750$

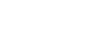

Hydrostratigraphic units (HSU)— on profile through 3D HFM

$\square$ RC-river channel and floodplain Quaternary alluvium

$\square$ USF-upper member of Santa Fe Group (informal)

MSF-middle member of Santa Fe Group (informal)

LSF-lower member of Santa Fe Group (informal)

BSMT-all pre-Santa Fe Group rocks (undivided)

\section{Fault, arrows denote relative sense} of motion

Fault that cuts upper member of Santa Fe Group (informal)

__ Fault that cuts middle member of Santa Fe Group (informal)

\section{East}

$C^{\prime}$ METERS

Figure 4. - Continued 


\section{Hydrogeologic Framework}

The three-dimensional hydrogeologic framework model uses information from a variety of datasets, including lithologic and electrical geophysical logs from oil and gas wells and water wells, cross sections, and geologic maps, to delineate the volumes of the aquifer system bounded by faults and relevant depositional or formational boundaries (Sweetkind, 2017). This model is the digital representation of the interpreted geometry and thickness of subsurface geologic units and geometry of structures in the study area. Specifically, the model was constructed to represent the subsurface geometry of the Quaternary alluvium aquifer in the Rio Grande floodplain corridor, the older alluvial aquifers in the Santa Fe Group, a variety of bedrock aquifers, and Tertiary volcanic units. This model provides the fundamental hydrogeologic framework for the development of the transient numerical model of surface-water and groundwater flow in the study area described in this report.

This hydrogeologic framework model shows the relations between layering, facies, and faults that control the distribution of hydraulic properties of the aquifers and confining layers and the related groundwater flow. The longitudinal section (A-A' in fig. $4 A$ ) is a roughly northwest-southeast section parallel to the major structural grain of the basin and is derived from section CD-O' from Sweetkind (2017; fig. 5). This section exhibits the partial to complete offset of the middle and lower members of the Santa Fe Group in the Mesilla Basin and the potential upwelling that could exist in Selden Canyon across the Selden Canyon fault zone. The transverse cross sections (B-B' and $\mathrm{C}-\mathrm{C}^{\prime}$ in fig. $4 B$ ) that are aligned roughly east-west, perpendicular to the rift structures and related traces of the intrabasin faults and fault zones, were derived from sections RB-RB' for the Rincon Valley and C-C' for the Mesilla Basin from Sweetkind (2017; figs. 5, 6). Sweetkind (2017; fig. 6) shows in more detail the relation of the facies and individual geologic units in the simplified hydrogeologic units. The sections also show the differences in thickness of the Quaternary alluvium aquifer in the axis of the valley relative to the underlying three units of the Santa Fe Group aquifers. These sections, together with the geologic and structural maps (figs. $3 A, B$ ), show the extent and thickness of the aquifers, the stratigraphic offsets along the uplifts and fault zones that control the distribution of facies and related hydraulic properties, and the resultant compartmentalizing of groundwater flow into subbasins. This also could affect the lateral and vertical flow of groundwater; related attributes, such as salinity and upwelling of thermal waters; as well as gains and losses to the surface-water network. 
A

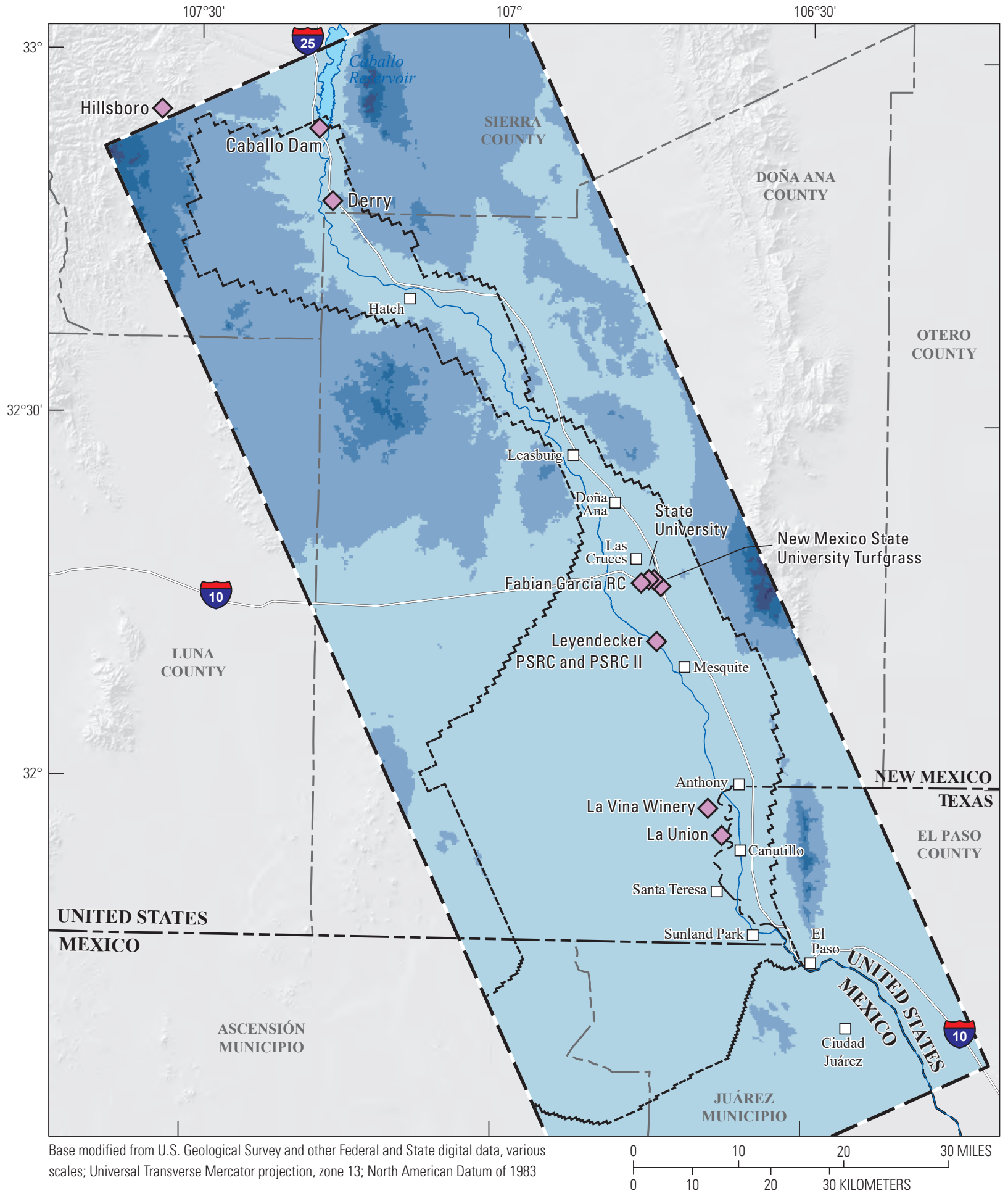

EXPLANATION

Average annual precipitation, in inches, for period 1939-2015 (modified from Cimate Source, 2016)

$\leq 10 \quad>12$ to 14

$>10$ to 12
$>14$ to 16

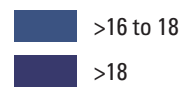

$\Gamma 7$ Maximum extent of Rio Grande Transboundary Integrated Hydrologic Model (RGTIHM)

\section{RGTIHM active model boundary}

Climate station and identifier

Figure 5. Average annual values for Transboundary Rio Grande, New Mexico, Texas, and Mexico, for $A$, precipitation (1939-2015) and $B$, potential evapotranspiration (1939-2015). 
$B$

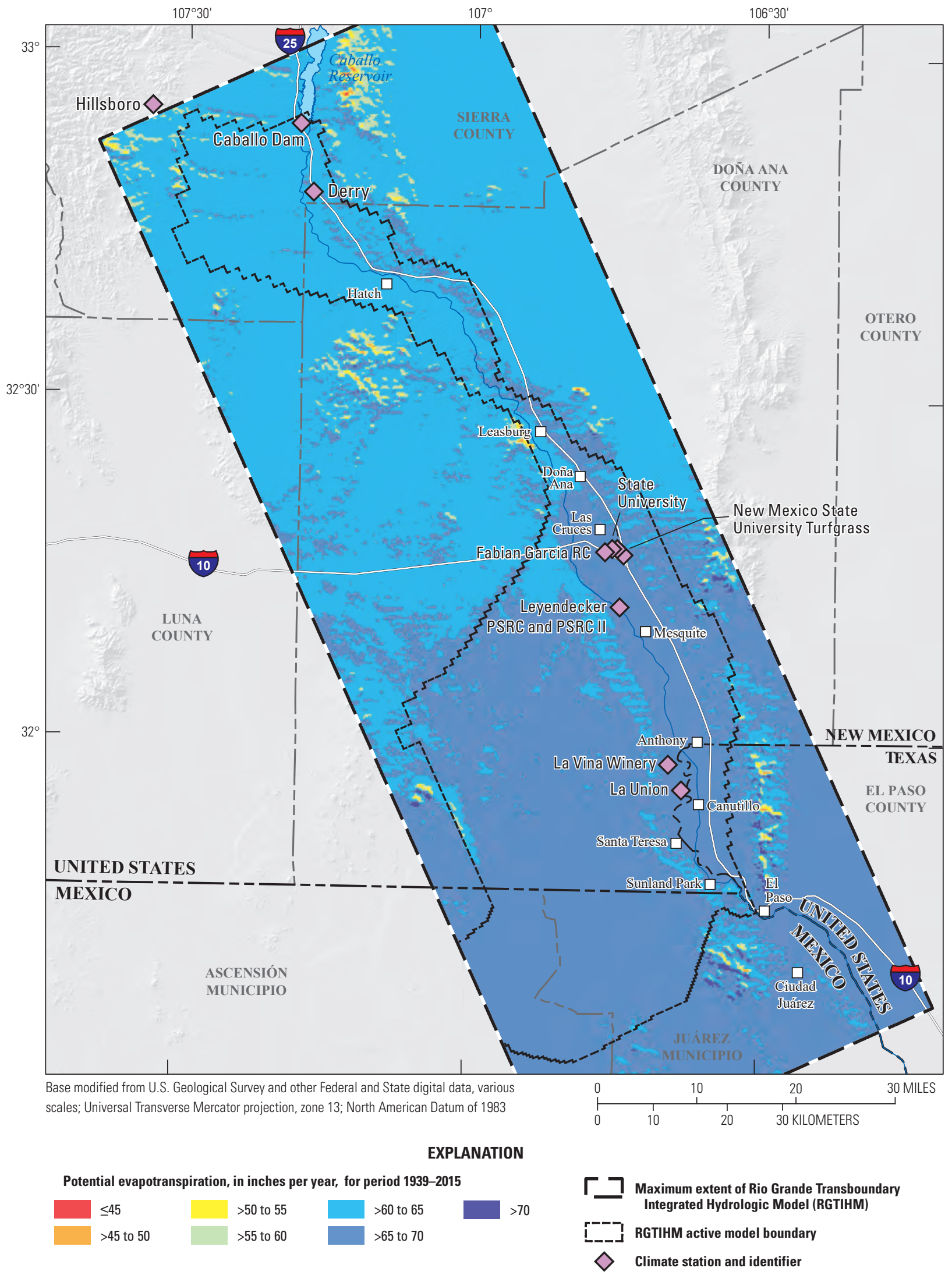

Figure 5. - Continued 


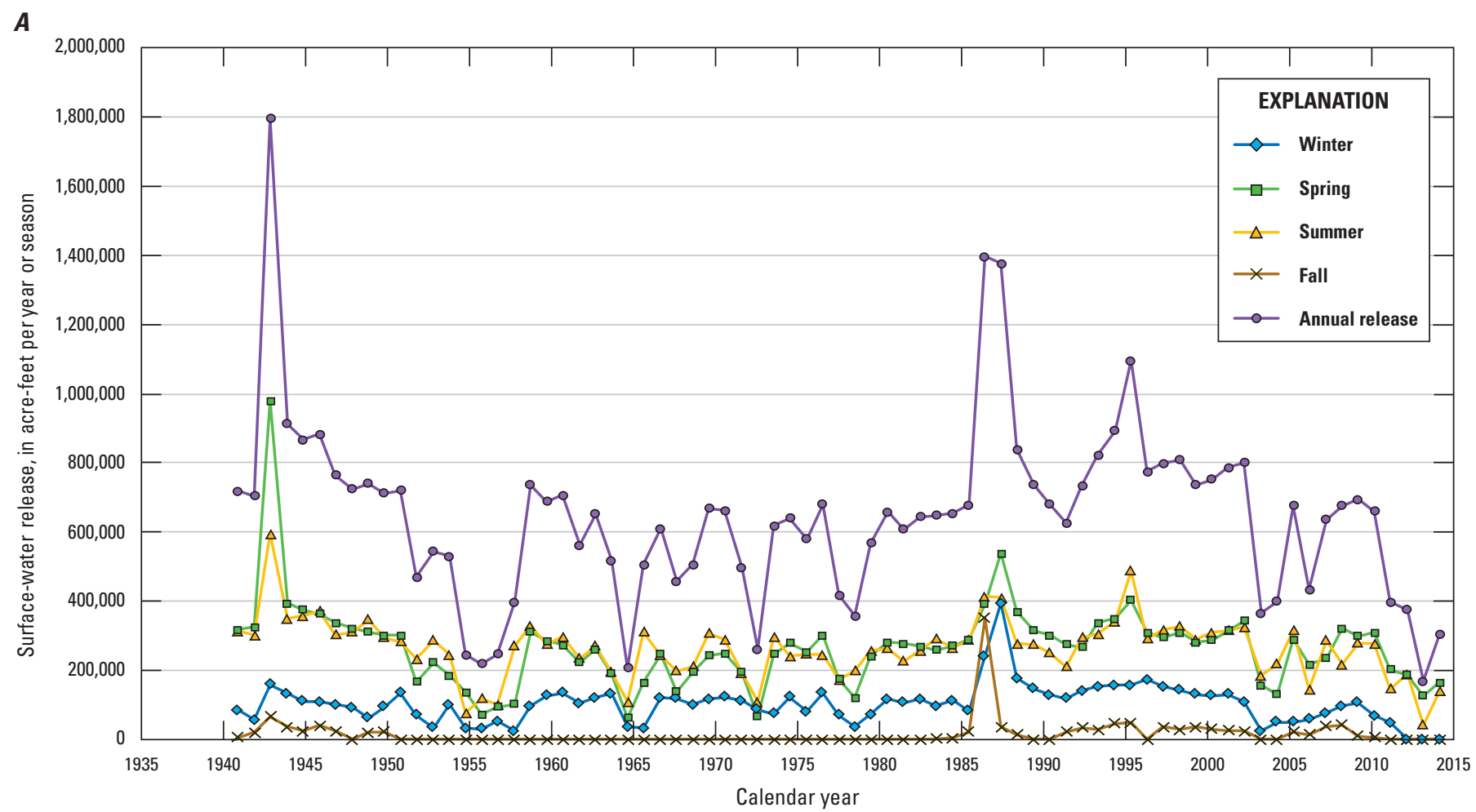

B

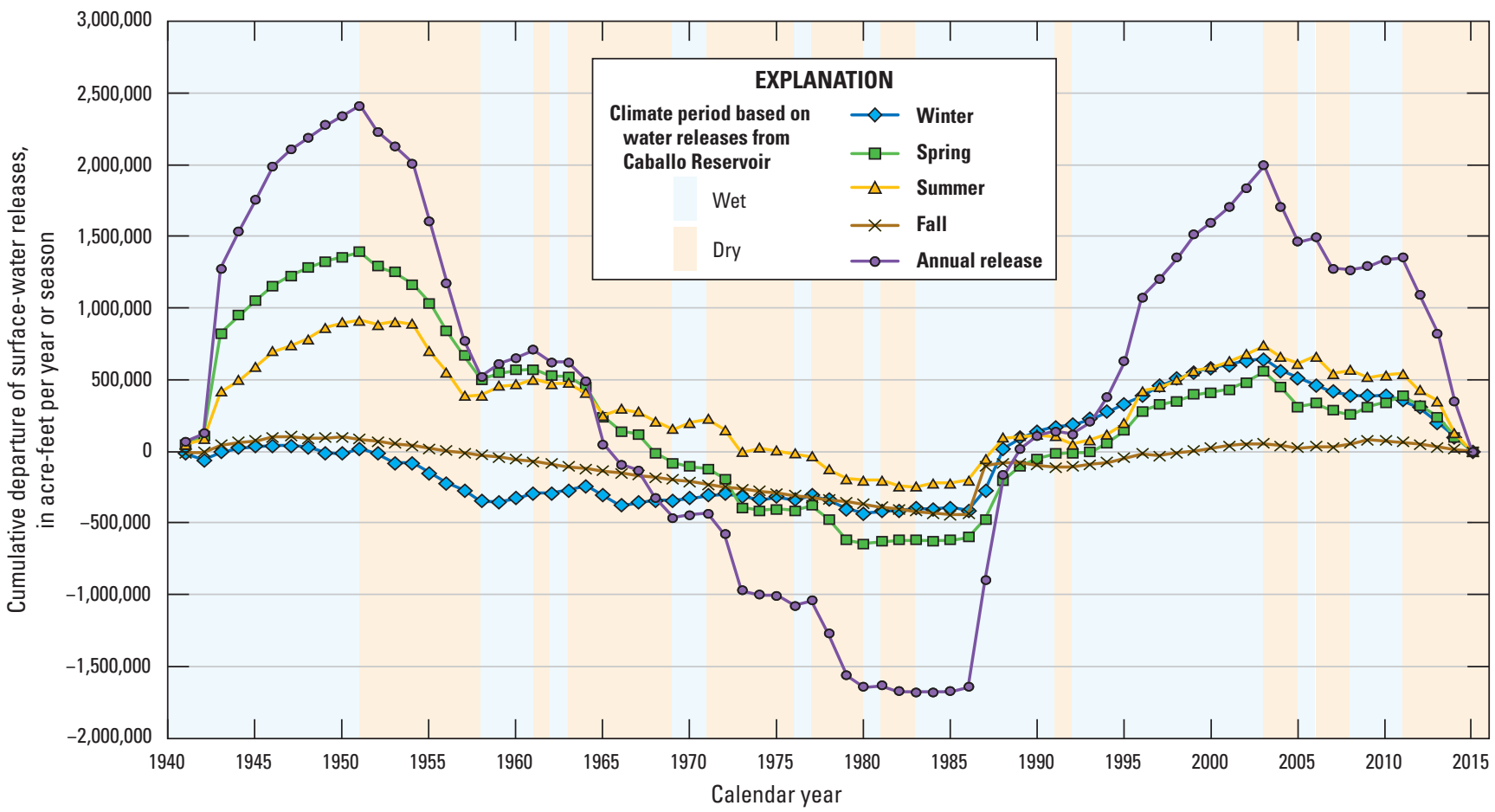

Figure 6. Annual and seasonal variability of surface-water releases at Caballo Reservoir and precipitation in the Transboundary Rio Grande: $A$, surface-water releases from Caballo Reservoir, 1940-2014; $B$, cumulative departure from the average of annual and seasonal reservoir releases, 1940-2014; $C$, annual and seasonal variation as a percentage of average surface-water releases for common climate indices; $D$, annual cumulative departure from the mean annual precipitation for 1939-2015 at Caballo Dam and New Mexico State University with wet and dry climate periods; $E$, seasonal cumulative departure of precipitation from the 1939-2015 seasonal averages at New Mexico State University, New Mexico; and $F$, annual and seasonal variation as a percentage of average precipitation at New Mexico State University, for common climate indices. 
C

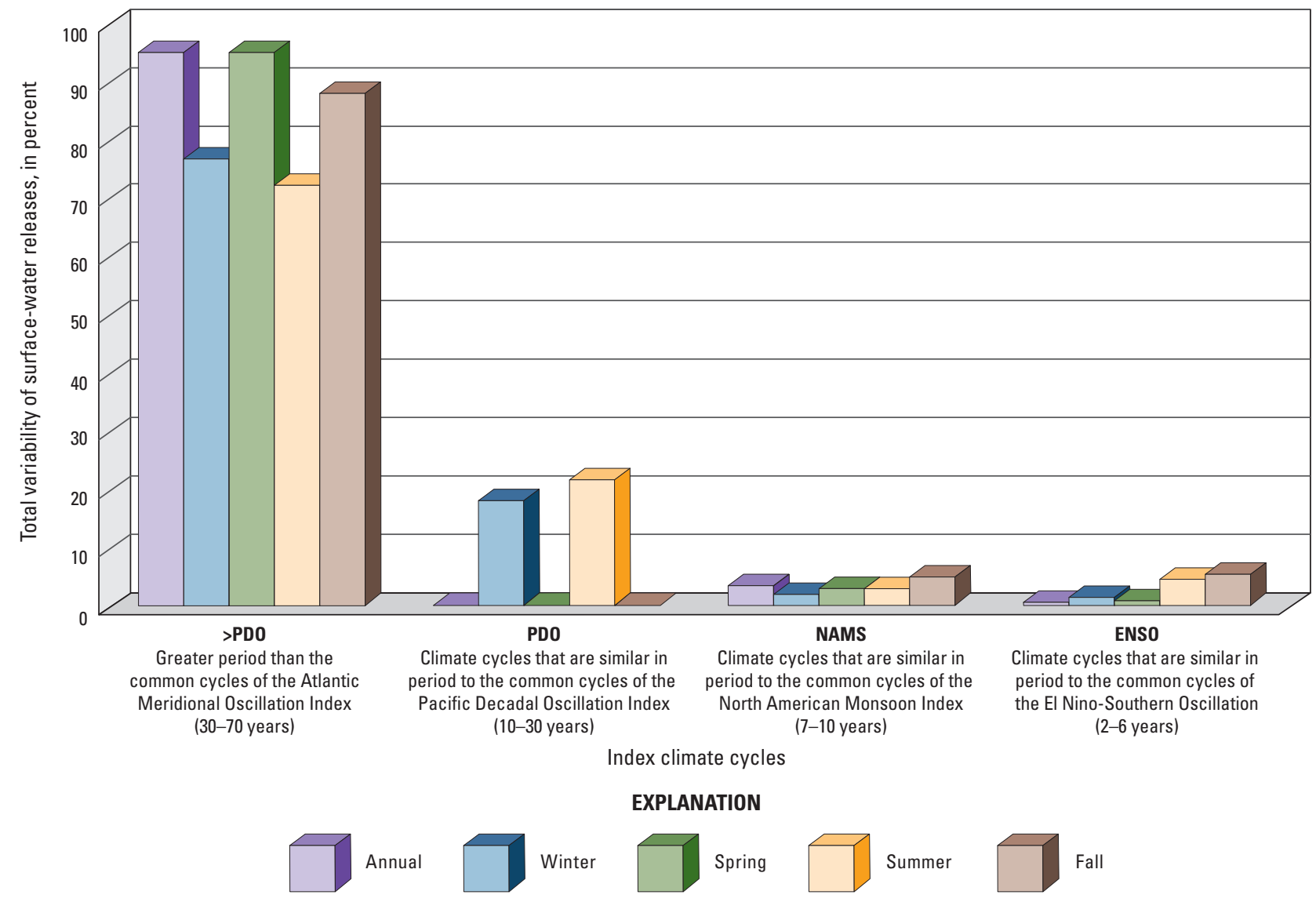

D

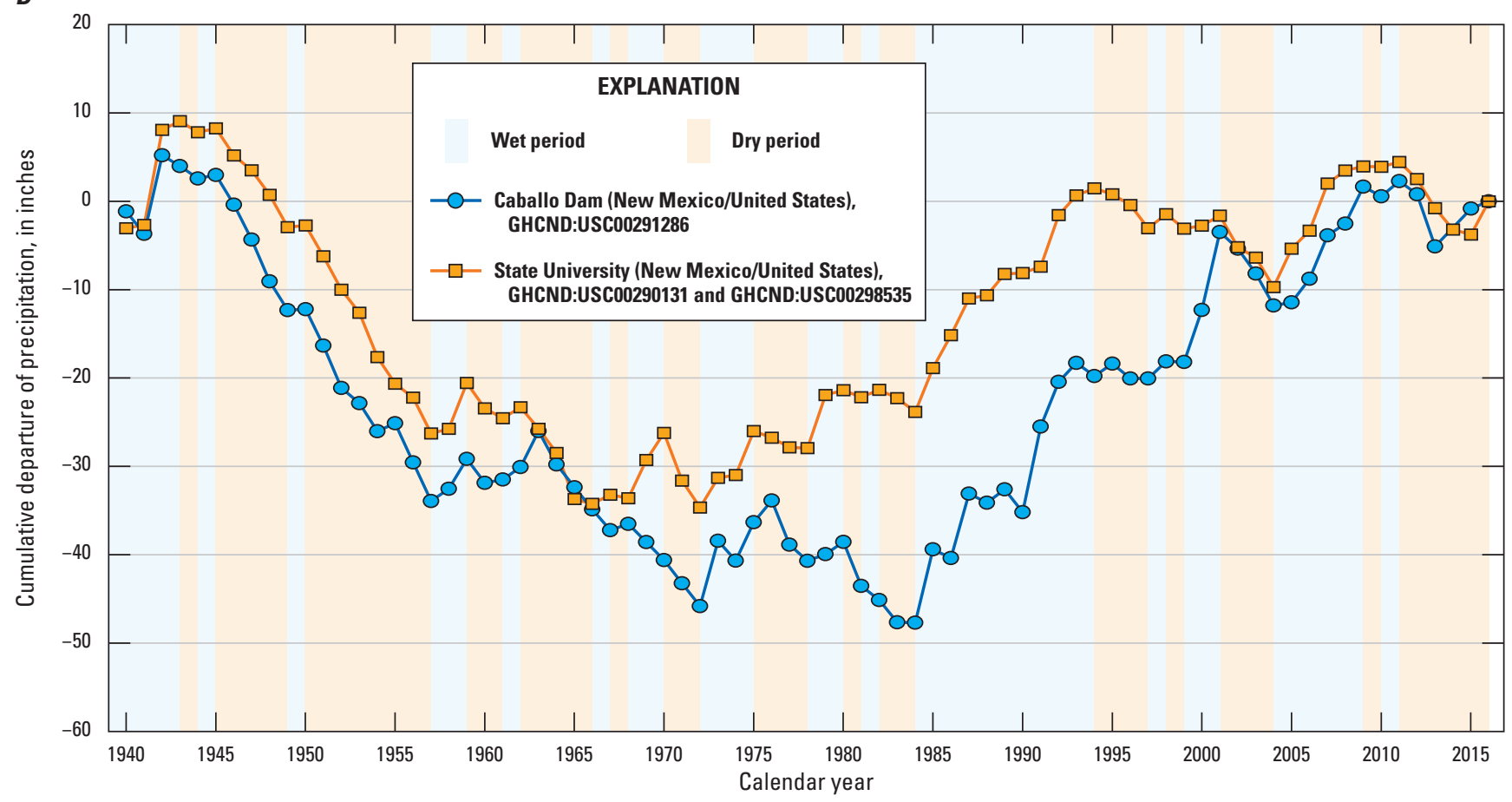

Figure 6. - Continued 


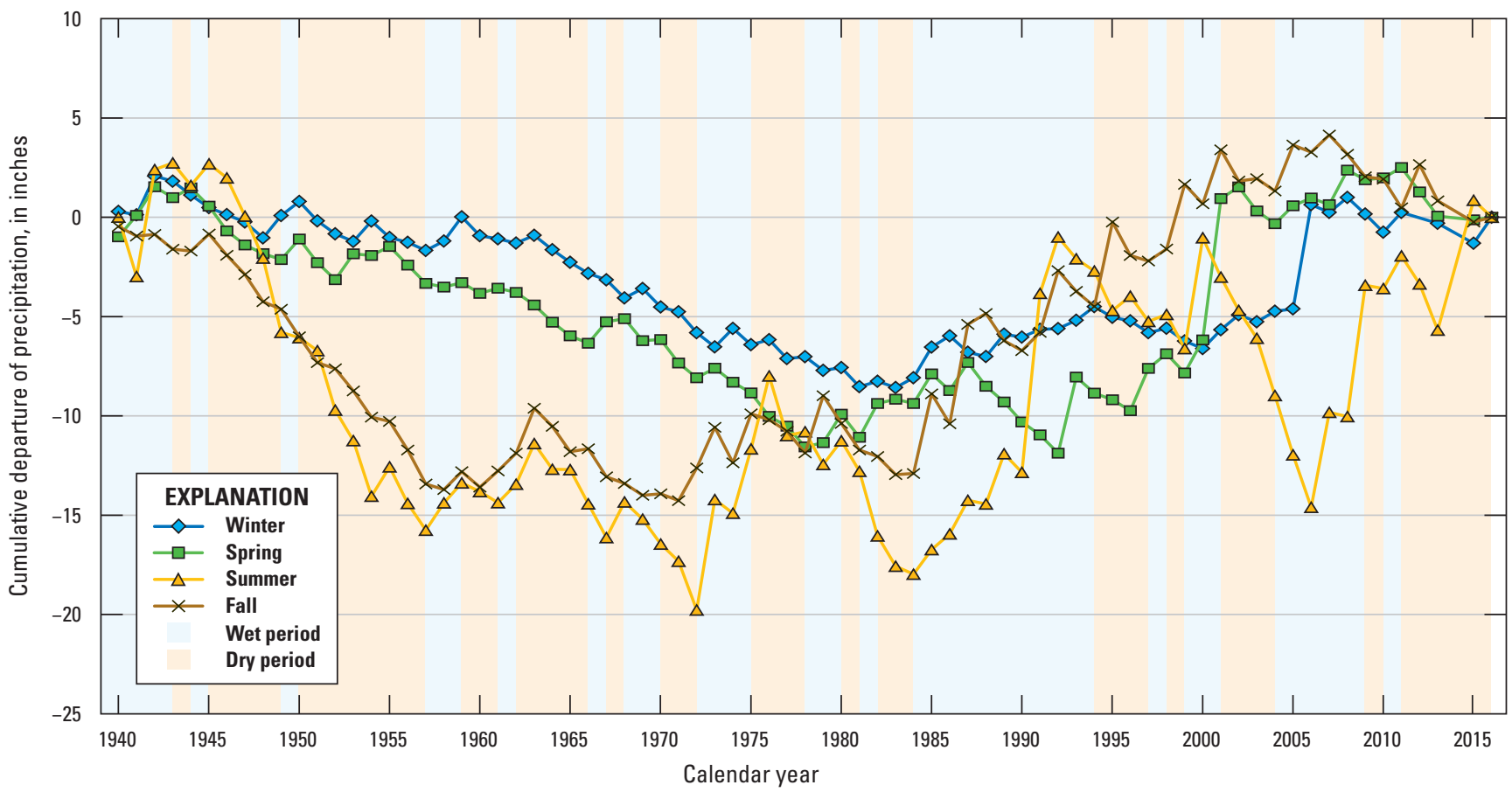

$\boldsymbol{F}$

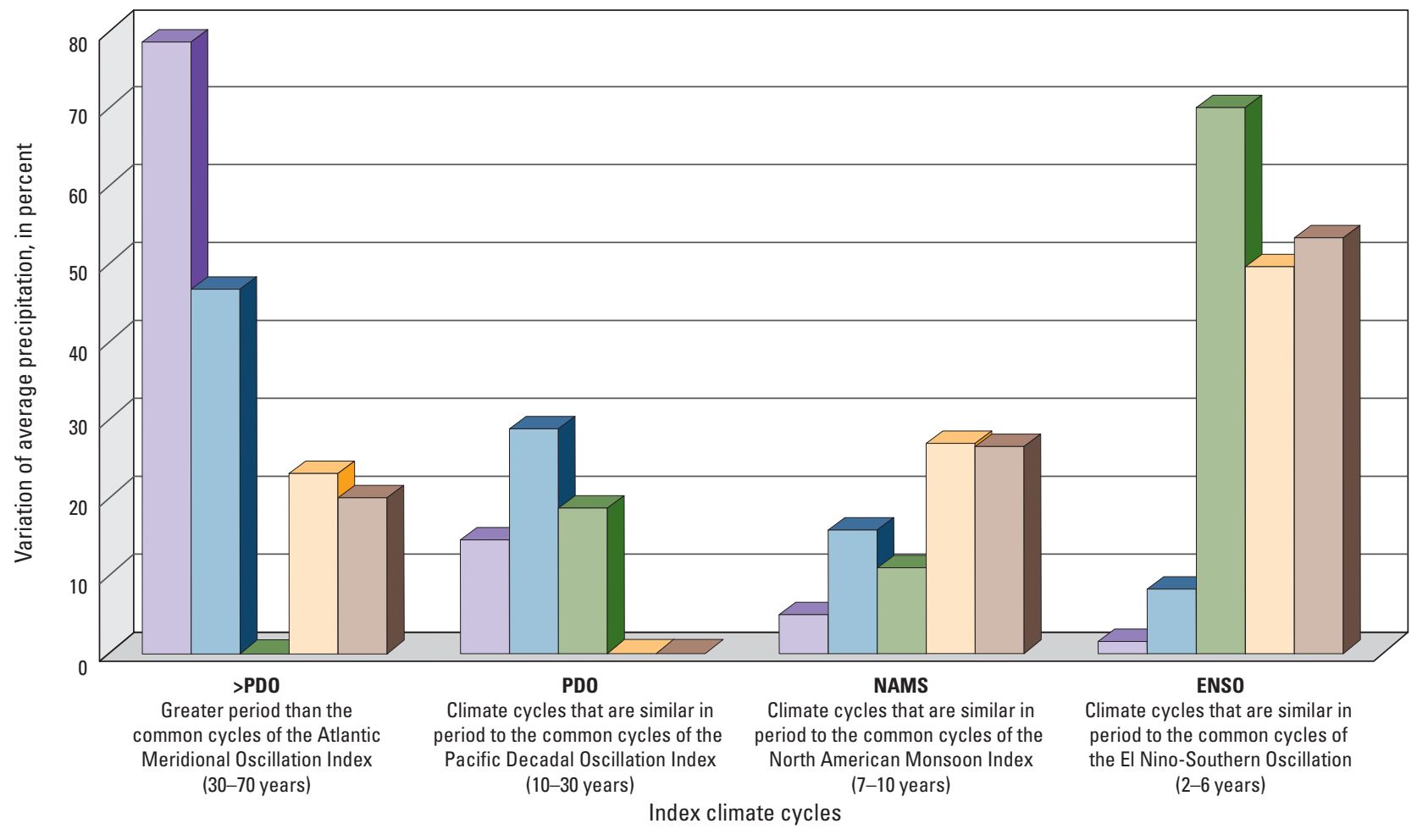

Figure 6. - Continued 


\section{Hydrogeologic Units}

The hydrogeologic framework of the TRG region was developed through a reevaluation and synthesis of geologic information from previous studies, which resulted in a simplified grouping of geologic units into hydrogeologic units (Hawley and others, 2001, 2009; Hawley and Kennedy, 2004; Sweetkind and others, 2017; Sweetkind, 2017). Geologic units in the TRG region include unconsolidated Pleistocene and Holocene alluvial deposits and fluvial deposits of the Rio Grande drainage and the underlying, partly consolidated, upper, middle, and lower members of the Santa Fe Group of Pliocene to Pleistocene ages (Sweetkind, 2017). These deposits are intersected in some subregions by Middle to Late Tertiary volcanics. These alluvial deposits and sedimentary-rock units unconformably overlie pre-Santa Fe Group basement rocks that include a mix of Precambrian rocks; Paleozoic (Pennsylvanian and Permian) limestones, red beds, sandy mudstones, shales, sandstones, and gypsite units; and Cretaceous sandstone, shales, siltstones, and limestones (Sweetkind, 2017; fig. 3A). Previous studies of the Transboundary Rio Grande Valley (Wilson and White, 1984; Hawley and Kennedy, 2004; International Boundary and Water Commission, 2011) delineated aquifers in the younger alluvium and uppermost parts of the Santa Fe Group - units that historically have yielded most of the water pumped in the study area. Since these studies were completed, water levels have declined in some areas to the upper and middle members of the Santa Fe Group. The hydrogeologic framework (figs. $4 A-C$ ) was used to represent nine discrete hydrologic model layers determined by Sweetkind (2017):

1. Quaternary alluvium aquifer - two layers of the younger alluvial deposits representing an alluvial-deposit layer in the present-day Rio Grande floodplain corridor.

2. Upper member of the Santa Fe Group aquifer - two layers representing units of the upper member of the Santa Fe Group.

3. Middle member of the Santa Fe Group aquifer-two layers representing units of the middle member of the Santa Fe Group.

4. Lower member of the Santa Fe Group aquifer - two layers representing units of the lower member of the Santa Fe Group.

5. Basement units - one layer representing a composite of older bedrock units that outcrop or underlie the Santa Fe Group (previously called pre-Santa Fe Basement, Sweetkind, 2017).

Collectively, all of these aquifers are variable in areal extent and range in thickness from a few feet up to thousands of feet. The outcrops and extent of these units are superimposed on the TRGWM and the RGTIHM active model grids (fig. $3 A$ ).

The Quaternary alluvium and members of the Santa Fe Group were each split into two model layers. The Quaternary alluvium was split into two layers to try to further separate the inflows and outflows (seepage) of the stream network and related flows on the landscape in the uppermost layer from the shallow pumpage and underflow in the lowermost layer of the Quaternary alluvium. The fluvial sediments of the Quaternary alluvium and the members of the Santa Fe Group generally represent a fining-upward sequence of sediments, so the subdivisions of the Santa Fe Group members were used to delineate a potentially coarse-grained basal unit from an upper, fine-grained unit. Although the Quaternary alluvium and upper member of the Santa Fe Group represent throughflowing fluvial systems and the middle and lower members of the Santa Fe Group represent a period of closed drainage, they both have a basal, coarse-grained facies and an upper, finegrained facies unit.

In each hydrostratigraphic unit, geologic depositional facies represent differences in texture that control hydraulic properties, such as skeletal specific storage, porosity, and permeability. Textural variability in the basin-filling units is ultimately a function of sedimentary facies, environment of deposition, and depositional history of the basin. Facies zones derived from Hawley and others (2001) form the geologic basis for estimating the hydraulic properties for the numerical hydrologic-flow model. In addition, the distribution of zones for a bedrock layer that represents pre-Santa Fe bedrock units and the later Tertiary volcanic units was delineated by Sweetkind (2017). The analysis of variability of lithology and grain size in the context of depositional facies was synthesized by Sweetkind (2017) from previous studies (Hawley and Lozinsky, 1992; Hawley and others, 2001; Hawley and Kennedy, 2004; Hawley and others, 2009) for the Quaternary alluvium and the members of the Santa Fe Group. The definitions and related codes for these facies are summarized for use in the RGTIHM (table 3) and for the bedrock units (table 4).

The Quaternary alluvium represents the deposits of the modern through-flowing river system and adjacent alluvial fans (Sweetkind, 2017, fig. 9). These deposits are represented by four depositional facies groups: the fluvial basal-channel deposits ( $\mathrm{RC} 10)$, the braided plain ( $\mathrm{RC} 20)$, the overbank and meander belt (RC30), and the combined terrace deposits and reworked distal alluvial-fan deposits (RC51; table 3).

The upper member of the Santa Fe Group also represents a through-flowing depositional system of the ancestral Rio Grande (Sweetkind, 2017, fig. 12). The upper member is represented by nine depositional lithofacies grouped as a basin-floor fluvial plain (USF15); a fluvial plain that is also partly aeolian deposits (USF25); groups of fine-grained deposits that include fluvial overbank, deltaic, and playa lake deposits with some aeolian deposits (USF35); grouped aeolian and basin-floor deposits (USF40); distal-to-medial piedmontslope and alluvial fan deposits (USF50); river valley fluvialterrace deposits and reworked distal alluvial fan deposits (USF51); distal-to-medial piedmont-slope and alluvial-fan deposits (USF55); proximal-to-medial piedmont-slope and alluvial-fan deposits (USF60); and mixtures of fine-grained alluvial-flat, playa, lake, and fluvial-lacustrine deposits mixed with distal-piedmont deposits (USF90; table 3). 
Table 3. Summary of alluvial facies codes used to represent the hydrogeologic properties used in the Rio Grande Transboundary Integrated Hydrologic Model, Transboundary Rio Grande, New Mexico, Texas, and Mexico.

[LSF, lower member of Santa Fe Group; MSF, middle member of Santa Fe Group; RC, recent alluvium (Quaternary alluvium); USF, upper member of Santa Fe Group; \%, percent]

\begin{tabular}{|c|c|c|c|c|c|c|}
\hline $\begin{array}{l}\text { Model zone code } \\
\text { [units] } \\
\text { (model layers) }\end{array}$ & $\begin{array}{c}\text { Lithofacies; } \\
\text { dominant } \\
\text { depositional setting }\end{array}$ & $\begin{array}{l}\text { Lithology, } \\
\text { sediment texture }\end{array}$ & Location & $\begin{array}{c}\text { Ratio of } \\
\text { sand+gravel } \\
\text { to silt+clay }\end{array}$ & $\begin{array}{l}\text { Estimated } \\
\text { hydraulic } \\
\text { conductivity }\end{array}$ & $\begin{array}{l}\text { Equivalent } \\
\text { Hawley }^{3} \text { facies } \\
\text { designation }^{\text {desion }}\end{array}$ \\
\hline $\begin{array}{l}10 \\
{[\mathrm{RC}]} \\
(1-2)\end{array}$ & $\begin{array}{l}\text { River-valley, fluvial—- } \\
\text { Basal channel deposits }\end{array}$ & $\begin{array}{l}\text { Pebble to cobble gravel } \\
\text { and sand }\end{array}$ & Axial parts of RC unit & High & High & A1 \\
\hline $\begin{array}{l}15 \\
{[\mathrm{USF}]} \\
(3-4)\end{array}$ & Basin-floor fluvial plain & $\begin{array}{l}\text { Sand and pebble gravel, } \\
\text { lenses of silty clay }\end{array}$ & Common in USF & High & High & 1 \\
\hline $\begin{array}{l}20 \\
{[\mathrm{RC}]} \\
(1-2)\end{array}$ & $\begin{array}{l}\text { River-valley, fluvial- } \\
\text { Braided plain, channel } \\
\text { deposits }\end{array}$ & Sand and pebbly sand & Adjacent to axis of $\mathrm{RC}$ unit & - & Moderate & $\mathrm{A} 2$ \\
\hline $\begin{array}{l}25 \\
{[\mathrm{USF}-\mathrm{MSF}]} \\
(3-6)\end{array}$ & $\begin{array}{l}\text { Basin-floor fluvial, locally } \\
\text { aeolian }\end{array}$ & $\begin{array}{c}\text { Sand; lenses of pebble } \\
\text { sand, and silty clay }\end{array}$ & Common in USF & High to moderate & $\begin{array}{l}\text { High to } \\
\text { moderate }\end{array}$ & 2 \\
\hline $\begin{array}{l}30 \\
{[\mathrm{RC}]} \\
(1-2)\end{array}$ & $\begin{array}{r}\text { River-valley, fluvial- } \\
\text { Overbank, meander- } \\
\text { belt, oxbow deposits }\end{array}$ & Silty clay, clay, and sand & Adjacent to axis of $\mathrm{RC}$ unit & - & $\begin{array}{l}\text { Moderate to } \\
\text { low }\end{array}$ & A3 \\
\hline $\begin{array}{l}35 \\
{[\mathrm{USF}-\mathrm{LSF}]} \\
(3-8)\end{array}$ & $\begin{array}{l}\text { Basin-floor, fluvial- } \\
\text { Overbank, fluvial- } \\
\text { deltaic, and playa-lake; } \\
\text { aeolian }\end{array}$ & $\begin{array}{l}\text { Interbedded sand and } \\
\text { silty clay; lenses of } \\
\text { pebbly sand }\end{array}$ & $\begin{array}{l}\text { Major component of middle Santa Fe } \\
\text { hydrostratigraphic unit and minor } \\
\text { constituent of unit upper Santa Fe: sand, } \\
\text { pebbly sand, and silty sand beds form a } \\
\text { major part of the medial aquifer system }\end{array}$ & Moderate & Moderate & 3 \\
\hline $\begin{array}{l}40 \\
{[\mathrm{USF}-L S F]} \\
(3-8)\end{array}$ & $\begin{array}{l}\text { Aeolian, basin-floor } \\
\text { alluvial }\end{array}$ & $\begin{array}{l}\text { Sand and sandstone; } \\
\text { lenses of silty sand to } \\
\text { clay }\end{array}$ & $\begin{array}{l}\text { Major component of lower Santa Fe } \\
\text { hydrostratigraphic unit; sand and silty } \\
\text { sand beds form a large part of deep } \\
\text { aquifer system in LSF }\end{array}$ & $\begin{array}{l}\text { Moderate to low; significant } \\
\text { amounts of cementation } \\
\text { of coarse-grained beds } \\
\text { (as much as } 30 \% \text { ) }\end{array}$ & Moderate & 4 \\
\hline $\begin{array}{l}50 \\
{[\mathrm{USF}-\mathrm{MSF}]} \\
(3-6)\end{array}$ & $\begin{array}{l}\text { Distal to medial } \\
\text { piedmont-slope, } \\
\text { alluvial fan }\end{array}$ & $\begin{array}{l}\text { Gravel, sand, silt, and } \\
\text { clay; common loamy } \\
\text { (sand-silt-clay) }\end{array}$ & $\begin{array}{l}\text { Component of both the USF and MSF } \\
\text { hydrostratigraphic units; clean to loamy } \\
\text { sand and gravel lenses form parts of the } \\
\text { medial and upper aquifer system }\end{array}$ & Moderate to high & $\begin{array}{l}\text { Moderate to } \\
\text { low }\end{array}$ & 5 \\
\hline $\begin{array}{l}51 \\
{[\mathrm{RC}-\mathrm{MSF}]} \\
(3-6)\end{array}$ & $\begin{array}{l}\text { River-valley, fluvial- } \\
\text { Terrace deposits and } \\
\text { reworked distal alluvial } \\
\text { fan }\end{array}$ & $\begin{array}{l}\text { Sand, gravel, silt, and } \\
\text { clay }\end{array}$ & Margins of RC deposit & - & $\begin{array}{l}\text { Moderate to } \\
\text { low }\end{array}$ & $\mathrm{b}$ \\
\hline
\end{tabular}


Table 3. Summary of alluvial facies codes used to represent the hydrogeologic properties used in the Rio Grande Transboundary Integrated Hydrologic Model, Transboundary Rio Grande, New Mexico, Texas, and Mexico.-Continued

[LSF, lower member of Santa Fe Group; MSF, middle member of Santa Fe Group; RC, recent alluvium (Quaternary alluvium); USF, upper member of Santa Fe Group; \%, percent]

\begin{tabular}{|c|c|c|c|c|c|c|}
\hline $\begin{array}{l}\text { Model zone code } \\
\text { [units] } \\
\text { (model layers) }\end{array}$ & $\begin{array}{l}\text { Lithofacies; } \\
\text { dominant } \\
\text { depositional setting }\end{array}$ & $\begin{array}{l}\text { Lithology, } \\
\text { sediment texture }\end{array}$ & Location & $\begin{array}{c}\text { Ratio of } \\
\text { sand+gravel } \\
\text { to silt+clay }\end{array}$ & $\begin{array}{l}\text { Estimated } \\
\text { hydraulic } \\
\text { conductivity }{ }^{2}\end{array}$ & $\begin{array}{l}\text { Equivalent } \\
\text { Hawley }{ }^{3} \text { facies } \\
\text { designation }\end{array}$ \\
\hline $\begin{array}{l}55 \\
{[\mathrm{USF}-\mathrm{LSF}]} \\
(3-8)\end{array}$ & $\begin{array}{l}\text { Distal to medial } \\
\text { piedmont-slope, } \\
\text { alluvial fan }\end{array}$ & $\begin{array}{l}\text { Partly indurated gravel, } \\
\text { sand, silt, and clay; } \\
\text { common loamy (sand- } \\
\text { silt-clay) }\end{array}$ & $\begin{array}{l}\text { Major component of LSF } \\
\text { hydrostratigraphic unit; weakly- } \\
\text { cemented sand and gravel beds form } \\
\text { part of the deep aquifer system }\end{array}$ & $\begin{array}{l}\text { Moderate; significant } \\
\text { amounts of cementation } \\
\text { of coarse-grained beds } \\
\text { (as much as } 30 \% \text { ) }\end{array}$ & Low & 7 \\
\hline $\begin{array}{l}60 \\
{[\mathrm{USF}]} \\
(3-4)\end{array}$ & $\begin{array}{l}\text { Proximal to medial } \\
\text { piedmont-slope, } \\
\text { alluvial fan }\end{array}$ & $\begin{array}{l}\text { Coarse gravelly, loamy } \\
\text { sand and sandy loam; } \\
\text { lenses of sand and } \\
\text { cobble to boulder } \\
\text { gravel }\end{array}$ & $\begin{array}{l}\text { Component of both the USF and MSF } \\
\text { hydrostratigraphic units; clean to loamy } \\
\text { sand and gravel lenses form parts of the } \\
\text { medial and upper aquifer system }\end{array}$ & Moderate to low & $\begin{array}{l}\text { Moderate to } \\
\text { low }\end{array}$ & 6 \\
\hline $\begin{array}{l}65 \\
{[\mathrm{MSF}-\mathrm{LSF}]} \\
(5-8)\end{array}$ & $\begin{array}{l}\text { Proximal to medial } \\
\text { piedmont-slope, } \\
\text { alluvial fan }\end{array}$ & $\begin{array}{l}\text { Partly indurated coarse } \\
\text { gravelly, loamy sand } \\
\text { and sandy loam; lenses } \\
\text { of sand and cobble to } \\
\text { boulder gravel }\end{array}$ & $\begin{array}{l}\text { Minor component of all thee SF Group } \\
\text { hydrostratigraphic units; weakly- } \\
\text { cemented sand and gravel beds form } \\
\text { part of the upper, medial, and deep } \\
\text { aquifer systems }\end{array}$ & $\begin{array}{l}\text { Moderate to low; significant } \\
\text { amounts of cementation } \\
\text { of coarse-grained beds } \\
\text { (as much as } 30 \% \text { ) }\end{array}$ & Low & 8 \\
\hline $\begin{array}{l}90 \\
{[\mathrm{USF}-\mathrm{LSF}]} \\
(3-8)\end{array}$ & $\begin{array}{l}\text { Basin-floor-Alluvial flat, } \\
\text { playa, lake, and fluvial- } \\
\text { lacustrine; distal- } \\
\text { piedmont alluvial }\end{array}$ & $\begin{array}{l}\text { Silty clay interbedded } \\
\text { with sand, silty sand, } \\
\text { and clay }\end{array}$ & $\begin{array}{l}\text { Makes up fine-grained part of MSF } \\
\text { hydrostratigraphic unit; sand and silty } \\
\text { beds form very minor to negligible } \\
\text { component of the medial aquifer system }\end{array}$ & Low & Very low & 9 \\
\hline $\begin{array}{l}100 \\
{[\mathrm{MSF}-\mathrm{LSF}]} \\
(5-8)\end{array}$ & $\begin{array}{l}\text { Basin-floor-Alluvial } \\
\text { flat, playa, lake, with } \\
\text { evaporite processes }\end{array}$ & $\begin{array}{l}\text { Silty clay interbedded } \\
\text { with sand, silty } \\
\text { sand, and clay with } \\
\text { gypsiferous and alkali- } \\
\text { impregnated zones }\end{array}$ & $\begin{array}{l}\text { Major component of LSF } \\
\text { hydrostratigraphic unit; weakly- } \\
\text { cemented sand and gravel beds form a } \\
\text { very minor to negligible component of } \\
\text { the deep aquifer system }\end{array}$ & Low & Very low & 10 \\
\hline
\end{tabular}

${ }^{1}$ High is greater than 2 ; moderate is between 0.5 and 2 ; low is less than 0.5 .

${ }^{2} \mathrm{High}$ ranges from greater than 30 to 100 feet per day (ft/day); moderate ranges from greater than 1 to $30 \mathrm{ft} /$ day; low is less than $1 \mathrm{ft} / \mathrm{day}$; very low is less than $0.1 \mathrm{ft} / \mathrm{day}$.

${ }^{3}$ Hawley and Kennedy (2004), Hawley and others (2001, 2009), and Hawley and Lozinsky (1992). 
Table 4. Summary of basement-rock zone codes for categories of pre-Santa Fe Group rocks (basement and volcanic units) used to represent the hydrogeologic properties used in the Rio Grande Transboundary Integrated Hydrologic Model, Transboundary Rio Grande, New Mexico, Texas, and Mexico.

[Sweetkind, 2017]

\begin{tabular}{|c|c|}
\hline $\begin{array}{c}\text { Zone code } \\
\text { (RGTIHM } \\
\text { parameter } \\
\text { code) }\end{array}$ & $\begin{array}{l}\text { Rock unit } \\
\text { (name and description) }\end{array}$ \\
\hline \multicolumn{2}{|r|}{ Bedrock units } \\
\hline $\begin{array}{l}10 \\
(\mathrm{BSMT} 11)\end{array}$ & $\mathrm{XY}$-PreCambrian rocks, undifferentiated \\
\hline $\begin{array}{l}30 \\
(\mathrm{BSMT} 31)\end{array}$ & $\begin{array}{l}\text { Pzu-Pennsylvanian and Permian rocks, undifferentiated-primarily limestone and "red beds", sandy mudstone, with shale, } \\
\text { sandstone, and gypsite }\end{array}$ \\
\hline $\begin{array}{l}40 \\
(\mathrm{BSMT} 41) \\
\end{array}$ & $\begin{array}{l}\mathrm{K} \text { - Cretaceous rocks, undivided; soft sandstone, shale, and siltstone; limestone-pebble conglomerate, sandy limestone, } \\
\text { calcareous sandstone }\end{array}$ \\
\hline $\begin{array}{l}55 \\
(\mathrm{BSMT} 56) \\
\end{array}$ & Tlvs-Lower Tertiary: volcaniclastic sedimentary rocks and some andesite flows and breccias \\
\hline \multicolumn{2}{|r|}{ Intrusive rocks } \\
\hline $\begin{array}{l}60 \\
(\text { BSMT61) }\end{array}$ & $\begin{array}{l}\text { Tmi-Middle Tertiary intermediate to silicic plutonic rocks (Oligocene), monzodiorite to cyenite stocks in the Organ and } \\
\text { Doña Ana Mountains }\end{array}$ \\
\hline $\begin{array}{l}65 \\
(\text { BSMT61) }\end{array}$ & $\begin{array}{l}\text { Tli-Lower Tertiary: intermediate-composition volcanic rocks, latite, dacite, and andesite intrusions, flows, and laharic } \\
\text { breccia; aphyric to moderately porphyritic; generally fine grained }\end{array}$ \\
\hline \multicolumn{2}{|r|}{ Volcanic rocks } \\
\hline $\begin{array}{l}70 \\
(\mathrm{BSMT} 71)\end{array}$ & $\begin{array}{l}\text { Tmrv-Middle Tertiary: silicic to intermediate composition lavas, mainly rhyolite, latite, and dacite domes and flows; with } \\
\text { some dacite breccias, silicic ash-flow tuffs, and andesite flows }\end{array}$ \\
\hline
\end{tabular}

The middle and lower members of the Santa Fe Group were deposited during periods of closed drainage (Sweetkind, 2017, figs. 16, 20). The middle Santa Fe is represented by nine depositional groups, and the lower Santa Fe by six depositional groups. These groups include basin-floor and aeolian deposits (MSF25); fine-grained deposits grouped similarly to those of the USF (MSF35/LSF35); aeolian and basin-floor alluvium (MSF40/LSF40); distal-to-medial piedmont-slope and alluvial-fan deposits (MSF50); grouped river valley fluvial, terrace, and reworked distal alluvialfan deposits (MSF51); distal-to-medial piedmont-slope and alluvial-fan deposits (MSF55/LSF55); proximal-to-medial piedmont-slope and alluvial-fan deposits (MSF65/LSF65); mixtures of fine-grained alluvial-flat, playa, lake, and fluviallacustrine deposits mixed with distal piedmont deposits (MSF90/LSF90); and basin-floor alluvial-flat, playa and lake with evaporate-process deposits (MSF100/LSF100; table 3). 
The basement units in the TRG were grouped into seven groups that represent the bedrock units, Tertiary sediments, intrusive rocks, and volcanics (table 4; Sweetkind, 2017, fig. 23). The bedrock units were further divided into undifferentiated Precambrian rocks (BSMT11); lower and middle Paleozoic rocks that are primarily carbonate (BSMT21); Pennsylvanian and Permian undifferentiated units that are primarily limestones, "red beds," and sandy mudstone with shale, sandstone, and gypsite (BSMT31); and undifferentiated Cretaceous rocks that are primarily soft sandstone, shale, and siltstone or limestone-pebble conglomerate, sandy limestone, and calcareous sandstones (BSMT41; table 4). All four of these groups were represented separately in the RGTIHM. The Tertiary sediments were combined into lower Tertiary (lower Eocene-Paleocene) sedimentary rocks that are mostly sandstones, mudstones, and conglomerates with minor or no volcaniclastic constituents, including the Love Ranch Formation (zone code 50), and a lower Tertiary unit that is mostly volcaniclastic sedimentary rocks with some andesite flows and breccias (zone code 55; table 4). To simplify representation in the RGTIHM, these groups were combined into one group in the RGTIHM (RGTIHM parameter BSMT56). The intrusive rocks were combined into a middle Tertiary group of intermediate to silicic plutonic rocks (of Oligocene age), specifically, monzodiorite to syenite stocks in the Organ and Doña Ana Mountains (zone code 60); aphyric to moderately porphyritic, generally fine-grained lower Tertiary intermediate-composition volcanic rocks, including latite, dacite, and andesite intrusions, flows, and laharic breccia (zone code 65; table 4). These intrusive rocks were combined into one group in the RGTIHM (RGTIHM parameter BSMT61). The volcanic rocks were combined into three groups with middle Tertiary silicic to intermediate composition lavas, mainly rhyolite, latite, and dacite domes and flows, and some dacite breccias, silicic ash-flow tuffs, and andesite flows (zone code 70); a middle Tertiary group of silicic pyroclastic and volcaniclastic rocks that are mainly rhyolite and latite ash-flow tuffs and tuffaceous sandstones that have some basaltic-andesite flows (zone code 73); and a middle to late Tertiary basaltic-andesite and other intermediate composition flows (zone code 76; table 4). These volcanic units were combined into one group in the RGTIHM (RGTIHM parameter BSMT71).

\section{Faults, Subbasins, and Groundwater Flow System}

The Rincon Valley, Selden Canyon, Mesilla Basin, and Conejos-Médanos Basin subregions were divided into subbasins and uplifts bounded by faults of various extent and age. There are faults of potential hydrologic importance throughout the region (figs. $3 A, B$ ). Where faults have offset stratigraphic units, basin-fill sediments are juxtaposed against older consolidated rocks, or if within the basin fills, contrasting basin-fill units of differing water-transmitting ability are juxtaposed or are locally disrupted by the Tertiary volcanic dikes and lava flows. These faults and dikes and related uplifts contribute to the compartmentalization of the region into subbasins that could affect the development and management of water resources.

Sweetkind (2017) identified 54 different fault traces, which offset sedimentary units to varying degrees, and 7 volcanic dikes; collectively these could represent potential groundwater-flow barriers in the TRG region. The faults generally trend either north-south or northwest-southeast and are generally related to rifting deformation or older deformation events (fig. $3 B$ ). In particular, the potential impediment to groundwater flow from these faults could be related to the hydraulic properties of the fault itself or to the offset stratigraphic units at faults that juxtapose sedimentary units against older, slightly less permeable material or bedrock units. A fault (or fault zone) could also be coincident with Tertiary volcanic flows and related feeder dikes that are also potential subsurface hydrologic-flow barriers.

Geological features in the Rincon Valley that could act as hydrologic barriers include the Derry (DF), Red Hills (RHF), Ward Tank (WTF), Central (CF), and Jornada faults as well as several unnamed faults. In the Selden Canyon narrows, there are several unnamed faults as well as the Selden Canyon fault zone (SCF) which offsets the outcropping middle member of the Santa Fe Group rocks, is coincident with historical seismic activity (Sanford and others, 2002, 2006), and is a potentially important barrier to groundwater flow (fig. $3 B$ ).

The Mesilla Basin is dissected by numerous faults that result in a series of uplifts and basins. Along the eastern boundary, the basin is bounded by the Doña Ana, Tortuga, Organ, and Franklin uplifts, which are separated from the La Union-Mesquite and southeastern and south-central subbasins by the Mesilla Valley fault zone (MVFZ), Three Sisters (TSF), Interstate-10 West (I10WF), and Rio Grande faults (RGF). These eastern uplifts also separate the Mesilla Basin from the Jornada del Muerto Basin to the east and Hueco Bolson of the El Paso Valley to the southeast. These subbasins are variously separated: the South-central subbasin by the Mastodon fault (MF) in the southern Mesilla Basin and from the Midbasin uplift by the Midbasin fault zone and Transboundary fault. Farther west, the Fitzgerald fault zone (FFZ) separates the Midbasin uplift from the Northwestern and Southwestern subbasins. These western subbasins are bounded on the west by the Robledo and East Potrillo uplifts and the related Sierra de las Uvas fault zone, the West Robledo fault (WRF), East Robledo fault zone (ERF), and East Potrillo fault zone (EPFZ; fig. 3B).

The northern Conejos-Médanos Basin contains the extension of these subbasins; the East Potrillo fault zone; the Fitzgerald, Transboundary, and Mastodon faults; and various other unnamed faults. This southern region is also bounded on the southeast by the Cristo Rey-Juarez uplift, which is bounded by the West Sierra de Juarez fault zone and unnamed Cretaceous outcrops along the southern boundary of the RGTIHM (figs. $3 A, B$ ). 


\section{Hydrologic System}

\section{Conceptual Model}

The conceptual model of the TRG region consists of groundwater and surface water forming an interconnected hydrologic system that has been altered from predevelopment conditions by streamflow regulation of the Rio Grande since the construction of Elephant Butte and Caballo Reservoirs, groundwater development to provide supplemental water for irrigation and municipal uses, and the various diversion and conveyance structures of the RGP (fig. 1A). The RGP controls the flow of surface water into the study area through the Rio Grande and the distribution of surface water in the study area and to downstream users in El Paso Valley. The Rio Grande is regulated by storage and releases from Elephant Butte Reservoir and releases from the proximal downstream Caballo Reservoir (fig. 1A). Releases from Elephant Butte and Caballo Reservoirs are jointly managed to provide water for irrigation and municipal uses; Elephant Butte Reservoir is also operated for hydropower generation, and Caballo Reservoir is also operated for flood control. Downstream from Caballo Reservoir, surface water is contributed to the study area from the surrounding low-permeability uplands, and the TRG region corresponds to the regional aquifer system generally coincident with the fault-bounded Santa Fe Group (figs. $1 B, C, 3$ ). To the south, the El Paso narrows, where the Rio Grande leaves the Mesilla Basin, was selected to be the TRG region boundary. This is partly coincident with the outcrop of Cretaceous basement rocks and alluvial aquifers equivalent to the upper and middle members of the Santa $\mathrm{Fe}$ Group, where groundwater flows north under low hydraulic gradients from farther south in Mexico.

Overall, the groundwater inflows to the aquifers are dominated by regional streamflow from the Rio Grande along with relatively minor recharge contributions from local mountain-front runoff, from vertical flow (upwelling) of geothermal waters from basement aquifers as underflow and thermal springs, and from mountain-block recharge (groundwater underflow). Although local runoff from the surrounding subwatersheds that does not reach the Rio Grande during RGP operations (sometimes referred to locally as "wild water") has probably been relatively minor historically, most arroyos that originally drained to the Rio Grande downstream from the reservoirs have been blocked with earthen check dams, further minimizing their potential contribution to the Rio Grande.

Groundwater inflow includes underflow by a small amount of leakage below Caballo Reservoir in the alluvial channel of the Rio Grande and as potential underflow beneath Rincon Arroyo north of the Doña Ana Mountains and through the Fillmore Pass between the Organ and Franklin Mountains from the region east of the Mesilla Valley (fig. 1A). Additional minor amounts of groundwater could also inflow from bedrock units owing to regional fault systems acting as flow barriers that cause vertical-flow upwelling of thermal and other potential sources of saline groundwater.

Several new conceptual models have been developed since the development of the previous hydrologic simulation models (S.S. Papadopulos and Associates, Inc., 2007; Hanson and others, 2013; Ferguson and Llewellyn, 2015; Knight, 2015). These conceptual models have focused on specific features of the regional system. One of the conceptual models analyzed the contribution of anthropogenic sulfate loading and related salinity to the Rio Grande by using sulfur isotopic geochemistry along with other geochemical attributes and principal components analysis (Szynkiewicz and others, 2011). This study concluded that about 38 percent of the variation in the geochemical attributes of the Rio Grande could be attributed to flow from bedrock and possible high-temperature sources of groundwater flow, and another 35 percent could be from agricultural activities such as irrigation return flows. Another conceptual model of the Mesilla Basin infers features of the groundwater flow (Teeple, 2017) from geochemical attributes represented by five water groups: (1) ancestral Rio Grande (pre-Pleistocene) geochemical group, (2) modern Rio Grande (Pleistocene to present) geochemical group, (3) mountain-front geochemical group, (4) deep-groundwater upwelling geochemical group, and (5) unknown freshwater geochemical group (inferred to be underflow from the Jornada del Muerto Basin). The ancestral Rio Grande water group could also represent some component of upwelling of sedimentary brines and geothermal waters. Overall, the groundwater flow, partially restricted by the Mid-basin uplift, is laterally south toward the El Paso narrows between the Franklin and Sierra de Juarez Mountains.

The existing conceptual model for the hydrologic system starts with inflows from precipitation and streamflow. Streamflow enters the TRG through reservoir releases from Caballo Dam and as ephemeral runoff from side slopes and local stream networks that drain the surrounding mountains. Infiltration of runoff as stream seepage, along with percolation of some precipitation and irrigation below the root zone, contributes to groundwater recharge. Additional underflow of groundwater along the Rio Grande channel inflows at the northern boundary and outflows at the southern boundary of the valley in the alluvial aquifers (fig. $2 A$ ). Groundwater inflow represents a combination of potential underflow in the Santa Fe Group northward from the southern part of the Conejos-Médanos Basin; a small amount of leakage under the Caballo Dam; and potential, relatively small inflows along the Rincon Arroyo channel and through Fillmore Pass along the eastern boundary. Some relatively small additional upflow from bedrock units could be contributed along the southern part of the Selden Canyon narrows and in the upper and lower Mesilla Basin. Outflow leaves as a relatively small amount of groundwater underflow in the alluvium beneath the Rio Grande at the El Paso narrows (fig. 2A). Water also leaves the system through evapotranspiration (ET) from native vegetation, urban landscapes, and irrigated agriculture. 
Additional outflow is groundwater pumpage for agricultural, urban, and domestic uses. These natural and man-made inflows and outflows represent the supply-and-demand components of water use of the hydrologic cycle in the Transboundary Rio Grande Valley.

\section{Climate}

The climate of the TRG region is arid, with hot summers and cool winters. The map of average annual precipitation indicates that relatively more precipitation falls in the high mountain-front regions that bound the valley along its eastern and northwestern perimeter than in the valley (fig. $5 \mathrm{~A}$ ). Average rainfall along the RGV from 1939 to 2015 (National Climatic Data Center, 2016a-d) ranged from about 9.5 inches per year (in/yr) downstream from Caballo Dam to about $8.8 \mathrm{in} / \mathrm{yr}$ at New Mexico State University (NMSU) in Las Cruces, New Mexico. At the Hillsboro National Climatic Data Center (NCDC) station on the eastern slope of the Black Range (fig. $1 A$ ), the average annual rainfall was 11.9 inches. Precipitation ranged from 7.6 to $30 \mathrm{in} / \mathrm{yr}$ in the region, as estimated from PRISM data (Daly and others, 2008; Climate Source, 2016) using the TRGWM described in the "Model Development" section (fig. $5 A$ ).

The average annual reference evapotranspiration $\left(\mathrm{ET}_{\mathrm{h}}\right.$ or $\mathrm{ET}_{\mathrm{o}}$, depending on the model designation) values showed orographic effects similar to those of the precipitation values. The estimated $\mathrm{ET}_{\mathrm{h}}$ in the valley transitioned from about $73.6 \mathrm{in} / \mathrm{yr}$ along the Rio Grande Valley to lower values of about $31.2 \mathrm{in} / \mathrm{yr}$ in the surrounding mountains of the region analyzed as part of the TRGWM according to climate data from PRISM (fig. 5B).

The water resources of the TRG are affected by regional and local climate. The regional climate of the southern Rocky Mountains determines the potential runoff that becomes regional streamflow in the Rio Grande watershed and the net inflow, after consumption by other upstream uses, to Elephant Butte and Caballo Reservoirs operated by the RGP. Although the inflows to the TRG region are largely composed of streamflow from the Rio Grande, local climate also can be a factor. Local climate can affect both the supply and demand components of agriculture, as well as local runoff, effective precipitation, potential evapotranspiration, and related demand for surface water for irrigation. Although these components of supply are relatively small compared to regional streamflow, they can become relatively more important when summer monsoons or extra-cyclonic events potentially contribute locally to increased supply and reduced demand during the growing season. The climate signals from surface-water releases and from local precipitation were assessed to help scale selected supply-and-demand attributes, such as cropirrigation requirement (CIR), on-farm efficiency (OFE), and fractions of transpiration (FTR) in the RGTIHM simulation of the agricultural consumption of water.

The wet and dry periods represented by the cumulative departure curves of surface water and precipitation are the composite signal of multiple climate cycles that have different periodicities and have been observed across the southwestern United States (Hanson and others, 2006; Gurdak and others, 2009). The climate cycles that most commonly influence water resources include the Atlantic Multidecadal Oscillation (AMO, 30-70 year cycles), the Pacific Decadal Oscillation (PDO, 10-30 year cycles), the North American Monsoon (NAMS, $7-10$ year cycles) along with Caribbean and Pacific cyclonic events, and the El Nino-Southern Oscillation (ENSO, 2-6 year cycles; Hanson and others, 2006; Gurdak and others, 2009; Dickinson and others, 2014). These climate cycles have different periodicities that phase in and out with each other to create the seasonal to interdecadal climate variability that result in the wet and dry periods in seasonal and annual time frames. For example, the combination of a cool phase of the PDO with the warm phase of the AMO is typical of drought in the southwestern United States (McCabe and others, 2004; Stewart, 2009; New Mexico Office of the State Engineer, 2017). Annual and seasonal surface-water releases and precipitation are viewed as a cumulative departure time series because this helps to embed serial correlation and makes these time series comparable to groundwater-level hydrographs, which are cumulative departure curves of changes in groundwater storage (Hanson and others, 2004).

Regional climate was partly represented by the variability in surface water as changes in reservoir storage and related reservoir releases available for irrigation (fig. $6 A$ ). The total and seasonal reservoir releases from Caballo Reservoir varied annually during $1940-2014$ by about 40 percent relative to the mean reservoir release (fig. $6 \mathrm{~A}$ ). The cumulative-departure curve and related frequency analysis showed that reservoir releases corresponded to the longer climate cycles (fig. 6B). The surface-water releases, as shown in the cumulativedeparture curve, represent 42 wet years and 33 dry years in 10 wet-year (rising limbs of curve) and 10 dry-year (falling limbs of curve) periods (fig. $6 \mathrm{~B}$ ). Time-series analysis of the residuals from a second-order polynomial detrended cumulative-departure curve of reservoir releases showed that more than 96 percent of the "surface-water climate variability" represented by the annual variability in releases from Caballo Reservoir were coincident with longer climate cycles, such as the AMO cycles (greater than the PDO; fig. $6 C$ ). The seasonal and annual surface-water variability of releases also contain minor contributions coincident with shorter climate cycles (the PDO, NAMS, and ENSO; fig. 6C). 
The local precipitation variability differed from the surface-water variability reflected in the reservoir releases. The record of annual cumulative departure from the 19392015 mean precipitation at the Caballo Dam (fig. 1B) and NMSU (fig. 1C) climate stations showed that wet (rising limbs of curve) periods and dry (falling limbs of curve) periods were typical of the interannual climate variability for the TRG (data from the National Climatic Data Center, 2016a-d; fig. $6 D$ ). The cumulative departure curve for local annual precipitation indicated 38 wet years and 39 dry years in 16 wet periods and 15 dry periods (fig. $6 D$, table 5). The seasonal distribution of wet and dry periods indicated some marked differences between wet and dry seasons in the winter and spring compared to the summer and fall (fig. $6 E$ ), however, that indicated interannual seasonal variations were probably influenced by different climate cycles.

Time-series analysis of the residuals from a secondorder polynomial detrended cumulative-departure curve of annual precipitation from the climate station at NMSU (fig. $6 F$ ) showed that about 78 percent of the variation could represent a predominant long-term cycle coincident with the longer periodicity of the AMO (30-70 year cycles), 15 percent of the variation could represent cycles coincident with the PDO (10-30 year cycles), 5 percent of the variation could represent NAMS (7-10 year cycles), and 2 percent could represent ENSO (2-6 year cycles). The seasonal variation of residuals from the cumulative departure of seasonal NMSU precipitation indicated that winter and spring were most influenced by the PDO and AMO (longer than PDO) cycles, but that summer and fall were more influenced by the NAMS and ENSO. Spring seasons also showed a relatively large percentage of variation coincident with ENSO cycles.

Regional climate cycles that control precipitation from the north dominated the annual and seasonal surface-water cycles and the winter and spring precipitation cycles, whereas southerly climate cycles dominated the summer and fall precipitation cycles. Thus, almost all of the variation in annual surface-water releases and precipitation was associated with the longer climate cycles. The longer cycles are therefore important periods for the evaluation of interdecadal variability of the water resources that influence consumptive use, whereas the shorter cycles could influence precipitation important to local runoff and agricultural demand from the amount of crop canopy as fractions of transpiration (FTR) and as on-farm efficiency (OFE) of irrigation.
Table 5. Summary of climate periods for the Rio Grande Transboundary Integrated Hydrologic Model, Transboundary Rio Grande, New Mexico, Texas, and Mexico.

\begin{tabular}{|c|c|c|c|c|c|}
\hline Precipitation ${ }^{1}$ & Climate & Years & $\begin{array}{l}\text { Surface } \\
\text { water }^{2}\end{array}$ & Climate & Years \\
\hline $1939-42^{3}$ & WET & 4 & $1940-50$ & WET & 11 \\
\hline 1943 & DRY & 1 & $1951-57$ & DRY & 7 \\
\hline 1944 & WET & 1 & $1958-60$ & WET & 3 \\
\hline $1945-48$ & DRY & 4 & 1961 & DRY & 1 \\
\hline 1949 & WET & 1 & 1962 & WET & 1 \\
\hline $1950-56$ & DRY & 7 & 1963-68 & DRY & 6 \\
\hline $1957-58$ & WET & 2 & 1969-70 & WET & 2 \\
\hline 1959-60 & DRY & 2 & $1971-75$ & DRY & 5 \\
\hline 1961 & WET & 1 & 1976 & WET & 1 \\
\hline $1962-65$ & DRY & 4 & 1977-79 & DRY & 3 \\
\hline 1966 & WET & 1 & 1980 & WET & 1 \\
\hline 1967 & DRY & 1 & 1981-82 & DRY & 2 \\
\hline $1968-69$ & WET & 2 & 1983-90 & WET & 8 \\
\hline 1970-71 & DRY & 2 & 1991 & DRY & 1 \\
\hline $1972-74$ & WET & 3 & $1992-2002$ & WET & 11 \\
\hline 1975-77 & DRY & 3 & 2003-04 & DRY & 2 \\
\hline 1978-79 & WET & 2 & 2005 & WET & 1 \\
\hline 1980 & DRY & 1 & 2006-07 & DRY & 2 \\
\hline 1981 & WET & 1 & 2008-10 & WET & 3 \\
\hline $1982-83$ & DRY & 2 & 2011-14 & DRY & 4 \\
\hline 1984-93 & WET & 10 & - & - & - \\
\hline 1994-96 & DRY & 3 & - & - & - \\
\hline 1997 & WET & 1 & - & - & - \\
\hline 1998 & DRY & 1 & - & - & - \\
\hline 1999-2000 & WET & 2 & - & - & - \\
\hline 2001-03 & DRY & 3 & - & - & - \\
\hline 2004-08 & WET & 5 & - & - & - \\
\hline 2009 & DRY & 1 & - & - & - \\
\hline 2010 & WET & 1 & - & - & - \\
\hline 2011-14 & DRY & 4 & - & - & - \\
\hline 2015 & WET & 1 & - & - & - \\
\hline
\end{tabular}

${ }^{1}$ Calendar years based on cumulative departure from average of annual precipitation from New Mexico State University, New Mexico (fig. 6D).

${ }^{2}$ Calendar years based on cumulative departure from average of annual surface-water releases from Caballo Reservoir (fig. 6B).

${ }^{3}$ Portion of climate periods prior to model simulation period that begins in March 1940. 


\section{Development of Water Resources}

As in much of the western United States, the development of water resources in the TRG region began with the construction of the surface-water infrastructure and was later supplemented with extensive development of the groundwater resources. This development included expansion of anthropogenic land use in the valley, from early post-dam developments of the canal and drain networks to modern agriculture, urbanization, and industry. The RGP used and expanded existing irrigation systems and built important infrastructure to provide surface-water storage and delivery for agriculture. The RGP also built and later expanded a system of irrigation canals in southern New Mexico and western Texas to provide water for irrigation of up to 90,640 acres of land in the Rincon Valley and Mesilla Basin of New Mexico (managed by EBID), up to 12,200 acres of land in the Mesilla Basin in Texas, and up to 56,000 acres south of the study area in the El Paso Valley, Texas (managed by EPCWID1; Valdes and Maddock, 2010; Bureau of Reclamation, 2013; fig. 7A). A 1906 international treaty with Mexico apportioned up to 60,000 acre-feet of RGP water annually to Mexico. In addition, the 1938 Rio Grande Compact divided the surface water of the Rio Grande flowing from the headwaters in Colorado to Fort Quitman, Texas, among the states of Colorado, New Mexico, and Texas.

Several major periods of agricultural development and intensification have passed in the TRG region. Following the completion of Elephant Butte Dam in 1916 and the enhancement of a system of irrigation canals, cotton and alfalfa were the primary agricultural crops in the valley. After the consistent source of water from reservoir releases through widespread irrigation canals resulted in rising water tables, resulting in poorly drained conditions in some agricultural fields, a network of drains was built in the 1920s to lower the water table to maintain optimal growing conditions and reduce waterlogged soils in the agricultural regions. In 1938, Caballo Dam was completed approximately 25 miles downstream from Elephant Butte Dam to store water for use in the growing season following water release from Elephant Butte for flood control and power generation during the winter. Starting with the severe drought of the early 1950s and again during a sustained dry-climate cycle through the 1970s, the shortage of surface water and the growing irrigation demand required development of supplemental groundwater supplies (fig. 7A).

Farming evolved from the planting of primarily cotton and alfalfa during the 1920s through 1960s to a doubling of the acreage of pecan orchards by the late 1970s to early 1980s (Conover, 1954; J. Narvaez, Elephant Butte Irrigation District, written commun., 2017). The acreage of pecan orchards has steadily grown from 13 percent $(10,264$ acres) of the total EBID irrigated acreage in 1979 to 47 percent (about
25,000 acres) in 2014, primarily at the expense of cotton and chili, which decreased from 40 percent $(31,304$ acres) and 14 percent (11,137 acres) of the total EBID irrigated acreage in 1979, respectively, to 15 percent (about 8,000 acres) and 3 percent (1,584 acres) in 2014 (J. Narvaez, EBID, written commun., 2017).

Urban, industrial, and domestic water use in the study area is primarily in Doña Ana County and around the northern parts of El Paso County, Texas. Estimates of population were not available for the parts of El Paso and Ciudad Juárez that are in the TRG region; however, estimates from New Mexico were used to indicate urban growth and related water demand. Population growth in the New Mexico part of the TRG region was estimated from census tract data for Doña Ana County (U.S. Census Bureau, 2017a, b) and indicated a steady increase from just over 10,000 inhabitants to more than 200,000 inhabitants from 1900 through 2010 (fig. 7B).

Las Cruces is the largest city in the study area and the second largest city in New Mexico (U.S. Census Bureau, 2017a). Las Cruces Utilities supplies the majority of water customers in the Las Cruces city limits through a network of groundwater-supply wells in the Mesilla Basin (Valley and West Mesa Well Fields) and Jornada del Muerto Basin (East Mesa Well Field; Camp, Dresser, and McGee, 2008; McCoy and Peery, 2008). City of Las Cruces municipal pumping began in the 1920s (Petronis and others, 2006). Some areas in the city limits of Las Cruces, surrounding areas, and smaller towns in the study area are served water from a variety of smaller water utilities, including Doña Ana Mutual Domestic Water Consumers Association, Moongate Water Company, Jornada Water Company, Transboundary Rio Grande Public Water Works Authority, the town of Mesilla and the city of Anthony in New Mexico, the town of Anthony in Texas, and NMSU, among others (S.S. Papadopulos and Associates, Inc., 2007; Camp, Dresser, and McGee, 2008). Water for the developments of Santa Teresa and Sunland Park in southern Doña Ana County along the New Mexico-Texas border is supplied by Camino Real Regional Utility Authority through a network of groundwater wells drilled in the early 1970s (S.S. Papadopulos and Associates, Inc., 2007). El Paso Water Utilities operates a water-supply well field in the study area in Canutillo, Texas, that began production in the early 1950s and provides water to residents of El Paso County (S.S. Papadopulos and Associates, Inc., 2007; Hutchison, 2008). These urban clusters in the United States represent less than 10 percent of the land in the study area. Other residents are served water by their own wells. Ciudad Juárez Municipal Water and Sanitation Board operates a water-supply well field south of the Unites States-Mexico border in the ConejosMédanos Basin that began withdrawals in mid-May 2010 (International Boundary and Water Commission, 2011). 
$\boldsymbol{A}$

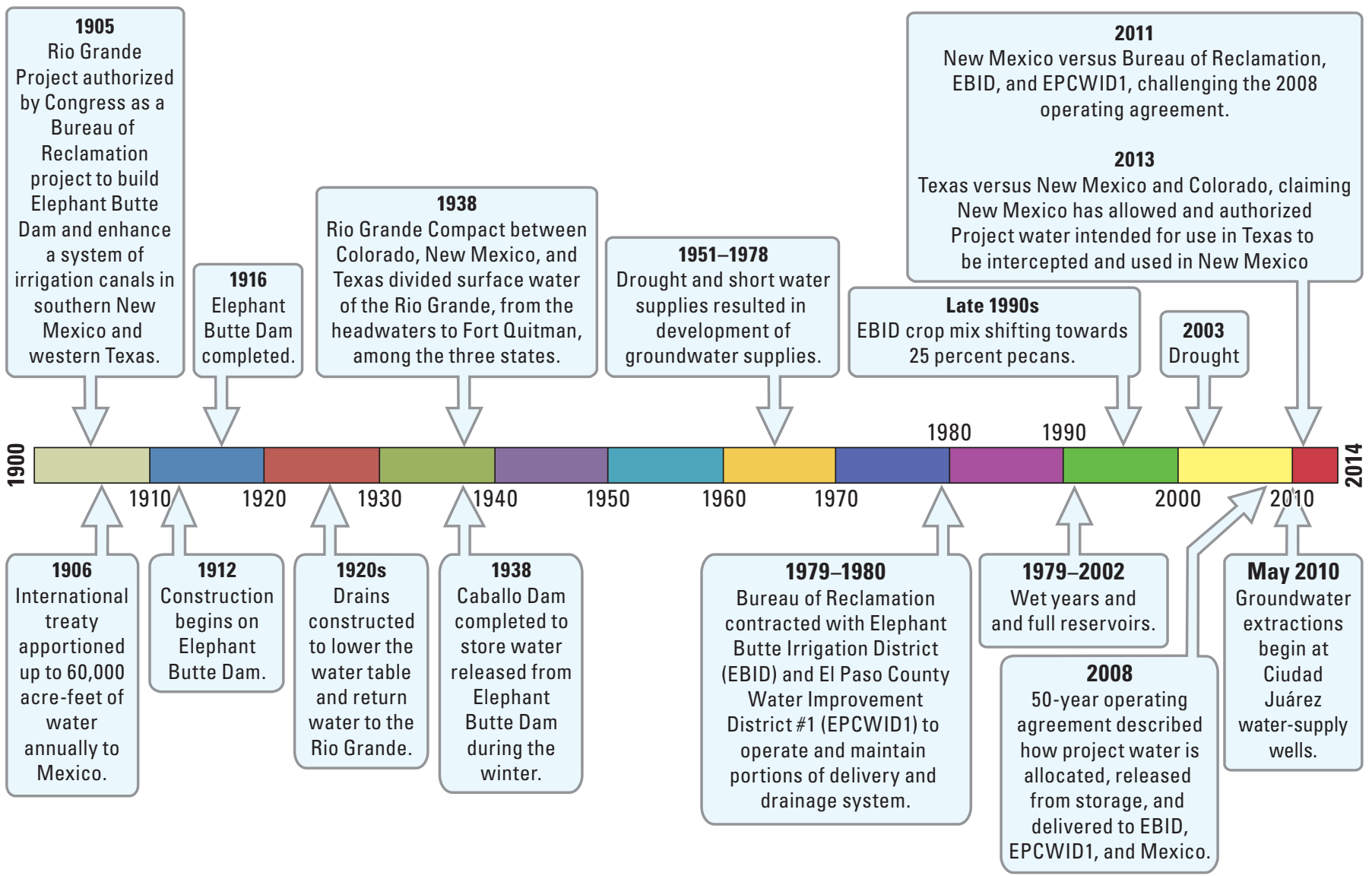

B

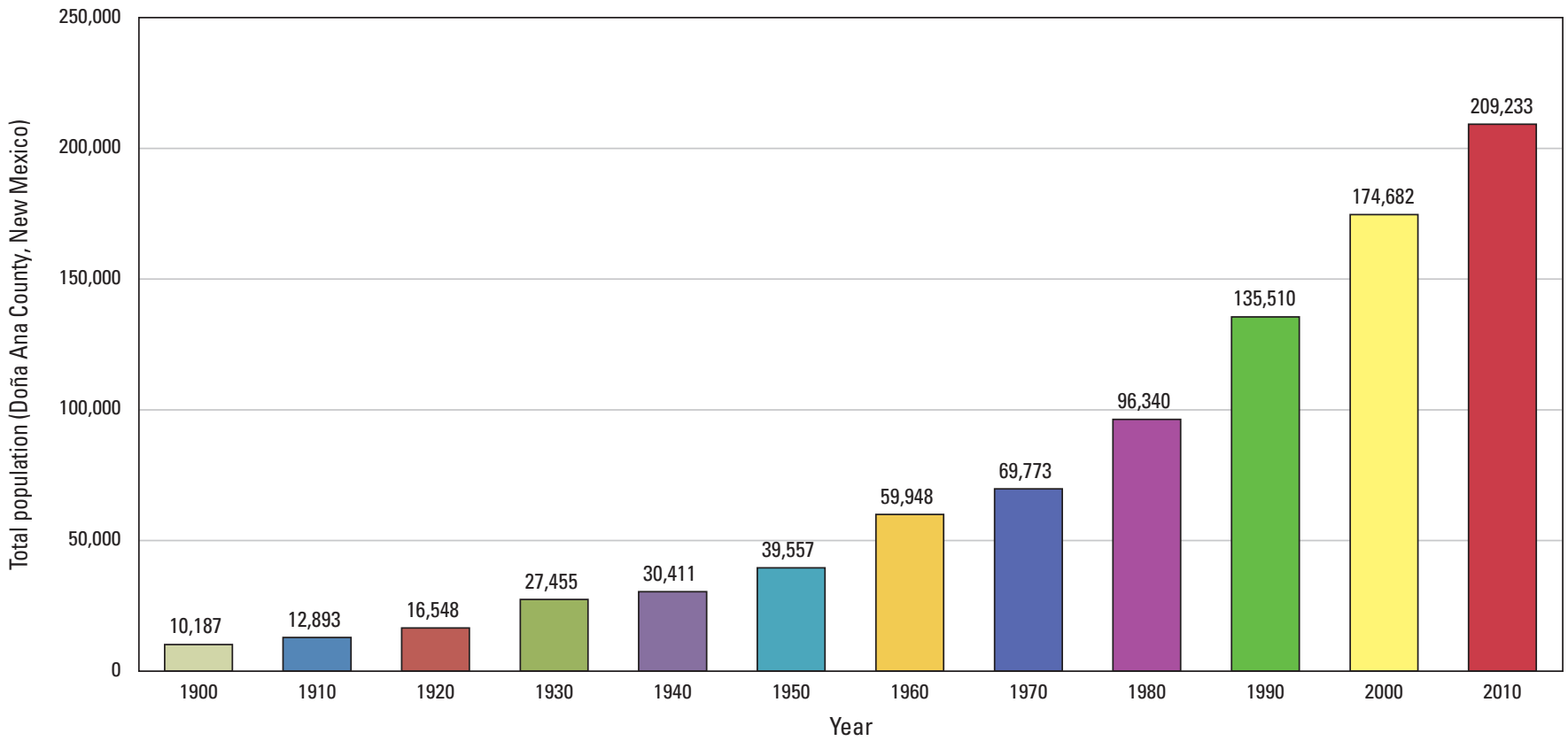

Figure 7. Generalized history of human development: $A$, water and land-use development timeline for Transboundary Rio Grande, New Mexico, Texas, and Mexico, 1905-2013 (International Boundary and Water Commission, 2011; Valdes and Maddock, 2010; Bureau of Reclamation, 2013, 2017); B, population growth for Doña Ana County, New Mexico, 1900-2010; and C, irrigated acreage for New Mexico and Texas, 1939-2010. (Colored bars in A and B indicate decades). 
$c$

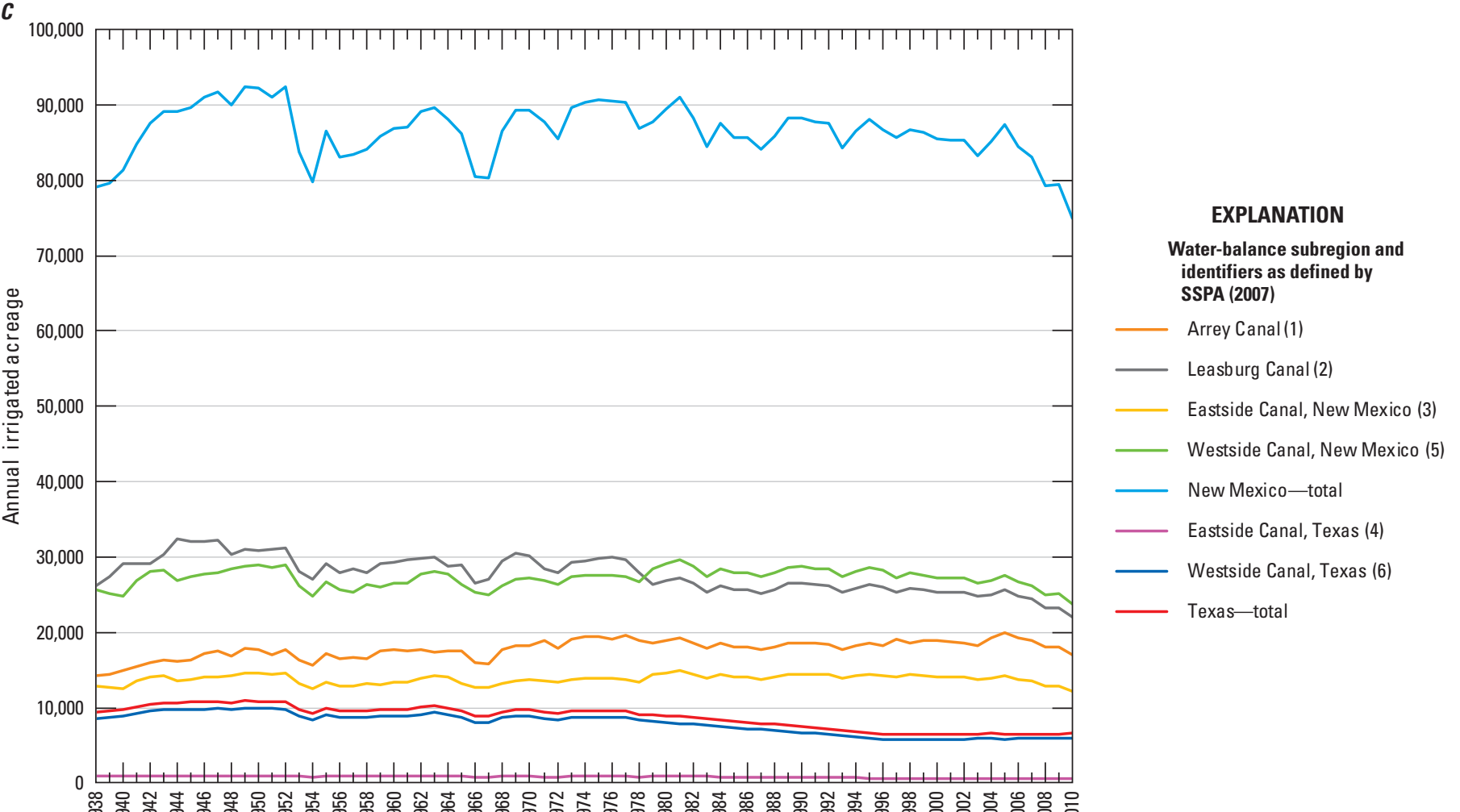

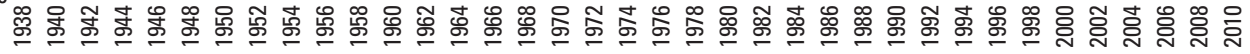

Year

Figure 7. - Continued

Development of land use in the TRG region is largely driven by a combination of changes in agricultural practices and land ownership and related land use. For the purpose of modeling the hydrologic system, however, the changes in land use and the changes of land used for agriculture, urban, and industrial purposes were held constant for the entire period of simulation. The total irrigated acreage changed from about 81,300 to about 75,000 acres in New Mexico and from about 9,700 to 6,600 acres in Texas between 1940 and 2010 (fig. 7C). The largest irrigated acreage in New Mexico, about 92,500 acres, was planted during 1949-52 and in Texas, it reached about 10,900 acres during 1949-51; irrigated acreage in both states declined through 2010 (fig. 7C). Instead of directly representing changing land use through the FMP in the RGTIHM, the temporal changes in the land ownership and related land use were embedded with changes in irrigated acreage represented by using varying monthly estimates of consumptive use provided by the NMOSE for 1938-2010 for 6 agricultural service areas (Arrey, Leasburg, and Eastside Canals-New Mexico, Eastside Canal-Texas, Westside CanalNew Mexico, and Westside Canal-Texas; P. Barroll, New Mexico Office of the State Engineer, written commun., 2011; Ritchie and others, 2018). The estimates of consumptive use were distributed across 20 total land-use categories (table 2) for these 6 agricultural units in the RGTIHM. Land-use categories 1 and 2 in the RGTIHM correspond to the Arrey Canal service area from the NMOSE, and land-use categories 3 through 7 in the RGTIHM correspond to the Leasburg Canal, Eastside Canal-New Mexico, Westside Canal-New Mexico, Eastside Canal-Texas, and Westside Canal-Texas service areas from the NMOSE, respectively. The NMOSE discontinued estimating consumptive use after 2010. The last 4 years (2011-14) of consumptive-use estimates for the simulations from the study were extrapolated from years with similar precipitation. Thus, monthly estimates of consumptive use were compiled for 57 static WBSs (figs. 2B,C) for 19402010. These estimates were required to simulate agricultural demands for surface-water deliveries and groundwater pumpage.

The remaining 14 WBSs consisted of urban regions; regions of native vegetation with evapotranspiration from groundwater only; and golf courses with evapotranspiration from groundwater, but that also use irrigation from groundwater pumpage. Urban and domestic areas were served by separate specified sources of groundwater pumpage. 
Monthly estimates of consumptive use for the three urban WBS were derived from an estimated consumption for an urban landscape with drought-tolerant shrubs, flowers, trees, native vegetation, and rocks in place of turf grass for an average-sized lot (Hurd, 2006). Consumptive use was estimated at 1.3 feet per year ( $\mathrm{ft} / \mathrm{yr}$ ), based on an urban lot of 5,000 square feet $\left(\mathrm{ft}^{2}\right)$ minus a 1,500 $\mathrm{ft}^{2}$ house and an estimated landscape irrigation of 35,000 gallons per year. This annual consumptive-use value was distributed to monthly values on the basis of monthly percentages of evaporation from an evaporative pan near Caballo Dam (Blaney and Hanson, 1965, table 26). Urban-landscape water consumption was assumed to be 100 percent for urban areas in New Mexico, 75 percent for urban areas in Texas, and 50 percent for urban areas in Mexico, based on visual inspection of aerial imagery (Ritchie and others, 2018). The monthly urban consumptive-use estimates were also used for the six native vegetation WBSs, with the full consumption used for native vegetation regions east of the Rio Grande, 75 percent used for the native vegetation of the Rio Grande Valley terrace composing the region outside the RGV in the active model grid, and 50 percent used for the native vegetation regions west of the Rio Grande and in Mexico (Ritchie and others, 2018). Monthly estimates of consumptive use for the two golf course WBSs were based on monthly $\mathrm{ET}_{\mathrm{h}}$ values from 2010 measured at the NMSU turf-grass weather station (New Mexico State University, 2015). These values were extrapolated for the RGTIHM input to fill the average active time interval of the golf courses in each WBS, but were adjusted to the consumptive-use rates used for surrounding native vegetation regions used during inactive time intervals (Ritchie and others, 2018).

\section{Surface Water}

Surface water in the TRG region consists of streamflow in the Rio Grande downstream from Caballo Dam and storm runoff through ephemeral tributaries that discharge to the Rio Grande downstream from Caballo Dam. Streamflow in the Rio Grande downstream from Caballo Dam is primarily controlled by operation of the RGP. Although there are small check dams on several of the ephemeral channels that feed the TRG, storm runoff through ephemeral tributaries has been largely uncontrolled. Because of the intermittent and flashy nature of storm runoff in the TRG and the general lack of infrastructure to control and utilize runoff from most ephemeral channels in the study area, storm runoff is generally not considered a major component of the surface-water supply.

The RGP provides water to the EBID and El Paso County Water Improvement District No. 1 (EPCWID1) for authorized agricultural and municipal uses. The EBID comprises 90,640 acres authorized to receive RGP water in the Rincon and Mesilla Valleys of New Mexico; the EPCWID1 comprises 69,010 acres authorized to receive RGP water in the Mesilla and El Paso Valleys of Texas. In the EBID, RGP water is used for irrigation; in the EPCWID1, RGP water is used for irrigation as well as municipal demands with the city and county of El Paso through sale of water to El Paso Water Utility. The RGP also delivers water to Mexico at the heading of the Acequia Madre, as accorded by the Convention of 1906. The RGP operations involve four primary functions:

- Storage of Rio Grande streamflow and San JuanChama Project (SJCP) water in RGP storage.

- Allocation of RGP water to the EBID, to the EPCWID1, and for delivery to Mexico.

- Release of RGP water from storage and delivery of RGP water to authorized diversion points.

- Diversion of RGP water from the Rio Grande for delivery to individual farms and municipal water treatment facilities for beneficial use.

Detailed descriptions of RGP facilities and of the history of RGP operations, including allocation of RGP water to EBID, EPCWID1, and the United States for delivery to Mexico, are provided by the Reclamation (Bureau of Reclamation, 2013, 2016).

Streamflow in the Rio Grande Basin upstream from Elephant Butte Dam is largely governed by climate and hydrologic conditions in the upper and middle parts of the Rio Grande Basin, including snow accumulation and snowmelt in the basin headwaters in southern Colorado as well as monsoon precipitation and runoff in the watersheds that feed the middle Rio Grande Valley of New Mexico. The amount of Rio Grande streamflow that reaches Elephant Butte Reservoir and the subsequent quantity of water that is available to the RGP is governed by the Rio Grande Compact. The amount of RGP water available for diversion by the EBID, EPCWID1, and Mexico subsequently depends on the allocation for each entity under the RGP operating procedures; details of historical and present-day RGP operating procedures are provided by the Reclamation (Bureau of Reclamation, 2013, 2016).

The quantity and timing of streamflow entering the TRG region are governed by RGP releases from Caballo Dam. The RGP releases, in turn, are governed by water-delivery orders from the EBID, EPCWID1, and the International Boundary and Water Commission (IBWC) on behalf of Mexico. Delivery orders are driven by water demands by each entity for irrigation and municipal uses and are constrained by the RGP delivery allocation for each.

Interannual and interdecadal fluctuations in the RGP surface-water supply can differ greatly from fluctuations in climate conditions in the TRG. These differences stem from differences between climate variability in TRG relative to the upstream parts of the Rio Grande Basin, where most runoff is, as well as the ability to store Rio Grande streamflow in the RGP reservoirs from one year to the next. As a result, large amounts of surface water could be available during periods of low precipitation in the TRG, and smaller amounts could be available during periods of more precipitation. 
Surface water released from Caballo Dam to the Rio Grande is measured at the "Rio Grande below Caballo Dam streamgage" (USGS 08362500; fig. 8A). Average annual releases for 1940-2014 were approximately 650,000 acrefeet (standard deviation of 260,000 acre-feet; I. Ferguson, Bureau of Reclamation, written commun., 2016; Ritchie and others, 2018). Water is also diverted from Caballo Reservoir to the Bonita Private Lateral (fig. $8 \mathrm{~A}$ ) to irrigate lands between Caballo Dam and the Percha Diversion Dam. Average annual diversions to the Bonita Private Lateral for 1940-2014 were approximately 1,000 acre-feet (standard deviation of 440 acre-feet; Tillery and others, 2009; D. Blatchford, Bureau of Reclamation, written commun., 2016; Ritchie and others, 2018).

Surface water is diverted from the Rio Grande for agricultural and municipal uses at a series of diversion dams (Percha, Leasburg, Mesilla, American, and International, from north to south; figs. $1 B, C, 8 A, B)$. Diversions enter a network of irrigation canals and laterals, which convey and deliver surface water to farm headgates for irrigation and to water-treatment plants for municipal use (S.S. Papadopulos and Associates, Inc., 2007; Bureau of Reclamation, 2017). Historically, canals and laterals in the TRG were primarily unlined earthen structures; over recent decades, however, an increasing number of canals and laterals have been lined or converted to pipe to reduce seepage losses.

A part of the water applied as irrigation percolates below the root zone and contributes to groundwater recharge. Drainage canals capture excess groundwater from irrigated areas throughout the RGP and deliver water back to the Rio Grande; drainage return flows contribute to the amount of surface water available for diversion at downstream diversion dams (S.S. Papadopulos and Associates, Inc., 2007). There also could be some small amount of head-gate and tailwater surface-water return flows in some agricultural areas.

The irrigation-canal system is entirely gravity-driven; delivery canals and laterals were constructed higher than the surrounding fields, and drainage canals were constructed lower than the surrounding fields (DeMouche, 2004; S.S. Papadopulos and Associates, Inc., 2007). Surface water at Percha Diversion Dam, 1.2 miles downstream from Caballo Dam, is diverted to the Arrey Canal and Percha Private Lateral (S.S. Papadopulos and Associates, Inc., 2007; Bureau of Reclamation, 2012). As the Rio Grande exits Selden Canyon and enters the Mesilla Valley, approximately 44 miles downstream from Percha Diversion Dam, surface water is diverted at Leasburg Diversion Dam to the Leasburg Canal (S.S. Papadopulos and Associates, Inc., 2007; Bureau of Reclamation, 2012). Twenty-three miles downstream from Leasburg Diversion Dam, surface water is diverted at Mesilla Diversion Dam to the West Side and East Side Canals (S.S. Papadopulos and Associates, Inc., 2007; Bureau of Reclamation, 2012). At the upstream end of the El Paso narrows, approximately 39 miles downstream of Mesilla Diversion Dam, water is diverted at the American Diversion Dam to the American Canal; the American Canal delivers water for irrigation and municipal uses in the El Paso Valley (fig. 8B; Bureau of Reclamation, 2012, 2016; International Boundary and Water Commission, 2017b). Finally, shortly downstream from the El Paso narrows, approximately 2 miles downstream from the American Diversion Dam, water is diverted at the International Dam to the Acequia Madre for delivery to Mexico (Bureau of Reclamation, 2012; International Boundary and Water Commission, 2017a). Diversions are measured at or near the heading of each canal, at various locations throughout the network of canals and drains, and at various locations along the Rio Grande (Bureau of Reclamation, 2008, 2012). There is no streamgage to measure flow in the Rio Grande downstream from the International Dam (fig. 8B).

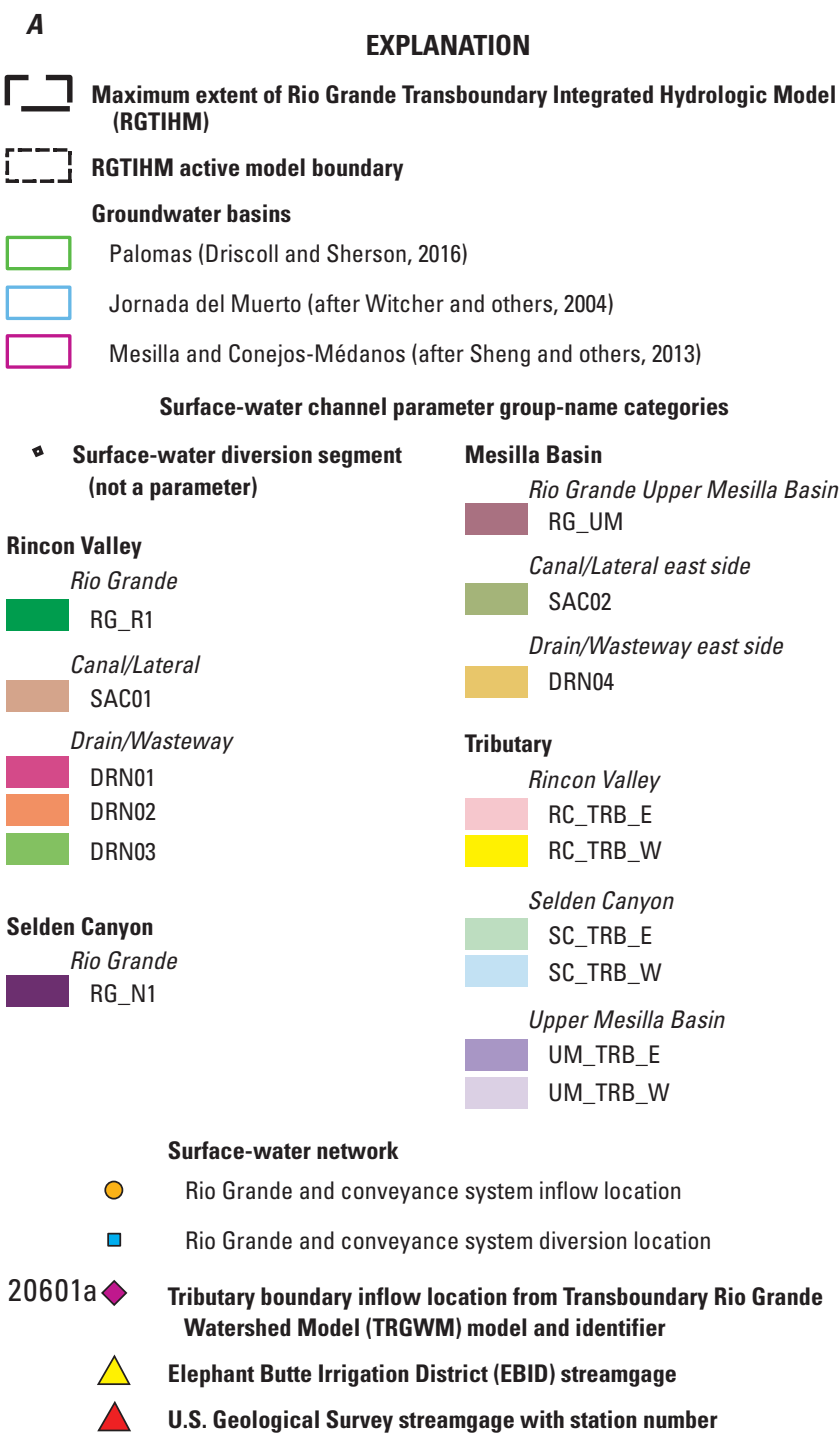

Figure 8. Distribution of streams with parameter groups of streamflow-routing cells and segments, parameter groups, and location of inflows and diversions of the Rio Grande transboundary integrated hydrologic model (RGTIHM) in the Transboundary Rio Grande, New Mexico, Texas, and Mexico, for $A$, the Rincon Valley; $B$, the Mesilla and Conejos-Médanos Basins; and $C$, the Rio Grande. 


\section{A-Continued}

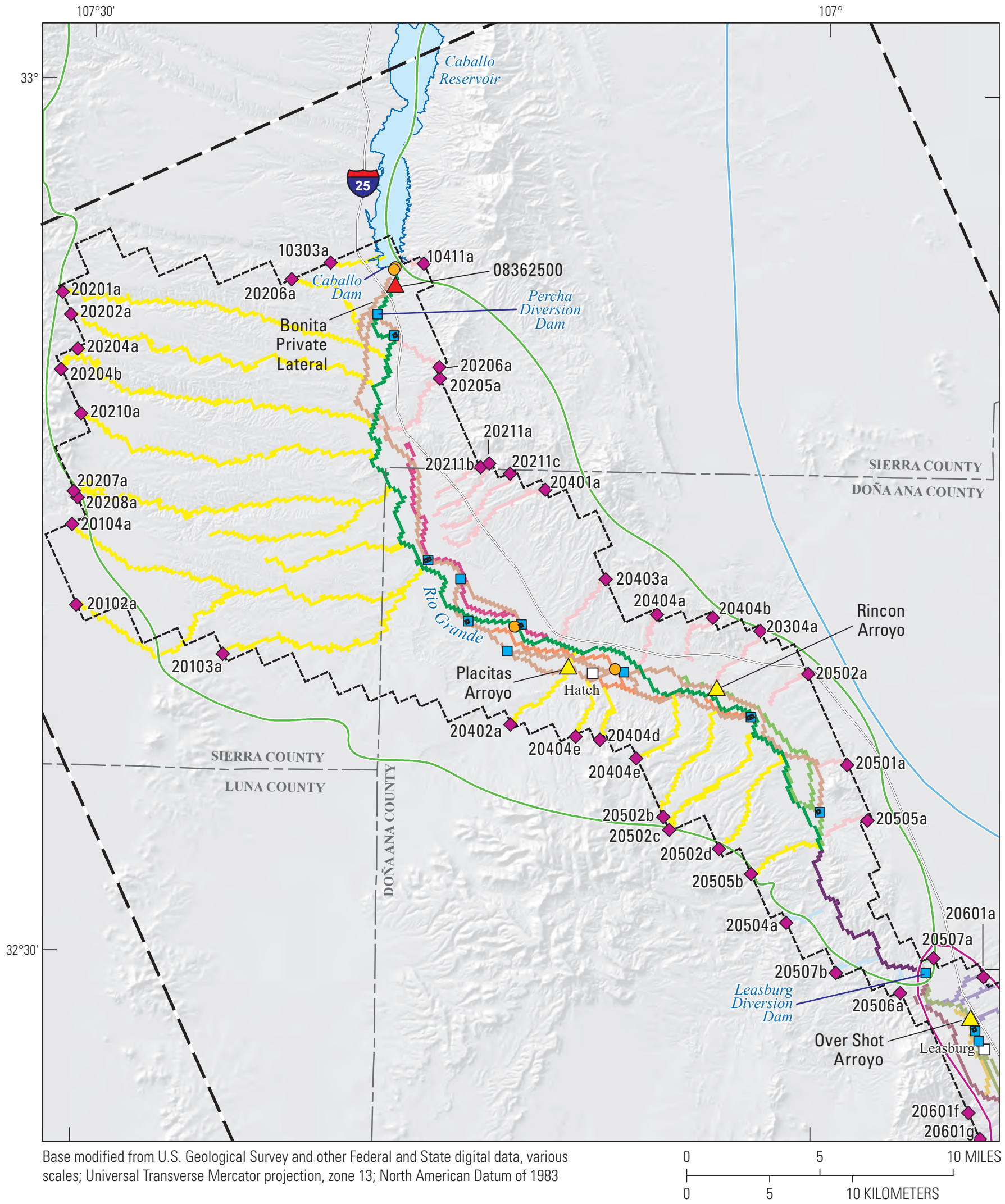

Figure 8. - Continued 


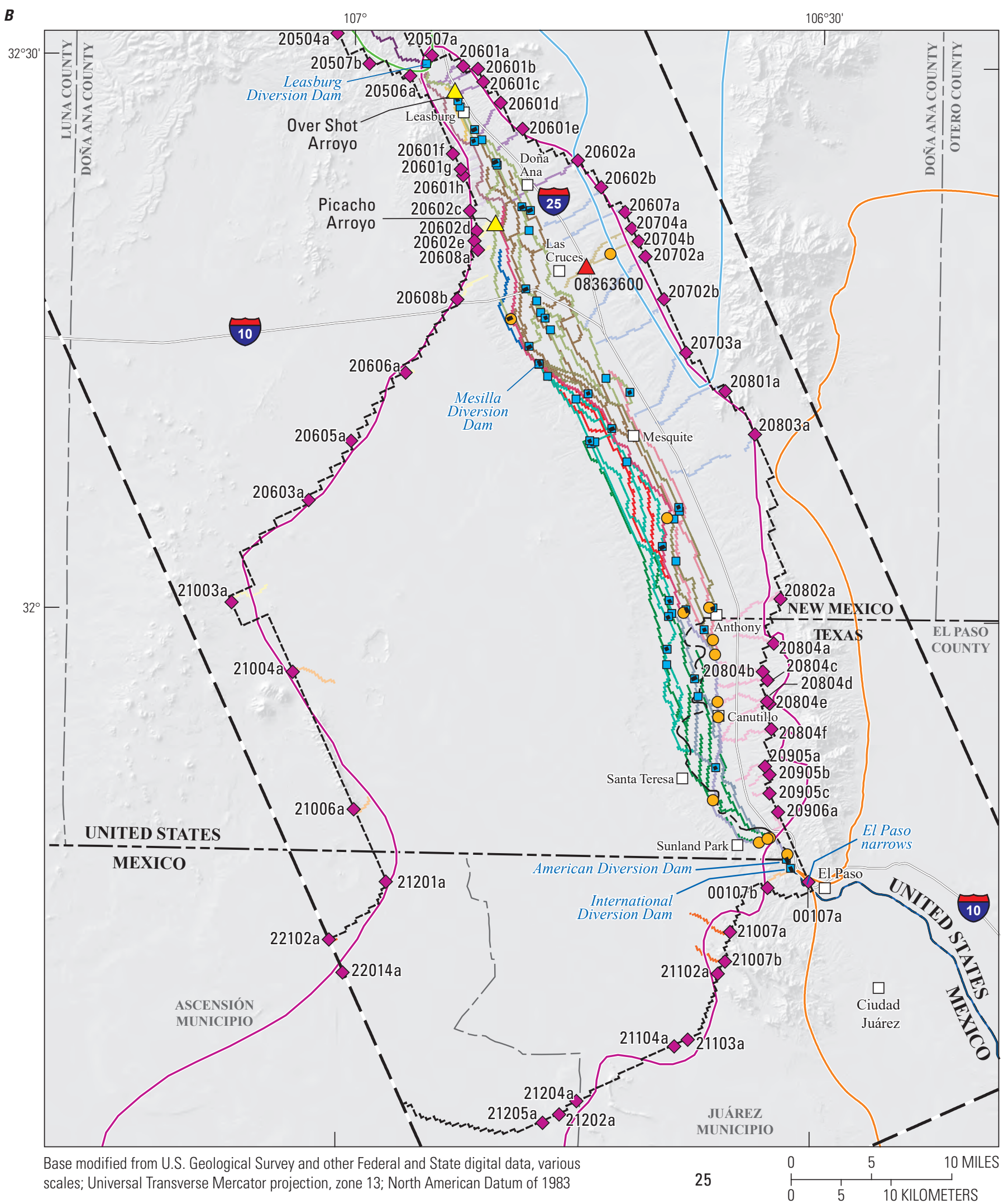

Figure 8. - Continued 


\section{B-Continued}

\section{EXPLANATION}

$\Gamma 7$ Maximum extent of Rio Grande Transboundary Integrated Hydrologic Model (RGTIHM)

[-_ RGTIHM active model boundary

Groundwater basins

Hueco (Driscoll and Sherson, 2016)

Palomas (Driscoll and Sherson, 2016)

Jornada del Muerto (after Witcher and others, 2004)

Mesilla and Conejos-Médanos (after Sheng and others, 2013)

Surface-water channel parameter-group name categories

- Surface-water diversion (not a parameter)

Selden Canyon

Rio Grande

RG N1

Tributary

Las Cruces Canyon

LC CYN

Upper Mesilla Basin

UM_TRB_E

UM_TRB_W

Middle Mesilla Basin

MM_TRB_E

MM_TRB_W

Lower Mesilla Basin

LM_TRB_E

LM_TRB_W

Conejos-Médanos Basin

CM_TRIB
Mesilla Basin

Rio Grande Upper Mesilla Basin

RG_UM

Rio Grande Middle Mesilla Basin

RG_MM

Rio Grande Lower Mesilla Basin

RG_LM

Canal/Lateral east side

SACO2

SAC34

Canal/Lateral west side

SAC05

SACO6

Drain/Wasteway east side

DRNO4

DRN06

DRN08

Drain/Wasteway west side

DRN05

DRN07

DRN09

\section{Surface-water network}

- Rio Grande and conveyance system inflow location

$\square \quad$ Rio Grande and conveyance system diversion location

$21007 a \quad$ Tributary boundary inflow location from Transboundary Rio Grande Watershed Model (TRGWM) and identifier

$\triangle$ Elephant Butte Irrigation District (EBID) streamgage

$\triangle$ U.S. Geological Survey streamgage with station number

Figure 8. -Continued 


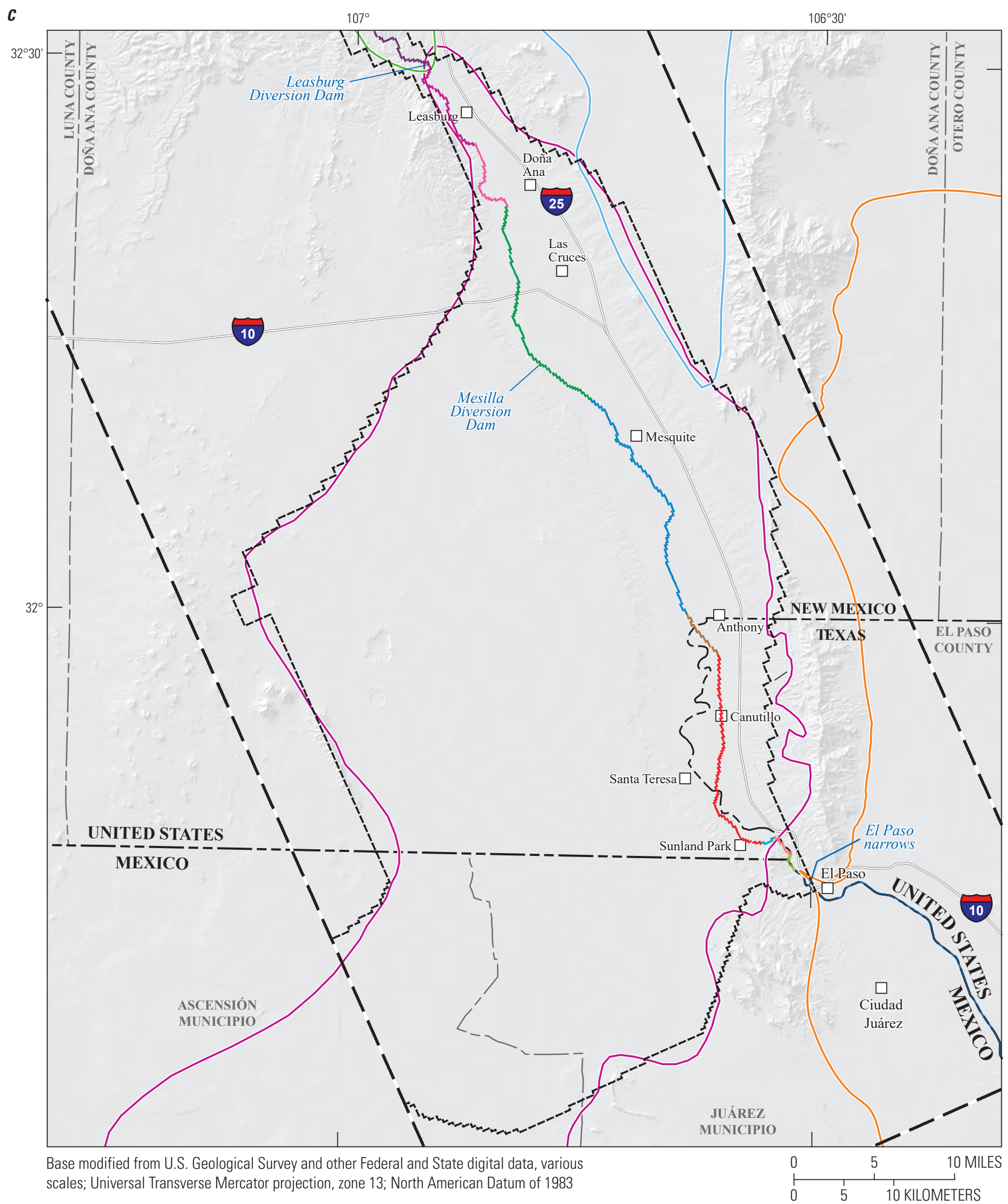

Figure 8. - Continued 
$\Gamma$ _ (RGTIHM)

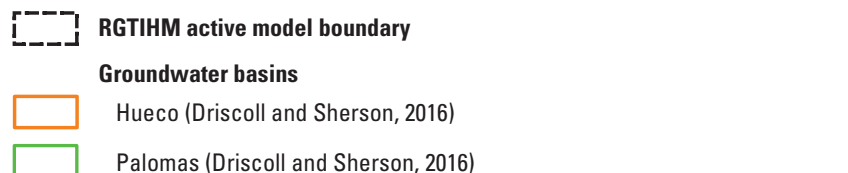

Jornada del Muerto (after Witcher and others, 2004)

Mesilla and Conejos-Médanos (after Sheng and others, 2013)

Surface-water channel parameter names

Mesilla Basin

\begin{tabular}{|c|c|}
\hline $\begin{array}{l}\text { Rio Grande Upper Mesilla Basin } \\
\text { RG_UM1 }\end{array}$ & $\begin{array}{l}\text { Rio Grande Lower Mesilla Basin } \\
\text { RG_LM1 }\end{array}$ \\
\hline RG_UM2 & RG_LM2 \\
\hline Rio Grande Middle Mesilla Basin & RG_LM3 \\
\hline RG_MM1 & RG_LM4 \\
\hline RG_MM2 & RG_LM5 \\
\hline \multicolumn{2}{|c|}{ Selden Canyon } \\
\hline \multicolumn{2}{|c|}{ Rio Grande } \\
\hline & \\
\hline
\end{tabular}

Figure 8. -Continued

During occasional periods of large precipitation storms, runoff is generated throughout much of the TRG region and can flow through the tributaries of the Rio Grande, the irrigation canals and laterals, and the drains, or it infiltrates through the streambeds (figs. 1, 8). Flood-control dams have been constructed across many of the mouths of the tributaries to prevent damage to agricultural fields and property

(Tectonic, 2013). Thus, most tributary flows are not likely to reach the Rio Grande, the irrigation canals and laterals, or the drains. Instead, tributary flow usually either infiltrates through the streambed along the course of the arroyos, is transpired by vegetation, or evaporates from water surfaces along the arroyo course or in detention basins on the upstream side of the floodcontrol dams. Tributary streamflow was measured historically by the USGS at the Las Cruces Arroyo near Las Cruces, New Mexico (USGS 08363600; period of record October 1958September 1966; fig. 8) and is measured at present by EBID at four gages that record the flow entering the Rio Grande Valley: Over Shot Arroyo (period of record 2011-16), Picacho Arroyo (period of record 2009-16), Placitas Arroyo (period of record 2008-16), and Rincon Arroyo (period of record 2008-16). Streamflow from the remainder of the tributary canyons is unmeasured, except for occasional historical field and peakflow measurements collected by the USGS.

\section{Groundwater}

The following sections summarize the general components of the movement and use of groundwater in the TRG region. This includes the distribution of groundwater flows, development of groundwater for agriculture, municipal and industrial supply, and domestic use.

\section{Groundwater Flow}

Groundwater from the surrounding uplands flows through the Santa Fe Group aquifers toward the Rio Grande and generally from northwest to southeast in the Quaternary alluvium aquifer of the RGV (fig. $9 \mathrm{~A}$ ) toward the distal ends of the Rincon Valley and the Mesilla Basin. Water-table contours from January 1976 for the Rincon Valley (Wilson and others, 1981) indicated relatively steep horizontal hydraulic gradients from the Black Range to the east and southeast and from the Caballo Mountains toward the west and southwest. The contours from Wilson and others (1981) were used for initial water levels only in the far northern part of RGTIHM, where water-level data prior to 1976 were mostly confined to the modern-day alluvial valley along the Rio Grande. The contours from Wilson and others (1981) provided a more regional interpretation of water levels for this area in the RGTIHM, including areas outside the alluvial valley, than could be interpreted from data prior to 1976. Areas outside the alluvial valley were expected to have a lagged response to increased pumping stresses imposed in the alluvial valley beginning in the 1950s. In addition, the initial heads derived from these contours were refined during model calibration.

The structurally high pre-Santa Fe Group basement rocks and faulting associated with the constriction of the Rio Grande Valley around Selden Canyon (figs. $3 A, B$ ) are likely to act as a barrier to horizontal groundwater flow and to drive vertical flow from deep groundwater flowpaths in the Santa Fe Group toward the surface at the distal end of the Rincon Valley (Sweetkind, 2017). This type of structural fault control along with the uplifts in the Mesilla and Conejos-Médanos Basins compartmentalize the TRG region into multiple groundwater subregions. Early (1947) watertable contours for Doña Ana County from Conover (1954) indicated relatively steep horizontal hydraulic gradients from the Robledo Mountains, Sleeping Lady Hills, and Aden Hills toward the southeast and from the Doña Ana and Organ Mountains toward the southwest (fig. 9A). Although Conover (1954) did not extend contours to the Conejos-Médanos Basin, projection of contours from the Mesilla Basin indicated that groundwater historically flowed at an unquantified rate from the Conejos-Médanos Basin to the Mesilla Basin near the El Paso narrows (fig. 9A). 


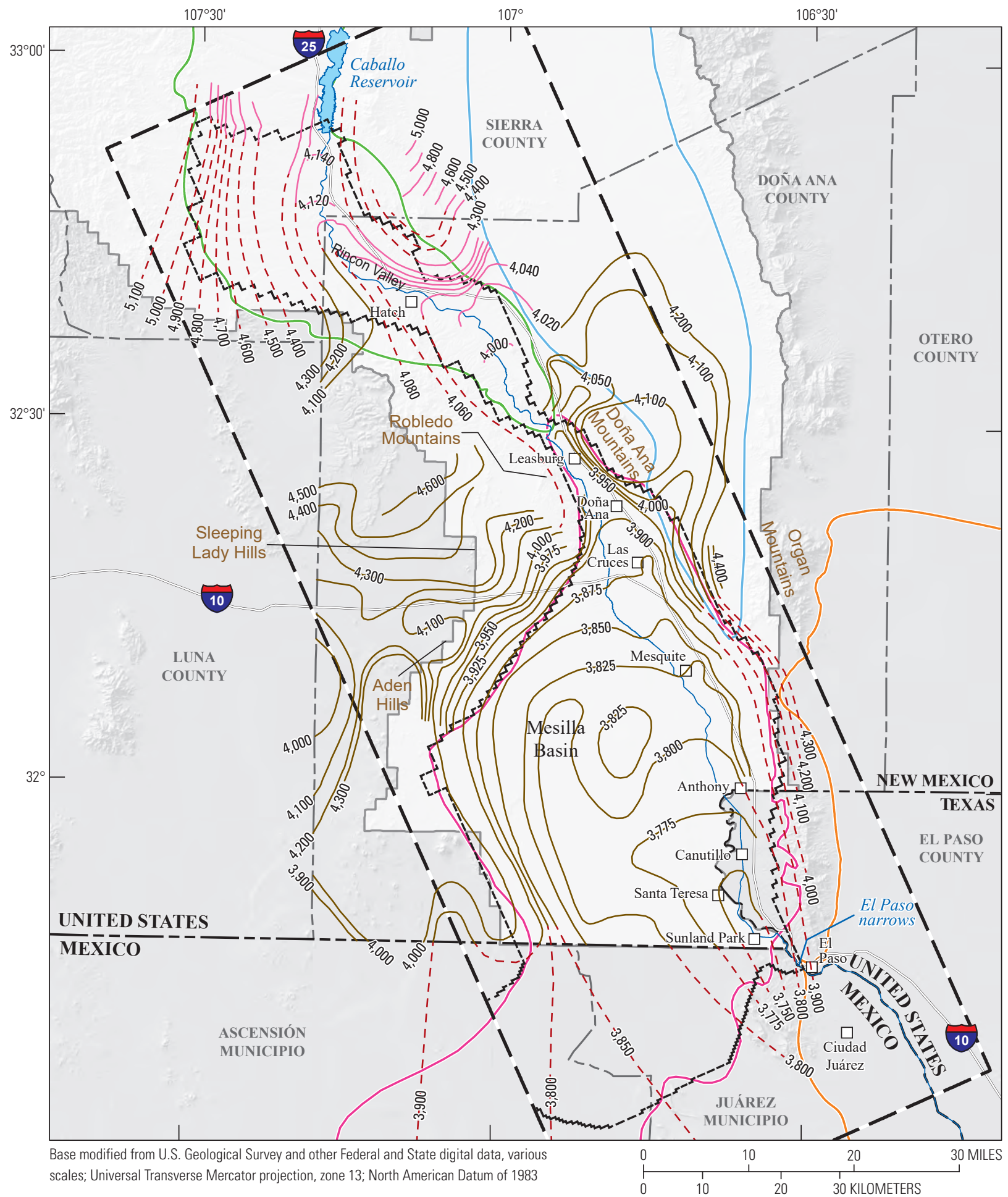

EXPLANATION

\section{Groundwater basins}

Hueco (Driscoll and Sherson, 2016)

Palomas (Driscoll and Sherson, 2016)

Jornada del Muerto (after Witcher and others, 2004)

Mesilla and Conejos-Médanos (after Sheng and others, 2013)
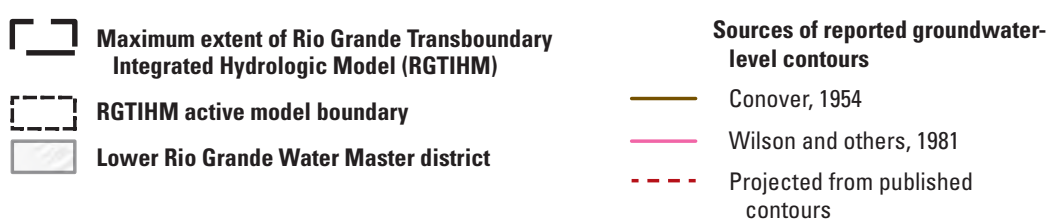

Figure 9. Compilation of reported groundwater levels for the Transboundary Rio Grande, New Mexico, Texas, and Mexico: $A$, initial water levels; $B$, mean non-growing season (November through April) 2008-09 or 2010-11 in the Rio Grande alluvium in the Rincon Valley and Mesilla Basin; and C, mean non-growing season (November through April) 2008-09 in the Santa Fe Group in the Rincon Valley, mean non-growing season (November through April) 2010-11 in the Santa Fe Group in the Mesilla Basin, and 2010 in the Santa Fe Group in the Conejos-Médanos Basin. 
B

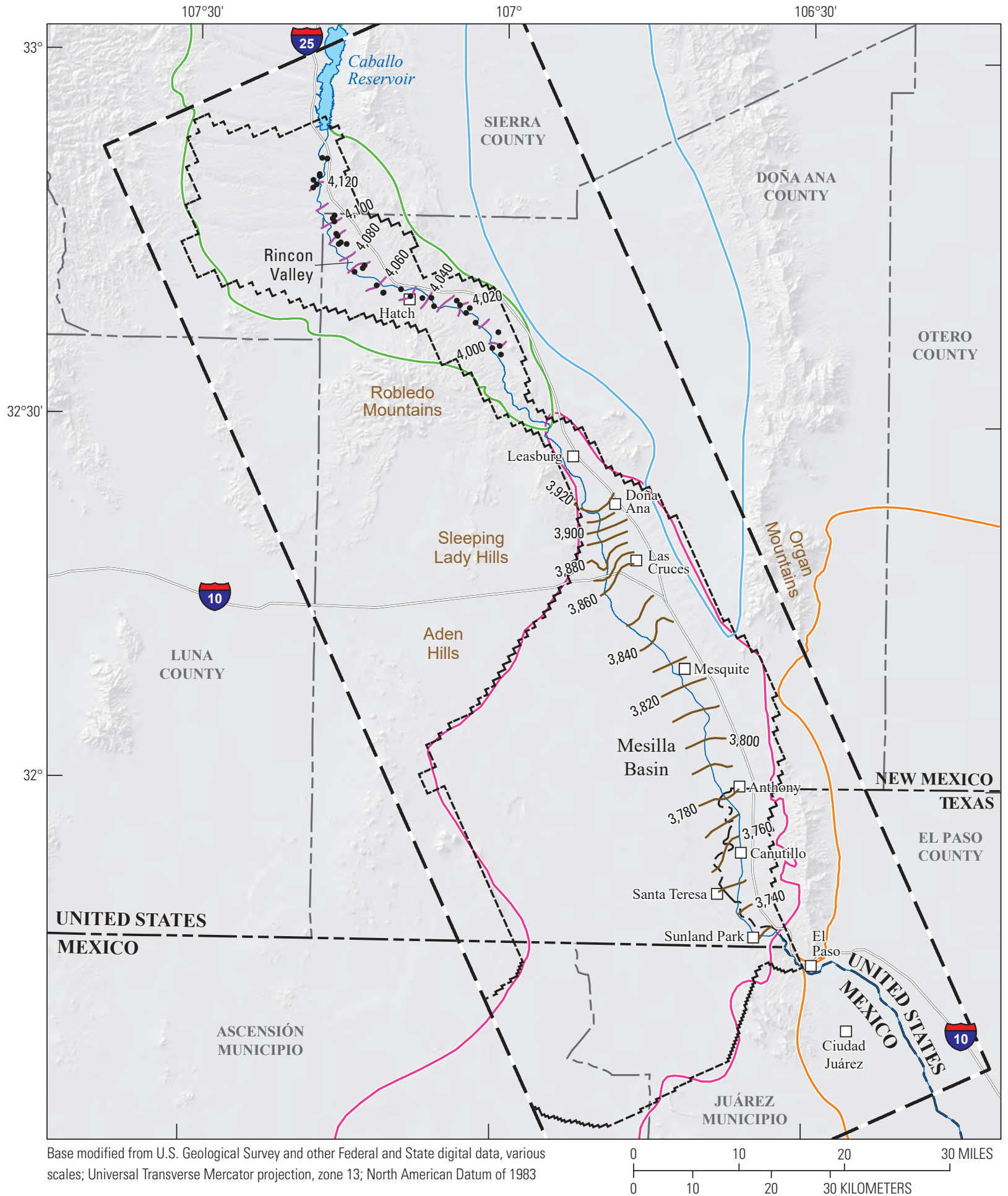

\section{EXPLANATION}

Groundwater basins

Hueco (Driscoll and Sherson, 2016)

Palomas (Driscoll and Sherson, 2016)

Jornada del Muerto (after Witcher and others, 2004)

Mesilla and Conejos-Médanos (after Sheng and others, 2013)
Rio Grande alluvium groundwater-level elevation (November through April)

2008-09 or 2010-11

2010-11 (Teeple, 2017)

$\Gamma$ Maximum extent of Rio Grande Transboundary Integrated Hydrologic Model (RGTIHM)
[-_- RGTIHM active model boundary

- Wells with greater than $\mathbf{5 0}$ percent of its screen completed in the river channel (Quaternary alluvium) hydrostratigraphic unit used for water-level contours, in the Rincon Valley

Figure 9. - Continued 
c

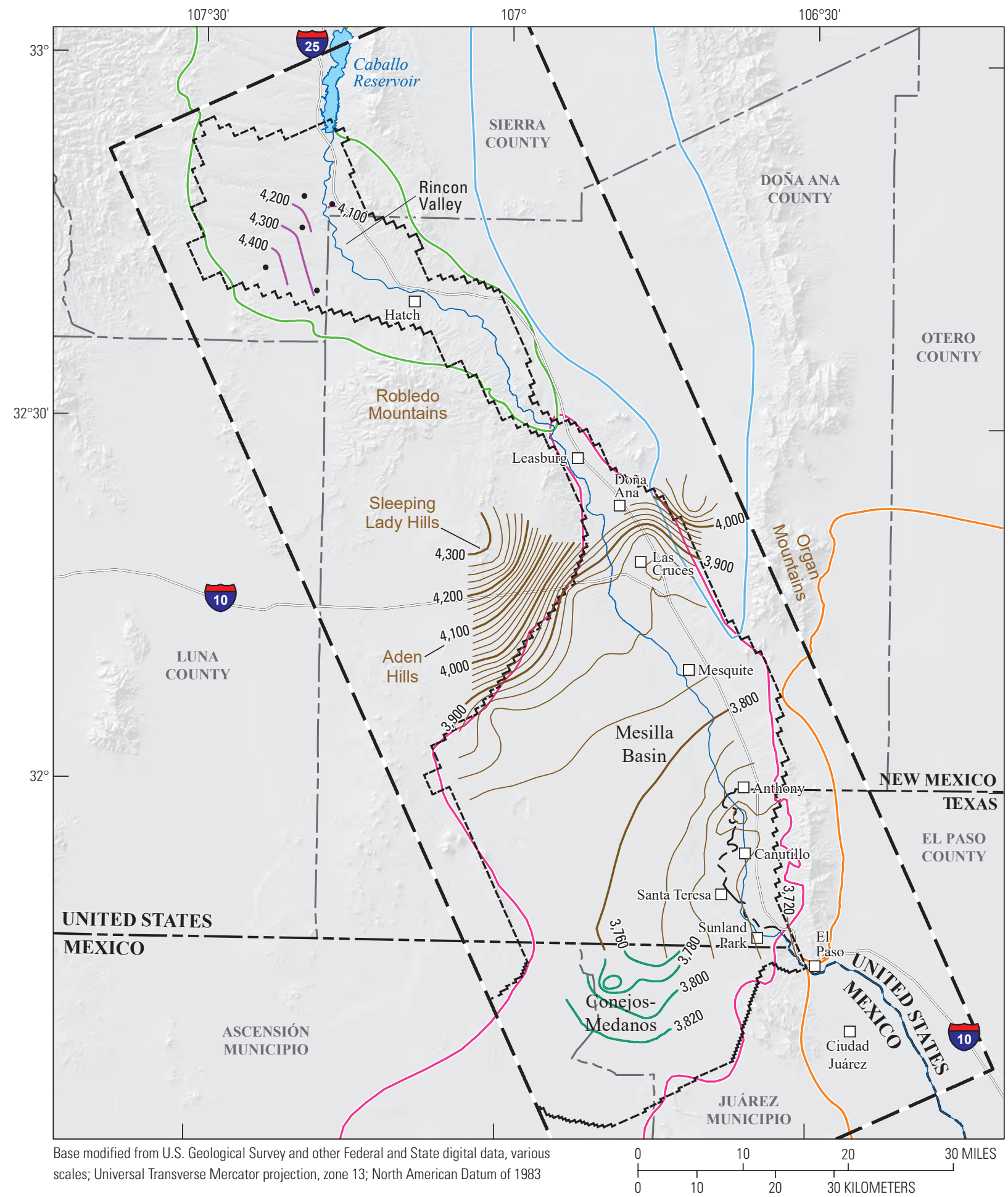

\section{Groundwater basins}

Hueco (Driscoll and Sherson, 2016)

Palomas (Driscoll and Sherson, 2016)

Jornada del Muerto (after Witcher and others, 2004)

Mesilla and Conejos-Médanos (after Sheng and others, 2013)

\section{EXPLANATION}

Santa Fe Group groundwater-level elevation

Mean winter (November through April 2008-09, contour interval is 100 feet)

Mean winter (November through April 2010-11; contour interval is 20 feet; Teeple, 2017)

2010 - contour interval is 20 feet (modified from International Boundary and Water Commission [IBWC, 2011])

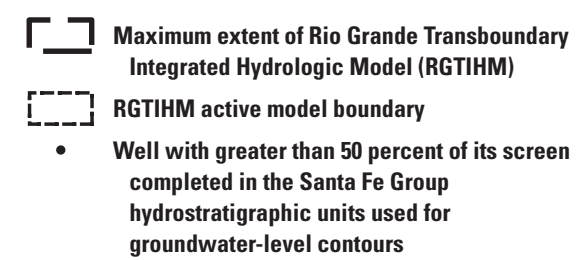

$\Gamma$ Maximum extent of Rio Grande Transboundary Integrated Hydrologic Model (RGTIHM) RGTIHM active model boundary completed in the Santa Fe Group hydrostratigraphic units used for groundwater-level contours

Figure 9. - Continued 
Under developed conditions, pumpage has periodically exceeded recharge and has altered groundwater flows in response to pumpage and related storage depletion, resulting in regional cones of depression (or drawdown) in groundwater levels in the central parts of the Mesilla Basin (figs. 9B, C). Groundwater levels in these persistent depressions also show additional seasonal decline in response to a combination of agricultural plus municipal and industrial pumpage. November 2010-April 2011 groundwater-level contours for the Santa Fe Group aquifers in the Mesilla Basin indicated flow from the north and northwest to the south and southeast, with cones of depression near Las Cruces, New Mexico, and Canutillo, Texas (Teeple, 2017). Relatively steep horizontal hydraulic gradients with groundwater flow oriented toward the interior of the Mesilla Basin were observed in the Organ and Robledo Mountains and Sleeping Lady Hills (Teeple, 2017). Teeple (2017) noted that relatively lower horizontal hydraulic gradients near the El Paso narrows supported geophysical and geochemical interpretations that the El Paso narrows is a region of upwelling of deep groundwater. In addition, Teeple (2017) noted that the buried mid-basin uplift in the Mesilla Basin west of the alluvial Rio Grande Valley compartmentalizes groundwater flow in the Santa Fe Group.

Inflow as recharge to groundwater comes from infiltration of precipitation, streamflow, and irrigation. Additional recharge comes from underflow across the southern boundary of the TRG region in Santa Fe Group sediments from the southern part of the Conejos-Médanos Basin, as indicated by groundwater-level monitoring wells along the boundary of the RGTIHM (International Boundary and Water Commission, 2011). Additional, likely small, unquantified components of groundwater underflow to the TRG region are associated with leakage from Caballo Reservoir under Caballo Dam and underflow from the Jornada del Muerto Basin to the northeast and the Hueco Bolson to the east. Hawley and Kennedy (2004) postulated that groundwater underflow from the Jornada del Muerto Basin to the Rincon Valley part of the Palomas Basin flows between San Diego Mountain and the Rincon Hills, represented in the RGTIHM at the intersection of Rincon Arroyo with the active model boundary (figs. $1 A$, $B, 2 A)$. In addition, Hawley and Kennedy (2004) indicated there was no evidence of meaningful underflow from the Hueco Bolson to the Mesilla Basin through Fillmore Pass between the Organ and Franklin Mountains (fig. 2A). Outflow from groundwater includes pumpage, base flow or rejected recharge along streams, evapotranspiration, and subsurface underflow to the southeast from the alluvial deposits along the Rio Grande corridor at El Paso narrows into the El Paso Valley (figs. 1A, C, 2A, 8). Hawley and Kennedy (2004) noted that groundwater outflow from the Mesilla Basin to the El Paso Valley part of the Hueco Bolson was mostly hindered by the bedrock high at El Paso narrows.

\section{Groundwater Development for Agriculture}

Development of groundwater for irrigation in the TRG region began in earnest in the early 1950s owing to drought conditions that resulted in reduced surface-water supplies (S.S. Papadopulos and Associates, Inc., 2007; Valdes and Maddock, 2010; fig. 7A). The number of irrigation wells in the Rincon Valley and Mesilla Basin increased from 11 at the end of 1946 to 70 by early 1948 to over 1,000 by 1957 (Conover, 1954; S.S. Papadopulos and Associates, Inc., 2007). Recent estimates indicated that there are over 1,700 active irrigation wells in the Mesilla Valley (S.S. Papadopulos and Associates, Inc., 2007). The NMOSE lists about 3,744 wells in the New Mexico part of the active RGTIHM area (Rincon Valley and Mesilla Basin) used for irrigation (fig. 10A), but detailed information on the status of these wells is scarce, and thus the total number of active irrigation wells in the TRG is difficult to determine (Hayes, 2015; New Mexico Office of the State Engineer, 2015). The Texas Water Development Board (TWDB) lists about 215 agricultural wells in the Texas part of the active RGTIHM area (fig. 10A), but again, the total number of active irrigation wells is difficult to determine (Submitted Drillers Reports Database, 2015; Texas Water Development Board, 2015b).

Well-specific records of historic and recent pumpage for agricultural wells are scarce and difficult to obtain, but in 1975 the NMOSE began compiling estimates of annual agricultural groundwater withdrawals by county in 5-year intervals (Sorensen, 1977, 1982; Wilson, 1986, 1992; Wilson and Lucero, 1997, 1998; Wilson and others, 2003; Longworth and others, 2008, 2013). These NMOSE estimates of agricultural pumpage for Doña Ana County along with additional NMOSE estimates in the NMOSE-CIR spreadsheet for EBID pumpage were used in the RGTIHM as selected observations of annual composite pumpage, as Doña Ana County composes the majority of the active RGTIHM area. In addition, the NMOSE Lower Rio Grande Water Master tabulated annual agricultural groundwater withdrawals for the Lower Rio Grande Water Master District in New Mexico beginning in 2009 on 1-year intervals (Stangl, 2010; Serrano, 2014, 2015). Also, the NMOSE provided estimates of monthly agricultural groundwater pumpage from 1938 through 2010 for groundwater-only regions in the four agricultural service areas in New Mexico included in the TRG modeling (S.S. Papadopulos and Associates, Inc., 2007; P. Barroll, New Mexico Office of the State Engineer, written commun., 2011; Ritchie and others, 2018). These estimates of annual agricultural pumpage in New Mexico were used as observations during manual and automated parameterestimation calibration. Estimates of agricultural pumpage in the Texas part of the TRG were not available. 
A

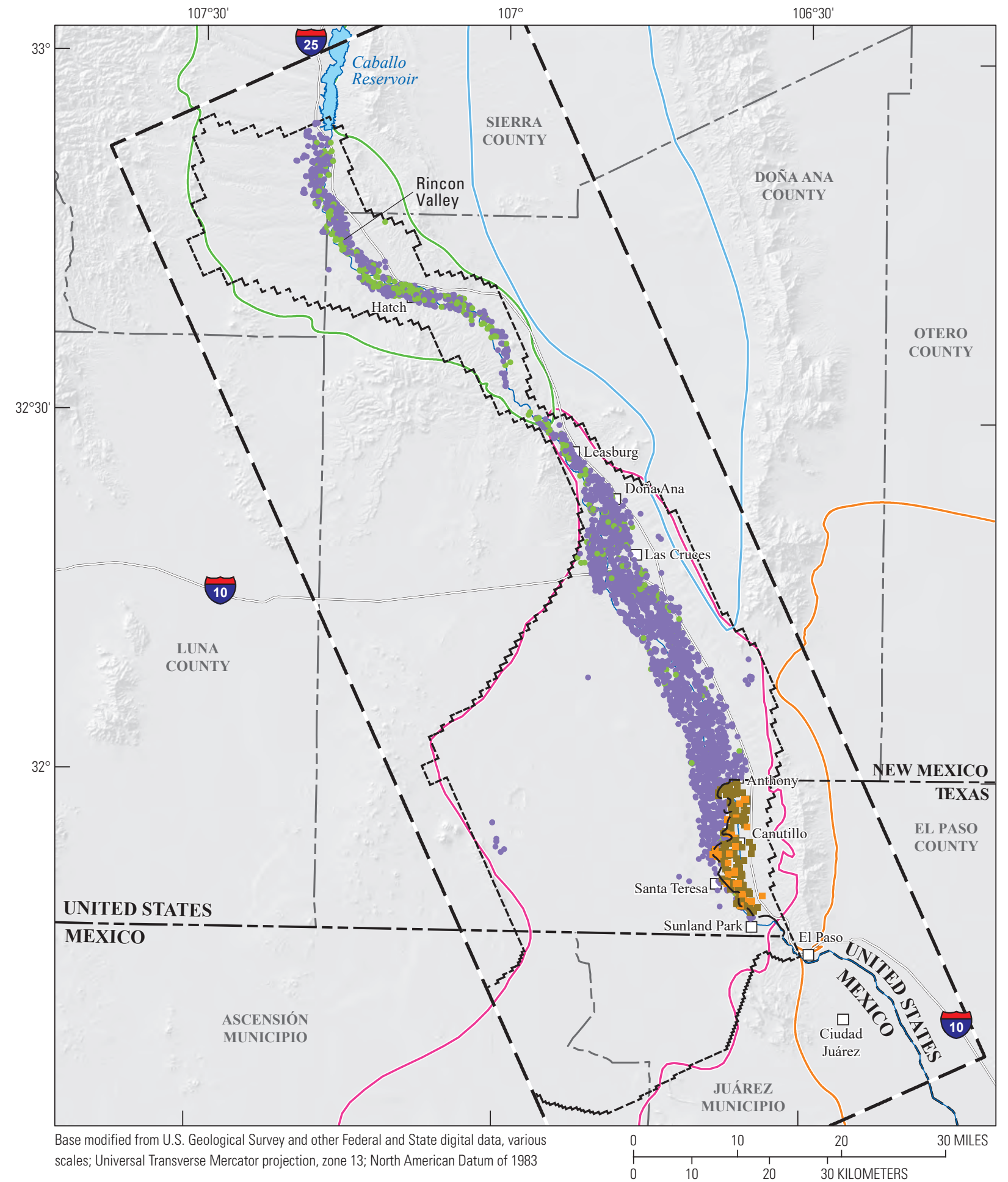

\section{EXPLANATION}

Groundwater basins

Hueco (Driscoll and Sherson, 2016)

Palomas (Driscoll and Sherson, 2016)

Jornada del Muerto (after Witcher and others, 2004)

Mesilla and Conejos-Médanos (after Sheng and others, 2013)

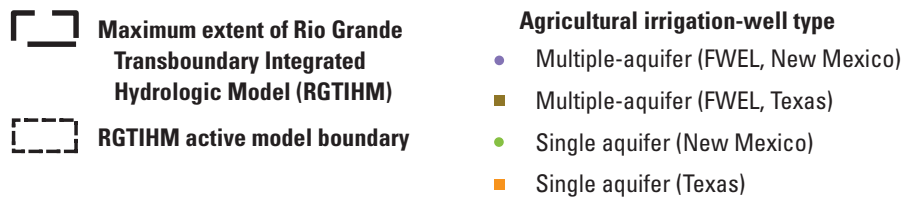

Figure 10. Rio Grande Transboundary Integrated Hydrologic Model (RGTIHM) well distribution in the Transboundary Rio Grande, New Mexico, Texas, and Mexico, by groups of $A$, agricultural; $B$, urban, municipal, and industrial supply; and $C$, domestic wells. 


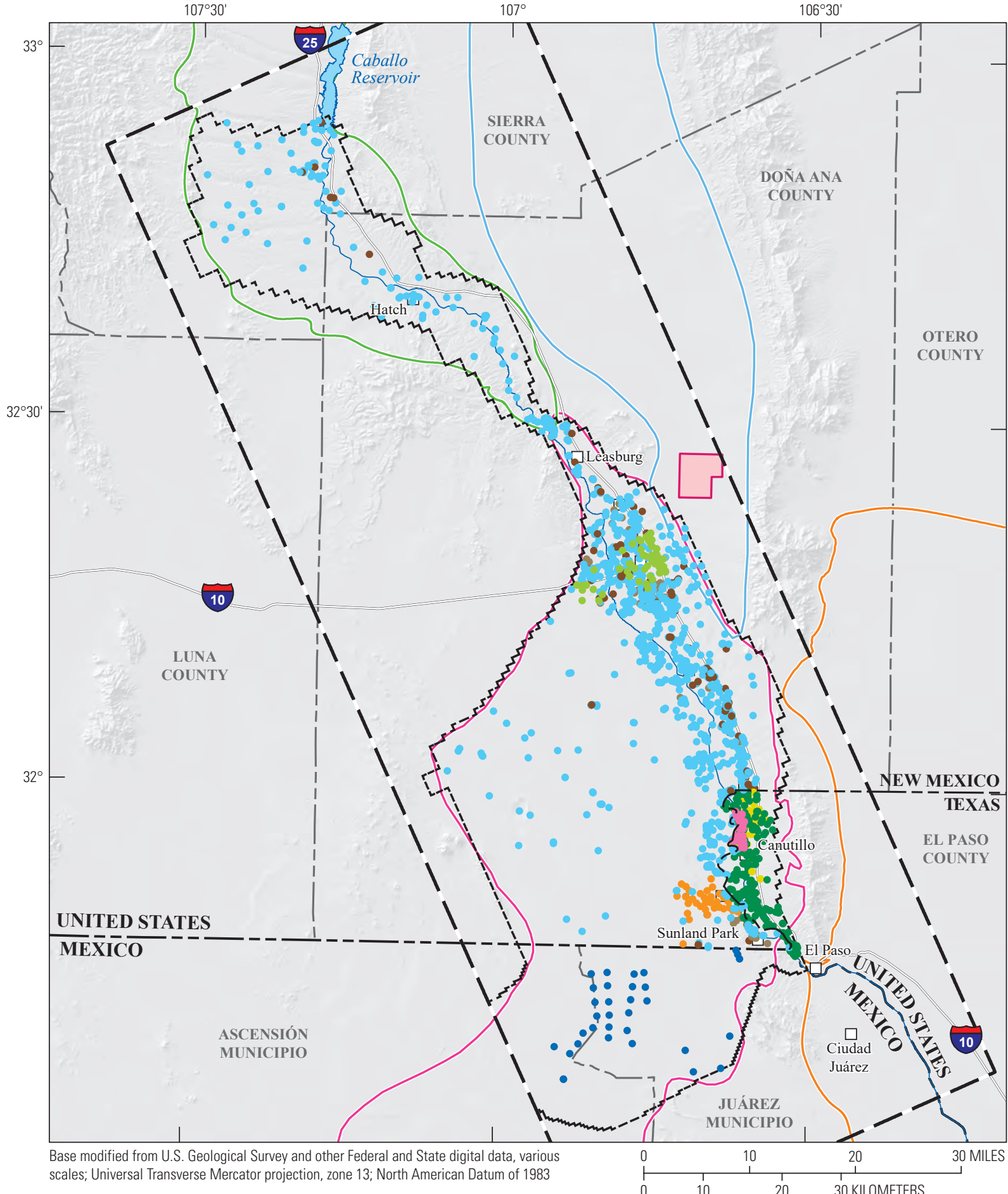

Groundwater basins

Hueco (Driscoll and Sherson, 2016)

Palomas (Driscoll and Sherson, 2016)

Jornada del Muerto (after Witcher and others, 2004)

Mesilla and Conejos-Médanos (after Sheng and others, 2013)

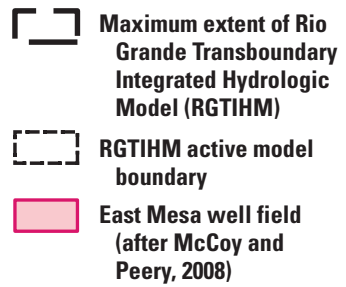

EXPLANATION

New Mexico
Las Cruces (LCNM)
New Mexico Office of the State Engineer
Municipal and Industrial Supply
(NMOSE_Mnl)
- Santa Teresa, New Mexico (NMST)
- Other New Mexico wells (ONM)
- Other New Mexico extra wells (ONMXA)

Texas

- Other Texas wells (OTX)

- Canutillo wellfield (TXCN)

- Texas Water Development Board (TXWDB)

Mexico

- Mexico Batería and other supply wells (MX)

Figure 10. - Continued 
C

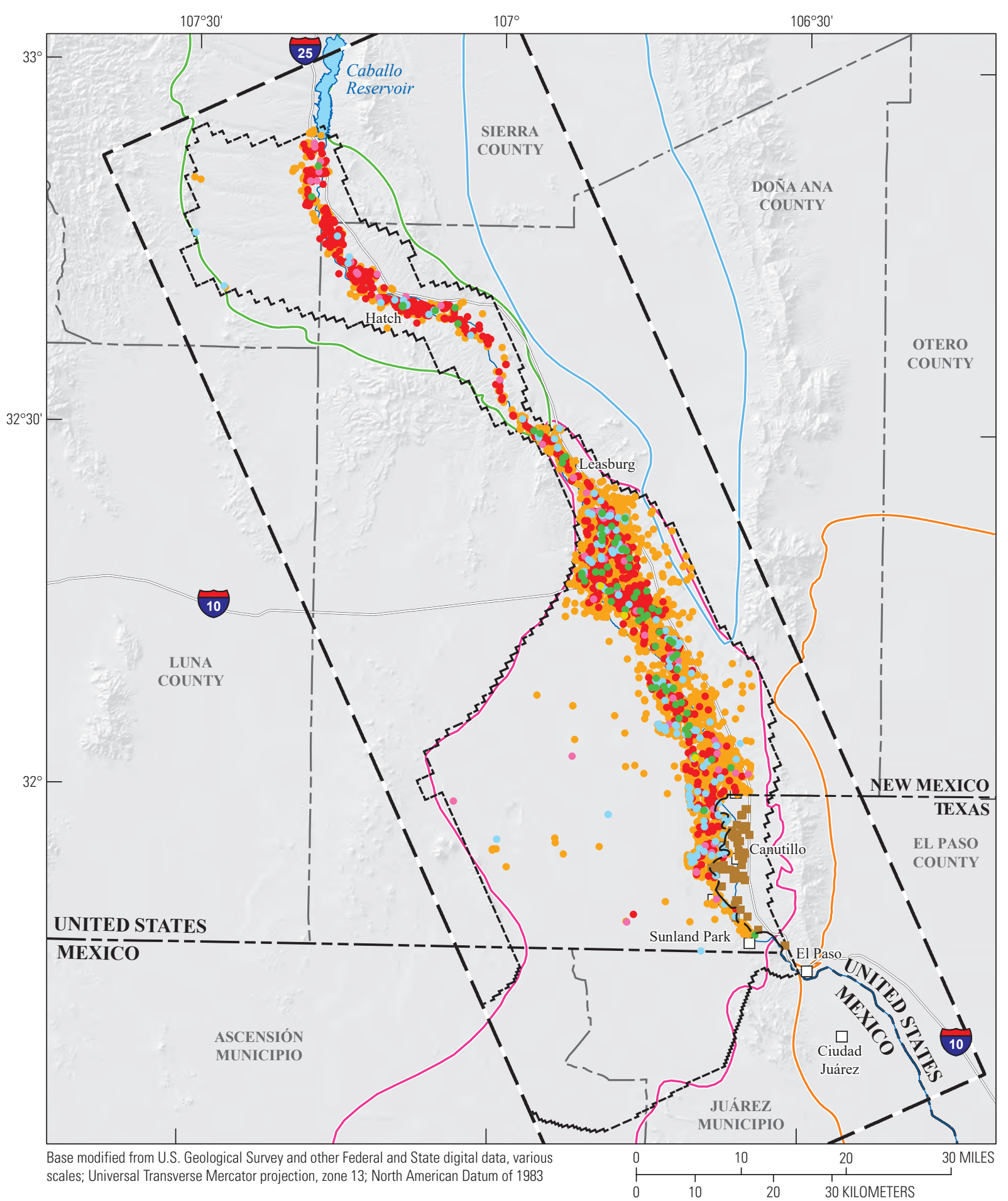

EXPLANATION

Groundwater basins

Hueco (Driscoll and Sherson, 2016)

Palomas (Driscoll and Sherson, 2016)

Jornada del Muerto (after Witcher and others, 2004)

Mesilla and Conejos-Médanos (after Sheng and others, 2013)

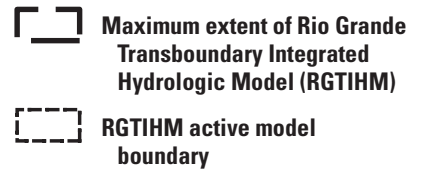

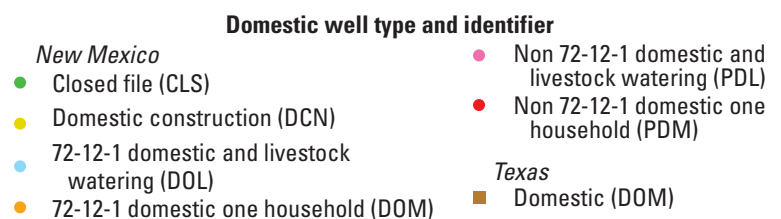

Figure 10. - Continued 
Estimates of agricultural pumpage in the TRG region showed a trend of increasing groundwater withdrawals, with interannual fluctuations that were likely due in part to climate cycles. Agricultural pumpage in Doña Ana County was about 73,000 acre-feet in 1975 during the tail end of the 1951-78 drought, decreased to about 57,000-58,000 acre-feet during the wet years of the $1980 \mathrm{~s}$, and increased to about 95,000 acre-feet during the drought years of the late 1990s to early 2000s (Sorensen, 1977, 1982; Wilson, 1986; Wilson and Lucero, 1997, 1998; Wilson and others, 2003). The NMOSE county and Lower Rio Grande Water Master estimates indicated an approximate doubling of agricultural withdrawals in the Lower Rio Grande Water Master District from about 140,000 acrefeet in 2010 to about 280,000 acre-feet in 2011 (Longworth and others, 2013; Serrano, 2014). The NMOSE estimates for groundwater-only regions also showed a distinct increase in pumpage during the early 2000 s, with a peak in 2004 at about 86,000 acre-feet, over twice the estimate in 2000 at about 31,000 acre-feet. In 2014, the Lower Rio Grande Water Master estimated agricultural pumpage in the Lower Rio Grande Water Master District at about 250,000 acre-feet (Serrano, 2015).

\section{Groundwater Development for Municipal and Industrial Supply}

Municipal and industrial pumping in the TRG region has increased steadily since the 1940s, peaking in New Mexico around 2005 at about 60,000 acre-feet (acre-ft; fig. 11 A) and again in 2009 at about 64,000 acre-ft (fig. 11B). Increasing population in the region (fig. $7 B$ ) has resulted in this increased development of groundwater for domestic and municipal and industrial water supply. In Texas, pumpage increased through the 1970s, fell off in the 1980s, and then increased again, peaking around the year 2000 at about 28,000 acre-feet. Municipal pumpage in the Mexico well field began in 2010, and the total pumpage has continued to increase (fig. 11B).

The largest municipal and industrial users of groundwater in the TRG region are the city of Las Cruces (LCNM, fig. 10B), the City of El Paso (TXCN, fig. 10B), and the Camino Real Regional Utility Authority, New Mexico, which supplies Santa Teresa and Sunland Park (NMST, fig. 10B; S.S. Papadopulos and Associates, Inc., 2007). Las Cruces Utilities has an unadjudicated annual groundwater-use claim of 21,869 acre-feet (Camp Dresser and McKee, Inc., 2008; McCoy and Peery, 2008) and permits to develop annual groundwater rights of 15,200 acre-feet in the Mesilla and Jornada del Muerto Basins (McCoy and Peery, 2008). Las Cruces Utilities supplies the majority of customers through the RGV and West Mesa Well Fields (LCNM, fig. 10B) in the Mesilla Basin and the East Mesa Well Field (fig. 10B) in the Jornada del Muerto Basin. City of Las Cruces municipal pumping began in the 1920s (Petronis and others, 2006). Wells in the Valley Well Field have screen depths ranging from about 400 to more than 1,000 feet below land surface (McCoy and Peery, 2008). Wells in the West Mesa Well Field began operation in the early 1980s and have screen depths ranging from about 500 feet to more than 1,000 feet below land surface (McCoy and Peery, 2008; Hayes, 2015; New Mexico Office of the State Engineer, 2015).
The city of El Paso through El Paso Water Utilities began pumping from a well field near Canutillo, Texas, in 1952, providing water to the greater El Paso County area (Gates and others, 1984; S.S. Papadopulos and Associates, Inc., 2007; Hutchison, 2008). Initial groundwater withdrawals were entirely from a shallow aquifer zone, generally less than 200 feet below land surface (White, 1983; Gates and others, 1984; S.S. Papadopulos and Associates, Inc., 2007). In 1956, El Paso Water Utilities began to develop the intermediate (generally from 200 to 500 feet below land surface) and deep (generally greater than 500 feet below land surface) aquifer zones (White, 1983; Gates and others, 1984; S.S. Papadopulos and Associates, Inc., 2007). Annual groundwater pumping at the Canutillo well field increased steadily through the $1950 \mathrm{~s}$, from about 3,000 acre-feet in 1952 to about 15,000 acre-feet in 1960, and has remained at about 15,000 to 25,000 acre-feet since then (White, 1983; Gates and others, 1984; Hutchison, 2008). Extractions from the shallow aquifer zone have decreased during the history of the well field, with only 107 acre-feet pumped from the shallow aquifer in 2002 (S.S. Papadopulos and Associates, Inc., 2007).

Developments of Santa Teresa and Sunland Park in southern Doña Ana County along the New Mexico-Texas border are provided water supply by Camino Real Regional Utility Authority through a network of groundwater wells in the Mesilla Basin drilled in the early 1970s (S.S. Papadopulos and Associates, Inc., 2007). Well screens range from about 100 feet below land surface to over 500 feet below land surface (Hayes, 2015; New Mexico Office of the State Engineer, 2015). Annual groundwater withdrawal has increased steadily during the history of the well field from 2,000 acre-feet to more than 5,600 acre-feet in 2003 (S.S. Papadopulos and Associates, Inc., 2007).

The water-supply well field operated by the Ciudad Juárez Municipal Water and Sanitation Board south of the international border in the Conejos-Médanos Basin began withdrawals of a small supplemental supply for Ciudad Juárez in mid-May 2010 (International Boundary and Water Commission, 2011). The well field supplies water to Ciudad Juárez through the Conejos-Médanos Aqueduct (International Boundary and Water Commission, 2011). Although detailed monthly pumpage on a well-by-well basis remains unavailable, the International Boundary and Water Commission (2011) reported about 13,000 acre-feet of groundwater was pumped by the well field from mid-May through December 2010.

A number of smaller utilities supply groundwater to users in the TRG, including the Doña Ana Mutual Domestic Water Consumers Association; Moongate Water Company; Jornada Water Company; Transboundary Rio Grande Public Water Works Authority; the town of Mesilla; the city of Anthony; and NMSU, New Mexico; and the town of Anthony, Texas (S.S. Papadopulos and Associates, Inc., 2007; Camp Dresser and McKee, Inc., 2008). In the active RGTIHM area, about 1,414 and 427 wells were identified in New Mexico and Texas, respectively, for municipal and industrial use (fig. 10B; Ritchie and others, 2018), and 33 municipal and industrial use wells were identified in the Chihuahua, Mexico, part of the active RGTIHM area (International Boundary and Water Commission, 2011). 
$\boldsymbol{A}$
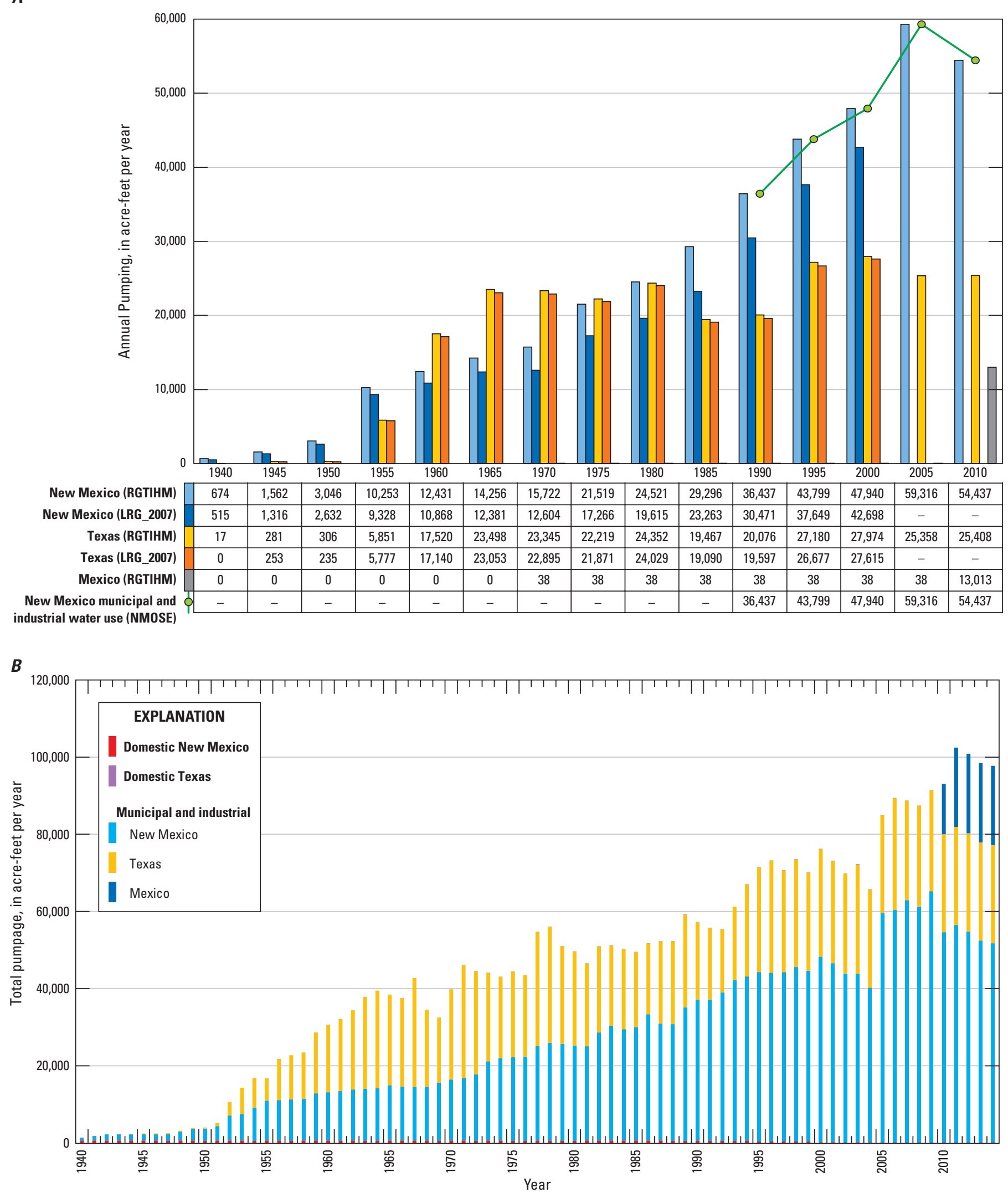

Figure 11. Estimated groundwater pumpage in the Transboundary Rio Grande, New Mexico, Texas, and Mexico: $A$, New Mexico Office of the State Engineer (NMOSE) reported municipal and industrial pumpage used for the Rio Grande Transboundary Integrated Hydrologic Model (RGTIHM) and the Lower Rio Grande-2007 model (LRG_2007; S.S. Papadopulos and Associates, Inc., 2007) and the New Mexico Office of the State Engineer; and $B$, from municipal and industrial and from domestic wells. 


\section{Groundwater Development for Domestic Use}

Domestic-well pumpage estimates for Doña Ana County compiled by the NMOSE in 5-year intervals from 1990 to 2010 (Wilson, 1992; Wilson and Lucero, 1997; Wilson and others, 2003; Longworth and others, 2008, 2013) were used to simulate domestic groundwater withdrawals in the RGTIHM (fig. 10C). Domestic pumpage estimates from these sources decreased from about 2,300 acrefeet in 1990 to about 650 acre-feet in 2010. Domestic use in New Mexico was grouped in six categories that included "closed files" (CLS), "domestic construction" (DCN), wells under the New Mexico statue 72-12-1 used for domestic and livestock (DOL), wells used only for one-household (DOM), wells not under statute 72-12-1 for these same two categories (PDL, PDM; fig. 10C). The 2006 New Mexico Statutes - Section 72-12-1 defines "Underground waters declared to be public; applications for livestock watering, domestic and temporary uses of water." The NMOSE listed about 8,817 domestic wells in the New Mexico part of the active RGTIHM area (fig. 10C), but detailed information about the status of these wells was scarce, and thus the total number of active domestic wells in the TRG was difficult to determine (Hayes, 2015; New Mexico Office of the State Engineer, 2015; Ritchie and others, 2018). The TWDB listed 60 domestic wells in the Texas part of the active RGTIHM area (fig. 10C), but again, the total number of active domestic wells was difficult to determine (Texas Water Development Board, 2015a,b,c; Ritchie and others, 2018).

\section{Model Development}

Two hydrologic models were developed for the TRG region (fig. 12). One is a landscape-based water-balance model, referred to as the Transboundary Rio Grande Watershed Model (TRGWM) that was developed by using the Basin Characterization Model (BCM; Flint and Flint, 2012; Flint and others, 2012; Thorne and others, 2012), and represents the watersheds in the mountains surrounding the valley. The second model, the Rio Grande Transboundary Integrated Hydrologic Model (RGTIHM), is an integrated hydrologic model that was developed using the MODFLOWOne-Water Hydrologic Flow Model version 2 (MF-OWHM2; Hanson and others, 2010, 2014b; Boyce and others, 2020) to simulate the use and movement of water in its active model region. Simulations made by the TRGWM model provided input to the RGTIHM model, in particular, the runoff estimates for all of the ungaged ephemeral streams and arroyos flowing into the RGTIHM domain at the tributary boundary inflow locations (fig. 12).

\section{Water-Balance Model-Transboundary Rio Grande Watershed Model}

\author{
Estimation of Recharge and Runoff
}

The TRGWM uses the Basin Characterization Model $(\mathrm{BCM})$, which is a grid-based, regional water-balance model that can provide process-based estimates of recharge and runoff for ungaged locations (figs. $8 A, B, 12 A$ ). The estimate of recharge and runoff for water year 1993, one of the wettest of the wet years, shows relatively little annual recharge and runoff except in a few subwatersheds along the eastern boundary of the RGTIHM (fig. 12B). Although there is occasional flooding from storm-related tributary runoff, such as the 2006 flooding of the town of Hatch, New Mexico, the synoptic events that contribute to occasional extreme runoff events and related "wild water" are relatively short lived and infrequent during the historical period of simulation. The water-balance estimates were performed at a monthly time step and evenly distributed across square grid cells $886 \mathrm{ft}$ on each side (270 meters to provide estimates of monthly runoff for use as input to the RGTIHM. The TRGWM inputs include (1) topography (U.S. Geological Survey, 2013a-f), soil properties from the SSURGO database (Natural Resources Conservation Service, 2009a-c), and geology (Sweetkind, 2017) datasets, all of which did not change with time; (2) monthly gridded precipitation and temperature datasets that were spatially downscaled (Flint and Flint, 2012) from PRISM (Parameter-Elevation Regressions on Independent Slopes Model, PRISM; Daly and others, 2008) 2,625-ft (800meter) transient dataset; and (3) monthly gridded potential evapotranspiration (PET) developed by the TRGWM.

The monthly gridded PET is the average for a month of PET estimated using an hourly energy-balance calculation that is based on solar radiation, air temperature, and the Priestley-Taylor equation (Flint and Childs, 1987) to calculate potential evapotranspiration (Flint and Childs, 1991). Clear sky PET is calculated using a solar-radiation model that incorporates seasonal atmospheric transmissivity parameters and site-specific parameters of slope, aspect, and topographic shading. Hourly PET is averaged to a monthly rate, and cloudiness corrections are made using cloudiness data from the National Renewable Energy Laboratory (2014). Modeled PET for the southwestern United States was calibrated to the measured PET rates from California Irrigation Management Information System (California Department of Water Resources, 2007) and University of Arizona Meteorological Network (2012) stations. The Natural Resources Conservation Service (NRCS) soil texture and organic matter data (Natural Resources Conservation Service, 2005) were used to calculate soil properties (porosity, water content at field capacity, and wilting point) using equations from Saxton and Rawls (2006). 


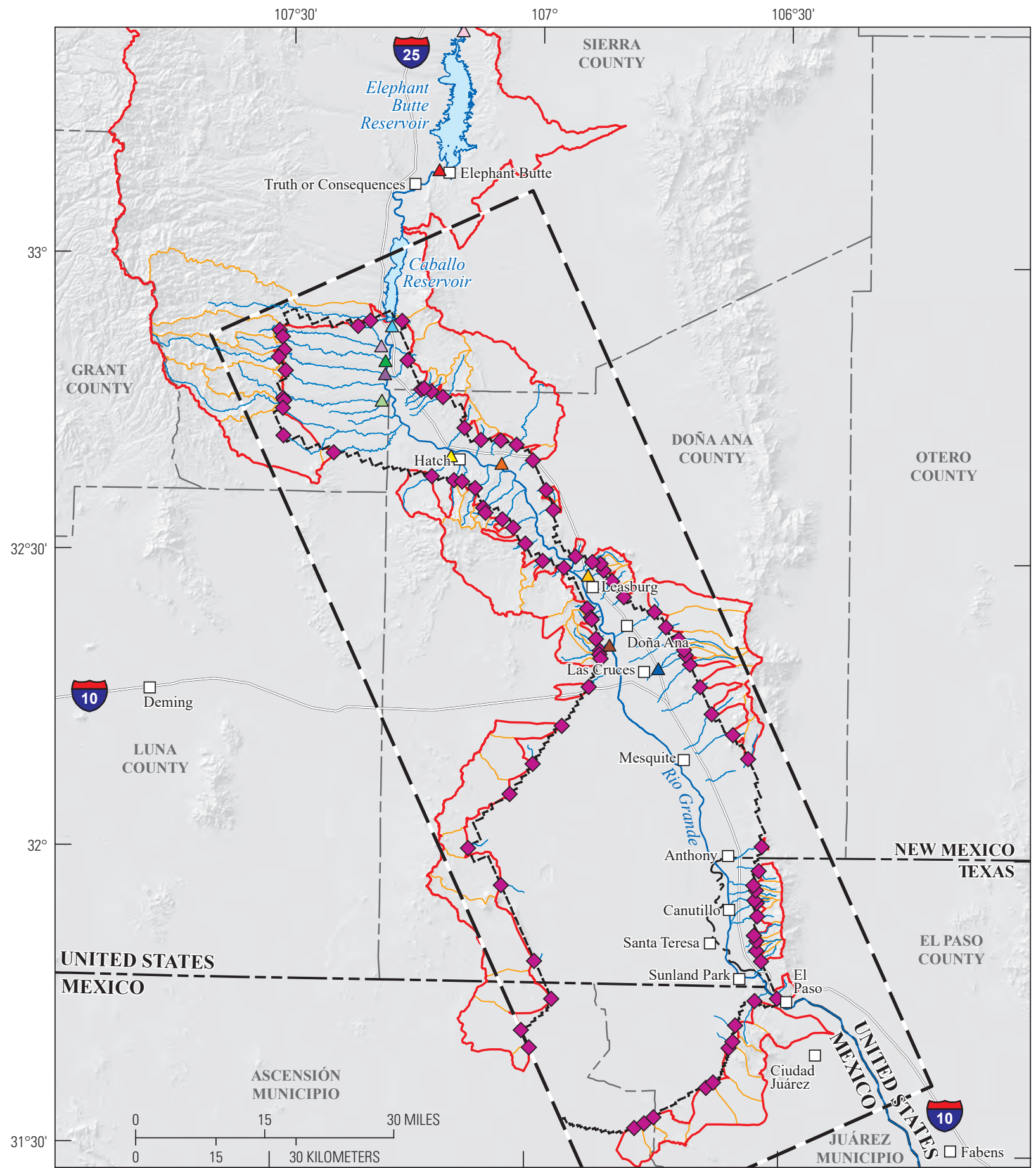

Base modified from U.S. Geological Survey and other Federal and State digital data, various scales; Universal Transverse Mercator projection, zone 13; North American Datum of 1983

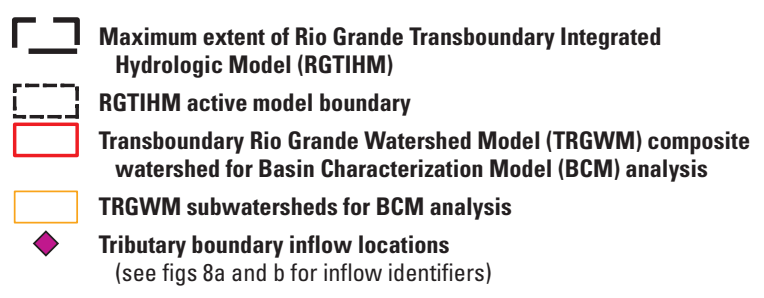

\section{EXPLANATION}

Elephant Butte Irrigation District (EBID) or U.S. Geological Survey (with USGS station ID) stream gage

$\triangle$ Rio Grande at Narrows in Elephant Butte Reservoir (08359500)

$\triangle$ Rio Grande below Elephant Butte Dam (08361000)

$\triangle$ Rio Grande below Caballo Dam (08362500)

$\triangle$ Las Cruces Arroyo near Las Cruces (08363600) $\triangle$ Over Shot Arroyo

$\triangle$ Picacho Arroyo

$\triangle$ Placitas Arroyo

$\triangle$ Rincon Arroyo
TRGWM comparison arroyo gages

$\triangle$ Jaralosa

$\triangle$ Montoya

$\triangle$ Nordstrom

$\triangle$ Tierra Blanca

Figure 12. Points used to estimate recharge by the Transboundary Rio Grande Watershed Model (TRGWM) for Transboundary Lower Rio Grande, New Mexico, Texas, and Mexico: $A$, the subwatersheds related inflow points and comparison observation points (streamgages) used for recharge-runoff estimates; and $B$, the TRGWM estimated recharge and runoff for water year 1993. 
$\boldsymbol{B}$

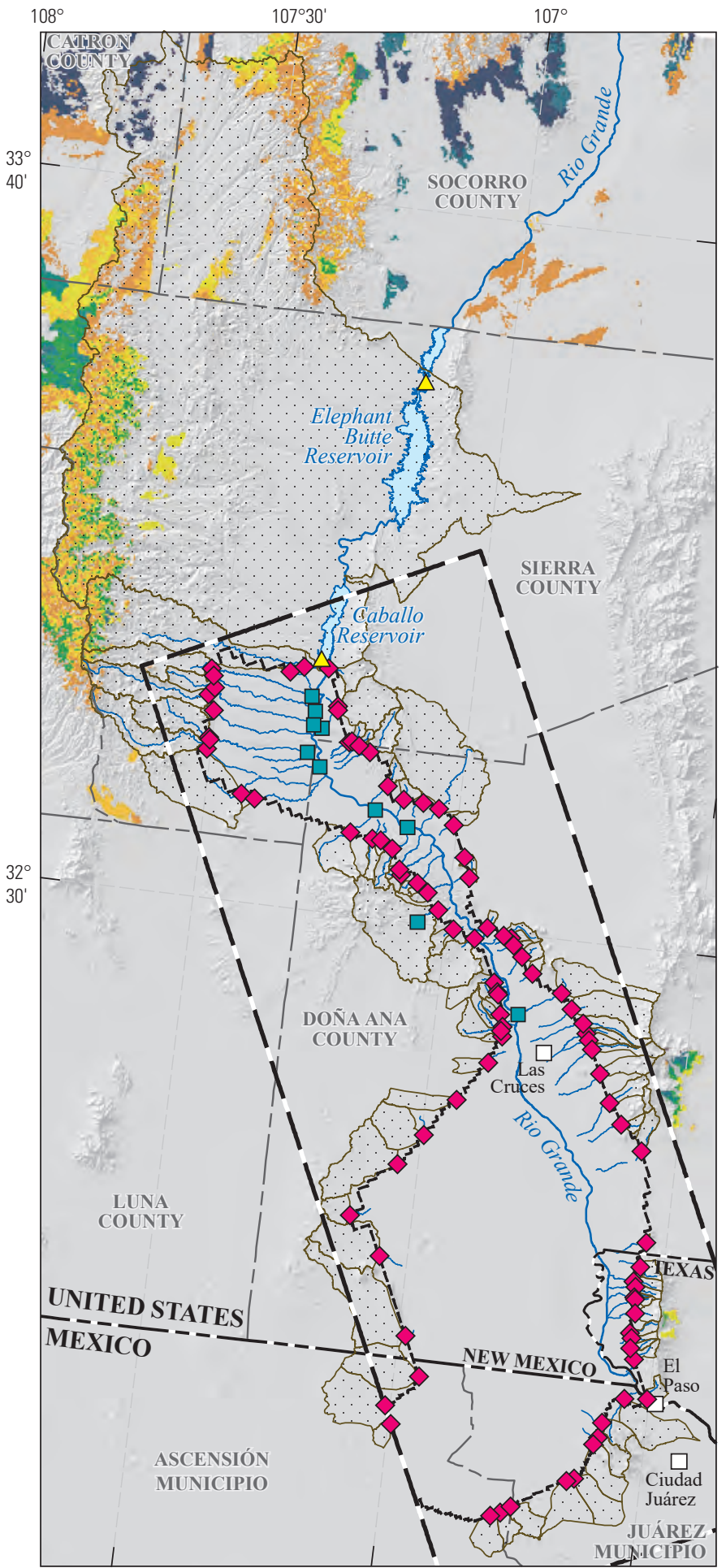

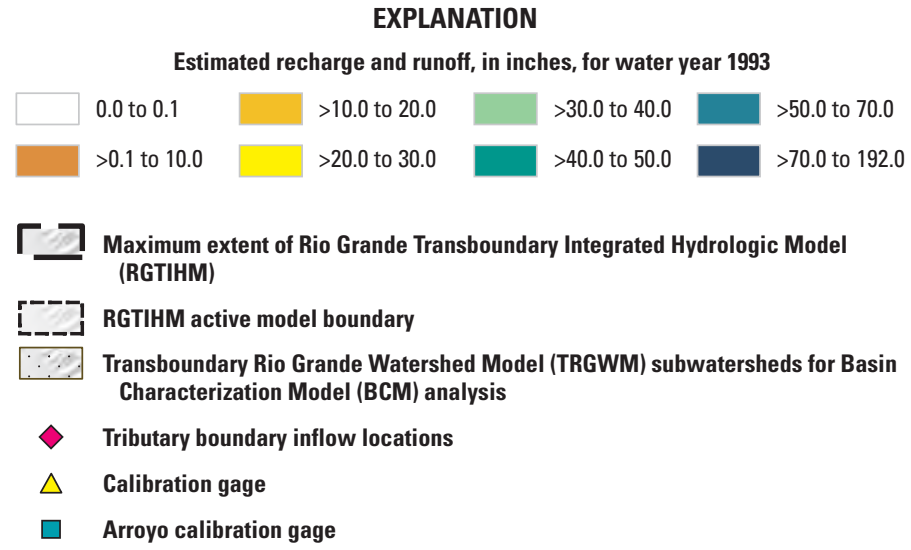

After available monthly water in excess of soil moisture and consumption as ET is calculated, water may exceed total soil storage and become runoff or may be less than total soil storage, but greater than field capacity, and become potential recharge. Anything less than field capacity is lost to actual evapotranspiration (AET) at the rate of PET for that month until soil water content reaches wilting point. If potential recharge is greater than bedrock permeability $(\mathrm{Kv})$, then the rate of recharge equals $\mathrm{Kv}$, and potential recharge that exceeds $\mathrm{Kv}$ becomes runoff, or else this excess water recharges at $\mathrm{Kv}$ until the soil moisture reaches field capacity. Additional details of model operation and input and output datasets can be found in Flint and others (2013).

To interface with the RGTIHM, the TRGWM model domain was based on the HUC-12 subwatersheds, and USGS streamgages and EBID-gaged arroyos were used for TRGWM model calibration along with inflow points for ungaged arroyos at the boundary of the active RGTIHM model grid to develop estimated runoff inflows to use as RGTIHM model input. The TRGWM domain included the 133 subwatersheds in and around the RGTIHM model grid as well as drains for 80 boundary arroyos that flow into the active model grid of RGTIHM (figs. 8A, $B, 12 A$ ). Elevation was derived from 98.4-ft (30-meter) digital elevation models (Elevation Derivatives for National Applications, http://edna.usgs.gov), soil properties were obtained from the SSURGO soil databases (Natural Resources Conservation Service, 2005), and basement sub-soil geologic vertical hydraulic conductivity was estimated on the basis of geology (Sweetkind, 2017).

Base modified from U.S. Geological Survey and other Federal and State digital data, various scales; Albers Equal-Area Conic projection, standard parallels $29^{\circ} 30^{\prime}$ N.and $45^{\circ} 30^{\prime}$ N.; North American Datum of 1983

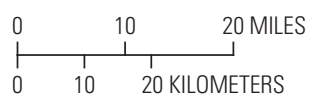

Figure 12. - Continued 


\section{Calibration and Comparison to Measured Streamflows}

The simulated PET for water years 1940-2015 was compared to the estimates from the NMSU meteorological station (potential ET, ET; fig. 13A). Although no error analysis was done for the PET, the analysis of PET for May 2009 through September 2015 was used to assess the goodness-of-fit by simple linear regression analysis relative to the NMSU data (fig. 13A). The TRGWM PET matched the station data at a regression coefficient of 0.88 and a coefficient of determination $\left(\mathrm{R}^{2}\right)$ of 0.69 (fig. $13 \mathrm{~A}$ ). There was a small amount of bias in the comparison to estimated $\mathrm{ET}_{\mathrm{o}}$ on the valley floor; TRGWM PET underestimated the station $\mathrm{ET}_{\mathrm{o}}$ by about 1.16 inches per month for the months with the highest $\mathrm{ET}_{\mathrm{o}}$ and underestimated it by about 0.74 inches per month for months with the lowest ET (fig. 13B).

To ensure that the TRGWM model was accurately representing soil-moisture storage, actual evapotranspiration (AET) calculated by the TRGWM was compared to AET calculated by regional models (Reitz and others, 2017) that used remotely sensed estimates of evapotranspiration and AET calibrated and validated to be close to the water balance for the United States. The comparison for calendar years 2000-13 indicated a close correspondence for the two methods over a range of climatic conditions (fig. 13C). The estimated annual AET from the TRGWM, averaged for the whole model domain, also compared favorably with AET estimates from Reitz and others (2017), which were based on remote sensing and a water-balance closure calculation (fig. 13C).

The TRGWM model calibration to partition water in excess of soil moisture and ET consumption to groundwater recharge and runoff was done by comparing model results for runoff with measured surface-water flows for selected arroyos and for the drainage area for Elephant Butte Reservoir between Elephant Butte Dam and the USGS gage "Rio Grande at the Narrows, in Elephant Butte Reservoir, NM" (USGS STAID 08359500; fig. 12). This was done by iteratively changing basement-rock vertical hydraulic conductivity $\left(\mathrm{K}_{\mathrm{v}}\right)$ by trial-and-error calibration until a reasonable match was achieved. The total volumes of streamflow (flows at "Rio Grande below Elephant Butte Dam, NM," USGS STAID 08361000, minus flows at "Rio Grande at the Narrows, in Elephant Butte Reservoir, NM," USGS STAID 08359500) was compared to flows derived from the TRGWM for several iterations of bedrock $\mathrm{K}_{\mathrm{v}}$, where $\mathrm{K}_{\mathrm{v}}$ was reduced to very low values for all geologic types. This was a reasonable estimate for a location with high seasonal air temperatures and evapotranspiration, but low precipitation, resulting in indurated alluvial deposits and underlying bedrock fractures filled with caliche. The final calibration had the volume of total modeled flows at 99 percent of measured flows from June 2012 to September 2015 (fig. 14). Because the TRGWM simulates unimpaired conditions without reservoirs, modeled flows could not match the reservoir operations-induced hydrograph of the TRG region.

The TRGWM was calibrated using intermittent stormbased streamflow data collected for a series of arroyos downstream from Elephant Butte Dam (F. Cortez, Bureau of Reclamation, written commun., 2014). These are shown in figure 12 as "comparison arroyos" where tributaries meet the mainstem of the Rio Grande. The calibration to vertical hydraulic conductivity resulted in the generation of storm-based arroyo flows, even using a monthly model for a selection of the arroyos; monthly results (figs. 15A-E) show discontinuous measurements as red triangles and continuous monthly TRGWM flows in blue. Because measured streamflow data were scarce, comparisons of total volumes of flows for arroyo runoff were not possible. Using the existing intermittent data, the TRGWM was able to represent flows fairly well for some of the locations (Arroyos Jaralosa, Nordstrom, and Tiera Blanca), but not as well for others (Arroyo Montoya). Although not available during calibration, the additional data from an eastern arroyo (Rincon Arroyo) monitored by the EBID showed general agreement with the occasional storm flows (fig. 15E). Although partitions of runoff and recharge were represented separately for three main geologic units (granite, metamorphics, and alluvium), it was ultimately all treated as runoff (table 6). Conceptually, a general lack of direct infiltration is likely to be consistent with the presence of caliche layers that could retard deep percolation of rainfall or infiltrated recharge.

\section{Transboundary Rio Grande Watershed Model Results}

The TRGWM was developed for water years 1940-2015 using 80 tributary boundary inflow locations that represented tributary boundary inflows to the RGTIHM active model grid (fig. 12). Recharge and runoff were developed as the sum of all grid cells for each subwatershed for each month to produce runoff for ephemeral arroyo stream inflows. Given the indurated nature of the alluvial surfaces in the boundary watersheds of the TRG region, there was very little recharge in comparison to runoff; post calibration TRGWM estimates of direct recharge averaged about 1 percent of all the estimated excess water available for recharge and runoff (fig. 16A). Therefore, estimated recharge for the subsurface was included with runoff for these inflows. The resulting estimates of runoff and recharge were highly variable from year to year and throughout the TRG region. For example, in a relatively wet year, at about 83 percent of average annual precipitation, water-year 2012, runoff and recharge were estimated to be about 21,436 acre-ft per year (acre-ft/yr), which was about 44 percent of the average annual recharge. The TRGWM data also demonstrated large variation between wet and dry years in mean recharge and runoff, at an average change of 140 and 107 percent, respectively (table 7). 


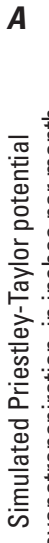

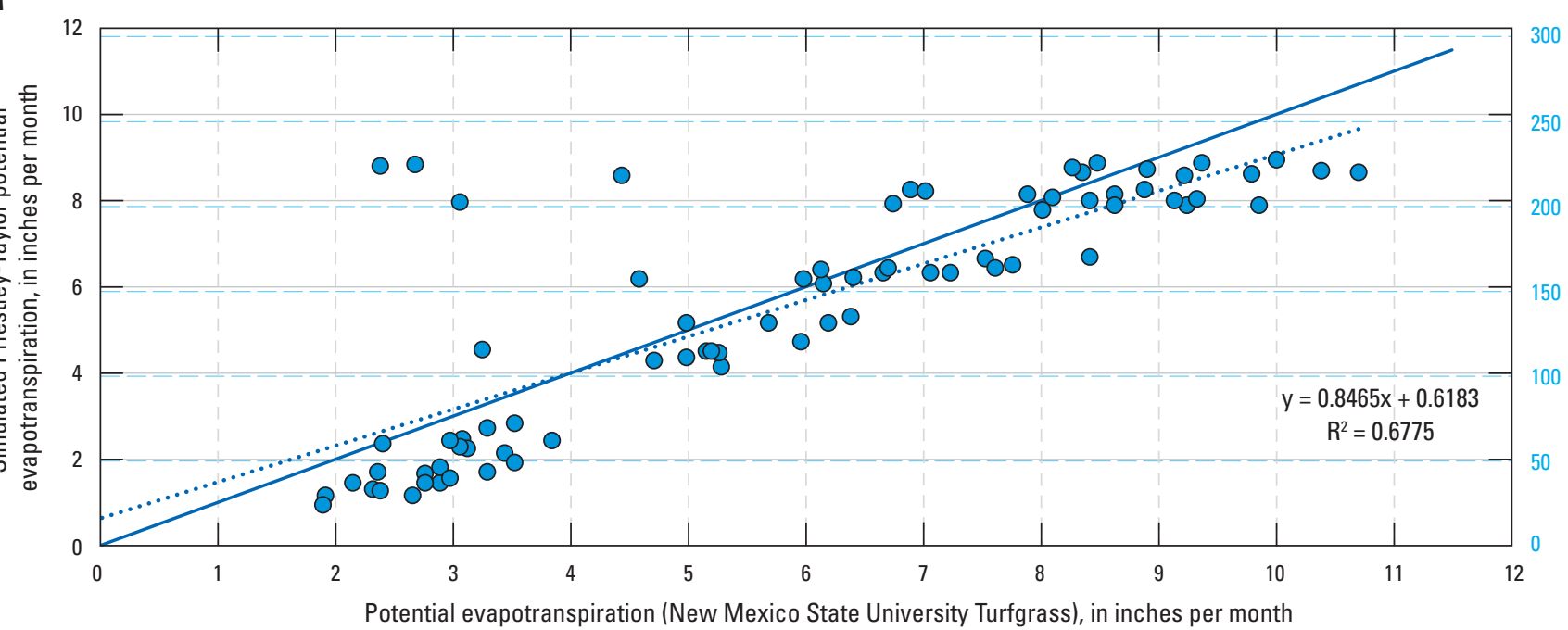

B

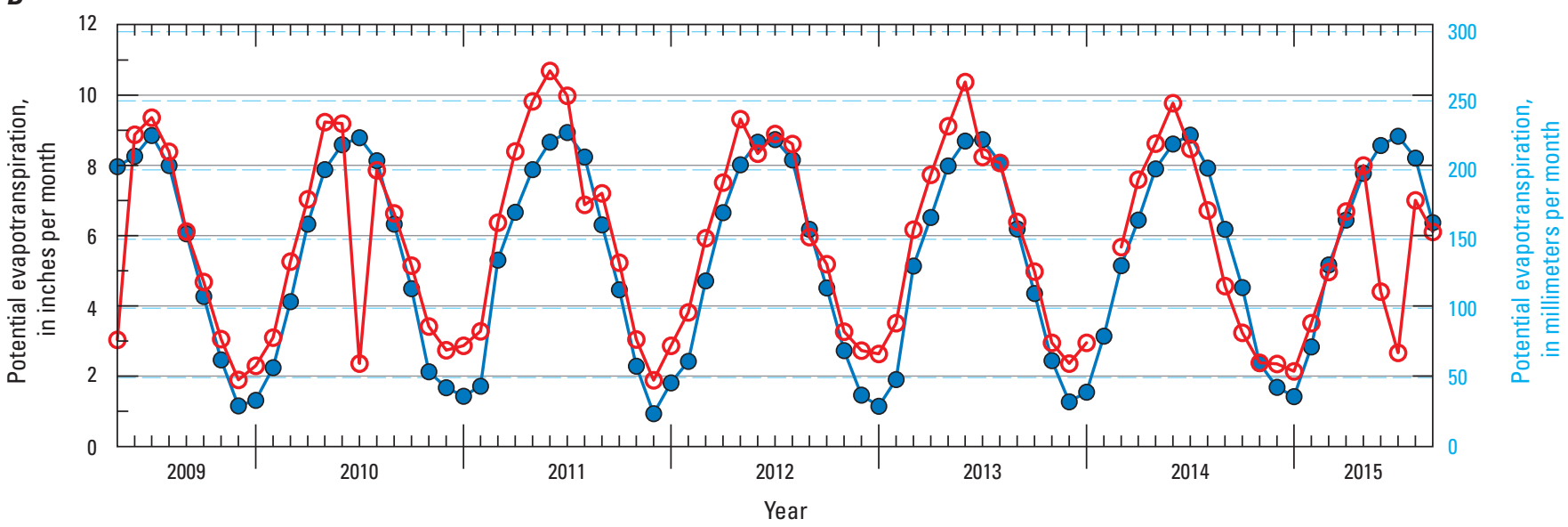

EXPLANATION

- - Transboundary Rio Grande Watershed Model (TRGWM) potential evapotranspiration (PET)

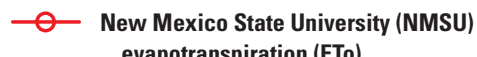

C

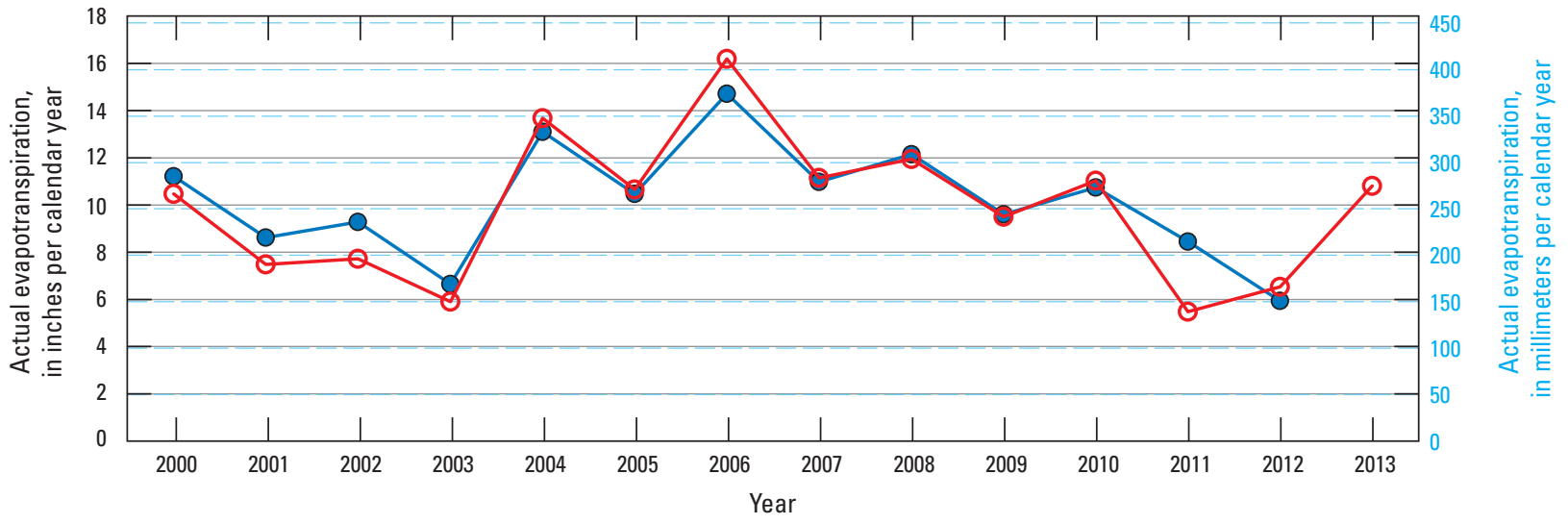

EXPLANATION

- Reitz and others, $2017 \quad-\quad$ Transboundary Rio Grande Watershed Model (TRGWM)

Figure 13. Comparisons of evapotranspiration (ET) for the Transboundary Rio Grande, New Mexico, Texas, and Mexico: $A$, simulated estimated potential ET by the Priestley-Taylor approach compared with measured reference ET (ET) from the New Mexico State University (NMSU) climate station; $B$, monthly potential ET from the TRGWM and from the NMSU climate station, 2009-15; and $C$, annual actual ET for 2000-13 from the TRGWM and from Reitz and others (2017). 


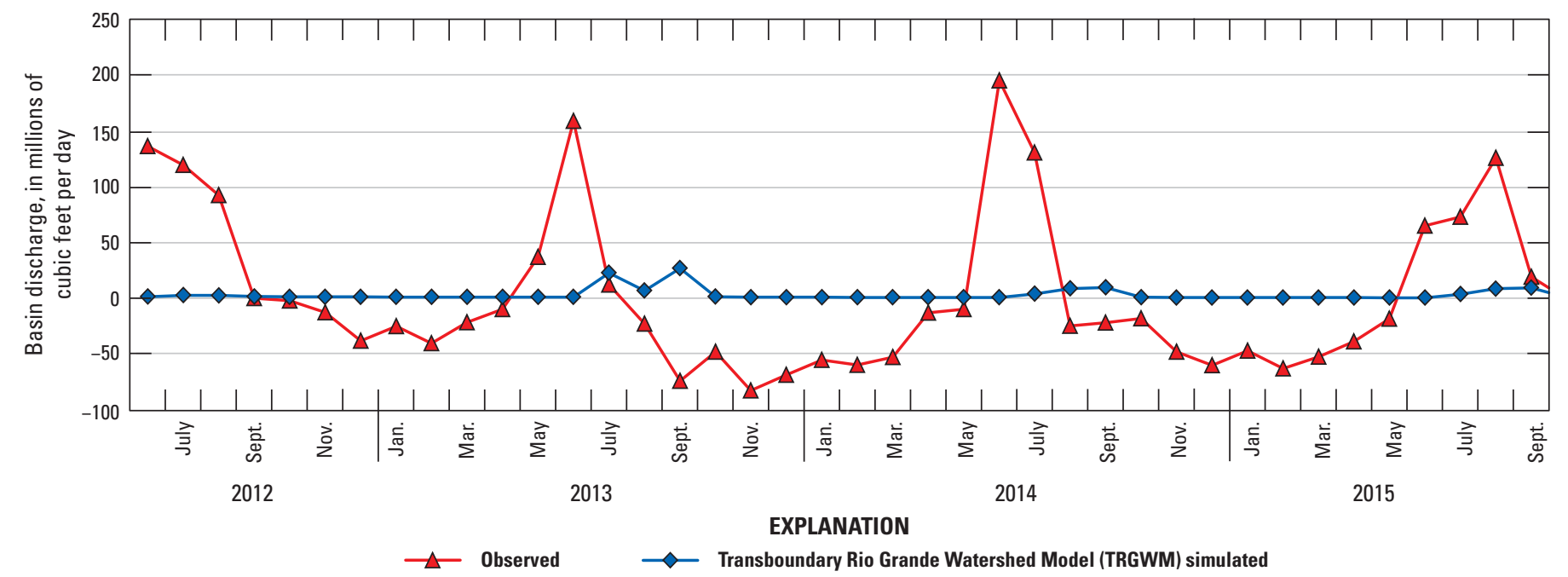

Figure 14. Comparison of measured and simulated basin streamflow for the Rio Grande between Elephant Butte Dam and the narrows, using the Transboundary Rio Grande Watershed Model (TRGWM), New Mexico. Measured streamflow difference equals flows at the “Rio Grande below Elephant Butte Dam, NM" streamgage (STAID 08361000) minus those at the "Rio Grande at the Narrows, in Elephant Butte Reservoir, NM" streamgage (STAID 08359500).

$\boldsymbol{A}$

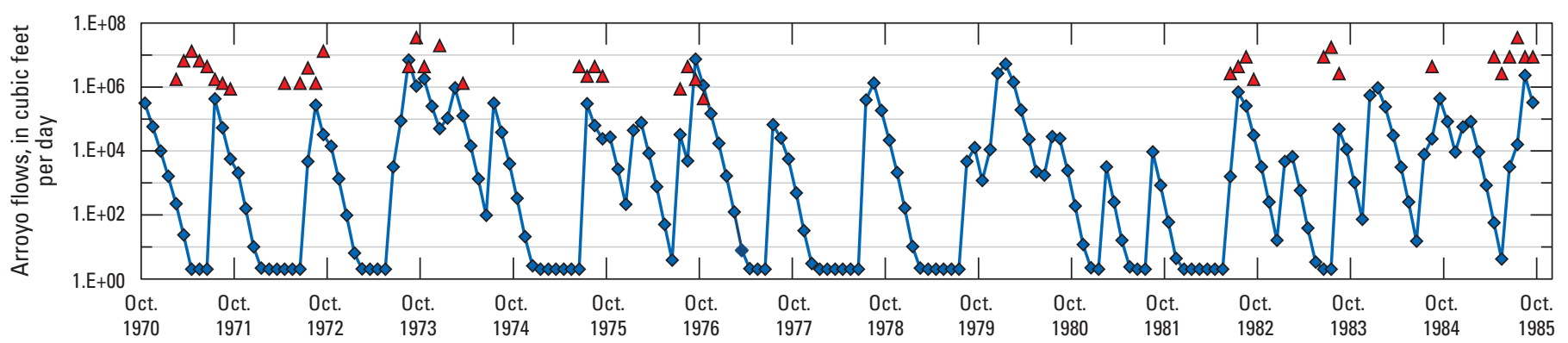

$\boldsymbol{B}$

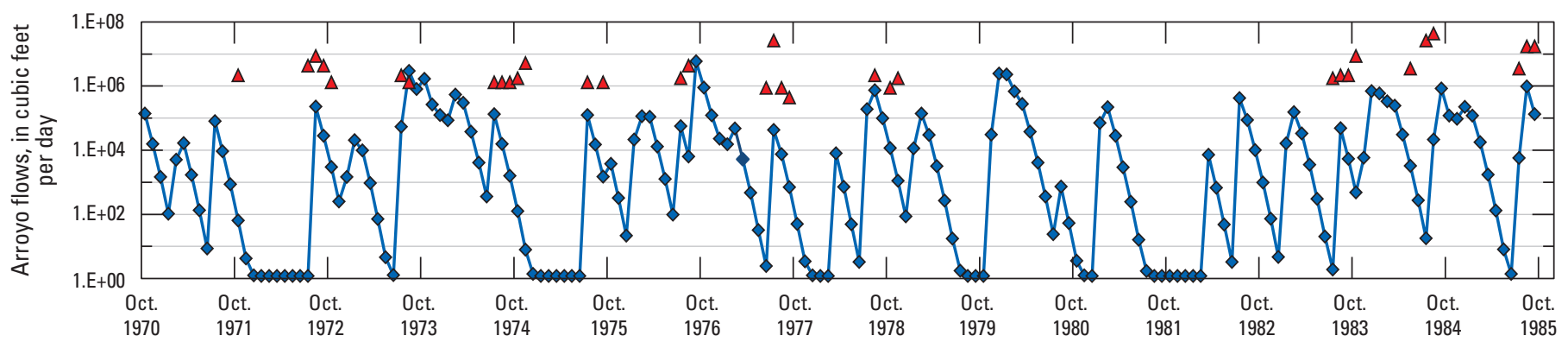

EXPLANATION

$\triangle$ Observed $\neg$ Simulated

Figure 15. Annual flows for selected gaged inflows for arroyos in and near the model domain of the Rio Grande Transboundary Integrated Hydrologic Model (RGTIHM) for the Transboundary Rio Grande, New Mexico, Texas, and Mexico: $A$, Jaralosa; $B$, Nordstrom; $C$, Tierra Blanca; $D$, Montoya; and $E$, Rincon. 

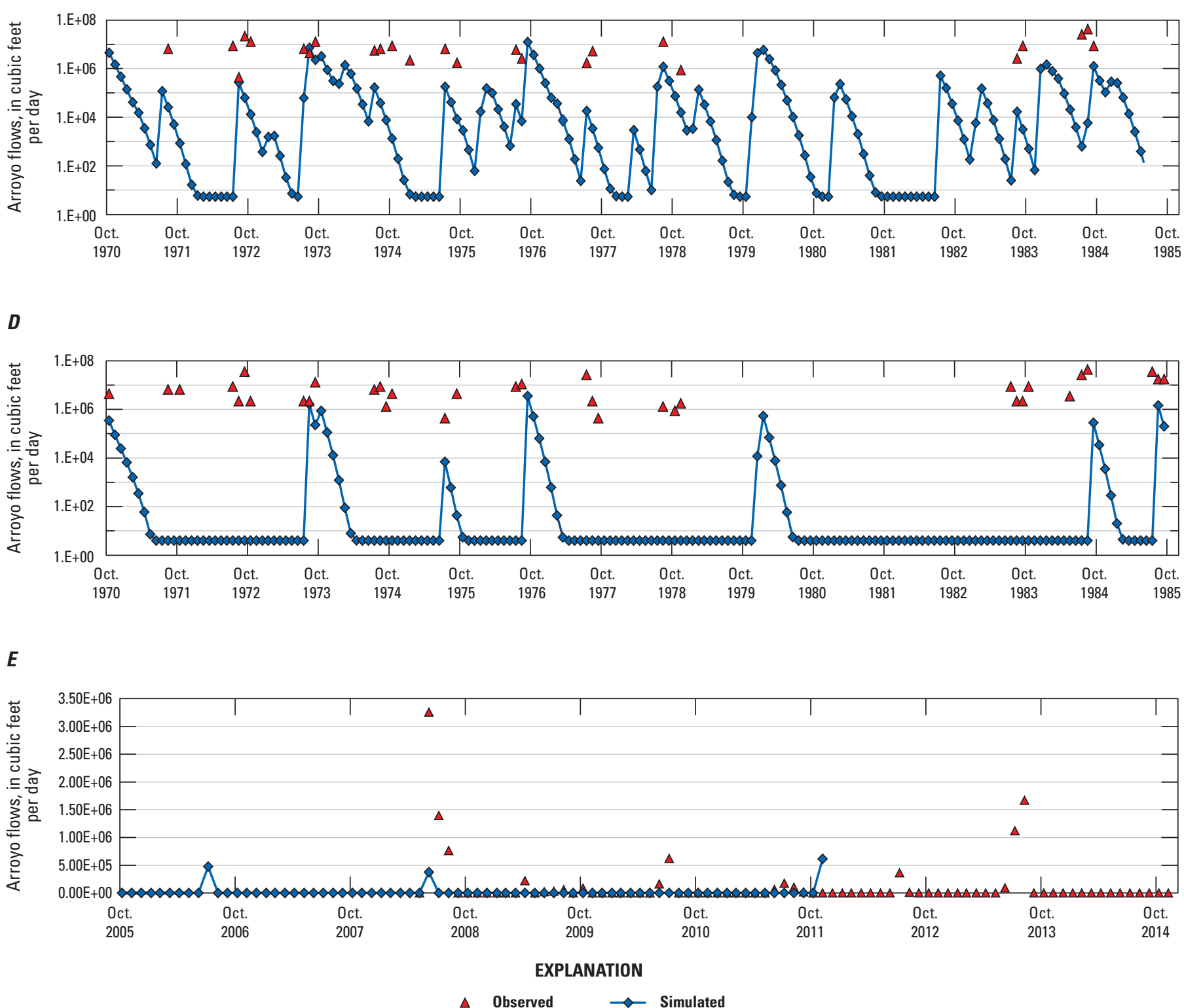

Figure 15. - Continued

Table 6. Scaling coefficients for estimation of streamflow for the MODFLOW "Streamflow Routing" (SFR) package from recharge and runoff maps developed by the Basin Characterization Model for ungaged basins in three geologic types for the Transboundary Rio Grande Valley, New Mexico, Texas, and Mexico.

$[-$, not applicable $]$

\begin{tabular}{lccc}
\hline $\begin{array}{c}\text { Geologic } \\
\text { type }\end{array}$ & $\begin{array}{c}\text { Shallow subsurface flow from } \\
\text { recharge that becomes baseflow } \\
\text { (SFR recharge) }\end{array}$ & $\begin{array}{c}\text { Runoff that becomes } \\
\text { streamflow } \\
\text { (SFR runoff) }\end{array}$ & $\begin{array}{c}\text { Runoff that becomes } \\
\text { deep recharge } \\
\text { (subsurface recharge) }\end{array}$ \\
\hline Alluvium & 1.00 & 1.00 & - \\
Granite & 1.00 & 1.00 & 1.00 \\
Metamorphics & 1.00 & 1.00 & 1.00 \\
\hline
\end{tabular}




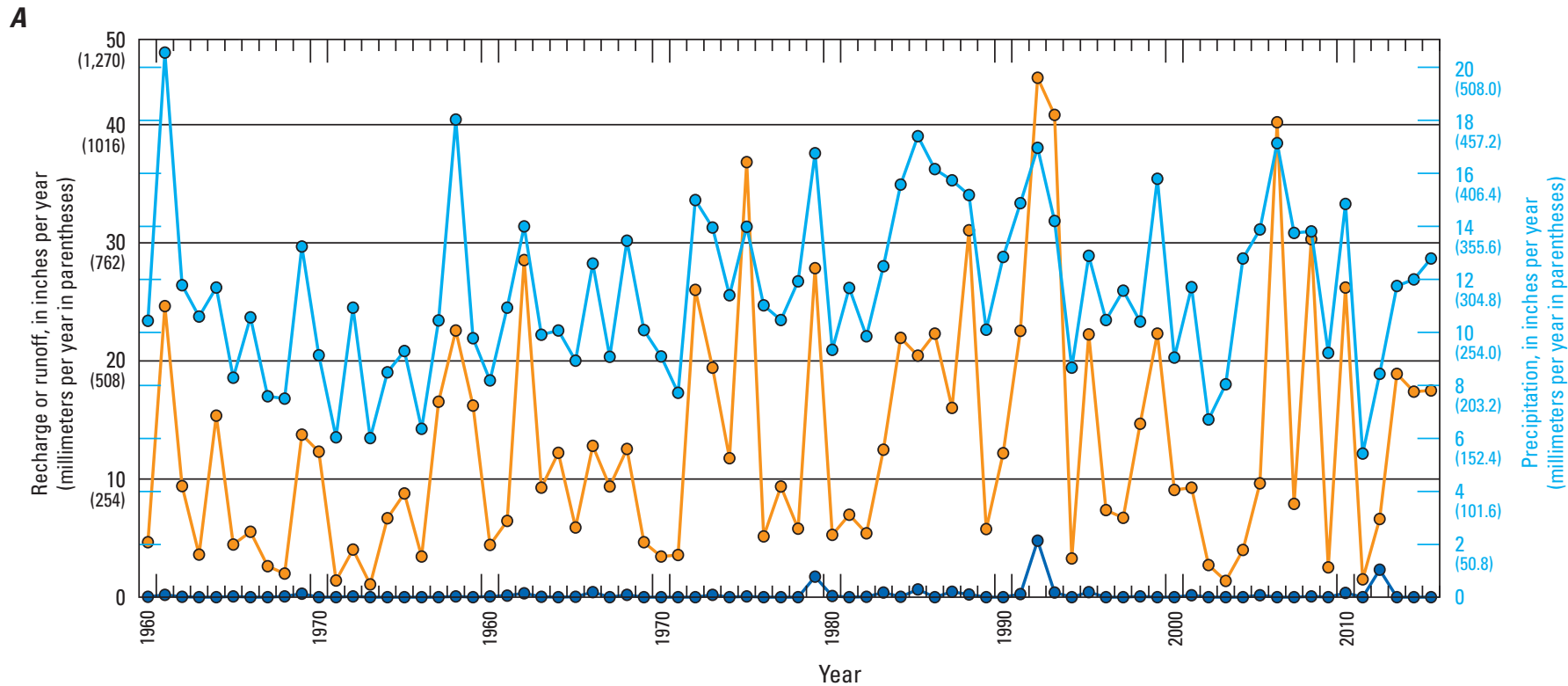

EXPLANATION

-0 - Sum of runoff -2 Sum of recharge -0 Average precipitation

$\boldsymbol{B}$

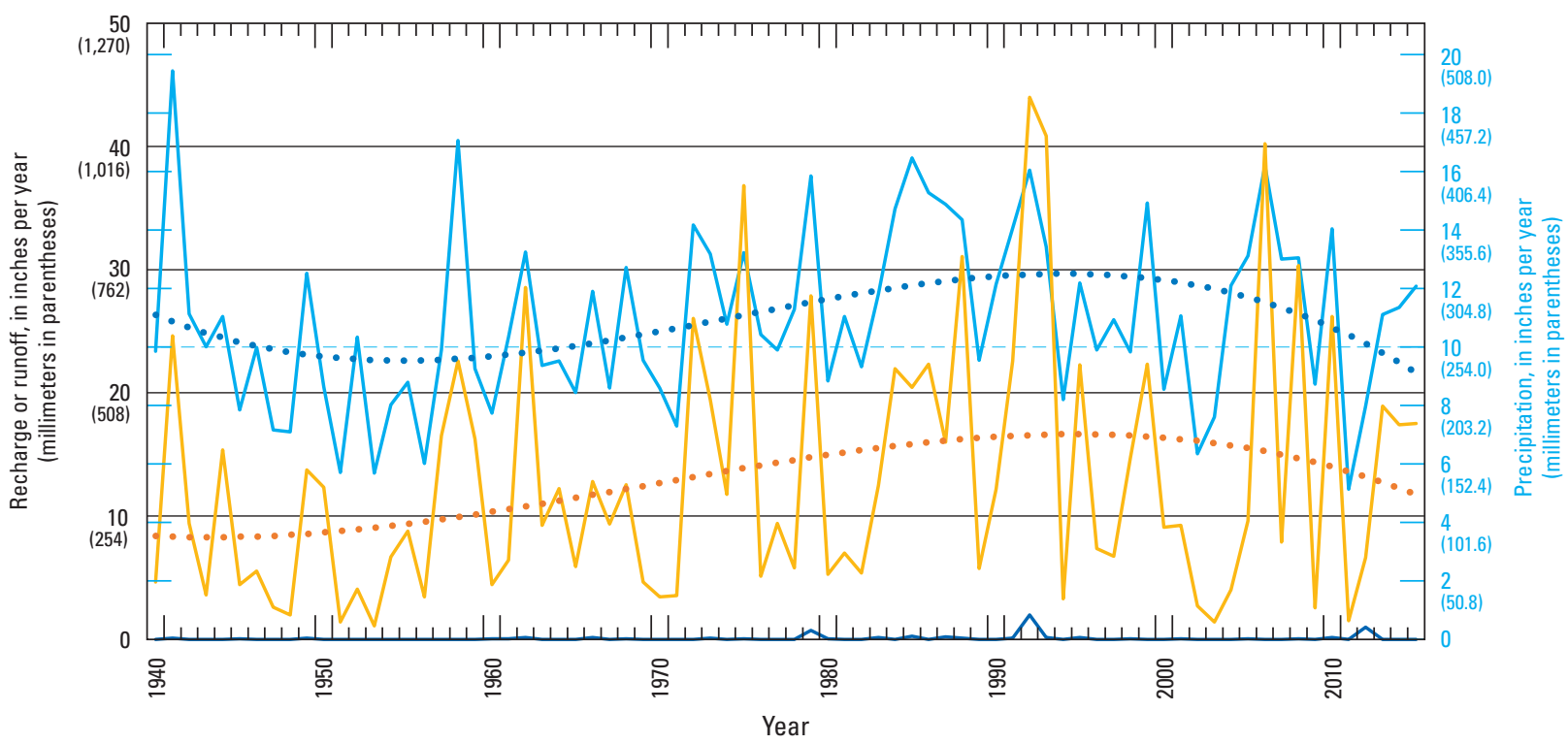

EXPLANATION

Runoff

Recharge

Precipitation

... 3rd-order polynomial fit (precipitation)

3rd-order polynomia fit (runoff)

Figure 16. Simulated subwatershed inflows as annual precipitation and recharge and runoff for selected ranges of water years for the active region of the Rio Grande Transboundary Integrated Hydrologic Model (RGTIHM), the Transboundary Rio Grande, New Mexico, Texas, and Mexico. 
Table 7. Mean annual precipitation, recharge, and runoff during water years 1940-2015 as simulated by the Basin Characterization Model for dry and wet periods based on precipitation from New Mexico State University (NMSU) for the Transboundary Rio Grande, New Mexico, Texas, and Mexico.

\begin{tabular}{lcrlrrr}
\hline \multirow{2}{*}{$\begin{array}{c}\text { Water- } \\
\text { budget } \\
\text { component }\end{array}$} & \multicolumn{2}{c}{$\begin{array}{c}\text { Mean } \\
\text { (inches/ } \\
\text { year) }\end{array}$} & $\begin{array}{c}\text { Standard } \\
\text { deviation }\end{array}$ & $\begin{array}{c}\text { Mean } \\
\text { (inches/ } \\
\text { year) }\end{array}$ & $\begin{array}{c}\text { Standard } \\
\text { deviation }\end{array}$ (percent) \\
\hline Precipitation & 8.86 & 49.6 & & 12.85 & 61.5 & 45 \\
Recharge & 0.05 & 4.0 & & 0.12 & 8.7 & 161 \\
Runoff & 8.51 & 198.3 & 17.65 & 271.3 & 107 \\
\hline
\end{tabular}

The arroyo flows estimated by the TRGWM showed a similar magnitude as some of the peak measured runoffs (figs. 15A, $B$ ). Third-order polynomials fit through the annual precipitation data and runoff data indicate some long-term trends, with a general cyclic pattern comparable to the PDO climate cycles estimated for the TRG region for the 75-year period (fig. 16). The average precipitation data were the $2,625 \mathrm{ft}(800-\mathrm{m})$ PRISM precipitation downscaled to the $886 \mathrm{ft}$ (270-m) BCM grid used by the TRGWM, averaged for the same domain as the recharge and runoff. More apparent was the increase in extremes for runoff and precipitation between wet and dry years, which can be compared by calculating the means and standard deviations for wet and dry years during the 75-year period (table 7). There was a greater increase in runoff than in precipitation for wet years relative to dry years, and a corresponding increase in variability, indicating precipitation that exceeded a threshold resulted in runoff more often during the wet years (table 7).

Recharge as underflow (mountain-block recharge) was considered negligible because faults bound most of the valley and caliche is common in the sediments at most locations. Consequently, the small amount of the TRGWM recharge as groundwater underflow to the valley (mountain-block recharge) was considered to discharge locally by ET or by additional baseflow as rejected mountain-front recharge.

The sum of the TRGWM simulated inflows indicated an average inflow to the RGTIHM active model grid for $1940-2015$ of about 14,620 acre-ft/yr, which is about half of the amount previously estimated for 1940-2004 (S.S. Papadopulos and Associates, Inc., 2007). Runoff ranged from about 570 acre-ft/yr in 1951 (dry year) to about 62,800 acre-ft in 1993 (wet year). The majority of the average annual runoff for 1940-2015 was from the eastern watersheds, where runoff ranged from a few or a few hundred acre-ft/yr up to a total of about 9,250 acre-ft/yr. Average annual runoff in tributary streamflow exceeded 100 acre-ft/yr in only 15 of 80 subwatersheds for the 75 years, and contributed more than
98 percent of the total estimated runoff as mountain-front recharge.

\section{Integrated Hydrologic Model-Rio Grande Transboundary Integrated Hydrologic Model}

The Rio Grande Transboundary Integrated Hydrologic Model, or RGTIHM, was developed to (1) characterize the historical conditions for the analysis of the use and movement of water in the valley and (2) provide a tool for stakeholders to address surface-water operations, water availability, and water-use issues in the valley. Although the RGTIHM was calibrated for the historical period of 1940-2014, models are dynamic tools that require periodic updates, upgrades, and refinements. In order to maintain the usefulness of the RGTIHM, periodic updates are required as conditions change in the hydrologic system in response to stresses and as new information about the surface-water and groundwater systems becomes available. The RGTIHM is an integrated numerical hydrologic flow model developed using the finite-difference hydrologic modeling software MODFLOW-One Water Hydrologic Flow Model (MF-OWHM; Hanson and Schmid, 2013; Hanson and others, 2014a, b; and MF-OWHM2: Boyce and others, 2020) that incorporates MODFLOW-2005 (Harbaugh, 2005) and an updated version of the Farm Process (FMP4; Boyce and others, 2020; Hanson and others, 2010; Schmid and Hanson, 2009). The MF-OWHM2 incorporates a dynamically integrated water supply-and-demand accounting framework for specific agricultural areas and areas of native vegetation. Thus, MF-OWHM2 enables a detailed, coupled, and realistic simulation of hydrologic systems. Because of the coupling of the systems, MF-OWHM2 can incorporate the simulation of conjunctive use with linkages of supplyconstrained and demand-driven use, and MF-OWHM2 facilitates the simulation of the use and movement of water across the landscape, surface-water, and groundwater-flow systems throughout the TRG region (Boyce and others, 2020).

The RGTIHM was constructed in three major phases. The first phase was the collection of new data and compilation of existing data (Ritchie and others, 2018; Blatchford, 2017). The hydrogeologic framework model was then developed on the basis of information from previous studies and analysis of new data (Sweetkind and others, 2017; Sweetkind, 2017). The hydrogeologic framework development included addition of the water inflows and outflows summarized in the conceptual model, creating a hydrogeologic model framework that distributes the hydraulic properties. Finally, in the third phase, the hydrologic model itself was constructed along with developing a calibration framework using related observations and analysis of hydrologic flow. These components of model development were completed interactively during the development and calibration of the RGTIHM. 
The development of the hydrologic model started with the transformation of the landscape subregions by using new WBSs and related components based on the refinements developed by Ferguson and Llewellyn (2015), as discussed in the "Hydrologic and Water-Balance Subregions" section. The surface-water network and the spatial and temporal discretization were also refined beyond those of previous model frameworks to further separate the supply and demand components of water use and movement. The hydrogeologic framework replaced the previous framework used in other recent hydrologic models and updated the wells and other components representing the inflows and outflows. Then, the stream networks were extended to include the ungaged inflows estimated at 80 points by the TRGWM.
Similar to previous models of the TRG region (LRG_2007, LRG_FMP2011, and LRG_USBR_EIS), the RGTIHM used consumptive-use estimates from the NMOSECIR spreadsheet (P. Barroll, New Mexico Office of the State Engineer, written commun., 2011). By using the NMOSE-CIR approach, this RGTIHM still does not explicitly calculate within the model some of the critical components needed to simulate the supply-and-demand framework, such as actual and changing land use (instead using inferred, static land use), actual estimates of monthly distributed climate variables (precipitation and potential ET), or the related potential runoff. The components of the MF-OWHM2 (processes and packages) used for the RGTIHM are summarized in table 8.

Table 8. Summary of MF-OWHM2 packages and processes used to simulate the Rio Grande Transboundary Integrated Hydrologic Model (RGTIHM) of the Transboundary Rio Grande, New Mexico, Texas, and Mexico.

\begin{tabular}{|c|c|c|}
\hline $\begin{array}{l}\text { Computer program } \\
\text { (packages, processes, } \\
\text { parameter estimation) }\end{array}$ & Function & Reference \\
\hline \multicolumn{3}{|c|}{ Processes and solver } \\
\hline $\begin{array}{l}\text { Groundwater Flow (GWF) } \\
\text { Processes of MODFLOW-2005 }\end{array}$ & $\begin{array}{l}\text { Setup and solve equations simulating a basic groundwater flow } \\
\text { model. }\end{array}$ & $\begin{array}{l}\text { Harbaugh and others (2000), } \\
\text { Hill and others (2000), } \\
\text { Harbaugh (2005). }\end{array}$ \\
\hline Farm process (FMP4) & $\begin{array}{l}\text { Setup and solve equations simulating use and movement } \\
\text { of water on the landscape as irrigated agriculture, urban } \\
\text { landscape, and natural vegetation. }\end{array}$ & $\begin{array}{l}\text { Schmid and others (2006a, b), } \\
\text { Schmid and Hanson (2009), } \\
\text { Boyce and others (2020). }\end{array}$ \\
\hline \multicolumn{3}{|c|}{ Files } \\
\hline List File & $\begin{array}{l}\text { Output file for allocation information, values used by the GWF } \\
\text { process, and calculated results such as head, drawdown, and } \\
\text { the water budget. }\end{array}$ & Harbaugh (2005). \\
\hline \multicolumn{3}{|c|}{ Discretization } \\
\hline Basic Package (BAS6) & $\begin{array}{l}\text { Defines the initial conditions and some of the boundary } \\
\text { conditions of the model. }\end{array}$ & $\begin{array}{l}\text { Harbaugh (2005), } \\
\text { Boyce and others (2020). }\end{array}$ \\
\hline Discretization Package (DIS) & Space and time information. & Harbaugh (2005). \\
\hline Multiplier Package (MULT) & $\begin{array}{l}\text { Defines multiplier arrays for calculation of model-layer } \\
\text { characteristics from parameter values. }\end{array}$ & $\begin{array}{l}\text { Harbaugh (2005), } \\
\text { Hanson and others (2014), } \\
\text { Boyce and others (2020). }\end{array}$ \\
\hline Hydrologic Flow Barriers (HFB6) & $\begin{array}{l}\text { Simulates a groundwater barrier by defining a hydraulic } \\
\text { conductance between two adjacent cells in the same layer. }\end{array}$ & $\begin{array}{l}\text { Hsieh and Freckelton (1993), } \\
\text { Hanson and others (2014). }\end{array}$ \\
\hline
\end{tabular}


Table 8. Summary of MF-OWHM packages and processes used to simulate the Rio Grande Transboundary Integrated Hydrologic Model (RGTIHM) of the Transboundary Rio Grande, New Mexico, Texas, and Mexico.-Continued

\begin{tabular}{|c|c|c|}
\hline $\begin{array}{l}\text { Computer program } \\
\text { (packages, processes, } \\
\text { parameter estimation) }\end{array}$ & Function & Reference \\
\hline \multicolumn{3}{|c|}{ Groundwater boundary conditions } \\
\hline General Head Boundaries (GHB) & $\begin{array}{l}\text { Head-dependent boundary condition used along the edge of the } \\
\text { model to allow groundwater to flow into or out of the model } \\
\text { under a regional gradient. }\end{array}$ & $\begin{array}{l}\text { Harbaugh (2005), } \\
\quad \text { Boyce and others (2020). }\end{array}$ \\
\hline Single-aquifer Wells (WEL) & Simulates pumpage from wells within individual model layers. & $\begin{array}{l}\text { Harbaugh (2005), } \\
\quad \text { Boyce and others (2020). }\end{array}$ \\
\hline $\begin{array}{l}\text { Multi-node Wells (MNW2, } \\
\text { MNWI) }\end{array}$ & $\begin{array}{l}\text { Simulates pumpage from wells with screens that span multiple } \\
\text { layers (multi-aquifer wells). }\end{array}$ & $\begin{array}{l}\text { Konikow and others (2009), } \\
\text { Boyce and others (2020). }\end{array}$ \\
\hline Streamflow Routing (SFR2) & $\begin{array}{l}\text { Simulates the routed streamflow, infiltration, exfiltration, runoff, } \\
\text { and returnflows from FMP. }\end{array}$ & $\begin{array}{l}\text { Niswonger and Prudic (2005), } \\
\text { Boyce and others (2020). }\end{array}$ \\
\hline Head Observation (HOB) & $\begin{array}{l}\text { Defines the head observation and weight by layer(s), row, } \\
\text { column, and time and generates simulated values for } \\
\text { comparison with observed values. }\end{array}$ & $\begin{array}{l}\text { Hill and others (2000), } \\
\text { Harbaugh (2005), } \\
\text { Boyce and others (2020). }\end{array}$ \\
\hline Hydmod (HYD) & $\begin{array}{l}\text { Generates simulated values for specified locations at each time- } \\
\text { step for groundwater levels and streamflow attributes. }\end{array}$ & Hanson and Leake (1999). \\
\hline Sensitivity (PVAL) & $\begin{array}{l}\text { Specifies parameter values used in LPF, GHB, and HFB } \\
\text { packages. }\end{array}$ & Harbaugh (2005). \\
\hline Reservoir (RES) & $\begin{array}{l}\text { Simulates leakage from the bottom of a reservoir into } \\
\text { groundwater flow. }\end{array}$ & Fenske and other (1996). \\
\hline
\end{tabular}

Input parameters to the RGTIHM were adjusted during model development phases using trial-and-error and automated parameter-estimation calibration. The parameterestimation code PEST (Doherty, 2004, 2010a-c; Doherty and Hunt, 2010) was used to help calculate sensitivities and parameter estimation. The RGTIHM was calibrated to heads (groundwater levels), vertical-head differences, head changes through time (drawdown), annual and monthly pumpage estimates, streamflow, surface-water deliveries, and differences in streamflow. During construction and calibration of the RGTIHM model, several updates and enhancements were needed in MF-OWHM. These updates and enhancements are summarized in the documentation of MF-OWHM2 (Boyce and others, 2020). The RGTIHM model components can be grouped in terms of the discretization and boundaries, landuse, streamflow, aquifer characteristics, initial conditions, and water budgets. The next few sections of the report describe the RGTIHM model components for each of these groups.

\section{Discretization-Rio Grande Transboundary Integrated Hydrologic Model}

The RGTIHM domain includes the major alluvial deposits of the modern-day and ancestral Rio Grande, as well as deposits that pre-date the Rio Grande and Rio Grande rift (Sweetkind, 2017). The finite-difference model grid used to represent the land surface and subsurface deposits consists of a series of 660-ft-square model cells of variable thickness. Spatial and temporal discretization were held to uniform increments through space and time.

\section{Spatial Discretization and Layering}

The total active modeled area is $1,760 \mathrm{mi}^{2}$ on a finite-difference grid consisting of 912 rows, 328 columns (299,136 cells), and 9 layers having a varying number of active cells in each layer, for a total of 805,886 active model cells (figs. 1B, $C$; Ritchie and others, 2018). In the horizontal dimension, about 38 percent of the cells (112,576 cells) were used to define the active part of the hydrologic model grid. The RGTIHM has a uniform horizontal discretization of 10 acres per cell (660-by-660 ft, 201-by-201 m) and is rotated 24 degrees west of due north (table 9) to align with the tectonic structure of the TRG (figs. $1 B, C, 2 A$ ). This cell size is one-fourth of that used in previous models, which used 1,320- by-1,320 ft cells (S.S. Papadopulos and Associates, Inc., 2007; Hanson and others, 2013; Ferguson and Llewellyn, 2015; Knight, 2015). The smaller cell size was necessary to distinguish critical supply and demand components, such as land use, the location of water-supply wells, and location of the Rio Grande, as well as effects on ET from variable topography (Kambhammettu and others, 2012). 
Table 9. Coordinates defining extent and rotation of the Rio Grande Transboundary Integrated Hydrologic Model of Transboundary Rio Grande, New Mexico, Texas, and Mexico.

[Model grid is rotated 24 degrees west of north; coordinates below are calculated at the outer corner of the total model grid using the North American Datum of 1983 in the Universal Transverse Mercator (UTM) projection of North America, zone 13; each model cell is 660 feet by 660 feet. Abbreviation: DMS, degree, minute, second]

\begin{tabular}{|c|c|c|c|c|c|c|}
\hline $\begin{array}{l}\text { Corner of } \\
\text { model grid }\end{array}$ & $\begin{array}{l}\text { Model } \\
\text { coordinates X } \\
\text { (column) }\end{array}$ & $\begin{array}{c}\text { Model } \\
\text { coordinates } Y \\
\text { (row) }\end{array}$ & $\begin{array}{c}\text { Latitude } \\
\text { (DMS) }\end{array}$ & $\begin{array}{l}\text { Longitude } \\
\text { (DMS) }\end{array}$ & $\begin{array}{c}\text { UTM coordinates } X \\
\text { (easting) } \\
\text { (feet) }\end{array}$ & $\begin{array}{c}\text { UTM coordinates } Y \\
\text { (northing) } \\
\text { (feet) }\end{array}$ \\
\hline Northwest & 1 & 1 & $32^{\circ} 52^{\prime} 01^{\prime \prime}$ & $-107^{\circ} 39^{\prime} 19^{\prime \prime}$ & 825,260 & $11,941,136$ \\
\hline Northeast & 328 & 1 & $33^{\circ} 07^{\prime} 15^{\prime \prime}$ & $-107^{\circ} 01^{\prime} 01^{\prime \prime}$ & $1,023,024$ & $12,029,186$ \\
\hline Southwest & 1 & 912 & $31^{\circ} 22^{\prime} 12^{\prime \prime}$ & $-106^{\circ} 49^{\prime} 40^{\prime \prime}$ & $1,070,083$ & $11,391,256$ \\
\hline Southeast & 328 & 912 & $31^{\circ} 37^{\prime} 11^{\prime \prime}$ & $-106^{\circ} 11^{\prime} 50^{\prime \prime}$ & $1,267,847$ & $11,479,306$ \\
\hline
\end{tabular}

The RGTIHM includes nine model layers within the active extents, corresponding to the five hydrogeologic units described in Sweetkind (2017) and Sweetkind and others (2017). The top of RGTIHM is represented by the elevation of the land surface, but because hydrostratigraphic units are discontinuous in the study area, the uppermost active layer is a composite of model layers 1, 3, 5, 7, and 9 . Each hydrostratigraphic unit described in Sweetkind and others (2017), with the exception of the pre-Santa Fe Group (basement) unit, was subdivided into two model layers in the RGTIHM, with each pair of model layers representing half the thickness of each hydrogeologic unit, as described in the "Hydrogeologic Units" section. The uppermost Rio Grande alluvial aquifer (Quaternary alluvium) model layer (layer 1) ranges in thickness from an assumed minimum of $50 \mathrm{ft}$ $(15 \mathrm{~m})$ to an estimated maximum of about $110 \mathrm{ft}(34 \mathrm{~m})$. The lowermost Rio Grande alluvial aquifer model layer (layer 2) has an assumed thickness of $30 \mathrm{ft}(9 \mathrm{~m})$. The third and fourth model layers are coincident with the extent of the upper member of the Santa Fe Group and range in thickness from an assumed minimum of $2 \mathrm{ft}(0.6 \mathrm{~m})$ to an estimated maximum of about 1,097 ft (334 m). The fifth and sixth model layers are coincident with the extent of the middle member of the Santa Fe Group and range in thickness from an assumed minimum of $1 \mathrm{ft}(0.3 \mathrm{~m})$ to an estimated maximum of about $1,120 \mathrm{ft}$ (341 m). The seventh and eight model layers are coincident with the extent of the lower member of the Santa Fe Group and range in thickness from an assumed minimum of $2 \mathrm{ft}$ $(0.6 \mathrm{~m})$ to an estimated maximum of about $1,252 \mathrm{ft}(382 \mathrm{~m})$. The ninth layer is coincident with the pre-Santa Fe Group (basement) rocks and ranges in thickness from an assumed minimum of $500 \mathrm{ft}(152 \mathrm{~m})$ to an assumed maximum of about $607 \mathrm{ft}(185 \mathrm{~m})$.

\section{Temporal Discretization}

To represent the dynamics of changing climate, streamflow, and the growing season (irrigation supply and demand components) better, the RGTIHM is discretized to monthly stress periods and semi-monthly time steps to reflect the common frequency of some of the reported data, such as groundwater pumpage. A model stress period is an interval of time in which the user-specified (or TRGWM simulated) inflows and outflows are held constant. Variations in stresses are simulated by changing inflows, outflows, and boundary heads, which include releases from Caballo Reservoir, municipal and industrial pumpage, stream inflows, irrigation, and underflow beneath Caballo Dam, from one stress period to the next. Stress periods were further divided into semimonthly (approximately 15-day) time steps, which are units of time for which water levels and flows are calculated in all model cells. The total simulation period was 74.8 years (or 898 monthly stress periods) from March 1940 through December 2014.

\section{Groundwater Conditions-Rio Grande Transboundary Integrated Hydrologic Model}

Boundary conditions were applied at some model cells to simulate the inflows and outflows from the active model region as groundwater underflow (inflows and outflows) and aquifer interaction along intermittent streams, as well as interaction with landscape processes (figs. 2, 8). Inflows and outflows simulated across the hydrologic boundaries include recharge to and discharge from the groundwater system as well as interdependent flows between the groundwater, streams, and landscape processes such as ET and irrigation. The intermittent stream-aquifer interaction and landscape process interactions are discussed in later sections. 


\section{Initial to 2011 Groundwater Conditions}

The initial, March 1940, water levels in all active cells were set as a composite of water-table contours from the 1947 groundwater contours for Doña Ana County (Conover, 1954) and from the January 1976 water-table contours for the Rincon Valley and adjacent areas (Wilson and others, 1981). The January 1976 groundwater-level contours were chosen because few data were available for the 1940s in the northern part of the RGTIHM active area outside of the Rio Grande alluvial valley, and these groundwater-level contours provided the most extensive coverage of the northern part of the RGTIHM. The 1947 groundwater-level contours for Doña Ana County were used because they covered most of the southern part of the active RGTIHM area, and any groundwater-level changes during the early to mid-1940s prior to extensive groundwater development for agriculture and water supply were assumed to have been negligible. Contours from these two sources were projected onto regions of the RGTIHM active area not covered by these two sets of contours and were connected where deemed appropriate (fig. 9A; Ritchie and others, 2018).

All model layers were simulated as confined, yet still represent the drawdown and resultant cones of depression in the groundwater levels near the Las Cruces and Canutillo well fields. For the parts of model layers that represent areas of the aquifers represented as the uppermost layer that may be unconfined or semiconfined, the simulated groundwater-levels still vary within these confined layers. The saturated thickness and hydraulic properties of specific yield and transmissivity are held constant during declining or rising water levels. Although all layers are treated as confined in RGTIHM during the simulation, parts of model layers 3, 5, 7, and 9 remain unconfined where they are the uppermost model layer. This is considered a reasonable approximation as long as changes in groundwater levels are a relatively small percentage of the layer's saturated thickness. This approach is used for calibration of most TRG models, including LRG_2007; provides additional speed and stability during calibration and related parameter estimation; and is a common practice for development of regional hydrologic flow models that does not degrade the accuracy of the simulated heads (Faunt and others, 2011). The lowermost subdivisions of each hydrostratigraphic unit (that is, layers 2, 4, 6, and 8) remain confined during the simulation. Storage properties in the outcrop subregions (fig. $3 A$ ) of the uppermost layers $(1,3,5,7$, or 9) are represented by specific yield and are adjusted as necessary to represent the unconfined part of the system (see "Hydraulic Properties" section). The regions of large water-level declines and related large unsaturated zones along the Rio Grande alluvial valley near the well fields in Las Cruces, New Mexico, and Canutillo, Texas, are illustrated by the mean groundwaterlevel maps from winter (November through April) 2010-11 in the Rio Grande alluvium (fig. 9B; Teeple, 2017) and in the Santa Fe Group (fig. 9C; Teeple, 2017).

\section{No-Flow Boundaries}

No-flow boundaries were used for the bottom of the RGTIHM and for the lateral boundaries that are coincident with faults. The lower boundary was limited to the bottom of the basement bedrock units or at a total thickness for the formation of $980 \mathrm{ft}(300 \mathrm{~m})$, which is deeper than the deepest supply wells. Although there could be some relatively small and deep geothermal upwelling in some regions of the bedrock (Szynkiewicz and others, 2011; Teeple, 2017), these flows were not included in this version of the RGTIHM. Lateral no-flow boundaries represented the contact between the low-permeability bedrock and faults that bound parts of the foothills and the Santa Fe Group in the TRG (figs. 3A, 17).

\section{General-Head Boundaries}

Selected downstream and northern upstream regions of the Rio Grande are lateral hydrologic boundaries of the groundwater flow system simulated as head-dependent flow boundaries (figs. $2 \mathrm{~A}, 17$ ). These regions were simulated by using the "General Head Boundary" (GHB) package of MODFLOW (Harbaugh, 2005). General-head boundaries were specified for model cells in layers 1-3 for the inflow region by spatially and temporally constant boundary heads and cell-specific hydraulic conductance. The groundwaterinflow components associated with underflow from the Conejos-Médanos Basin, the Rincon Arroyo, and Fillmore Pass are simulated in the RGTIHM as general-head boundary conditions (figs. $2 A, 17$ ). The groundwater-outflow components associated with underflow south of the El Paso narrows beneath the Rio Grande channel is also simulated in the RGTIHM as a general-head boundary condition (figs. $2 A, 17$ ). The hydraulic conductances of the lateral boundary cells were based on the facies-derived hydraulic conductivity of the aquifer sediments (described in the "Aquifer Characteristics" section). Hydraulic conductances were adjusted during model calibration and are prorated by the time-varying saturated thickness of the GHB model cells through the Variable Conductance option of the GHB package in MF-OWHM2 (Boyce and others, 2020).

The GHB boundary heads were held at constant values of head at all boundaries. The GHB boundary cells along the southwestern and southeastern edges of the active flow region in Mexico were combined into seven groups. The boundary heads were held constant for the entire simulation and were based on recent (2007-10) groundwater levels in wells just outside and adjacent to the RGTIHM boundary for the groups in Mexico (figs. 2A, 17). The boundary heads for the Fillmore Pass were assumed to be at 10 feet below land surface for the two cells used for inflow. The boundary heads for the Rincon Arroyo inflow cell and for the cell used for outflow beneath the Rio Grande were both set at heads equivalent to the base of the streambed. 


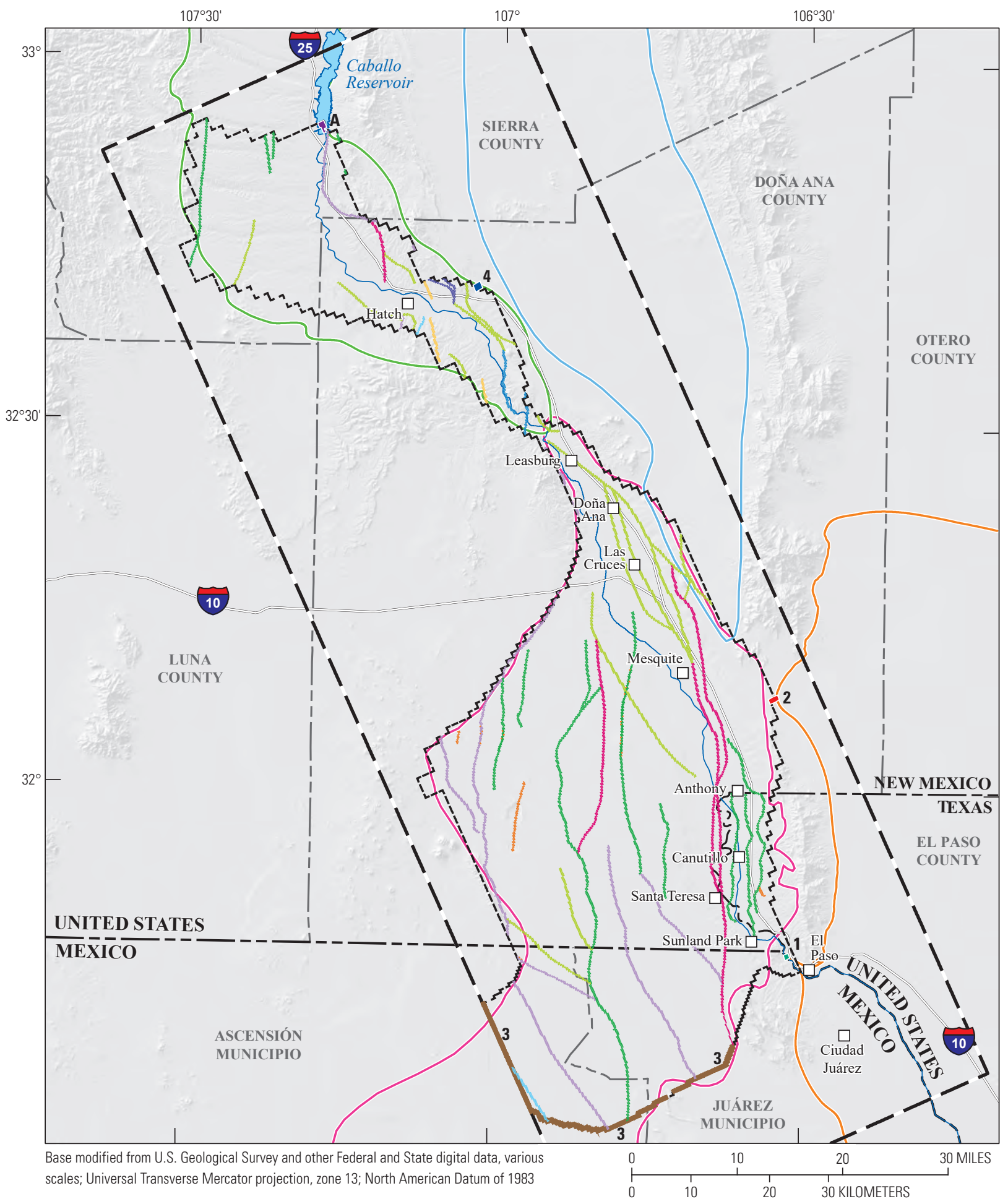

Figure 17. Model cells where reservoir leakage is simulated and parameter groups where faults and volcanic dikes are simulated as groundwater-flow barriers for the Transboundary Rio Grande, New Mexico, Texas, and Mexico. 


\section{EXPLANATION}

Groundwater basins

Hueco (Driscoll and Sherson, 2016)

Palomas (Driscoll and Sherson, 2016)

Jornada del Muerto (after Witcher and others, 2004)

Mesilla and Conejos-Médanos (after Sheng and others, 2013)

Horizontal Flow Barrier (HFB) cell parameter name

Intrusion or dike (VOLCDIKES)

Fault that cuts upper member of Santa Fe Group (informal), northwest or northeast trend (USF NWNE

Fault that cuts upper member of Santa Fe Group (informal), northerly trend (USF_N)

Selden Canyon fault zone, cuts middle member of Santa Fe Group (informal) (MSF_RinMes)

Fault that cuts middle member of Santa Fe Group (informal), northwest or northeast trend (MSF_NWNE)

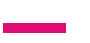

Fault that cuts middle member of Santa Fe Group (informal), northerly trend (MSF_N)

Fault that cuts middle member of Santa Fe Group (informal), northwest or northeast trend (LSF_NWNE)

Fault that cuts lower member of Santa Fe Group (informal), northerly tren (LSF_N)

Fault that cuts pre-Santa Fe Group rocks, northwest or northeast trend (PSF_NWNE)

$\Gamma$ Maximum extent of Rio Grande Transboundary Integrated Hydrologic Model (RGTIHM)

RGTIHM active model boundary

A Reservoir package boundary (RES) cells at Caballo Reservoir General-head boundary (GHB) cells

1. El Paso narrows 2 Fillmore Pass 3 Mexico 4 Rincon Arroyo

Figure 17. -Continued

\section{Reservoir Head Boundaries}

The leakage under the earthen dam at Caballo Reservoir is small, but substantial enough to warrant inclusion as a headdependent flow as underflow beneath the reservoir entering the middle member of the Santa Fe Group (model layer 5; fig. 17). The leakage under the Caballo Dam is simulated using the "Reservoir" package. The leakage is controlled by the vertical hydraulic conductivity of the reservoir bottom sediment and a time series of monthly reservoir stage (I. Ferguson, Bureau of Reclamation, written commun., 2016).

\section{Surface-Water Network—Rio Grande Transboundary Integrated Hydrologic Model}

\section{Surface-Water Framework}

The surface-water network simulates the distribution and conveyance of RGP surface water in the RGTIHM (figs. 8A, $B$ ). The network is simulated in the RGTIHM using the "Streamflow-Routing" package SFR2, which has been updated in MF-OWHM2 (Boyce and others, 2020). The network was updated from the structure developed for previous models (LRG_2007, LRG_FMP2011, and LRG_USBR_EIS; S.S. Papadopulos and Associates, Inc., 2007; Hanson and others, 2013; Ferguson and Llewellyn, 2015; Knight, 2015). The fundamental structural changes from previous versions included additional FMP semi-routed delivery segments to enable deliveries to all $31 \mathrm{WBSs}$ that receive surface water for irrigation, additional segmentation to facilitate inflows from wastewater-treatment plant outflows, minor adjustments to segment locations and lengths based on a review of aerial imagery (Environmental Systems Research Institute, 2016), redefinition of canal and drain properties, implementation of surface-water allotments for the $31 \mathrm{WBSs}$, and the addition of the tributaries. As in the previous versions of the network, starting with the LRG_2007 model, not every wasteway and lateral are represented in this network. The RGTIHM network includes the Rio Grande, major canals, laterals, and drains, selected larger wasteways, and the arroyo tributaries that drain each surrounding subwatershed.

The Rio Grande, each of the major and minor tributary drainages, and the major canals, laterals, and drains are represented by a collection of stream cells referred to as "reaches." The reaches were combined to form a collection of reaches known as a segment within a network in the SFR2. The total SFR2 surface-water network contains 566 segments, represented by 9,774 reaches, 61 diversions, 98 inflows, and 3 outflows (figs. $8 A, B$ ). The head-dependent boundary condition used in SFR2 allowed for streamflow routing, streamflow infiltration to the aquifer (losing stream reaches), and potential base flow as groundwater discharge to streams (gaining stream reaches). Runoff from inefficient irrigation and from precipitation was not simulated in this version of the RGTIHM. 
An additional semi-routed delivery (SRD) segment was added for each of the 31 WBSs receiving surface water for irrigation. The addition of the SRD allowed the coupling of FMP and SFR2 and separated the supply (specified delivery) of surface water by SFR from the demand for irrigation water by FMP, which maintains the MF-OWHM2 framework of demand-driven and supply-constrained conjunctive use. If excess water is delivered, this surface water is returned to the surface-water network for potential reuse downstream. The addition of SRD segments also allowed calibration analysis to assess the canal deliveries and assess if conveyance was achieved at the point of delivery to satisfy irrigation demands.

The properties of the surface-water network were also modified relative to previous model versions. Flow in the Rio Grande and its major and minor tributaries was simulated using Manning's equation and assuming a wide rectangular channel. Manning's roughness coefficient was specified to be 0.02 (Arcement and Schneider, 1989) for each segment and was allowed to increase to the range of $0.02-0.03$ when supported by previous modeling efforts (S.S. Papadopulos and Associates, Inc., 2007; Hanson and others, 2013; Ferguson and Llewellyn, 2015). The channel-bed elevations were specified on a cell-by-cell (reach) basis on the finer grid of the RGTIHM using 3.28-ft (1-m) horizontal-resolution light detection and ranging (lidar) data (International Boundary and Water Commission, 2015; U.S. Geological Survey, 2015), where available, or a 32.8-ft (10-m) horizontal-resolution digital elevation model (DEM; U.S. Geological Survey, 2013a-f). Streambed thicknesses were specified to be 1-ft thick throughout the network.

Hydraulic properties for groups of segments were parameterized to help calibration of the surface-water flows, and the geometry of the canals and drains was reestimated. For example, the LRG_2007 model represented all canals and drains with a 6-point stage-width-flow relation, but only used rectangular channel cross sections. This was partly modified for the original service units 2 and 5 in the LRG_FMP2011 and LRG_USBR_EIS with use of trapezoidal channel crosssectional shapes. In the RGTIHM, all canals and drains are represented with a 6-point stage-width-discharge relation with trapezoidal channels based on reported construction information (Tetra Tech EM, Inc., 2004). The stage-widthdischarge relations for groups of similar canals and drains was estimated by the Manning equation. The Rio Grande was also simulated with a broad channel, about $225 \mathrm{ft}$ wide, and stagedependent flow by the Manning equation.

With the inclusion of estimated runoff from surrounding watersheds in the TRGWM, the surface-water network was extended to include at least one major arroyo tributary (figs. $1 B, C$ ) in each of these subwatersheds to link and distribute the external runoff to the active RGTIHM model grid. These additional tributary segments were represented by constant widths, assumed unit bed thicknesses, and Manning roughness dependent flow stages. The location of the tributaries was primarily derived from the National
Hydrography Dataset (NHD; U.S. Geological Survey, 2016a), but two tributaries were derived from the Servicio Geológico Mexicano (SGM, 2011). Some minor adjustments were also made to tributary segment locations and lengths, based on a review of aerial imagery (Environmental Systems Research Institute, 2016). Many of the tributary segments (figs. $8 A, B$ ) were not directly linked to the original network, but instead, the tributaries that aerial imagery (Environmental Systems Research Institute, 2016) indicated were connected to the Rio Grande or a drain segment had the ability to route any excess water at the terminus to the Rio Grande or drain segment, respectively.

\section{Surface-Water Flows}

Surface-water inflows and diversions were simulated with 159 total flows and diversions specified on a monthly basis (Ritchie and others, 2018). The monthly inflows included the releases from Caballo Reservoir, additional inflow from the Bonita Private Lateral (Bonita Community Ditch), 16 outfall discharge points from wastewater-treatment plants and El Paso Electric, and the TRGWM-estimated runoff and recharge in 80 arroyo tributaries that drain surrounding subwatersheds (figs. 8A, $B$ ). The monthly diversions included the 30 for direct irrigation delivery, an additional 31 diversions that represent inflows from the Rio Grande at major canals and laterals, and the outflow diversions at the American Diversion Dam and for the Acequia Madre diversion to Mexico at the International Dam (fig. $8 B$ ). Of the 31 non-farm-delivery diversions, only 9 were simulated using measured and estimated flows, and the remaining 22 diversions were simulated as fractional splits that were initially estimated from the LRG_2007 model SFR framework. Fractional splits are described in the second following paragraph.

Surface-water inflows to the SFR2 network were specified as monthly releases from Caballo Dam to the Rio Grande, as measured at the "Rio Grande below Caballo Dam" streamgage (USGS STAID 08362500; fig. 8A; Ritchie and others, 2018), and as monthly diversions from Caballo Reservoir to the Bonita Private Lateral (fig. 8A; Ritchie and others, 2018). Additional surface-water inflows to the SFR2 network were specified as monthly estimates of runoff and rejected baseflow in the 80 major and minor Rio Grande tributaries at the boundary of the active RGTIHM area based on the TRGWM and as monthly discharge from 16 wastewater-treatment facilities to the Rio Grande and from drains compiled from various sources (Tillery and others, 2009; A. Widmer, Las Cruces Utilities Water Resources, written commun., 2016; C. Trujillo, Anthony Water and Sanitation District, written commun., 2016; H. Ruiz, El Paso Water John T. Hickerson Water Reclamation Facility, written commun., 2016; U.S. Environmental Protection Agency, 2016a-c; U.S. Geological Survey, 2016b) compiled in the data release by Ritchie and others (2018). 
Monthly diversions from the Rio Grande at dams and from the Three Saints Main Lateral at the Three Saints Main Canal Wasteway 19 were specified as flows by using observed data compiled from multiple sources, data from previous modeling efforts, or assumed values to fill gaps in the available data sources (S.S. Papadopulos and Associates, Inc., 2007; Tillery and others, 2009; Hanson and others, 2013; Ferguson and Llewellyn, 2015; D. Blatchford, Bureau of Reclamation, written commun., 2016; International Boundary and Water Commission, 2016; S. Tillery, NMSU, written commun., 2016), which were compiled in the USGS data release by Ritchie and others (2018). For other diversion points along the SFR2 network, including locations where water is diverted from main canals to smaller canals and laterals, the monthly diversions were specified as fractional splits of the flow in the segment upstream from the diversion. The fractional split at each of these locations was derived from observed flows in the segments downstream from the diversion, compiled from multiple sources. Where sufficient data were not available to estimate fractional splits, fractional splits were derived from the maximum flow in the segments downstream from each diversion, as estimated from the stage-discharge relations developed for the canals, laterals, and drains (Tillery and others, 2009; Blatchford, 2017) and compiled in the USGS data release by Ritchie and others (2018).

Surface-water deliveries to the agricultural WBS were specified as a series of diversions through the SFR network. Diversions from the Rio Grande to each canal heading were specified as diversion flow rates. Diversions from main canals to smaller canals and laterals, and ultimately to the semi-routed delivery (SRD) segments defined in FMP, were specified primarily as fractional splits, except for the diversion to WBS number 1 (fig. 2B), which was based on flow data from a previous modeling effort (Ferguson and Llewellyn, 2015). The diversion splits also were obtained from previous modeling efforts (S.S. Papadopulos and Associates, Inc., 2007; Ferguson and Llewellyn, 2015) and were adjusted during model calibration.

In addition to constraining surface-water deliveries on the basis of the WBS demands (for example, total farm-delivery requirement) and the amount of surface water available, the FMP also allows surface-water deliveries to be constrained on the basis of a specified surface-water allotment (Boyce and others, 2020). Surface-water deliveries to agricultural WBSs were constrained on the basis of historical RGP allotments. As detailed by Reclamation (Bureau of Reclamation, 2013, 2016), the RGP surface-water supplies have historically been allocated such that each acre of authorized land in the RGP received an equal allotment of RGP water; however, the method used to compute RGP allocations and allotments has evolved over time as a result of changes in the RGP operations and maintenance responsibilities among Reclamation, EBID, and EPCWID1. The RGP water was initially allocated as a height of water - that is, acre-feet per acre - available to each acre of authorized land in the RGP. Beginning in the early 1980s, allotments were determined as a volume of water available for diversion by each irrigation district, where the volumetric diversion allocation was developed to provide an equal amount of water to all RGP lands, assuming no change in canal operations and efficiencies. The allotment, as a height of water equivalent to a given volumetric diversion allocation, can be estimated on the basis of the authorized RGP acreage and estimated historical canal efficiency. Additional details about historical and present-day RGP allocation procedures were provided by Reclamation (Bureau of Reclamation, 2013, 2016).

Surface-water allotments in the RGTIHM were derived from historical annual RGP surface-water allocation volumes to the EBID and EPCWID1 (I. Ferguson, Bureau of Reclamation, written commun., 2016; Ritchie and others, 2018). Annual allotments for each agricultural WBS were developed by prorating district allocation volumes on the basis of the irrigated acreage in each WBS that receives RGP surface water (figs. $2 B, C$ ). Surface-water allotments were specified on a monthly basis by further prorating on the basis of the fraction of the historical annual release from Caballo Dam in a given month, where historical annual releases were determined from flow measured at the "Rio Grande below Caballo Dam" streamgage (USGS 08362500; fig. 8A; I. Ferguson, Bureau of Reclamation, written commun., 2016; Ritchie and others, 2018).

\section{Groundwater Supply—Rio Grande Transboundary Integrated Hydrologic Model}

Groundwater pumpage in the TRG region was grouped into two types of pumpage as simulated agricultural pumpage and pre-estimated and specified municipal and industrial and domestic pumpage. Estimated agricultural pumpage (or "agricultural supply") includes water withdrawn from all irrigation wells used to supply water for irrigation. Specified groundwater withdrawals (or "water supply") includes water for municipal, domestic and rural residential, and industrial uses. Some irrigation wells and municipal and industrial wells were simulated as multi-aquifer (MNW2) wells that can extract water from more than one aquifer model layer (figs. 10A, $B$ ).

\section{Agricultural Supply}

Agricultural pumpage is estimated in the FMP of the MF-OWHM2 model (Boyce and others, 2020). Irrigation wells were simulated as a combination of single-aquifer wells and multi-aquifer wells (fig. 10A). Irrigation wells that are single-aquifer wells are simulated as wells in the WEL package (Harbaugh, 2005), and multi-aquifer wells are simulated by the "Multi-Node Well" (MNW2) package (Konikow and others, 2009). The previous models (LRG_2007, LRG_FMP2011, and LRG_USBR_EIS) had an agricultural well in every cell coincident with agricultural areas. In the RGTIHM, wells were simulated only in model cells coincident with actual well locations. 
Well-specific records of pumpage from agricultural wells were scarce and difficult to obtain for the TRG; therefore, pumpage was indirectly estimated for simulating and analyzing water use. Two common methods of indirectly estimating pumpage are through analysis of data for power consumption by well pumps and using data from a farm waterbudget based crop consumptive use of water (Frenzel, 1984) or estimates of a crop irrigation requirement (CIR) as used by the NMOSE (P. Barroll, New Mexico Office of the State Engineer, written commun., 2011). The use of electric power records is considered unreliable for estimating agricultural pumpage in the TRG because many wells are driven by either electric or diesel power sources and because of the inherent complexity of accounting for additional uses for electricity on a farm-by-farm basis. Although crop consumptive-use estimates have been used previously (Frenzel, 1984), they can also be potentially unreliable if this method does not account for the combined consumption of water supplied from other water sources, such as precipitation, surface water or groundwater for irrigation, and direct uptake from shallow groundwater to satisfy ET consumption. The consumptive-use method does capture some of the variability in consumption with changing climate, but might not capture all the dynamics of farming, including potential water stacking; deficit irrigation; multiple harvests, such as multiple cuttings of alfalfa; and changes in specific acreages or land use, such as changing crops or fallowing. The estimation of agricultural pumpage through application of the FMP provides physically based, dynamic, and linked pumpage estimates as an alternative to indirect methods (Hanson and others, 2014b).

Although estimates of pumpage from a CIR-based method varied in approach, by including groundwater uptake, the FMP provides added detail compared with many applications of this method. Other methods can provide alternate aspects of consumption, such as the soil-waterbalance method (Westenbroek and others, 2010), which uses a Thornthwaite-Mather soil-moisture-balance approach based on daily soil moisture to estimate consumption, potential irrigation or pumpage demand, and potential recharge. Pumpage for supplemental or primary agricultural supply is estimated by the FMP as a combination of crop-irrigation requirement and inefficient losses minus any potential available surface-water supply required to satisfy the total farm-delivery requirement for all wells that deliver water to a particular WBS. Inefficient losses include those from on-farm conveyance of irrigation water, as well as potential losses from deep percolation below the root zone from inefficient irrigation. The crop-irrigation requirement in this context refers to all evaporation and transpiration of water by a particular crop in a model cell, which is a part of the total consumptive use, or the water consumed by evaporation and transpiration from all sources of water. Groundwater pumpage needed to satisfy the total farm-delivery requirement can be estimated by accounting for any potential surfacewater supply, the efficiency of irrigation, fractions of transpiration and evaporation in each model cell, and the fraction of inefficient losses to deep percolation. Runoff from precipitation on native vegetation, urban, or agricultural land areas was not simulated in this version of the RGTIHM, but a small amount of runoff from irrigation was simulated in the RGTIHM, so most of the inefficient losses from irrigation are simulated as deep percolation to groundwater. Unmetered pumpage is estimated through consumptive use by the FMP on the basis of monthly consumptive-use estimates from the NMOSE for 1938-2010 for 6 agricultural service areas (Arrey Canal, Leasburg Canal, Eastside Canal-New Mexico, Eastside Canal-Texas, Westside Canal-New Mexico, and Westside-Canal Texas; P. Barroll, New Mexico Office of the State Engineer, written commun., 2011; Ritchie and others, 2018) distributed across 7 of the 20 land-use categories in the RGTIHM (table 2).

Reported data from as many as 3,949 actual agricultural wells and 10 cloned agricultural wells (a clone well is one for which an existing farm well was associated with another WBS for part of its delivery of irrigation water) were used for simulating pumpage for irrigation (fig. 10A); the number of active wells for any given month varied through time on the basis of reported drill dates and destruction dates (Ritchie and others, 2018; Hayes, 2015; New Mexico Office of the State Engineer, 2015; Texas Water Development Board, 2015c). If the construction or destruction date was before the middle of the month, the well was assumed to have the potential to be active or to have been destroyed, respectively, during the entire month. If the construction or destruction date was after or equal to the middle of the month, the well was assumed to have the potential to be active or to have been destroyed, respectively, during the following month. If the construction date was not available, the well was assumed to be potentially active the beginning of January 1950, based on reports of extensive agricultural groundwater development in the early 1950s (S.S. Papadopulos and Associates, Inc., 2007). If the destruction date was not available, the well was assumed to be potentially active through the end of the simulation period. As discussed previously in the "Groundwater" section, annual estimates of agricultural pumpage in New Mexico were used as observations during calibration. No estimates of irrigation pumpage were available in the Texas part of the TRG region. 
The FMP computes the collective, potential pumping capacity of all wells that can provide groundwater for supplemental irrigation water. Although this total capacity is a physical constraint on the ability to provide groundwater for irrigation, this engineered capacity is typically much more than the requirements for irrigation. The total simulated irrigation pumpage required for each WBS is distributed among all single-aquifer and multi-aquifer wells that collectively supply groundwater to that WBS as needed for irrigation in each monthly stress period (figs. $2 B, C$ ). The pumpage is distributed on the basis of a pumping capacity for each well that is proportional to the specified maximum capacity of each well (Boyce and others, 2020). Thus, wells with more specified capacity supply more of the groundwater for irrigation. Because wells are not operated all day and every day, the pumping capacities were further scaled to a reduced amount of capacity to better represent well operation for supplemental irrigation. Wells used for irrigation in a WBS that receives surface water were assumed to be operated about 2 days a week, and wells for a WBS that only receives groundwater were assumed to be operated 3 days a week. For example, the frequency of irrigation for pecan orchards ranges from about every 4 to 18 days for sand to silty-clay loam, respectively, resulting in intermittent irrigation (Kallestad and others, 2008). Limiting the number of days wells are operated further constrains the amount of groundwater that can be provided for irrigation.

The total pumpage for irrigation in any WBS was distributed to all wells that were associated with that WBS. When well-screen intervals spanned multiple model layers, the well was simulated as a multi-aquifer well, allowing pumping to be dynamically distributed, along with intra-wellbore flow, among all of the corresponding layers. Thus, pumpage for each well was dynamically allocated to individual model layers on the basis of the construction information indicating which layers contributed to a well's potential pumpage or intra-wellbore flow. Multi-aquifer pumpage is applied in the simulation by using the MNW2 package of the MF-OWHM2 to make this dynamic apportioning among layers penetrated by each multi-aquifer well. The open-screen interval was used to identify the RGTIHM layers from which water was withdrawn, assuming the wells partially to fully penetrate the layers they pump from. If a well contained multiple openscreen intervals, all layers from the top of the uppermost open interval to the bottom of the lowermost interval were included, and that interval was assumed to be completely screened and to fully penetrate those model layers. Partial penetration would apply to parts of the uppermost and lowermost layer penetrated if the range of elevations was within the modellayer top and bottom elevations. If open-screen information was not available but total well depth was available, a well was assumed to be screened from the land surface to the total depth, which also could represent partial penetration in the lowermost layer if the elevation of the total depth of a well is above the elevation of the bottom of the lowermost layer penetrated by a well. If neither open-screen nor total depth information was available, a well was assumed to be screened from the land surface to the median total well depth of other agricultural wells in the area, based on groups defined by construction date (prior to 1960, 1960 onward, or no drill-date available), geographic region (Rincon Valley, Selden Canyon, Upper Mesilla Basin, Middle Mesilla Basin, or Lower Mesilla Basin; fig. 2A), and whether the well was inside or outside the RGV, as defined by the extent of the river-channel hydrostratigraphic unit (figs. $3 A, 4 A$; Sweetkind and others, 2017). The median total depth of all wells for which total depth information was available for a particular group was applied to wells without total depth information in that group. This assignment of model layer interval could also result in partial penetration in the lowermost layer penetrated by wells with unknown construction information.

Each agricultural well was assumed to deliver groundwater locally and was assigned to the agricultural WBS in which the well was located according to coordinates in shapefiles from the NMOSE (Hayes, 2015) and the TWDB (Texas Water Development Board, 2015a,b,c). If the well coordinates did not place the well in an agricultural WBS, the New Mexico Water Rights Reporting System database (New Mexico Office of the State Engineer, 2015), the NMOSE Transboundary Rio Grande Hydrographic Survey (New Mexico Office of the State Engineer, 2016), and the TWDB database (Texas Water Development Board, 2015a,b,c) were searched to determine if the well coordinates provided in Hayes (2015), SDR Database (2015), or TWDB Groundwater Database (Texas Water Development Board, 2015a,b,c) were correct. If the well coordinates were incorrect, they were modified, and if the well coordinates were correct, the well was assigned to a nearby agricultural WBS. If the modified well coordinates still did not place a well inside the boundary of an agricultural WBS, the well was assigned to a nearby agricultural WBS. Some groundwater-only agricultural WBSs contained no agriculture wells within their boundaries, in which case a clone of at least one agriculture well serving a groundwater/surface-water WBS was created and assigned to the groundwater-only WBS. Each agricultural WBS had at least one assigned agriculture well. Conversely, some irrigation wells in the TRG region are used to deliver irrigation water to multiple land parcels in more than one WBS; therefore, additional clone wells were simulated to satisfy delivery of groundwater to selected groundwater-only WBSs that did not have a well in its WBS subregion. 
The capacity and casing diameter of each farm well was obtained from Hayes (2015), New Mexico Office of the State Engineer (2015), Submitted Drillers Reports Database (Texas Water Development Board, 2015a,b,c), and TWDB Groundwater Database (Texas Water Development Board, 2015a,b,c). Similar to missing open-screen or total-depth information, missing capacity and casing-diameter information was estimated as the median value of all agricultural wells that had this information, grouped by drill dates (prior to 1960, 1960 onward, or no drill date available) and location in one of five informal geographic regions (Rincon Valley, Selden Canyon, Upper Mesilla Basin, Middle Mesilla Basin, and Lower Mesilla Basin; fig. $2 A$ ). The resulting capacity of farm wells ranged from 3 to 5,000 gallons per minute, and the casing diameters ranged from 0.4 to 30 inches.

\section{Water Supply}

Pumpage information for municipal and industrial uses and for domestic water-supply wells was specified according to reported and estimated values. Pumpage information for each of the wells identified as a municipal and industrial well was obtained from a number of sources: previous modeling studies (S.S. Papadopulos and Associates, Inc., 2007; Hanson and others, 2013; Ferguson and Llewellyn, 2015; S.S. Papadopulos and Associates, Inc., 2016); John Shomaker and Associates, Inc., pumping compilations for wells in the city of Las Cruces based on estimates from well-service history, well yield, and population-based demand, and city of Las Cruces pumping records (Petronis and others, 2006; S. Finch, John Shomaker and Associates, Inc., written commun., December 14, 2015); extraction volumes reported for the Mexico wells (International Boundary and Water Commission, 2011); the New Mexico Water Rights Reporting System (NMWRRS) database (New Mexico Office of the State Engineer, 2015); or estimates based on pumping capacities (Hayes, 2015; Ritchie and others, 2018). The previous modeling studies assigned pumping rates to 4 and 8-month stress periods (November-February and March-October, respectively); the other data sources contained pumping information at a range of temporal scales. The RGTIHM uses monthly stress periods, thus pumping information from these different data sources was converted to monthly values for input to the RGTIHM. Operational history information (drill dates, active pumping periods, and destruction dates, if applicable) was used to construct estimates of monthly pumping for each well (Ritchie and others, 2018).

Pumping rates for New Mexico and Texas municipal and industrial wells that were not simulated from individual wells in the previous modeling studies (S.S. Papadopulos and Associates, Inc., 2007; Hanson and others, 2013; Ferguson and Llewellyn, 2015) were based on reported pumping capacities. For these wells, pumping rates were assumed to equal a fraction of the pumping capacity listed for each well. If no pumping capacity was available for a well, the pumping rate was assumed to equal a fraction of the median pumping capacity of all municipal and industrial wells that had the same use and the same data source (for example, Hayes, 2015; Texas Water Development Board, 2015c). The scalefactor applied to the pumping capacities for these wells was determined by comparing annual pumpage for all other New Mexico municipal and industrial wells to annual estimates of municipal and industrial groundwater withdrawals in Doña Ana County compiled by the NMOSE for 5-year intervals from 1990 to 2010 (Longworth and others, 2008, 2013; Wilson, 1992; Wilson and Lucero, 1997; Wilson and others, 2003). Scale-factors were determined for $1990,1995,2000$, 2005, and 2010 to scale the pumping capacities of these wells, such that the annual pumpage for the New Mexico wells was equal to the difference between the annual pumpage for all other New Mexico municipal and industrial wells and the NMOSE annual estimates for Doña Ana County. The scalefactor determined for 1990 was applied to all prior years to the start of the simulation, and the scale-factor determined for each successive NMOSE annual estimate was applied to the next 4 years.

Without additional information about operational history, municipal and industrial pumping in Mexico was assumed to begin in 1970 at a few livestock and services wells at rates based on extraction volumes measured at these wells in 2010 (International Boundary and Water Commission, 2011). Municipal and industrial extractions in Mexico associated with the water-supply well field began in mid-May 2010 (International Boundary and Water Commission, 2011), and were held constant at these rates through the end of the simulation period in December 2014.

As many as 1,874 municipal and industrial wells were represented for various periods during the 74-year simulation in the RGTIHM (fig. 10B; Ritchie and others, 2018). The actual locations of municipal and industrial wells were used in the model, and the MNW2 package was used to simulate groundwater pumpage. The open-screen interval or total depth was used to identify the RGTIHM model layers from which groundwater was pumped. If a well contained multiple open-screen intervals, a composite open-screen interval was used from the top of the uppermost open-screen interval to the bottom of the lowermost open-screen interval. If openscreen information was not available and total well depth was available, a well was assumed to be screened from the land surface to the total depth. If neither open-screen nor totaldepth information was available, municipal and industrial wells were assumed either to be screened in layers assigned in previous modeling studies (S.S. Papadopulos and Associates, Inc., 2007; Hanson and others, 2013; Ferguson and Llewellyn, 2015) or, in the case of the Mexico wells, to fully penetrate the upper hydrostratigraphic unit of the Santa Fe Group (Sweetkind and others, 2017); if neither of these two cases applied, then the wells were not simulated. 
The casing diameter of each municipal and industrial well was obtained from any of a number of sources (Ritchie and others, 2018). If casing diameter was not available for a well, the well either was assigned a casing diameter from a nearby well or was assumed to have the median casing diameter of all municipal and industrial wells in the same well-use category (Ritchie and others, 2018). The diameter of the well skin, or the region of disturbed aquifer material resulting from drilling activities surrounding the well casing, was assumed on the basis of the drill date and casing diameter of the well. If there was no drill date available for a well or if the drill date was prior to 1960, the well skin was assumed to extend 2 inches from the well casing. If the drill date was from 1960 onward, the well skin was assumed to extend 2 inches from a well casing with a diameter less than or equal to 10 inches and to extend 4 inches from a well casing with a diameter greater than 10 inches. The underlying assumption was that wells drilled prior to 1960 were installed using cable-tool drilling methods and did not have as wide a radius of disturbed aquifer surrounding the well as those installed using borehole drilling and the subsequent emplacement of well casing and filter-pack well methods assumed to be prevalent from 1960 onward.

As many as 8,865 domestic wells were represented at various periods during simulation period (fig. 10C; Ritchie and others, 2018). The actual locations of domestic wells were used in the model, and the "Well" package (WEL) was used to simulate the domestic pumpage from single aquifer model layers. The open-screen interval or total depth was used to identify the uppermost active model layer from which groundwater was pumped. If a well contained multiple openscreen intervals, a composite open-screen interval from the top of the uppermost open-screen interval to the bottom of the lowermost open-screen interval was used to determine the uppermost active model layer assigned to a well. If openscreen information was not available and total well depth was available, the interval from the land surface to the total depth was used to determine the uppermost active model layer assigned to a well. If neither open-screen nor total depth information was available, a well was assumed to pump from the uppermost active model layer at the well location.

Pumping rates for each domestic well in New Mexico were estimated as the NMOSE-estimated annual domestic pumpage volume divided by the number of domestic wells on record. Water pumped from domestic wells is not all consumptively used, because some of it recharges groundwater through the septic system and beneath watered lawns. Septic return-flow was assumed to equal 68 percent of domestic pumpage (fig. 11B; Balleau and Silver, 2005), but recharge from watering a lawn was assumed to be negligible by comparison because of evapotranspiration. Prior to 1990 , annual domestic pumpage for New Mexico was estimated to be equal to the 1990 pumpage estimate from the NMOSE (fig. 10B). For years between NMOSE estimates, the domestic pumpage for the earliest year of successive 5-year annual estimates from the NMOSE was applied to the next 4 years (fig. 11B). Similar to the LRG_2007 model (and related LRG_ FMP2011 model), the assumed number of domestic wells could be underrepresented in Texas, and thus, active domestic wells in Texas were assumed to have three times the septic return-flow-adjusted pumping rates as those in New Mexico (S.S. Papadopulos and Associates, Inc., 2007; fig. 11B).

For the operational history of all domestic wells, construction and destruction dates were used, when available, to activate individual wells; otherwise, the wells were assumed to persist from the drilling or construction date to end of the simulation period or for the entire simulation period, if neither the drilling or construction dates nor destruction date was known. Nine domestic wells had construction dates after the end of the simulation period, one in 2015 and the other eight from 2026 onward, likely due to a data-entry error in Hayes (2015). In addition, three domestic wells were constructed prior to 1900 in Hayes (2015). As a result, these 12 wells were not considered to be present or actively pumping during the simulation period. Total domestic pumpage was estimated to range from about 750 acre-ft/yr in 1940 to 214 acre-ft/yr in 2014 (fig. 11B). The reduction in domestic pumpage could be due to increased incorporation of domestic users into municipal and industrial distribution systems.

All municipal and industrial wells without drilling or construction dates or destruction dates were either not simulated or assumed to be active for the period of simulated pumping from previous modeling studies (S.S. Papadopulos and Associates, Inc., 2007; Hanson and others, 2013; Ferguson and Llewellyn, 2015; Knight, 2015). In the case of the Mexico wells, however, those without construction or destruction dates either were assumed to be present from the beginning of January 1970 through the end of the simulation, if identified as services wells, or were assumed to be present from the beginning of May 2010 through the end of the simulation, if identified as public supply wells (International Boundary and Water Commission, 2011). Overall, the combined municipal and industrial and domestic pumpage was less than agricultural pumpage, but it can be important locally. 


\section{Landscape Features-Rio Grande Transboundary Integrated Hydrologic Model}

The FMP provides coupled simulation of the groundwater and surface-water components of the hydrologic cycle for irrigated and non-irrigated areas. A dynamic allocation of groundwater recharge and groundwater pumping is simulated on the basis of residual crop water demand after surface-water deliveries and root uptake from shallow groundwater. The estimation of irrigation pumpage in the FMP is dependent on contributions of water from precipitation (if climate options are implemented) and variable irrigation efficiencies and is also connected to irrigation inefficiency losses as return flows (deep percolation and runoff combined). The FMP not only estimates supply and demand, movement, and consumption of agricultural irrigation water, but also estimates these components for native vegetation and for landscape irrigation in urban areas. Thus, the use of the FMP in MF-OWHM2 enables the simulation of fully coupled flow of water by surface-water, land-use, and groundwater processes (Boyce and others, 2020). Because the use of pre-computed consumptive use provided by the NMOSE was required for this study by Reclamation, water use and movement in the landscape was not directly dependent on precipitation and reference ET because the simulation of actual ET was not coupled to inputs of changing actual agricultural land use and related crop properties (Schmid and others, 2006b; Schmid and Hanson, 2009; Hanson and others, 2014b). For this version of the RGTIHM, the monthly consumptive use was specified and MF-OWHM2 was then used to simulate the demand components representing crop-irrigation requirements (CIR), which are subject to crop and farm-specific inefficiency losses, and the supply components representing surface-water deliveries, direct uptake from groundwater, and irrigation from pumped groundwater. Soil moisture was not considered an important source or storage component for the water budget of well-managed, irrigated agriculture over periods of weeks to a month, which are the typical time spans used with regionalscale applications of MF-OWHM (Schmid and others, 2006a; Schmid, 2004). Although the FMP can also simulate additional head-dependent inflows and outflows from the landscape, such as a monthly approximation of surface runoff from precipitation and surface-water return flows, only a fraction of irrigation return flow as runoff was simulated to represent delivery wastage and potential return flow of tail water in this version of the RGTIHM. Artificial groundwater recharge was simulated by way of deep percolation of irrigation water in excess of AET in this version of the RGTIHM (Boyce and others, 2020).

The WBS inflows and outflows on the landscape are simulated by the FMP as mass balances in each WBS and are calculated and balanced for each simulation time step. A summary of how the FMP accounts for inflows and outflows for each WBS follows; more details can be found in the FMP and MF-OWHM documentation (Schmid and others, 2006a, b; Schmid and Hanson, 2009; Hanson and others, 2014b; Boyce and others, 2020). The FMP dynamically integrates irrigation-water demand with direct uptake of groundwater to satisfy evapotranspiration on the landscape along with losses from irrigation efficiency. The FMP allocates water, simulates landscape processes, and computes the surfacewater and groundwater inflows and outflows to and from the landscape for each WBS in the active model domain. On the basis of cell-by-cell estimations for each WBS, the FMP first calculates water demand as uptake and transpiration by plants and the associated evaporation. The FMP then determines a residual water demand that cannot be satisfied by root uptake from shallow groundwater near the root zone. Next, the FMP equates this residual water demand to the irrigation requirement from the specified consumptive use prorated by the fraction of transpiration for all cells with irrigated crops (that is, exclusive of any native vegetation), thus producing estimates of the CIR in each WBS for each time step. Because demand needs to balance supply, the additional constraint of a deficit-irrigation option in the FMP was used in the RGTIHM to reduce demand relative to available supply.

The CIR is then adjusted (increased) by accounting for evaporative losses from irrigation and other inefficiency losses to yield a final total farm-delivery requirement (TFDR). For the TRG, where the conjunctive use of surface water and groundwater are major sources of water used for irrigation ( 31 of the 57 agricultural WBSs), the FMP attempts to satisfy the TFDR by using surface water first, with residual demand satisfied by groundwater. For the 26 WBSs that receive only groundwater, the TFDR is entirely satisfied by groundwater. The amount of excess water from irrigation that is not effectively used for crop growth or is otherwise "lost," as described previously, becomes groundwater recharge as deep percolation below the root zone. In addition, the RGTIHM uses the deficit-irrigation scenario with the FMP to reduce demand to the available supply, if supply cannot meet demand. Thus, the FMP dynamically links the demand, supply, and related change in aquifer storage to reconcile the balance between supply and demand for irrigation. All of the supply and demand components are then tabulated into the WBS landscape budgets that complement the groundwater-flow and streamflow budgets, which collectively represent the hydrologic cycle in the TRG.

In order to estimate the inflows and outflows, the FMP integrates various components of supply and demand data that can be specified through time or held constant for the entire simulation. For complete applications of the FMP, the user is required to specify soil, crop, and climate data to compute consumptive use and specify the groundwater pumping capacity of all wells that serve a WBS. In this version of the RGTIHM, the consumptive-use option in the FMP is used with the NMOSE-CIR values as a pre-specified consumptive use, instead of full crop and climate attributes to internally compute the CIR. 
The FMP dynamically simulates these supply and demand components for a WBS in MF-OWHM2 by integrating the following computational components specific to the TRG's hydrologic setting:

1. The TFDR, which is primarily dependent on the specified CIR, but also on irrigation efficiency and variable groundwater level and associated capillary fringe.

2. Surface-water deliveries are limited by a specified allocation (surface-water allotments) to the agricultural WBSs that use both surface-water and groundwater.

3. Supplemental groundwater pumpage, which is estimated as the TFDR, but is limited by a specified maximum WBS well-pumping capacity on a well-by-well basis.

4. Net recharge (deep percolation) to groundwater, calculated as the sum of excess irrigation minus ET from groundwater (Schmid and others, 2006a, p. 20; excess precipitation as surface-water runoff is not simulated in the RGTIHM; runoff from groundwater discharge to streams is accounted for by the FMP and SFR2 package).

The MF-OWHM2 code maintains a mass balance of the landscape for each WBS, for the streamflow network, and for the groundwater-flow system. Flows between these budgets are accommodated by head- and flow-dependent inflows and outflows, such as the surface-water deliveries, AET, runoff and infiltration, or transpiration from groundwater. Quantities of interest, such as the TFDR, surface-water and groundwater supply, and excess applied-irrigation water depend on these head- and flow-dependent inflows and outflows.

For the RGTIHM, the processes of evaporation, transpiration, deep percolation to groundwater, as well as surface-water deliveries and groundwater pumpage, were estimated by MF-OWHM2. The simulated deliveries and groundwater pumpage reflect some climate variability that was partially embedded in the NMOSE CIR consumptiveuse estimates and the surface-water deliveries (Ritchie and others, 2018). Superimposed on the consumptive-use estimates are additional climatic-stress scale factors applied as seasonal wet or dry scale-factor parameters derived from the seasonal cumulative departure from mean seasonal precipitation at the NMSU climate station (fig. $5 B$ ) that were adjusted during calibration. These scale factors are used to more appropriately reflect potential differences in agricultural practices among defined WBSs embedded in the NMOSE consumptive-use estimates (P. Barroll, New Mexico Office of the State Engineer, written commun., 2011; Ritchie and others, 2018) as well as the year-to-year changes in surface-water allocations and deliveries during the 1940-2014 simulation period (I. Ferguson, Bureau of Reclamation, written commun., 2016b). The RGTIHM provides a detailed transient analysis of changes in groundwater and surface-water availability, movement, use, and reuse.

\section{Total Farm Delivery Requirement}

For the RGTIHM, the TFDR is computed for each WBS as the sum of consumptive use of all WBS cells for irrigated crops and the inefficient losses from irrigation. In order to calculate the components of the water budget for each WBS, the FMP not only requires estimates of surface-water and groundwater deliveries for irrigation but also the ET groundwater components and the total AET.

Total AET is the sum of consumption of water for each WBS, as derived from the NMOSE-CIR values (table 2), which for this version of the RGTIHM is one virtual crop in each WBS. The AET is simulated using steadystate transpiration for each time step, which varies with changing groundwater level, as approximated in the FMP by an analytical solution (Schmid and others, 2006a; Boyce and others, 2020). Thus, the amount of evaporation and transpiration from the water table are both a function of soil type, water-table elevation, the root depth of each crop type, and the user-specified anoxia and wilting point for each crop. As mentioned previously, soil moisture is not accounted for directly, but by a capillary fringe based on soil type; therefore, the computation of TFDR requires soil, land use (specifically distribution of crop types), and climate data to compute consumptive use on a cell-by-cell basis.

\section{Soils}

Soils in the RGTIHM were simplified to 13 categories, based on data from the Soil Survey Geographic Database (SSURGO; Natural Resources Conservation Service, 2005, 2006), that ranged from sand to clay and rock (fig. 18). The capillary fringe was estimated for each soil type, and it ranged from 3.2 to 16.4 feet thick. These soil attributes are used for the entire simulation period, and cell-by-cell distribution is independent of the crop and WBS. The FMP associates the distributed soil types with the specified capillary fringes and internal coefficients to provide individual analytical solutions for the calculation of the potential ET from above the groundwater level in each active model (Schmid and others, 2006a). This feature of FMP does not overlap the Rio Grande riparian corridor where riparian ET from groundwater is simulated with the RIP package. 


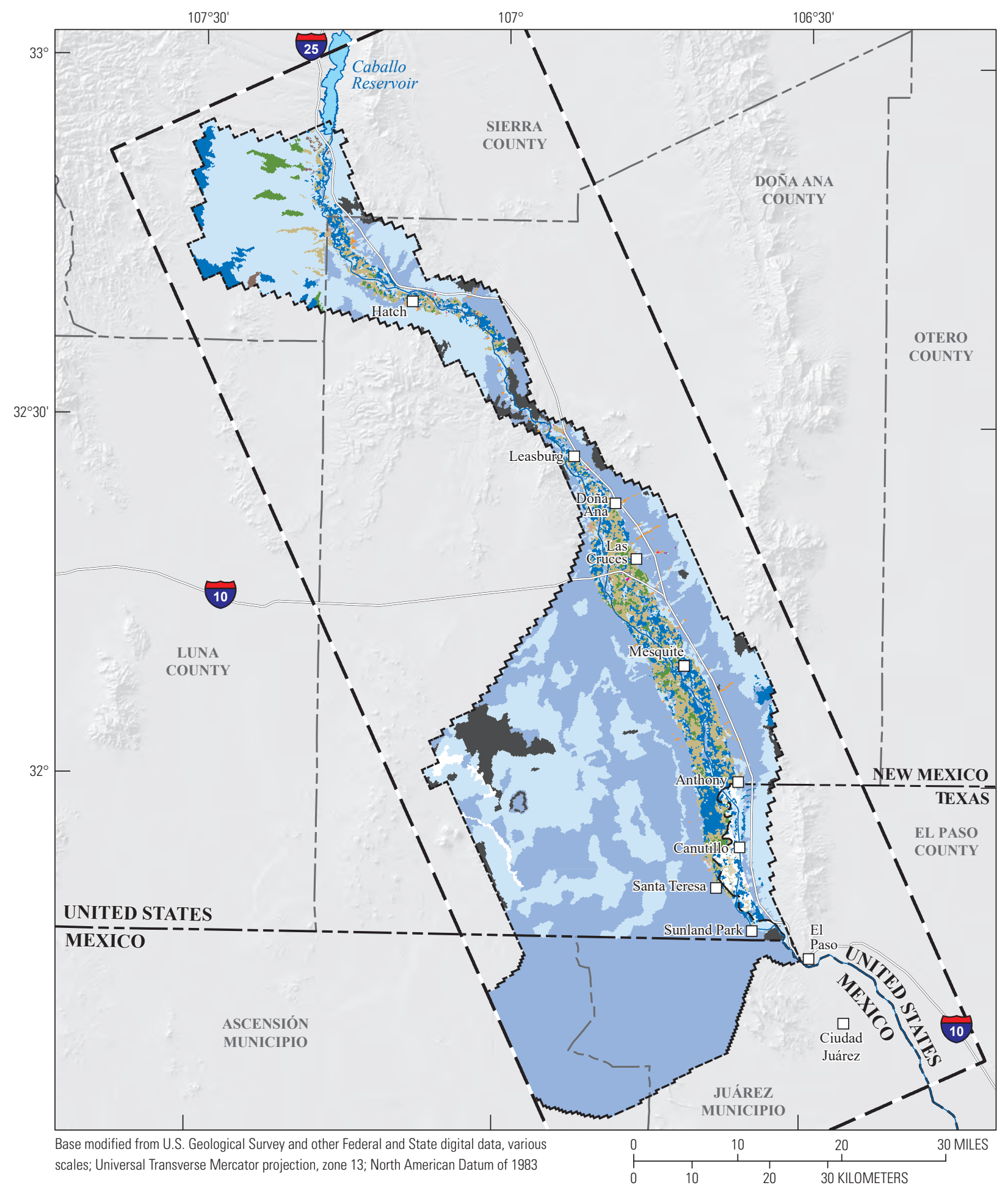

$\Gamma$ Maximum extent of

Rio Grande Transboundary Integrated Hydrologic Model (RGTIHM)

[--_ RGTIHM active model boundary

\section{EXPLANATION}

RGTIHM model grid soil texture and (capillary fringe)

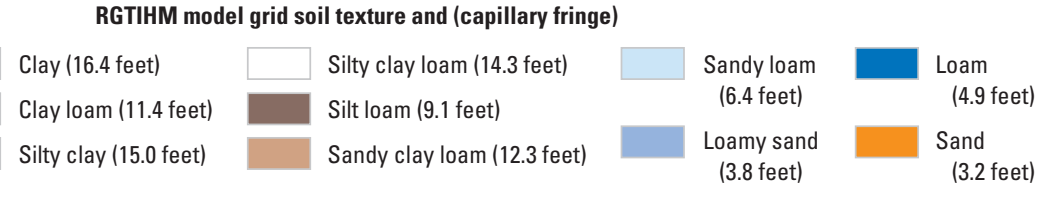

Figure 18. Agricultural soil groups for the Rio Grande Transboundary Integrated Hydrologic Model (RGTIHM) simplified from Soil Survey Geographic Database (Natural Resources Conservation Service, 2005, 2006, 2008, 2009a-c) for the Transboundary Rio Grande, New Mexico, Texas, and Mexico. 


\section{Land Use}

For the 1940-2014 period, specified virtual crop and land use were based on the subdivision to 58 subregions used for the Lower Rio Grande Bureau of Reclamation Environmental Impact Statement study (Ferguson and Lewellyn, 2015; Bureau of Reclamation, 2017; fig. 19A), which receive a combination of surface-water and groundwater supplies or only groundwater for irrigation, as initially used in the six units developed for the SSPA model (S.S. Papadopulos and Associates, Inc., 2007). The more refined TRG region of 71 WBSs also includes 3 urban land-use subregions, 2 golf course subregions, and the well field in Mexico as separate WBS. Native vegetation is represented by seven WBSs that make up about 43 percent of the landscape in New Mexico and Texas and an additional 23 percent in Mexico in the active model region of the RGTIHM (fig. 19A). Less than 5 percent of land use is made up of urban areas and golf courses, and the remaining 29 percent of the land use is agriculture (fig. 19A). These subregions are shown as different percentages based on their extent in the RGTIHM model (fig. 19B).

Separate, or representative groups, of crops or vegetation were not used in this version of the RGTIHM to represent land use; the land use is based on "virtual crops" that represent groups of agricultural land use related to the NMOSE-CIR values in the agricultural WBSs and represent generalized vegetation for the non-agricultural WBSs. There are a total of 20 virtual crops, of which 7 are linked to the original 6 units of CIR values for agricultural demand for irrigation (table 2).

The virtual crops and associated CIR values provide a basis for estimating the consumptive use of water at the land surface and are a key component of the TFDR (Schmid and others, 2006a) because the TFDR is largely composed of the CIR. Although the full implementation of the FMP determines the CIR from the product of a reference $\mathrm{ET}\left(\mathrm{ET}_{\mathrm{h}}\right)$ and an area-weighted crop coefficient $\left(\mathrm{K}_{\mathrm{c}}\right)$ on a cell-by-cell basis, this version of the RGTIHM uses pre-calculated and specified monthly CIR values for each of the land-use and virtual-crop categories (fig. 20, table 10). These CIR values are summed over all cells in each WBS. The agricultural CIR values are specified monthly on the basis of the data from the NMOSE (P. Barroll, New Mexico Office of the State Engineer, written commun., 2011). The agricultural CIRs for the 6 virtual crops used in the 58 agricultural WBS (fig. 20A) and for the 3 virtual crops used for the native vegetation (fig. 20B), 2 golf course, and 3 urban land-use WBSs were distributed temporally, such that the CIR values for the virtual crops representing native vegetation were varied according to a regular annual pattern (fig. 20C).

Specified root depths and fractions of transpiration and evaporation affect the consumption and movement of water for each crop category (Schmid and Hanson, 2009). For the RGTIHM, the root depths were held constant for the entire simulation and were based on values from the literature and previous studies (table 10).
The CIR is first satisfied from direct uptake of groundwater if the capillary fringe above the water table is in the root zone. The amount of groundwater uptake can vary with location of the water table through time. In general, direct transpiration from groundwater is active with a rising water table when the top of the capillary fringe above the water table reaches the bottom of the root zone of plants, and direct evaporation is active when the top of the capillary fringe above the water reaches the land surface. For changing water tables, the direct transpiration from groundwater is eliminated when the top of the capillary fringe above the water table falls below the bottom of the root zone and direct evaporation is eliminated when the top of the capillary fringe above the water table falls below the land surface (Schmid and others, 2006a).

The total crop water demand is typically the product of the CIR values and a crop-stress coefficient, and demand is varied to represent additional seasonal climate-based ET stress for the original six irrigation units simulated in the previous models (LRG_2007, LRG_FMP2011, and LRG_USBR_EIS; S.S. Papadopulos and Associates, Inc., 2007). Monthly consumption estimates of the NMOSE CIR values were modified in this version of the RGTIHM by changing the cropstress coefficient for different wet- and dry-year seasons to reflect changes in climate, fractions of crops, total acreage, and soil moisture. Seasonal stress factors were classified by wet and dry seasons according to the climate records and seasonal variability discussed previously.

The CIR values were adjusted by climate-based, stresscoefficient scale factors. These CIR wet- and dry-year scale factors were grouped into three agricultural periods primarily based on reported annual agricultural pumpage as well as climate and surface-water supplies. This resulted in an early period of more traditional seasonal agriculture in the TRG from 1940 to 2001; an intermediate period of intensified agriculture combined with reduced surface-water supplies during drought and increased groundwater pumpage to supplement reduced surface-water deliveries (2002-10); and a more recent period (2011-14) of agricultural intensification and even more reduced surface-water supplies that were then supplemented by an increase in supplementary groundwater pumpage and sustained drought. These periods were based on inspection of groundwater level hydrographs, climate periods, surface-water deliveries, and changes in reported annual agricultural pumpage from various sources for selected years in New Mexico. The CIR values were multiplied by a cropstress scale factor (Schmid and Hanson, 2009), the values of which depended on climatic conditions, surface-water supplies, and other factors. The climatic stress on irrigated agriculture has been shown to vary by more than 20 percent between wet and dry seasons (Hanson and others, 2010). Twelve stress coefficients were used to represent the wet- and dry-year seasons in these three pumping periods. These stresscoefficient scale factors for CIR values were adjusted during model calibration. 
$\boldsymbol{A}$

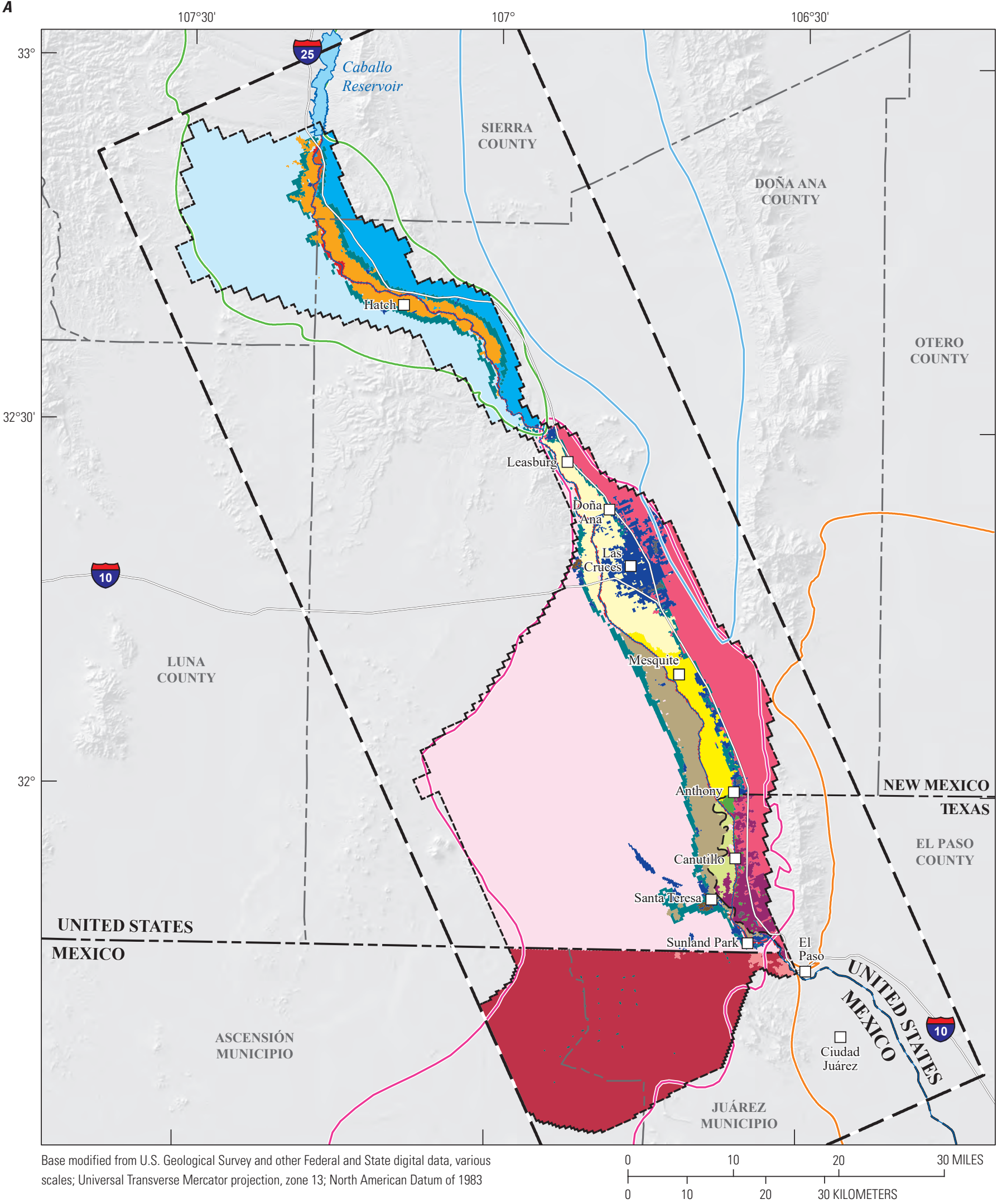

Figure 19. Land use in the Rio Grande Transboundary Integrated Hydrologic Model (RGTIHM), New Mexico, Texas, and Mexico: $A$, map showing virtual crop and land-use distributions used to estimate consumptive water use; and $B$, pie chart showing percentages of total land use for virtual crops and land-use categories that made up less than 1 percent of the RGTIHM active region. 
EXPLANATION

Water-balance subregions (WBS) and WBS identifier (see table 1)

\section{Composite Agriculture}

Percha Private Lateral WBS (1)

Arrey Canal WBS (2)

Leasburg Canal WBS (3)

Eastside Canal-New Mexico WBS (4)

\section{Rio Grande Valley corridors}

Rio Grande/floodplain/RIP area/Caballo Reservoir, no demand from FMP (8) Native Rio Grande Valley terrace (9)

\section{Native vegetation}

Native west side Rincon Valley, New Mexico (10)

ative east side Rincon Valley, New Mexico (11)

Native west side Mesilla Basin, New Mexico/Texas (12)

Native east side Mesilla Basin, New Mexico/Texas (13)

Native Conejos-Médanos, Mexico (14)

Native Batería well field ConejosMédanos, Mexico (15)
Westside Canal-New Mexico WBS $(5)$

Eastside Canal-Texas WBS (6)

Westside Canal-Texas WBS (7)

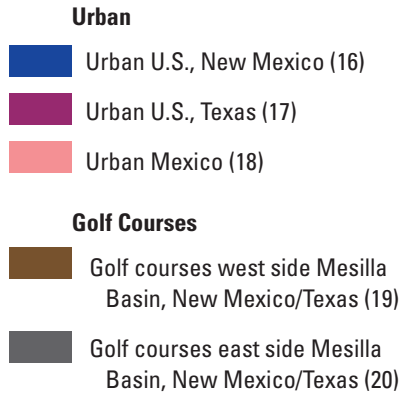

Golf courses east side Mesilla
$\Gamma$ Maximum extent of Rio Grande Transboundary Integrated Hydrologic Model (RGTIHM)

\section{RGTIHM active model boundary}

Hueco groundwater basin boundary (Driscoll and Sherson, 2016)

Palomas groundwater basin boundary (Driscoll and Sherson, 2016)

Jornada del Muerto groundwater basin boundary (after Witcher and others, 2004)

Mesilla and Conejos-Médanos groundwater basin boundary (after Sheng and others, 2013) Mexico/Texas (20) 


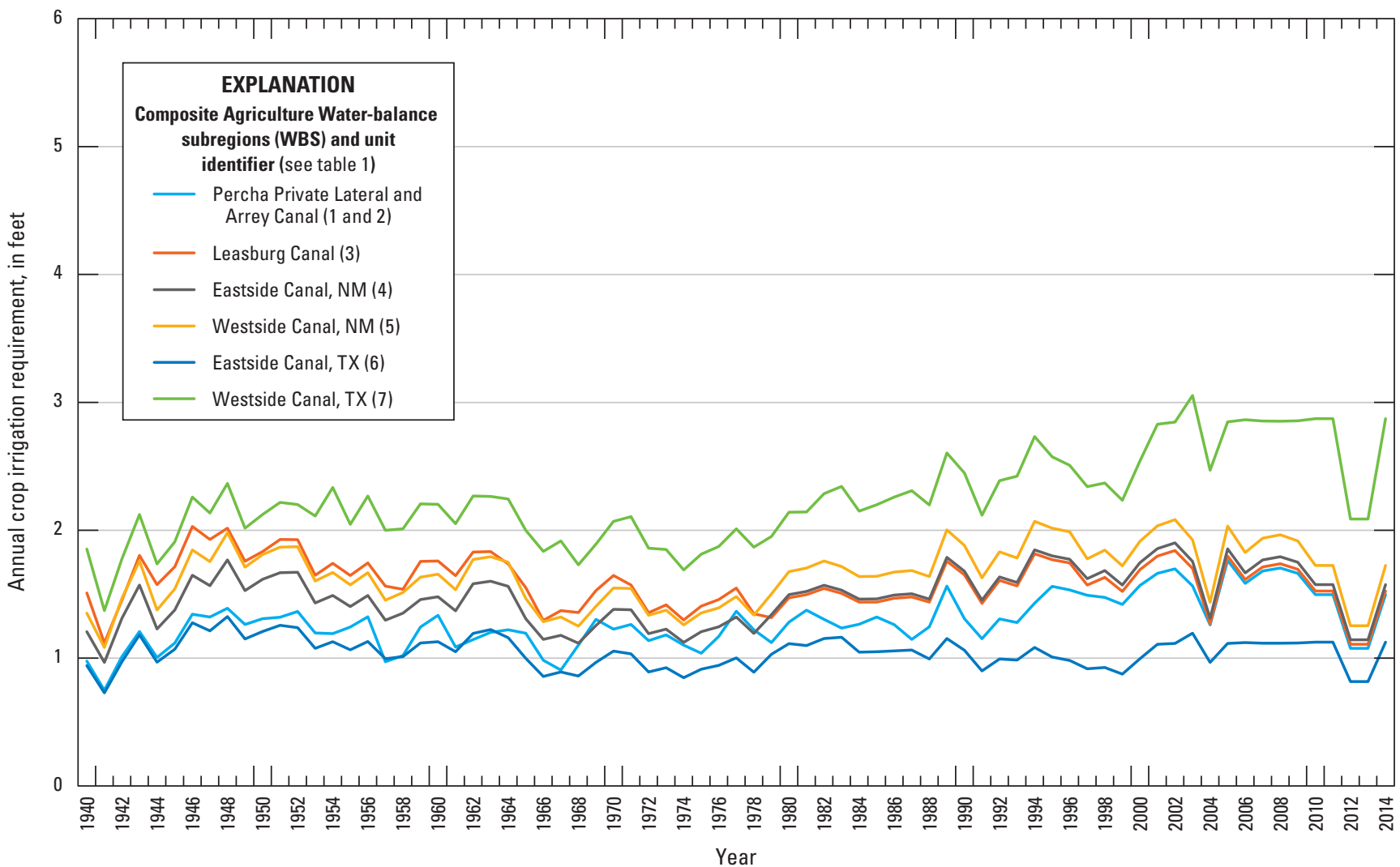

B

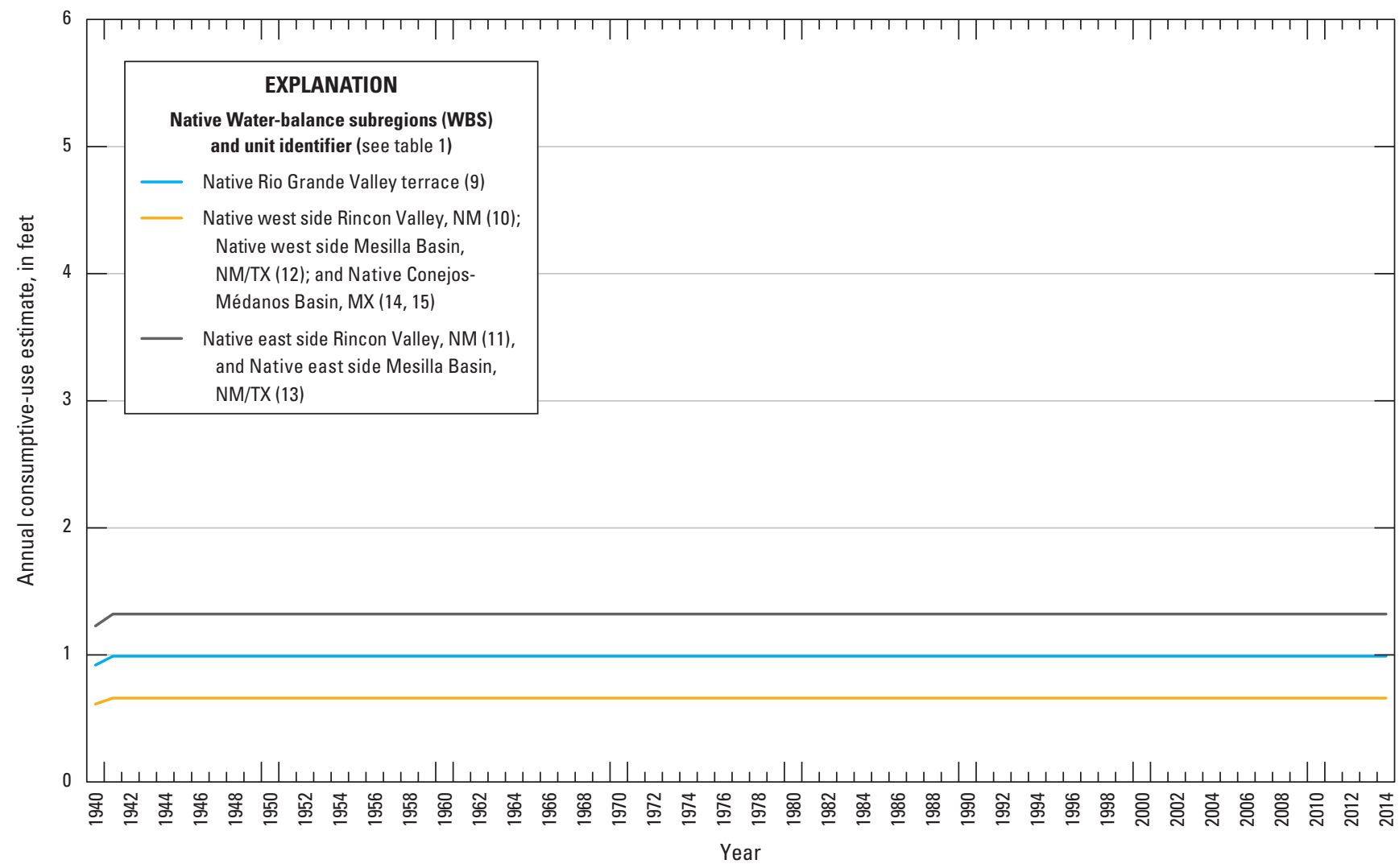

Figure 20. Initial estimates of factors related to water use by land-use category in the Transboundary Rio Grande, New Mexico, Texas, and Mexico: $A$, New Mexico Office of the State Engineer estimates of crop irrigation requirement used for the estimation of irrigation demand; $B$, annual consumptive-use estimates for native vegetation and urban land-use regions; $C$, annual consumptive-use estimates for urban land-use regions; $D$, monthly consumptive-use estimates of native vegetation land-use regions; and $E$, monthly consumptiveuse estimates for urban land-use regions. 
C

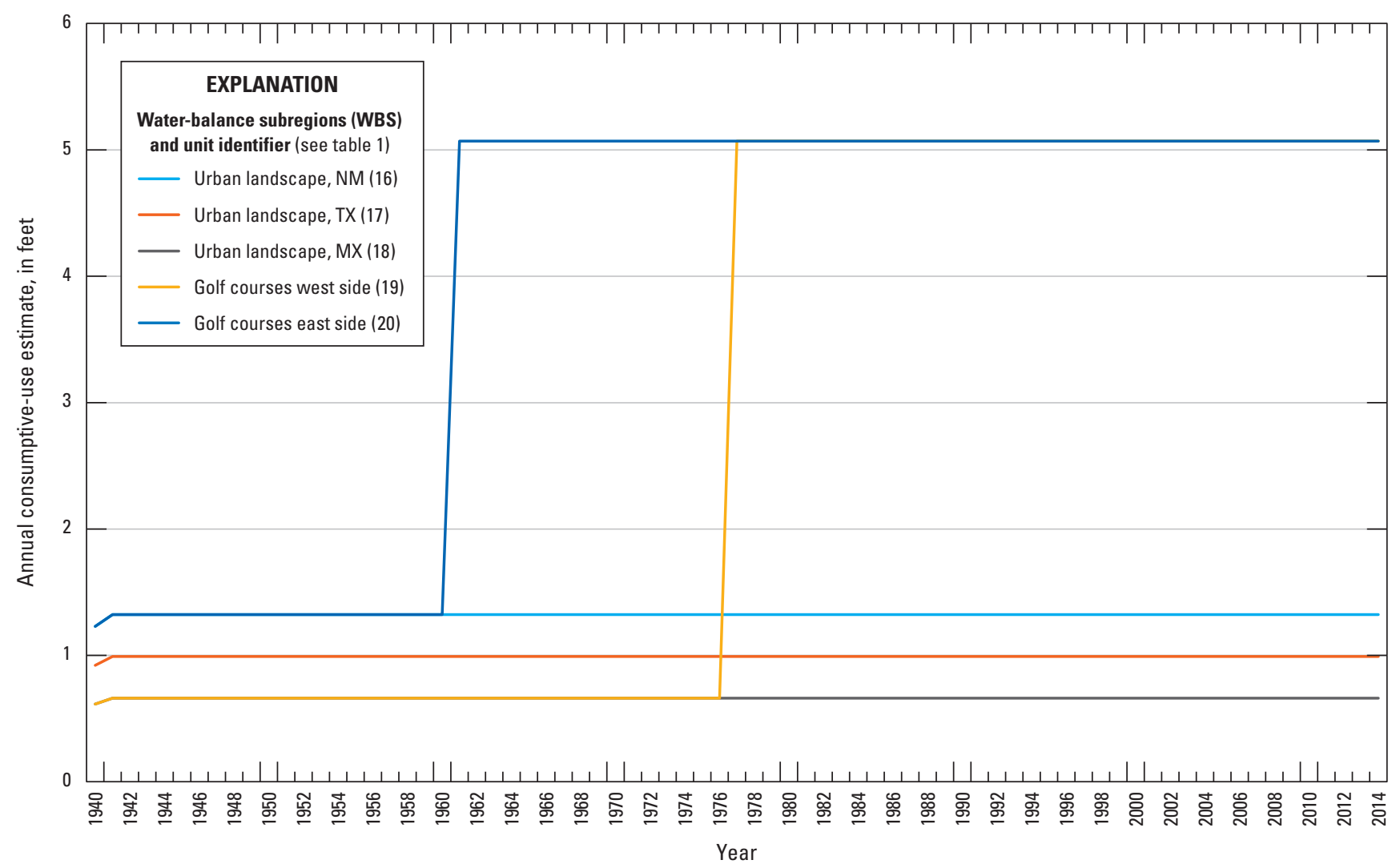

D

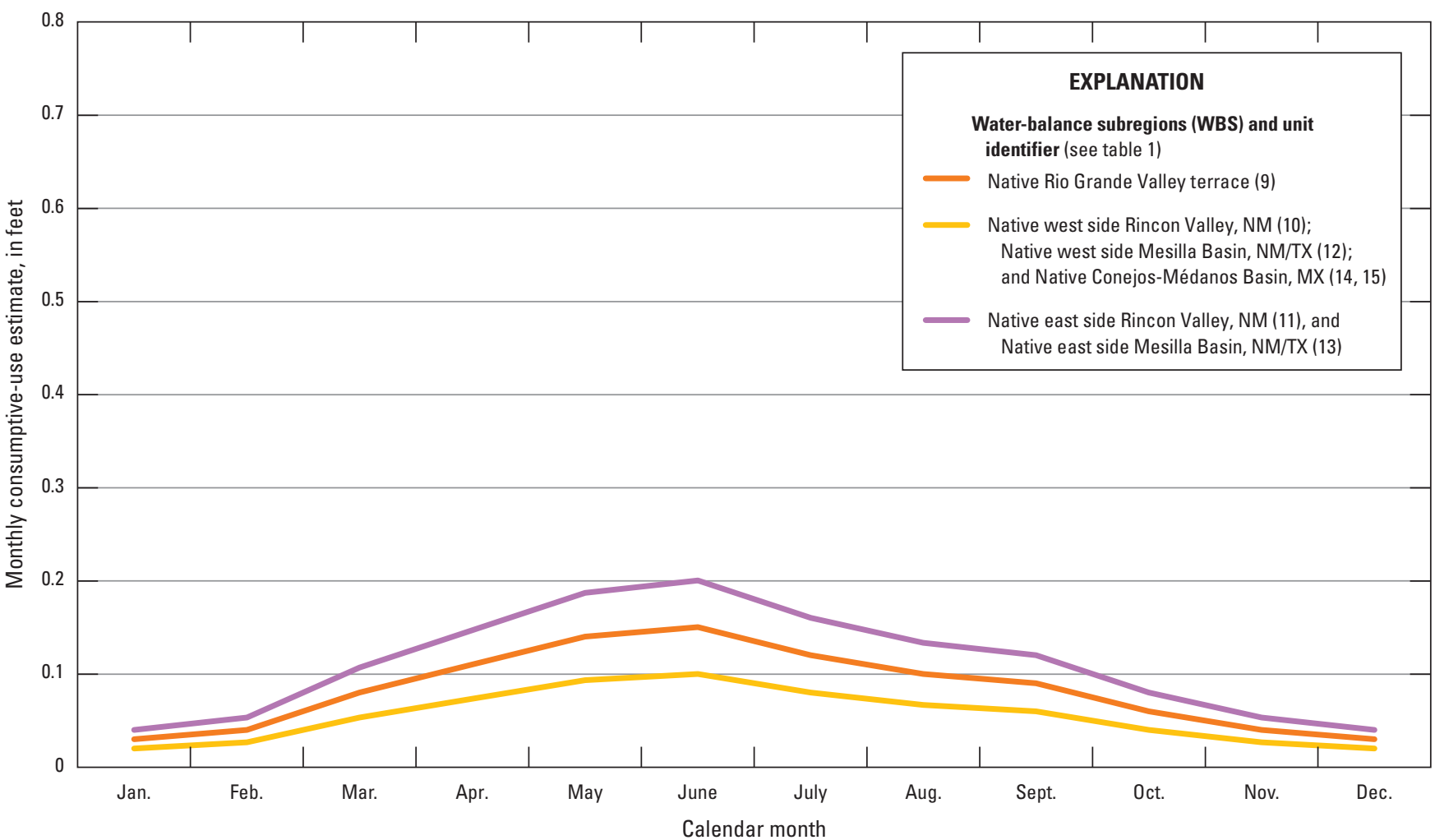

Figure 20. - Continued 
$\boldsymbol{E}$

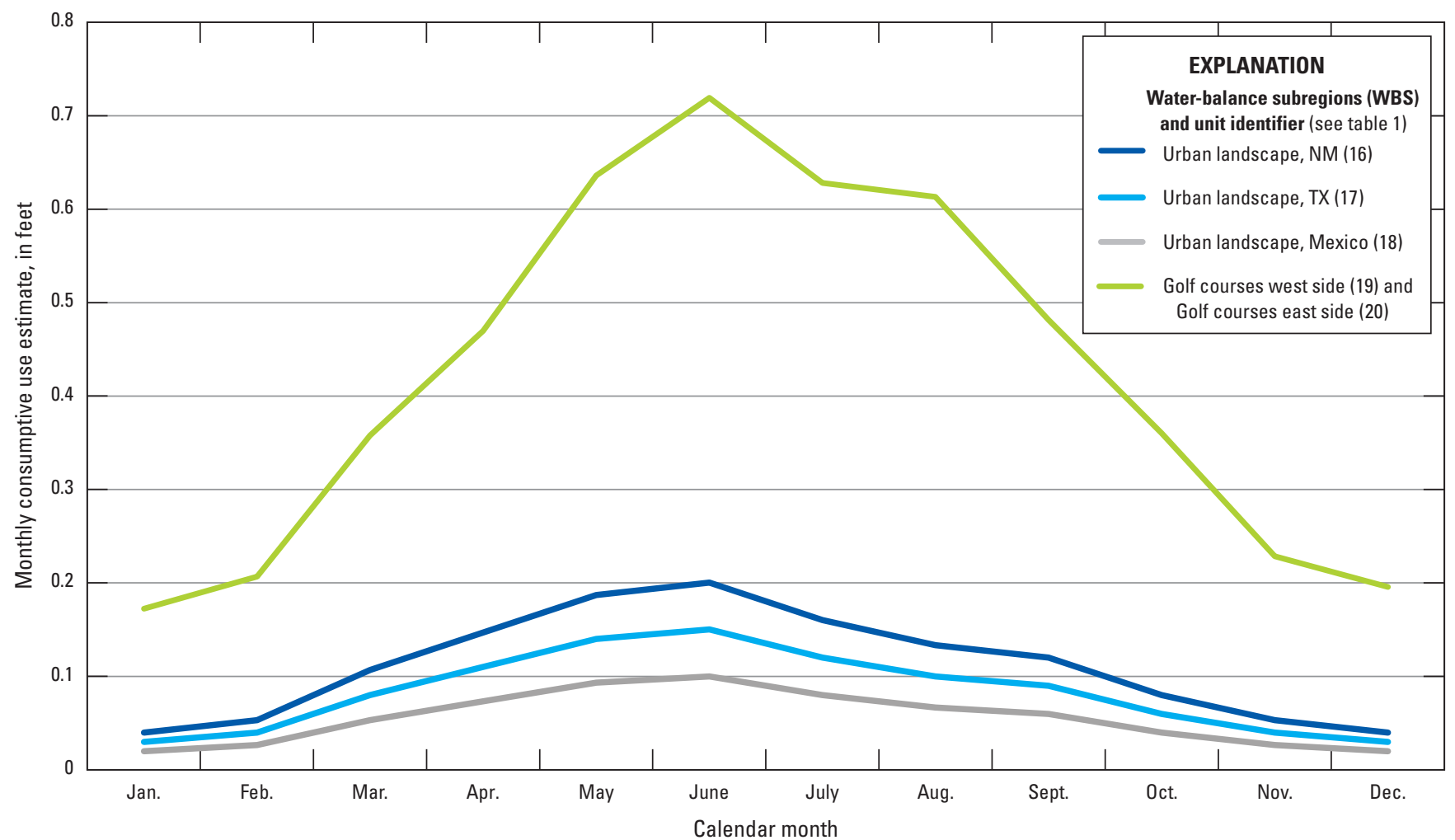

Figure 20. - Continued

Table 10. Summary of root depths, range in monthly consumptive use values, and fractions of runoff from irrigation for land use in the Rio Grande Transboundary Integrated Hydrologic Model for the Transboundary Rio Grande, New Mexico, Texas, and Mexico.

\begin{tabular}{|c|c|c|c|}
\hline $\begin{array}{l}\text { Farm Process (FMP) crop index number } \\
\text { and land-use category }{ }^{1}\end{array}$ & $\begin{array}{l}\text { Root depth } \\
\text { (feet) }\end{array}$ & $\begin{array}{l}\text { Range of consumptive-use values }{ }^{2,3} \\
\text { March 1940-December } 2014 \\
\text { (feet per day) }\end{array}$ & $\begin{array}{l}\text { Fraction of } \\
\text { surface-water runoff } \\
\text { from irrigation }\end{array}$ \\
\hline Composite Agriculture Unit 1 (1) & 1.0 & $0-0.011$ & 0.07 \\
\hline Composite Agriculture Unit 3 (3) & 1.0 & $0-0.014$ & 0.07 \\
\hline Composite Agriculture Unit 4 (4) & 1.0 & $0-0.013$ & 0.07 \\
\hline Composite Agriculture Unit 7 (7) & 1.0 & $0-0.019$ & 0.07 \\
\hline Rio Grande/Floodplain/RIP area/Caballo Reservoir (8) & 0.0 & 0 & $0.0^{3}$ \\
\hline Native Rio Grande Valley Terrace (9) & 1.5 & $0.001-0.005$ & $0.0^{3}$ \\
\hline Native west side Rincon Valley, NM (10) & 1.5 & $0.001-0.003$ & $0.0^{3}$ \\
\hline Native east side Rincon Valley, NM (11) & 1.5 & $0.001-0.007$ & $0.0^{3}$ \\
\hline Native Batería well field Conejos-Médanos, MX (15) & 1.5 & $0.001-0.003$ & $0.0^{3}$ \\
\hline Urban landscape NM, TX, and MX $(16,17,18)$ & 0.5 & $0.001-0.007$ & $0.0^{3}$ \\
\hline Golf courses west and east side $(19,20)$ & 0.7 & $0.001-0.007$ & $0.0^{3}$ \\
\hline
\end{tabular}

${ }^{1}$ Refer to table 2 for relation to land-use groupings and identifier numbers.

${ }^{2}$ Values of crop irrigation requirement (CIR) are area-adjusted values from the consumptive use spreadsheet (Peggy Berroll, written commun., 2011). Base value listed do not include scale-factor adjustments made during RGTIHM calibration.

${ }^{3}$ A zero value is specified but not used for urban and native land use since no irrigation occurs within FMP. 
The fraction of transpiration (FTR) and of evaporation from irrigation (FEI) were additional virtual-crop related properties that were specified to adjust CIR values each month (table 11). During the non-growing season, transpiration is minimal, and during the growing season, transpiration becomes increasingly important with increased leaf area and accompanying transpiration. Thus, the fraction of the consumptive use from transpiration (FTR) or evaporation (FEI) is highly dependent on growing season and crop growth. This shift between transpiration and evaporation is controlled by the FTR and FEI parameters, which in turn adjust the CIR and related TFDR. These fractions (FTR and FEI) vary linearly with the respective area used for crops and the area open to soil evaporation (Schmid and others, 2006a). Because the cropped area and the exposed wetted area amount to the entire area, FTR plus FEI equal one. The FTR is assumed to be independent of whether the transpiration for consumptive use is satisfied by irrigation or groundwater uptake. When the vegetation cover reaches nearly 100 percent, then FTR $=1$ and $\mathrm{FEI}=0$. As a result, the fractions of transpiration and evaporation vary by virtual crop for different months of the year (table 11).

Table 11. Summary of fractions of transpiration and evaporation of virtual land-use categories by regions for the Transboundary Rio Grande.

[Refer to table 2 for explanation of land-use and vegetation groupings. Base values listed do not include scale-factor adjustments made during Rio Grande Transboundary Integrated Hydrologic Model calibration. Abbreviations: FEI, fraction of evaporation from irrigation; FTR, fraction of transpiration; RIP, riparian evapotranspiration package]

\begin{tabular}{llllll}
\hline \multirow{2}{*}{$\begin{array}{c}\text { Land use (Iland use } \\
\text { identifier) }\end{array}$} & \multicolumn{2}{c}{$\begin{array}{c}\text { November- } \\
\text { February }\end{array}$} & & \multicolumn{2}{c}{$\begin{array}{c}\text { March- } \\
\text { October }\end{array}$} \\
\cline { 2 - 3 } \cline { 6 - 6 } \cline { 5 - 6 } Composite agriculture 1 (1) & 0.1 & 0.99 & & 0.95 & 0.05 \\
Composite agriculture 2 (2) & 0.1 & 0.99 & & 0.95 & 0.05 \\
Composite agriculture 3 (3) & 0.1 & 0.99 & & 0.95 & 0.05 \\
Composite agriculture 4 (4) & 0.1 & 0.99 & & 0.95 & 0.05 \\
Composite agriculture 5 (5) & 0.1 & 0.99 & & 0.95 & 0.05 \\
Composite agriculture 6 (6) & 0.1 & 0.99 & & 0.95 & 0.05 \\
Composite agriculture 7 (7) & 0.1 & 0.99 & & 0.95 & 0.05 \\
Rio Grande/RIP (8) & 0 & 0 & & 0 & 0 \\
Native (9) & 0.1 & 0.99 & & 0.2 & 0.8 \\
Native (10) & 0.1 & 0.99 & & 0.05 & 0.95 \\
Native (11) & 0.1 & 0.99 & & 0.1 & 0.9 \\
Native (12) & 0.1 & 0.99 & & 0.1 & 0.9 \\
Native (13) & 0.1 & 0.99 & & 0.05 & 0.95 \\
Native (14, 15) & 0.1 & 0.99 & & 0.01 & 0.99 \\
Urban (16, 17, 18) & 0.1 & 0.99 & & 0.10, & 0.90 \\
& & & 0.05, & 0.95, \\
& & & 0.01 & 0.99 \\
Golf courses (19, 20) & 0.1 & 0.99 & 0.1 & 0.9 \\
\hline
\end{tabular}

Irrigation efficiency is defined as the fraction of applied water consumed by crops, and it was also specified for each virtual crop and WBS (table 12). The applied water that is not consumed, as a result of excess irrigation, is lost to deep percolation or runoff in the RGTIHM (Schmid and others, 2006a). In the RGTIHM, the irrigation efficiencies are specified as matrix base-value efficiencies for each WBS and were scaled by climate-based factors for the monthly stress periods (Schmid and Hanson, 2009). In this way, the efficiencies can differ from crop to crop for different WBSs and can change through time. The base values for irrigation efficiency for each land-use or virtual-crop group are reported in table 12. Irrigation efficiencies were assumed to remain relatively similar through time but were scaled to vary with precipitation-based climate (fig. $6 E$ ).

In general, on-farm irrigation efficiencies (OFE) are poorly known, and in RGTIHM, the base-value for irrigation efficiencies specified in the FMP was held constant at 70 percent in accord with local field estimates (Ahadi and others, 2013), but the climate-based scale factors associated with them were varied to lower values in wet seasons and higher values in dry seasons and in more recent years to reflect improved irrigation methods. Generally, irrigation operations seemed to be operated more efficiently in dry years, when supplies were constrained, and to use more water during wet periods including use for non-CIR demands such as soil preparation, leaching, or other ancillary uses. Irrigation efficiencies also can vary between seasons, and this variability can differ between wet-year and dry-year periods. Irrigation efficiencies were scaled on the basis of wet- and dry-year seasons, and these scale factors were adjusted during model calibration.

\section{Groundwater Agricultural Supply}

The groundwater pumped for irrigation in each WBS was simulated using a series of single-model-layer farm wells by the FMP or multi-aquifer wells by the MNW2 package coupled to the FMP (Konikow and others, 2009). Any multiaquifer irrigation wells that did not include more than 20 feet of a second and final model-layer thickness were treated as single-aquifer farm wells. All remaining, non-multi-aquifer wells were simulated as single-aquifer farm wells through the farms-wells feature in the FMP. This resulted in specifying as many as 509 single-aquifer farm wells and 3,450 multi-aquifer farm wells (Ritchie and others, 2018). The wells are in New Mexico and Texas; no agricultural wells were identified in the Conejos-Médanos Basin. The TFDR required for groundwater pumpage was estimated by the FMP, minus available surfacewater supply for WBSs that receive both groundwater and surface-water supply. This allowed a way to estimate historical, unmetered, pumpage for 1940-2014 for groups of wells that serve each WBS. 
Table 12. Irrigation efficiency for virtual crops and related pumping-capacity scale factors for wells serving the regions of the Transboundary Rio Grande, New Mexico, Texas, and Mexico.

[Base values of irrigation efficiencies are adjusted seasonally for wet and dry climatic periods with multipliers. Refer to table 2 for explanation of land use (crop and vegetation) groupings. Abbreviations: GW, groundwater; RIP, Riparian Evapotranspiration package; SW, surface water; WBS, water-balance subregions]

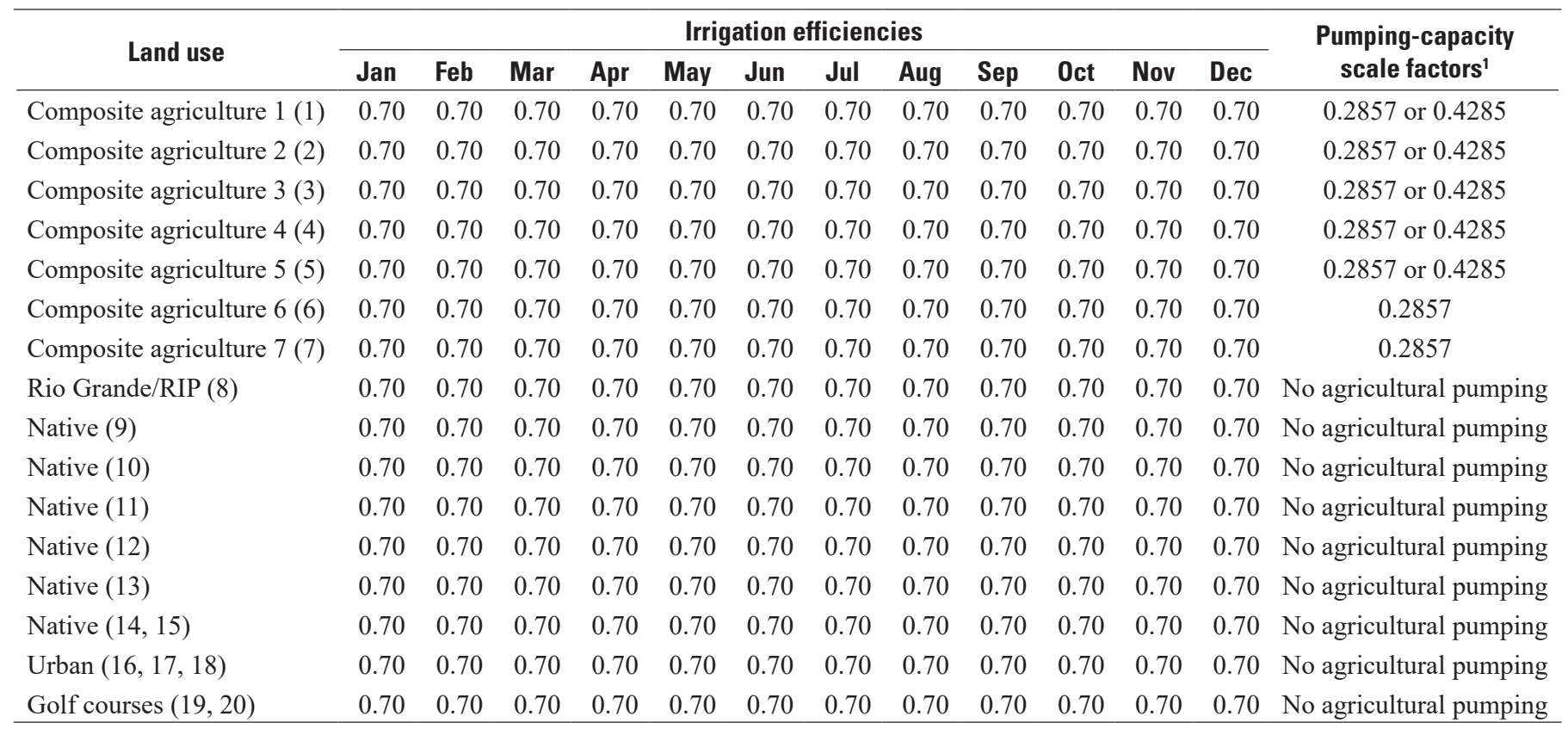

${ }^{1}$ Agricultural well pumping capacities were scaled by these factors based on the following assumptions: SW/GW WBS (see table 1) had agricultural pumping two days per week ( 0.2857 scale factor) and GW only WBS (see table 1$)$ had agricultural pumping three days per week $(0.4285$ scale factor).

\section{Riparian Vegetation}

Consumptive use from riparian vegetation along the Rio Grande was simulated in the RGTIHM with the "Riparian Evapotranspiration" (RIP-ET) package (Maddock and others, 2012). The distribution of RIP-ET cells was modified from the LRG_2007 model to include 1,344 cells, which visual inspection of aerial imagery (Environmental Systems Research Institute, 2016) indicated mostly contained the Rio Grande and surrounding riparian vegetation. The smaller model cells and this revised distribution avoided the double-accounting of ET along the Rio Grande corridor, because RIP-ET cells (WBS 67, table 1) did not overlap or leave any gaps in relation to adjacent agricultural WBSs, where ET was calculated by the FMP. In addition, the land-use attributes for WBS 67 were set to zero (FMP land-use identifier 8, table 2) so that there would not be any ET from this WBS, but this region would still be represented in the model. The LRG_2007 model simulated a spatially variable RIP-ET area through time, based on aerial imagery from 1936, 1955, 1967, 1986, and 1997 (S.S. Papadopulos and Associates, Inc., 2007). The RGTIHM assumes a constant riparian vegetation area during the simulation represented by WBS 67, but incorporates seasonally variable fractions of plant functional groups (tree, shrub, herbaceous, and bare ground or open water) simulated by the LRG_2007 model using 4- and 8-month periods transposed to the equivalent monthly periods of the RGTIHM. In regions of WBS 67 not previously simulated with RIP-ET in the LRG_2007 model, fractions of plant functional groups were copied from the nearest RIP cell.

\section{Net Recharge}

The net recharge in a WBS is defined as the after ET consumption losses resulting from excess irrigation and excess precipitation, reduced by losses to surface-water runoff and ET from groundwater (Schmid and others, 2006a). The fraction of irrigation losses to surface-water runoff were assumed to be relatively small, about 7 percent for this version of the RGTIHM (table 10). Losses from excess irrigation were assumed to mostly be deep percolation to groundwater along with subsequent lateral flow and capture by nearby drain canals (fig. $8 B$ ). The ET from groundwater was subtracted from the potential net downward flux as deep percolation to the uppermost aquifer. Hence, net recharge to groundwater can be affected both by user-specified and by head-dependent parameters. This definition of net recharge requires the following assumptions: deep percolation below the active root zone is equal to groundwater recharge; ET from groundwater equals an instantaneous outflow from aquifer storage in any time step; and the net change in soil-moisture storage for irrigated, well-managed agricultural areas for periods of weeks to months is negligible (Schmid and others, 2006a). The net recharge to the aquifers is applied on a cell-by-cell basis to the uppermost active model cell in each WBS. 


\section{Aquifer Characteristics-Rio Grande Transboundary Integrated Hydrologic Model}

Nine model-layers were used to represent five hydrostratigraphic units in the regional aquifer system: the unconsolidated alluvial deposits; the upper, middle, and lower members of the Santa Fe Group; and basement units. Each hydrostratigraphic unit can be characterized by variations in hydraulic properties, which are based on the textural distribution of coarse- and fine-grained sediments and zones representing subregions where the sediments accumulated in particular depositional environments referred to as facies (Sweetkind, 2017; Hawley and Kennedy, 2004). The hydraulic water-transmitting properties of the aquifer sediments are represented by horizontal $\left(\mathrm{K}_{\mathrm{h}}\right)$ and vertical $\left(\mathrm{K}_{\mathrm{v}}\right)$ hydraulic conductivity and hydraulic storage properties of the hydrogeologic units. The relation between hydrogeologic units in the aquifer system, lithology, and hydraulic properties has been developed in many previous studies; they include the properties of the aquifers and those of any fine-grained interbeds or confining units (Hanson and others, 1990, 2003, 2004, 2014a, b; Laudon and Belitz, 1991; Phillips and Belitz, 1991; Hanson and Benedict, 1994; Leighton and others, 1995; Fio and Leighton, 1995; Belitz and Phillips, 1995; Burow and others, 2004; Phillips and others, 2007; and Faunt and others, 2009, 2010). The RGTIHM does not include the distribution of hydraulic properties based on regionalized layer-specific estimates of texture, but instead uses the previously defined facies as a surrogate for distributed hydraulic properties.

\section{Facies Analysis}

Lateral and vertical variations in sediment texture affect the direction and rate of groundwater flow as well as the magnitude and distribution of aquifer-system storativity. The facies distribution zones of Sweetkind (2017) were used as surrogates to define the vertical and lateral hydraulic conductivity and storage property distributions for the RGTIHM.

Based on the distribution of facies zones in the TRG region and the reanalysis of the hydrogeology (Sweetkind, 2017), the groundwater system was split into nine model layers. For each hydrogeologic model layer, the facies zones within the thickness of each layer were estimated on a cell-bycell basis. Facies were estimated for the model-cell centers of the RGTIHM model grid for each model layer coincident with the hydrogeologic units.

\section{Hydraulic Properties}

Hydraulic properties were estimated for each faciesbased zone in all five hydrostratigraphic units. Aquifer tests were compiled for these units (Hawley and Kennedy, 2004; S.S. Papadopulos and Associates, Inc., 2007, tables B-1, D-1) from Theim approximations based on specific capacity tests, short-term aquifer tests, and values used in previous models for the Mesilla Basin that were based on the facies delineations (Hawley and Kennedy, 2004). These approximations were extended to include the Rincon Valley, Mesilla Basin, and the northern part of the Conejos-Médanos Basin, Mexico (Sweetkind, 2017). These types of estimates typically overestimate hydraulic conductivity by as much as a factor of 2, however (Hanson and Nishikawa, 1996; Molz and others, 1996; Hanson, 1996). The hydraulic properties for the five model layers of the previous model (S.S. Papadopulos and Associates, Inc., 2007, figs. D-1 to D-15) were used, in part, as initial values for model calibration of the RGTIHM (S.S. Papadopulos and Associates, Inc., 2007, table 8.2). The distribution of facies zones for each of the pairs of model layers in each hydrogeologic unit was used for model calibration (fig. 21; table 13). 
A

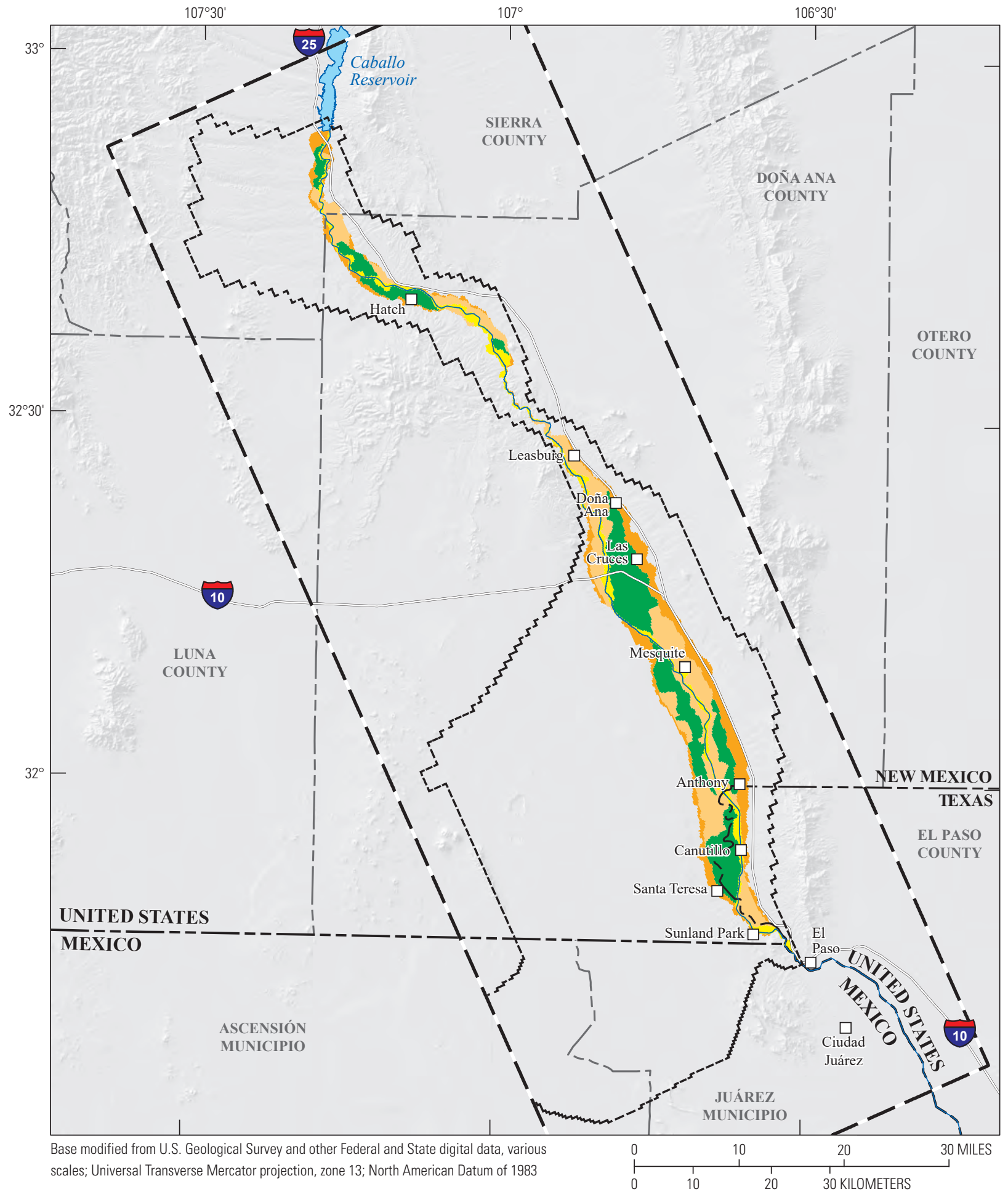

EXPLANATION

Hydraulic property zone-code number (layers 1 and 2)Refer to table 3 for parameter descriptions and model-zone code

$\square 10 \quad \square \quad 20 \quad \square \quad 30 \quad \square 1$
$\Gamma$ Maximum extent of Rio Grande Transboundary Integrated Hydrologic Model (RGTIHM)

Figure 21. Distribution of parameter zones used for model calibration of hydraulic properties in the Transboundary Rio Grande, New Mexico, Texas, and Mexico, for the nine model layers by hydrostratigraphic unit: $A$, river channel (model layers 1 and 2); $B$, upper Santa Fe Group (model layer 3); $C$, upper Santa Fe Group (model layer 4); $D$, middle Santa Fe Group (model layer 5); $E$, middle Santa Fe Group (model layer 6); F, lower Santa Fe Group (model layer 7); G, lower Santa Fe Group (model layer 8); and $H$, basement (model layer 9). 
B

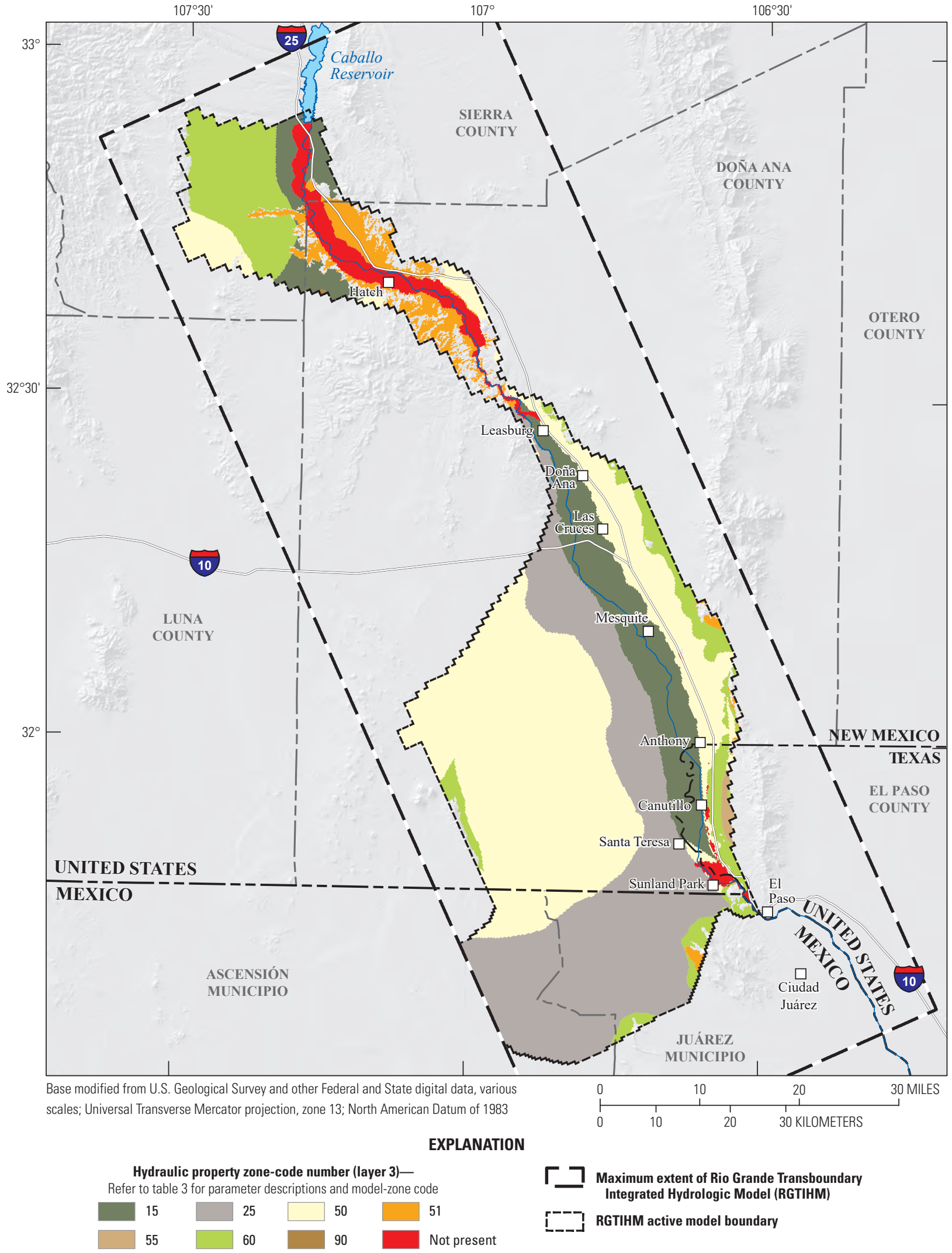

Figure 21. - Continued 
C

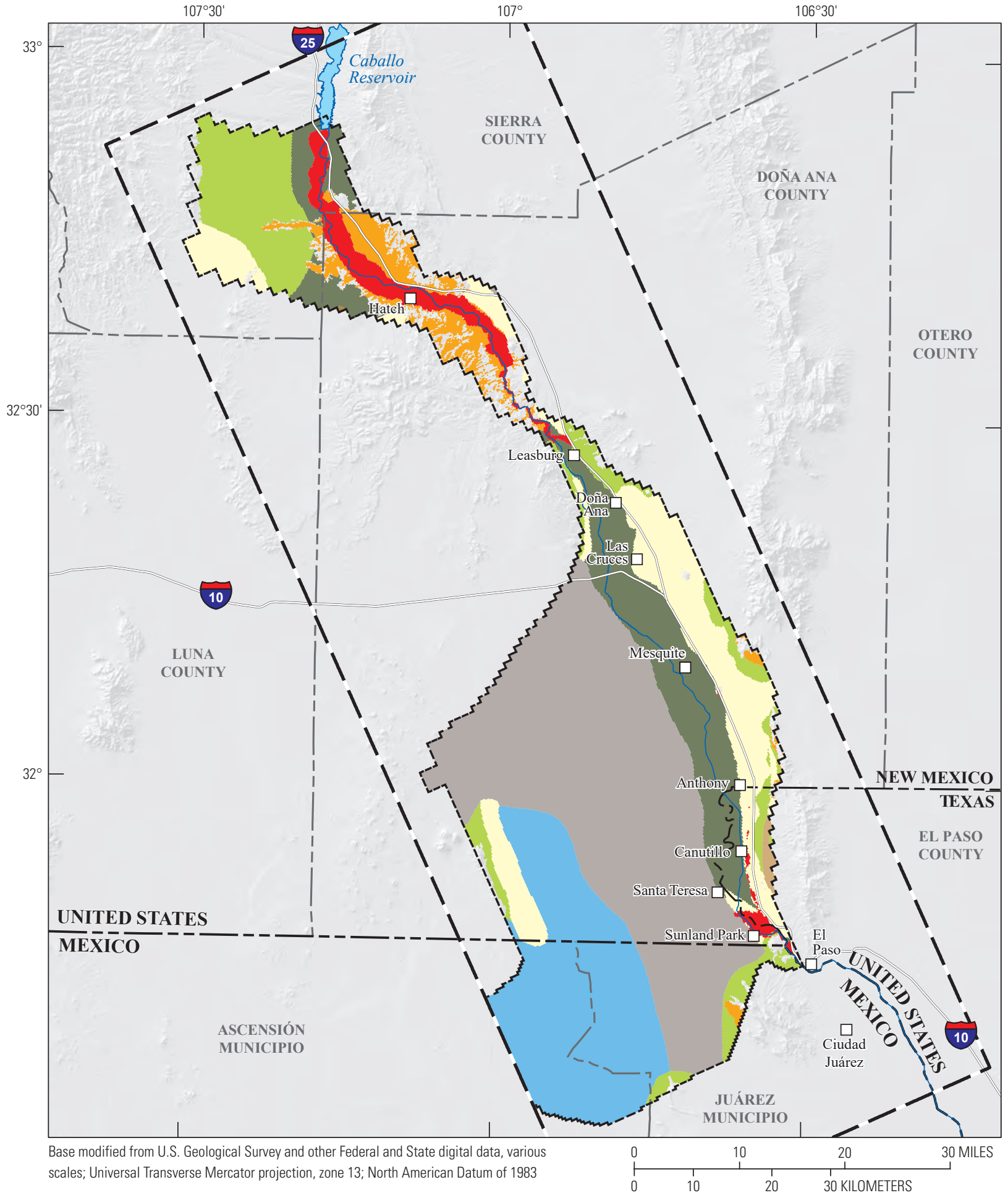

EXPLANATION

Hydraulic property zone-code number (layer 4) Refer to table 3 for parameter descriptions and model-zone code

\begin{tabular}{l|l|l|l|l}
15 & 25 & & 35 & $\square$ \\
51 & 55 & & 60 & \\
51 & & 50 & 90 \\
Not present & & & &
\end{tabular}

$\Gamma \neg$ Maximum extent of Rio Grande Transboundary Integrated Hydrologic Model (RGTIHM)

[--_] RGTIHM active model boundary

Figure 21. -Continued 
D

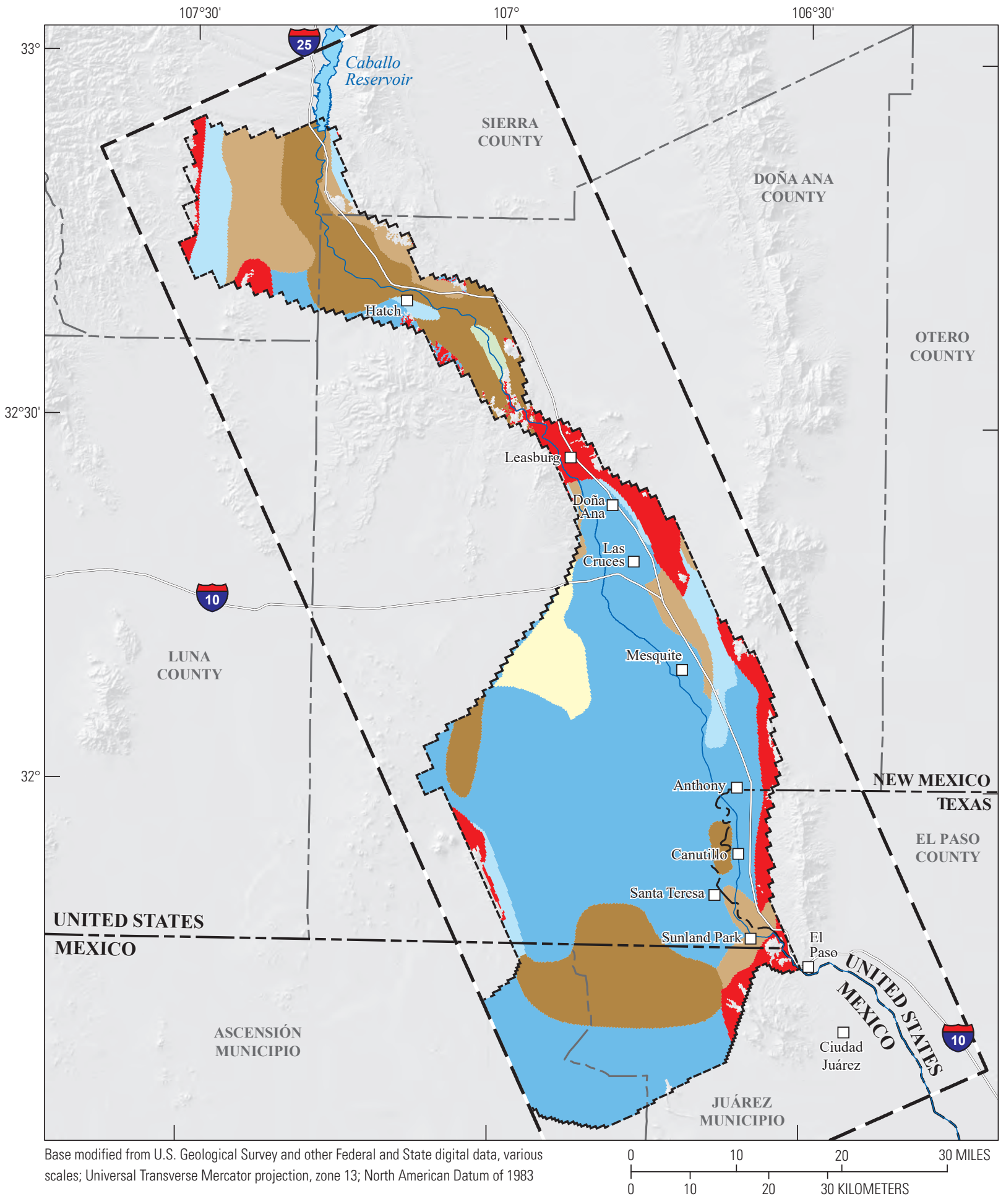

\section{EXPLANATION}

Hydraulic property zone-code number (layer 5)Refer to table 3 for parameter descriptions and model-zone code

\begin{tabular}{lll|l}
35 & $\square$ & $\square 0$ & $55 \quad \square$ \\
90 & $\square$ & $\square$ & \\
90 & & &
\end{tabular}

Figure 21. - - Continued
$\Gamma \neg$ Maximum extent of Rio Grande Transboundary Integrated Hydrologic Model (RGTIHM)

[-_ RGTIHM active model boundary 
E

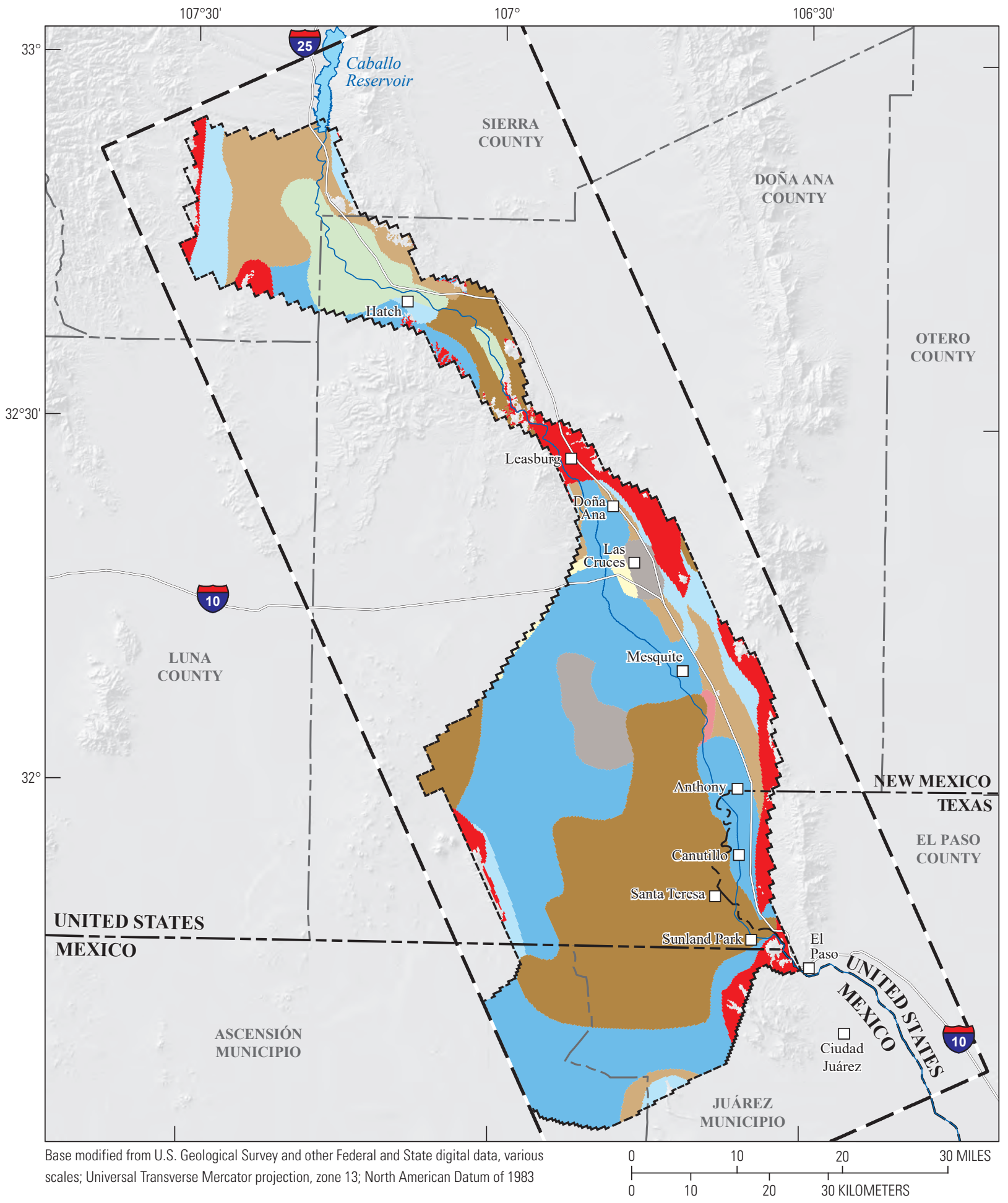

EXPLANATION

Hydraulic property zone-code number (layer 6)Refer to table 3 for parameter descriptions and model-zone code

\begin{tabular}{|c|c|c|c|}
\hline 25 & 35 & 40 & 50 \\
\hline 55 & 65 & 90 & 100 \\
\hline
\end{tabular}

Figure 21. - Continued 
$F$

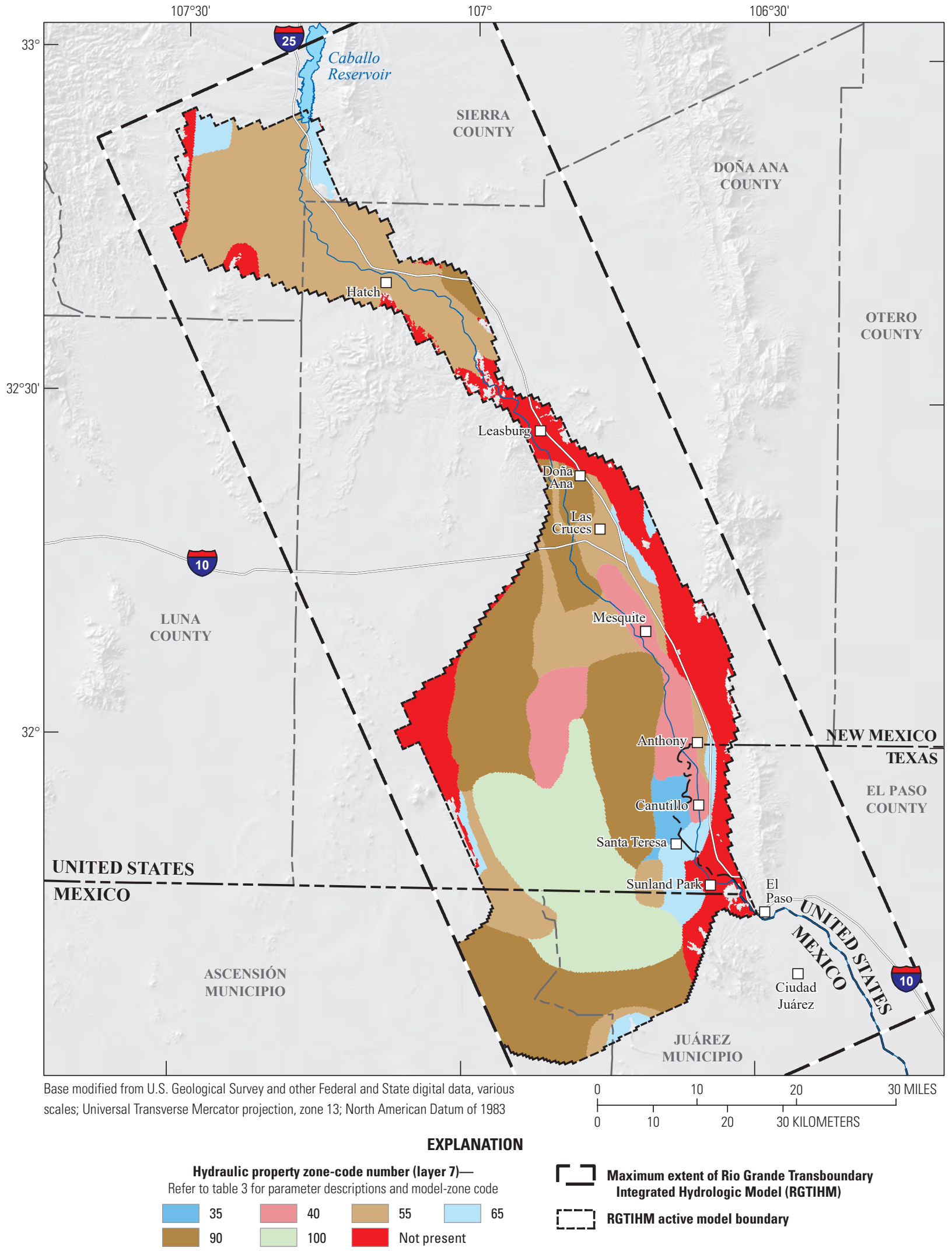

Figure 21. - Continued 
G

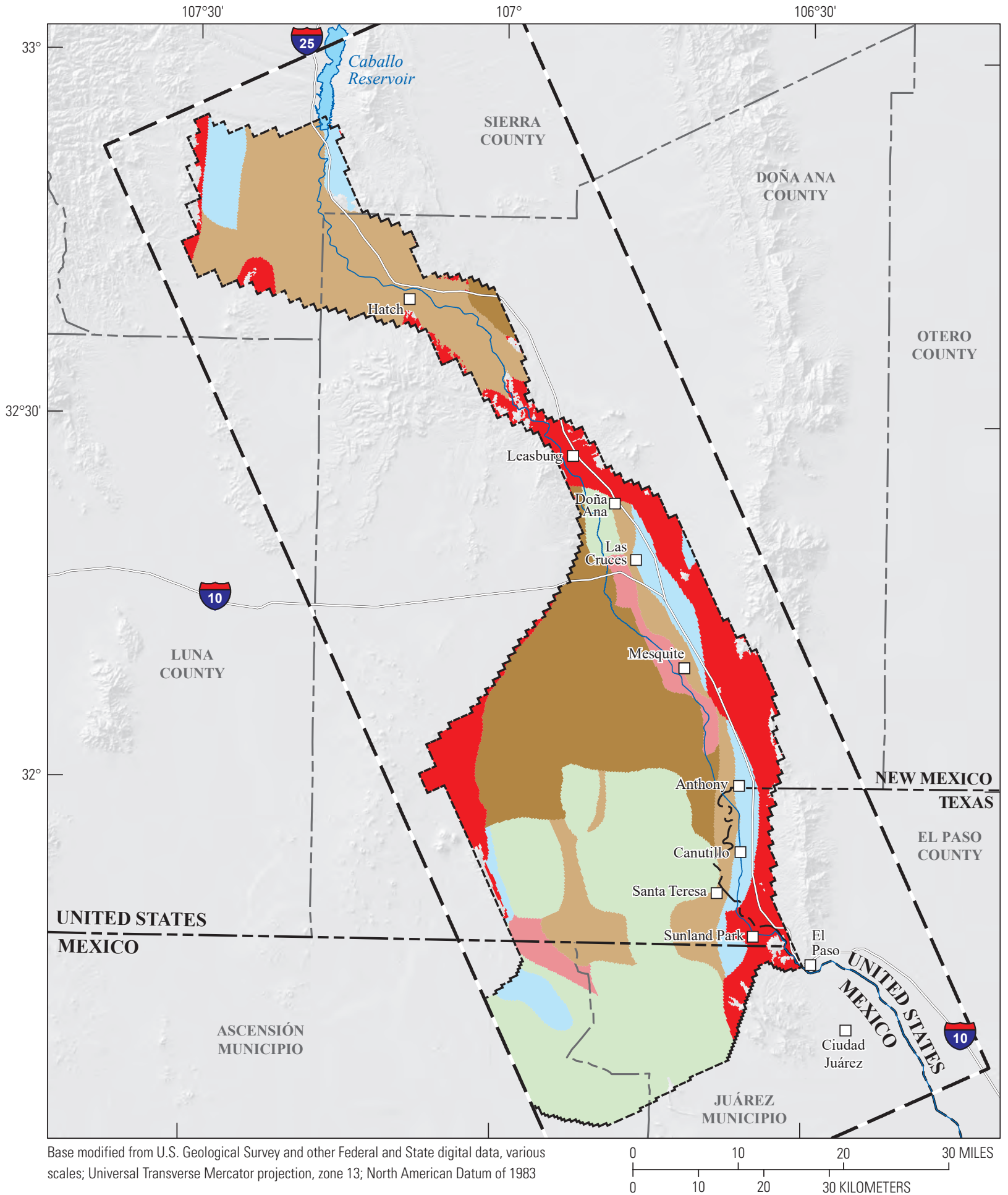

EXPLANATION

Hydraulic property zone-code number (layer 8)Refer to table 3 for parameter descriptions and model-zone code

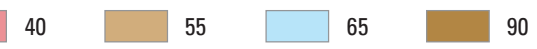
$100 \quad$ Not present
$\Gamma \neg$ Maximum extent of Rio Grande Transboundary Integrated Hydrologic Model (RGTIHM)

[--

Figure 21. - Continued 
H

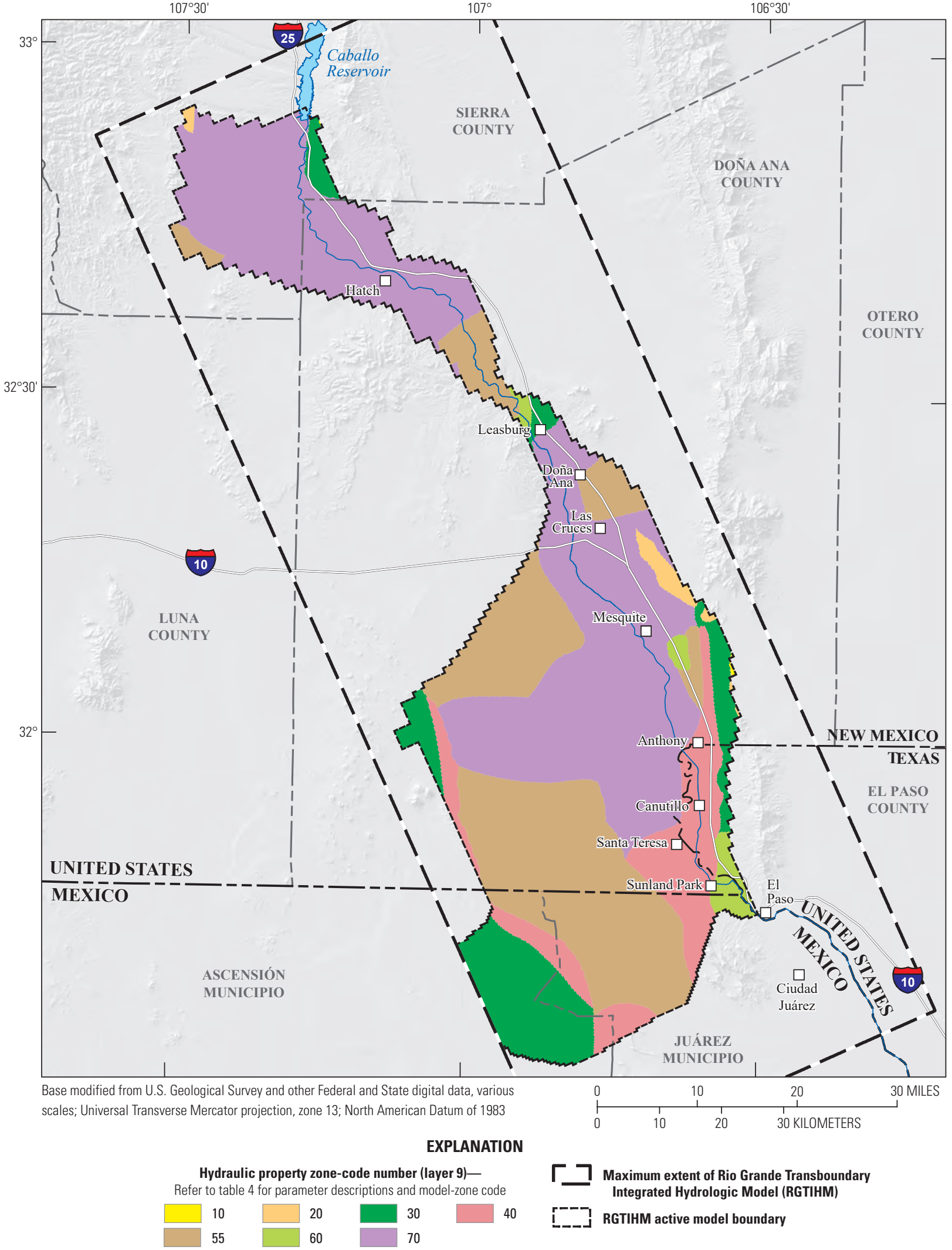

Figure 21. - Continued 
Table 13. Summary of parameter zones and related property parameter names used to calibrate horizontal hydraulic conductivity (HK), vertical hydraulic conductivity (VK), and aquifer specific storage (SS) in the Rio Grande Transboundary Integrated Hydrologic Model, Transboundary Rio Grande, New Mexico, Texas, and Mexico.

[See tables 3 and 4 for description of zone codes. Abbreviation: - , not applicable]

\begin{tabular}{|c|c|}
\hline $\begin{array}{c}\text { Root parameter names }{ }^{1,3} \\
\text { (zone number) } \\
\text { upper layer of unit }\end{array}$ & $\begin{array}{c}\text { Root parameter names } \\
\text { (zone number) } \\
\text { lower layer of unit }\end{array}$ \\
\hline \multicolumn{2}{|c|}{ River channel (RC)-Layers 1 and 2} \\
\hline 10 & 10 \\
\hline 20 & 20 \\
\hline 30 & 30 \\
\hline 51 & 51 \\
\hline \multicolumn{2}{|c|}{ Upper member of the Santa Fe Group (USF)_Layers 3 and 4} \\
\hline 15 & 15 \\
\hline 25 & 25 \\
\hline 50 & 35 \\
\hline 51 & 50 \\
\hline 55 & 51 \\
\hline 60 & 55 \\
\hline 90 & 60 \\
\hline 999 & 90 \\
\hline- & 999 \\
\hline \multicolumn{2}{|c|}{ Middle member of the Santa Fe Group (MSF)—Layers 5 and 6} \\
\hline 35 & 25 \\
\hline 50 & 35 \\
\hline 55 & 40 \\
\hline 65 & 50 \\
\hline 90 & 55 \\
\hline 100 & 65 \\
\hline 999 & 90 \\
\hline- & 100 \\
\hline- & 999 \\
\hline
\end{tabular}

\begin{tabular}{cc}
\hline $\begin{array}{c}\text { Root parameter names } \\
\text { (zone number) } \\
\text { upper layer of unit }\end{array}$ & $\begin{array}{c}\text { Root parameter names } \\
\text { (zone number) } \\
\text { lower layer of unit }\end{array}$ \\
\hline Lower member of the Santa Fe Group (LSF) - Layers 7 and 8 \\
\hline 35 & 40 \\
40 & 55 \\
55 & 65 \\
65 & 90 \\
90 & 100 \\
100 & 999 \\
999 & - \\
\hline 10 & - \\
20 & - \\
30 & - \\
40 & - \\
50 & - \\
70 & - \\
\hline
\end{tabular}

${ }^{1}$ Root parameter names have L\#, where \# represents the layer number, and $\mathrm{HK}, \mathrm{VK}$, or SS added to the front of these numbers for parameter names used in PVAL and LPF input files.

${ }^{2}$ Root parameter names for the Basement hydrostratigraphic unit are increased by 1, prior to adding L\# and HK, VK, or SS to the front of these numbers for parameter names used in PVAL and LPF input files.

${ }^{3}$ Root parameter name 999 represents cells where the hydrostratigraphic unit is not present in the stratigraphic stack but the cells are still active and simulated.

${ }^{4}$ Root parameter names 55, 60, and 70 for the Basement hydrostratigraphic unit are a composite of all zone codes for Tertiary sediments, intrusive rocks, and volcanic rocks, respectively (table 4).

\section{Hydraulic Conductivity}

Hydraulic conductivity $(\mathrm{K})$ values were used to estimate the horizontal and vertical $\mathrm{K}$ for each cell in the model, which were then related to zonal facies subareas (table 13; figs. $21 A-G$ ) to estimate final values by model calibration. The "Layer Property Flow" package (LPF) was used to simulate the hydraulic properties and groundwater flow in the RGTIHM. In subareas where upper, middle, or lower members of the Santa Fe Group (layers 3-8) were missing between younger and older units, the hydraulic properties were specified as relatively large $\mathrm{K}_{\mathrm{v}}$ and low $\mathrm{K}_{\mathrm{h}}$ and $S s$ values to allow communication between the RGTIHM model layers that are present. The final parameters from model calibration representing hydraulic properties and related scale factors are included in the summary of parameter values in table 14 .

The parameters used to control the hydrostratigraphic units in each model layer represent unconfined aquifers in the outcrop areas as well as subareas of confined aquifers that underlie other aquifers. The hydraulic properties of each of these subareas were therefore estimated using separate model parameters during model calibration (table 13). The estimated values of hydraulic conductivity for the Quaternary alluvium ranged from $120 \mathrm{ft} / \mathrm{d}$ for the channel deposits to $0.02 \mathrm{ft} / \mathrm{d}$ for the playa, lake, and evaporate deposits of the middle member of the Santa Fe Group. For each unit, the distribution of horizontal $\left(\mathrm{K}_{\mathrm{h}}\right)$ and vertical $\left(\mathrm{K}_{\mathrm{v}}\right)$ hydraulic conductivities varied with the distribution of sedimentary facies-based zones in each layer (figs. 4, 21). During calibration, a multiplier was used for each zone, and the final range of vertical and horizontal hydraulic conductivities was estimated (fig. 21; tables 12-14). 
Table 14. Summary of parameter values estimated for the Rio Grande Transboundary Integrated Hydrologic Model, Transboundary Rio Grande, New Mexico, Texas, and Mexico.

[See table 8 for package/process abbreviations. Abbreviations: $\mathrm{ft} / \mathrm{day}$, foot per day; $\mathrm{ft}$ /day, square foot per day; —, not estimated with parameter estimation; $\mathrm{n} / \mathrm{a}$, not applicable]

\begin{tabular}{|c|c|c|c|c|c|}
\hline Model layers & Parameter name & Final values & Units & $\begin{array}{l}\text { Rank and } \\
\text { composite } \\
\text { sensitivity }\end{array}$ & Package/process (parameter group) \\
\hline \multicolumn{6}{|c|}{$\begin{array}{l}\text { Crop-irrigation requirement scale factors } \\
\qquad 1940-2002\end{array}$} \\
\hline Uppermost layer & CIR_DRY_WIN & 1.38 & Multiplier & $254 / 0.013$ & FMP-CIR-scale factors (CIR_WET and CIR_DRY) \\
\hline Uppermost layer & CIR_DRY_SPR & 1.48 & Multiplier & $36 / 0.305$ & FMP-CIR-scale factors (CIR_WET and CIR_DRY) \\
\hline Uppermost layer & CIR_DRY_SUM & 1.06 & Multiplier & $15 / 0.552$ & FMP-CIR-scale factors (CIR_WET and CIR_DRY) \\
\hline Uppermost layer & CIR_DRY_FAL & 1.33 & Multiplier & $83 / 0.110$ & FMP_CIR-scale factors (CIR_WET and CIR_DRY) \\
\hline Uppermost layer & CIR_WET_WIN & 1.17 & Multiplier & $218 / 0.016$ & FMP_CIR-scale factors (CIR_WET and CIR_DRY) \\
\hline Uppermost layer & CIR_WET_SPR & 1.39 & Multiplier & $24 / 0.388$ & FMP_CIR-scale factors (CIR_WET and CIR_DRY) \\
\hline Uppermost layer & CIR_WET_SUM & 0.48 & Multiplier & $22 . / 0.420$ & FMP_CIR-scale factors (CIR_WET and CIR_DRY) \\
\hline Uppermost layer & CIR_WET_FAL & 1.19 & Multiplier & $112 / 0.070$ & FMP_CIR-scale factors (CIR_WET and CIR_DRY) \\
\hline \multicolumn{6}{|c|}{$\begin{array}{l}\text { Crop-irrigation requirement scale factors } \\
\qquad 2003-10\end{array}$} \\
\hline Uppermost layer & CIR_DRY2_WIN & 0.81 & Multiplier & $264 / 0.011$ & FMP_CIR-scale factors (CIR_WET and CIR_DRY) \\
\hline Uppermost layer & CIR_DRY2_SPR & 0.97 & Multiplier & $41 / 0.276$ & FMP_CIR-scale factors (CIR_WET and CIR_DRY) \\
\hline Uppermost layer & CIR_DRY2_SUM & 1.32 & Multiplier & $33 / 0.327$ & FMP_CIR-scale factors (CIR_WET and CIR_DRY) \\
\hline Uppermost layer & CIR_DRY2_FAL & 1.16 & Multiplier & $103 / 0.078$ & FMP_CIR-scale factors (CIR_WET and CIR_DRY) \\
\hline Uppermost layer & CIR_WET2_WIN & 1.21 & Multiplier & $308 / 0.005$ & FMP-CIR-scale factors (CIR_WET and CIR_DRY) \\
\hline Uppermost layer & CIR_WET2_SPR & 1.13 & Multiplier & $34 / 0.318$ & FMP_CIR-scale factors (CIR_WET and CIR_DRY) \\
\hline Uppermost layer & CIR_WET2_SUM & 0.8 & Multiplier & $32 / 0.343$ & FMP-CIR-scale factors (CIR_WET and CIR_DRY) \\
\hline Uppermost layer & CIR_WET2_FAL & $8.00 \mathrm{E}-09$ & Multiplier & “—_ $"$ & FMP_CIR-scale factors (CIR_WET and CIR_DRY) \\
\hline
\end{tabular}

Crop-irrigation requirement scale factors

$$
2011-14
$$

(no wet years during this period)

\begin{tabular}{|c|c|c|c|c|c|}
\hline Uppermost layer & CIR_DRY3_WIN & 0.79 & Multiplier & $274 / 0.01$ & FMP_CIR-scale factors (CIR_WET and CIR_DRY) \\
\hline Uppermost layer & CIR_DRY3_SPR & 0.94 & Multiplier & $48 / 0.258$ & FMP-CIR-scale factors (CIR_WET and CIR_DRY) \\
\hline Uppermost layer & CIR_DRY3_SUM & 1.3 & Multiplier & $25 / 0.367$ & FMP_CIR-scale factors (CIR_WET and CIR_DRY) \\
\hline Uppermost layer & CIR_DRY3_FAL & 1.14 & Multiplier & $117 / 0.62$ & FMP-CIR-scale factors (CIR_WET and CIR_DRY) \\
\hline
\end{tabular}


Table 14. Summary of parameter values estimated for the Rio Grande Transboundary Integrated Hydrologic Model, Transboundary Rio Grande, New Mexico, Texas, and Mexico.-Continued

[See table 8 for package/process abbreviations. Abbreviations: $\mathrm{ft} / \mathrm{day}$, foot per day; $\mathrm{ft} / \mathrm{day}$, square foot per day; —, not estimated with parameter estimation; $\mathrm{n} / \mathrm{a}$, not applicable]

\begin{tabular}{|c|c|c|c|c|c|}
\hline Model layers & Parameter name & Final values & Units & $\begin{array}{l}\text { Rank and } \\
\text { composite } \\
\text { sensitivity }\end{array}$ & Package/process (parameter group) \\
\hline \multicolumn{6}{|c|}{$\begin{array}{l}\text { Fraction of transpiration } \\
1940-2014 \\
\end{array}$} \\
\hline Uppermost layer & FTR_DRY_WIN & 1 & Multiplier & $222 / 0.016$ & FMP-FTR-scale factors (FTR_WET and FTR_DRY) \\
\hline Uppermost layer & FTR_DRY_SPR & 0.95 & Multiplier & $11 / 0.651$ & FMP-FTR-scale factors (FTR_WET and FTR_DRY) \\
\hline Uppermost layer & FTR_DRY_SUM & 0.95 & Multiplier & $14 / 0.594$ & FMP-FTR-scale factors (FTR_WET and FTR_DRY) \\
\hline Uppermost layer & FTR_DRY_FAL & 1 & Multiplier & $260 / 0.012$ & FMP-FTR-scale factors (FTR_WET and FTR_DRY) \\
\hline Uppermost layer & FTR_WET_WIN & 1 & Multiplier & $259 / 0.012$ & FMP-FTR-scale factors (FTR_WET and FTR_DRY) \\
\hline Uppermost layer & FTR_WET_SPR & 1.05 & Multiplier & $167 / 0.031$ & FMP-FTR-scale factors (FTR_WET and FTR_DRY) \\
\hline Uppermost layer & FTR_WET_SUM & 1.05 & Multiplier & $150 / 0.042$ & FMP-FTR-scale factors (FTR_WET and FTR_DRY) \\
\hline Uppermost layer & FTR_WET_FAL & 1 & Multiplier & $255 / 0.013$ & FMP-FTR-scale factors (FTR_WET and FTR_DRY) \\
\hline \multicolumn{6}{|c|}{$\begin{array}{l}\text { Irrigation efficiency } \\
\text { 1940-2002 }\end{array}$} \\
\hline Uppermost layer & OFE_DRY_WIN & 0.918 & Multiplier & $193 / 0.021$ & FMP (OFE_WET and OFE_DRY) \\
\hline Uppermost layer & OFE_DRY_SPR & 1.027 & Multiplier & $39 / 0.296$ & FMP (OFE_WET and OFE_DRY) \\
\hline Uppermost layer & OFE_DRY_SUM & 1.049 & Multiplier & $54 / 0.225$ & FMP (OFE_WET and OFE_DRY) \\
\hline Uppermost layer & OFE_DRY_FAL & 0.984 & Multiplier & $105 / 0.076$ & FMP (OFE_WET and OFE_DRY) \\
\hline Uppermost layer & OFE_WET_WIN & 1.174 & Multiplier & $231 / 0.015$ & FMP (OFE_WET and OFE_DRY) \\
\hline Uppermost layer & OFE_WET_SPR & 0.966 & Multiplier & $35 / 0.306$ & FMP (OFE_WET and OFE_DRY) \\
\hline Uppermost layer & OFE_WET_SUM & 0.947 & Multiplier & $46 / 0.263$ & FMP (OFE_WET and OFE_DRY) \\
\hline Uppermost layer & OFE_WET_FAL & 1.018 & Multiplier & $122 / 0.059$ & FMP (OFE_WET and OFE_DRY) \\
\hline \multicolumn{6}{|c|}{$\begin{array}{l}\text { Irrigation efficiency } \\
\text { 2003-14 }\end{array}$} \\
\hline Uppermost layer & OFE_DRY2_WIN & 0.976 & Multiplier & $268 / 0.011$ & FMP (OFE_WET and OFE_DRY) \\
\hline Uppermost layer & OFE_DRY2_SPR & 1.096 & Multiplier & $42 / 0.273$ & FMP (OFE_WET and OFE_DRY) \\
\hline Uppermost layer & OFE_DRY2_SUM & 0.997 & Multiplier & $37 / 0.302$ & FMP (OFE_WET and OFE_DRY) \\
\hline Uppermost layer & OFE_DRY2_FAL & 0.749 & Multiplier & $99 / 0.079$ & FMP (OFE_WET and OFE_DRY) \\
\hline Uppermost layer & OFE_WET2_WIN & 1.014 & Multiplier & $273 / 0.010$ & FMP (OFE_WET and OFE_DRY) \\
\hline Uppermost layer & OFE_WET2_SPR & 0.841 & Multiplier & $80 / 0.124$ & FMP (OFE_WET and OFE_DRY) \\
\hline Uppermost layer & OFE_WET2_SUM & 1.0017 & Multiplier & $28 / 0.349$ & FMP (OFE_WET and OFE_DRY) \\
\hline Uppermost layer & OFE_WET2_FAL & 0.512 & Multiplier & $72 / 0.140$ & FMP (OFE_WET and OFE_DRY) \\
\hline
\end{tabular}


Table 14. Summary of parameter values estimated for the Rio Grande Transboundary Integrated Hydrologic Model, Transboundary Rio Grande, New Mexico, Texas, and Mexico.-Continued

[See table 8 for package/process abbreviations. Abbreviations: ft/day, foot per day; $\mathrm{ft}^{2} /$ day, square foot per day; —, not estimated with parameter estimation; $\mathrm{n} / \mathrm{a}$, not applicable]

\begin{tabular}{|c|c|c|c|c|c|}
\hline Model layers & Parameter name & Final values & Units & $\begin{array}{l}\text { Rank and } \\
\text { composite } \\
\text { sensitivity }\end{array}$ & Package/process (parameter group) \\
\hline \multicolumn{6}{|c|}{ Horizontal hydraulic conductivity } \\
\hline $1-2$ & RCHK10 & 125 & $\mathrm{ft} /$ day & $70 / 0.152$ & LPF/PVAL (hk_RC) \\
\hline $1-2$ & RCHK20 & 50 & $\mathrm{ft} /$ day & $43 / 0.272$ & LPF/PVAL (hk_RC) \\
\hline $1-2$ & RCHK30 & 9 & $\mathrm{ft} /$ day & $38 / 0.300$ & LPF/PVAL (hk_RC) \\
\hline $1-2$ & RCHK51 & 50 & $\mathrm{ft} /$ day & $62 / 0.177$ & LPF/PVAL (hk_RC) \\
\hline $3-4$ & USFHK15 & 120 & $\mathrm{ft} /$ day & $8 / 0.878$ & LPF/PVAL (hk_USF) \\
\hline $3-4$ & USFHK25 & 70 & $\mathrm{ft} /$ day & $44 / 0.267$ & LPF/PVAL (hk_USF) \\
\hline $3-4$ & USFHK35 & 90 & $\mathrm{ft} /$ day & $175 / 0.029$ & LPF/PVAL (hk_USF) \\
\hline $3-4$ & USFHK40 & 5 & $\mathrm{ft} /$ day & $328 / 0.00$ & LPF/PVAL (hk_USF) \\
\hline $3-4$ & USFHK 50 & 95 & $\mathrm{ft} /$ day & $27 / 0.351$ & LPF/PVAL (hk_USF) \\
\hline $3-4$ & USFHK51 & 4.8 & $\mathrm{ft} /$ day & $258 / 0.012$ & LPF/PVAL (hk_USF) \\
\hline $3-4$ & USFHK55 & 2.8 & $\mathrm{ft} /$ day & $286 / 0.008$ & LPF/PVAL (hk_USF) \\
\hline $3-4$ & USFHK60 & 6 & $\mathrm{ft} /$ day & $127 / 0.057$ & LPF/PVAL (hk_USF) \\
\hline $3-4$ & USFHK90 & 0.8 & $\mathrm{ft} /$ day & $283 / 0.008$ & LPF/PVAL (hk_USF) \\
\hline $3-4$ & USFHK999 & 0.01 & $\mathrm{ft} /$ day & - & LPF/PVAL (hk_USF) \\
\hline $5-6$ & MSFHK25 & 6.8 & $\mathrm{ft} /$ day & $289 / 0 / 008$ & LPF/PVAL (hk_MSF) \\
\hline $5-6$ & MSFHK35 & 10 & $\mathrm{ft} /$ day & $19 / 0.485$ & LPF/PVAL (hk_MSF) \\
\hline $5-6$ & MSFHK40 & 4 & $\mathrm{ft} /$ day & $295 / 0.007$ & LPF/PVAL (hk_MSF) \\
\hline $5-6$ & MSFHK50 & 1.2 & $\mathrm{ft} /$ day & $287 / 0.008$ & LPF/PVAL (hk_MSF) \\
\hline $5-6$ & MSFHK51 & 2 & $\mathrm{ft} /$ day & $329 / 0.00$ & LPF/PVAL (hk_MSF) \\
\hline $5-6$ & MSFHK55 & 0.5 & $\mathrm{ft} /$ day & $164 / 0.034$ & LPF/PVAL (hk_MSF) \\
\hline $5-6$ & MSFHK65 & 1 & $\mathrm{ft} /$ day & $263 / 0.011$ & LPF/PVAL (hk_MSF) \\
\hline $5-6$ & MSFHK90 & 7 & $\mathrm{ft} /$ day & $69 / 0.154$ & LPF/PVAL (hk_MSF) \\
\hline $5-6$ & MSFHK100 & 0.02 & $\mathrm{ft} /$ day & $298 / 0.007$ & LPF/PVAL (hk_MSF) \\
\hline $5-6$ & MSFHK999 & 0.01 & $\mathrm{ft} /$ day & - & LPF/PVAL (hk_MSF) \\
\hline $7-8$ & LSFHK35 & 3.2 & $\mathrm{ft} /$ day & $261 / 0.012$ & LPF/PVAL (hk_LSF) \\
\hline $7-8$ & LSFHK40 & 0.04 & $\mathrm{ft} /$ day & $217 / 0.016$ & LPF/PVAL (hk_LSF) \\
\hline $7-8$ & LSFHK55 & 4 & $\mathrm{ft} /$ day & $29 / 0.348$ & LPF/PVAL (hk_LSF) \\
\hline $7-8$ & LSFHK65 & 0.5 & $\mathrm{ft} /$ day & $279 / 0.009$ & LPF/PVAL (hk_LSF) \\
\hline $7-8$ & LSFHK90 & 0.08 & $\mathrm{ft} /$ day & $285 / 0.008$ & LPF/PVAL (hk_LSF) \\
\hline
\end{tabular}


Table 14. Summary of parameter values estimated for the Rio Grande Transboundary Integrated Hydrologic Model, Transboundary Rio Grande, New Mexico, Texas, and

Mexico.-Continued

[See table 8 for package/process abbreviations. Abbreviations: ft/day, foot per day; $\mathrm{ft}^{2} / \mathrm{day}$, square foot per day; —, not estimated with parameter estimation; n/a, not applicable]

\begin{tabular}{|c|c|c|c|c|c|}
\hline Model layers & Parameter name & Final values & Units & $\begin{array}{l}\text { Rank and } \\
\text { composite } \\
\text { sensitivity }\end{array}$ & Package/process (parameter group) \\
\hline \multicolumn{6}{|c|}{ Horizontal hydraulic conductivity-Continued } \\
\hline $7-8$ & LSFHK100 & 0.2 & $\mathrm{ft} /$ day & $157 / 0.036$ & LPF/PVAL (hk_LSF) \\
\hline $7-8$ & LSFHK999 & 0.1 & $\mathrm{ft} /$ day & - & LPF/PVAL (hk_LSF) \\
\hline 9 & BSMTHK11 & 0.08 & $\mathrm{ft} /$ day & $294 / 0.007$ & LPF/PVAL (hk_BSMT) \\
\hline 9 & BSMTHK21 & 3.2 & $\mathrm{ft} /$ day & $284 / 0.008$ & LPF/PVAL (hk_BSMT) \\
\hline 9 & BSMTHK31 & 1.8 & $\mathrm{ft} /$ day & $203 / 0.018$ & LPF/PVAL (hk_BSMT) \\
\hline 9 & BSMTHK41 & 1 & $\mathrm{ft} /$ day & $84 / 0.104$ & LPF/PVAL (hk_BSMT) \\
\hline 9 & BSMTHK56 & 4.2 & $\mathrm{ft} /$ day & $256 / 0.013$ & LPF/PVAL (hk_BSMT) \\
\hline 9 & BSMTHK61 & 2.7 & $\mathrm{ft} /$ day & $265 / 0.011$ & LPF/PVAL (hk_BSMT) \\
\hline 9 & BSMTHK71 & 1.8 & $\mathrm{ft} /$ day & $143 / 0.044$ & LPF/PVAL (hk_BSMT) \\
\hline \multicolumn{6}{|c|}{ Vertical hydraulic conductivity } \\
\hline $1-2$ & RCVK10 & 1.25 & $\mathrm{ft} /$ day & $155 / 0.038$ & LPF/PVAL (vk_RC) \\
\hline $1-2$ & RCVK20 & 0.6 & $\mathrm{ft} /$ day & $140 / 0.046$ & LPF/PVAL (vk_RC) \\
\hline $1-2$ & RCVK30 & 0.35 & $\mathrm{ft} /$ day & $97 / 0.082$ & LPF/PVAL (vk_RC) \\
\hline $1-2$ & RCVK51 & 2 & $\mathrm{ft} /$ day & $269 / 0.011$ & LPF/PVAL (vk_RC) \\
\hline $3-4$ & USFVK15 & 0.25 & $\mathrm{ft} /$ day & $16 / 0.546$ & LPF/PVAL (vk_USF) \\
\hline $3-4$ & USFVK 25 & 3 & $\mathrm{ft} /$ day & $270 / 0.011$ & LPF/PVAL (vk_USF) \\
\hline $3-4$ & USFVK35 & 0.1 & $\mathrm{ft} / \mathrm{day}$ & $288 / 0.008$ & LPF/PVAL (vk_USF) \\
\hline $3-4$ & USFVK40 & 0.1 & $\mathrm{ft} /$ day & $330 / 0.00$ & LPF/PVAL (vk_USF) \\
\hline $3-4$ & USFVK50 & 0.01 & $\mathrm{ft} /$ day & $134 / 0.052$ & LPF/PVAL (vk_USF) \\
\hline $3-4$ & USFVK51 & 0.3 & $\mathrm{ft} /$ day & $300 / 0.007$ & LPF/PVAL (vk_USF) \\
\hline $3-4$ & USFVK55 & 0.005 & $\mathrm{ft} /$ day & $276 / 0.009$ & LPF/PVAL (vk_USF) \\
\hline $3-4$ & USFVK60 & 0.2 & $\mathrm{ft} /$ day & $277 / 0.009$ & LPF/PVAL (vk_USF) \\
\hline $3-4$ & USFVK90 & 0.005 & $\mathrm{ft} /$ day & $304 / 0.006$ & LPF/PVAL (vk_USF) \\
\hline $3-4$ & USFVK999 & 0.7 & $\mathrm{ft} /$ day & - & LPF/PVAL (vk_USF) \\
\hline $5-6$ & MSFVK25 & 0.75 & $\mathrm{ft} / \mathrm{day}$ & $293 / 0.007$ & LPF/PVAL (vk_MSF) \\
\hline $5-6$ & MSFVK35 & 0.2 & $\mathrm{ft} /$ day & $6 / 1.05$ & LPF/PVAL (vk_MSF) \\
\hline $5-6$ & MSFVK40 & 0.005 & $\mathrm{ft} /$ day & $153 / 0.040$ & LPF/PVAL (vk_MSF) \\
\hline $5-6$ & MSFVK50 & 0.01 & $\mathrm{ft} /$ day & $291 / 0.008$ & LPF/PVAL (vk_MSF) \\
\hline $5-6$ & MSFVK51 & 0.1 & $\mathrm{ft} /$ day & $331 / 0.00$ & LPF/PVAL (vk_MSF) \\
\hline
\end{tabular}


Table 14. Summary of parameter values estimated for the Rio Grande Transboundary Integrated Hydrologic Model, Transboundary Rio Grande, New Mexico, Texas, and Mexico.-Continued

[See table 8 for package/process abbreviations. Abbreviations: ft/day, foot per day; $\mathrm{ft}^{2} /$ day, square foot per day; —, not estimated with parameter estimation; $\mathrm{n} / \mathrm{a}$, not applicable]

\begin{tabular}{|c|c|c|c|c|c|}
\hline Model layers & Parameter name & Final values & Units & $\begin{array}{l}\text { Rank and } \\
\text { composite } \\
\text { sensitivity }\end{array}$ & Package/process (parameter group) \\
\hline \multicolumn{6}{|c|}{ Vertical hydraulic conductivity-Continued } \\
\hline $5-6$ & MSFVK55 & 0.1 & $\mathrm{ft} /$ day & $169 / 0.030$ & LPF/PVAL (vk_MSF) \\
\hline $5-6$ & MSFVK65 & 0.005 & $\mathrm{ft} /$ day & $275 / 0.009$ & LPF/PVAL (vk_MSF) \\
\hline $5-6$ & MSFVK90 & 0.07 & $\mathrm{ft} /$ day & $40 / 0.291$ & LPF/PVAL (vk_MSF) \\
\hline $5-6$ & MSFVK100 & 0.005 & $\mathrm{ft} /$ day & $204 / 0.018$ & LPF/PVAL (vk_MSF) \\
\hline $5-6$ & MSFVK999 & 0.5 & $\mathrm{ft} /$ day & - & LPF/PVAL (vk_MSF) \\
\hline $7-8$ & LSFVK35 & 0.005 & $\mathrm{ft} /$ day & $271 / 0.010$ & LPF/PVAL (vk_LSF) \\
\hline $7-8$ & LSFVK40 & 10 & $\mathrm{ft} /$ day & $253 / 0.013$ & LPF/PVAL (vk_LSF) \\
\hline $7-8$ & LSFVK55 & 0.2 & $\mathrm{ft} /$ day & $59 / 0.200$ & LPF/PVAL (vk_LSF) \\
\hline $7-8$ & LSFVK65 & 0.0003 & $\mathrm{ft} /$ day & $301 / 0.007$ & LPF/PVAL (vk_LSF) \\
\hline $7-8$ & LSFVK90 & 0.001 & $\mathrm{ft} /$ day & $278 / 0.009$ & LPF/PVAL (vk_LSF) \\
\hline $7-8$ & LSFVK100 & 0.005 & $\mathrm{ft} /$ day & $299 / 0.007$ & LPF/PVAL (vk_LSF) \\
\hline $7-8$ & LSFVK999 & 0.5 & $\mathrm{ft} /$ day & - & LPF/PVAL (vk_LSF) \\
\hline 9 & BSMTVK11 & 0.005 & $\mathrm{ft} /$ day & $296 / 0.007$ & LPF/PVAL (vk_BSMT) \\
\hline 9 & BSMTVK21 & 0.05 & $\mathrm{ft} /$ day & $280 / 0.009$ & LPF/PVAL (vk_BSMT) \\
\hline 9 & BSMTVK31 & 0.05 & $\mathrm{ft} /$ day & $282 / 0.008$ & LPF/PVAL (vk_BSMT) \\
\hline 9 & BSMTVK41 & 0.1 & $\mathrm{ft} / \mathrm{day}$ & $91 / 0.094$ & LPF/PVAL (vk_BSMT) \\
\hline 9 & BSMTVK56 & 0.1 & $\mathrm{ft} /$ day & $297 / 0.007$ & LPF/PVAL (vk_BSMT) \\
\hline 9 & BSMTVK61 & 0.4 & $\mathrm{ft} /$ day & $290 / 0.008$ & LPF/PVAL (vk_BSMT) \\
\hline 9 & BSMTVK71 & 0.1 & $\mathrm{ft} /$ day & $281 / 0.008$ & LPF/PVAL (vk_BSMT) \\
\hline \multicolumn{6}{|c|}{ Specific yield } \\
\hline 1 & SY_RC & 0.15 & Fraction & $1 / 3.18$ & LPF/MULT (SYmlt_prop) \\
\hline 3 & SY_USF1 & 0.13 & Fraction & $2 / 2.17$ & LPF/MULT (SYmlt_prop) \\
\hline 5 & SY_MSF1 & 0.08 & Fraction & $120 / 0.060$ & LPF/MULT (SYmlt_prop) \\
\hline 7 & SY_LSF1 & 0.07 & Fraction & $128 / 0.057$ & LPF/MULT (SYmlt_prop) \\
\hline 9 & SY_BD & 0.08 & Fraction & $66 / 0.161$ & LPF/MULT (SYmlt_prop) \\
\hline
\end{tabular}


Table 14. Summary of parameter values estimated for the Rio Grande Transboundary Integrated Hydrologic Model, Transboundary Rio Grande, New Mexico, Texas, and Mexico.-Continued

[See table 8 for package/process abbreviations. Abbreviations: ft/day, foot per day; $\mathrm{ft}^{2} / \mathrm{day}$, square foot per day; —, not estimated with parameter estimation; n/a, not applicable]

\begin{tabular}{|c|c|c|c|c|c|}
\hline Model layers & Parameter name & Final values & Units & $\begin{array}{l}\text { Rank and } \\
\text { composite } \\
\text { sensitivity }\end{array}$ & Package/process (parameter group) \\
\hline \multicolumn{6}{|c|}{ Porosity } \\
\hline $1-2$ & PHI_RC & 25 & Percentage & $251 / 0.013$ & LPF/MULT (PHImlt_prop) \\
\hline $3-4$ & PHI_US & 22 & Percentage & $196 / 0.020$ & LPF/MULT (PHImlt_prop) \\
\hline $5-6$ & PHI_MS & 12 & Percentage & $176 / 0.028$ & LPF/MULT (PHImlt_prop) \\
\hline $7-8$ & PHI_LS & 8 & Percentage & $142 / 0.045$ & LPF/MULT (PHImlt_prop) \\
\hline 9 & PHI_BD & 7 & Percentage & $130 / 0.055$ & LPF/MULT (PHImlt_prop) \\
\hline \multicolumn{6}{|c|}{ Specific storage } \\
\hline 2 & SS_RC12 & $3.50 \mathrm{E}-05$ & $1 /$ feet & $267 / 0.011$ & LPF/MULT (SSmlt_prop) \\
\hline $3-4$ & SS_USF1A & $1.50 \mathrm{E}-05$ & $1 /$ feet & $248 / 0.014$ & LPF/MULT (SSmlt_prop) \\
\hline $3-4$ & SS_USF2B & $1.50 \mathrm{E}-05$ & $1 /$ feet & $171 / 0.029$ & LPF/MULT (SSmlt_prop) \\
\hline $5-6$ & SS_MSF1A & $1.00 \mathrm{E}-05$ & $1 /$ feet & $190 / 0.022$ & LPF/MULT (SSmlt_prop) \\
\hline $5-6$ & SS_MSF2B & $1.00 \mathrm{E}-06$ & $1 /$ feet & $292 / 0.008$ & LPF/MULT (SSmlt_prop) \\
\hline $7-8$ & SS_LSF1A & $2.50 \mathrm{E}-06$ & $1 /$ feet & $226 / 0.016$ & LPF/MULT (SSmlt_prop) \\
\hline $7-8$ & SS_LSF2B & $2.50 \mathrm{E}-06$ & $1 /$ feet & $149 / 0.042$ & LPF/MULT (SSmlt_prop) \\
\hline 9 & SS_BDA & $8.50 \mathrm{E}-06$ & $1 /$ feet & $58 / 0.203$ & LPF/MULT (SSmlt_prop) \\
\hline $1-2$ & RCSS10 & 1 & Multiplier & $86 / 0.102$ & LPF/PVAL (ss_RC) \\
\hline $1-2$ & $\mathrm{RCSS} 20$ & 3 & Multiplier & $94 / 0.087$ & LPF/PVAL (ss_RC) \\
\hline $1-2$ & RCSS30 & 2 & Multiplier & $82 / 0.117$ & LPF/PVAL (ss_RC) \\
\hline $1-2$ & RCSS51 & 3 & Multiplier & $154 / 0.039$ & LPF/PVAL (ss_RC) \\
\hline $3-4$ & USFSS15 & 0.35 & Multiplier & $123 / 0.059$ & LPF/PVAL (ss_USF) \\
\hline $3-4$ & USFSS25 & 1 & Multiplier & $129 / 0.055$ & LPF/PVAL (ss_USF) \\
\hline $3-4$ & USFSS35 & 1 & Multiplier & $311 / 0.004$ & LPF/PVAL (ss_USF) \\
\hline $3-4$ & USFSS40 & 1 & Multiplier & $332 / 0.00$ & LPF/PVAL (ss_USF) \\
\hline $3-4$ & USFSS50 & 1 & Multiplier & $63 / 0.175$ & LPF/PVAL (ss_USF) \\
\hline $3-4$ & USFSS51 & 1 & Multiplier & $183 / 0.026$ & LPF/PVAL (ss_USF) \\
\hline $3-4$ & USFSS55 & 1 & Multiplier & $320 / 0.003$ & LPF/PVAL (ss_USF) \\
\hline $3-4$ & USFSS60 & 1 & Multiplier & $76 / 0.131$ & LPF/PVAL (ss_USF) \\
\hline $3-4$ & USFSS90 & 1 & Multiplier & $321 / 0.003$ & LPF/PVAL (ss_USF) \\
\hline $3-4$ & USFSS999 & $1.00 \mathrm{E}-09$ & Multiplier & - & LPF/PVAL (ss_USF) \\
\hline $5-6$ & MSFSS25 & 0.2 & Multiplier & $208 / 0.017$ & LPF/PVAL (ss_MSF) \\
\hline
\end{tabular}


Table 14. Summary of parameter values estimated for the Rio Grande Transboundary Integrated Hydrologic Model, Transboundary Rio Grande, New Mexico, Texas, and Mexico.-Continued

[See table 8 for package/process abbreviations. Abbreviations: $\mathrm{ft} / \mathrm{day}$, foot per day; $\mathrm{ft} / \mathrm{day}$, square foot per day; —, not estimated with parameter estimation; $\mathrm{n} / \mathrm{a}$, not applicable]

\begin{tabular}{|c|c|c|c|c|c|}
\hline Model layers & Parameter name & Final values & Units & $\begin{array}{l}\text { Rank and } \\
\text { composite } \\
\text { sensitivity }\end{array}$ & Package/process (parameter group) \\
\hline \multicolumn{6}{|c|}{ Specific Storage-Continued } \\
\hline $5-6$ & MSFSS35 & 0.1 & Multiplier & $156 / 0.036$ & LPF/PVAL (ss_MSF) \\
\hline $5-6$ & MSFSS40 & 0.5 & Multiplier & $303 / 0.007$ & LPF/PVAL (ss_MSF) \\
\hline $5-6$ & MSFSS50 & 1 & Multiplier & $318 / 0.003$ & LPF/PVAL (ss_MSF) \\
\hline $5-6$ & MSFSS51 & 1 & Multiplier & $333 / 0.00$ & LPF/PVAL (ss_MSF) \\
\hline $5-6$ & MSFSS55 & 0.1 & Multiplier & $166 / 0.033$ & LPF/PVAL (ss_MSF) \\
\hline $5-6$ & MSFSS65 & 1 & Multiplier & $312 / 0.004$ & LPF/PVAL (ss_MSF) \\
\hline $5-6$ & MSFSS90 & 1.5 & Multiplier & $302 / 0.007$ & LPF/PVAL (ss_MSF) \\
\hline $5-6$ & MSFSS 100 & 1 & Multiplier & $314 / 0.004$ & LPF/PVAL (ss_MSF) \\
\hline $5-6$ & MSFSS 999 & $1.00 \mathrm{E}-09$ & Multiplier & - & LPF/PVAL (ss_MSF) \\
\hline $7-8$ & LSFSS35 & 1 & Multiplier & $313 / 0.004$ & LPF/PVAL (ss_LSF) \\
\hline $7-8$ & LSFSS40 & 0.4 & Multiplier & $224 / 0.016$ & LPF/PVAL (ss_LSF) \\
\hline $7-8$ & LSFSS55 & 0.5 & Multiplier & $198 / 0.020$ & LPF/PVAL (ss_LSF) \\
\hline $7-8$ & LSFSS65 & 1 & Multiplier & $315 / 0.004$ & LPF/PVAL (ss_LSF) \\
\hline $7-8$ & LSFSS90 & 1 & Multiplier & $309 / 0.004$ & LPF/PVAL (ss_LSF) \\
\hline $7-8$ & LSFSS 100 & 1 & Multiplier & $316 / 0.003$ & LPF/PVAL (ss_LSF) \\
\hline $7-8$ & LSFSS999 & $1.00 \mathrm{E}-09$ & Multiplier & - & LPF/PVAL (ss_LSF) \\
\hline 9 & BSMTSS11 & 1 & Multiplier & $216 / 0.017$ & LPF/PVAL (ss_BSMT) \\
\hline 9 & BSMTSS21 & 1 & Multiplier & $305 / 0.006$ & LPF/PVAL (ss_BSMT) \\
\hline 9 & BSMTSS31 & 1 & Multiplier & $272 / 0.010$ & LPF/PVAL (ss_BSMT) \\
\hline 9 & BSMTSS41 & 2 & Multiplier & $146 / 0.044$ & LPF/PVAL (ss_BSMT) \\
\hline 9 & BSMTSS56 & 1 & Multiplier & $307 / 0.005$ & LPF/PVAL (ss_BSMT) \\
\hline 9 & BSMTSS61 & 1 & Multiplier & $319 / 0.003$ & LPF/PVAL (ss_BSMT) \\
\hline 9 & BSMTSS71 & 1 & Multiplier & $262 / 0.011$ & LPF/PVAL (ss_BSMT) \\
\hline \multicolumn{6}{|c|}{ Skin factor for multi-node wells } \\
\hline $1-9$ & $\begin{array}{l}\text { KskNM_SM_OLD Casing diameter }<\text { or }=\text { to } \\
10 \text {-inches }\end{array}$ & 7 & $\mathrm{ft} /$ day & $325 / 0.001$ & MNW2 (MNW_Kskin1) \\
\hline $1-9$ & KskNM_BG_OLD Casing diameter $>10$-inches & 8 & $\mathrm{ft} /$ day & $310 / 0.004$ & MNW2 (MNW_Kskin3) \\
\hline $1-9$ & KskTX_SM_OLD Casing diameter $<$ or $=$ to & 7 & $\mathrm{ft} /$ day & $324 / 0.001$ & MNW2 (MNW_Kskin1) \\
\hline
\end{tabular}


Table 14. Summary of parameter values estimated for the Rio Grande Transboundary Integrated Hydrologic Model, Transboundary Rio Grande, New Mexico, Texas, and Mexico.-Continued

[See table 8 for package/process abbreviations. Abbreviations: ft/day, foot per day; $\mathrm{ft}^{2} / \mathrm{day}$, square foot per day; —, not estimated with parameter estimation; n/a, not applicable]

\begin{tabular}{|c|c|c|c|c|c|}
\hline Model layers & Parameter name & Final values & Units & $\begin{array}{l}\text { Rank and } \\
\text { composite } \\
\text { sensitivity }\end{array}$ & Package/process (parameter group) \\
\hline \multicolumn{6}{|c|}{ Skin factor for multi-node wells-Continued } \\
\hline $1-9$ & KskTX_BG_OLD Casing diameter $>10$-inches & 8 & $\mathrm{ft} /$ day & $326 / 0.001$ & MNW2 (MNW_Kskin1) \\
\hline $1-9$ & $\begin{array}{c}\text { KskNM_SM_NEW Casing diameter }<\text { or }=\text { to } \\
10 \text {-inches }\end{array}$ & 4 & $\mathrm{ft} / \mathrm{day}$ & $317 / 0.003$ & MNW2 (MNW_Kskin2) \\
\hline $1-9$ & KskNM_BG_NEW Casing diameter $>10$-inches & 5 & $\mathrm{ft} / \mathrm{day}$ & $322 / 0.002$ & MNW2 (MNW_Kskin4) \\
\hline $1-9$ & $\begin{array}{c}\text { KskTX_SM_NEW Casing diameter }<\text { or }=\text { to } \\
10 \text {-inches }\end{array}$ & 4 & $\mathrm{ft} / \mathrm{day}$ & $323 / 0.001$ & MNW2 (MNW_Kskin2) \\
\hline $1-9$ & KskTX_BG_NEW Casing diameter $>10$-inches & 5 & $\mathrm{ft} / \mathrm{day}$ & $306 / 0.006$ & MNW2 (MNW_Kskin4) \\
\hline \multicolumn{6}{|c|}{ Reservoir package vertical hydraulic conductivity } \\
\hline $3-4$ & Res_BotKv & 0.007 & $\mathrm{ft} /$ day & $266 / 0.011$ & RES (ResKv_prop) \\
\hline \multicolumn{6}{|c|}{ General-head boundary conductance ${ }^{1}$} \\
\hline $3-4$ & EPNarrow & $8.75 \mathrm{E}+03$ & $\mathrm{ft}^{2} /$ day & $221 / 0.016$ & GHB (EPNarrowGHB) \\
\hline $3-4$ & Filmore & $1.35 \mathrm{E}+02$ & $\mathrm{ft}^{2} /$ day & $191 / 0.021$ & GHB (FillmoreGHB) \\
\hline $3-4$ & RinconAr & $1.35 \mathrm{E}+02$ & $\mathrm{ft}^{2} /$ day & $210 / 0.017$ & GHB (RinconArGHB) \\
\hline $3-4$ & MXSB & $2.64 \mathrm{E}+04$ & $\mathrm{ft}^{2} /$ day & $246 / 0.014$ & GHB (MXSB_GHB) \\
\hline $3-4$ & MXSWB & $2.50 \mathrm{E}+04$ & $\mathrm{ft}^{2} /$ day & $247 / 0.014$ & GHB (MXSWB_GHB) \\
\hline $3-4$ & MXWB & $1.23 \mathrm{E}+04$ & $\mathrm{ft}^{2} /$ day & $243 / 0.014$ & GHB (MXWB_GHB) \\
\hline \multicolumn{6}{|c|}{ Horizontal flow-barrier conductance ${ }^{2}$} \\
\hline $1-9$ & USF_N & $1.00 \mathrm{E}-09$ & $\mathrm{ft}^{2} /$ day & $214 / 0.016$ & HFB (hyd_flt4) \\
\hline $1-9$ & USF_NWNE & $1.00 \mathrm{E}-08$ & $\mathrm{ft}^{2} /$ day & $228 / 0.015$ & HFB (hyd_flt4) \\
\hline $1-9$ & MSF_N & $1.50 \mathrm{E}-09$ & $\mathrm{ft}^{2} /$ day & $227 / 0.015$ & HFB (hyd_flt2) \\
\hline $1-9$ & MSF_NWNE & $1.50 \mathrm{E}-06$ & $\mathrm{ft}^{2} /$ day & $250 / 0.013$ & HFB (hyd_flt2) \\
\hline $1-9$ & MSF_RinMes & $1.00 \mathrm{E}-11$ & $\mathrm{ft}^{2} /$ day & $257 / 0.013$ & HFB (hyd_flt5) \\
\hline $1-9$ & LSF_N & $5.00 \mathrm{E}-06$ & $\mathrm{ft}^{2} /$ day & $101 / 0.079$ & HFB (hyd_flt1) \\
\hline $1-9$ & LSF_NWNE & $5.00 \mathrm{E}-05$ & $\mathrm{ft}^{2} /$ day & $220 / 0.016$ & HFB (hyd_flt1) \\
\hline $1-9$ & PSF_NWNE & $1.00 \mathrm{E}-10$ & $\mathrm{ft}^{2} /$ day & $249 / 0.014$ & HFB (hyd_flt3) \\
\hline $1-9$ & VOLCDIKES & $5.00 \mathrm{E}-09$ & $\mathrm{ft}^{2} /$ day & $240 / 0.014$ & HFB (hyd_dik6) \\
\hline
\end{tabular}


Table 14. Summary of parameter values estimated for the Rio Grande Transboundary Integrated Hydrologic Model, Transboundary Rio Grande, New Mexico, Texas, and Mexico.-Continued

[See table 8 for package/process abbreviations. Abbreviations: ft/day, foot per day; $\mathrm{ft}^{2} / \mathrm{day}$, square foot per day; —, not estimated with parameter estimation; n/a, not applicable]

\begin{tabular}{|c|c|c|c|c|c|}
\hline Model layers & Parameter name & Final values & Units & $\begin{array}{l}\text { Rank and } \\
\text { composite } \\
\text { sensitivity }\end{array}$ & Package/process (parameter group) \\
\hline \multicolumn{6}{|c|}{ Scale factor of initial groundwater levels } \\
\hline 1 & SCL_HedLy1 & 0.99905 & Multiplier & - & BAS (bas_prop) \\
\hline 2 & SCL_HedLy2 & 0.99905 & Multiplier & - & BAS (bas_prop) \\
\hline 3 & SCL_HedLy3 & 0.999 & Multiplier & - & BAS (bas_prop) \\
\hline 4 & SCL_HedLy4 & 0.9989 & Multiplier & - & BAS (bas_prop) \\
\hline 5 & SCL_HedLy5 & 0.9988 & Multiplier & - & BAS (bas_prop) \\
\hline 6 & SCL_HedLy6 & 0.997 & Multiplier & - & BAS (bas_prop) \\
\hline 7 & SCL_HedLy7 & 0.9962 & Multiplier & - & BAS (bas_prop) \\
\hline 8 & SCL_HedLy8 & 0.996 & Multiplier & - & BAS (bas_prop) \\
\hline 9 & SCL_HedLy9 & 0.995 & Multiplier & - & BAS (bas_prop) \\
\hline
\end{tabular}

${ }^{1}$ EPNarrow is coincident with Rio Grande channel alluvium below the El Paso narrows; Filmore is coincident with Filmore Pass; MXSB is the southern boundary of the RGTIHM in Mexico; MXSWB is the south-western boundary of the RGTIHM in Mexico; MXWB is the western boundary of the RGTIHM in Mexico; and RinconAr is coincident with the Rincon Arroyo.

${ }^{2}$ USF N are faults that cut the Upper Santa Fe and older hydrostratigraphic units and have a northerly trend; USF NWNE are faults that cut the Upper Santa Fe and older hydrostratigraphic units and have a north-easterly or north-westerly trend; MSF_N are faults that cut the Middle Santa Fe and older hydrostratigraphic units and have a northerly trend; MSF_NWNE are faults that cut the Middle Santa Fe and older hydrostratigraphic units and have a north-easterly or north-westerly trend; MSF_RinMes are faults near Selden Canyon that cut the Middle Santa Fe and older hydrostratigraphic units; LSF_N are faults that cut the Lower Santa Fe and older hydrostratigraphic units and have a northerly trend; LSF NWNE are faults that cut the Lower Santa Fe and older hydrostratigraphic units and have a north-easterly or north-westerly trend; PSF NWNE are faults that cut the Basement hydrostratigraphic unit and have a north-easterly or north-westerly trend; and VOLCDIKES are intrusive dikes. 
Unlike previous analysis of the TRG region, in which the hydraulic conductivity was not differentiated for the various model layers, the Quaternary alluvium and three members of the Santa Fe Group were delineated as separate units, each with an upper and lower unit that helped further distinguish upper and lower depositional environments for some facies by separate estimates of the hydraulic conductivity for this zonation of the coarse- and fine-grained facies values. Hydraulic conductivities generally decrease with depth and with increasing distance from the original source of the sediments (eroded or transported from the adjacent mountain ranges and river channels), which is consistent with the colluvial, fluvial, and aeolian processes that result in sequential fining upward and fining away from source area or toward the basin center; such sequences typify the aquifer sediments and are represented in the lithofacies model (Sweetkind, 2017). In several subregions, lesser values of hydraulic conductivity were estimated in fine-grained facies that could also reflect secondary alteration such as cementation (Sweetkind, 2017).

The hydraulic properties used to simulate the changes in storage of water in the saturated parts of the aquifer system consist of three components (Hanson, 1989):

1. Specific yield for unconfined subregions.

2. Elastic specific storage plus the compressibility of water for unconfined and confined subregions.

3. Inelastic specific storage.

The first two components, specific yield and the elastic specific storage, represent and govern the reversible uptake and release of water to and from storage, respectively. Specific yield is unconfined storage and represents gravity-driven draining or filling (resaturation) of sediments concomitant with changes of the water table. The elastic storage coefficient represents the component of confined storage resulting from the compressibility of water and to the reversible compressibility of the matrix or the skeletal framework of the aquifer system (Jacob, 1940; Hanson, 1989). The inelastic storage coefficient governs the irreversible release of water from the inelastic compaction of the fine-grained deposits or permanent reduction of pore space, which can lead to land subsidence. Although there might be evidence of inelastic compaction in some regions of the TRG, such as near the Canutillo well field, and subsidence is an issue in the alluvial aquifers of the Mimbres Basin (Contaldo and Mueller, 1991), this feature was not explicitly simulated in this version of the RGTIHM model. Specific yield is typically orders of magnitude larger than specific storage and is volumetrically the dominant storage parameter for the outcrop regions of the
Quaternary alluvium, upper and middle members of the Santa Fe Group, and basement aquifers.

The LPF package was used to define storage properties in each of the aquifers represented in the model. The LPF along with the "Parameter Value" (PVAL) and "Multiplier" (MULT) packages were used to calculate and specify the aquiferstorage components, which included the compressibility of water for all model layers and the specific yield for parts of the uppermost active layers (layers 1, 3, 5, 9; fig. 3A). The resulting equation for the composite storage is represented (Hanson and others, 2014a) as follows:

$$
S^{*}=S+S^{\prime}+S_{y}
$$

where

$$
\begin{aligned}
& S^{*} \quad \begin{array}{l}
\text { is the total storage of the aquifer layer, } \\
S \quad \text { is the elastic storage of the coarse-grained } \\
\text { facies component, }
\end{array} \\
& S^{\prime} \quad \text { is the elastic and inelastic storage of the } \\
& \quad \text { component for each facies, and } \\
& S_{y} \quad \text { is the specific yield from water-table drainage } \\
& \text { for the unconfined parts of an aquifer. }
\end{aligned}
$$

Both $S$ and $S^{\prime}$ can be further represented by the respective components as follows:

$$
S=b \times S_{x}=p g(a+n \beta) \times b
$$

where

$$
\begin{aligned}
& b \quad \text { is the cell-by-cell thickness of the aquifer } \\
& \text { layer }(\mathrm{ft}) \text {, } \\
& S_{x} \quad \text { is the total specific storage }\left(\mathrm{ft}^{-1}\right) \text {, } \\
& \rho g \text { is the weight of water (pounds/ } \mathrm{ft}^{3} \text { ), } \\
& \alpha \quad \text { is the compressibility of the coarse- or fine- } \\
& \text { grained facies matrix material }\left(\mathrm{ft}^{-1}\right) \text {, } \\
& n \quad \text { is the total porosity of the coarse- or fine- } \\
& \text { grained facies as a decimal fraction (0), } \\
& \text { and } \\
& \beta \quad \text { is the compressibility of water }\left(\mathrm{ft}^{-1}\right) \text {. }
\end{aligned}
$$

Although all model layers are simulated as confined, parts of the uppermost active model layer represent unconfined conditions and therefore are assigned a specific storage value representative of a specific yield. Specific yield, which is a function of sediment porosity and moisture-retention characteristics, cannot exceed the estimated sediment porosity. The zones used to specify the subareas of the storage properties (eqn. 2) are similar to the layers used for the other hydraulic properties (tables 13, 14; fig. 21), except for the unconfined subareas of the uppermost layers, which have a specific yield assigned. 
The specific storage of water (eqn. 1) is dependent on the specified porosities for the coarse- and fine-grained facies of each hydrostratigraphic unit (model layer). The estimated total porosities from selected core samples of typical alluvial sediments from Santa Clara Valley, California, ranged from 23 to 43 percent, and the effective porosity ranged from 22 to 40 percent, based on laboratory tests of selected cores (Newhouse and others, 2004). For the RGTIHM, porosity values ranged from 25 percent for the coarse-grained sediments of the Quaternary alluvium to 8 percent for the lower member of the Santa Fe Group and 7 percent for the bedrock model layer (table 14). The product of average porosity and the compressibility of water $\left(1.4 \times 10^{-6} \mathrm{ft}^{-1}\right)$ yields one part of the composite aquifer specific-storage value for each active cell of every layer.

Specific yield was specified for all active cells of each layer in which the model cells represented the uppermost model cell and potentially unconfined conditions. Specific yield was assigned to each model layer; maximum values ranged from 0.14 for the alluvium to 0.07 for the lower member of the Santa Fe Group (table 14). During calibration, a multiplier was used for each zone and to determine the final range in specific yield (fig. 21; tables 12-14).

\section{Conductance of Faults and Dikes}

Most of the TRG (fig. 3B) subsurface is dissected by faults that act as potential barriers to groundwater flow. The faults along the edges of the active flow region in the RGTIHM delineate most of the external no-flow boundaries. The Fitzgerald (FFZ), Interstate 10 West (I10WF), Rio Grande (RGF), Mesilla Valley fault zone (MVFZ), Mastodon (MF), Transboundary (TF), and Selden Canyon fault zone (SCF) subdivide and compartmentalize the subbasins and the Midbasin uplift (Sweetkind, 2017; fig. 3B). These interior faults separate the TRG region into a set of subregions that respond differently to climate and water-resource development.

Volcanic intrusion, dikes, and necks (fig. $3 B$ ) associated with a few of these faults also contribute to horizontal subsurfaceflow barriers. The "Horizontal Flow Barrier" (HFB) package (Hsieh and Freckelton, 1993) was used to simulate resistance to horizontal flow across these structures. The effectiveness of these faults as partial flow barriers was then estimated by a parameter representing the conductance of the vertical modelcell faces aligned with the fault trace (table 14). Groundwater levels at selected wells that straddle the faults traversing the northern Conejos-Médanos Basin showed lateral groundwaterlevel differences that could reflect a combination of screened depths and the faults acting as flow barriers.

\section{Initial Conditions}

Although the effects of climate variability preclude steady-state conditions, prior to development that started in the 1920s, the basin was largely responding to changes driven by the natural cycles of climate variability, and no regulated streamflows or groundwater pumpage affected changes in groundwater levels. The initial conditions used in the RGTIHM represent composite estimates of hydrologic conditions before the extensive groundwater development for irrigation that began in the 1950s. The initial heads were periodically adjusted by scale factors during calibration to refine the estimates of initial heads. This adjustment of scaling parameters for the overall elevation of initial water levels helped refine the initial heads for all nine model layers during parameter estimation.

For transient models, initial conditions define the system state at the beginning of the simulation. When the simulation is started, the simulated heads and flows change in response to the initially specified and simulated inflows and outflows. Because the irrigation and pumping stresses on the system change rapidly, the inconsistencies between the initially specified conditions and the simulated initial processes and properties generally are not problematic because the next stress regime soon dominates the solution (Hill and Tiedeman, 2007). As a result, comparing observed and simulated values becomes meaningful after a relatively short simulation time. This study and previous studies (Belitz and Phillips, 1995; Faunt and others, 2009) showed that the time frame for the stabilization is typically less than several months to several years in the simulation, depending on the magnitude of the changes in the stresses that drive inflows and outflows and the overall hydraulic diffusivity of the aquifer systems. 


\section{Calibration and Sensitivity- Rio Grande Transboundary Integrated Hydrologic Model}

The RGTIHM was calibrated by a combination of trialand-error and a computer-assisted process of minimizing differences between observations and simulated values. The model calibration not only requires matching of observations and estimation of parameters to help with these matches, but also requires adjustments in the framework of the RGTIHM to facilitate those matches in a conceptually consistent manner. As such, the hydrologic framework and definitions of waterbalance zones were modified as part of this process to create a more consistent framework for model calibration. Once the structural framework is consistent, then observations and parameters can be compiled and grouped. The following subsections summarize the parameter groups and calibration adjustments, the observations and results from calibration, and the related sensitivity analysis based on these observations and parameters. Simulation using the RGTIHM requires specification of several hundred parameters that vary spatially and temporally, some of which are correlated through their process-based relations; thus, developing an optimized set of calibrated parameter values in an integrated hydrologic model can be a challenge (Hanson and others, 2014a). Accordingly, a parameterization procedure was employed that allows a limited number of parameter values to control the temporal and spatial variability of a much larger number of model properties specified as inputs. The parameterization procedure followed that of Hill and Tiedeman (2007) by defining the term "parameters" to mean model inputs of hydraulic and hydrologic properties; this definition was extended to include landscape and land-use-related properties from the FMP. All surface inflow to the RGTIHM domain is in the SFR2 inflows and subsurface inflows in the GHB and RES inflows. Although some parameters demonstrated significant correlations, those parameters selected for model calibration were assumed to be independent. Parameter-estimation software package, PEST (Doherty, 2010a-c; Doherty and Hunt, 2010) was used to help with sensitivity analyses and computer-assisted parameter estimation.

Calibration of the RGTIHM to observations of transientstate conditions was dependent on the components of the use and movement of water across the landscape as well as exchanges with the streamflow network and groundwater-flow system. Calibration started with adjustments of all parameters representing the landscape, such as fractions of transpiration, irrigation efficiencies, and stress factors for the CIR. Then, adjustments were made to other factors related to movement of water across the landscape as surface-water conveyance; return flows; and discharges, including the hydraulic conductivity of the streambeds, canals, and drains in the streamflow network. The calibration related to groundwater flow involved adjustment of parameters that control the inflows and outflows to the surface-water and groundwater flow systems, including fault characteristics and skin factors for multi-aquifer wells. The dominant sources of inflow to the groundwater system are surface-water infiltration and recharge from irrigated agriculture. The dominant sources of outflow from the groundwater system are pumpage, ET, and surfacewater flows.

The number of adjustable parameters changed during calibration. A total of 354 parameters were initially created to facilitate model calibration; this number was reduced to 203 parameters after initial global sensitivity and calibration analysis. The number was further reduced to about 91 parameters determined to be relatively sensitive that were subsequently considered important and were included in the automated and trial-and-error calibration process, which finally reduced the number to 44 adjustable parameters. These parameters included landscape and land-use related properties, hydraulic parameters of aquifers and multi-node wells, fault conductances (table 14), diversion fractional splits, and streambed conductivities (table 15). Hydraulic properties were initially assigned values based on previous modeling studies, then adjusted during model calibration. Model parameters were adjusted within ranges of reasonable values to closely fit historical hydrologic conditions observed in the groundwater, surface-water network, and landscape.

Calibration was started by refining the landscape processes, followed by adjustment of hydraulic properties, streambed properties, multi-aquifer well properties, generalhead boundary conductances, and fault conductances. Because many of these properties are head-dependent or were correlated through exchange of water (flow-dependent), parameters controlling each set of processes were adjusted recursively through automated and trial-and-error analysis. The calibration process also required modifications to the parameter framework. For example, parameters and observations for the stream network were further partitioned, and the CIR scale factors were included for improved consumptive-use and related agricultural pumpage estimates. Parameters that were determined to be meaningfully sensitive were adjusted during calibration. 
Table 15. Summary of surface-water channel conductivity and the "Streamflow Routing" package diversion parameters and final values, in the Rio Grande Transboundary Integrated Hydrologic Model, Transboundary Rio Grande, New Mexico, Texas, and Mexico.

[ft/day, foot per day]

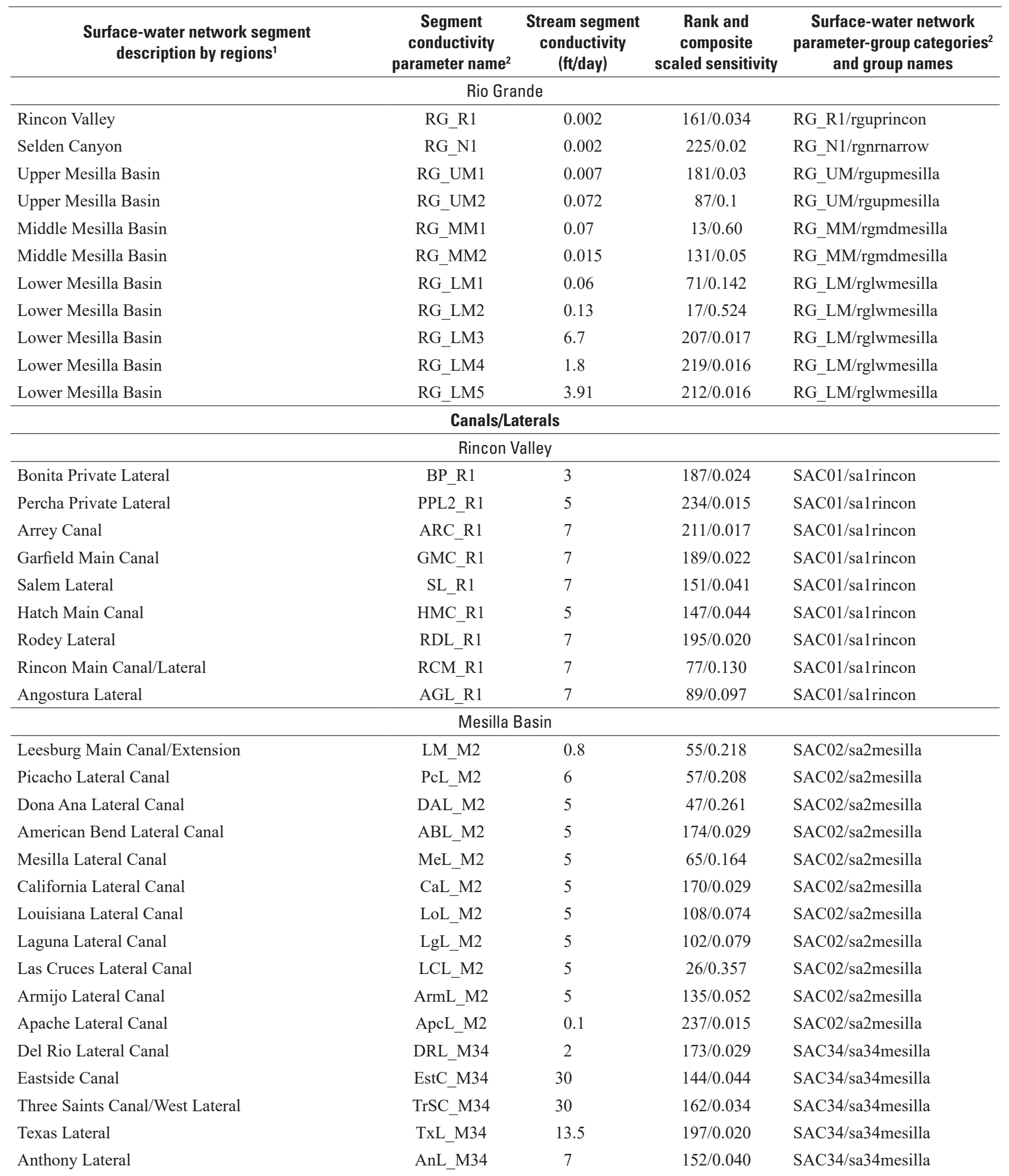


Table 15. Summary of surface-water channel conductivity and the "Streamflow Routing" package diversion parameters and final values, in the Rio Grande Transboundary Integrated Hydrologic Model, Transboundary Rio Grande, New Mexico, Texas, and Mexico.-Continued

[ft/day, foot per day]

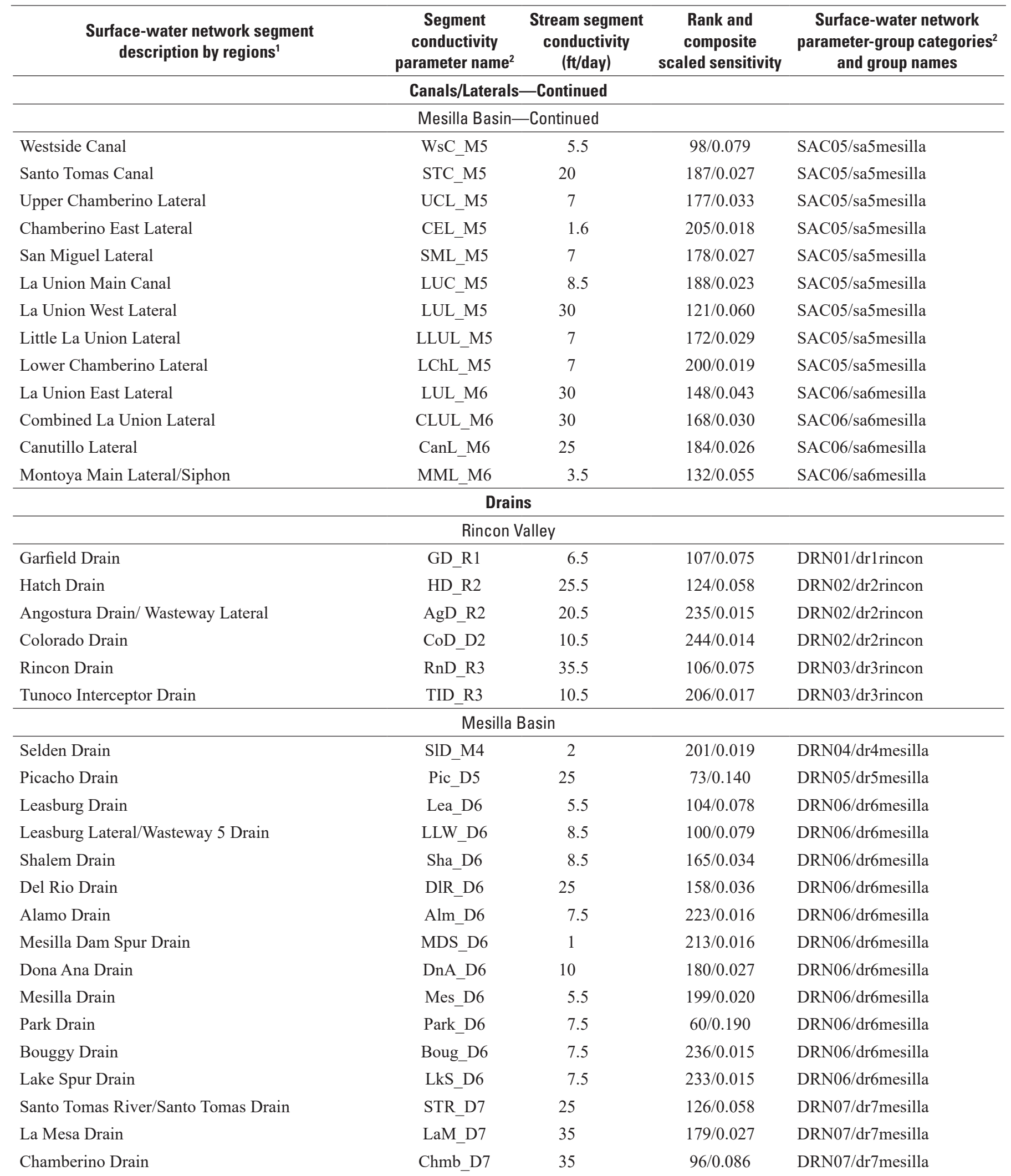


Table 15. Summary of surface-water channel conductivity and the "Streamflow Routing" package diversion parameters and final values, in the Rio Grande Transboundary Integrated Hydrologic Model, Transboundary Rio Grande, New Mexico, Texas, and Mexico.-Continued

[ft/day, foot per day]

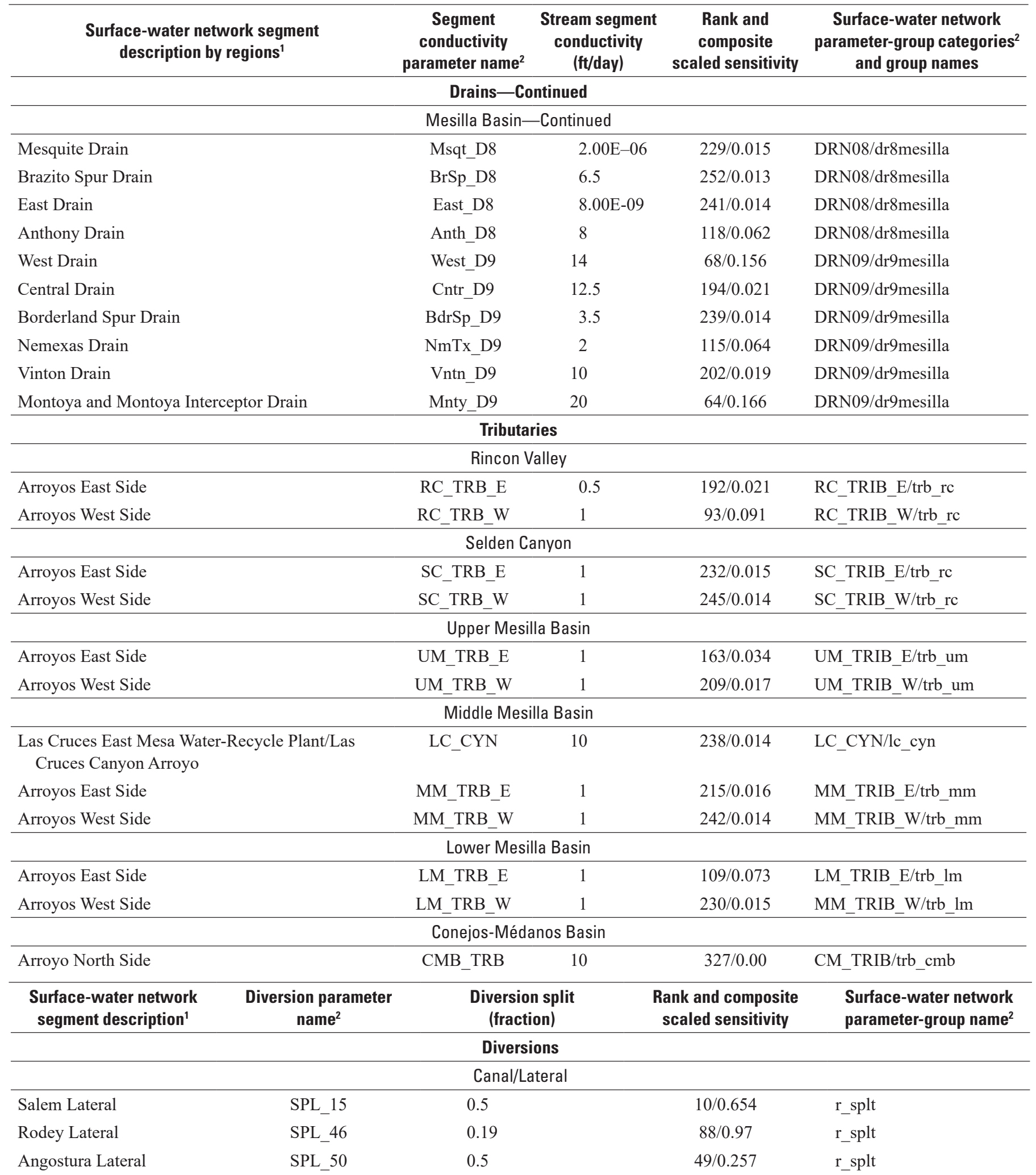


Table 15. Summary of surface-water channel conductivity and the "Streamflow Routing" package diversion parameters and final values, in the Rio Grande Transboundary Integrated Hydrologic Model, Transboundary Rio Grande, New Mexico, Texas, and Mexico.-Continued

[ft/day, foot per day]

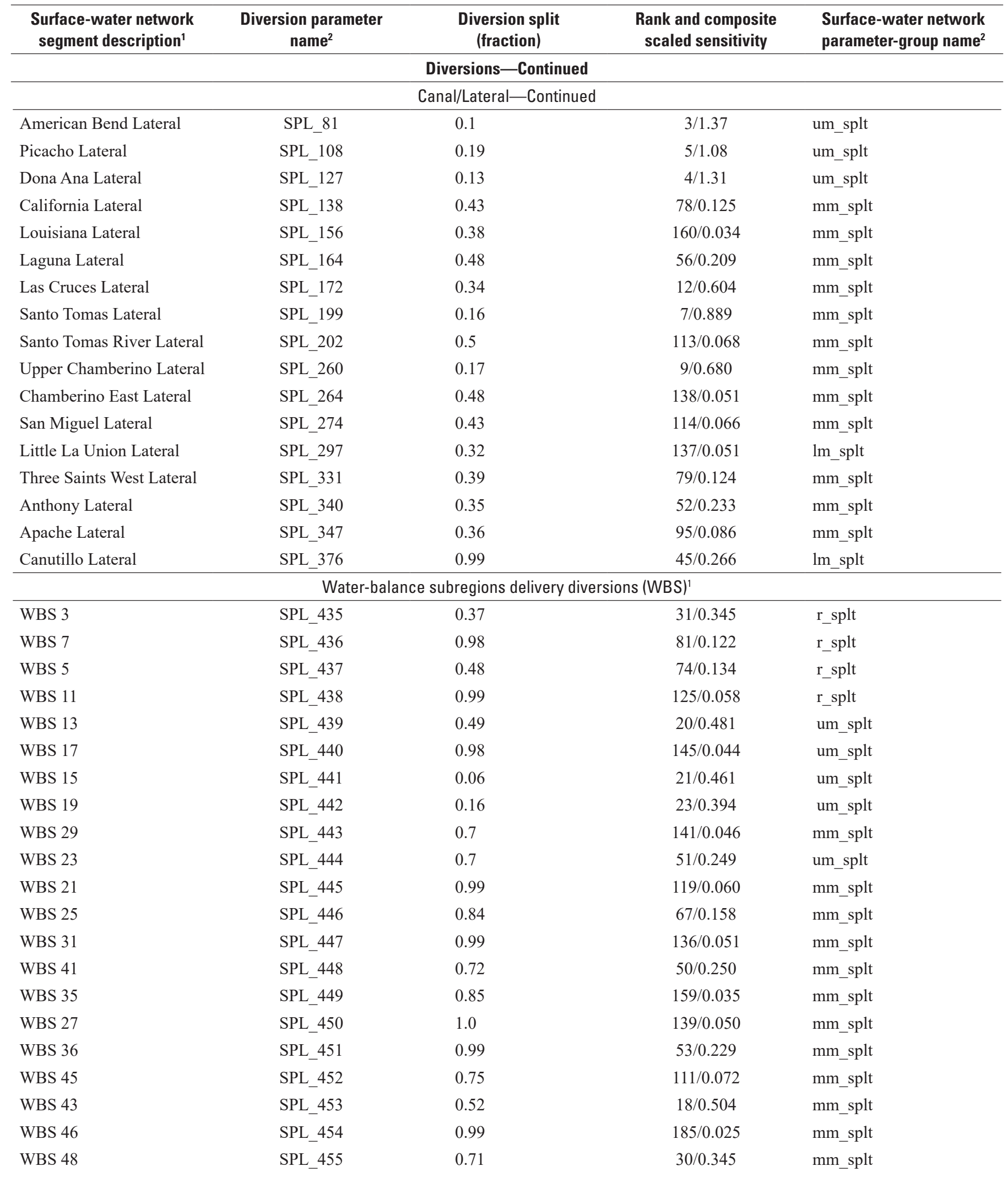


Table 15. Summary of surface-water channel conductivity and the "Streamflow Routing" package diversion parameters and final values, in the Rio Grande Transboundary Integrated Hydrologic Model, Transboundary Rio Grande, New Mexico, Texas, and Mexico.-Continued

[ft/day, foot per day]

\begin{tabular}{|c|c|c|c|c|}
\hline $\begin{array}{l}\text { Surface-water network } \\
\text { segment description }{ }^{1}\end{array}$ & $\begin{array}{c}\text { Diversion parameter } \\
\text { name }^{2}\end{array}$ & $\begin{array}{l}\text { Diversion split } \\
\text { (fraction) }\end{array}$ & $\begin{array}{l}\text { Rank and composite } \\
\text { scaled sensitivity }\end{array}$ & $\begin{array}{l}\text { Surface-water network } \\
\text { parameter-group name }\end{array}$ \\
\hline \multicolumn{5}{|c|}{ Diversions-Continued } \\
\hline WBS 54 & SPL_456 & 0.76 & $61 / 0.186$ & mm_splt \\
\hline WBS 50 & SPL_457 & 0.6 & $75 / 0.132$ & lm_splt \\
\hline WBS 56 & SPL_460 & 0.81 & $133 / 0.054$ & mm_splt \\
\hline WBS 33 & SPL_461 & 0.99 & $85 / 0.104$ & lm_splt \\
\hline WBS 52 & SPL_462 & 0.98 & $186 / 0.025$ & mm_splt \\
\hline WBS 9 & SPL_463 & 0.95 & $116 / 0.063$ & lm_splt \\
\hline
\end{tabular}

${ }^{1}$ Refer to figure $2 A$ for distribution of Rio Grande Transboundary integrated hydrologic model (RGTIHM) hydrologic analysis subregions. Refer to figures $2 B$, $C$ and table 1 for distribution and summary of RGTIHM water-balance subregions,

${ }^{2}$ Refer to figure 8 for distribution of stream segments, diversion locations, and parameter distributions. Diversion splits occur at diversion points shown on figures $8 A, B$. The diversions at Del Rio Lateral (DRL_146) and La Union East Lateral (LUEL_287) were time-varying splits and were not parameterized. The diversions at Del Rio Lateral (DRL_146) and La Union East Lateral (LUEL_287) were time-varying splits and were not parameterized.

\section{Rio Grande Transboundary Integrated Hydrologic Model Parameters for Calibration}

\section{Landscape-Process Parameters}

Landscape-process parameters in the FMP that were adjusted during calibration included selected properties related to land use. Some parameters were fixed; some were adjusted manually; and some were adjusted using PEST. Tables 13-15 indicate which parameters were estimated during the calibration. These included climate-based seasonal-scale factors that were surrogates for variable demand that could represent processes such as irrigation stress or water stacking for seasonal CIR values, fractions defining the division of water at selected surface-water diversions used in previous models (LRG_2007, LRG_FMP_2011), or seasonal climatebased scale factors for irrigation efficiencies (OFE). The scale factors for seasonal CIR are used to represent the stress factors (Allen and others, 1998) that amplify or reduce the CIR estimates from the NMOSE. By analogy, when $\mathrm{K}_{\mathrm{c}}$ values are used to estimate CIR values, they are typically estimated under unstressed conditions and require adjustment for stressed conditions. Because it is not known if the NMOSE spreadsheet calculations of the CIR values accounted for stress related to irrigation, these surface-water release climate-based stress scale factors were implemented. The monthly estimates of the CIR values from the NMOSE used in this study were scaled according to a seasonal distribution of wet and dry seasons based on the river-based climate variability (fig. $6 B$ ). These wet and dry seasons were then scaled by factors that were multiplied with the CIR values to align estimated agricultural pumpage with reported annual pumpage in New Mexico and with the related groundwater-level declines. These adjustments ranged from increases of about 17-39 percent during wet winter, spring, and fall in the early years. Wet summers for early years required a 52 percent reduction in CIR. For the early-year dry years, required increases in seasonal CIR values were 6 percent for summer to 48 percent for spring, 38 percent for winter, and 33 percent for fall. For the recent years, wet-season increases for winters and spring were 21 and 13 percent, respectively, whereas the summer CIR was reduced by 20 percent. The seasonal CIR scale factors for dry years of the recent years were decreased by 19 and 4 percent for winter and spring, respectively (table 14). The recent-year dry seasonal CIR values were increased for the summer and fall by 32 and 16 percent, respectively. The most-recent dryyear seasonal CIR values were decreased for winter and spring by 21 and 6 percent and increased by 30 and 14 percent for summer and fall seasons, respectively. 
Irrigation efficiencies were specified at a constant background value of 70 percent (table 12) and were adjusted during calibration for precipitation-based months for wet- and dry- seasons (fig. $6 E$ ). These wet- and dry-year seasons were then scaled according to the estimated relative variation in the estimated NMOSE pumpage for the groundwater-only regions and varied during model calibration. Based on these relative changes in pumpage for the years prior to 2003, wetyear spring and summer seasons were adjusted to decrease efficiency by increasing pumpage from 3.5 to 5.4 percent, but dry-year spring and summer efficiency increased and decreased pumpage from 2.7 to 4.9 percent. Conversely, wet winter and fall seasons were relatively more efficient by 17.4 and 1.8 percent, respectively, and dry-year winter and fall seasons were relatively less efficient with according decreases of 8.2 and 1.7 percent, respectively, for the years prior to 2003 . This resulted in a range of efficiencies from 82 percent for wet winter seasons to about 66-68 percent for wet spring and summers. Conversely dry winters were estimated to have a lower efficiency of about 64 percent, and efficiencies of about 72-73 percent for dry spring and summer seasons (tables 12 , 14). For the more recent years, 2003-14 the irrigation efficiencies were scaled differently during calibration, with increases of 1.4 and 0.2 percent in wet winters and summers, respectively, and decreases of 16 and 49 percent for wet spring and fall respectively. For these recent years in dry seasons there was additional decrease of efficiency of 2.4, 0.3 , and 25 percent in winter, summer, and fall, respectively, and an increase of 9.6 percent in dry springs. This resulted in efficiencies for these more recent years ranging from 77 percent for dry springs to 36 percent for wet fall seasons. This could indicate irrigation was generally less efficient during the wetter spring and summer seasons and especially for fall seasons of the more recent years. Inefficient losses from irrigation are a direct control on the water available for deep percolation and an indirect control of irrigation return flows captured by peripheral drain canals used to control the water table. The fractions of inefficient losses to runoff from irrigation were set to 7 percent, based on the estimated wastage of water delivery (Terracon Consultants, Inc., 2003), but could be more with direct runoff to drains of tailwater in the RGTIHM; the percentage of surface-water return flow was not an adjustable parameter.

The fractions of transpiration (FTR), which represent the fractions of the model cells that are canopy and control the transpiration part of consumption, were also scaled based on precipitation-based wet- and dry-year seasons (fig. $6 E$ ). These scale factors were based on the relative variation in the annual NMOSE CIR values for 1953-2010. Relative to the average value, these CIR values increased in wet years by about 7 percent and decreased in dry years by about 8 percent. These variations were reduced to increases and decreases of 5 percent so not to exceed a value of 1 when multiplied by the seasonal FTR values (table 11).

\section{Hydraulic Parameters}

The RGTIHM was calibrated to determine the values of hydraulic properties in each hydrostratigraphic zone of each model layer. Parameters include the values of horizontal and vertical hydraulic conductivity, specific yield, and specific storage for each facies zone in each model layer. Defining these three parameters for each of the 38 textural zones (Sweetkind, 2017) yields 114 parameter values for the horizontal and vertical hydraulic conductivities and the multipliers for storage properties (figs. 21A-E). An additional group of 18 parameters for specific storage, porosities, and specific yields were included through the use of the MULT package, which was used to build the skeletal specific-storage values and the horizontal and vertical values of hydraulic conductivity $\left(\mathrm{K}_{\mathrm{h}}\right.$ and $\mathrm{K}_{\mathrm{v}}$. The compressibility of water was specified as a component of the storage properties proportional to the porosity, was held constant, and was not a parameter.

The calibration of hydraulic properties required the adjustment of $\mathrm{K}_{\mathrm{h}}$ and $\mathrm{K}_{\mathrm{v}}$ and a rescaling of specific yield and specific storage based on observations of groundwater-level hydrographs and vertical head differences. Some of the most sensitive hydraulic parameters were some of the horizontal and vertical hydraulic conductivities, which, in part, controlled the seasonal amplitudes and vertical water-level differences between aquifer layers. Reductions in vertical hydraulic conductivity and storage properties improved calibration of some confined zones, and scaled increases in these properties did so for certain unconfined zones. Horizontal hydraulic conductivities (represented by the hydraulic conductivity of the subregional facies) were increased during model calibration in many of the aquifer layers (table 14). Because RGTIHM was relatively less sensitive to values of porosity and specific storage, these were not included in the automated parameter estimation and remained fixed values or were manually adjusted. 


\section{Surface-Water Network Parameters}

The RGTIHM used the "Streamflow Routing" package (Niswonger and Prudic, 2005; Boyce and others, 2020) for simulation of the surface-water network. This network required calibration of the channel vertical hydraulic conductivity parameters and the splits (fractions of flow for diversion) of selected water-supply diversions. For the surfacewater network infrastructure, all channel-geometry parameters were held constant, and the only adjustable parameter was the vertical hydraulic conductivity of the bed material. This conductivity controls the leakage rate to or from a surfacewater feature, which in turn, controls artificial recharge, shallow groundwater heads, canal and river leakage, drain return flows, and conveyance of water through the network. Stream, canal, drain, and arroyo segments were combined in 93 groups with similar channel properties, resulting in 93 adjustable parameters for streambed hydraulic conductivity (figs. $8 A, B$; table 15). These were additionally grouped into 11 parameter groups for the Rio Grande streambed (fig. $8 C$ ), 12 tributary groups, 44 canal groups, and 26 drain groups.

The natural stream channels were combined into groups representing the Rio Grande and its tributaries. This resulted in one group of segments each for the Rincon Valley and Selden Canyon, multiple groups of segments that span the Mesilla Basin, and an additional segment downstream from the International Dam. The parameter grouping of segments for the Mesilla Basin was based on the general distributions of gains and losses estimated from the seepage runs. Because there were winter seepage runs (1988-2014) to estimate the gains and losses along the Rio Grande channel in the Mesilla Basin when the RGP was not in operation, the parameterization of the Rio Grande streambed was subdivided into two parameter groups in the Upper and Middle Mesilla and five parameter groups in the Lower Mesilla (fig. 8C). Additional observations were used from downstream gages, and selected differences between streamflow gages, interpreted as gains and losses on rivers, were also available to help calibrate streambed conductivities. In the final distribution of parameter groups for streambed and canal vertical hydraulic conductivities, the calibrated values ranged from $0.002 \mathrm{ft} / \mathrm{d}$ in the Rincon Valley and Selden Canyon region of the Rio Grande, and between the gages at Vinton Bridge and Sunland Park Bridge, to as much as $35.5 \mathrm{ft} / \mathrm{d}$ along some drainage canals (fig. 8; table 15). These values are comparable to the calibrated values for the Hueco Bolson groundwater model that averaged $5.9 \mathrm{ft} / \mathrm{d}$ ranging from 5.2 to $6.7 \mathrm{ft} / \mathrm{d}$ for the Rio Grande channel, averaged $19 \mathrm{ft} / \mathrm{d}$ ranging from 6.7 to $52.3 \mathrm{ft} / \mathrm{d}$ for the agricultural drains, and averaged $9.8 \mathrm{ft} / \mathrm{d}$ for irrigation canals (Heywood and Yager, 2003, table 3).

The diversion splits were also parameterized to better estimate the distribution and delivery of surface water for irrigation. There were 50 fractions of diversions used with the supply canals, and were adjusted manually. These fractional splits represent the portion of water eligible for diversion flows and ranged from values of 0.1 to 0.99 (table 15).

\section{Multiple-Aquifer Well Parameters}

The simulation of pumpage from wells screened across multiple aquifers (multi-aquifer wells) are simulated in the RGTIHM using the MNW2 package (Konikow and others, 2009; Boyce and others, 2020). The MNW package allows the simulation of two processes: the extraction of water from multiple aquifers during pumping and the potential for vertical flow of water between aquifers through the well bores screened across multiple aquifer layers when aquifers are at different heads. Although the flow rate from each aquifer depends on aquifer properties, including hydraulic head, this flow rate is restricted by flow through the well screen and the narrow zone of formation damage that was created during the well-drilling process. This zone of restriction is collectively known as the skin, and the hydraulic conductivity of the skin is selected as the only adjustable parameter for multi-aquifer wells. The skin factor affects the interlayer flow that occurs as wellbore flow and related vertical water-level difference between model layers. Eight skin factors were used as parameters to control the retardation of wellbore flow within all layers screened for all multi-aquifer wells in the United States part of RGTIHM (table 14). Wells were assigned skinfactor parameters based on whether they are wells constructed before 1960 (old) or after 1960 (new) and have casing diameters less than or equal to 10 inches (small) or casing diameters greater than 10 inches (large). This resulted in four parameter groups for wells in New Mexico and four groups for wells in Texas. The calibrated values of these parameters were relatively large, as was needed to maintain the observed vertical head differences and to control wellbore flow between layers. The final calibrated skin factors ranged from 7.0 square feet per day $\left(\mathrm{ft}^{2} / \mathrm{d}\right)$ to $4.0 \mathrm{ft}^{2} / \mathrm{d}$ for the older and newer, smalldiameter wells and $8.0-5.0 \mathrm{ft}^{2} / \mathrm{d}$ for the older and newer, largediameter wells in New Mexico and Texas (table 14). 


\section{Underflow Boundary Parameters}

The simulation of groundwater underflow to the TRG region from adjacent regions is simulated by the "GeneralHead Boundary" (GHB) package in the RGTIHM (Harbaugh, 2005; Boyce and others, 2020). The GHB conductance values that controlled lateral underflow of groundwater were manually adjusted during model calibration. The conductance factors in the GHB package, which simulated groundwater underflow, were specified in groups of cells and were tied to the hydraulic conductivity values of the GHB cells for each group of boundary cells (fig. 2). These conductances controlled the small inflows beneath Fillmore Pass and Rincon Arroyo, the outflow beneath the Rio Grande downstream from the El Paso narrows, and the inflows as underflow from the Conejos-Médanos Basin. The final conductances that control lateral inflow and outflow were adjusted to promote underflow from the southern boundaries. The GHB feature in MF-OWHM2 that allows the conductance to change through time and be proportional to the saturated thickness of the model cell and the model-cell lateral hydraulic conductivity also was used in all of these GHB lateral underflow cells. These conductances ranged from $8,750 \mathrm{ft}^{2} / \mathrm{d}$ beneath the Rio Grande south of El Paso narrows for outflow beneath the Rio Grande to values ranging from $2.6 \times 10^{4}$ to $1.4 \times 10^{4} \mathrm{ft}^{2} / \mathrm{d}$ along the southern boundary for inflow from the Conejos-Médanos Basin, Mexico. The conductances for the inflows were held at $135 \mathrm{ft}^{2} / \mathrm{d}$ for the Rincon Arroyo and Fillmore Pass regions (table 14). These conductance values restrict flow from the adjacent watersheds through the very narrow alluvial channel in the uppermost layer.

\section{Horizontal-Flow Barrier Parameters}

Barriers to horizontal groundwater flow in RGTIHM were represented using the HFB package across the faces of 34,932 model cells. The HFB cells were combined by faults and fault groups into nine parameter groups of interior faults and dikes that had the hydraulic characteristic of the horizontal-flow barriers specified as adjustable parameters. The characteristic values are used to rescale the face row and column conductance values between adjacent model cells that are coincident with the trace of the barrier. In addition, the faults were combined in groups, first based on the assigned age of faulting (youngest units faulted) and then grouped based on orientation of faulting (Sweetkind, 2017). Thus, the faults were grouped into those that cross-cut the pre-Santa $\mathrm{Fe}$, lower, middle, and upper members of the Santa Fe Group; the Selden Canyon cross-fault zone; and the volcanic dikes. Two sets of orientations were used to combine faults with north-south and with northwest and northeast trends. These different orientations were interpreted to be related to different types of deformation and faulting; the north-south faults are related to rifting, which is associated with relatively low permeability. Based on their tectonic setting, the north-south trending faults were assumed to be more of a barrier and had the characteristically lower values. The Selden Canyon fault zone, pre-Santa $\mathrm{Fe}$, and the volcanic dikes (fig. $3 B$ ) were all specified as separate parameters at the lowest characteristic values. Computer-assisted and manual calibration confirmed relatively low parameter values (table 14). Fault conductance values were initially model-estimated parameters, but ultimately were specified at low values, which were held constant for final calibration. These low conductance values were consistent with the discontinuities in the water levels in selected wells in the Conejos-Médanos Basin and with the concept of subregions having limited groundwater flow between them. For example, the Selden Canyon fault zone, the Fitzgerald, Transboundary, Mesilla Basin fault zone, and Mastadon fault appear to separate the Mesilla Basin into a sequence of subbasins and uplifts. The final calibrated conductance values for the modeled faults are summarized in table 14.

\section{Reservoir Parameters}

The simulation of relatively small amounts of leakage underneath the earthen dam of Caballo Reservoir was simulated using the "Reservoir" package. The leakage is controlled by varying stage of the reservoir and the vertical hydraulic conductivity of the reservoir bottom, which leaks vertically through the upper member of the Santa Fe Group and contributes to lateral groundwater flow downstream from the dam (table 14). Specified vertical hydraulic conductivity of the reservoir bottom was the only adjustable parameter, and the final calibrated value was $7.0 \times 10^{-3} \mathrm{ft} / \mathrm{d}$; this value resulted in an average of about 2.4 cubic feet per second $\left(\mathrm{ft}^{3} / \mathrm{s}\right)$ of leakage simulated by the RGTIHM over the period 1953-2014, which is comparable in magnitude to 7-day January low-flow gaged flows downstream from the reservoir of about $4.7 \mathrm{ft}^{3} / \mathrm{s}$. 


\section{Rio Grande Transboundary Integrated Hydrologic Model Observations and Results}

The ability of the RGTIHM to simulate the hydrologic system accurately was evaluated on the basis of comparisons to selected hydrologic observations, hydrologic timeseries data, and groundwater-level maps. A total of 82,224 observations from groundwater, surface water, and reported agricultural pumpage along with several groundwater contour maps from recent conditions were used in the calibration process. These comparisons were used to assess the capacity of the RGTIHM to simulate the effects of changing inflows and outflows on the hydrologic system, based on reasonable estimates of hydraulic, surface-water, and landscape properties to simulate surface-water flows, pumpage, recharge, and changes in groundwater storage. Model calibration was primarily based on comparisons of simulation results to spatially and temporally distributed observations of groundwater and surface-water conditions from the RGTIHM region and to selected annual agricultural groundwater pumpage estimates from New Mexico. This section describes the comparisons of measured and reported observations to simulated observations and also describes the model calibration results related to these comparisons and model parameters.

The importance of a parameter is also related to the observation weights. Observation weights are used for a variety of purposes, including accounting for differences in measurement units and quantification of measurement error, and these weights are sometimes used to help distribute the importance of observations among the many different types of observations (for example, to remove the effects of spatial or temporal clustering of measurements or to emphasize areas where a model can be used to simulate future conditions). For the RGTIHM, selected observations in the stream network were given relatively more importance to balance the fit of the drain flows to the fit of pumpage and groundwater levels. However, because the majority of the observations were groundwater levels, they still dominated the overall assessment of model fit and residual errors.

Simulated changes in groundwater levels, temporal changes in groundwater levels (drawdowns), and groundwaterlevel differences (vertical interlayer head differences) were compared to those measured in monitoring wells as part of the USGS Mesilla Basin Observation Well Network (MBOWN), those measured in the Mexican part of the RGTIHM active area (International Boundary and Water Commission, 2011), and measurements from additional wells that were not previously included with these two groups or in the previous calibration (S.S. Papadopulos and Associates, Inc., 2007). This resulted in 59,130 groundwater observations from 462 wells, a large increase in the quantity of data used for calibration of this model compared to the 2,024 observations used for the previous models.

Simulated surface-water flows in the Rio Grande, canals, laterals, and drains and streamflow-differences between gages were compared to those measured by various agencies; the previous models did not formally include these observations in the calibration and observation processes. The RGTIHM used 18,724 surface-water observations, including river flows, flow differences between selected streamgages, and seepagerun gains and losses. Surface-water observations also included selected canal flows and diversions as surface-water deliveries for irrigation represented by each WBS estimated surfacewater allotment constraint.

Estimates of agricultural groundwater pumpage in New Mexico were also used as observations. Reported annual values for 14 selected years spanning 1975-2014 were obtained from the NMOSE, and these were used to compare to annual agricultural pumpage simulated by the RGTIHM for New Mexico. Additional seasonal values from the NMOSE of estimated pumpage for the WBSs that use only groundwater for irrigation added 232 observations for 1953-2010. Although digital monthly values of reported well-by-well metered pumpage in New Mexico for 2009-14 have been compiled by the NMOSE, these data were not available to use as observations for calibration of this version of the RGTIHM.

Calibration adjustments were based on the combined fit of simulated values to the available groundwater, surfacewater, and pumpage observations (figs. 22, 23, 26, 27). The simulated values were compared to all observed values. The results of these comparisons provided a measure of model performance through various historical time intervals and TRG subregions. The resulting error distributions constrained the RGTIHM parameters, and the comparison between simulated and observed values provided a basis for sensitivity analysis of selected parameters. In addition, groundwater-level maps were used for qualitative comparisons. These maps were considered less reliable than time-series data, however, because the composite water-level measurements and manually drawn contour lines represented various combinations of depth and time-averaged conditions.

The RGTIHM model achieved a cumulative massbalance discrepancy of 0.11 percent. No individual flow mass-balance errors for any cell within any time step exceeded 5 percent of the flow in or out of any active cell. Numerical convergence was achieved for all time steps for the entire simulation period. Generally, models with cumulative massbalance discrepancies of less than 0.5 percent are considered acceptable (Reilly and Harbaugh, 2004). Owing to the complexity of this integrated hydrologic flow model and relatively large temporal changes in flows, the mass balance and convergence performance are considered adequate. 
$\boldsymbol{A}$

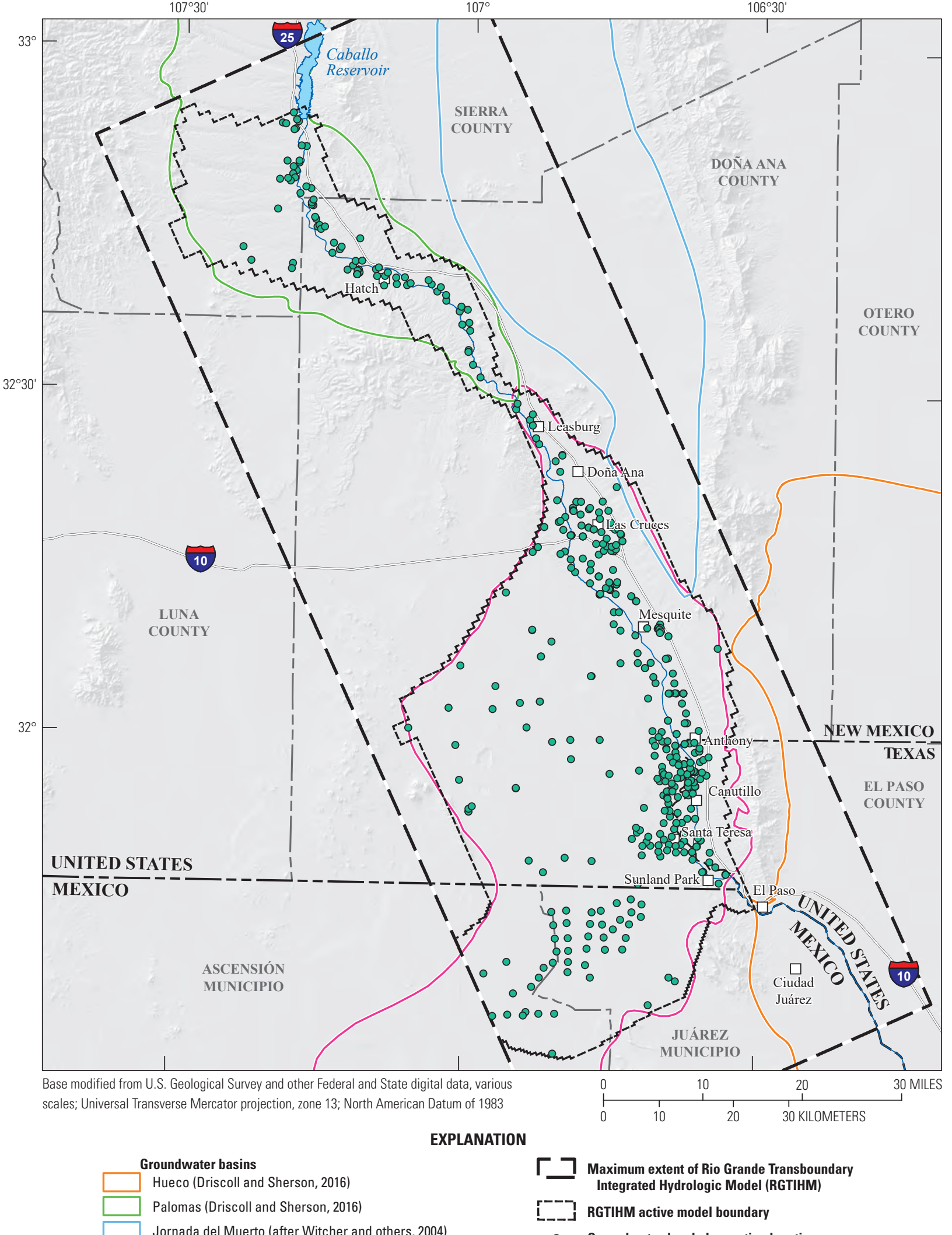

Mesilla and Conejos-Médanos (after Sheng and others, 2013)

○ Groundwater-level observation location

Figure 22. Calibration data sites for the Rio Grande Transboundary Integrated Hydrologic Model, Transboundary Rio Grande, New Mexico, Texas, and Mexico, of $A$, wells for groundwater levels; and $B$, groundwater-level vertical differences. 
B

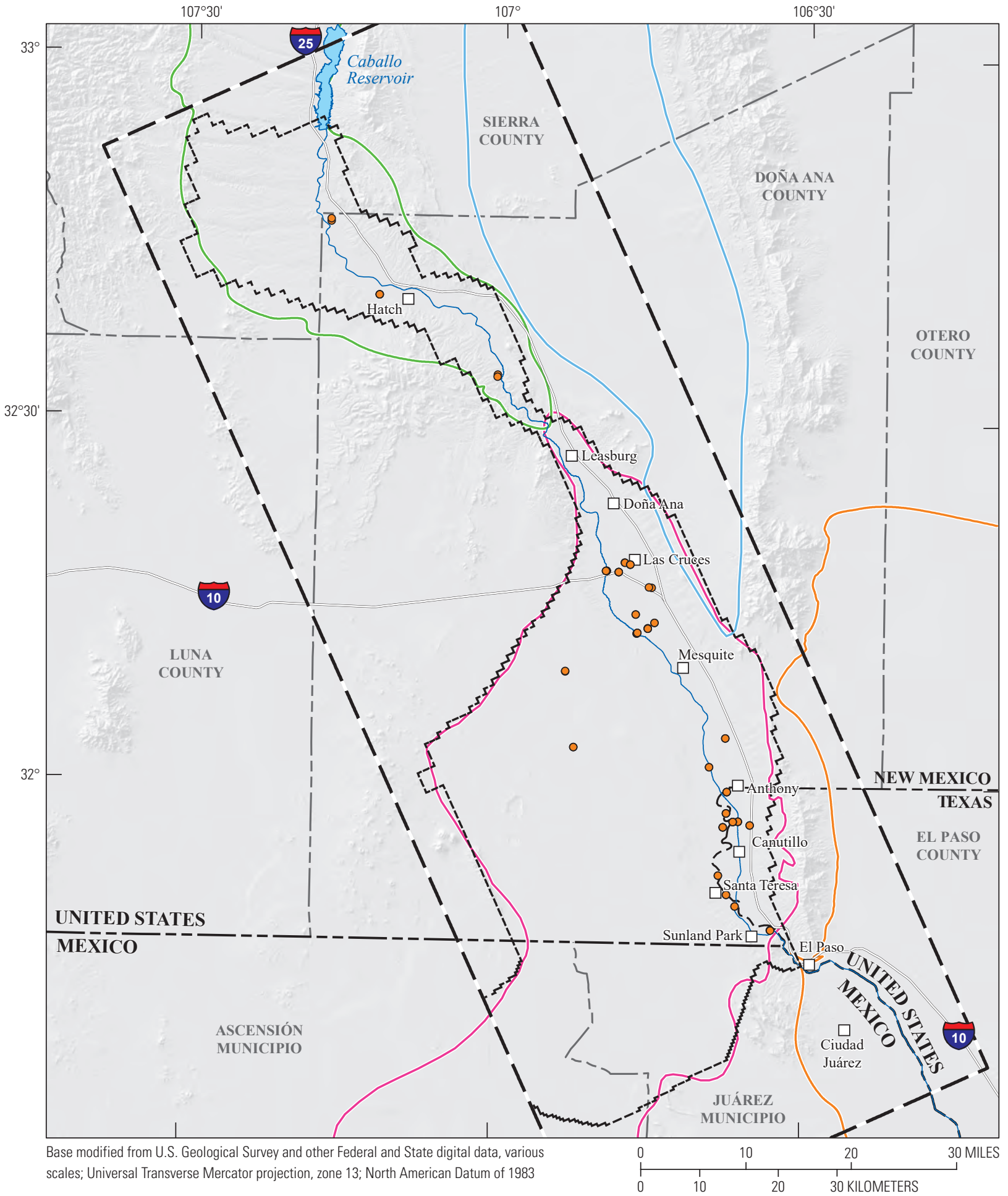

EXPLANATION

Groundwater basins

Hueco (Driscoll and Sherson, 2016)

Palomas (Driscoll and Sherson, 2016)

Jornada del Muerto (after Witcher and others, 2004)

Mesilla and Conejos-Médanos (after Sheng and others, 2013) $\lceil$ Maximum extent of Rio Grande Transboundary Integrated Hydrologic Model (RGTIHM)

\section{[-_-_ RGTIHM active model boundary}

- Groundwater-level vertical-head difference observation location

Figure 22. -Continued 
$\boldsymbol{A}$
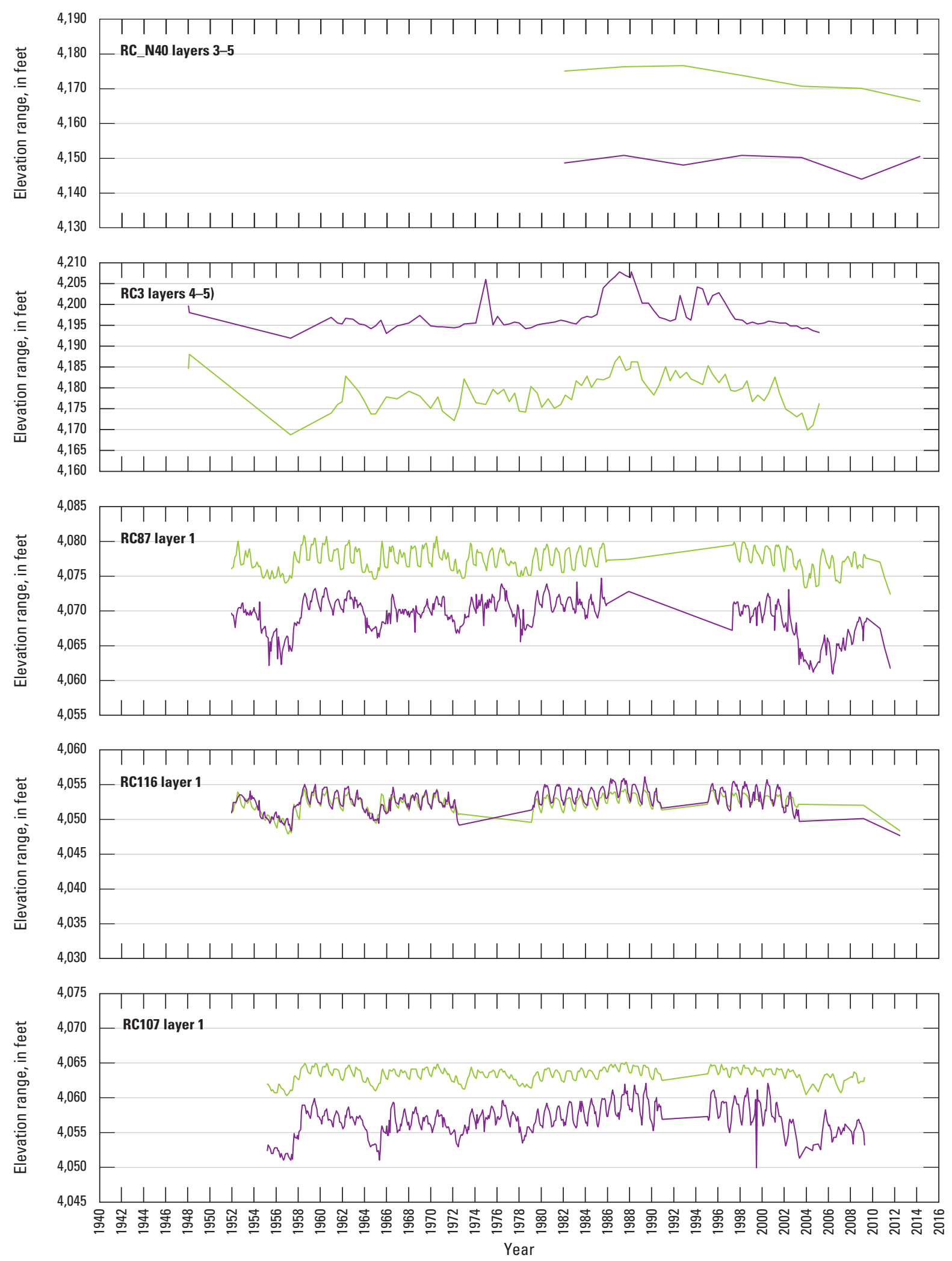

EXPLANATION

Observed groundwater levels

Simulated groundwater levels

Figure 23. Simulated and measured groundwater-level hydrographs for selected wells in the Transboundary Rio Grande, New Mexico, Texas, and Mexico, for $A$, Rincon Valley; $B$, Upper Mesilla Basin; $C$, Middle Mesilla Basin; $D$, Lower Mesilla Basin; E, Conejos-Médanos Basin; and $F$, selected vertical water-level differences. 


\section{B}
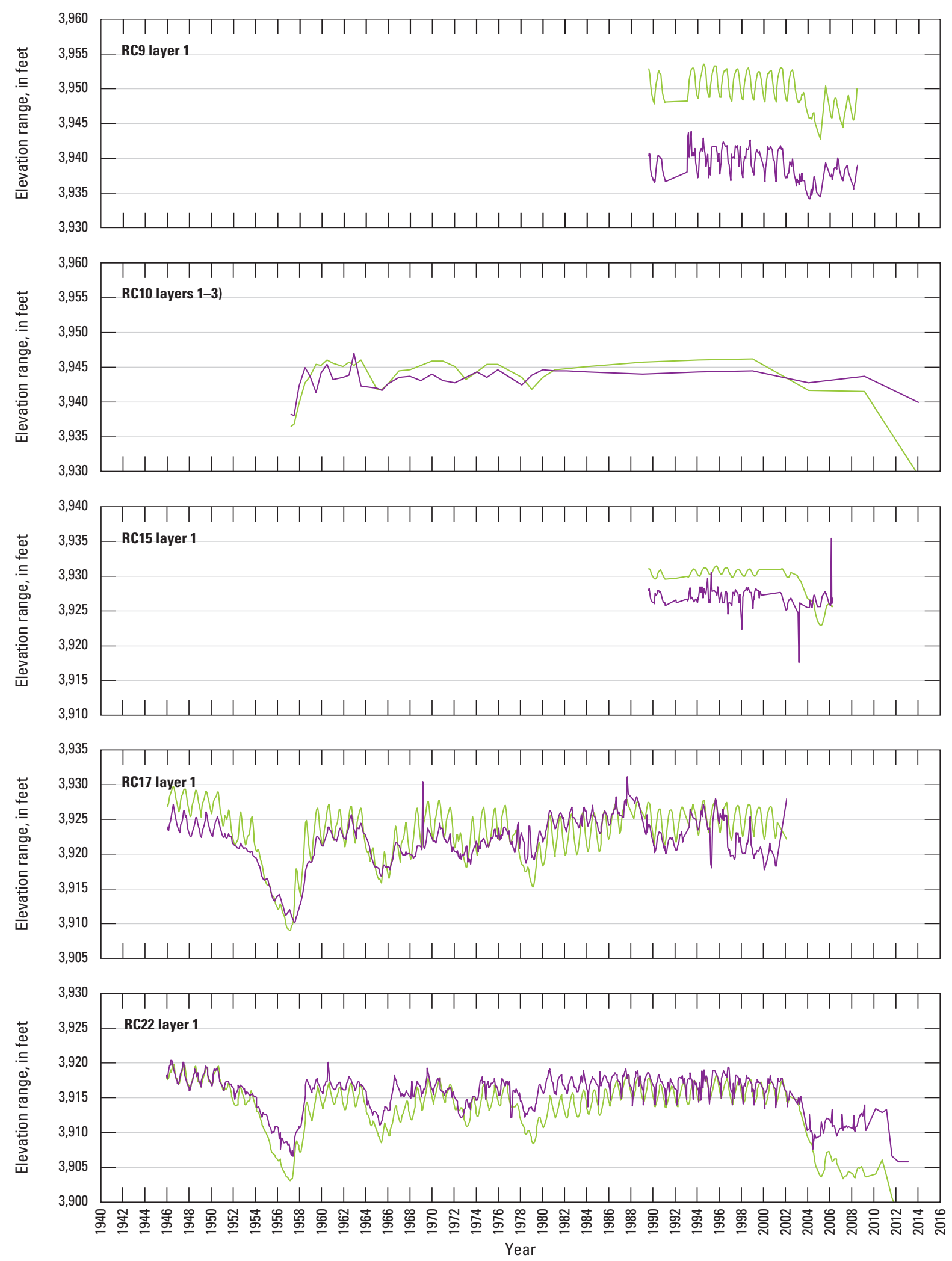
EXPLANATION

Observed groundwater levels $\longrightarrow$ Simulated groundwater levels

Figure 23. - Continued 


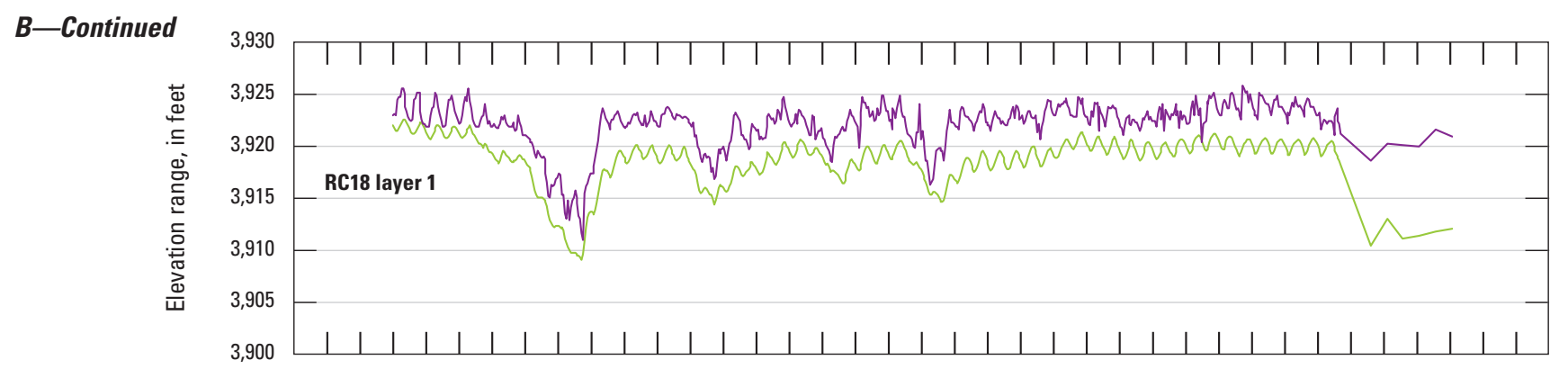

$c$
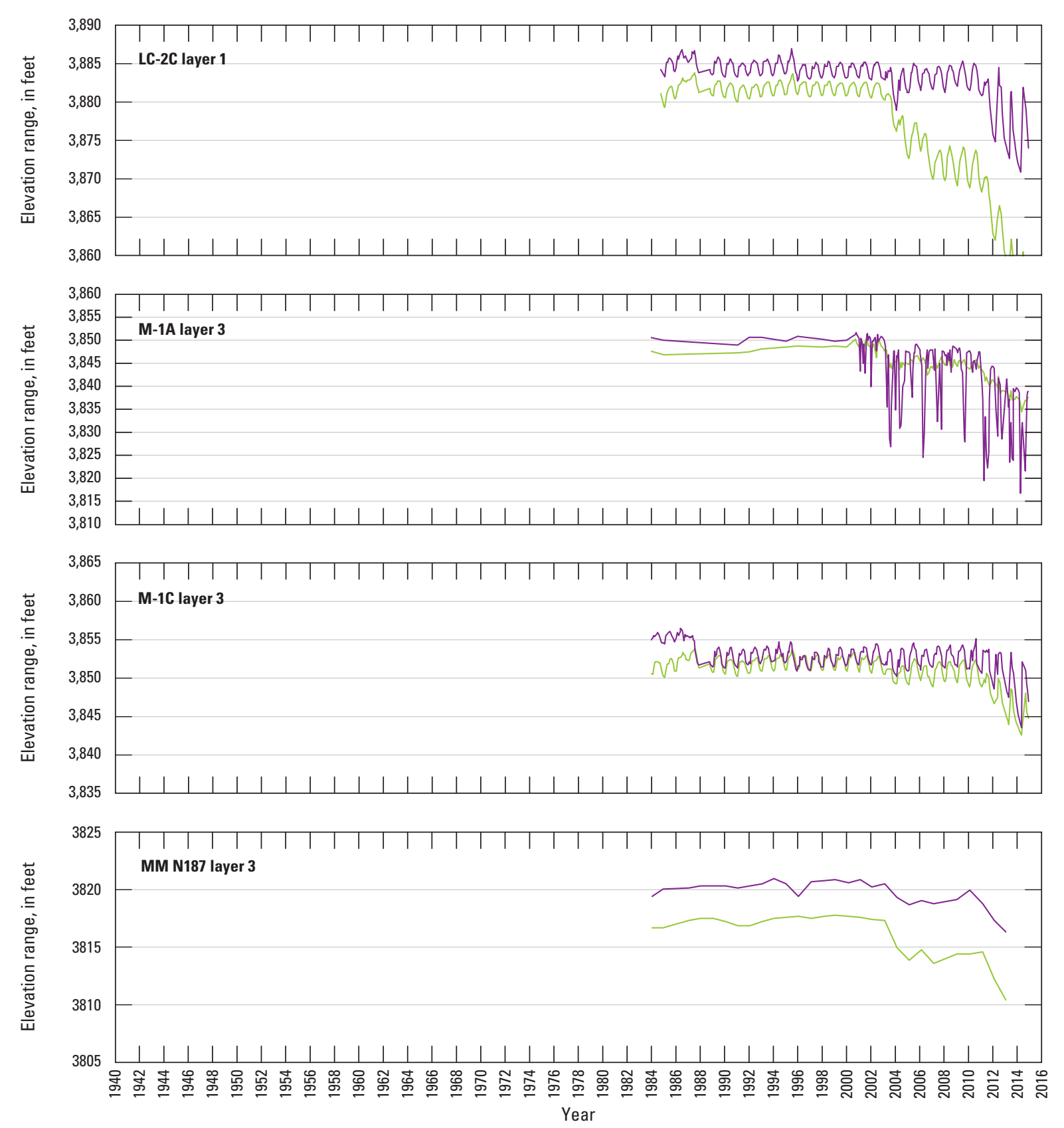
EXPLANATION

Observed groundwater levels $\longrightarrow$ Simulated groundwater levels

Figure 23. - Continued 


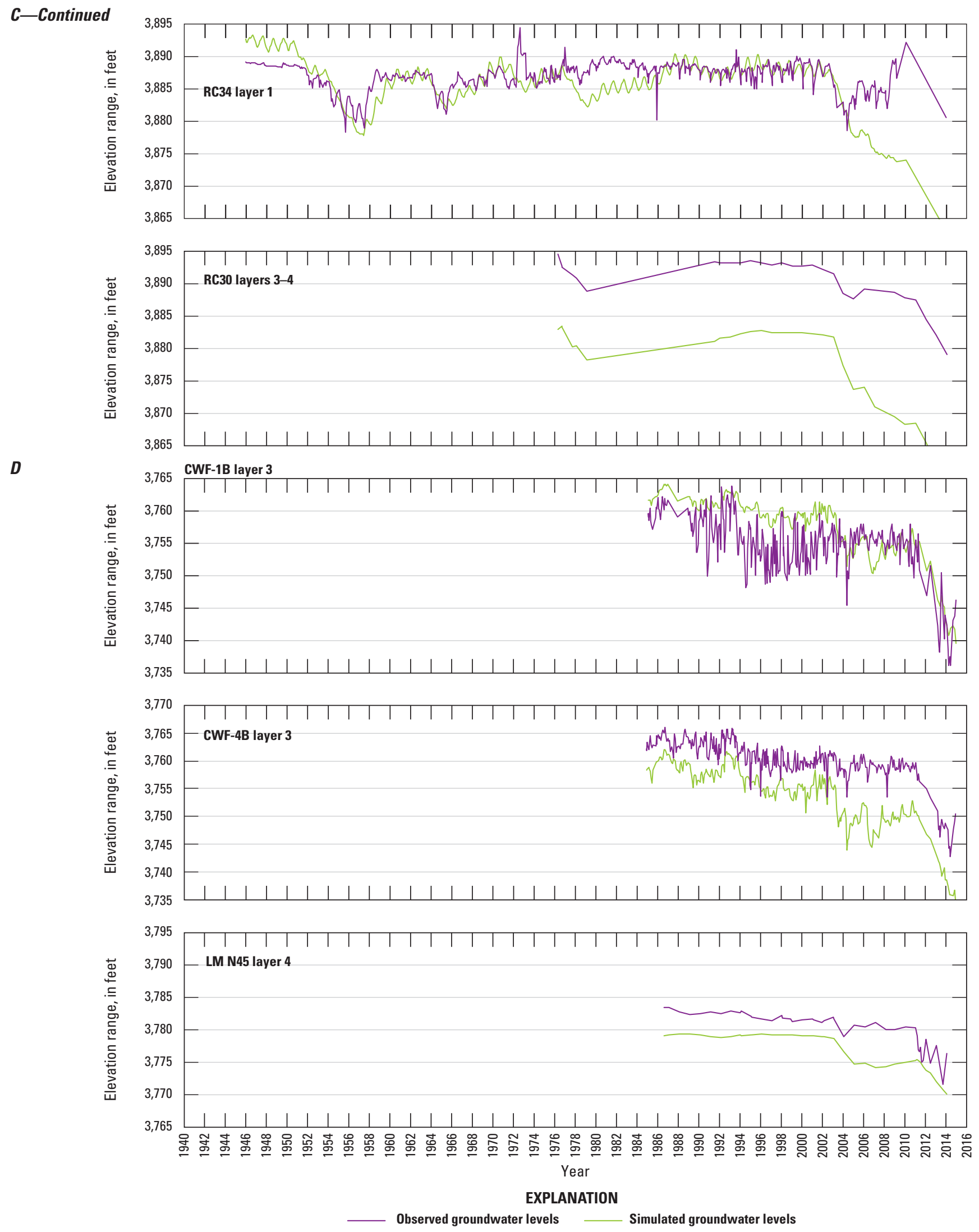

Figure 23. - Continued 


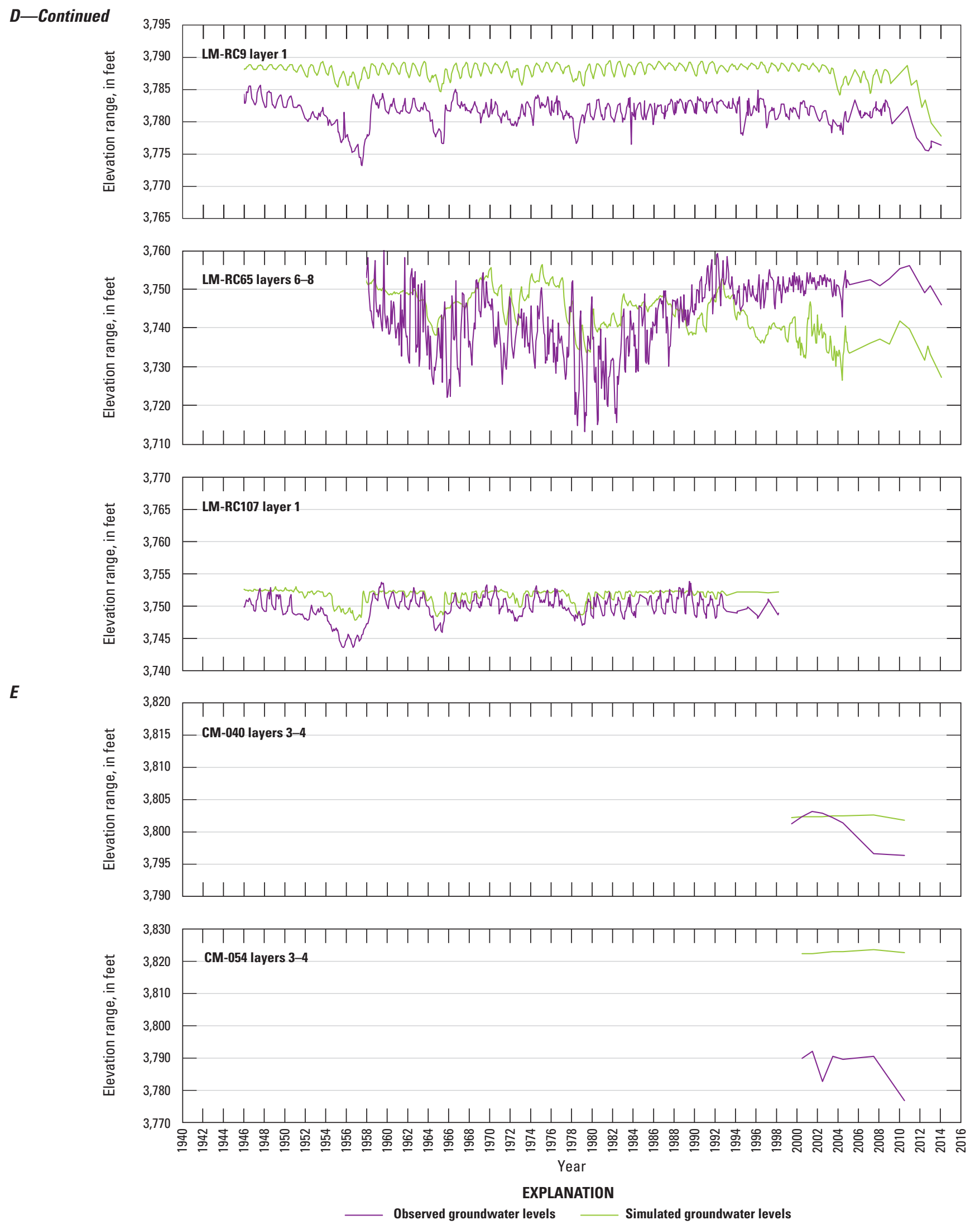

Figure 23. - Continued 

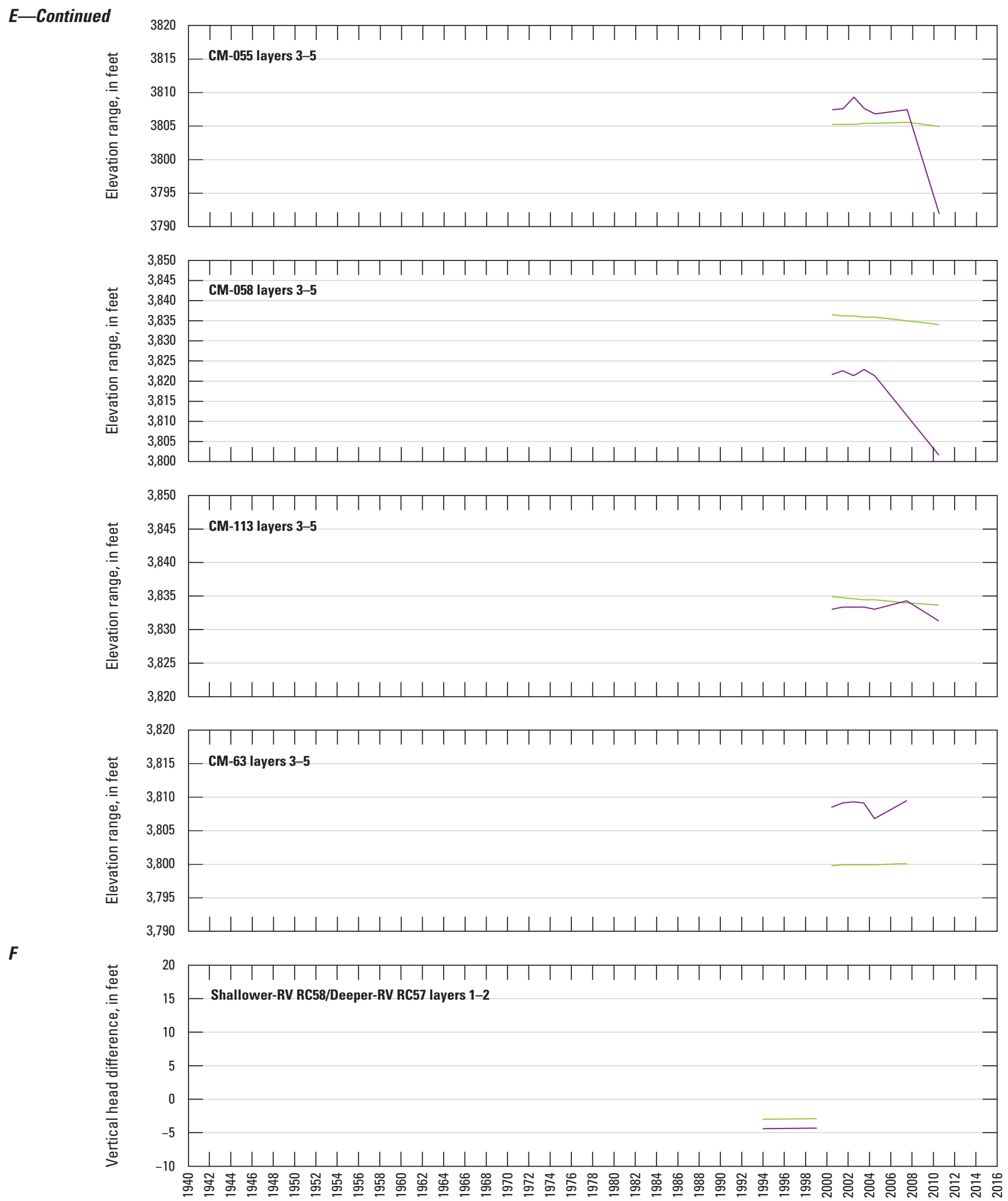

Figure 23. - Continued 

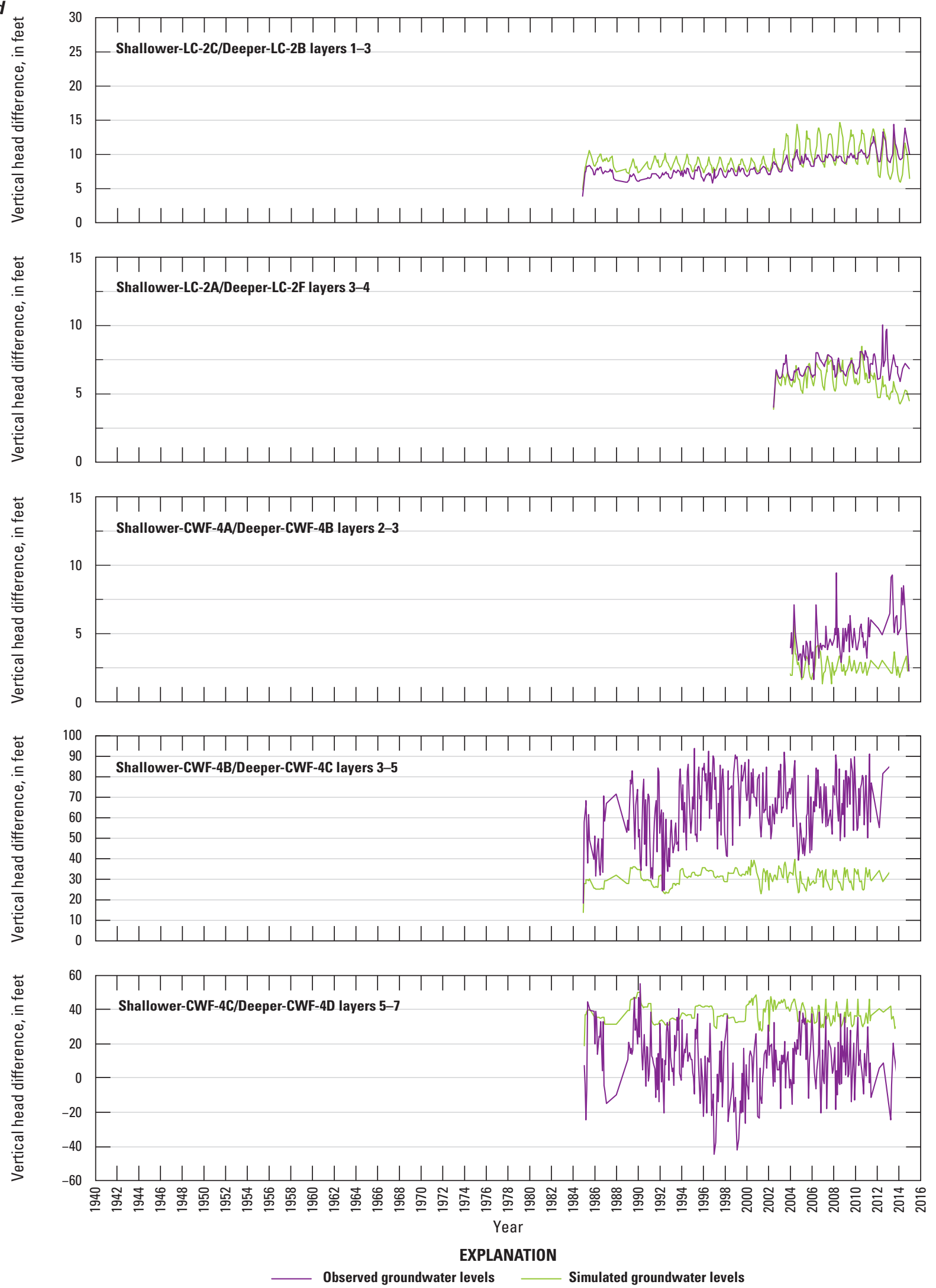

Figure 23. - Continued 
The overall correlation between observed and simulated values for the calibrated model was 93.9 percent. Correlations above about 90 percent are generally considered a good fit (Hill and Tiedeman, 2007). Although the RGTIHM was calibrated to available observations, model uncertainty remains because of the inherent uncertainty in some model properties and because selected observations and inputs were not available to further constrain or delineate landscape processes. In addition, limitations are inherent in the necessary simplifications and assumptions needed to represent a complex hydrologic system in a numerical model, particularly so when it represents an integrated hydrologic flow system with conjunctive use of surface water and groundwater. These uncertainties and model limitations are discussed in more detail in the "Model Limitations, Uncertainty, and Potential Improvements" section.

\section{Groundwater Observations}

There is a history of groundwater development and irrigation in the study area. The groundwater system has been under stress since the 1920s (Petronis and others, 2006), but extensive development of the groundwater system did not begin in earnest until the drought of the early 1950s (S.S. Papadopulos and Associates, Inc., 2007). The combined effects of groundwater pumping for irrigation and public water supply have periodically lowered the groundwater levels during dry periods, particularly in the area of and near the RGV, where most agriculture and urban development in the region is centered. Groundwater declines of up to about 50 feet have been observed in monitoring wells in the RGV (Ritchie and others, 2018), and the maximum groundwater declines were observed in wells screened across greater than 50 percent of the lower member of the Santa Fe Group (Ritchie and others, 2018; Sweetkind, 2017).

Observed groundwater-level changes in the RGV for the period of simulation at monitoring wells screened across more than 50 percent of the river-channel deposits averaged about 3 feet of decline, with a maximum decline of about 24 feet; wells screened across more than 50 percent of the upper member of the Santa Fe Group averaged about 9 feet of decline, with a maximum decline of about 33 feet; wells screened across more than 50 percent of the middle member of the Santa Fe Group averaged about 8 feet of decline, with a maximum decline of about 30 feet; and wells screened across more than 50 percent of the lower member of the Santa $\mathrm{Fe}$ Group, averaged about 22 feet of decline, with a maximum decline of about 53 feet (Ritchie and others, 2018; Sweetkind, 2017). Observed groundwater-level changes at monitoring wells outside the RGV generally declined at magnitudes less than those observed in the RGV for the RGTIHM active area, but there were localized areas of groundwater rise in the upper and middle members of the Santa Fe Group. Monitoring wells in the Mexican part of the RGTIHM active area averaged about 10 feet of decline, with a maximum decline of about 64 feet. The increase in pumpage and the greater pumpage from wells screened in deeper units also increased the vertical head differences in some parts of the TRG region. Downward head differences either have doubled or have relatively larger seasonal and interannual variations between the Quaternary alluvium (layers 1-2) and upper member of the Santa Fe Group (layers 3-4) for some areas of the Mesilla Basin since the 1980s.

The largest set of observed values used for calibration consisted of the groundwater levels and changes in groundwater levels over time. The overall suite of measurements was filtered to a reduced set to minimize autocorrelation by avoiding high-frequency measurements and data from wells near each other that showed similar temporal changes in groundwater levels. The reduced dataset used for model calibration contained 59,130 groundwaterlevel measurements from March 1940 to December 2014 (referred to as "head observations") from 462 single and multiple-aquifer wells and multi-well groundwater-level observation sites (referred to as "head-observation wells"; fig. 22A). Head-observation wells were identified from three main sources: (1) the previous groundwater-flow model of the area (S.S. Papadopulos and Associates, Inc., 2007, table $\mathrm{C}-3$ and table 8.1), (2) National Water Information System (U.S. Geological Survey, 2016b), and (3) published groundwater-level data from 47 wells in the Mexico part of the RGTIHM area (International Boundary and Water Commission, 2011). The head observations included 462 initial head observations that were the first water-level measurement at each well and 58,745 drawdown observations that were water-level declines relative to the first head observation. Thus, in order to represent the overall trends in heads throughout the region and to minimize the potential effects of initial conditions, a set of drawdown observations was made for each well, based on the overall change in head relative to the first head observation from each well. In addition to changes in groundwater levels (drawdown observations), vertical water-level differences were estimated between 42 pairs of collocated or closely located observation wells completed in vertically adjacent model layers (fig. 22B). These observations were used to help constrain the calibration of vertical hydraulic conductivity and the vertical distribution of pumpage during parameter estimation. Spatial and temporal data for these wells used for vertical head differences are available in the data release associated with this report (Ritchie and others, 2018).

Hydrographs that show the simulated and measured groundwater levels for selected wells illustrate how the model matched groundwater levels in the Rincon Valley, Mesilla Basin, and northern Conejos-Médanos Basin (fig. 23). The minimum time span for which model simulations could accurately reproduce fluctuations in the groundwater-flow system (the response time of the model) varied according to the depth to water, hydrologic setting, hydraulic properties, climate, and land use. The amplitude of monthly fluctuations in simulated groundwater levels was generally less than those of measured levels, was least at the water table, and increased with depth below the land surface, reflecting the proximity of wellbore screened intervals to the water table, the varying pumping rates during monthly stress periods, applications of irrigation water, and fluctuations in reservoir releases. 
The overall model fit for water-level comparisons was generally good when the simulated values were compared to the observed groundwater levels for the combined $807 \mathrm{ft}$ range of initial measured levels. The RGTIHM model calibration used almost 30 times more observations than did previous models (LRG_2007, TRG_FMP2011). The residuals of the groundwater-level values (observed minus simulated) indicated the RGTIHM simulated water levels had accuracies similar to those of the previous models. For the RGTIHM, 91 percent of the residuals were within $\pm 10 \mathrm{ft}$; 94 percent were within $\pm 15 \mathrm{ft}$; and 96 percent were within $\pm 20 \mathrm{ft}$ (fig. 24A). Simulated water levels generally matched measured water levels, as indicated by an average residual of $-1.8 \mathrm{ft}$ and a root mean sum of squared weighted residual (SOSWR) of $9.1 \mathrm{ft}$; the residuals ranged from about -114 to $130 \mathrm{ft}$, and the standard deviation was $8.9 \mathrm{ft}$. About 99 percent of all groundwater-level residuals calculated from results of the RGTIHM simulations were within $30 \mathrm{ft}$ of the observed values, with the SOSWR representing about 1.1 percent of the total elevation range for observed groundwater levels. The average and median land-surface elevation accuracy was about $5 \mathrm{ft}$ for the observation wells used in the United States part of RGTIHM. The simulated groundwater levels tended to overestimate observed groundwater levels (negative residuals). The total change in observed groundwater levels in wells ranged from $-107 \mathrm{ft}$ (rise) to $64 \mathrm{ft}$ (decline), and the total simulated change in groundwater levels at these wells ranged from -12 to 60 feet. The larger range in observed changes could reflect that some observed groundwater levels were affected by small-scale, localized effects, such as nearby pumping, and that simulated changes were affected by a subdued representation of climate variability and the lack of actual land use in this version of the RGTIHM. Similarly, for drawdown 82 percent of the residuals were within $10 \mathrm{ft}$, and 96 percent were within $20 \mathrm{ft}$ (fig. 24A).

Crossplots of simulated against measured water levels also indicated a generally good fit across the wide range of elevations for the various subregions in the valley, with few outliers (fig. 24B). Most of the outliers resulted from an overestimation of simulated relative to measured water-level changes in the lower Mesilla Basin subregion, where there were large interannual fluctuations in measured water levels in wells near the Rio Grande. Such large observed fluctuations could be related to climate cycles that are not well represented in the RGTIHM and to an underestimation of groundwater levels farther from the Rio Grande in the Mesilla Basin, where hydraulic properties were less certain. Overall, the time series of simulated and observed groundwater levels for the valley indicated the RGTIHM was most accurate in the Rincon Valley and upper and middle Mesilla Basin and also replicated some of the later observed groundwater levels from wells in parts of the Conejos-Médanos Basin (fig. 23C). The water levels fit better for later years of the simulation (the last 14 years, or 2000-14), for which the land use and related crop information could be more representative of actual conditions and the CIRs were scaled to larger values to match annual reported total pumpage and increased rates of declining water levels.

Observed vertical groundwater-level (head) differences ranged between $-52 \mathrm{ft}$ (upward gradient) and $75 \mathrm{ft}$ (downward gradient; fig. 23F). A histogram of residuals of vertical groundwater-level (head) differences (fig. 24C) showed that the RGTIHM was able to replicate the sense and magnitude of vertical head differences. The root-mean square error of residuals in vertical-head differences was $14.7 \mathrm{ft}$ with an average residual of $3.2 \mathrm{ft}$ and a standard deviation of residuals of $14.3 \mathrm{ft}$. About 60 percent of the simulated vertical-head differences were within $5 \mathrm{ft}$ of the observed vertical-head differences, 75 percent were within $10 \mathrm{ft}, 81$ percent were within $15 \mathrm{ft}, 85$ percent were within $20 \mathrm{ft}$, and 91 percent were within $30 \mathrm{ft}$ (fig. 24C). Residuals between observed and simulated vertical-head differences generally ranged from -63.9 to $62.2 \mathrm{ft}$; these were largest between the middle and lower members of the Santa Fe Group in the lower Mesilla Basin. The vertical-head differences had a median residual of $0.41 \mathrm{ft}$, and the RGTIHM model fit was best for the shallow layers, such as in the upper Mesilla Basin subregion. Overall, the simulated and observed vertical-head differences were similar in magnitude and sign. Many sites showed poorer model fit in later years of the simulation, when there could have been more pumpage from deeper wells or more changes in land use (for example, pecan orchards) that drive agricultural pumpage than were simulated. Despite the overall similarity, the agreement between observed and simulated values could be improved in some aspects. For example, the range of observed vertical head differences was about $128 \mathrm{ft}$, whereas the range of simulated differences was only $38 \mathrm{ft}$, indicating that the simulated vertical hydraulic conductivity might be too large in some areas, resulting in smaller head differences, or the vertical distribution of pumpage, which is controlled by the multi-aquifer wells, could be assigning more pumpage to the lower layers than was true. The large observed vertical-head differences could also reflect differences during short-term pumpage that could be greater than the average simulated pumping rates prorated over biweekly time steps and monthly stress periods. 


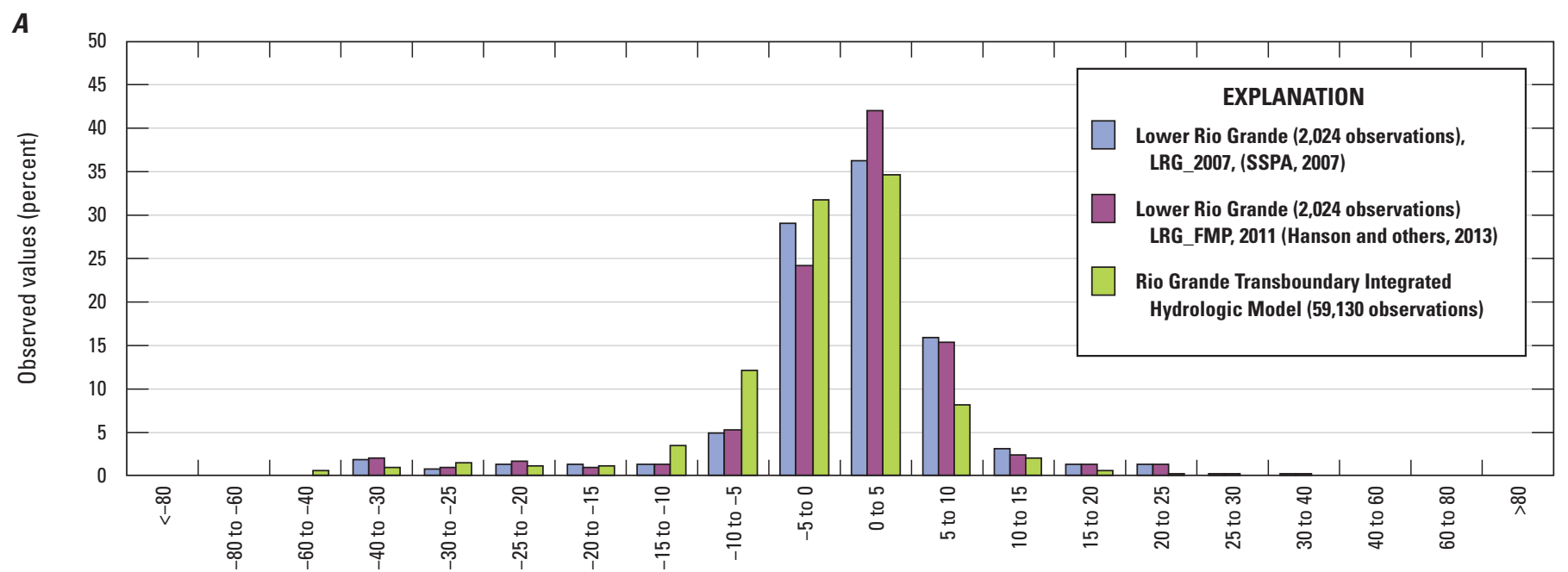

Range in residual groundwater levels, in feet

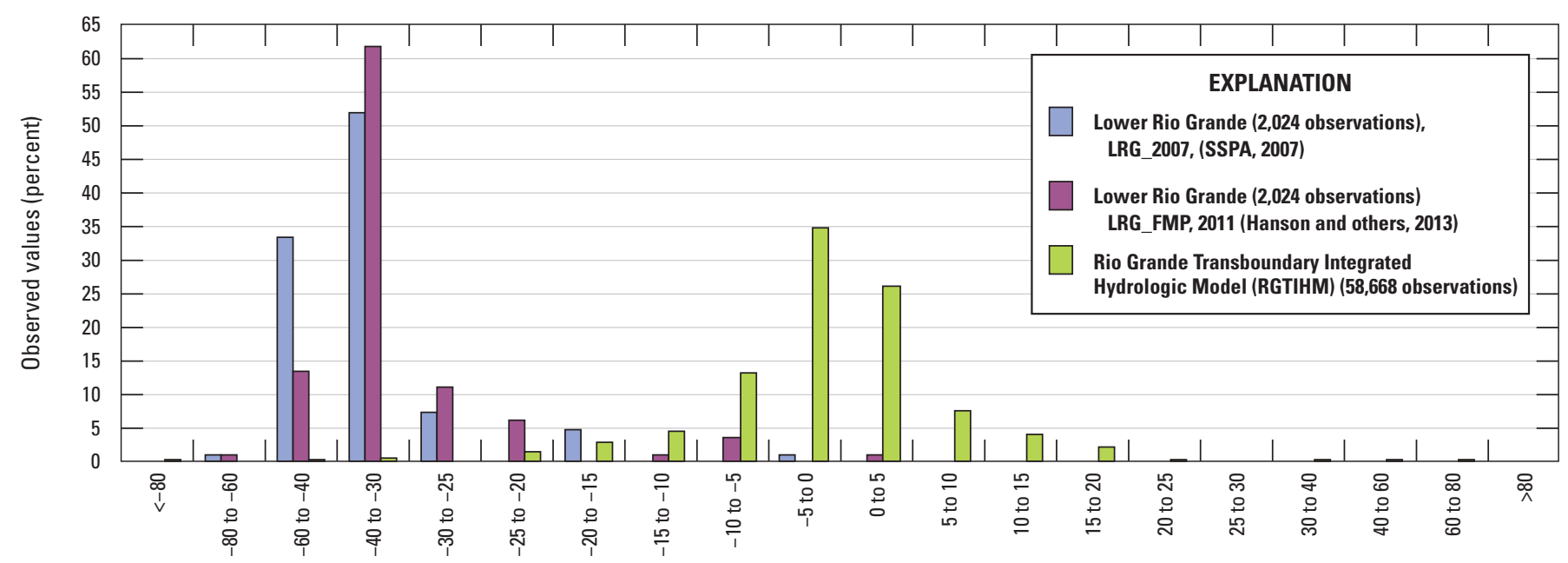

$\boldsymbol{B}$

Range in residual groundwater level drawdown, in feet

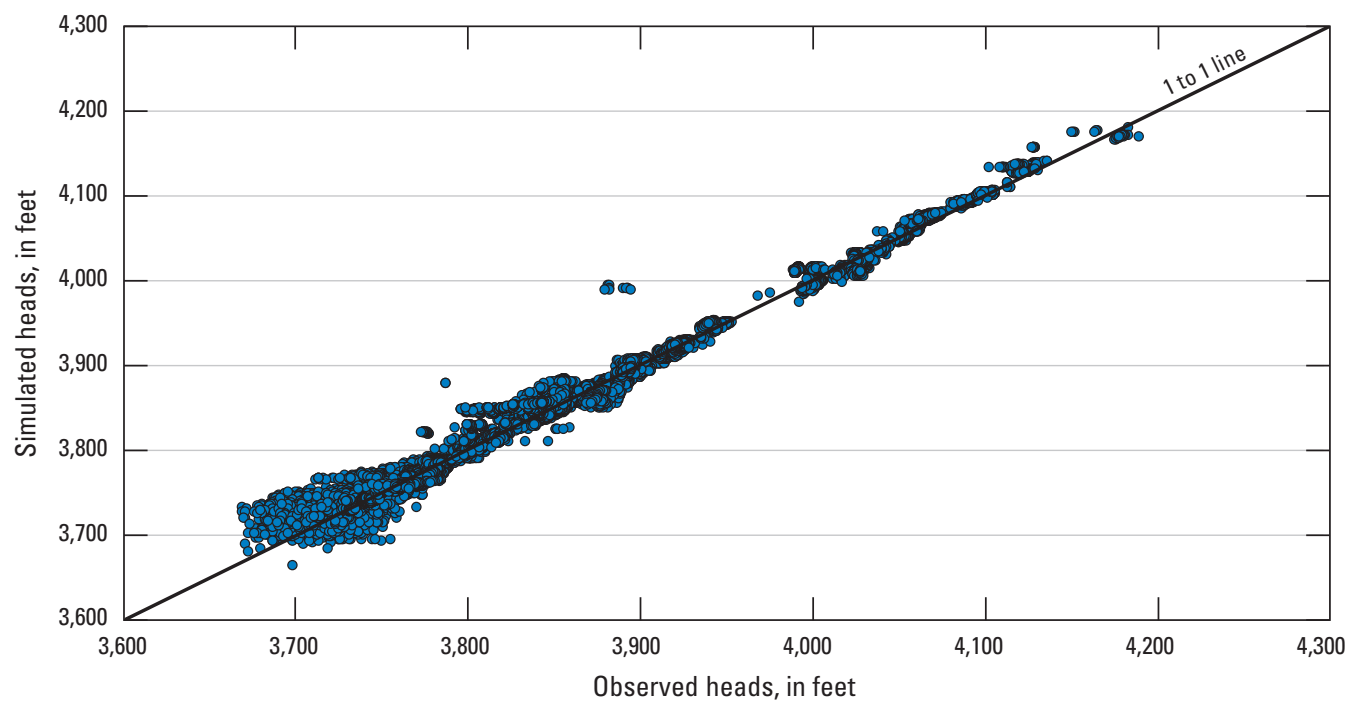

Figure 24. Measured and simulated groundwater levels in wells in the Transboundary Rio Grande, New Mexico, Texas, and Mexico, from the Rio Grande Transboundary Integrated Hydrologic Model: $A$, histograms of distribution of groundwater-level and drawdown residuals (observed minus simulated); $B$, regional and subregional correlation graphs of measured against simulated water levels; and $C$, histogram of distribution of residuals of vertical-head differences for selected wells. 

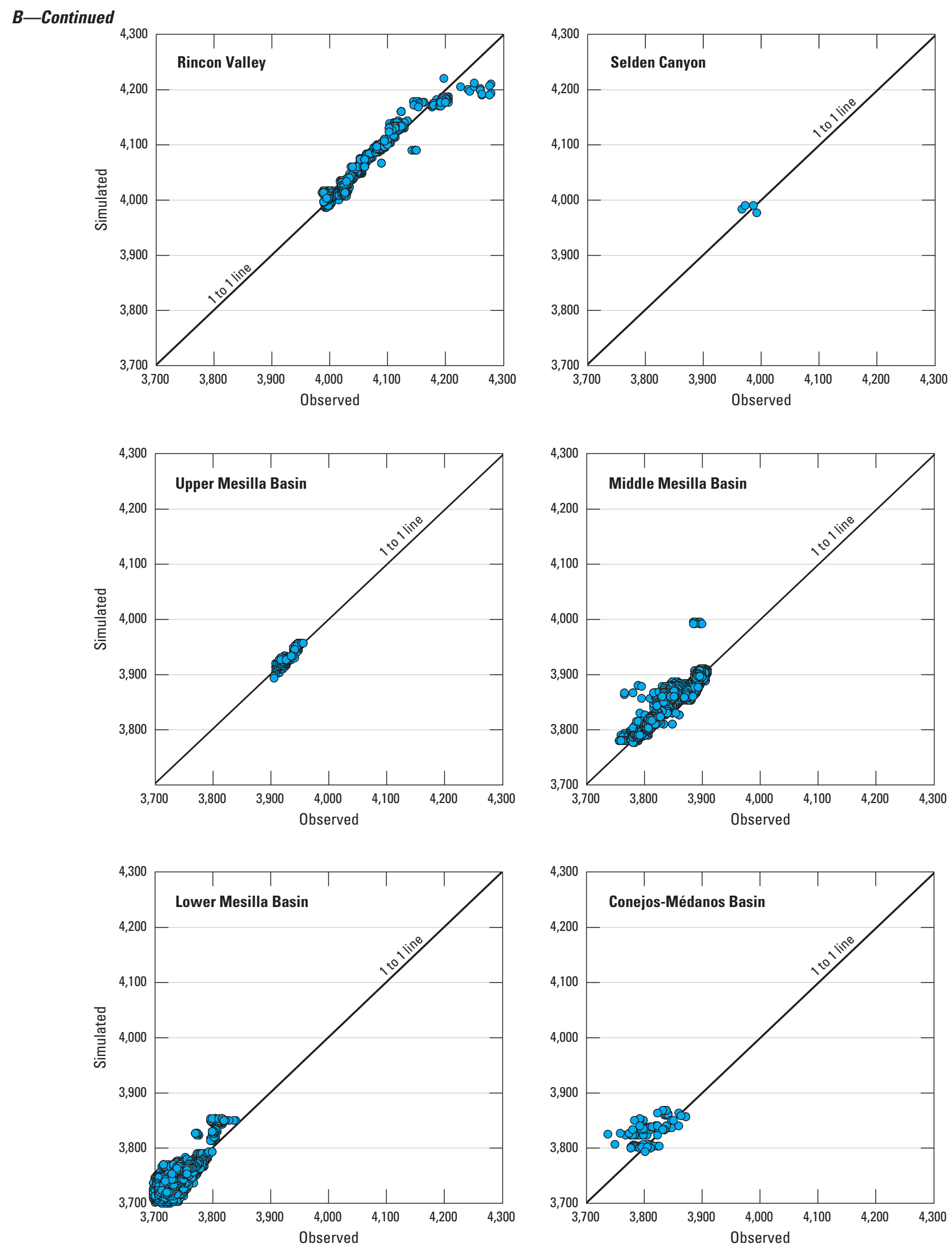

Figure 24. - Continued 


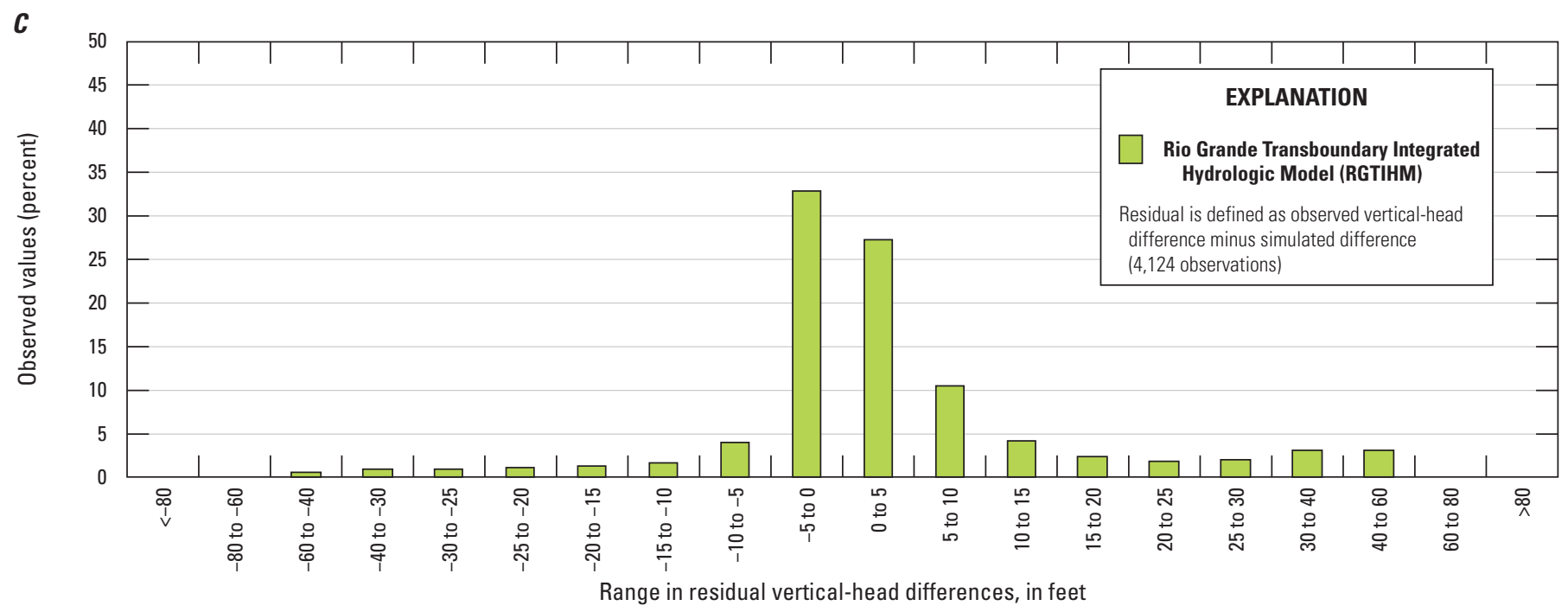

Figure 24. - Continued

The hydrographs for the Rincon Valley generally indicated a reasonable fit for rates of water-level decline and similar water-level elevations. Examples of hydrographs from the Rincon Valley, upper Mesilla, middle and lower Mesilla Basin, and from the Conejos-Médanos Basin are used to illustrate the temporal fit of the RGTIHM to groundwater levels (figs. 23A-E). Water-level histories in the Rincon Valley were largely restricted to the floodplain of the modern-day Rio Grande Valley and generally showed good agreement (within about 5 feet) between simulated and observed groundwater levels (fig. 23A). Although the rates of decline and the elevations were similar to those from historical records, some of the temporal changes were not reflected in the simulated values. This disparity could be a function of changes in landuse or irrigation practices that are not well represented in the CIR values. Moving downstream, south of Rincon Valley and Selden Canyon, to the upper Mesilla Basin, the simulated rates of decline showed variable matches to observed rates and potential to overestimate water levels by a few feet. The magnitude of changes in water levels coincident with the major droughts were not always well simulated, which also could be a result of incomplete land-use data.

Continuing downstream, the simulated hydrographs for the middle Mesilla Basin subregion were similar to those from historical records (fig. 23C). Although the simulated trend was similar to that of the historical record for most wells, it did not capture some of the amplitude of the interannual fluctuations in some wells near the Rio Grande, especially during the droughts of $\pm 2003-14$ and a concurrent transition to a greater demand for water to irrigate increased orchard acreage that is likely to be sustained for years to decades. Although the simulated trend was similar to that of the historical record for most wells, some of the annual fluctuations were not captured by the simulated water levels. This, again, is probably a function of using the NMOSE-CIR estimates to indirectly drive the demand for irrigation and related groundwater pumpage instead of using actual land-use data and having the model internally compute the consumptive use on the basis of the climatic conditions. The hydrographs for the lower Mesilla Basin subregion were more variable than other regions, matching trends in floodplain subregions for some wells and over- or underestimating trends for other wells farther from the floodplain (fig. 23D).

Finally, sparse groundwater-level measurements from 2007 to 2010 for some of the wells in the northern part of the Conejos-Médanos Basin showed little variation and appeared to be affected by the set of faults that partially offset parts of the upper and middle members of the Santa Fe Group (fig. 23E). With no agriculture and the recent pumpage from the well fields in this border region of Mexico, groundwater level declines were limited to some wells from pumpage of these well fields; effects from climate variability were also not pronounced in the limited groundwater-level records. Additional refinements of the model, combined with more detailed land-use and well data, could provide a better match to observed values in subsequent updates of the model.

Variations in matches of individual hydrographs indicated that simulation results generally provided a reasonable fit, given the general lack of information on the use and movement of water in the TRG region. The monthly to interannual fluctuations in the measured water levels indicated the influences of climate, streamflow infiltration, and annual changes in land use; these fluctuations were less well represented in the simulated water levels, which are driven primarily by monthly changes in streamflow and the estimated irrigation demands for groundwater pumpage. 
The goal of the RGTIHM model calibration was to match groups of hydrographs spatially to the subregions and model layers and to minimize the sum of squared weighted residuals (SOSWR) of all simulated heads. The use of WBSs that represent multiple actual farms, estimated pumpage rates, virtual surrogates (pre-estimated CIR values) for spatially and temporally coarse (multi-year) land-use and crop distributions for the entire period of simulation, and assumptions about spatially distributing splits of surface-water deliveries could limit the ability of RGTIHM to simulate groundwater levels more accurately without inputs for actual climate, all potential runoff from precipitation and irrigation, and annual land use. The spatial distribution of the residuals and water-level matches is discussed in more detail in the next paragraph. Much of the error, and the primary source of the average error, could be due to the lack of spatial and temporal detail in actual climate and land-use estimates for the TRG region and in related observations reported as monthly agricultural pumpage for 2009-14, which drives estimates of ET consumption and related irrigation, surface-water deliveries, and pumping.

To allow for a spatial comparison of the RGTIHMsimulated values to observed data, groundwater-level maps were developed for winter 2010-11 in the Quaternary Rio Grande alluvium (fig. 25A) and in the Santa Fe Group (fig. 25B). The simulated groundwater levels (fig. 25) generally agreed with these groundwater-level maps. The thematic pixels for the simulated water levels are a thicknessweighted average of composite water levels. The thicknessweighted average was used because it was more consistent with the observation process of multi-aquifer wells with multi-layer composite heads than single layer heads in MF-OWHM2 and with the composite groundwater levels from wells used to create the hand-contoured water-level maps and the composite simulated water levels from the HOB package (Hill and others, 2000; Harbaugh, 2005). The water-level maps were used during RGTIHM calibration to provide additional information about the effects of internal flow boundaries along faults and to help with adjustments to selected model hydraulic properties.

The simulated and measured groundwater-level maps both indicated regions in the center of the TRG where groundwater levels declined and changed shape relative to earlier groundwater levels (figs. 9A, 25). Specifically, they showed that the declines were concentrated in the middle and lower Mesilla Basin subregions (fig. 25). Changes in measured and simulated groundwater levels from spring to fall in 2010 ranged between -3 (rise) and $90 \mathrm{ft}$ (decline; fig. 23). By the fall of 2010, water levels below 3,900 ft persisted in the middle and lower Mesilla Basin subregions, a pattern replicated by output of the RGTIHM (fig. 25B). Simulated water levels underestimated the hand-drawn contours in northeastern parts of the RGTIHM (northeast of Rincon Valley), however, so additional refinement of aquifer properties, land use, or recharge may be required for that area (fig. 25).

\section{Surface-Water Observations}

Surface-water flows and flow differences between streamflow gages were used during calibration to constrain simulated flows in the surface-water network. Selected continuous and discrete monthly surface-water flow observations were compiled from 160 gages on the Rio Grande, canals, and drains (fig. 26) for the RGTIHM simulation period, yielding 26,367 flow observations (Ritchie and others, 2018). Of these, 8,598 continuous and 426 discrete surface-water flow observations were used for model calibration. The continuous observations were reduced from the entire record by filtering the entire flow-observation dataset to only the months with flows corresponding to the annual 25th, 50th, 75th, and 100th percentiles of the entire period-of-record of monthly flows reported at the "Rio Grande below Caballo Dam" streamgage (USGS 08362500; fig. 8A; Ritchie and others, 2018). Surface-water flow observations were obtained from a variety of sources, as documented in Ritchie and others (2018); the majority of observations were from Tillery and others (2009).

In addition to the selected surface-water flows, 31 pairs of observation gages were selected for flow-difference observations, including 21 pairs of gages along the Rio Grande. After filtering of the entire flow-observations dataset by quartiles, only 14 pairs of gages had at least 1 month of flow observations in common from which to calculate flow differences, resulting in 110 flow-difference observations. The estimates of gains and losses from the winter seepage runs for most of the Mesilla Basin were also used as observations for periods when the Rio Grande project is not releasing water from the reservoirs into the Rio Grande. These observations also were used to help calibrate streambed hydraulic conductivity during parameter estimation. The seepagerun observations contributed another 400 flow-difference observations that represented seepage as gains (flow into river) or losses (flow out of the river). Finally, the 9,300 monthly surface-water potential allotment targets also were used as pseudo-observations and surface-water allotment constraints to help enhance the surface-water delivery to the waterbalance subregions using surface-water irrigation to the fullest extent during model calibration. 
$\boldsymbol{A}$

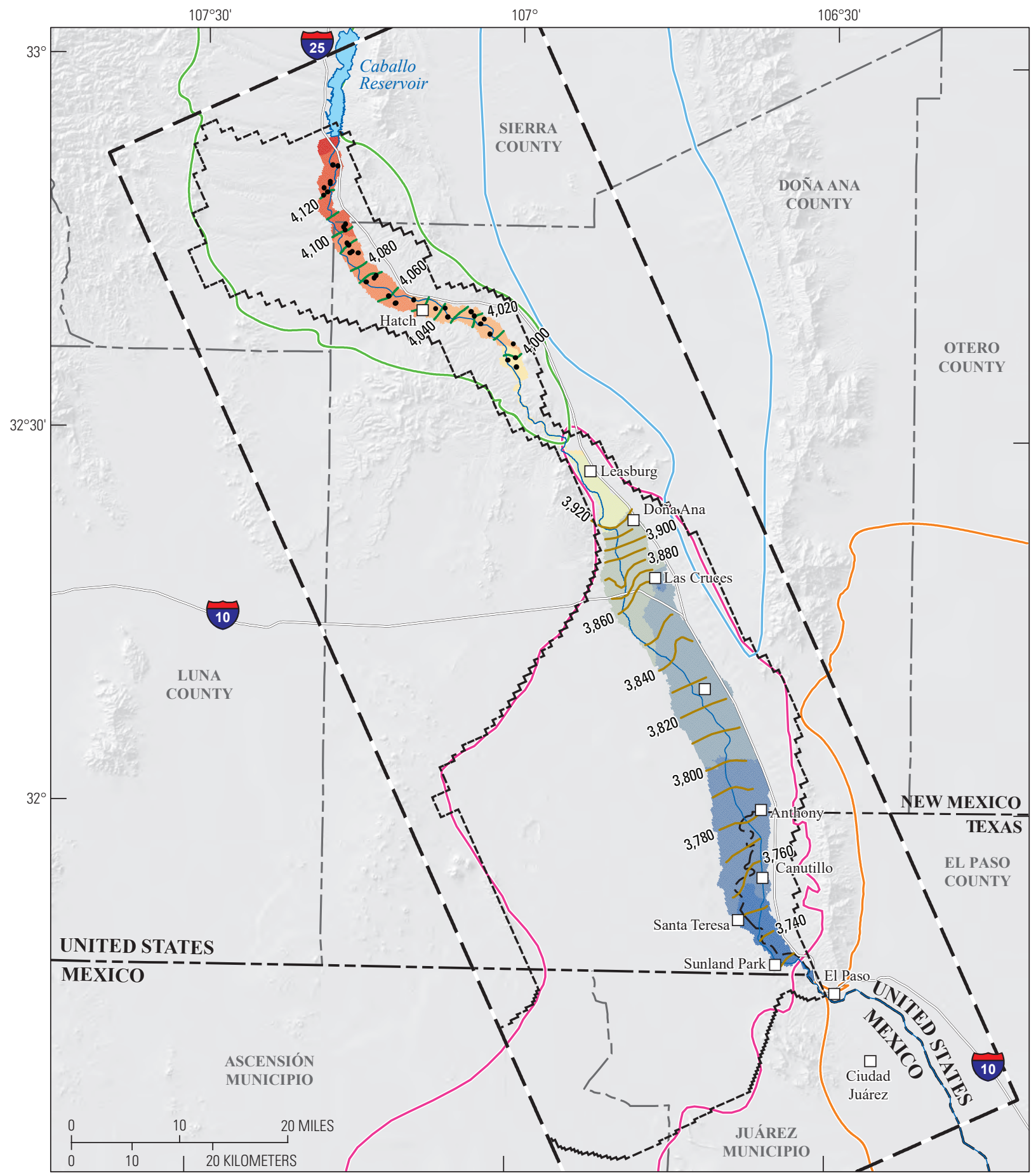

Base modified from U.S. Geological Survey and other Federal and State digital data, various scales; Universal Transverse Mercator projection, zone 13; North American Datum of 1983

EXPLANATION
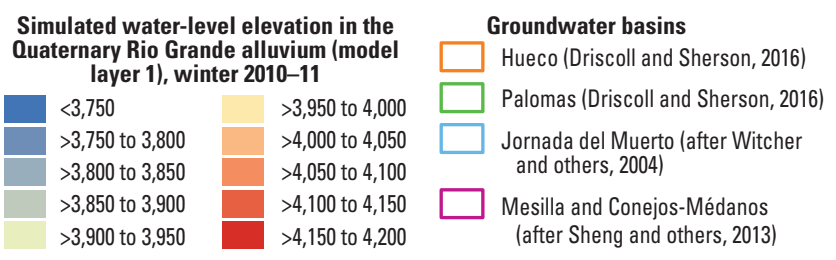

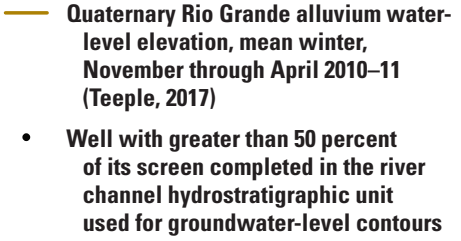

Figure 25. Contoured measured water levels compared to simulated water levels in the Transboundary Rio Grande, New Mexico, Texas, and Mexico, for $A$, the Quaternary Rio Grande alluvium in winter, 2010-11; and B, the Santa Fe Group in winter, 2010-11. 
B

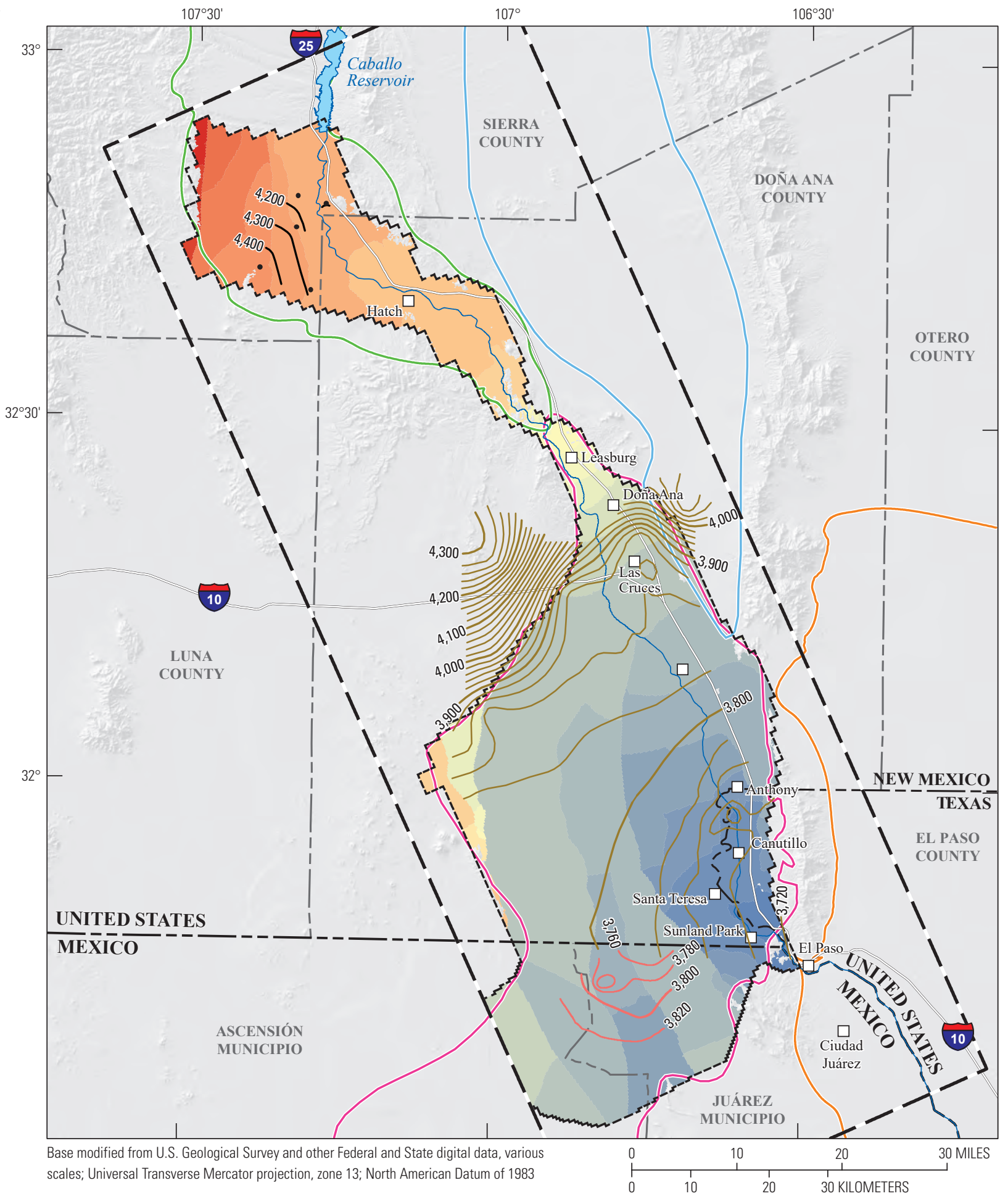

Figure 25. - Continued 


\section{EXPLANATION}

Simulated groundwater-level elevation contours as thickness weighted average values for the upper and middle members of the Santa Fe Group, winter 2010-11 (interval is $\mathbf{2 0}$ and $\mathbf{1 0 0}$ feet)

\begin{tabular}{|l|l|l|l|}
$>3,680$ to 3,700 & $>3,820$ to 3,840 & $>3,960$ to 3,980 & $>4,500$ to 4,600 \\
$>3,700$ to 3,720 & $>3,840$ to 3,860 & $>3,980$ to 4,000 & $>4,600$ to 4,700 \\
$>3,720$ to 3,740 & $>3,860$ to 3,880 & $>4,000$ to 4,100 & $>4,700$ to 4,800 \\
$>3,740$ to 3,760 & $>3,880$ to 3,900 & $>4,100$ to 4,200 & $>4,800$ to 4,900 \\
$>3,760$ to 3,780 & $>3,900$ to 3,920 & $>4,200$ to 4,300 & $>4,900$ to 5,000 \\
$>3,780$ to 3,800 & $>3,920$ to 3,940 & $>4,300$ to 4,400 & \\
$>3,800$ to 3,820 & $>3,940$ to 3,960 & $>4,400$ to 4,500 &
\end{tabular}

T] Maximum extent of Rio Grande Transboundary Integrated Hydrologic Model (RGTIHM)

[--I RGTIHM active model boundary

Groundwater basins

Hueco (Driscoll and Sherson, 2016)

Palomas (Driscoll and Sherson, 2016)

Jornada del Muerto (after Witcher and others, 2004)

Mesilla and Conejos-Médanos (after Sheng and others, 2013)

Santa Fe Group groundwater-level elevation, mean winter (November through April 2008-2009), interval is 100 feet

- Santa Fe Group groundwater-level elevation, mean winter (November through April 2010-2011), interval is 20 feet (from Teeple, 2017)

- Santa Fe Group groundwater-level elevation, 2010, interval is 20 feet (modified from International Boundary and Water Commission [IBWC, 2011])

- Well with greater than $\mathbf{5 0}$ percent of its screen completed in the Santa Fe Group hydrostratigraphic units used for groundwater-level contours

Figure 25. - - Continued
Hydrographs of surface-water flows (fig. 26) at selected gages of the Rio Grande, canals, and drains help illustrate the match of simulated and observed surface-water flows through time in the TRG region (figs. 27A-D). In addition, comparison of simulated stream-aquifer exchange to results from seepage runs on selected canals and drains, and along the Rio Grande in the Mesilla Basin, also showed that the RGTIHM generally replicates the gains and losses along the surface-water network (figs. 27E, F). The seepage losses along the Rio Grande also indicated that gains and losses changed with seasonal flow and streambed hydraulic conductivities and can vary from year to year. All of the residuals of annual canal and drain flows were within 10,000 acre- $\mathrm{ft} / \mathrm{yr}\left(13.8 \mathrm{ft}^{3} / \mathrm{s}\right)$, and 99 percent of the streamflows on the Rio Grande were within $100,000 \mathrm{acre}-\mathrm{ft} / \mathrm{yr}\left(138 \mathrm{ft}^{3} / \mathrm{s}\right.$; fig. 28A), which represents about 15 percent of the total annual median streamflow released from Caballo Reservoir in the TRG region; this magnitude was within the accuracy of the streamflow-gaging stations (fig. 28A). 


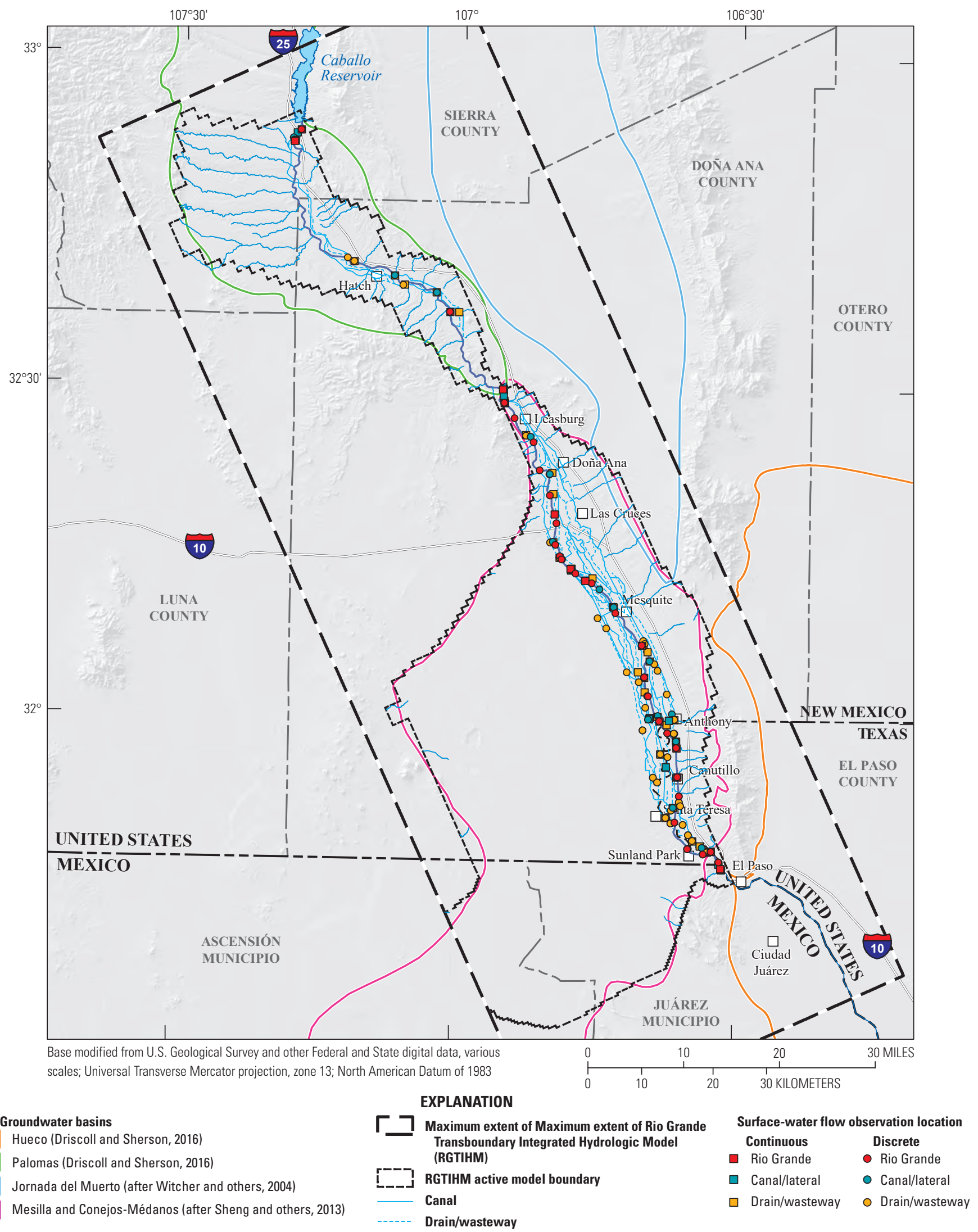

Figure 26. Calibration-data sites for Rio Grande streamflows and canal and drain flows for the Rio Grande Transboundary Integrated Hydrologic Model, Transboundary Rio Grande, New Mexico, Texas, and Mexico. 
$\boldsymbol{A}$
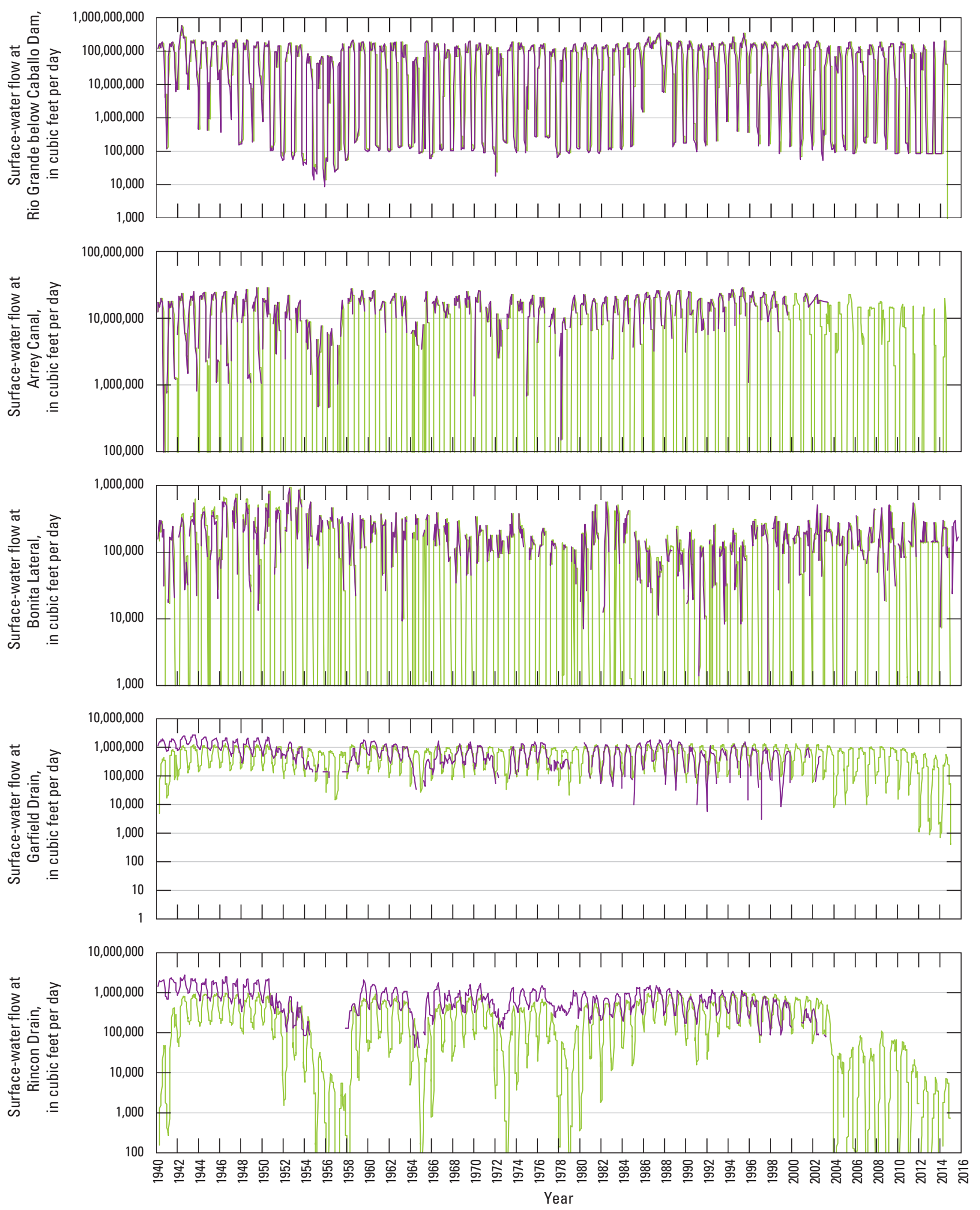

EXPLANATION

Observed surface-water flows _ Simulated surface-water flows

Figure 27. Simulated and observed streamflow hydrographs for selected river, canal and drain gages within the Rio Grande Transboundary Integrated Hydrologic Model (RGTIHM) in the Transboundary Rio Grande, New Mexico and Texas, for A, Rincon Valley; $B$, upper Mesilla Basin; $C$, middle Mesilla Basin; $D$, lower Mesilla Basin; $E$, selected Rio Grande winter-seepage estimates, where positive values represent gains, and negative values represent seepage losses; and $F$, selected drain-seepage estimates. 
$B$

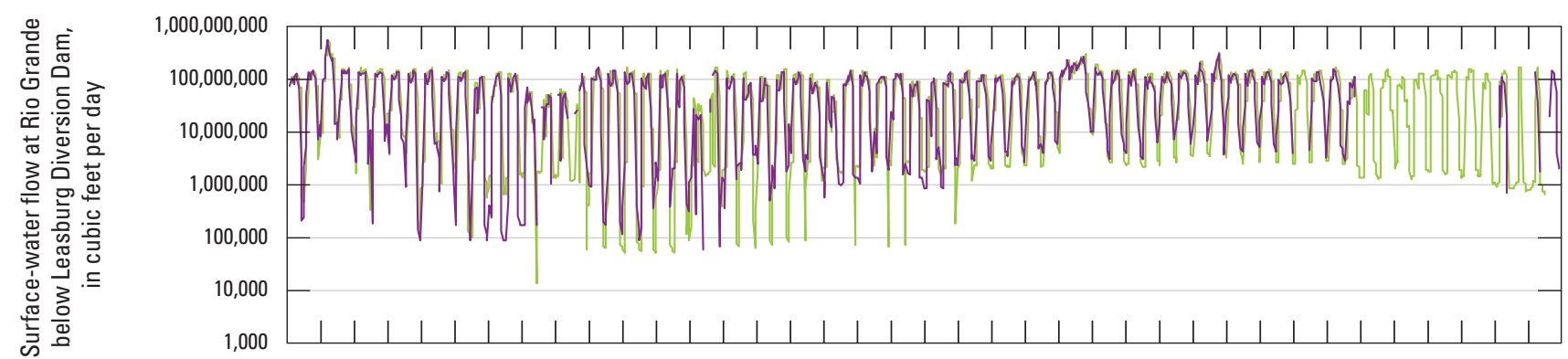

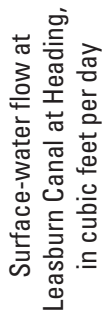

$100,000,000$

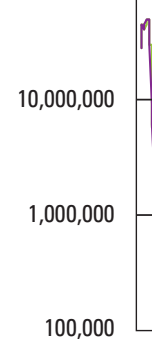

100,000

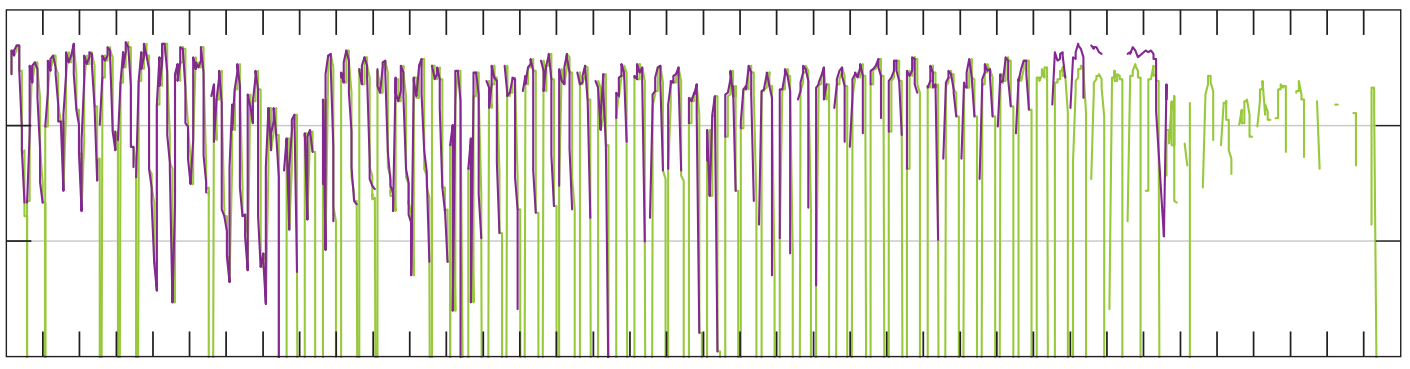

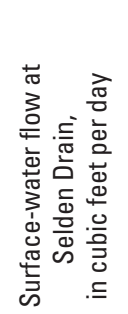

C

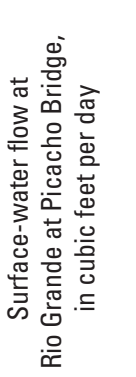

$$
10,000,000
$$

$1,000,000$

$$
\begin{array}{r}
1,000,000 \\
100,000 \\
10,000 \\
1,000
\end{array}
$$

100
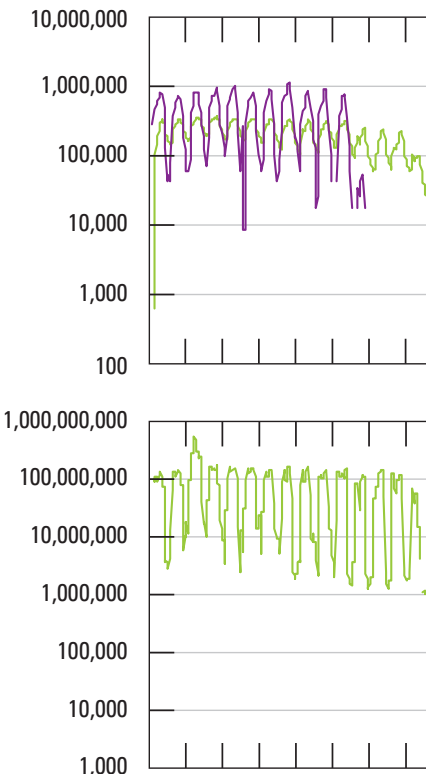

.
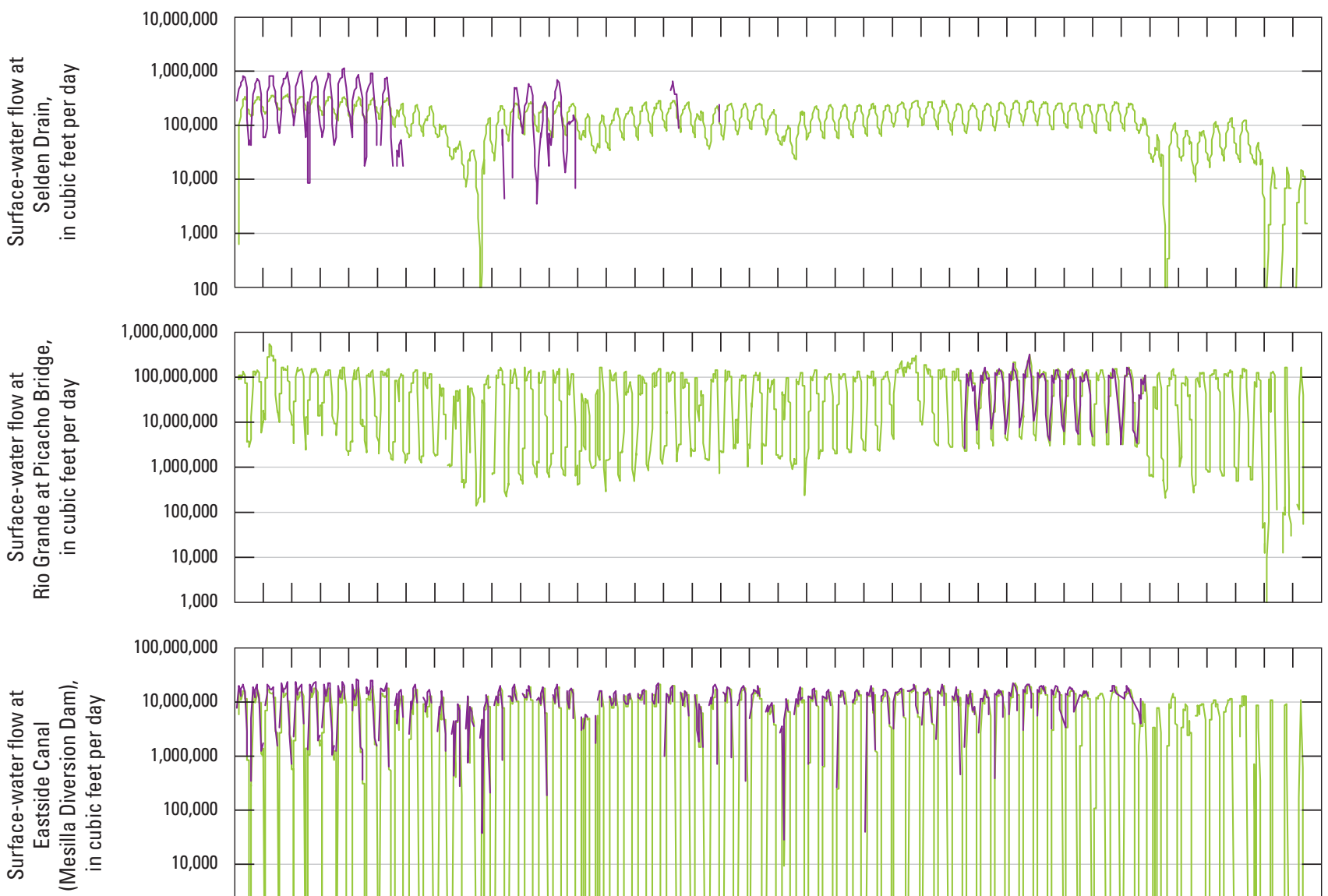

$100,000,000$

$10,000,000$

$1,000,000$

100,000

10,000

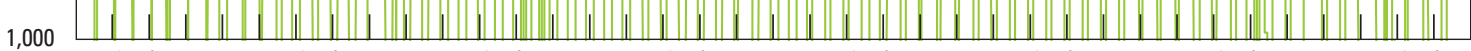

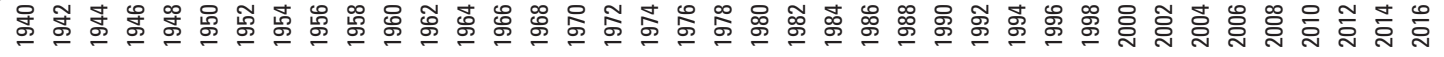

Figure 27. -Continued 

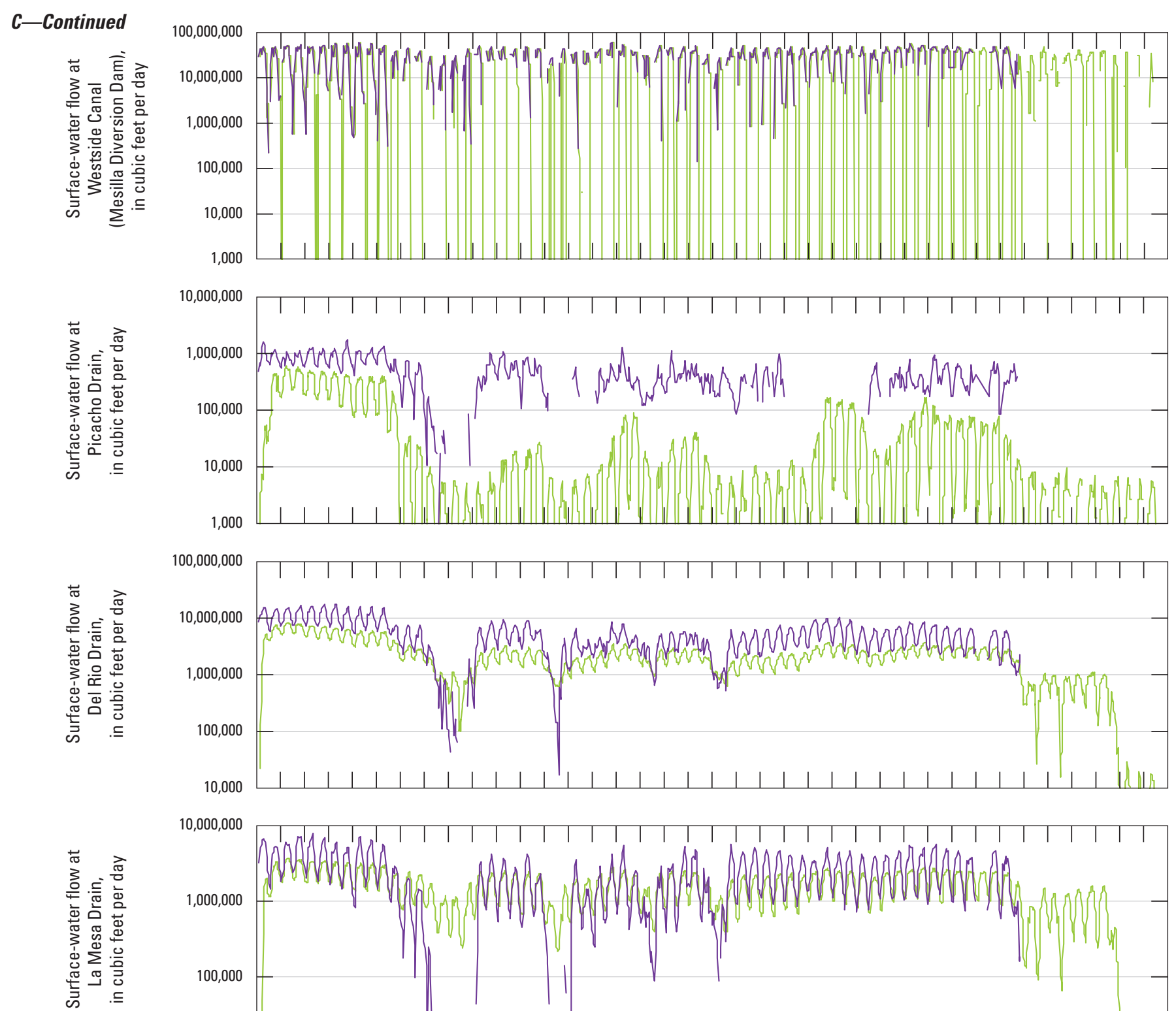

$10,000,000$

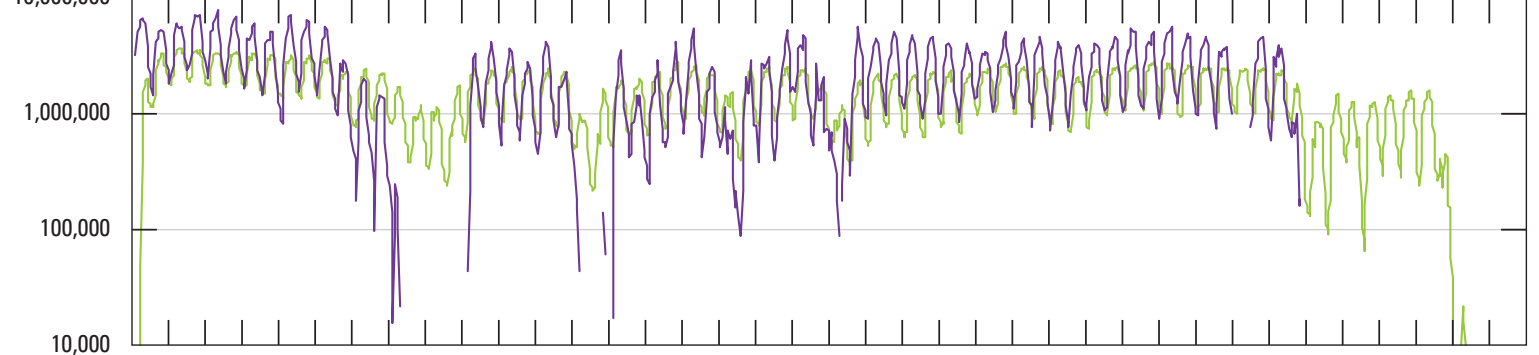

D

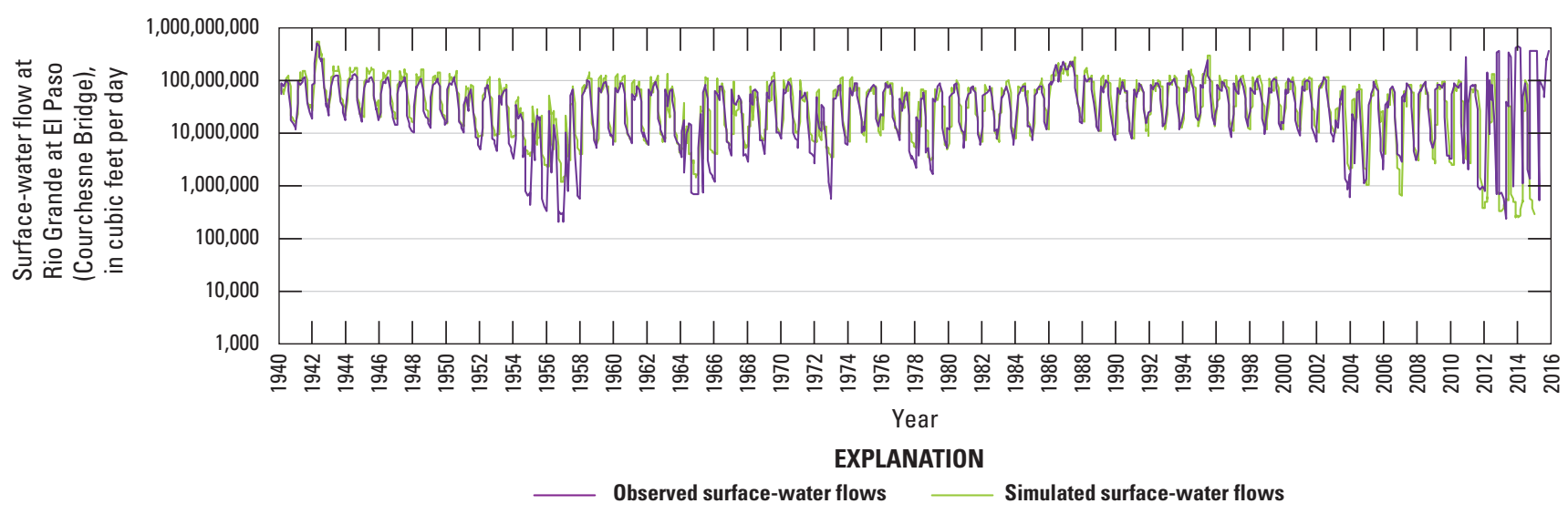

Figure 27. - Continued 

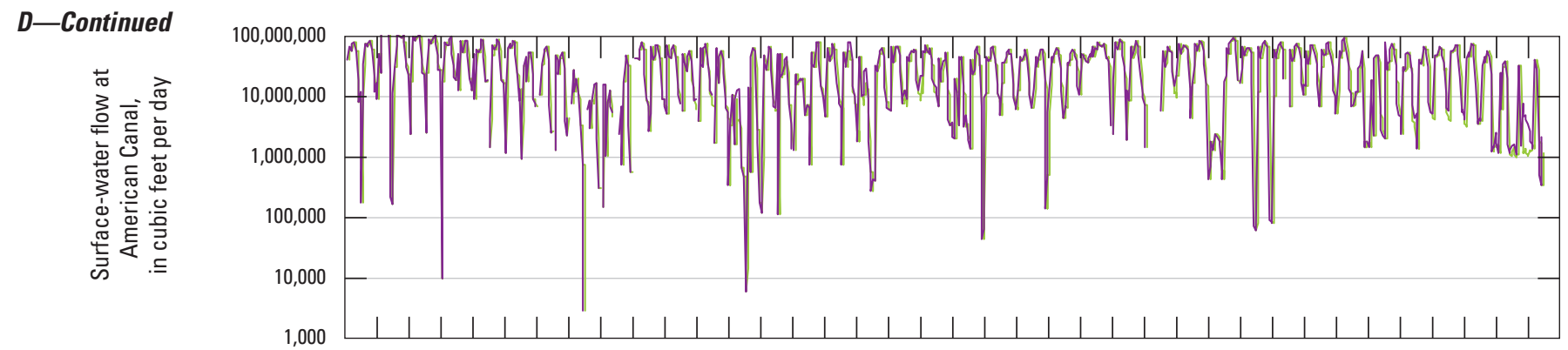

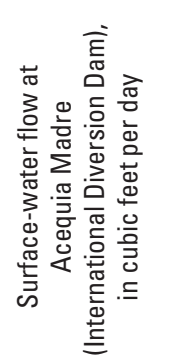
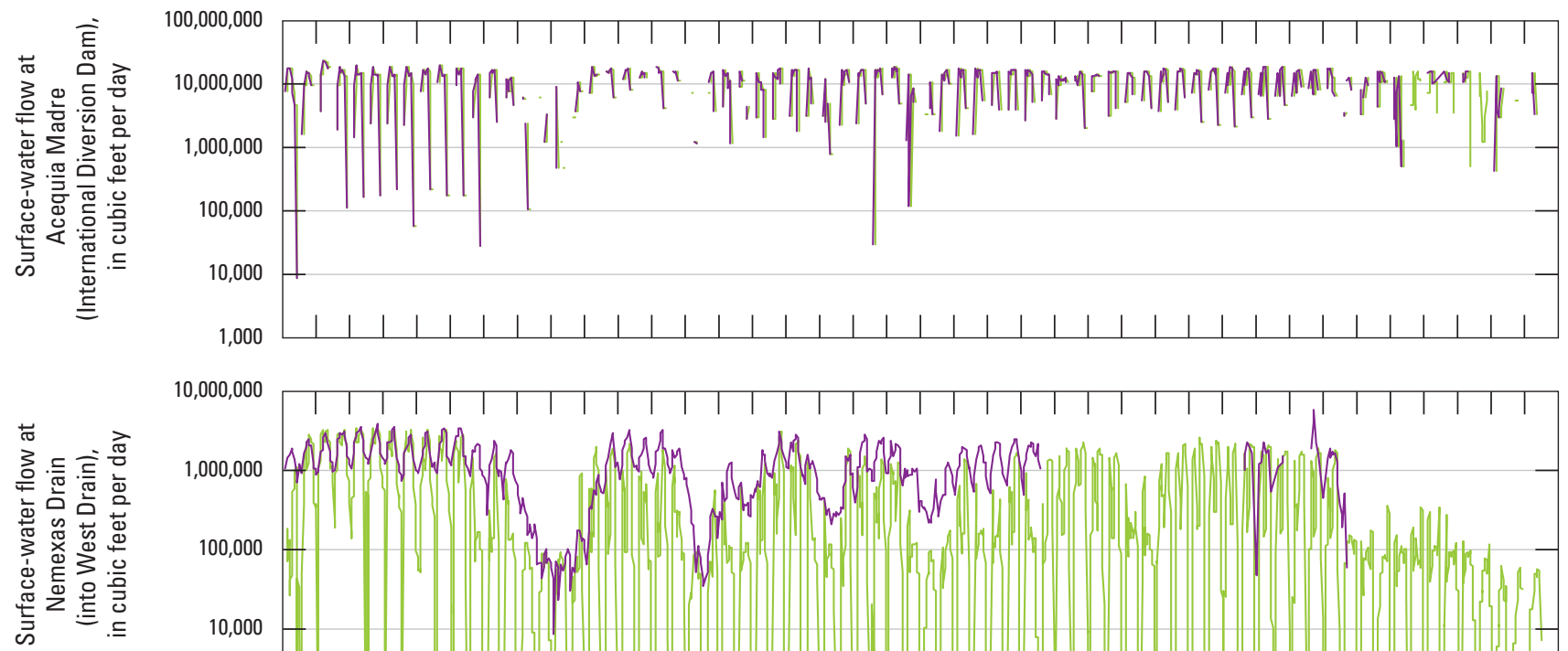

$10,000,000$
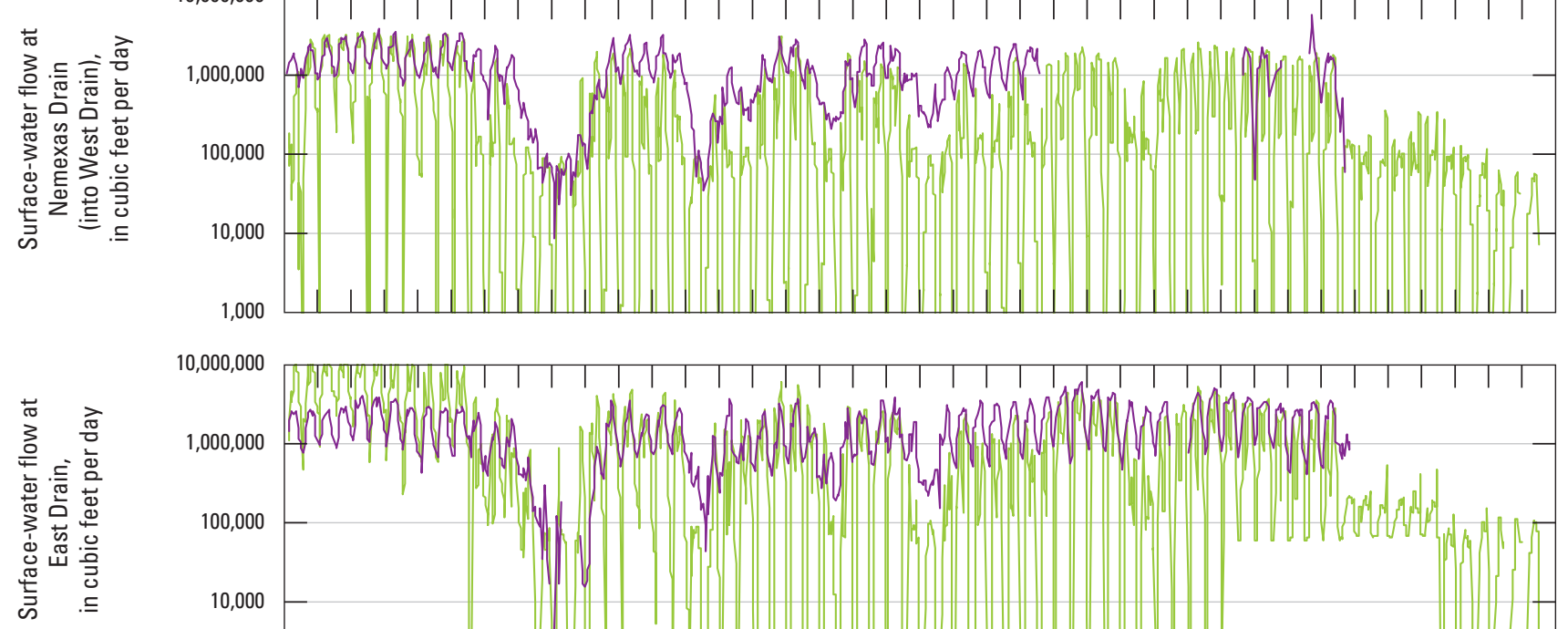

$10,000,000$
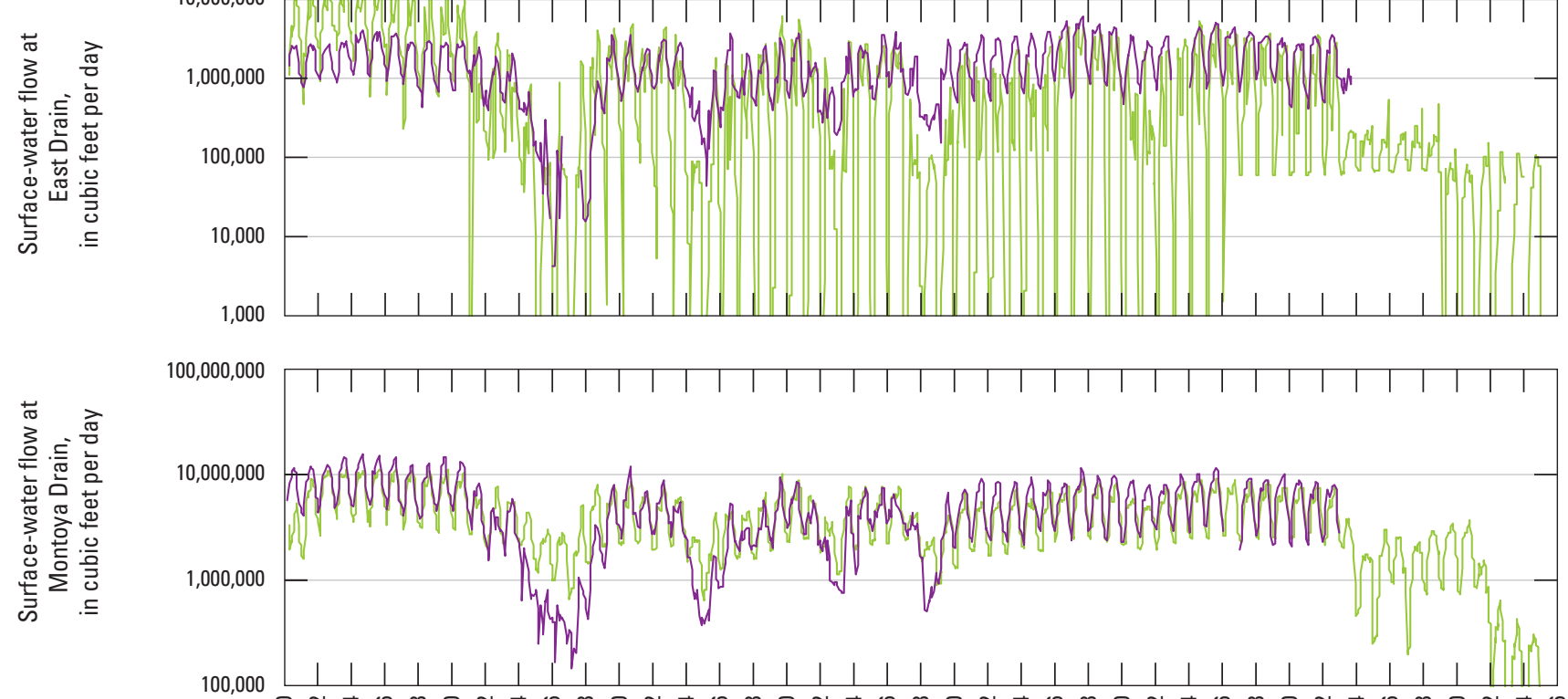

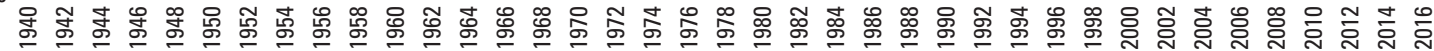

Figure 27. - Continued 
E
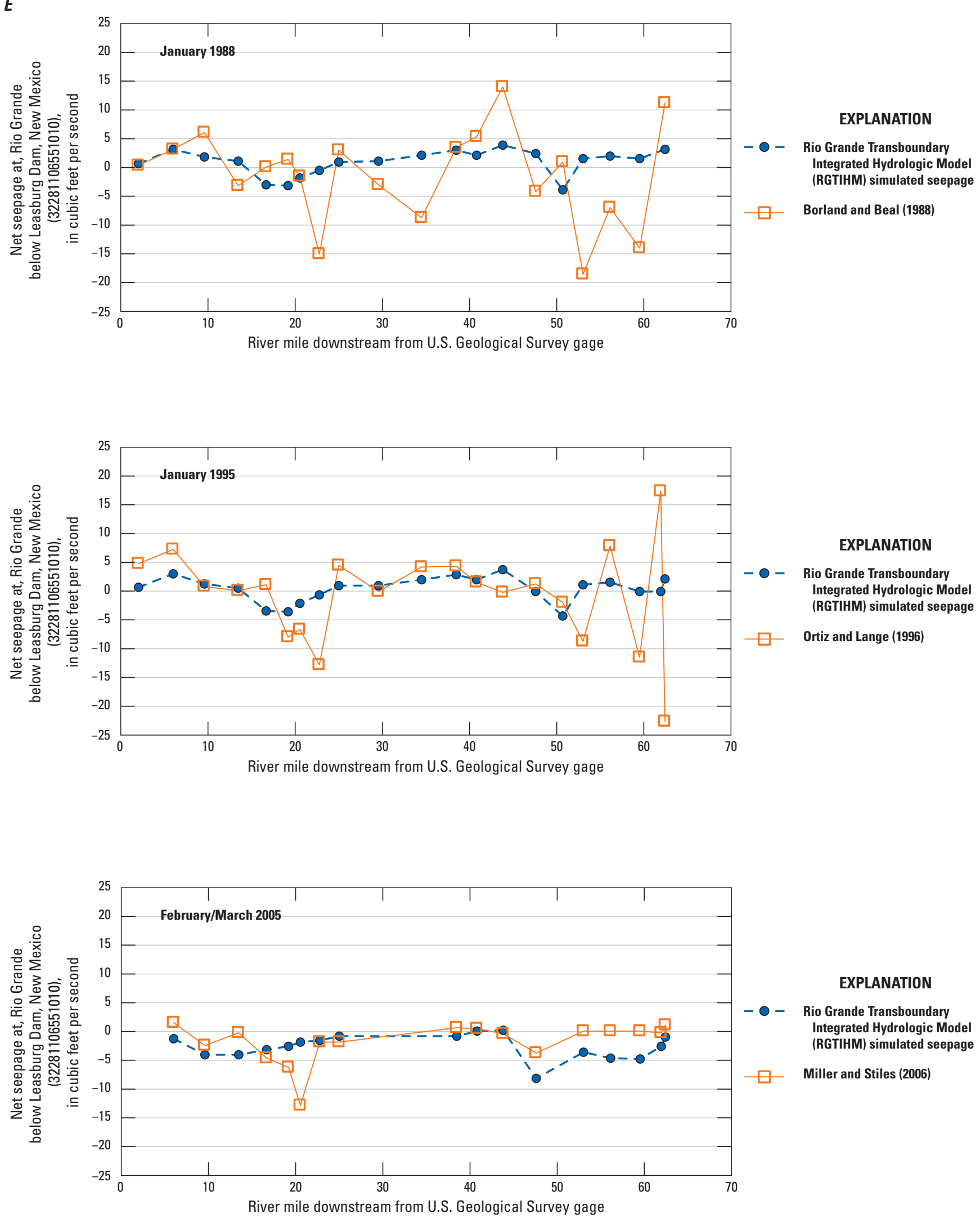

Figure 27. - Continued 


\section{E-Continued}
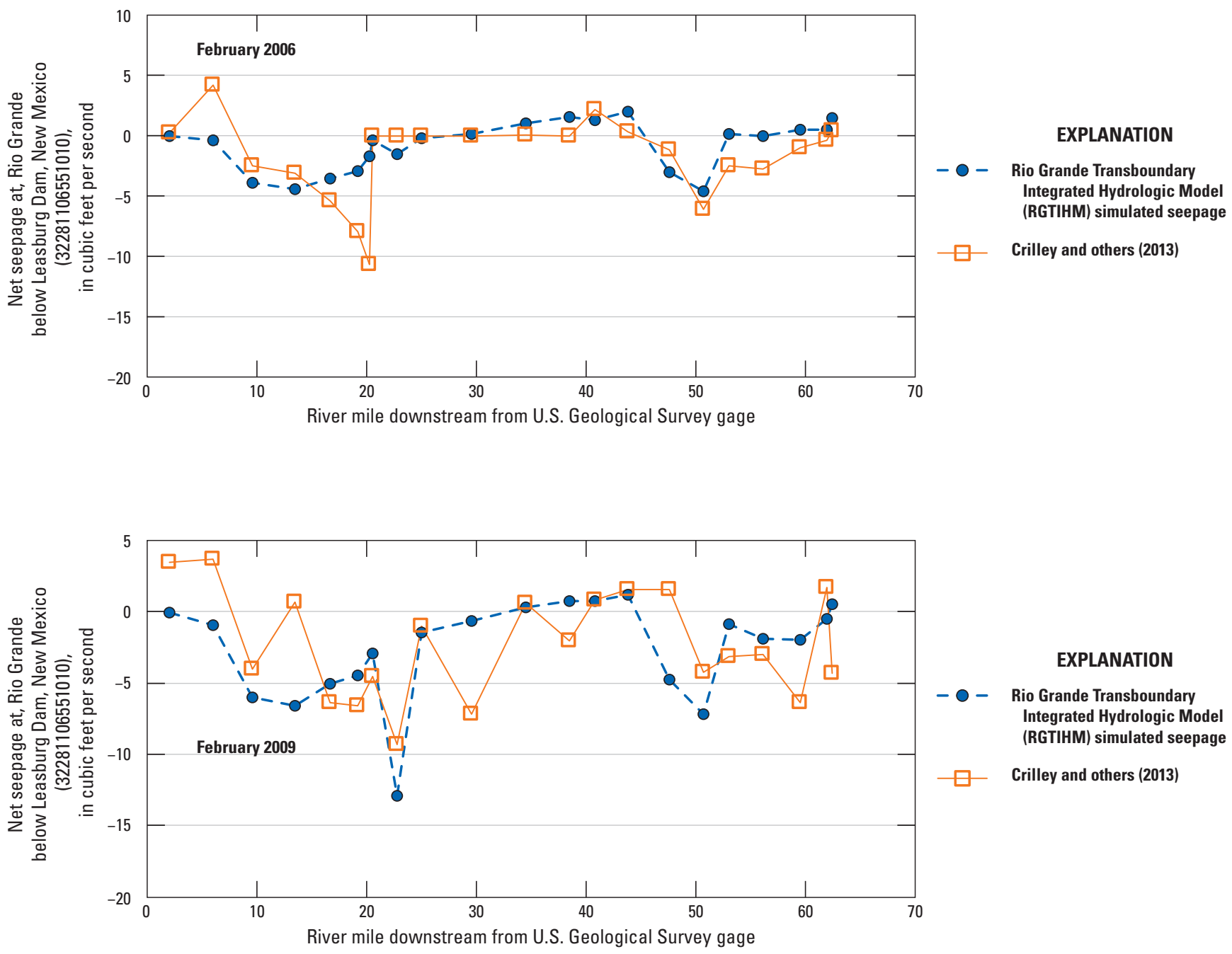

\section{EXPLANATION}

- O - Rio Grande Transboundary Integrated Hydrologic Model (RGTIHM) simulated seepage

Crilley and others (2013)

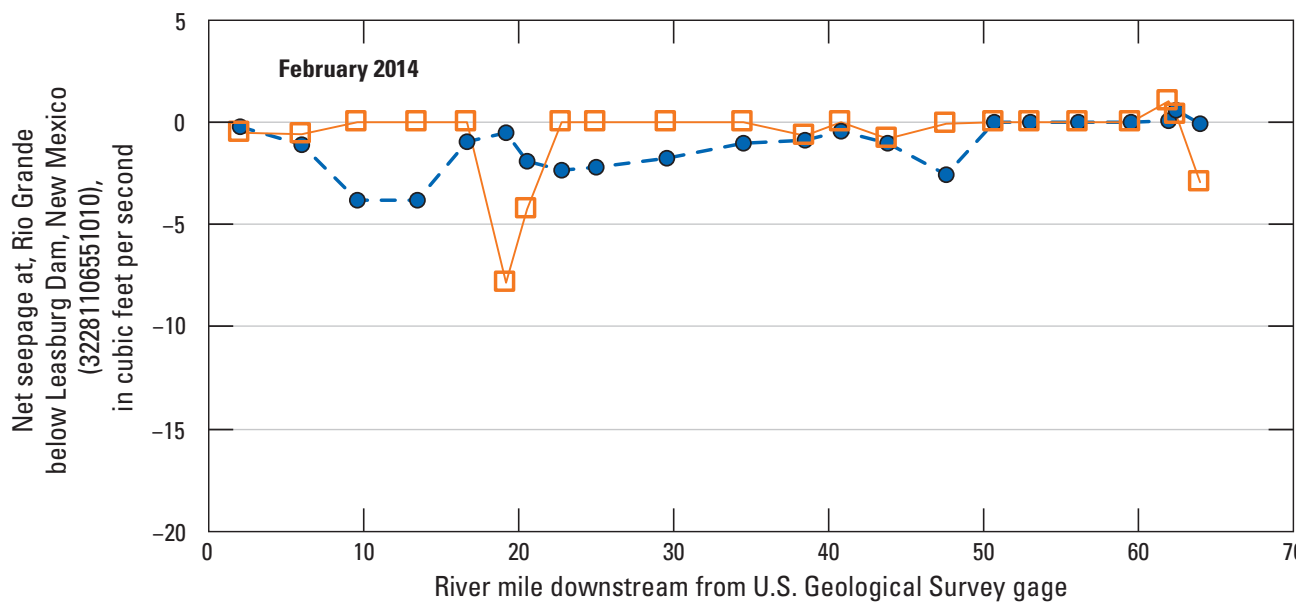

EXPLANATION

- O - Rio Grande Transboundary Integrated Hydrologic Model (RGTIHM) simulated seepage

Briody and others (2016)

Figure 27. - Continued 


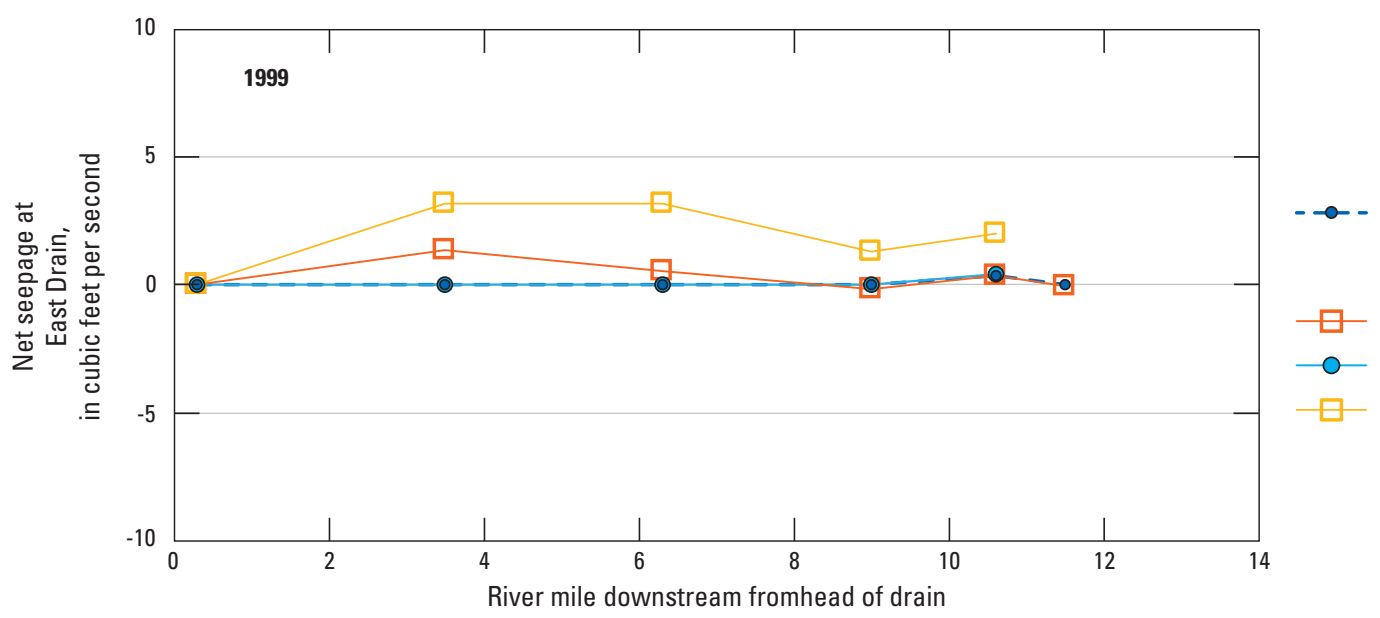

\section{EXPLANATION}

Rio Grande Transboundary Integrated Hydrologic Model (RGTIHM) simulated seepage, February

Ortiz and others (2000), February

RGTIHM simulated seepage, August

Ortiz and others (2000), August

\section{EXPLANATION}

Rio Grande Transboundary Integrated Hydrologic Model (RGTIHM) simulated seepage, February

Ortiz and others (2001), February RGTIHM simulated seepage, August Ortiz and others (2001), August

\section{EXPLANATION}

Rio Grande Transboundary Integrated Hydrologic Model (RGTIHM) simulated seepage, February

Byrd and others (2002), February

RGTIHM simulated seepage, August

Byrd and others (2002), August

Figure 27. - Continued 


\section{F-Continued}

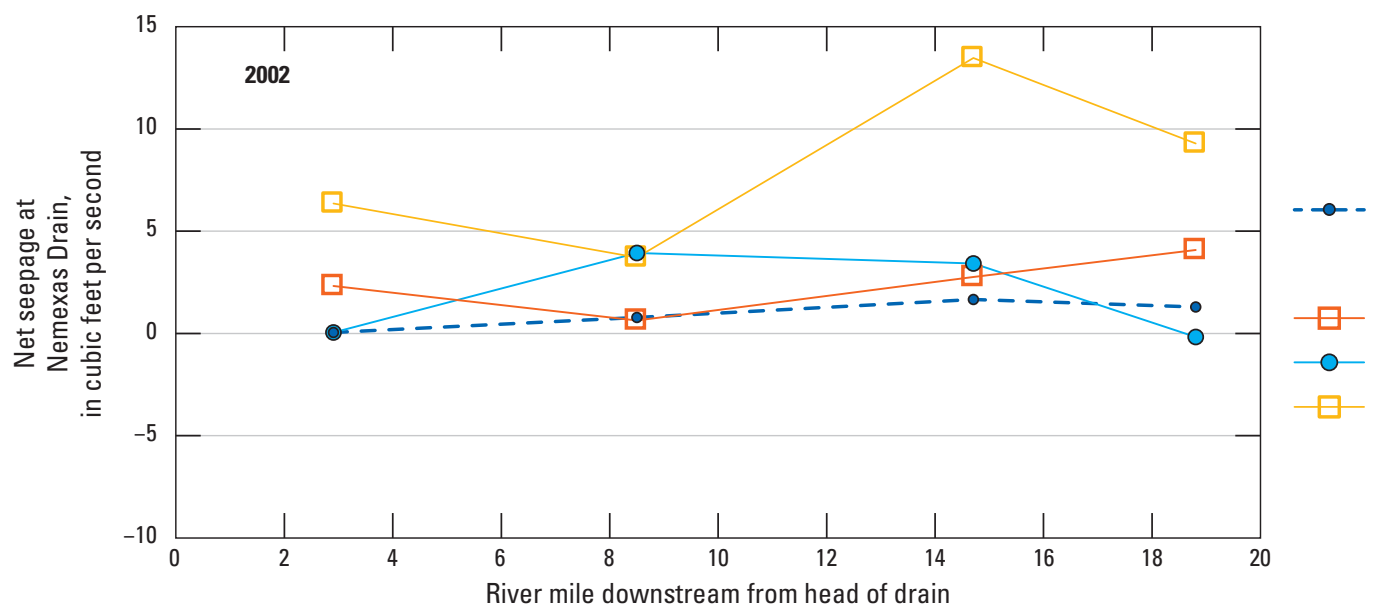

\section{EXPLANATION}

Rio Grande Transboundary Integrated Hydrologic Model (RGTIHM) simulated seepage, February

Byrd and others (2003), February

RGTIHM simulated seepage, August

Byrd and others (2003), August

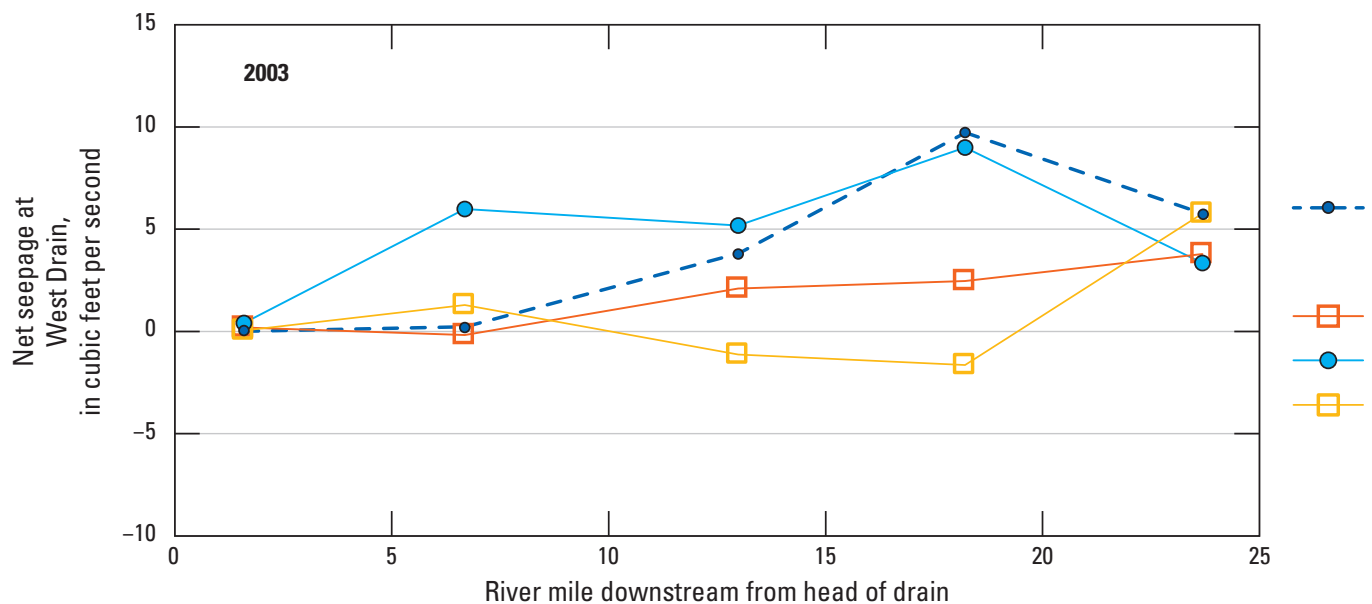

EXPLANATION

Rio Grande Transboundary Integrated Hydrologic Model (RGTIHM) simulated seepage, February

Byrd and others (2004), February

RGTIHM simulated seepage, August

Byrd and others (2004), August

Figure 27. -Continued 
$\boldsymbol{A}$
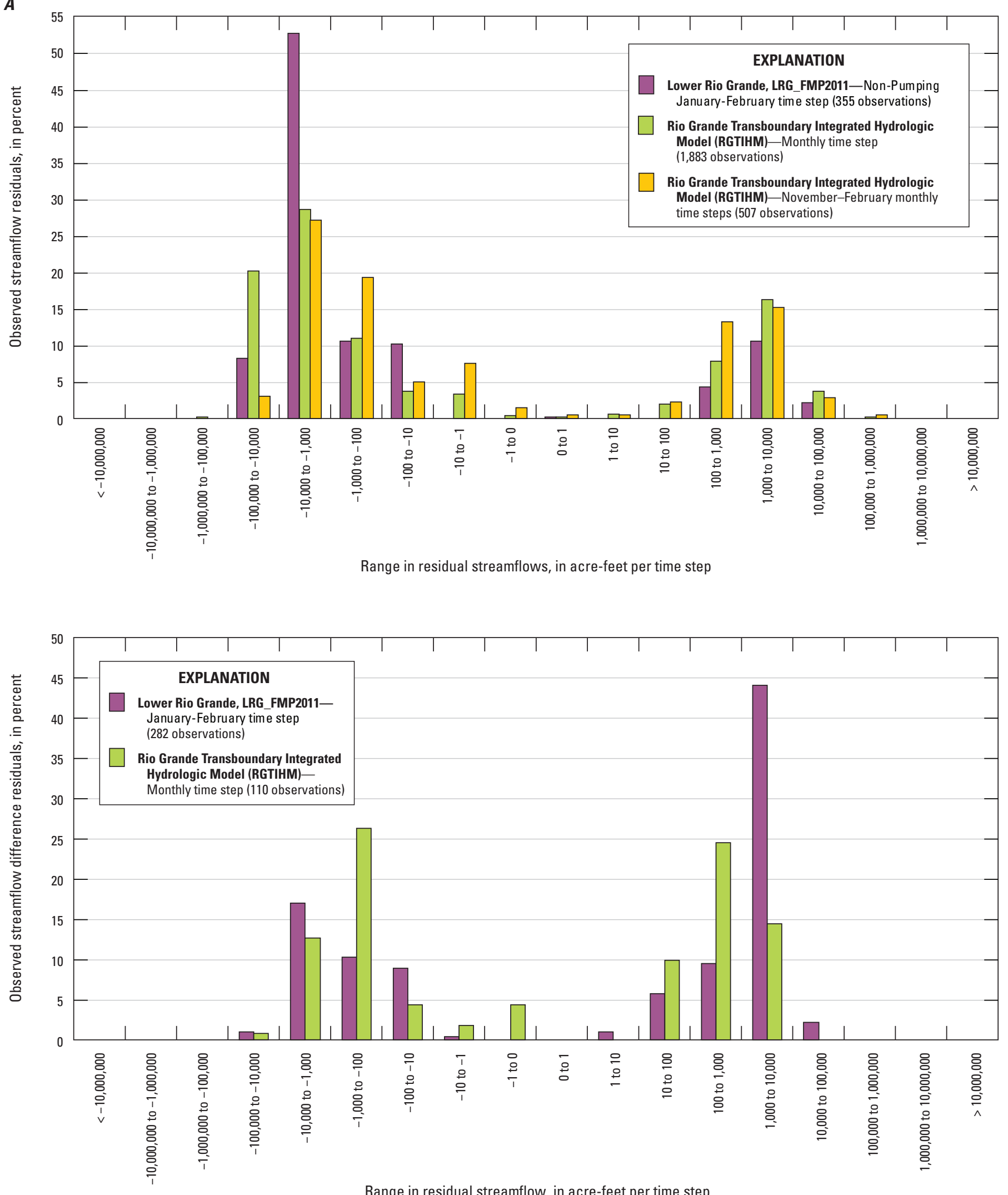

Range in residual streamflow, in acre-feet per time step

Figure 28. Histogram of residuals for the Transboundary Rio Grande, New Mexico and Texas, of $A$, streamflow and streamflow differences for selected months for Rio Grande streamgages; and $B$, canal and drain flows. 
B
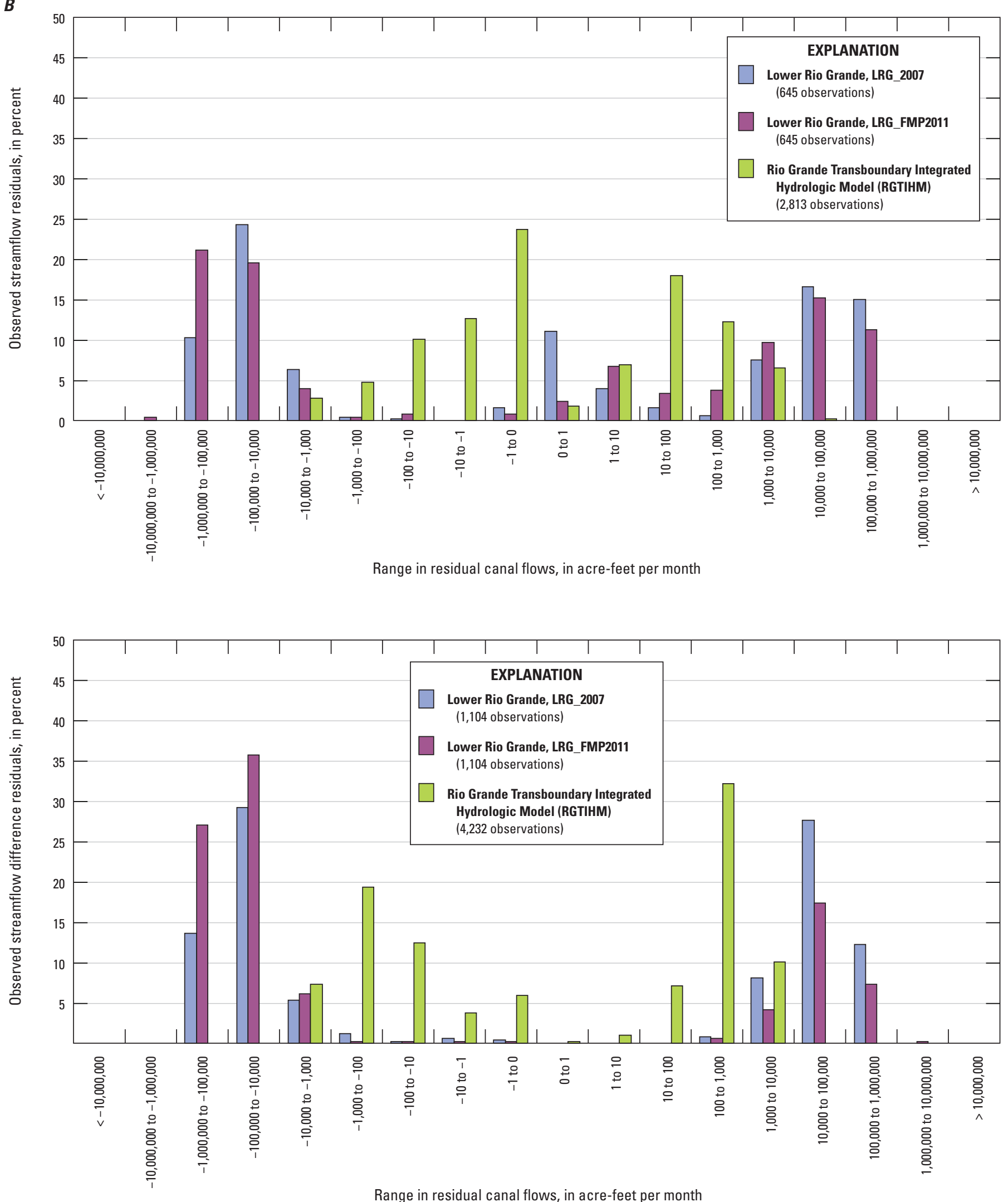

Figure 28. - Continued 
The RGTIHM simulates the conveyance of water in canals (fig. 27), and comparison of simulated to observed annual flows indicated that 90 percent of simulated canal flows and 82 percent of simulated drain flows (fig. 28B) agreed within 1,000 acre-ft/yr $\left(1.38 \mathrm{ft}^{3} / \mathrm{s}\right)$. The RGTIHM simulated water deliveries also compared well with many of the presumed surface-water delivery limits expressed as the potential area-weighted surface-water allotments, which are based on the area of WBSs and volumetric area-weighted fractions of deliveries (fig. 29). For these 9,300 potential surface-water allotments, the simulated surface-water diversions were compared with the respective WBS diversions from delivery canals (fig. 30A), indicating that 91 percent of the diversions within 5,000 acre- $\mathrm{ft} /$ month and 60 percent within 1,000 acre- $\mathrm{ft} /$ month of the potential surface-water allotment targets. The distribution of surface-water flow observation residuals also could be an artifact of streambed properties changing through time, which is apparent from the changing seepage-loss profiles as well as the multimodal distribution of releases from the Caballo Reservoir that do not have a normal, or Gaussian, distribution. The RGTIHM simulated diversions generally replicated the diversions for El Paso Valley at American Diversion Dam and the Acequia Madre for Mexico at the International Dam (figs. 8B, 30B); the correlation between observed and simulated deliveries to Mexico was generally good for the period of simulation (fig. 30C). The observed and simulated flows achieve the annual allotment to Mexico 91 percent of the time within $10,000 \mathrm{acre}-\mathrm{ft} / \mathrm{year}$. The relation between annual gross diversions and reservoir releases from Caballo Reservoir is shown for 1953-2014 in figure 30D. The annual gross diversions were the sum of diverted flows at Arrey, Leasburg, Eastside, and Westside Canals plus the Percha and Del Rio laterals and the Rio Grande at El Paso (IBWC gage at Courchesne Bridge). The RGTIHM is capable of representing RGP delivery performance in terms of the relationship between annual reservoir releases from Caballo Reservoir and annual gross diversions (fig. 30D) with 94 percent agreement of the total deliveries to within 50,000 acre-ft/year for the period 1953-2014. This represents 89 percent of the simulated deliveries are within 20 percent of the total reported deliveries for this historical period. Overall, the RGTIHM systematically overestimated the gross diversions. This could be related to a combination of the estimates of NMOSE-CIR and related underestimation of consumption, an overestimation of inefficient losses, or to an overestimation of drain-flow capture of groundwater. 
A

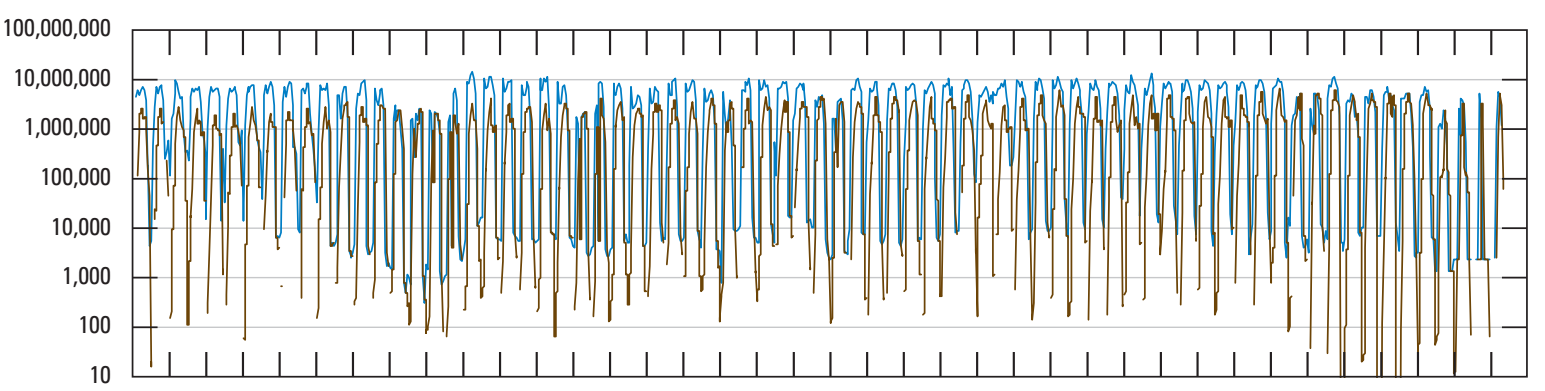

B

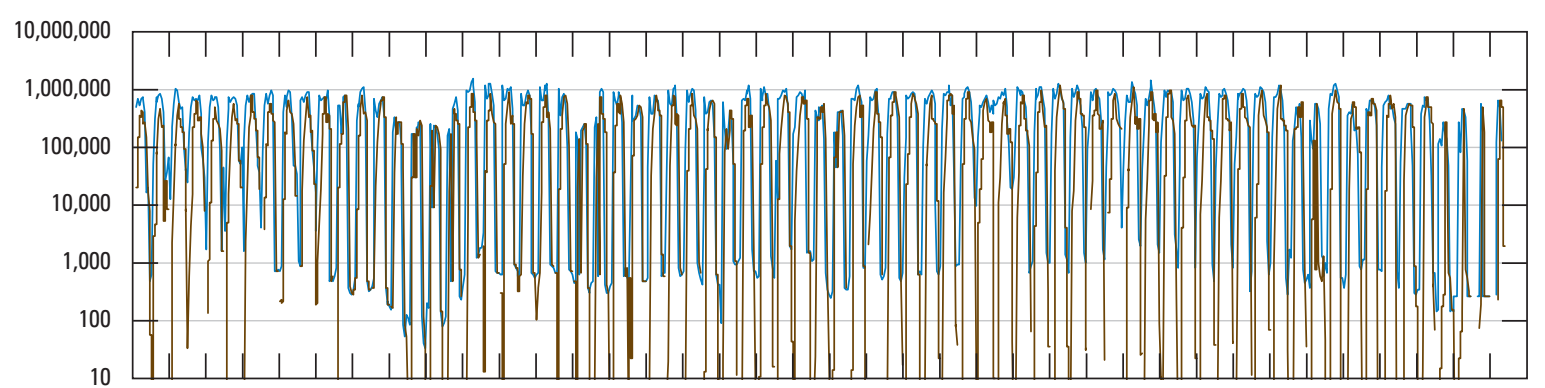

C

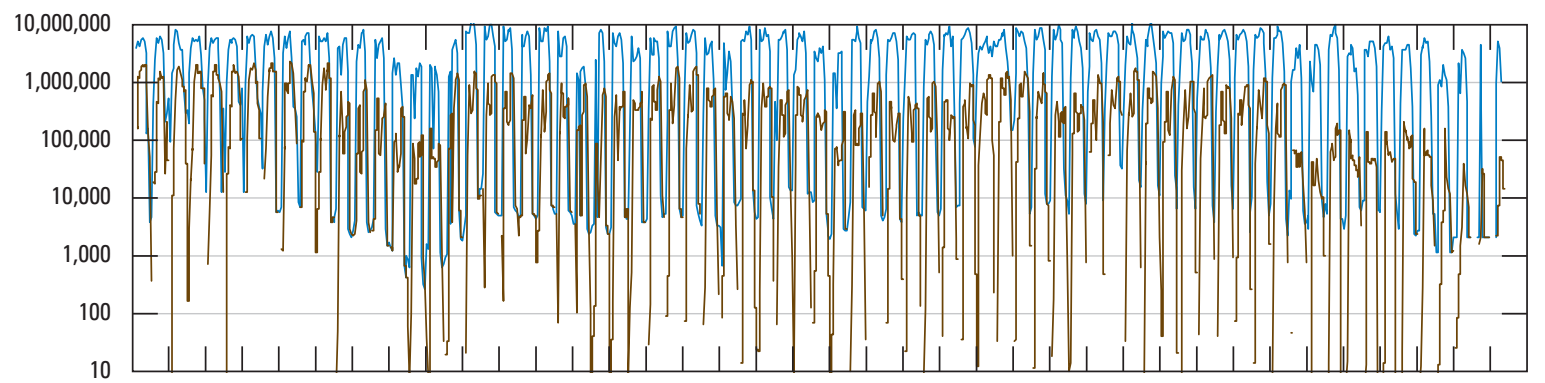

$\boldsymbol{D}$

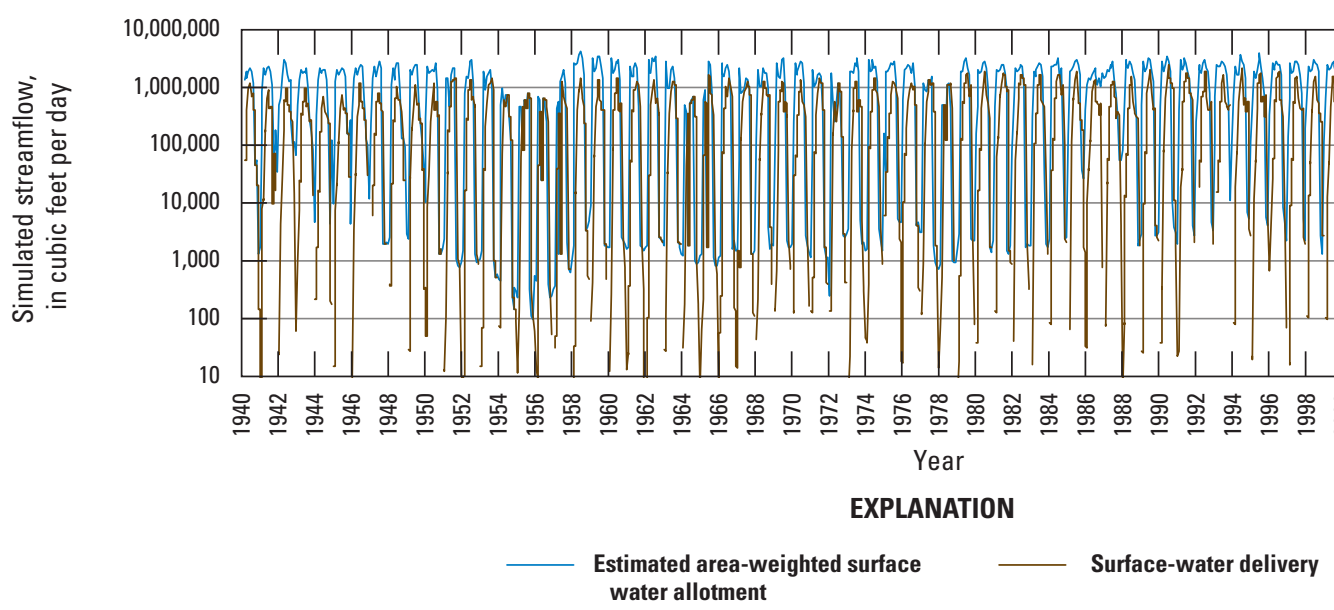

Figure 29. Simulated surface-water deliveries and estimated allotment limits for selected water-balance subregions for the Transboundary Rio Grande, New Mexico and Texas, 1940-2014: $A$, Rincon Valley water-balance subregion (WBS) 3; $B$, upper Mesilla Basin WBS 15; C, middle Mesilla Basin WBS 31; $D$, middle Mesilla Basin WBS 48; $E$, lower Mesilla Basin WBS 56; and $F$, lower Mesilla Basin WBS 57. 
$E$

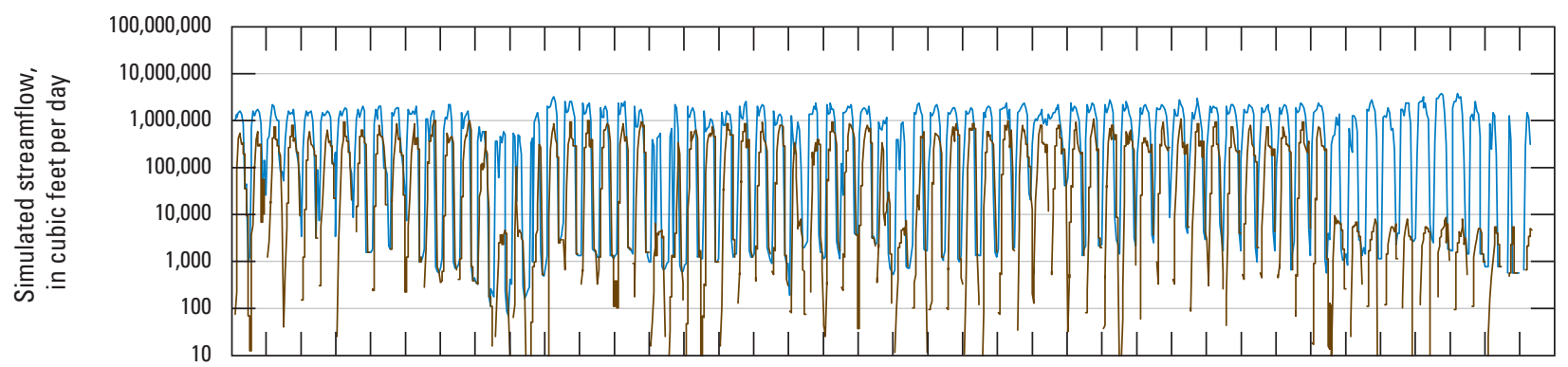

$\boldsymbol{F}$

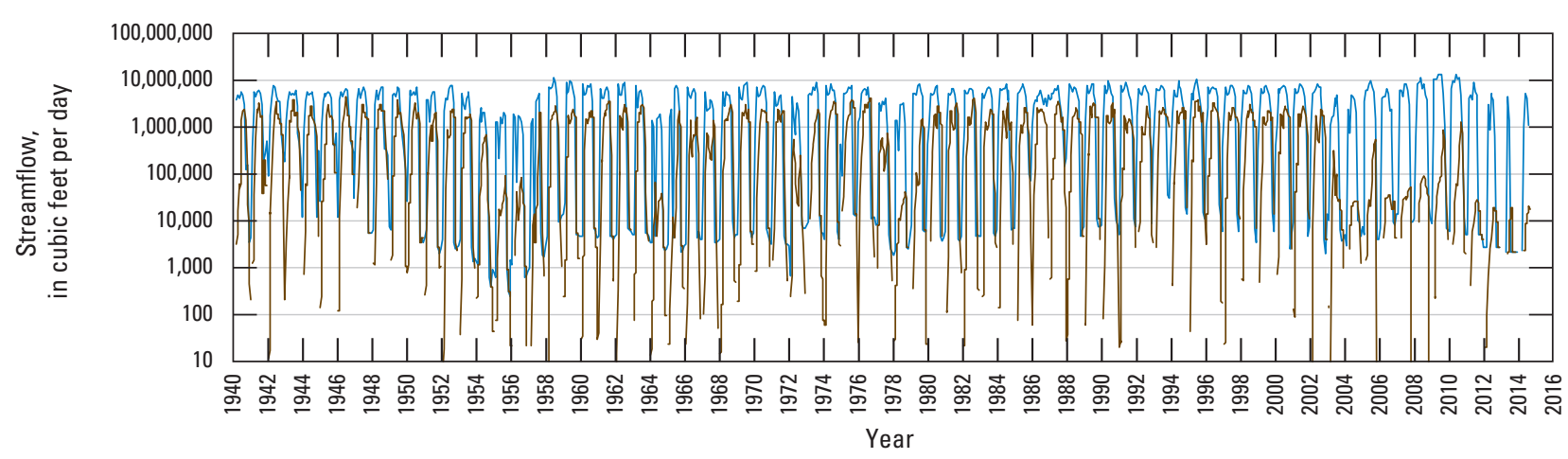
EXPLANATION

Estimated area-weighted surface Surface-water delivery water allotment

Figure 29. - Continued 
$\boldsymbol{A}$

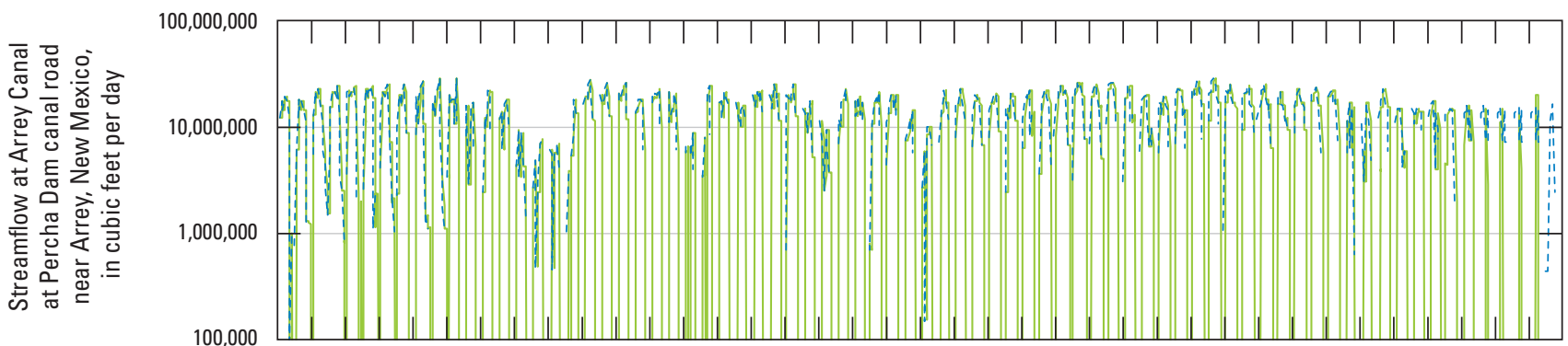

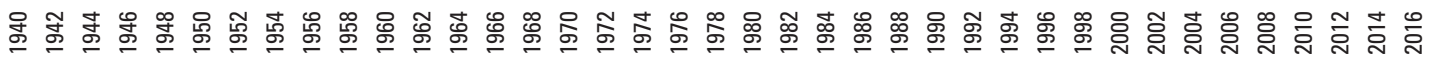

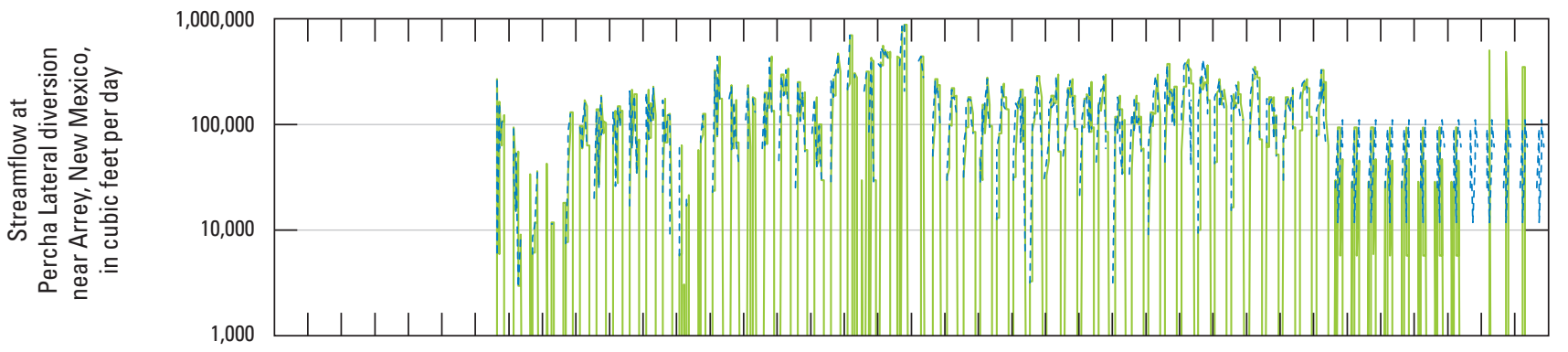

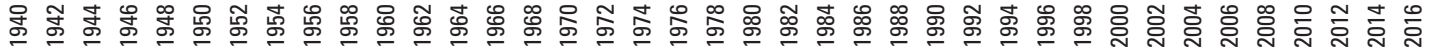
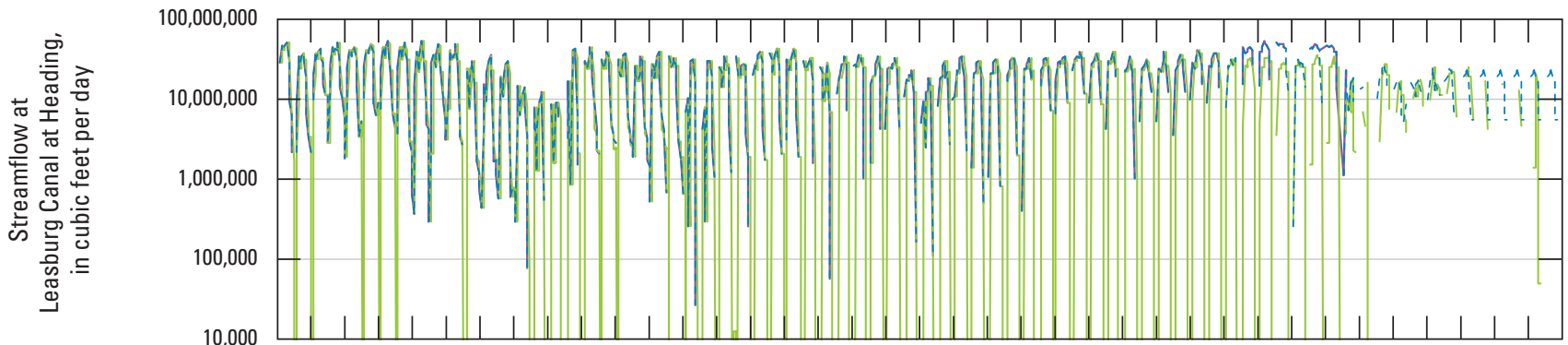

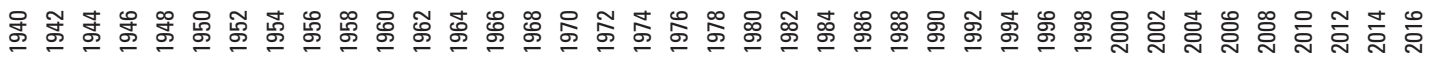

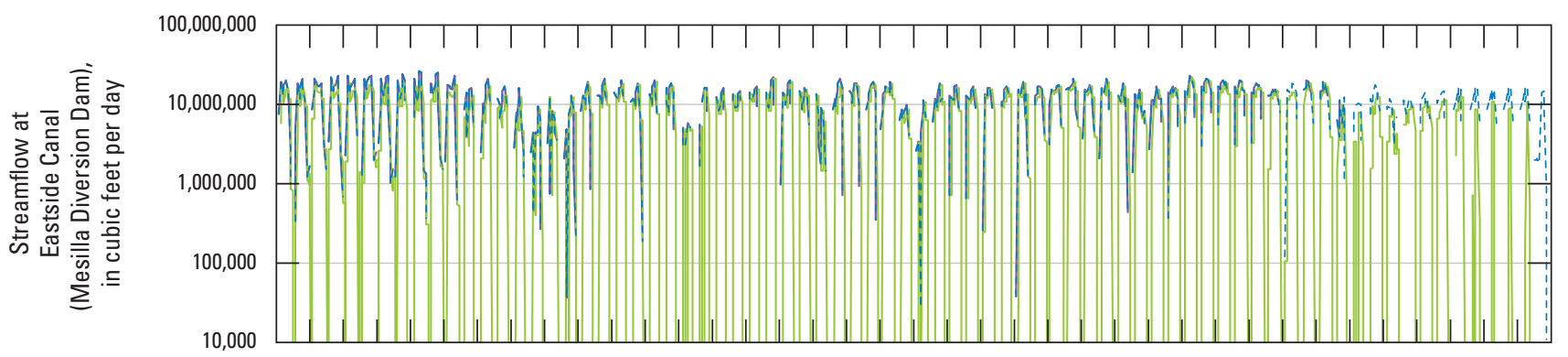

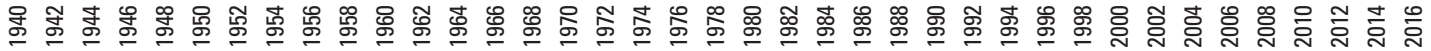

Year

\section{EXPLANATION}

— Observed flow $\quad$ Simulated flow _. - _ S Simulated canal diversion

Figure 30. Observed values compared to Rio Grande Transboundary Integrated Hydrologic Model (RGTIHM) simulated values for the Transboundary Rio Grande, New Mexico, Texas, and Mexico: $A$, diversions for selected canals; $B$, deliveries to El Paso Valley and Mexico; $C$, correlation for deliveries to Mexico as annual RGTIHM simulated diversions at the International Dam (Acequia Madre) compared to annual diversion allocation to Mexico; and $D$, annual sums of observed and simulated diversions at the Percha Lateral and Arrey, Leasburg, Eastside, and Westside Canals and divertible for Texas (Rio Grande streamflow at Courchesne Bridge at El Paso, 314809106322810) compared to the annual release from Caballo Reservoir, 1940-2016. 


\section{A-Continued}

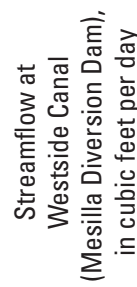

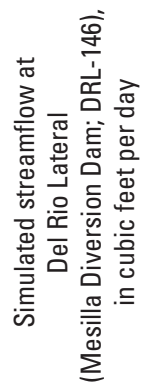

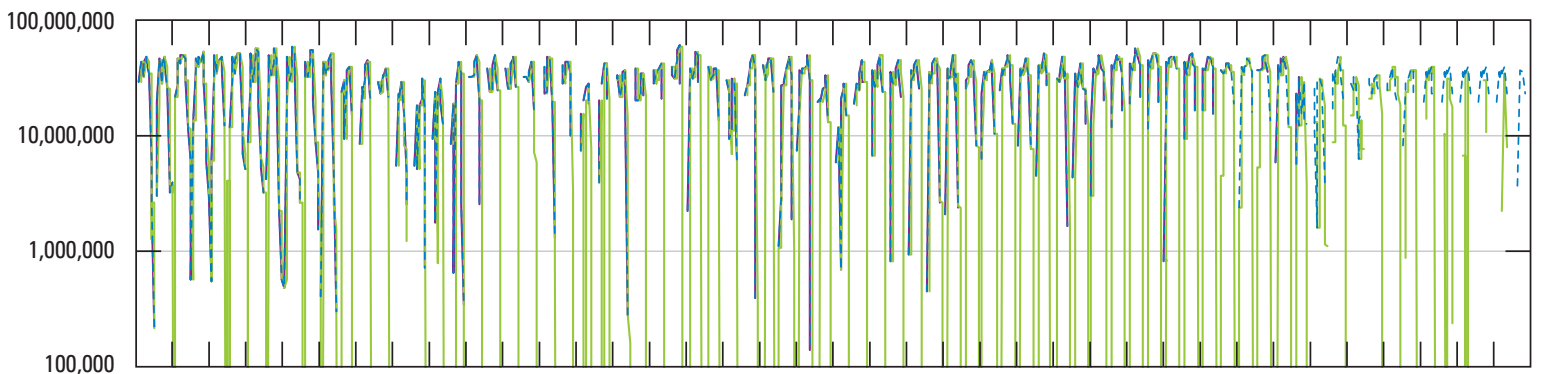

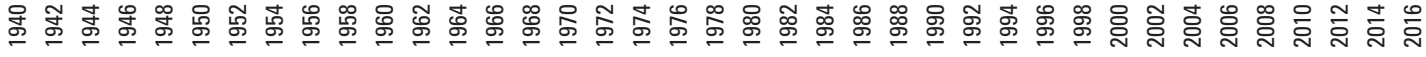

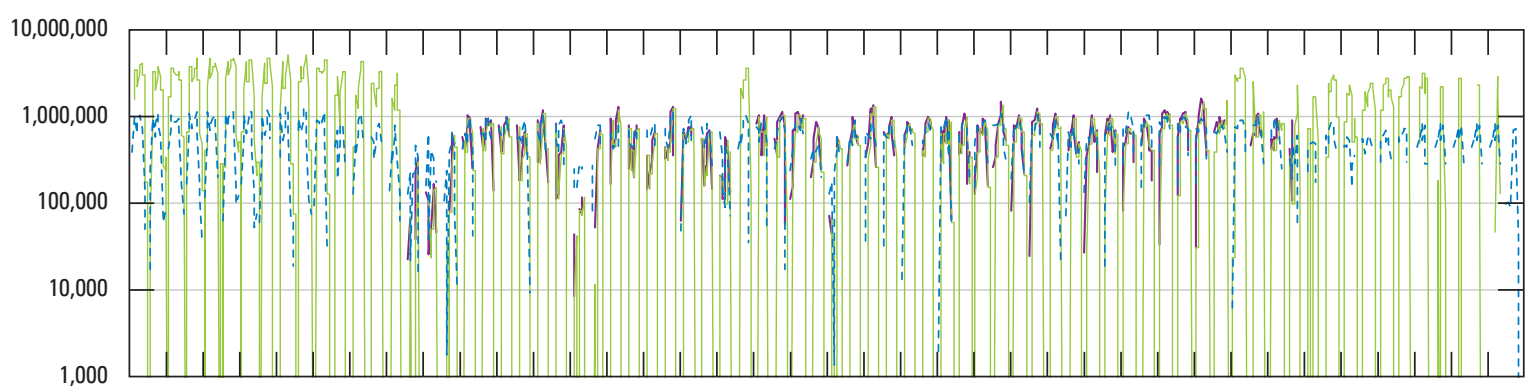

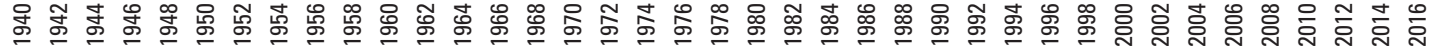
Year

EXPLANATION

Simulated flow _- - Simulated canal diversion

\section{B}

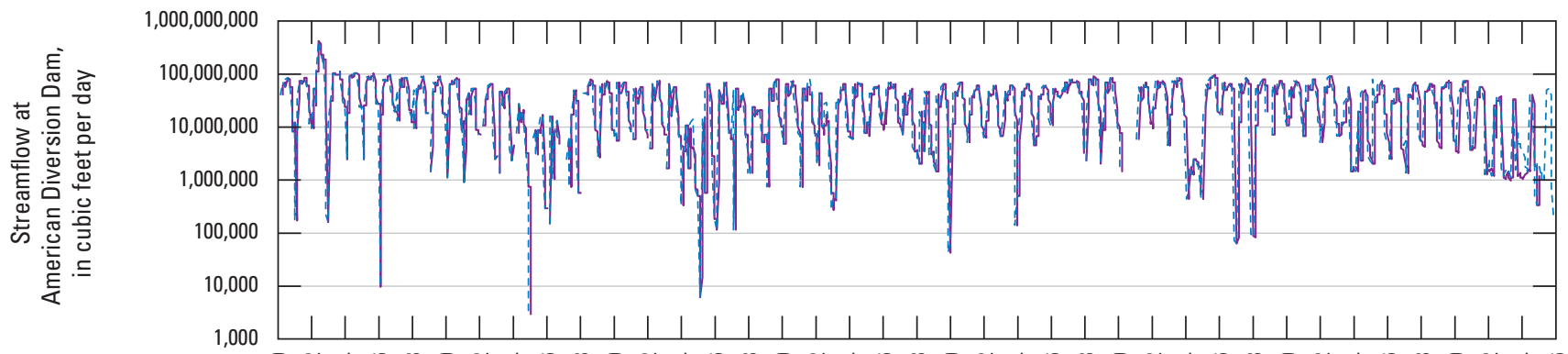

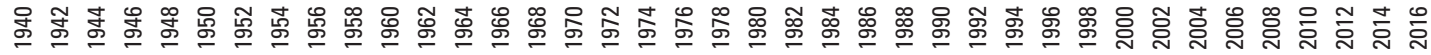
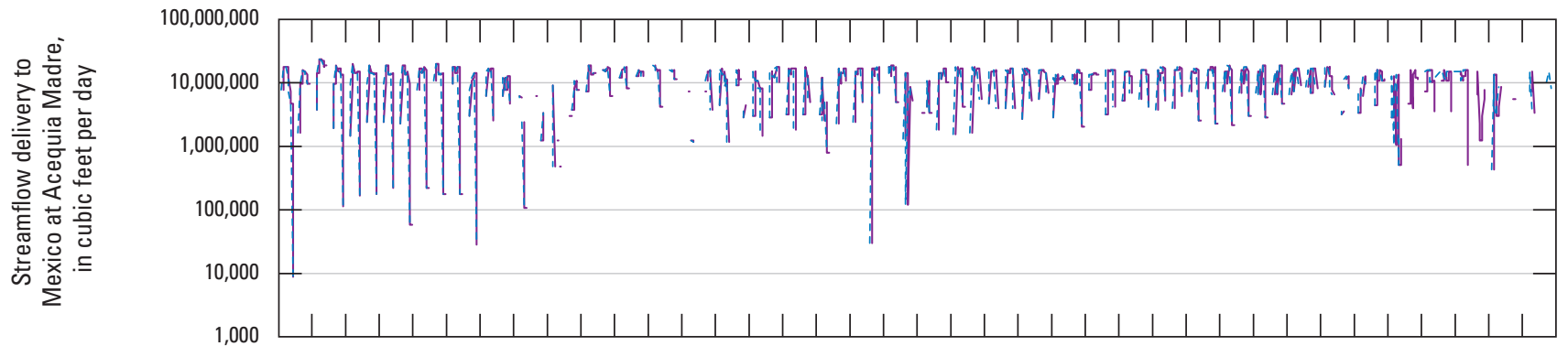

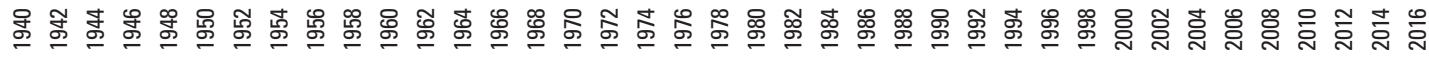
Year EXPLANATION

— Simulated diversion - - - - Observed diversion

Figure 30. - Continued 
C

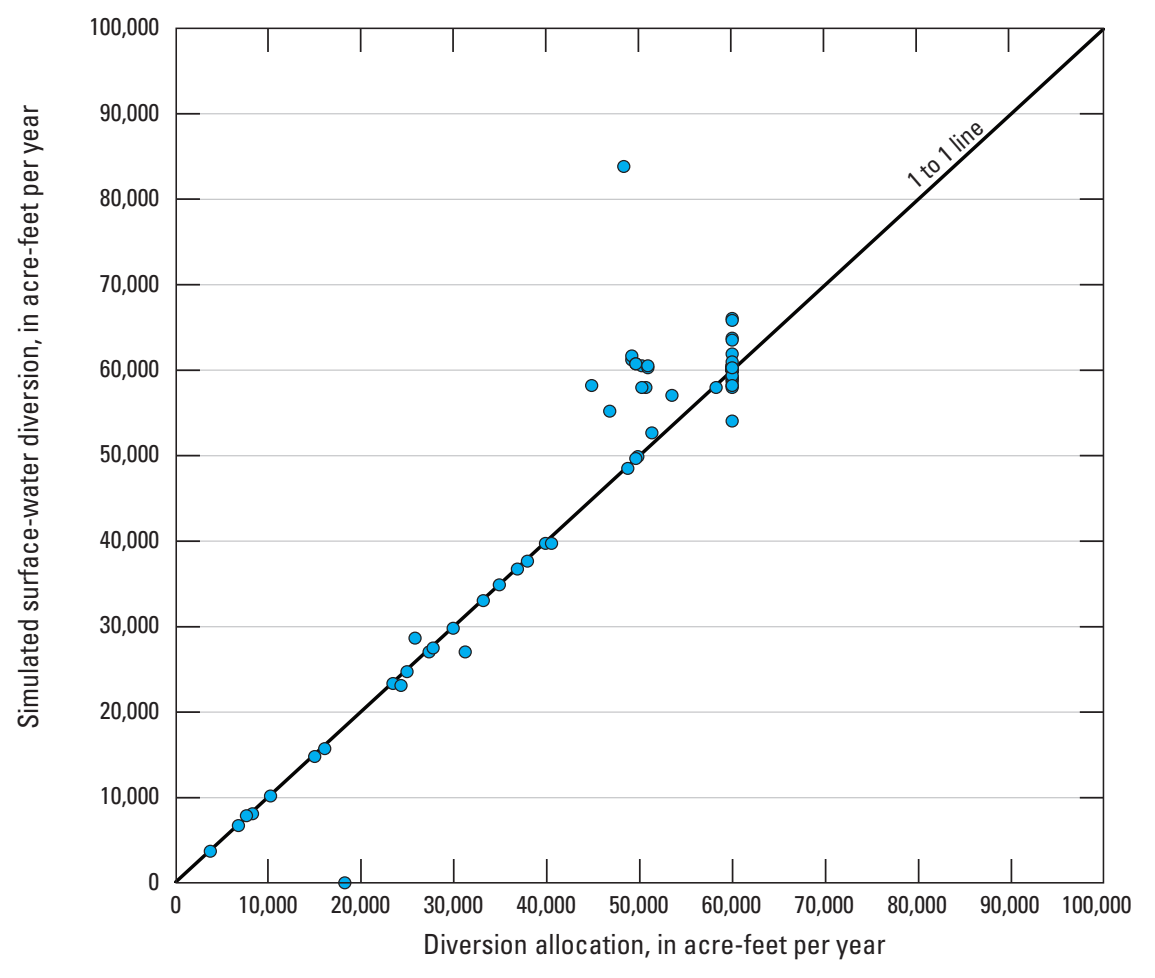

$\boldsymbol{D}$

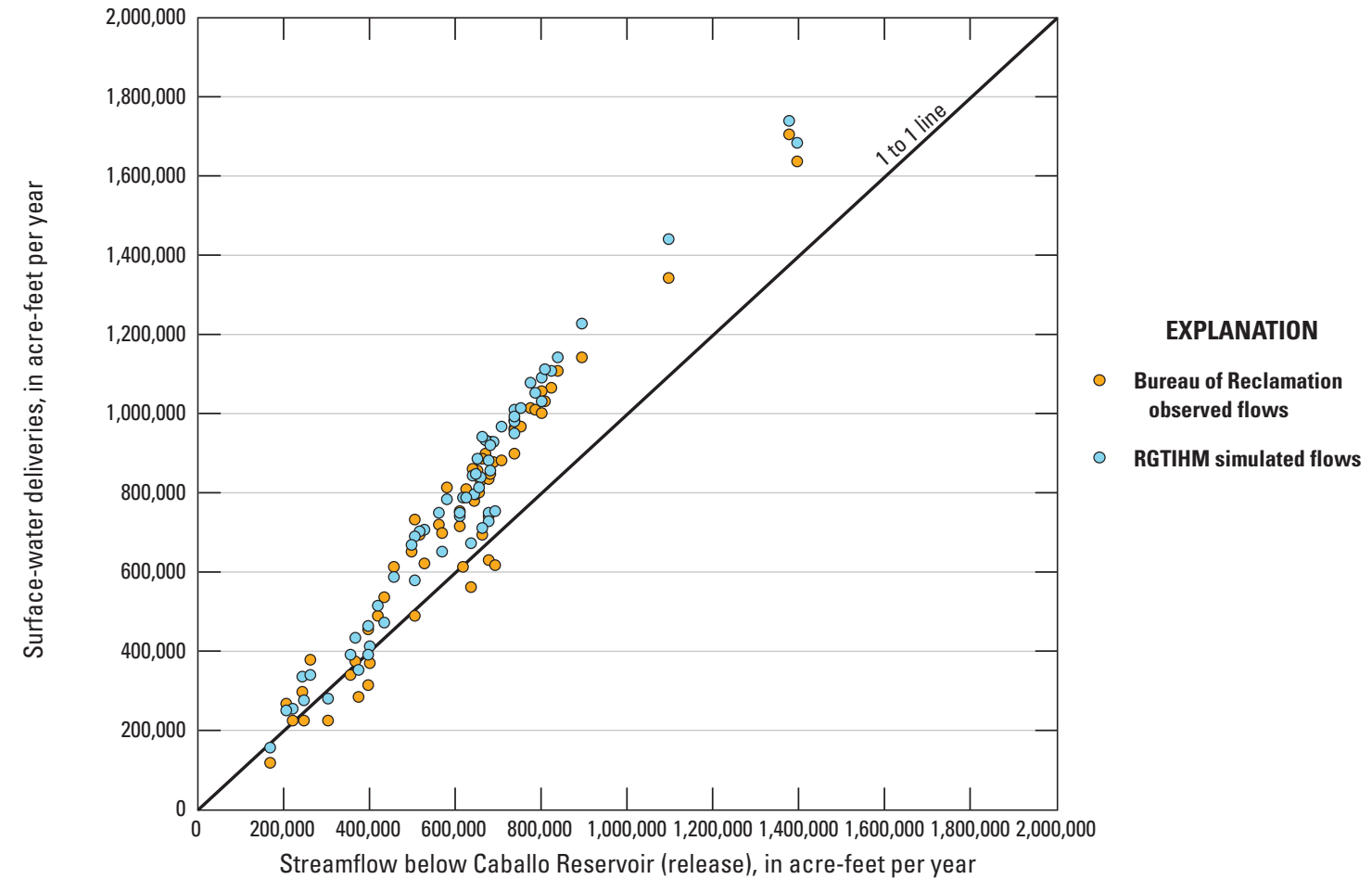

Figure 30. - Continued 


\section{Pumpage Observations}

As discussed previously in the "Groundwater" section, well-specific records of historical and modern-day (2009-14) pumpage for agriculture were scarce and difficult to obtain for the TRG, even with required metering since 2009 in New Mexico. As a result, estimates of annual total agricultural groundwater withdrawals in Doña Ana County compiled by the NMOSE every 5 years from 1975 to 2010 were used as overall pumpage observations for calibration of simulated agricultural pumpage in New Mexico. Additional observations were obtained from estimates of annual agricultural groundwater withdrawals for the Lower Rio Grande Water Master District (fig. 9A) in New Mexico compiled by the NMOSE from 2009 through 2014. Also, seasonal (January-March, April-June, July-September, and October-December) estimates of agricultural groundwater pumpage from 1953 through 2010, derived from the NMOSE estimates of monthly agricultural groundwater pumpage for groundwater-only regions in the four New Mexico agricultural service areas previously used in the LRG_2007 model (S.S. Papadopulos and Associates, Inc., 2007), were used as observations for calibration (Ritchie and others, 2018). These estimates of agricultural pumpage in New Mexico were used as observations both for manual and for computer-assisted parameter-estimation calibration. Estimates of monthly or annual agricultural pumpage in the Texas part of the TRG region were not found or were not available.

The RGTIHM simulated pumpage matched the reported annual agricultural pumpage for New Mexico within 6.9 percent for all three groups of reported annual pumpage in wet and dry years. The 14 semi-decadal estimates of annual pumpage for the New Mexico part of the RGTIHM were grouped in three periods 1975-2002 (early years), 2003-10 (recent years), and 2011-14 (most recent years) of pumpage in New Mexico on the basis of water-level histories, climate, and reported pumpage. Annual reported pumpage for the early years aligned with climate variability to some degree, but also indicated persistent pumping, even during wet years, as well as potential "water stacking" (selective irrigation on subregions of farms in times of supply shortages) or other land-use practices not well represented by the NMOSE-CIR.
For example, selected years, such as 1990 (overestimation) and 1995-2000 (underestimation), could have had different land use distributions or responses to mixed climate conditions that were not reflected in the NMOSE-CIR. Overall, the reported agricultural pumpage for the most recent years increased by about 70 percent relative to the early years and by 50 percent relative to the recent years, in agreement with potential historical changes in land use or land-use practices, such as local water transfers between farms or water stacking in times of reduced surface-water allotments. Estimates of recent agricultural pumpage (2005-14) also showed considerable variability that aligned with differences in climatic conditions. The overall variability in reported annual pumpage declined from 24 percent for the early years to about 6 percent for the most recent years. The recent (2010-14) consistency could reflect the transition to a more "hardened irrigation demand" from increased acreage of permanent crops, such as pecan orchards.

The 14 simulated annual agricultural pumpage estimates for New Mexico between 1975 and 2014 ranged from about 64,900 to 314,800 acre-ft/yr; the associated annual reported pumpage for selected years for New Mexico ranged from about 34,600 acre-ft in 1980 to 284,800 acre-ft/yr in 2013 (fig. $31 A$ ). The simulated annual agricultural pumpage totals were within an average of -10.9 percent of reported values for the early years, within -2.4 percent for the recent years, and within -0.04 percent for the most recent years. Additional comparisons were made for the monthly estimates of agricultural pumpage by the NMOSE for 1953-2010 in regions only irrigated with groundwater in New Mexico (fig. $31 B$ ). Overall the simulated annual agricultural pumpage was within -5.96 percent for all years with reported pumpage, and within 35 percent of the pumpage estimated by the NMOSE for regions with only groundwater irrigation for the years 1953-2010. This indicates that the NMOSE could have overestimated pumpage for the recent years. As did the annual reported pumpage, simulated pumpage increased rapidly in the drought period of 2011-14, which coincided with low reservoir storage and an intensification of agricultural land use that included conversion to orchards for pecan production, which leads to a "hardening" of irrigation demand (fig. 31C). 


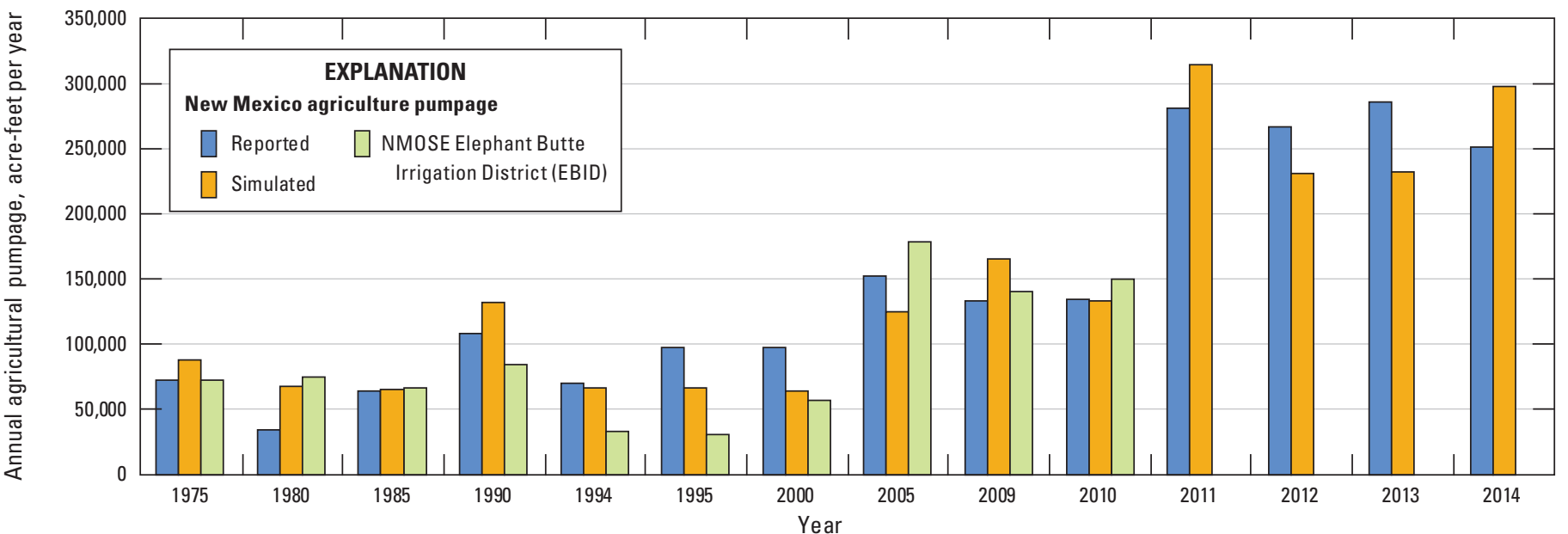

$\boldsymbol{B}$

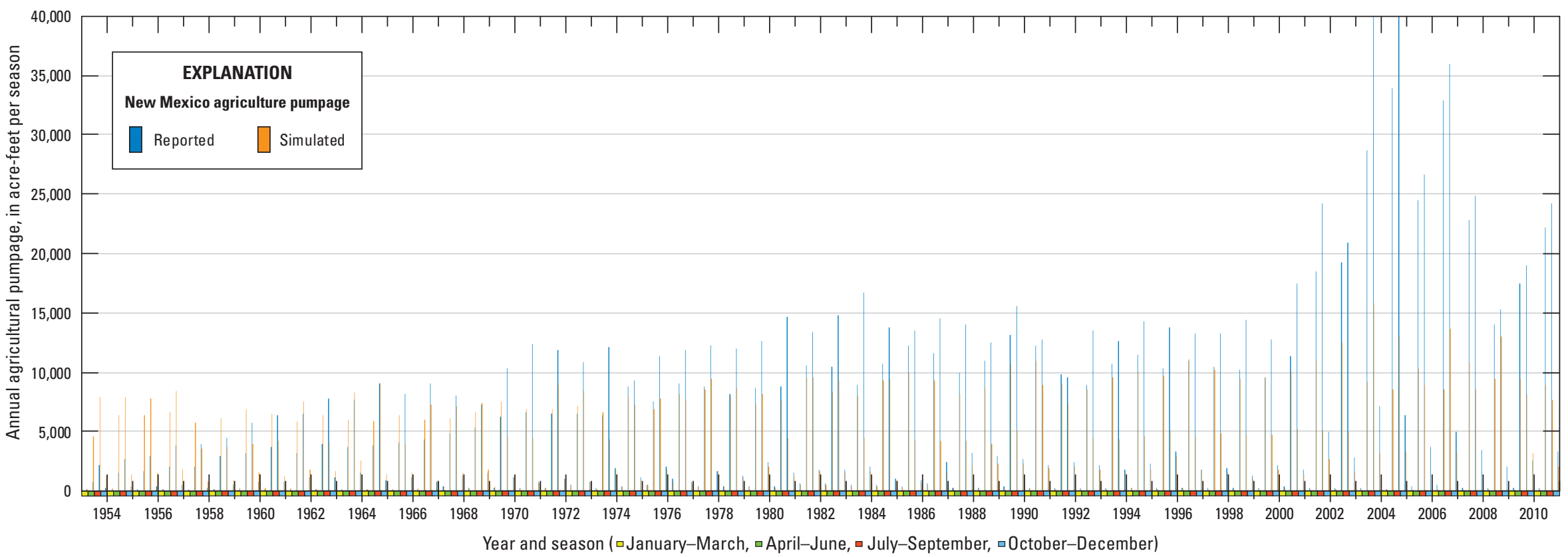

Figure 31. Agricultural pumpage or related land use: $A$, selected annual reported (NMOSE, 2015) and simulated agricultural pumpage for Transboundary Rio Grande in New Mexico; $B$, total monthly pumpage for regions irrigated only with groundwater in the New Mexico part of the Transboundary Rio Grande; and $C$, annual acreage irrigated only with surface water (NMOSE, 2016) for selected crop types in the Elephant Butte Irrigation District, New Mexico. 


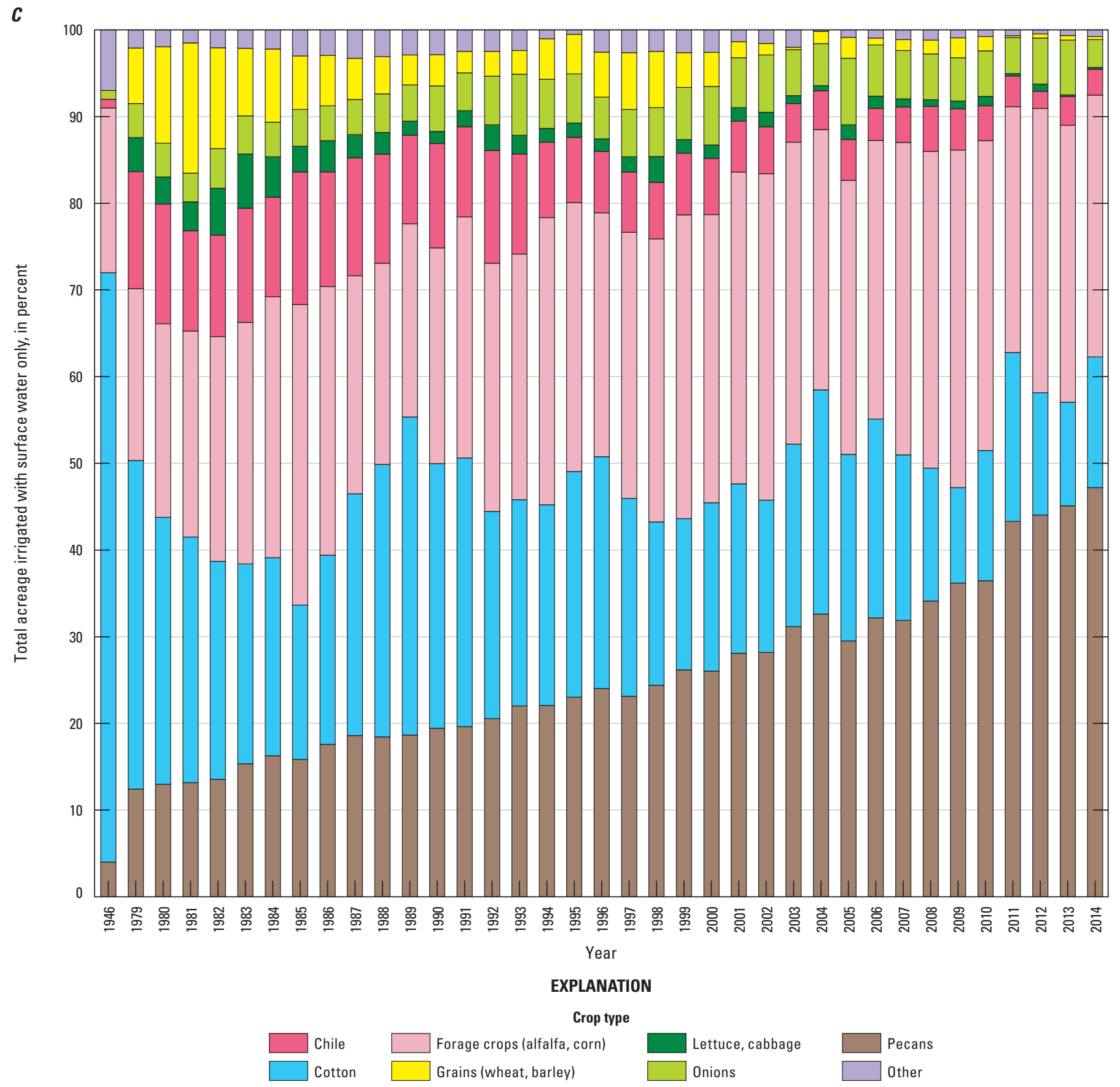

Figure 31. - Continued 


\section{Sensitivity Analysis}

The calibrated model was most sensitive to the scaling factors for initial heads in layers 1 and 2, secondarily to changes in selected landscape climate-scaling factors and surface-water irrigation diversion split fractions, and to a lesser extent to hydraulic properties for some parts of the aquifers and stream network. Computer-assisted parameterestimation techniques using PEST (Doherty, 2004, 2010a-c; Doherty and Hunt, 2010) were primarily used to estimate selected model parameters and related sensitivities, but additional insight was gained from trial-and-error analysis.

The sensitivity to initial conditions might be partially solved by simulating a longer initialization period. Groundwater levels adjusted relatively slowly until groundwater pumpage became important during the 1950s in the TRG region, however, so simulated changes in groundwater levels could take years to decades to mitigate poor estimates of initial or changing conditions. With little information on associated stresses such as pumpage or climate variability, arriving at a potentially less uncertain set of initial conditions is difficult, and the RGTIHM remains sensitive in early periods to estimates of initial conditions. PEST estimates the sensitivity of simulated values to changes in model parameters, where sensitivity is evaluated in relation to observed values at calibration points. Sensitive parameters were identified, which helped to guide subsequent adjustment of some of the parameters during the calibration process (Hill and others, 2000; Doherty and Hunt, 2010a-c). The measure of parameter sensitivity used to remove insensitive parameters was composite scaled sensitivity (CSS), which was computed for 335 of the 350 parameters, while holding the 9 initialhead scale factors and the phantom cells' hydraulic-property parameters fixed; the 51 parameters with a CSS greater than 0.25 are shown in figure 32. Because sensitivities can change with model calibration and adjustments to observation weights, parameter sensitivity depends on the combination of other parameters and observation weights; therefore, the CSS was periodically reevaluated during the calibration process to assess whether previously insensitive parameters became sensitive or previously sensitive parameters became insensitive. The selection of adjustable parameters was changed during manual and computer-assisted calibration.

The 51 most sensitive parameters were related to hydraulic properties (12) such as specific yields, splits for selected diversions (17), selected "stress coefficients" for the CIRs (10), climate-based scale factors for the FTRs (2) and OFEs (6), and selected surface-water bed conductivities (4), when all parameters were allowed to be adjustable except for the initial-head scaling factors and phantom cell hydraulic property parameters (fig. 32). The scale factors that represent climate-based "stress coefficients" for the CIRs estimated irrigation demands in the agricultural WBSs, and the related OFE and FTR scale factors provided additional control on the demand for irrigation. The OFE was also an important factor for determining the amount of artificial recharge through deep percolation as well as the drain return-flow contributions to the drain canals and shallow groundwater levels. The 20 most sensitive parameters (fig. 32, tables 14, 15) included specific yield values for the Quaternary alluvium (model layer 1; parameter SY_RC) and the upper member of the Santa Fe Group where it is exposed as the uppermost model layer (SY_USF1), followed by selected horizontal and vertical hydraulic conductivities (MSFVK35, USFHK15, USFVK15, MSFHK35), selected fractional splits of flow for surfacewater diversions (SPL_81, SPL_127, SPL_108, SPL_199, and others), and selected spring and summer scale factors for the CIRs and FTRs. Other parameters of relative sensitivity and importance during the automated and trial-and-error calibration included some spring and summer scale factors for OFEs (OFE_WET2_SUM, OFE_WET_SPR, OFE_DRY2 SUM, OFE_DRY_SPR, OFE_DRY2_SPR, and OFE_WET2 SUM), and channel vertical hydraulic conductivity parameters for some segments of the stream network, for example, some of the Mesilla Basin sections of the Rio Grande channel ( $\mathrm{RG}_{-}$ MM1, RG_LM2), various drains in the Rincon Valley and Lower Mesilla Basin subregion (LCL_M2), and the hydraulic conductivity of the Quaternary alluvium (RCHK30). 


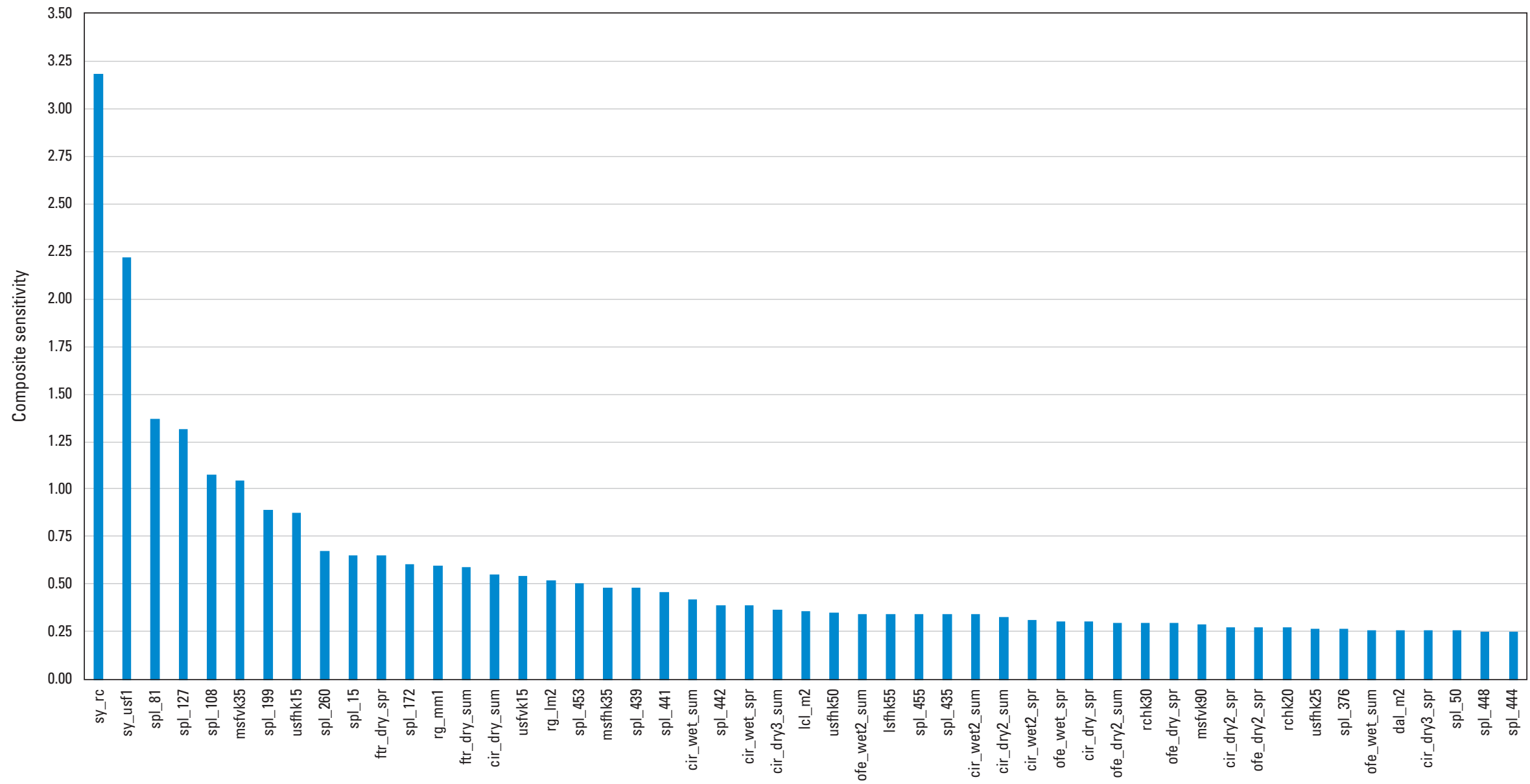

Figure 32. Magnitudes of the relative composite scaled sensitivity for selected parameters computed from observations at calibration points with PEST (see tables 14 and 15 for parameter symbol names). 


\section{Hydrologic Flow Budgets-Rio Grande Transboundary Integrated Hydrologic Model}

The RGTIHM simulation of the conjunctive use and movement of water in the TRG region showed that cyclic storage depletion and the onset of reduced surface-water conveyance efficiency in the RGP were driven by reduced supply during periodic droughts combined with sustained and intensified irrigation and related demands for water. These changes in supply and demand resulted in periodic groundwater overdraft and increased infiltration of RGP water to the groundwater-flow system, which affects conveyance and delivery of the RGP water. Additional recharge from the infiltrated RGP water partially offsets the periodic groundwater-storage depletion from groundwater withdrawals used to supplement surface-water irrigation. The RGTIHM simulations indicated periodic recharge from natural climate cycles, yet recent and historical sustained demand for water exceeded the long-term replenishment rate associated with quasi-periodic climate cycles. The RGTIHM confirmed that overdraft conditions have been periodic since the onset of increased groundwater development in the 1950s to the end of the historical simulation period (2014) and are related to periodic droughts and increased agricultural production. The RGTIHM indicated pumpage consistent with estimates from the selected years of reported total annual agricultural pumpage for part of Doña Ana County, New Mexico, and increases in water demand concomitant with increased agricultural development. The simulated periodic groundwater-storage depletion was predominantly the result of cycles of storage depletion along the Rio Grande in the Quaternary alluvium and the upper member of the Santa Fe Group, as well as sustained storage depletion in the middle and lower Santa Fe Group members, which was climatically driven over seasonal to interdecadal periods.

As with groundwater storage depletion and replenishment, the temporal distribution of inflows to and outflows from the landscape and surface-water systems also reflected a strong climatic influence. Although precipitation on agricultural land is only indirectly represented through the net CIR values, the RGTIHM estimates of total irrigation for the combined Rincon Valley and Mesilla Basin ranged from about 118,000 acre-ft in 1943, predominantly from surfacewater deliveries, to as much as 440,000 acre-ft in 2003 from combined surface-water and groundwater deliveries (fig. 33A). From 1953 to 2014, sources of water for agriculture and native vegetation averaged 39.6 percent surface water, 44.2 percent groundwater pumpage, and 12.4 percent direct uptake of groundwater by ET, with an additional 3.8 percent lost to riparian ET from groundwater (fig. 33B). Similarly, during the same period, simulated total outflow from the landscape averaged 58.3 percent ET from irrigation, 23.9 percent deep percolation to groundwater recharge, 12.4 percent ET from direct uptake of groundwater in agricultural areas, 1.7 percent direct runoff form irrigation, and an additional 3.7 percent of groundwater uptake along the riparian corridor (fig. 33B). Thus, about 39 percent of the inflow of water to the landscape comes from surface waters delivered for irrigation, 44 percent from a combination of groundwater pumpage for irrigation, and about 16 percent from direct uptake of groundwater by ET.

Although the ET from groundwater was less than a sixth of the water consumed, this consumption was an important component of inflow to the landscape that supplemented consumption by phreatophytic crops, such as pecan orchards, when groundwater levels were relatively high. Riparian ET appeared to be a relatively minor component in the entire landscape budget. Simulated deep percolation from irrigation persisted for all years, but generally was greater during wet years, although the effects of precipitation on runoff and deep percolation were not directly represented in the existing model structure. In the 74 years simulated (fig. $33 A$ ), the total demand for water on the landscape for irrigation was greater than the surface-water deliveries, and groundwater supplemented the water needed for agriculture. Average agricultural pumpage estimated by the NMOSE for the groundwater-only irrigated regions was about 7 percent greater than average annual groundwater irrigation for precipitationbased wet years during 1953-2014 and about 7 percent less than average for precipitation-based dry years, which could reflect lower irrigation efficiencies during precipitation-based wet years.

\section{Water-Balance Subregion Landscape- Delivery Budgets}

The WBS landscape-delivery budget represents the supply and demand components of agricultural lands in the TRG region. This includes an estimate of the demand component as a total farm delivery requirement (TFDR) and the supply components of irrigation from semi-routed surfacewater deliveries and groundwater pumpage (fig. $34 A$ ). In addition, the distribution of surface water in the TRG region is subject to RGP allocation and water accounting procedures, as summarized in the earlier "Surface Water" section and detailed by the Bureau of Reclamation $(2013,2016)$. 
$\boldsymbol{A}$

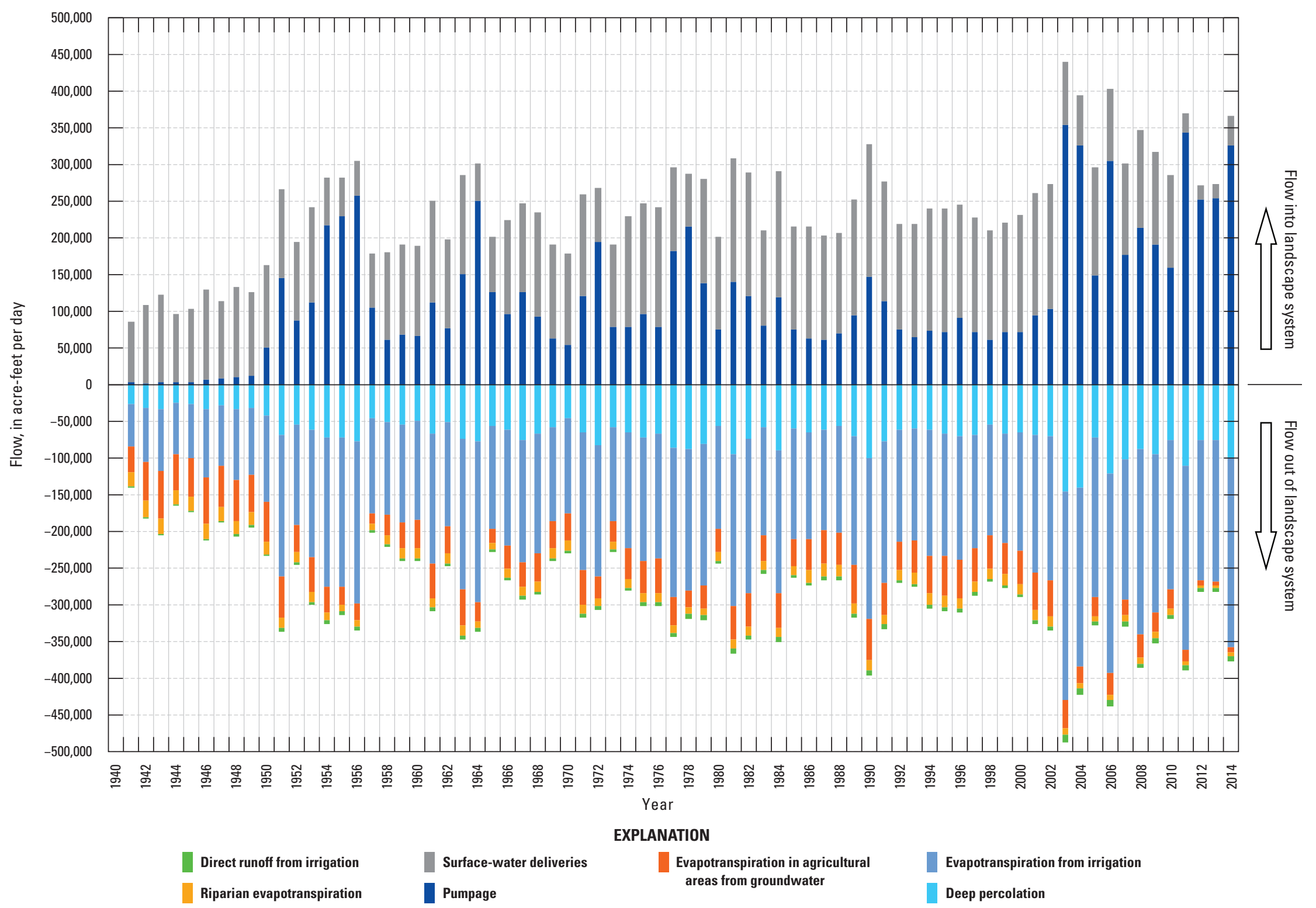

Figure 33. Distribution of water-budget components of inflows and outflows for the landscape and flow system of the Rio Grande Transboundary Integrated Hydrologic Model hydrologic model, Transboundary Rio Grande, New Mexico, Texas, and Mexico: $A$, stacked bar chart showing the annual distribution of contributors to total inflows and outflows, 1941-2014; and B, pie chart showing percentages of average annual components of inflows and outflows for a farm budget of the simulated landscape flow system, 1953-2014. 
B

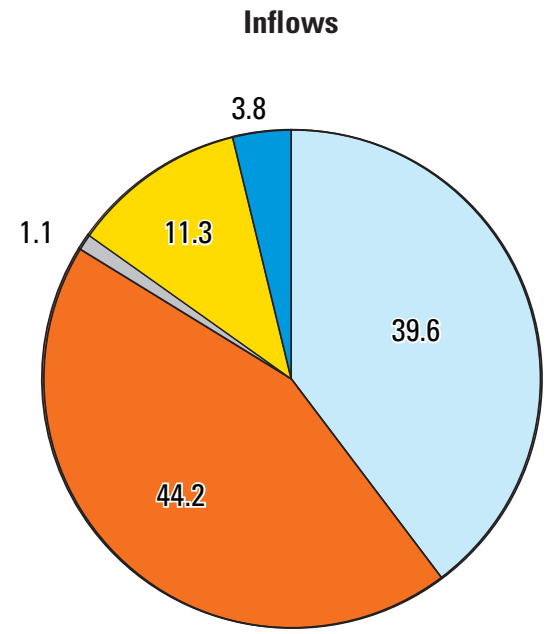

EXPLANATION

Semi-routed deliveries

Groundwater well pumping deliveries

Evaporation uptake directly from groundwater

Transpiration uptake directly from groundwater

Riparian evapotranspiration from groundwater

Figure 33. - Continued

The overall surface-water and groundwater supply and demand (TFDR) components simulated by the RGTIHM for agriculture in the TRG region indicated the following:

1. The TFDR increased over time as crops changed and agriculture intensified (fig. 31C), even though total irrigated acreage remained relatively constant or even decreased through 2010 (fig. 7C), and the TFDR also changed in response to river-based wet and dry periods and to the changing land use (fig. 31C), which resulted in an intensification of water demand with increased TFDR (fig. 34A). As discussed earlier, the wet and dry periods are driven by multiple climate cycles.

2. In any given year, the amount of delivered surface water depends on the water available from the previous year's snowmelt runoff in the upstream reservoirs, such that reservoir supply was typically less in riverbased dry years and was further depleted during

\section{Outflows}

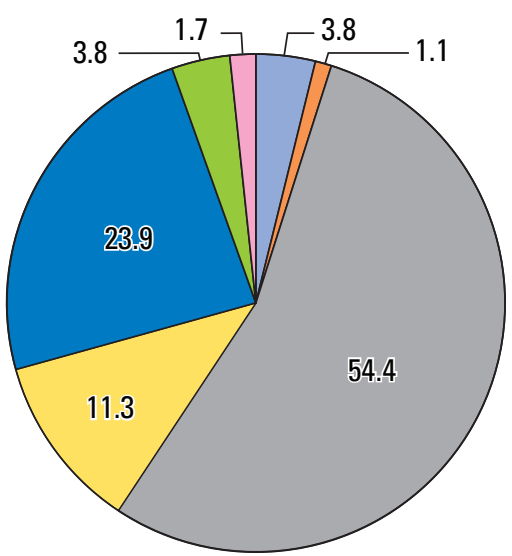

EXPLANATION

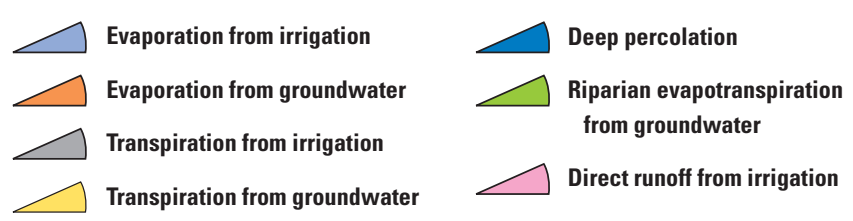

periods of extended drought and smaller reservoir releases (figs. $34 A, B$ ).

3. Groundwater pumping increased as a function of TFDR, and as TFDR exceeded available surface-water supplies, additional groundwater was pumped to supplement the deficit of surface-water supplies (fig. 34A).

4. During the recent drought years (2003-04, 2006-07, and 2011-14), depleted RGP water supply was not adequate to meet demand (fig. 34B).

5. Groundwater pumpage has become the relatively larger part of supply for irrigation during the largely dry surface-water years since 2003 (fig. 34B). 

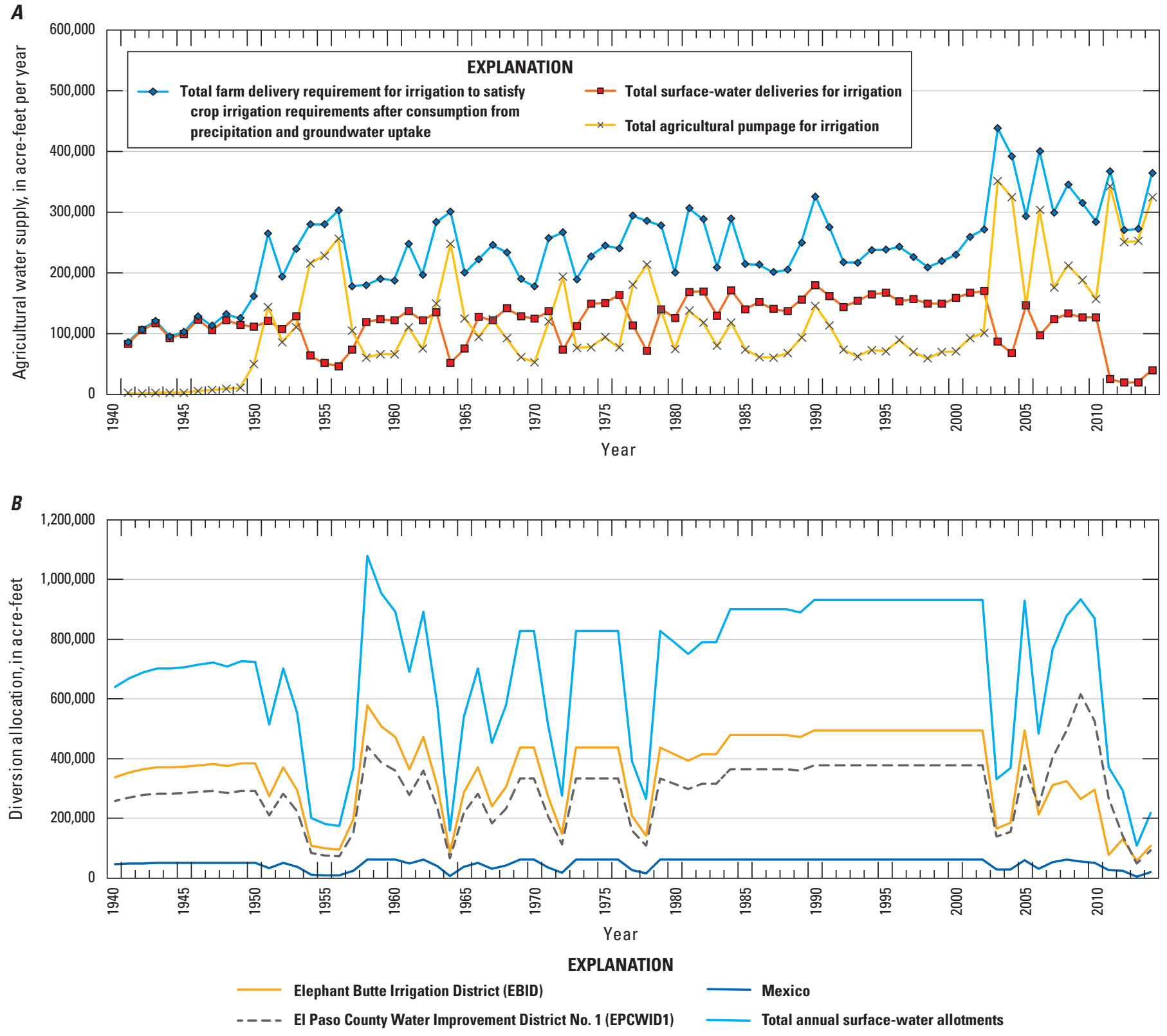

Figure 34. Agricultural irrigation components for the Rio Grande Transboundary region of New Mexico and Texas, 1940-2014: A, total agricultural water supply-and-demand; and $B$, the allotments from the Rio Grande Project. 


\section{Surface-Water Flow Budget}

The surface-water network provides the fundamental structure for the delivery and reuse of water for irrigation for the RGP in the TRG. The river, canal, and drain-flow budgets indicated that RGTIHM could simulate most of the surface-water flows, deliveries, diversions, and return flows throughout the Rincon Valley and Mesilla Basin parts of the RGP. Reservoir releases (1953-2014) ranged from 169,940 to about 1.4 million acre-ft/yr, and a median release from Caballo Reservoir was about 657,000 acre-ft/yr (Ritchie and others, 2018). The stream inflows from releases at Caballo Reservoir, specified at monthly intervals, provided the variable surface-water deliveries that supplied agricultural consumption and indirectly drove supplemental groundwater pumpage (fig. 27A); these releases were delivered through a complex network of canals (figs. 27A-D). Deep percolation of irrigation water was subsequently captured through a network of drainage canals and returned to the Rio Grande (figs. 27A-D). These drainage-return flows contributed to surface water deliveries at downstream diversion points in the RGP (fig. 30B).

The streamflow and surface-water conveyance changed during the historical period of simulation. For example, although the seepage runs generally indicated a common downstream pattern of gains and losses along the Rio Grande in the Mesilla Basin, the magnitude and distribution of the major gains and losses changed from year to year (fig. 27E). The overall simulated seepage of groundwater into the Rio Grande also changed through time (fig. 35A). The largest changes were in selected dry years and after 2003. The seepage changed most in the reaches of the Middle to Lower Mesilla basins, where the effects of drought years in combination with increased groundwater pumpage were more pronounced (fig. 35B), which was consistent with previous analysis from the LRG_FMP2011 model (Knight, 2015). Streamflow capture from agricultural pumpage was estimated to be on the order of about $1,000,000$ acre-ft of cumulative capture from groundwater pumpage between Caballo Reservoir and the New Mexico-Texas state line (Knight, 2015, figs. 5-32) for 1954-2009. The seepage estimates presented for the RGTIHM (fig. 35) only showed the simulated historical time series of seepage. Streamflow capture was implicit in these time series, but the quantification of that capture was outside the scope of the RGTIHM development and was not explicitly estimated as part of this study.

Finally, the RGTIHM was able to approximately reproduce the total volume of RGP surface-water diversions on an annual basis. Although the RGTIHM slightly overestimates the volume of divertible water, particularly during the wet years when reservoir releases are larger, the RGTIHM largely reproduces the relationship between the annual RGP releases and the total amount of RGP water available for diversion in the Rincon, Mesilla, and El Paso Valleys (fig. 30D). The ability of the RGTIHM to reproduce this relationship indicated that the RGTIHM realistically represented the water-management practices and hydrologic processes that drive this relationship, including reservoir release and diversions, groundwater pumping, and effects of groundwater and surface-water interactions on seepage losses and drainage return flows. As was demonstrated previously (Hanson and others, 2013), a fully integrated hydrologic model such as RGTIHM is able to assess some of the potential changes in water use and movement, because the MF-OWHM2 model structure of RGTIHM represents as much water as possible in the model without additional preprocessing of flows or loss of water in the simulation by using additional linkages that pass water from one model feature to another. This allows the potential analysis of changes in reservoir operations; new or alternate projects for reuse or water capture and storage or recharge; or changes in conveyance as well as changes in land use, irrigation efficiencies, or return flows (fig. 30D). 

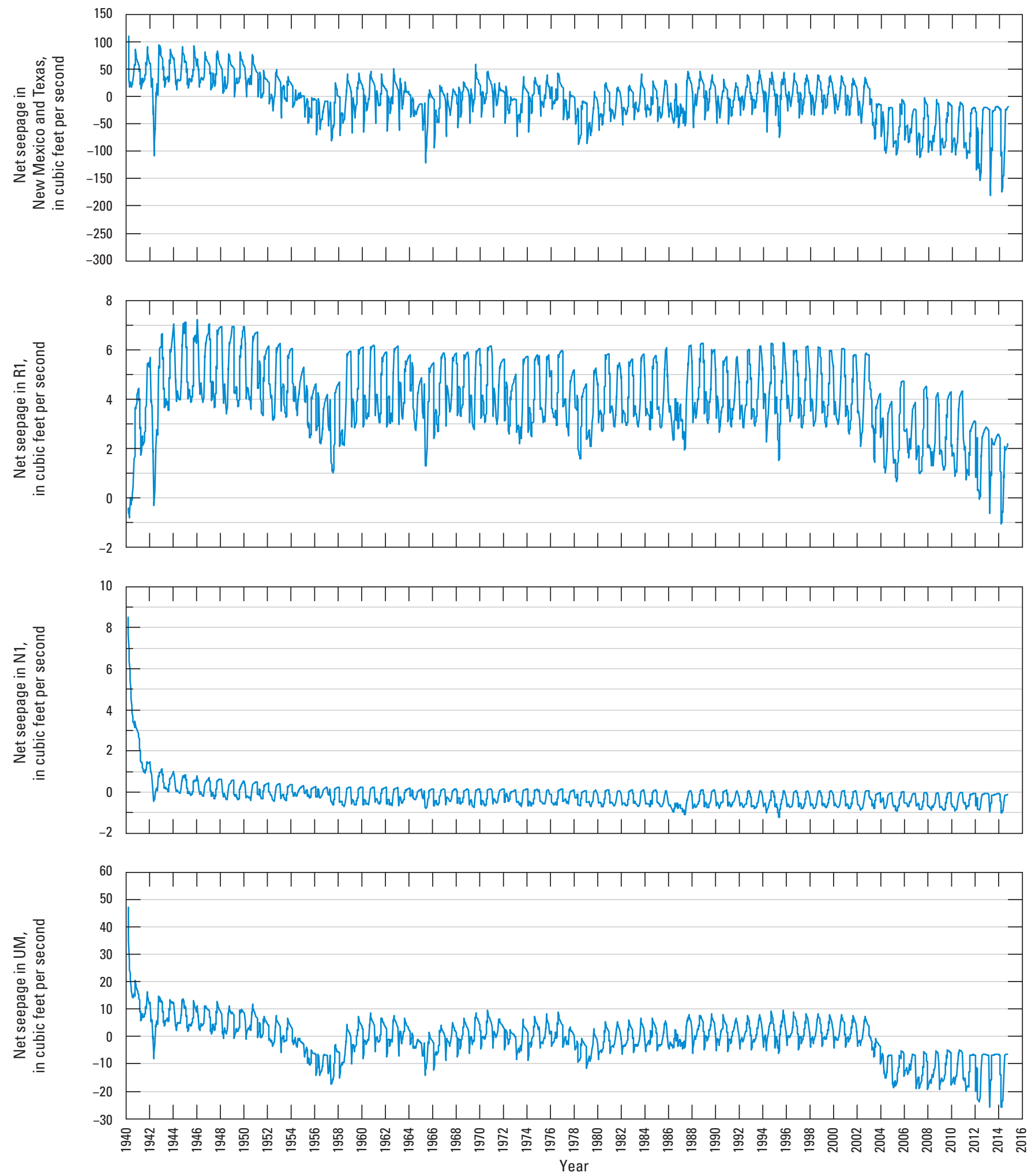

Figure 35. Simulated seepage along the Rio Grande for parameter groups of the Rio Grande Transboundary Integrated Hydrologic Model for the Transboundary Rio Grande, New Mexico, Texas, and Mexico, where positive values indicate gains, and negative values indicate seepage losses, for $A$, the major subregions; and $B$, the individual parameter groups in the upper and middle Mesilla Basin. 


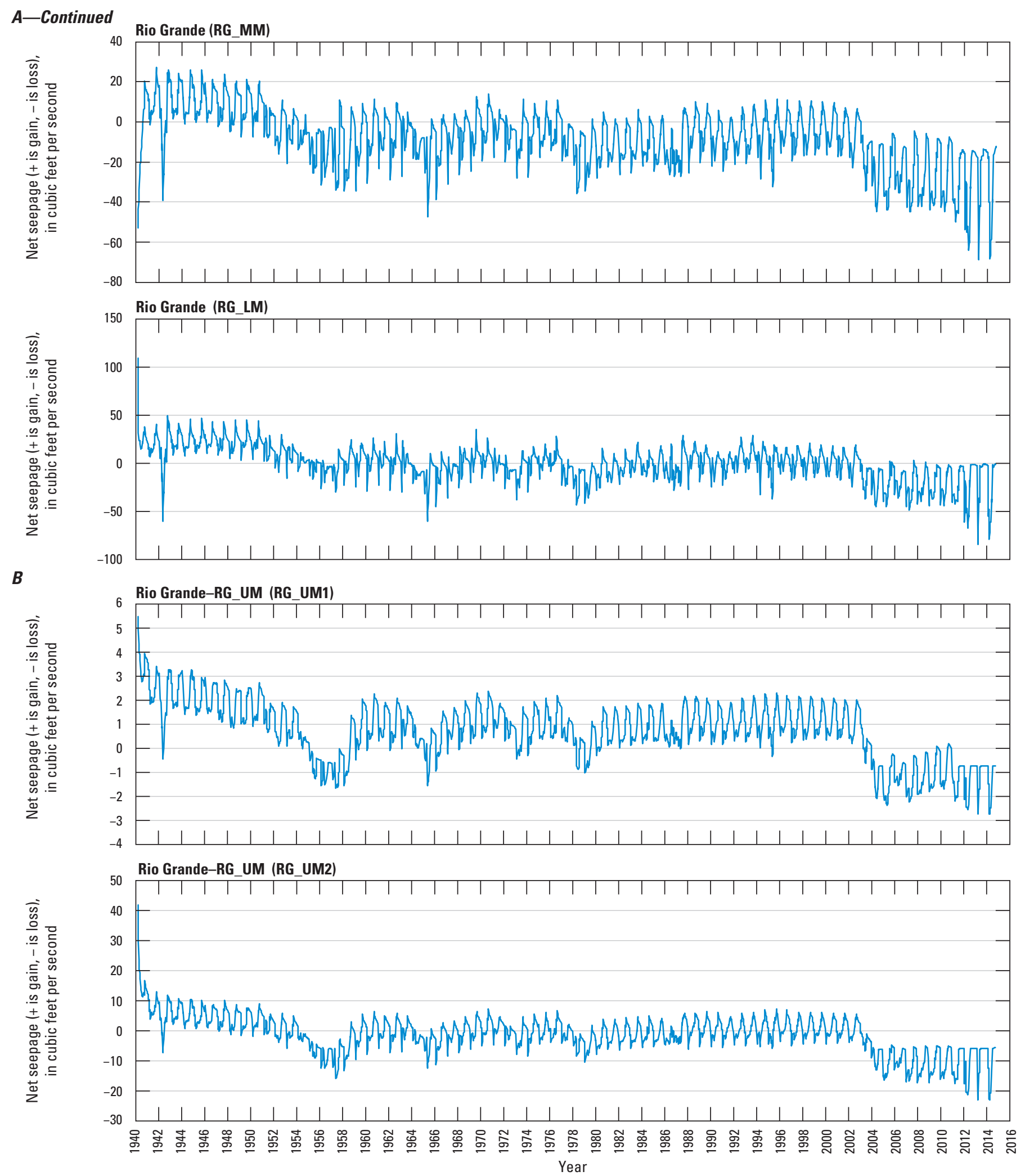

Figure 35. - Continued 


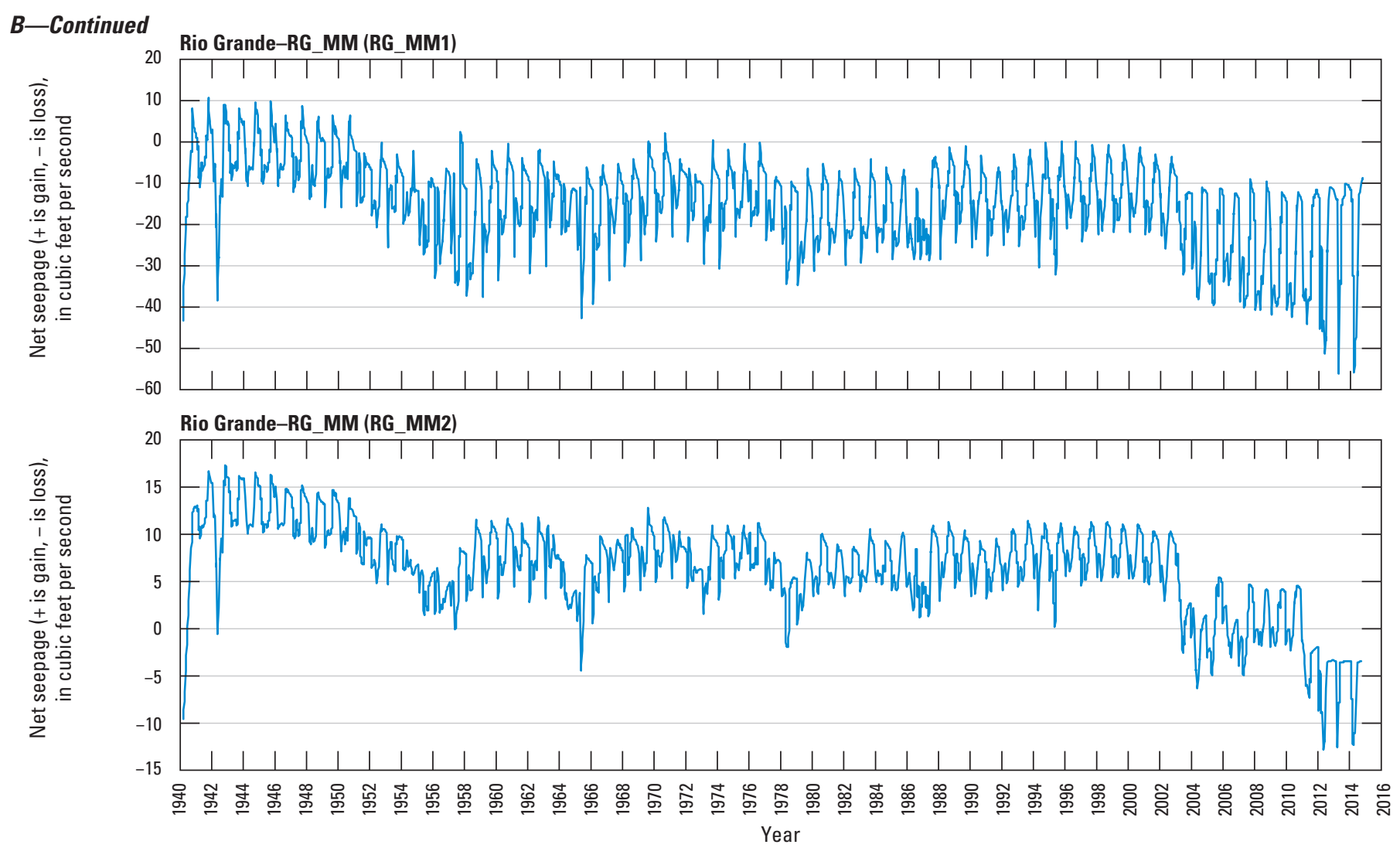

Figure 35. - Continued 


\section{Groundwater-Flow Budget}

The components of the net annual groundwater-flow budget (fig. 36) are similar to inflows and outflows for the landscape and vary with climate and changes in land use (fig. 33A). The average hydrologic budget overall, and for the most recent period (1994-2014), indicated that infiltration from irrigation (farm net recharge) was the largest inflow, and agricultural pumpage was the largest component of outflow, as summarized for selected periods (fig. 36B; table 16). Except for the occasional wet years, the major outflow was agricultural pumpage, most of which was supplied by a decrease in groundwater storage. The net groundwater-flow budget for 1953-2014 averaged about 551,500 acre-ft/yr (in and out of the groundwater-flow system), but can vary widely as shown by the difference between wet and dry years; storage depletions ranged from a storage accretion from groundwater flow of about 92,100 acre-ft in a wet year, such as 1958 , to a depletion of storage into groundwater flow of about 264,800 acre-ft in a dry year, such as 2003. On average and valley wide, water released from storage into groundwater flow averaged about 43,100 acre-ft/yr (table 16) and contributed about 18 percent to the average total groundwater inflow, along with a contribution of 1.1 percent from groundwater underflow, 80.3 percent from recharge as deep percolation and surface-water infiltration, and about 0.7 percent from reservoir leakage. This net surface-water infiltration to groundwater is the total net leakage from all the components of the surface-water network representing rivers, tributaries, canals, and drains and not just net leakage along the Rio Grande. About 56.4 percent of the average groundwater outflow was from agricultural pumpage, with an additional 22.6 percent of groundwater outflow from municipal and industrial pumpage (fig. 36B). The largest component (79 percent) of average groundwater outflow was pumpage, along with 16.1 percent as additional ET from groundwater in agricultural and urban areas, 4.8 percent of outflow as riparian ET, and 0.1 percent groundwater underflow flowing out of the model beneath the Rio Grande south of El Paso narrows (fig. 36B). Storage depletion was mainly from the lower and middle Santa Fe Group members, with small amounts of depletion from the upper Santa Fe Group member and Quaternary alluvium (fig. 36C). The total simulated storage depletion was about 2.67 million acre-ft for 19532014. The annual average storage depletion, $43,100 \mathrm{acre}-\mathrm{ft} / \mathrm{yr}$, was about 31 percent of the average agricultural pumpage, $136,870 \mathrm{acre}-\mathrm{ft} / \mathrm{yr}$ (table 16). The annual average depletion of groundwater flow was about 1,090 acre-ft/yr, resulting in a total overdraft of about 67,580 acre-ft for the 62-year period of 1953-2014. The simulated stream leakage to and from groundwater aquifers and groundwater underflow from adjacent areas increased since 2011 (fig. 36A). The majority of the storage depletion was in the Mesilla Basin from increased pumpage. The recent relatively wet (river-based) year of 2005 and dry (river-based) year of 2011 indicated large concurrent changes in estimated storage depletion, ET from groundwater uptake, agricultural pumpage, and a shift from reduced storage depletion in the upper aquifers and some storage accretion in the Quaternary alluvium (table 16; fig. 36C). Storage depletion can also be affected by capture of discharge, such as streamflow, and can vary temporally (Bredehoeft and others, 1982; Bredehoeft, 1997, 2002; Alley and Leake, 2004). The TRG region exhibited a cyclic pattern for the simulated change in storage that was probably related to both surface-water and local precipitation based climate cycles and long-term increased land-use development along with a related increased demand for water both for irrigation and for public supply.

The temporal distribution of groundwater pumpage is dominated by agricultural pumpage (fig. 37A). Most of the simulated flow of groundwater to wells was from the Quaternary alluvium and the upper member of the Santa Fe Group and collectively ranged between 83 and 98 percent (fig. 36B). Percentage of groundwater pumped from the middle and lower members of the Santa Fe Group and the basement ranged between 2 and 17 percent, and the drier years had less surface-water deliveries, showing the largest contributions from the lower aquifers (fig. 37B). The relative reductions in pumpage during the intervening wet periods showed the sensitivity to climate and related reservoir releases built into the FMP calculations, even without total implementation of climate and land-use features of the FMP. For example, agriculture and related irrigation were sensitive to climate and related surface-water deliveries that are supplemented by groundwater. Only a part of delivered surface water was consumed by crops, as demonstrated by the comparison of simulated agricultural pumpage to estimated pumpage for the early years of the simulation, when surfacewater deliveries were the primary source for irrigation (figs. 34, 37A). 
$\boldsymbol{A}$

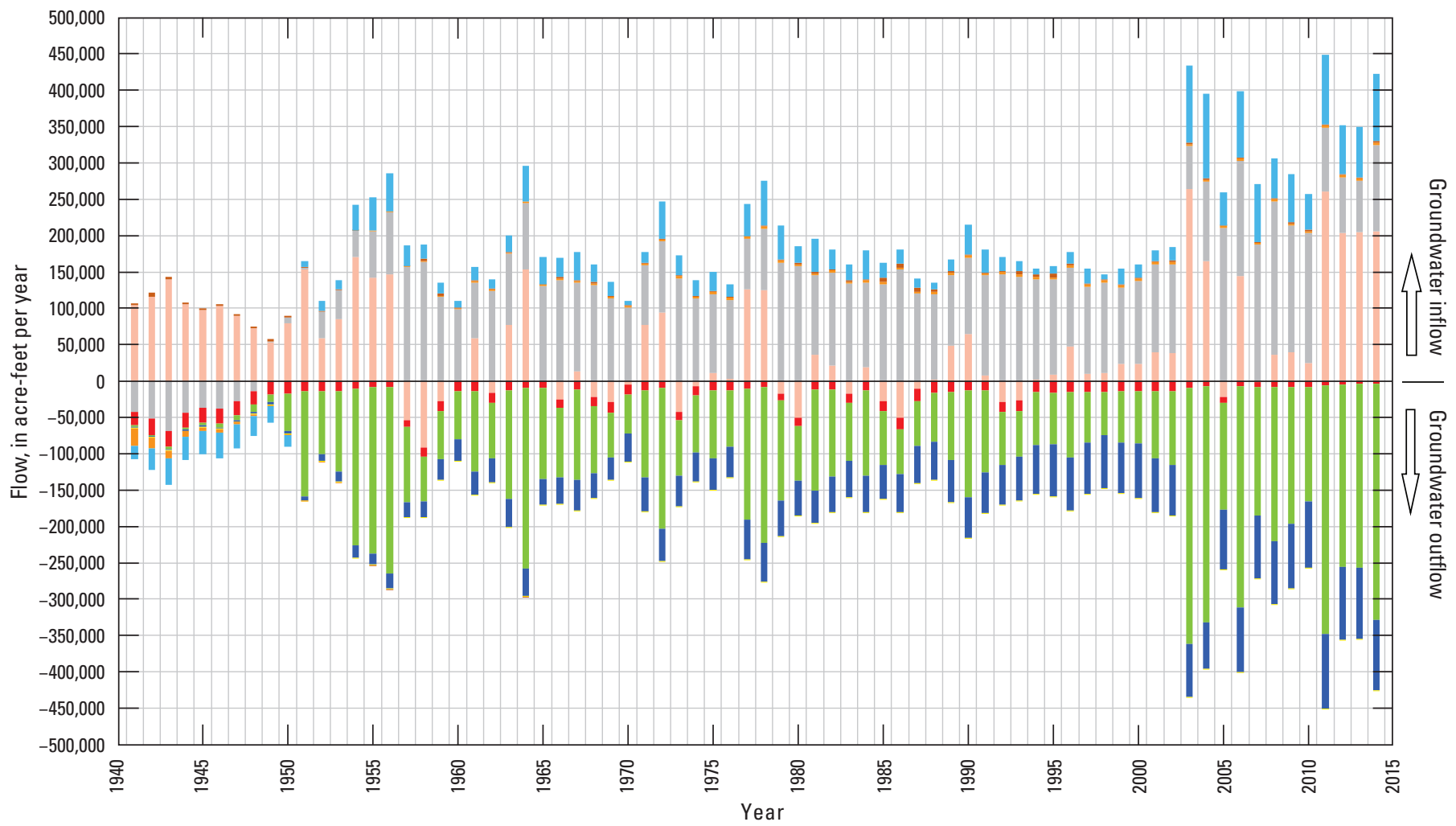

\section{EXPLANATION}

Farm-net recharge

Net head dependent bounds (underflow)

Municipal and industrial pumpage
Net riparian evapotranspiration

Net aquifer storage loss

Net reservoir leakage
Domestic pumpage

Agricultural pumpage

Net stream leakage from groundwater

B

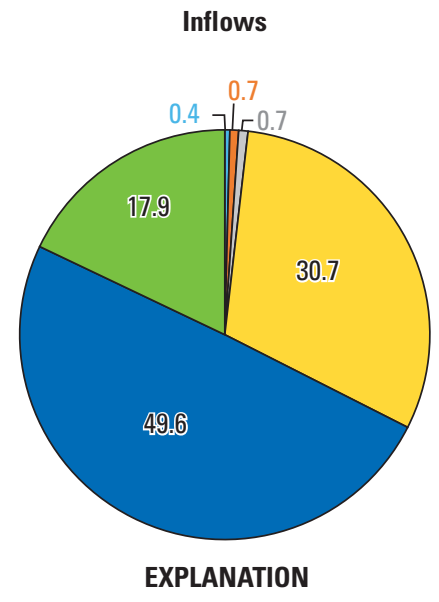

EXPLANATION
Groundwater underflow inflow from USA

Groundwater underflow inflow from Conejos-Médanos Basin, Mexico

Reservoir leakage groundwater

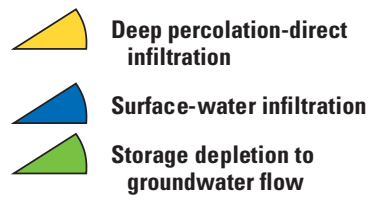

Deep percolation-direct groundwater flow

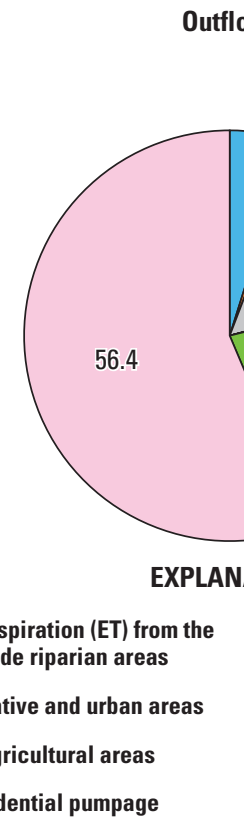

Outflows

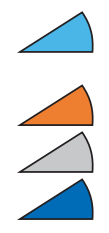

Evapotranspiration (ET) from the Rio Grande riparian areas

ET from native and urban areas

ET from agricultural areas

Rural residential pumpage

Figure 36. Results of simulated groundwater flow values for the hydrologic-flow budget from the Rio Grande Transboundary Integrated Hydrologic Model, New Mexico, Texas and Mexico: $A$, the net flow; $B$, pie charts showing percentages of the average net inflow and outflow components; and $C$, the changes in groundwater storage by groups of model layers. 
C

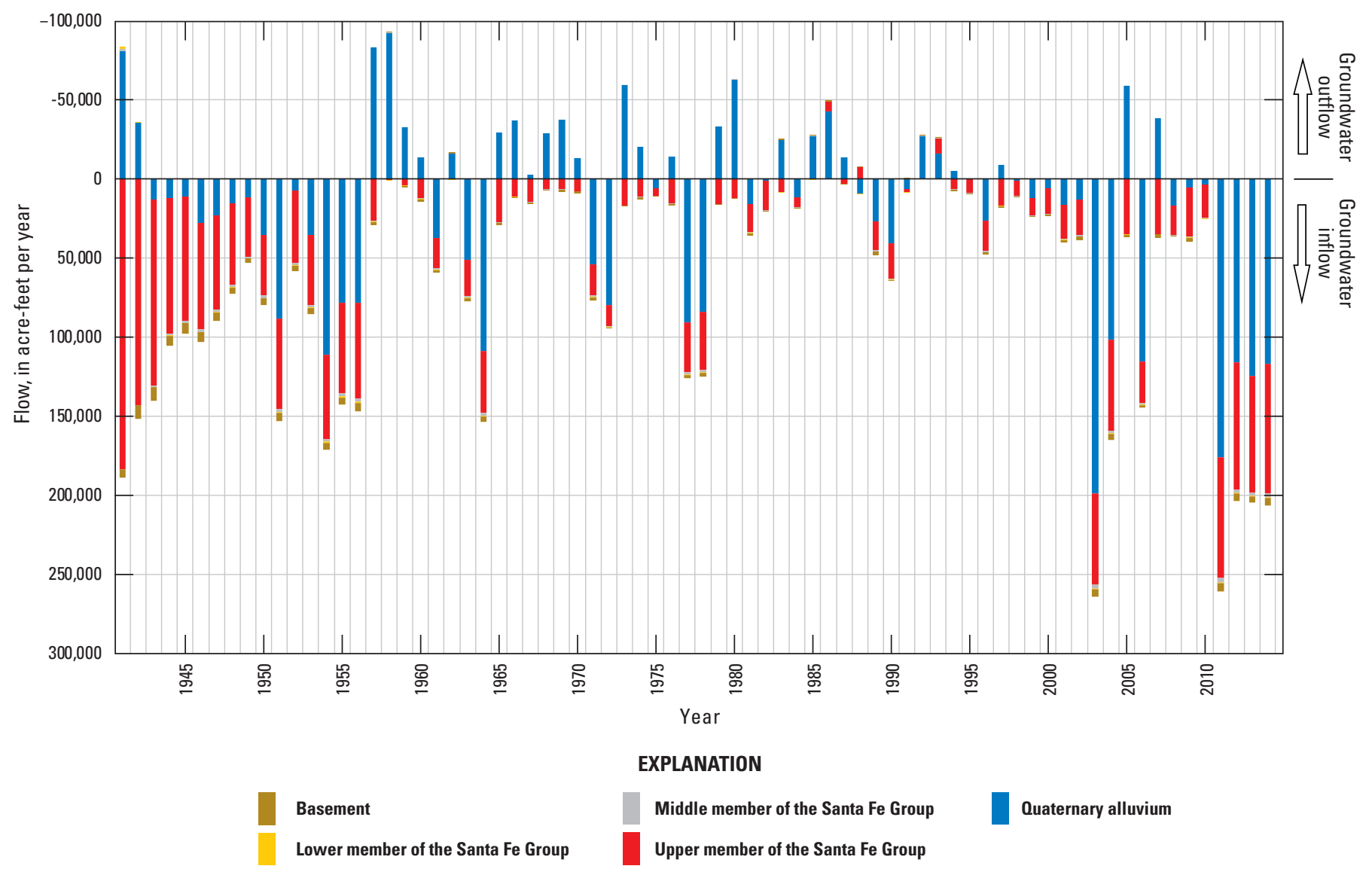

Figure 36. - Continued 
Table 16. Summary of groundwater-flow budgets for selected periods in the Rio Grande Transboundary Integrated Hydrologic Model, Transboundary Rio Grande, New Mexico, Texas, and Mexico.

[Calendar year is January through December. Abbreviations: ET, evapotranspiration; GW, groundwater; NM, New Mexico; TX, Texas; USA, United States of America; CM, Conejos-Médanos Basin; MX, Mexico]

\begin{tabular}{|c|c|c|c|c|c|c|c|c|c|c|}
\hline GW-flow components & RGTIHM & RGTIHM-USA & RGTIHM & RGTIHM-USA & RGTIHM-NM & RGTIHM-TX & RGTIHM-NM & RGTIHM-TX & RGTIHM & RGTIHM \\
\hline $\begin{array}{c}\text { Period } \\
\text { (calendar years) }\end{array}$ & 1953-2014 & 1953-2014 & 1994-2014 & 1994-2014 & 1953-2014 & 1953-2014 & 1994-2014 & 1994-2014 & $\begin{array}{c}2005 \\
\text { (wet/wet) }^{1}\end{array}$ & $\begin{array}{c}2011 \\
(\text { dry/dry) }\end{array}$ \\
\hline \multicolumn{11}{|c|}{ Net average GW inflows } \\
\hline Inflow GW underflow, USA & 950 & 950 & 950 & 950 & 950 & 0 & 950 & 0 & 950 & 960 \\
\hline Inflow GW underflow, CM Basin, MX & 1,650 & 0 & 2,180 & 0 & 0 & 0 & 0 & 0 & 2,090 & 2,130 \\
\hline Reservoir leakage underflow & 1,760 & 1,760 & 1,880 & 1,880 & 1,760 & 0 & 1,880 & 0 & 1,040 & 1,390 \\
\hline Deep percolation-direct infiltration (DI) & 73,890 & 73,890 & 85,800 & 85,800 & 68,360 & 5,530 & 79,530 & 6,270 & 72,470 & 111,560 \\
\hline Net streamflow infiltration ${ }^{3}$ (SI) & 119,540 & 119,750 & 130,190 & 130,380 & 115,820 & 3,930 & 126,530 & 3,850 & 211,190 & 88,510 \\
\hline Total recharge ${ }^{2}(\mathrm{DI}+\mathrm{SI})$ & 193,430 & 193,640 & 215,990 & 216,180 & 184,180 & 9,460 & 206,060 & 10,120 & 283,660 & 200,070 \\
\hline Storage depletion to GW flow & 43,100 & 40,790 & 82,700 & 79,040 & 39,710 & 1,080 & 75,900 & 3,140 & $-22,500$ & 260,960 \\
\hline Total net average inflows to GW flow & 240,890 & 237,140 & 303,700 & 298,050 & 226,600 & 10,540 & 284,790 & 13,260 & 265,240 & 465,510 \\
\hline \multicolumn{11}{|c|}{ Net average GW outflows } \\
\hline Riparian ET from GW along Rio Grande & 11,600 & 11,600 & 10,230 & 10,230 & 10,573 & 1,018 & 9,324 & 898 & 7,970 & 5,960 \\
\hline ET from GW in native and urban areas & 2,350 & 2,270 & 1,760 & 1,690 & 1,500 & 780 & 1,120 & 570 & 880 & 960 \\
\hline ET from GW in agricultural lands & 36,020 & 36,020 & 33,030 & 33,030 & 33,870 & 2,150 & 31,300 & 1,730 & 25,880 & 15,710 \\
\hline Outflow GW underflow, Rio Grande & 130 & 130 & 130 & 130 & 0 & 130 & 0 & 130 & 130 & 120 \\
\hline Rural residential pumpage & 640 & 640 & 360 & 360 & 630 & 10 & 350 & 10 & 240 & 210 \\
\hline Water-supply pumpage & 54,370 & 52,810 & 81,100 & 76,540 & 39,730 & 13,080 & 59,810 & 16,730 & 81,920 & 101,970 \\
\hline Agricultural pumpage & 136,870 & 136,870 & 178,620 & 178,620 & 124,140 & 12,730 & 161,880 & 16,740 & 147,700 & 343,690 \\
\hline Total GW pumpage ${ }^{3}$ & 191,880 & 190,320 & 260,080 & 255,520 & 164,500 & 25,820 & 222,040 & 33,480 & 229,860 & 445,870 \\
\hline Total net average outflow from GW flow & 241,980 & 240,340 & 305,230 & 300,600 & 210,443 & 29,898 & 263,784 & 36,808 & 264,720 & 468,620 \\
\hline Net change in GW flow ${ }^{4}$ & $-1,090$ & $-3,200$ & $-1,530$ & $-2,550$ & 16,157 & $-19,358$ & 21,006 & $-23,548$ & 520 & $-3,110$ \\
\hline
\end{tabular}

${ }^{1}$ River/precipitation-based climate years for wet and dry years (see table 5 and figure 6 ).

${ }^{2}$ Total net recharge is the sum of deep percolation-direct infiltration and net surface-water infiltration.

${ }^{3}$ Total pumpage is the sum of rural residential, water-supply, and agricultural pumpage.

${ }^{4} \mathrm{Net} \mathrm{GW}$ flow is total net GW inflow minus total net GW outflow. Negative number indicates reduced net-groundwater flow, and positive number indicates increased net-groundwater flow. 
A

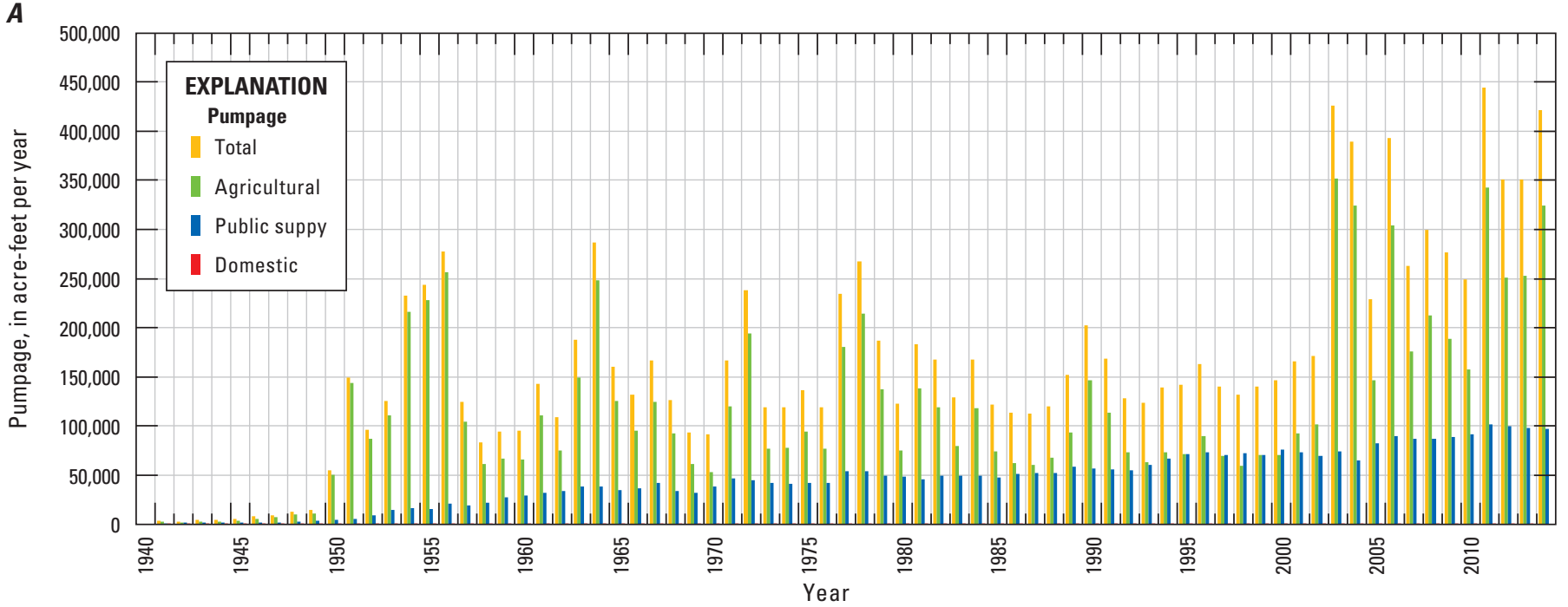

B

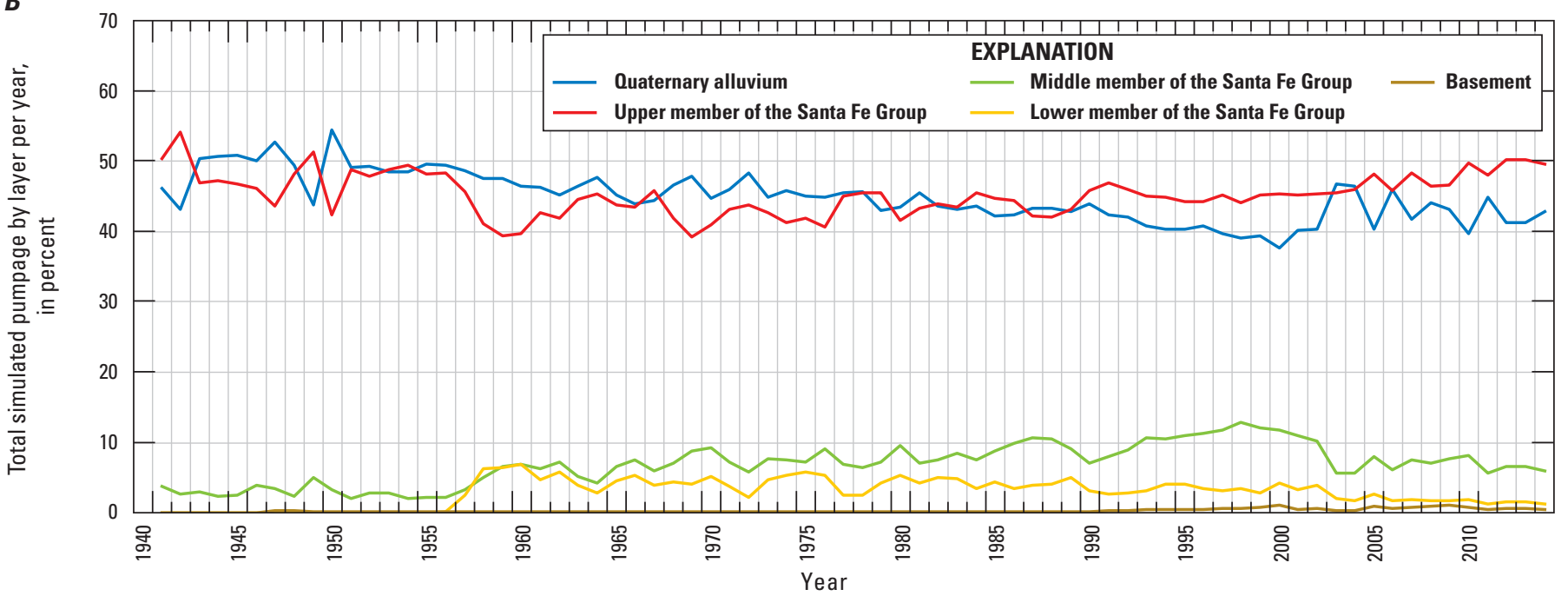

C

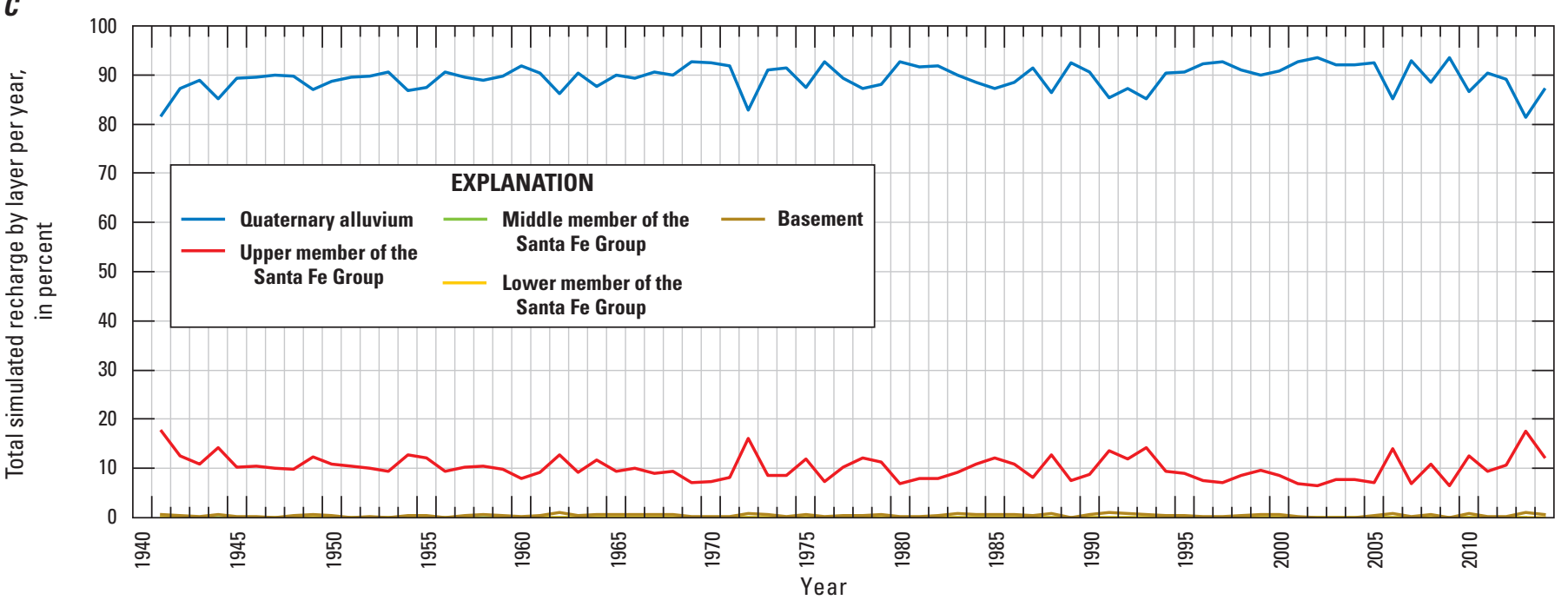

Figure 37. Simulated groundwater pumpage and recharge factors from the Rio Grande Transboundary Integrated Hydrologic Model, 1940-2014, Transboundary Rio Grande, New Mexico, Texas, and Mexico: $A$, annual groundwater pumpage by uses; $B$, the percentage of groundwater pumpage by groups of model layers; and $C$, the percentage of recharge by groups of model layers. 
More than 89 percent of the simulated total recharge was in the Quaternary alluvium layer as deep percolation from inefficient irrigation, surface-water infiltration, and some groundwater underflow (fig. 37C). An additional 10 percent entered the groundwater-flow system through the upper member of the Santa Fe Group from mountain-front recharge, net streamflow infiltration to groundwater aquifers, and deep percolation of inefficient irrigation. The fraction of recharge that entered the system in the deeper units was relatively minor. There was some variation in response to regional climate in the relative proportions of recharge by source from year to year (deep percolation, fig. 33A), but the overall percentages remained relatively constant valley wide (fig. 37C). The exchange of water between aquifers was largely across model-layer boundaries and, in relatively small amounts, by intra-borehole flow through long-screened supply wells that are open to multiple model layers. As indicated from the depth-specific water-level histories of the multiplewell monitoring sites (fig. $23 F$ ), the vertical head differences can result in both sustained upward (negative) and downward (positive) gradients as well as downward gradients during the growing season and upward gradients during the non-growing season. Vertical head gradients have increased with increased pumpage in the units below the Quaternary alluvium. Most of the vertical interlayer flow was focused in the regions where coarse-grained sediments are more prevalent, such as along stream channels in Quaternary alluvium in the floodplain and channel region of the Rio Grande. The majority of the net vertical flow was to the upper member of the Santa Fe Group from the Quaternary alluvium (downward flux) with diminished and minor vertical flows from the middle member (upward flux). The vertical influx into the upper member of the Santa Fe Group increased through time from about 9 percent to more than 20 percent of interlayer flow (fig. 38). Conversely, the net flow from lower layers into the Quaternary alluvium aquifer decreased from about 12 to less than 5 percent during the period of simulation. Interlayer flow remained relatively constant for middle and lower members of the Santa Fe Group at about 11 and 5 percent, respectively, and for the basement rocks at less than 2 percent with some relatively slight decline in more recent years for these lower layers (fig. 38). Overall, these changes in inter-formation vertical flow were consistent with the growing vertical head differences and the increased pumpage from the upper member of the Santa Fe Group in later years of the simulation. For example, the downward flux from the Quaternary alluvium was consistent with the increased vertical head gradients observed at some pairs of wells that straddle these model layers (fig. $23 F$ ). In contrast to this regional assessment of net vertical flow between the upper and the middle and lower members of the Santa Fe Group, some locales, such as in the vicinity of the Canutillo well field, showed relatively larger vertical flows with increasing downward-flow gradients (fig. 23F).

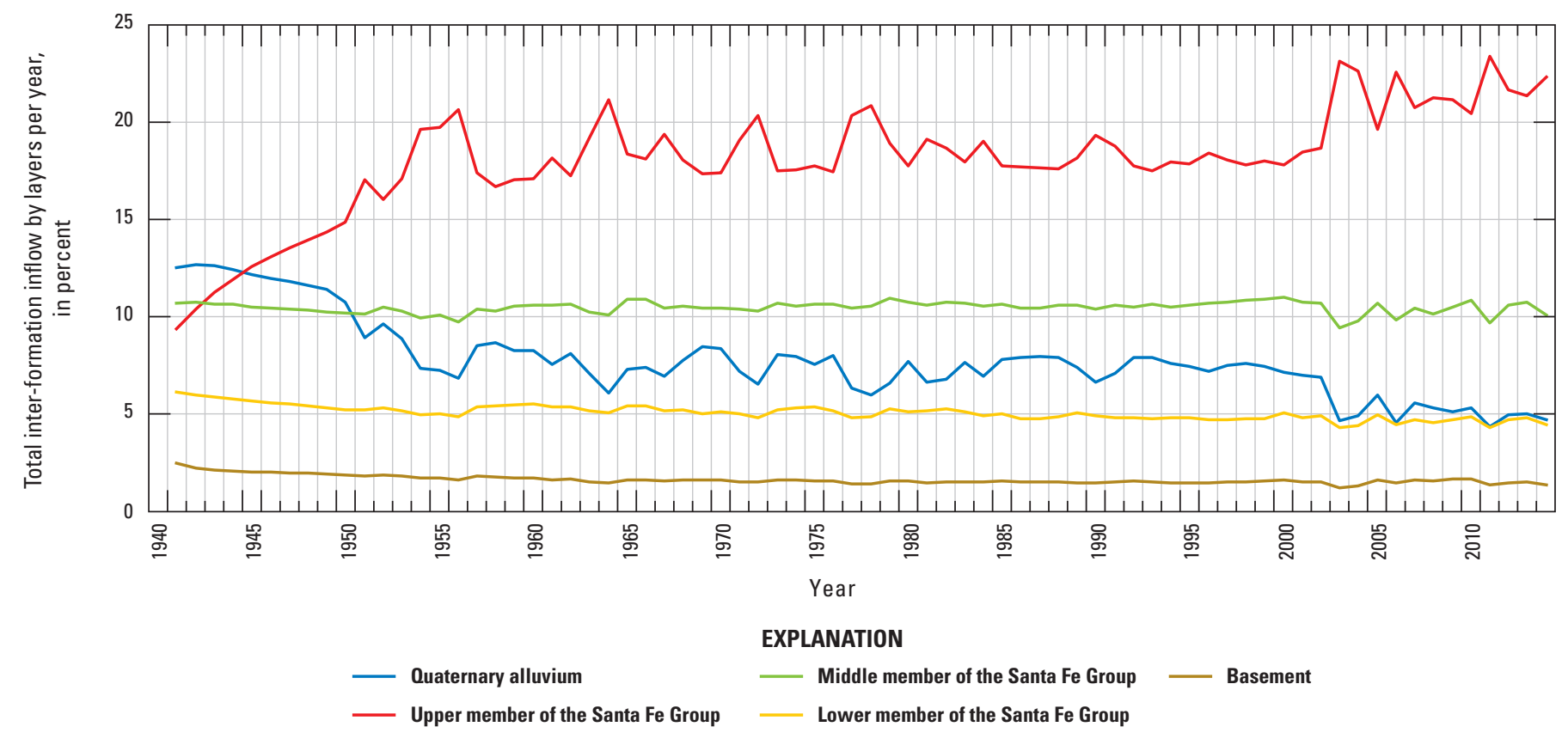

Figure 38. Net flow into groups of model layers from adjacent groups of layers, Rio Grande Transboundary Integrated Hydrologic Model, 1940-2014, Transboundary Rio Grande, New Mexico, Texas, and Mexico. 


\section{Model Limitations, Uncertainty, and Potential Improvements}

As with any model, the RGTIHM is a simplification of the real flow system, and, as such, has some inherent limitations. The accuracy of simulation results is strongly related to the quality and resolution (both spatial and temporal) of hydrologeologic input data and of hydrogeologic measurements of the system (such as precipitation, water levels, streamflow, and pumpage) used to drive and constrain the simulation and related calibration. The inflows and outflows simulated using the RGTIHM were a combination of measured values, simulated flows from adjustments to parameters to represent conceptualizations of the system, estimated inflows provided by the TRGWM model, and values specified through the use of the MF-OWHM2. Differences between simulated and actual hydrologic conditions arise from a number of sources and are collectively known as model error and model uncertainty. Although the RGTIHM was designed with the capability to be accurate at the regional, district, unit, and farm subregional scales, the conceptual and numerical models were developed on the basis of assumptions and simplifications that may restrict the use of the RGTIHM to regional and subregional levels of spatial analysis implemented at seasonal to interannual temporal scales.

The RGTIHM was developed in a "self-updating model structure" (Boyce and others, 2020), where model input data are easily updated and the RGTIHM can be periodically refined, including parameter and framework adjustments, as needed, to keep the RGTIHM available for operational and future scenario analysis. This structure facilitates any upgrades, updates, and recalibration that could be needed to address the changes in the important components of the water budget. These analyses could include aspects of operations of the RGP, sustaining the groundwater resources as a supplemental irrigation supply without interfering with RGP deliveries, and honoring related operations delivery obligations to the EBID and EPCWID1 and treaty obligations for the Rio Grande with Mexico.

Potential future refinements and enhancements can continue to improve the level of resolution and model accuracy and to reduce potential uncertainties. In general, proper design and calibration of flow models are an ongoing process that, along with better spatial and temporal estimates of inflows, outflows, and observational data, as well as inclusion of climate and land use, can minimize some of the inherent model limitations. Limitations of the modeling software, assumptions made during model development, and results of model calibration and sensitivity analysis are all factors that can further constrain the appropriate use of this model; in turn, these limitations can be used to identify where potential improvements for the simulation of specific processes are needed or where additional data are needed to improve the quality of the simulations.

Although the RGTIHM has the ability to resolve to monthly periods of supply-and-demand related flows, it is most suited to evaluate interannual to decadal patterns of subregional to regional water use and availability. Processes that vary at a spatial scale smaller than the model-grid spacing (10 acres, with variably thick layers) or at a temporal scale shorter than the stress periods (one month) cannot be represented explicitly by the RGTIHM. Model discretization in space and time can be a potential source of error and uncertainty. Models represent a hydrologic system as a series of discrete spatial units, in which intrinsic properties and flows are assumed to be uniform. Although the RGTIHM improves the spatial discretization from the 40 acres per cell used in the previous models to 10 acres per cell, the use of a discretized model to represent a highly variable hydrologic system still introduces limitations for features that are at scales smaller than the existing discretization. Transient models are further discretized to a series of discrete units of time, during which specified hydrologic inflows and outflows are held constant. The use of monthly stress periods and two semi-monthly time steps in the RGTIHM assumes that the variations of inflows and outflows and changes in water levels are piecewise linear changes. This represents an improvement over the previous models that used multi-month stress periods; nevertheless, changes at shorter time scales are not simulated and are not discernable in the RGTIHM results, which could contribute to some additional temporal uncertainty. For example, the actual distribution of daily precipitation and soil moisture in each monthly period used by the TRGWM and RGTIHM can result in large variations in recharge and runoff (for example, precipitation from a strong 1-day storm rather than as a series of weaker storms), which cannot be accounted for with the existing model. The temporal scale used in the RGTIHM was expressly designed to separate the supply-and-demand components of water use and movement for agriculture in the TRG region.

Differences between simulated and measured hydrologic features also can arise from the numerical solution that attempts to provide a cell-by-cell mass balance of inflows and outflows. Mass-balance errors are minimized by ensuring the model solution reaches a reasonable state of mass balance for each biweekly period. The twice-permonth time steps were used to remain consistent with the assumptions of the existing version of the FMP process (Boyce and others, 2020). The cumulative mass balance of the RGTIHM was within 0.11 percent of the total cumulative simulated flow for the 75 years of historical simulation, March 1940-December 2014. 
An additional component of model uncertainty arises as a consequence of how well model-input values, accuracy of observational data, and features represent the actual hydrologic system. Thus, the accuracy of the calibrated model is also contingent on the accuracy of the specified inflows and of the specified observed flows and groundwater levels used for model comparison. For example, the land-surface elevations for the wells used for calibration to groundwaterlevel observations had a mean land-surface elevation error of $5 \mathrm{ft}$, which could contribute to additional uncertainty in some areas of the model. Similarly, the observed surfacewater flows might only be accurate to within 5-20 percent, on the basis of the quality ratings of streamflow estimates developed from stage-discharge relations at surface-water gaging stations or from seepage runs. In addition, the flows at many of the diversions are estimated as fractional "splits," as opposed to actual estimated or measured canal or diversion flows, which could also contribute to uncertainty. Model calibration provides a means to use comparisons to indirectly constrain the differences between the real-world and simulated volumetric flows and groundwater levels. Thus, the degree to which a simulated construct provides a reasonable representation of the physical hydrologic system can be evaluated through comparing simulated hydrologic conditions to those observed, estimated, or measured in the field, which in turn, provides a volume-constrained calibration. Thus, the performance and accuracy of the RGTIHM are primarily constrained by groundwater levels and surfacewater flows, and to a lesser degree, by estimates of annual agricultural pumpage, differences in surface-water flows (gains and losses), and vertical groundwater-level differences. For example, small sources of error and uncertainty in the RGTIHM could include not simulating delayed recharge that could potentially be associated with unconfined conditions outside of the RGV, not representing selected faults or volcanic intrusions as potential conduits for vertical flow, subregional (facies-based) specific yield for the uppermost model layers, or not including layer-specific skin factors for multi-aquifer wells that could further accentuate the vertical distribution of groundwater pumpage. Finally, better estimates of land-surface elevations at all observation wells used for groundwater-level comparisons and better estimates of surface-water flows and related diversions could help reduce the uncertainty of observations used for model calibration and help improve model-based water-budget evaluations.

Several elements of RGTIHM remain uncertain and would require additional investigation to further improve the accuracy of the simulation of groundwater and surfacewater flow, regional storage changes, and the use and movement of water across the landscape. For example, this version of RGTIHM does not simulate the consumptive use directly from climate and detailed landscape features using the Farm Process. Rather than using actual land-use and climate as an input, an indirect approach is used to estimate ET consumption related to land use and climate variability (precipitation and potential ET) and related features such as potential runoff. This contributes to additional uncertainties in water use calculations because simulated pumpage, recharge, and other similar model outputs are sensitive to parameters such as the CIR, irrigation efficiencies, multiple cropping, or monthly land use. In particular, the direct and complete implementation in the FMP of the distribution and change in land-use patterns combined with comparisons against reported agricultural monthly pumpage for the later years (2009-14) of the simulation in New Mexico part of RGTIHM, and actual surface-water diversions for individual WBSs as observations would help to constrain irrigation demand better and increase simulation accuracy. Many of the stresses that are driven by these land uses varied during the simulation period at different spatial and temporal frequencies, and at smaller spatial resolution, than the NMOSE estimates of the CIR for entire irrigation units. This may be indicative of the additional divergence in the assumed CIR values during the drought period simulated for 2011-14, for which estimates from the NMOSE were not available. The intensification of agricultural demand for irrigation and related hardening of demand with a shift toward more pecan orchards, as well as additional urbanization, also illustrates the need for better representation of the landscape features and related climate directly in the RGTIHM model (fig. 31C). 
The final scale factors that were used to try to match annual pumpage also reflected the potential uncertainty embedded in the CIR estimates, which are distributed over the larger irrigation units instead of actual farms or land parcels. These variations are driven by potential changes in land use through CIR scale factors and climate variability as reflected in seasonal "river- and precipitation-based climatic periods" (fig. 6), as well as any potential changes in growing periods for specific crops. Given that local climate as precipitation and potential ET is not directly represented in the model, the monthly to interannual variations in climate are not well represented. For example, the groundwater responses to the drought periods in the early 1950s, late 1980s, and 2000s showed how the effects of regional "river-based climate" that controls the availability of surface water for irrigation were not well represented at smaller spatial scales of the individual WBSs represented in the RGTIHM. The existing approach of using CIR values from the six NMOSE irrigation units also homogenizes the crop distribution that varies in these units throughout the time frame of the hydrologic simulation. This indirect approach to preprocessing irrigation demand also might not take into account other possible behaviors by irrigators, such as potential water stacking or fallowing during times of insufficient surface-water supply. In some cases, such as the increase in acreage of pecan orchards, this homogenization could generally be an acceptable assumption; in others, annual crops could have changed several times during the years represented by the composite CIR estimates applied over the larger scale of the irrigation units. Estimates of $\mathrm{ET}_{\mathrm{o}}$ and growing periods are uncertain and could be better delineated, especially in relation to climate variability and surface-water availability. Finally, the native vegetation represents about 79 percent (historically) of the land use. Although this land use represents a small amount of consumption of water through ET, the native vegetation could be an important control for runoff and recharge in the upland regions of the TRG. Precipitation is not directly included as input to the model, and a small fraction of irrigation runoff is explicitly simulated in the RGTIHM to represent tail-water and head-gate wastage. However, direct simulation of runoff from precipitation could enable the assessment of the potential contributions or capture of "wild water" derived from the TRGWM in the TRG. Because the desert caliche layers likely control much of the runoff and deep percolation, as opposed to the soils, additional mapping of these layers would improve the simulation of runoff and recharge.

Some inflows and outflows, such as inflow along major arroyos (for example, Rincon Arroyo), remain relatively uncertain; the accuracy of the RGTIHM could benefit from additional observations and estimates of streamflow from such major ungaged drainages, especially if more precision in simulating groundwater inflow is needed to improve the overall hydrologic budget and estimates of local recharge and runoff. Continued monitoring of the inflows from the Rio Grande, as well as actual measured flows (instead of splits) of diversions and canals, would also be useful for maintaining an inventory of the major components of flows in the engineered parts of the surface-water network.

The accuracy of the RGTIHM could also be improved if the input values of selected hydraulic properties, such as aquifer horizontal and vertical hydraulic conductivities, specific yields, and storages, could be adjusted on the basis of additional field estimates, such as aquifer tests combined with wellbore flow and temperature logging, and could be used to improve assessments of the effects of multi-aquifer wells on the vertical distribution of pumpage through multiple aquifers. This could especially be important in the vicinity of well fields such as the Canutillo well field, where large vertical head differences are observed. Additional estimates of horizontal hydraulic conductivity to further constrain the RGTIHM model properties could be obtained from aquifer tests combined with wellbore flow logs at selected supply-well sites or well specific-capacity tests at single-aquifer supply wells. Also, the winter seepage estimates showed that seepage distributions along the Rio Grande vary from year to year in the Mesilla Basin. This variation could be a combination of vertical-head differences between the alluvial aquifer and the river, but also could be related to changes in the streambed conductivity. Time-varying streambed vertical hydraulic conductivity could be related to processes such as scour and bedload transport that could change the distribution and magnitude of vertical hydraulic conductivity values along the extent of the river in the Mesilla Basin.

There also is uncertainty in the geologic data used to characterize lithology and texture. Depositional facies distributions based on borehole lithologic data that become sparser at increasing depths cause additional uncertainty of hydraulic properties with increasing depth. The facies subregions could be further subdivided through the use of additional zones within facies and use of texture data estimated from lithologic data and drillers' logs. This could help alleviate the decreasing accuracy concurrent with depth of the facies distribution for the members of the Santa Fe Group used to specify the hydraulic conductivities. Uncertainty in the values used for the hydraulic properties of the bedrock units might be large, because few wells produce water from this unit in the TRG region. Thus, facies data uncertainty is less for the Quaternary alluvium and upper parts of the Santa Fe Group and greater for lower parts of the Santa Fe Group and underlying bedrock units. The need for additional subdivision of the facies is made apparent by the multitude of hydrographs used in this study. 
In addition, the layers might be improved by additional refinement in the Quaternary alluvium, which, in the existing model, is subdivided into two layers, each about $40 \mathrm{ft}$ thick. Further subdivision to 10 - to 20 -ft layers would help to further segregate the role of the river, drains, canals, and wells that influence the use and movement of water in the shallowest part of the aquifer system. Finally, additional parameterization of the facies hydraulic properties with separate specific yield values for each subregional facies may also improve the seasonal responses to pumpage for shallow observation wells.

Several of the processes in the RGTIHM could also potentially allow for a more refined simulation of selected flow features. Improved simulation of multi-aquifer wells to account for partial penetration with better information on screened depths and total depths of wells, and better estimates of actual pumping capacities of all wells could increase the accuracy of simulated pumpage. Some WBSs required assumptions about well construction, so improving the location of wells or water conveyances that are used to service these WBS is likely to reduce uncertainty. Similarly, actual data on monthly pumpage from the supply wells in Mexico would improve the simulation of the water-level declines in the Conejos-Médanos Basin area of the RGTIHM.

Future work could include data refinement and temporal updates of the RGTIHM, through additional calibration, additional model observations, and development of projections of alternative scenarios based on a new comprehensive basin-management plan simulated using the Surface-Water Operations Process (Ferguson and Llewellyn, 2015; Boyce and others, 2020). An expanded monitoring network would allow for a better understanding of changes in surface-water flows, diversions, streamflow, and streamflow infiltration (seepage runs), which are the main sources of recharge in the valley. In particular, the monitoring of crop-specific annual land use, canal and diversion inflows, monthly wellby-well groundwater pumpage, and wellbore flow in all areas of the valley would help to better quantify the state of the resources as well as provide a valuable comparison to model performance.

The calibration of the RGTIHM, based predominantly on groundwater levels and streamflows, could undergo additional calibration by using reported monthly agricultural pumpage for later years of the simulation (2009-14) for each waterbalance subregion in New Mexico and Texas. Better still, monthly pumpage data combined with climate data, actual land use from parcel-based observations, and ET observations based on remote-sensing estimates would provide a better representation of the water use and movement. This could improve model accuracy and include more of the natural variability in factors affecting the demand, as is observed in groundwater hydrographs. This was especially apparent during the droughts, because the CIR approach to the land use did not account for fallowing, changes in cropping, water stacking, or other agricultural practices used in response to drought conditions. In addition, the TRGWM watershed model could be recalibrated to daily flows to represent the monsoon storm flows better, which could be an important contributor to local runoff, and to estimate the potential gain by capture and reuse of any available "wild water."

Additional verification of the construction and conditions of wells used for irrigation and cropping practices could also potentially improve the accuracy of the RGTIHM and allow full implementation of all the FMP features, such as simulated responses to climate and actual land use. Projections of water availability and sustainability of supply could include the analysis of alternative scenarios of land use, crops, and irrigation practices, as well as additional capture of intermittent runoff from wet years (after climate and runoff are added to the model) for managed aquifer recharge or supplemental irrigation scenarios.

The RGTIHM might benefit from refinement of some additional features of the new geohydrologic framework. The additional layering and the facies approach to layers is a notable improvement from the relatively constant hydraulic properties of the previous models. The variability of hydrographs and variety of hydrologic response in the facies of each model layer, however, indicates that these facies could benefit from further subdivision into different subregions or replacement with a texture-based approach to the sedimentary distribution of the aquifers and confining layers. The RGTIHM might also benefit from additional refinement of the location of the Selden Canyon fault zone and Transboundary, Fitzgerald, Mastadon and other unnamed transboundary faults that help compartmentalize the flow system upstream from the Mesilla Basin and between the Mesilla Basin and the northern Conejos-Médanos Basin areas of the RGTIHM. This could be accomplished with new aeromagnetic and gravity mapping of the region as well as renewal of the micro-seismic monitoring network that was discontinued in the 1990s.

In summary, some potential components that could improve the accuracy and reduce the uncertainty of the simulation include, but are not limited to the following:

1. Improved temporal information for land-use and crop distributions.

2. Direct use of climate data (precipitation and potential ET) and land use to drive the demand for irrigation using the features available in a full FMP simulation.

3. Improved estimation and application of crop and irrigation properties for crops.

4. Improved estimates of ungaged stream inflows and outflows through additional streamflow gaging (either used directly or to improve the calibration of the TRGWM) and calibration to the EBID arroyoflow gaging.

5. More refined layering of the Quaternary alluvium to 10-20-ft-thick layers, especially in the Rincon Valley to improve the representation of the functioning of some of the drains and the Rio Grande in this region. 
6. Refined subregions for the facies or texture-based distributions of hydraulic properties with texturelithology based estimates of coarse- and fine-grained sediment fractions of the facies for the Quaternary alluvium and Santa Fe Group members.

7. Refined location and extents of the group of transboundary faults and potential role of the Texas Lineament as a control of groundwater flow in the transboundary region.

8. Improved monthly pumping estimates from all wells, and better well-construction information.

9. The ability to vary streambed vertical hydraulic conductivity temporally in the various river, canal, and drain segments in the MF-OWHM2 code.

10. Complete and continuous measurements of flow in all canals, diversions, and drains along with updates of canal and drain shape and dimensions.

11. Improved simulation of multi-aquifer wells with more complete construction information and pumping capacities to improve simulation of partial penetration, farm-well pumping capacities, and specific monthly pumpage for each well in the well field in Mexico.

12. Use of remotely sensed ET for additional comparisons with simulated consumptive use and calibration of landuse properties used to simulate consumptive use.

13. Surveys to establish land-surface elevation of all wells used for model calibration observations to within an accuracy of $0.1 \mathrm{ft}$.

Despite these potential limitations and possible future improvements, the RGTIHM is adequate for the intended purposes of simulating annual to decadal periods at subregional to transboundary scales of the RGP operations, surface-water and groundwater interactions, and hydrologic budget analysis needed for planning and evaluating alternatives for managing conjunctive use in the modeled area.

\section{Summary and Conclusions}

The Transboundary Rio Grande (TRG) Valley includes the Rincon Valley part of the Palomas Basin in New Mexico, the Mesilla Basin in New Mexico and Texas, and the northern part of the Conejos-Médanos Basin of northern Mexico. It is a complex region characterized by conjunctive use of surface water and groundwater near a state border in the United States and an international boundary with Mexico. Increases in population and transitions to crops that consume additional water and have an interannual to interdecadal period of irrigation demand have increased the demand for water in the TRG region. Although urban supply is pumped from groundwater only, water for irrigated agriculture is supplied by a combination of surface water and groundwater pumpage. This study provides a refined conceptual model, geohydrologic framework, and an integrated hydrologic model: the Rio Grande Transboundary Integrated Hydrologic Model (RGTIHM). The goal of this study was to produce a model capable of being accurate at scales relevant to water-supply analysis needed for the evaluation of water availability and sustainability, as well as evaluation of the interactions between groundwater use and Reclamation's Rio Grande Project (RGP) operation. The RGTIHM is the latest in a sequence of models that have been developed for the TRG region. The Transboundary Rio Grande Watershed model (TRGWM) and RGTIHM were calibrated to historical conditions of water use and movement and were used along with the new geohydrologic and conceptual models to assess the use and movement of water in the TRG region. These tools provide a means to understand the water resources of the TRG, water availability in the area, and the effects of the continued development of water use.

The conceptual model identified inflows and outflows that include the movement and use of water from natural and human components. The groundwater-flow system is characterized by a layered geologic sedimentary system that results in vertical hydraulic gradients due to the combined effects of the application of irrigation water and natural recharge from surface-water infiltration and exfiltration at the land surface combined with groundwater pumpage, evapotranspiration (ET), and underflow as inflows and outflows. Although surface water and groundwater have been used alternately between wet and dry years as the major source for irrigation during the historical period, groundwater has supplied most of irrigation demand since 2003. Overall, the demand for water for irrigation has steadily increased, especially in dry years.

The integrated hydrologic model RGTIHM includes new water-balance subregions; delineation of natural, municipal, and agricultural land-use subregions; streamflow networks; and groundwater-flow systems. The redefinition of the geohydrologic framework (including the internal architecture of the sedimentary deposits) and incorporation of these units in the simulation of the regional groundwater-flow system indicated the importance of facies subregions and faults for compartmentalizing parts of the aquifers into subregions, which have responded differently with respect to regional groundwater flow, locations of recharge, and the effects of development. Thus, the TRG region is composed of multiple subregions that are partly fault bounded and represent different proportions of the multilayered regional aquifer system. 
The TRGWM was used to estimate the monthly runoff and recharge in the 80 subbasin watersheds that surround the alluvial basin of the TRG region. The TRGWM-estimated basin discharge and measured streamflow averaged about $14,620 \mathrm{acre}-\mathrm{ft} / \mathrm{yr}$, which is about half of the runoff and recharge along basin boundaries that was previously estimated. Some additional recharge in these surrounding watersheds might also become rejected recharge and contribute to runoff into the valley. The TRGWM generally fit the limited streamflow data that were available from the region and provided a systematic estimate of runoff and recharge for the mostly ungaged watersheds surrounding the TRG region. The temporal variation of runoff ranged from about 570 acre-ft/yr in 1951 (dry year) to about 62,800 acre-ft in 1993 (wet year). The majority of the runoff was from the eastern watersheds and ranged from a few, to a few 100, up to a total of about 9,250 acre-ft/yr. Average annual runoff in tributary streamflow exceeded 100 acre-ft in only 15 of 80 subwatersheds during the last 75 years, but contributed more than 98 percent of the total estimated runoff as mountain-front recharge.

The RGTIHM was designed to reproduce the natural and human components of the hydrologic system, including components dependent on variations in climate, enabling an accurate assessment of surface-water and groundwater conditions and processes to inform water users and help improve planning for future conditions. Model development included a revised conceptual model of the flow system, construction of the TRGWM water-balance model using the BCM, and construction of an integrated hydrologic flow model with the MODFLOW-One-Water Hydrologic Flow Model version 2 (MF-OWHM2). The new geohydrologic, conceptual, and hydrologic models were developed, and the hydrologic models were calibrated to historical conditions of water use and movement and then used to assess the historical use and movement of water in the TRG region.

The RGTIHM simulates the use and movement of water, which includes the development of surface-water use and related, supplementary groundwater demands. Overall, the RGTIHM provides a good representation of the regional flow system and the movement and use of all water, and it is capable of being accurate at annual to inter-decadal time frames and subregional to valley-wide spatial scales. The RGTIHM allows for analysis of landscape and surface-water and groundwater hydrologic budgets for calendar years 1953-2014, as well as potential assessment of the effects of groundwater use and of the operating agreement used to apportion surface-water use and reuse.

Simulated changes in storage through time showed that notably large amounts of groundwater were withdrawn from storage not only during drought years, but also during the sustained increase of agricultural water demand that was initially dominated by field crops and has now largely been supplanted by demands of vegetable crops and pecan orchards. The shift in land use has increased demand on water resources in excess of the cycles of natural and artificial recharge.

Measured and simulated groundwater levels indicated sustained and periodic declines that have resulted in storage depletion to groundwater flow averaging about 1,090 acre-ft/yr over the entire RGTIHM region and about 3,200 acre-ft/yr within the United States part of the RGTIHM for 1953-2014 that has, in turn, reduced conveyance of surface-water deliveries from the RGP. Simulated groundwater flow indicated that vertical-head gradients between aquifer layers have increased as they fluctuate and even reverse in several parts of the basin as recharge and pumpage rates change seasonally and annually. The majority of recharge to the TRG region was from artificial recharge from deep percolation of irrigation water and additional contribution from surfacewater infiltration. The long-term imbalance between inflows and outflows resulted in a modeled overdraft of groundwater flow in the groundwater basin of about 67,580 acre-ft for the entire RGTIHM region, and about 198,400 acre-ft within the United States part of the RGTIHM for the 62 years from 1953 to 2014. Changes in storage varied considerably from year to year, depending on land use, surface-water availability, pumpage, and climate conditions and averaged a contribution to groundwater flow of about 43,100 acre-ft/yr for the entire RGTIHM region, and about 40,790 acre-ft/yr within the United States part of the RGTIHM. Climate-driven factors can greatly affect inflows, outflows, and water use by as much as a factor of 2 between wet and dry years. Although inflows during inter-decadal wet years partly replenished water in the basin, the long-term water use and storage depletion from pumping have started to diminish the effects of the wetter periods when surface-water deliveries are relatively more and contribute to natural and artificial recharge. Hydrographs of simulated and measured water-level elevations indicated large regions where water-level declines have resulted in storage depletion in many of the agricultural regions of the Mesilla Basin.

\section{Acknowledgments}

The authors acknowledge John Hawley and others, who contributed to the design and technical content of this study. This study used resources provided by the Core Science Analytics, Synthesis, and Libraries Advanced Research Computing group at the U.S. Geological Survey (Falgout and Gordon, 2017). 


\section{References Cited}

Ahadi, R., Samani, Z., and Skaggs, R., 2013, Evaluating on-farm irrigation efficiency across the watershed-A case study of New Mexico's Lower Rio Grande Basin: Agricultural Water Management, v. 124, p. 52-57, https://doi.org/10.1016/j.agwat.2013.03.010.

Allen, R.G., Pereira, L.S., Raes, D., and Smith, M., 1998, Crop evapotranspiration-Guidelines for computing crop water requirements: Food and Agriculture Organization of the United Nations, Irrigation and Drainage Paper 56, 300 p., http://www.fao.org/docrep/X0490E/X0490E00.htm.

Alley, W.M., and Leake, S.A., 2004, The journey from safe yield to sustainability: Ground Water, v. 42, no. 1, p. 12-16, https://doi.org/10.1111/j.1745-6584.2004.tb02446.x.

Arcement, G.J., Jr., and Schneider, V.R., 1989, Guide for selecting Manning's roughness coefficients for natural channels and flood plains: U.S. Geological Survey Water Supply Paper 2339, 38 p., https://doi.org/10.3133/wsp2339.

Balleau, W.P., and Silver, S.E., 2005, Hydrology and administration of domestic wells in New Mexico: Natural Resources Journal, v. 45, no. 4, p. 807-852, http://digitalrepository.unm.edu/cgi/viewcontent. cgi? article $=1374 \&$ context $=$ nrj.

Belitz, K., and Phillips, S.P., 1995, Alternative to agricultural drains in California's San Joaquin ValleyResults of a regional-scale hydrogeologic approach: Water Resources Research, v. 31, no. 8, p. 1845-1862, https://doi.org/10.1029/95WR01328.

Blaney, H.F., and Criddle, W.D., 1950, Determining water requirements in irrigated areas from climatological and irrigation data: Washington, D.C., U.S. Department of Agriculture, Soil Conservation Service, no. SCS-TP-96, 48 p., https://archive.org/details/determiningwater96blan.

Blaney, H.F., and Criddle, W.D., 1962,

Determining consumptive use and irrigation water requirements: Washington, D.C., U.S. Department of Agriculture, Agricultural Research Service, Technical Bulletin 1275, 59 p., https://naldc.nal.usda.gov/download/CAT87201264/PDF.

Blaney, H.F., and Hanson, E.G., 1965, Consumptive use and water requirements in New Mexico: New Mexico Office of the State Engineer Technical Report 32, 82 p.

Blatchford, D.B., 2017, Rio Grande Project, New Mexico and Texas, Upper Colorado Region: Bureau of Reclamation Data Series Report, v. 1, 81 p.
Borland, J.P., and Beal, L.V., 1988, Water resources data, New Mexico, water year 1988: U.S. Geological Survey Water Data Report NM-88-1, 504 p., accessed May 22, 2017, at https://doi.org/10.3133/wdrNM881.

Boyce, S.E., Hanson, R.T., Ferguson, I., Schmid, W., Henson, W., Reimann, T., Mehl, S.M., and Earll, M.M., 2020, One-Water Hydrologic Flow Model-A MODFLOW based conjunctive-use simulation software: U.S. Geological Survey Techniques and Methods 6-A60, 435 p., https://doi.org/10.3133/tm6a60.

Bredehoeft, J.D., 1997, Safe yield and the water budget myth: Ground Water, v. 35, no. 6, p. 929 , https://doi.org/10.1111/j.1745-6584.1997.tb00162.x.

Bredehoeft, J.D., 2002, The water budget myth revisited-Why hydrogeologists model: Ground Water, v. 40, no. 4, p. 340-345, https://doi.org/10.1111/j.1745-6584.2002.tb02511.x.

Bredehoeft, J.D., Papadopolous, S.S., and Cooper, H.H., Jr., 1982, Groundwater-The water-budget myth, in Scientific basis of water resources management: Studies in Geophysics, Washington, D.C., National Academy Press, p. 51-57.

Briody, A.C., Robertson, A.J., and Thomas, N., 2016, Seepage investigation of the Rio Grande from below Leasburg Dam, Leasburg, New Mexico, to above American Dam, El Paso, Texas, 2014: U.S. Geological Survey Scientific Investigations Report 2016-5010, 15 p., https://doi.org/10.3133/sir20165010.

Bureau of Reclamation, 2008, Operating agreement for the Rio Grande Project: Bureau of Reclamation, 23 p., accessed March 21, 2017, at https://www.usbr.gov/uc/albuq/rm/RGP/ pdfs/Operating-Agreement2008.pdf.

Bureau of Reclamation, 2012, Rio Grande ProjectOperations manual, revision of May 2012: Bureau of Reclamation, 39 p., accessed March 21, 2017, at https://www.usbr.gov/uc/albuq/rm/RGP/pdfs/RGP-OpsManual-2010.pdf.

Bureau of Reclamation, 2013, Supplemental environmental assessment-Implementation of Rio Grande Project operating procedures, New Mexico and Texas: Bureau of Reclamation, 89 p., accessed February 10, 2017, at https://www.usbr.gov/uc/albuq/envdocs/ea/riogrande/ op-Proced/Supplemental/Final-SuppEA.pdf.

Bureau of Reclamation, 2015, Bureau of Reclamation Library: Bureau of Reclamation, accessed January 1, 2017, https://www.usbr.gov/library/glossary/\#C. 
Bureau of Reclamation, 2016, Continued implementation of the 2008 operating agreement for the Rio Grande Project, New Mexico and Texas-Final environmental impact statement: Bureau of Reclamation, 582 p., accessed March 21, 2017, at https:/www.usbr.gov/uc/envdocs/eis/pdf /2008OperatingAgreementRioGrandeEIS_Final.pdf.

Bureau of Reclamation, 2017, Rio Grande operating agreement environmental impact statement: Bureau of Reclamation, 4 p., accessed February 10, 2017, at https:/www.usbr.gov/uc/albuq/rm/RGP/EIS/RGOA-EISBkgOvervInfo.pdf.

Burow, K.R., Shelton, J.L., Hevesi, J.A., and Weissmann, G.S., 2004, Hydrogeologic characterization of the Modesto area, San Joaquin Valley, California: U.S. Geological Survey Scientific Investigations Report 2004-5232, 62 p., https://doi.org/10.3133/sir20045232.

Byrd, D., Lange, K., and Beal, L., 2002, Water resources data, New Mexico, water year 2001: U.S. Geological Survey Water Data Report NM-01-1, 436 p., accessed May 23, 2017, at https://doi.org/10.3133/wdrNM011.

Byrd, F.D., Lange, K.M., and Beal, L.V., 2003, Water resources data, New Mexico, water year 2002: U.S. Geological Survey Water Data Report NM-02-1, 433 p., accessed May 23, 2017, at https://doi.org/10.3133/wdrNM021.

Byrd, D., Allen, H.R., and Montaño, M., 2004, Water resources data, New Mexico, water year 2003: U.S. Geological Survey Water Data Report NM-03-1, 437 p., accessed May 23, 2017, at https://doi.org/10.3133/wdrNM031.

California Department of Water Resources, 2007, California Irrigation Management Information System: California Department of Water Resources web page, accessed May 23, 2017, at http://www.cimis.water.ca.gov/cimis/welcome.jsp.

Camp Dresser and McKee, Inc., 2008, City of Las Cruces water and wastewater system master plan update-Final: Camp Dresser and McKee, Inc., 170 p., accessed October 15, 2015, at https://www.las-cruces.org/DocumentCenter/ View/867/Water-and-Wastewater-System-Master-Plan-PDF.

Climate Source, 2016, Precipitation data from PRISM data: Climate Source web page, accessed November 14, 2016, at http://www.climatesource.com/.

Conover, C.S., 1954, Ground-water conditions in the Rincon and Mesilla Valleys and adjacent areas in New Mexico: U.S. Geological Survey Water Supply Paper 1230, 200 p., accessed October 23, 2015, at https://doi.org/10.3133/wsp1230.
Contaldo, G.J., and Mueller, J.E., 1991, Earth fissures of the Mimbres Basin, southwestern New Mexico: New Mexico Geology, v. 13, no. 4, p. 69-74, accessed January 3, 2018, https://geoinfo.nmt.edu/publications/periodicals/nmg/13/n4/ nmg_v13_n4_p69.pdf.

Crilley, D.M., Matherne, A.M., Thomas, N., and Falk, S.E., 2013, Seepage investigations of the Rio Grande from below Leasburg Dam, Leasburg, New Mexico, to above American Dam, El Paso, Texas, 2006-13: U.S. Geological Survey Open-File Report 2013-1233, 34 p., https://doi.org/10.3133/ofr20131233.

Daly, C., Halbleib, M., Smith, J.I., Gibson, W.P., Doggett, M.K., Taylor, G.H., Curtis, J., and Pasteris, P.P., 2008, Physiographically sensitive mapping of climatological temperature and precipitation across the conterminous United States: International Journal of Climatology, v. 28, no. 15, p. 2031-2064, https://doi.org/10.1002/joc.1688.

DeMouche, L., 2004, Interpreting the Elephant Butte Irrigation District for water users: College of Agriculture, Consumer and Environmental Sciences, New Mexico State University Circular 590, accessed March 21, 2017, at http://aces.nmsu.edu/pubs/_circulars/CR590/welcome.html.

Dickinson, J.E., Hanson, R.T., and Predmore, S.K., 2014, HydroClimATe-Hydrologic and climatic analysis toolkit: U.S. Geological Survey Techniques and Methods 4-A9, 48 p., https://doi.org/10.3133/tm4A9.

Doherty, J., 2004, PEST-Model-independent parameter estimation-User manual (5th ed.): Brisbane, Australia, Watermark Numerical Computing, http://www.pesthomepage.org/About_Us.php.

Doherty, J., 2010a, PEST-Model-independent parameter estimation-User manual (5th ed., with slight additions): Brisbane, Australia, Watermark Numerical Computing, http://www.pesthomepage.org/About_Us.php.

Doherty, J., 2010b, Addendum to the PEST manual: Brisbane, Australia, Watermark Numerical Computing, http://www.pesthomepage.org/About_Us.php.

Doherty, J., 2010c, BeoPEST for Windows: Brisbane, Australia, Watermark Numerical Computing, http://www.pesthomepage.org/About_Us.php.

Doherty, J.E., and Hunt, R.J., 2010, Approaches to highly parameterized inversion-A guide to using PEST for groundwater-model calibration: U.S. Geological Survey Scientific Investigations Report 2010-5169, 59 p., https://doi.org/10.3133/sir20105169. 
Driscoll, J.M., and Sherson, L.R., 2016, Variability of surfacewater quantity and quality and shallow groundwater levels and quality within the Rio Grande Project area, New Mexico and Texas, 2009-13: U.S. Geological Survey Scientific Investigations Report 2016-5006, 33 p., https://doi.org/10.3133/sir20165006.

Environmental Systems Research Institute, 2016, World imagery: Environmental Systems Research Institute web page, accessed June 1, 2016, at https://www.arcgis.com/ home/item.html?id=10df2279f9684e4a9f6a7f08febac2a9.

Falgout, J.T., and Gordon, J.M., 2017, Advanced Research Computing (ARC), USGS Yeti Supercomputer:

U.S. Geological Survey, https://doi.org/10.5066/F7D798MJ.

Faunt, C.C., Hanson R.T., Schmid, W., Belitz, K., and Predmore, S., 2009, Numerical Model of the Hydrologic Landscape and Groundwater Flow in California's Central Valley, chap. C in Faunt, C., ed., Ground-water availability of the Central Valley Aquifer, California: U.S. Geological Survey Professional Paper 1766, p. 121-212, https://doi.org/10.3133/pp1766.

Faunt, C.C., Belitz, K., and Hanson, R.T., 2010, Development of a three-dimensional model of sedimentary texture in valley-fill deposits of Central Valley, California, USA: Hydrogeology Journal, v. 18, no. 3, p. 625-649, https://doi.org/10.1007/s10040-009-0539-7.

Faunt, C.C., Provost, A.M., Hill, M.C., and Belcher, W.R., 2011, Comment on "An unconfined groundwater model of the Death Valley Regional Flow System and a comparison to its confined predecessor" by R.W.H. Carroll, G.M. Pohll, and R.L. Hershey [Journal of Hydrology v. 373, no. 3-4, p. 316-328]: Journal of Hydrology, v. 397, no. 3-4, p. 306309, https://doi.org/10.1016/j.jhydrol.2010.11.038.

Fenske, J.P., Leake, S.A., and Prudic, D.E., 1996, Documentation of a computer program (RES1) to simulate leakage from reservoirs using the modular finitedifference ground-water flow model (MODFLOW): U.S. Geological Survey Open-File Report 96-364, 51 p., https://doi.org/10.3133/ofr96364.

Ferguson, I.A., and Llewellyn, D., 2015, Simulation of Rio Grande project operations in the Rincon and Mesilla Basins: Summary of model configuration and results: Bureau of Reclamation Technical Memorandum 86-68210-2015-05, $56 \mathrm{p}$.

Fio, J.L., and Leighton, D.A., 1995, Geohydrologic framework, historical development of the groundwater system, and general hydrologic and water-quality conditions in 1990, South San Francisco Bay and Peninsula area, California: U.S. Geological Survey Open-File Report 94-357, 46 p., https://doi.org/10.3133/ofr94357.
Flint, A.L., and Childs, S.W., 1987, Calculation of solar radiation in mountainous terrain: Journal of Agricultural and Forest Meteorology, v. 40, no. 3, p. 233-249, https://doi.org/10.1016/0168-1923(87)90061-X.

Flint, A.L., and Childs, S.W., 1991, Use of the PriestleyTaylor evaporation equation for soil water limited conditions in a small forest clearcut: Journal of Agricultural and Forest Meteorology, v. 56, p. 247-260, https://doi.org/10.1016/0168-1923(91)90094-7.

Flint, L.E., and Flint, A.L., 2012, Simulation of climate change in San Francisco Bay Basins, CaliforniaCase studies in the Russian River Valley and Santa Cruz Mountains: U.S. Geological Survey Scientific Investigations Report 2012-5132, 55 p, https://doi.org/10.3133/sir20125132.

Flint, A.L., Flint, L.E., and Masbruch, M.D., 2010, Appendix 3: Input, calibration, uncertainty, and limitations of the Basin Characterization Model, in Heilweil, V.M., and Brooks, L.E., eds., Conceptual model of the Great Basin carbonate and alluvial aquifer system: U.S. Geological Survey Scientific Investigations Report 2010-5193, 15 p., https://doi.org/10.3133/sir20105193.

Flint, L.E., Flint, A.L., Stolp, B.J., and Danskin, W.R., 2012, A basin-scale approach for assessing water resources in a semiarid environment - San Diego region, California, and Mexico: Hydrology and Earth System Sciences, v. 16, no. 10, p. 3817-3833, https://doi.org/10.5194/hess-16-3817-2012.

Flint, L.E., Flint, A.L., Thorne, J.H., and Boynton, R., 2013, Fine-scale hydrological modeling for climate change applications - The California basin characterization model development and performance: Ecological Processes, v. 2, no. 25, https://doi.org/10.1186/2192-1709-2-25.

Frenzel, P.F., Kaehler, C.A., and Anderholm, S.K., 1992, Geohydrology and simulation of ground-water flow in the Mesilla Basin, Doña Ana County, New Mexico, and El Paso County, Texas, with a section on water quality and geochemistry: U.S. Geological Survey Professional Paper 1407-C, 105 p., https://doi.org/10.3133/pp1407C.

Frenzel, S.A., 1984, Methods for estimating groundwater pumpage for irrigation: U.S. Geological Survey Water-Resources Investigations Report 83-4277, 15 p., https://doi.org/10.3133/wri834277.

Gates, J.S., White, D.E., and Leggat, E.R., 1984, Preliminary study of the aquifers of the lower Mesilla Valley in Texas and New Mexico by model simulation: U.S. Geological Survey Water-Resources Investigations Report 84-4317, 21 p., https://doi.org/10.3133/wri844317. 
Gurdak, J.J., Hanson, R.T., and Green, T.R., 2009, Effects of climate variability and change on groundwater resources of the United States: U.S. Geological Survey Fact Sheet 20093074, 4 p., https://doi.org/10.3133/fs20093074.

Hamilton, S.L., and Maddock, T., III, 1993, Application of a ground-water flow model to the Mesilla Basin, New Mexico and Texas: Tucson, Ariz., University of Arizona Department of Hydrology and Water Resources, no. 93-020, variously paginated, http://hdl.handle.net/10150/620116.

Hanson, R.T., 1989, Aquifer-system compaction, Tucson Basin and Avra Valley, Arizona: U.S. Geological Survey Water-Resources Investigation Report 88-4172, 69 p., https://doi.org/10.3133/wri884172.

Hanson, R.T., 1996, Postaudit of head and transmissivity estimates and ground-water flow models of Avra Valley, Arizona: U.S. Geological Survey WaterResources Investigation Report 96-4045, 84 p., https://doi.org/10.3133/wri964045.

Hanson, R.T., and Benedict, J.F., 1994, Simulation of ground-water flow and potential land subsidence, upper Santa Cruz Basin, Arizona: U.S. Geological Survey Water-Resources Investigation Report 93-4196, 47 p., https://doi.org/10.3133/wri934196.

Hanson, R.T., and Leake, S.A., 1999, Documentation for HYDMOD - A program for extracting and processing time-series data from the U.S. Geological Survey's modular three-dimensional finite-difference ground-water flow model: U.S. Geological Survey Open-File Report 98-564, 57 p., https://doi.org/10.3133/ofr98564.

Hanson, R.T., and Nishikawa, T., 1996, Combined use of flowmeter and time-drawdown data to estimate hydraulic conductivities in layered aquifer systems: Groundwater, v. 34, no. 1, p. 84-94, https://doi.org/10.1111/j.1745-6584.1996.tb01868.x.

Hanson, R.T., and Schmid, W., 2013, Economic resilience through "One-Water" Management: U.S. Geological Survey Open-File Report 2013-1175, 2 p., https://doi.org/10.3133/ofr20131175.

Hanson, R.T., Anderson, S.R., and Pool, D.R., 1990, Simulation of ground-water flow and potential land subsidence, Avra Valley, Arizona: U.S. Geological Survey Water-Resources Investigation Report 90-4178, 41 p., https://doi.org/10.3133/wri904178.

Hanson, R.T., McLean, J.S., and Miller, R.S., 1994, Hydrogeologic framework and preliminary simulation of ground-water flow in the Mimbres Basin, southwestern New Mexico: U.S. Geological Survey Water-Resources Investigation Report 94-4011, 118 p., https://doi.org/10.3133/wri944011.
Hanson, R.T., Martin, P., and Koczot, K.M., 2003, Simulation of ground-water/surface-water flow in the Santa Clara-Calleguas ground-water basin, Ventura County, California: U.S. Geological Survey Water-Resources Investigation 2002-4136, 214 p., https://doi.org/10.3133/wri024136.

Hanson, R.T., Li, Z., and Faunt C.C., 2004, Documentation of the Santa Clara Valley regional ground-water/surfacewater flow model, Santa Clara County, California: Scientific Investigations Report 2004-5231, 85 p., https://doi.org/10.3133/sir20045231.

Hanson, R.T., Dettinger, M.D., and Newhouse, M.W., 2006, Relations between climate variability and hydrologic time series from four alluvial basins across the southwestern United States: Hydrogeology Journal, v. 14, no. 7, p. 11221146, https://doi.org/10.1007/s10040-006-0067-7.

Hanson, R.T., Schmid, W., Faunt, C.C., and Lockwood, B., 2010, Simulation and analysis of conjunctive use with MODFLOW's farm process: Groundwater, v. 48 , no. 5, p. 674-689, https://doi.org/10.1111/j.1745-6584.2010.00730.x.

Hanson, R.T., Schmid, W., Knight, J., and Maddock T., III, 2013, Integrated hydrologic modeling of a transboundary aquifer system-Lower Rio Grande-MODFLOW and more 2013-Translating science into practice: Golden, Colo., Colorado School of Mines, Integrated Groundwater Modeling Center (IGWMC), June 2-5, 2013, 5 p., https://www.researchgate.net/publication/258698983 Integrated_hydrologic_modeling_of_a_transboundary_ aquifer_system_-_Lower_Rio_Grande.

Hanson, R.T., Schmid, W., Faunt, C.C., Lear, J., and Lockwood, B., 2014a, Integrated hydrologic model of Pajaro Valley, Santa Cruz and Monterey Counties, California: U.S. Geological Survey Scientific Investigations Report 2014-5111, 166 p., https://doi.org/10.3133/sir20145111.

Hanson, R.T., Boyce, S.E., Schmid, W., Hughes, J.D., Mehl, S.M., Leake, S.A., Maddock, T., III, and Niswonger, R.G., 2014b, One-water hydrologic flow model (MODFLOW-OWHM): U.S. Geological Survey Techniques and Methods 6-A51, 120 p., https://doi.org/10.3133/tm6A51.

Harbaugh, A.W., 2005, MODFLOW-2005-The U.S. Geological Survey modular ground-water modelThe ground-water flow process: U.S. Geological Survey Techniques and Methods 6-A16, variously paginated, https://doi.org/10.3133/tm6A16. 
Harbaugh, A.W., Banta, E.R., Hill, M.C., and McDonald, M.G., 2000, MODFLOW-2000, The U.S. Geological Survey modular ground-water modelUser guide to modularization concepts and the groundwater flow process: U.S. Geological Survey Open-File Report 2000-92, 121 p., https://doi.org/10.3133/ofr200092.

Hawley, J.W., and Kennedy, J.F., 2004, Creation of a digital hydrogeologic framework model of the Mesilla Basin and southern Jornada del Muerto Basin: Las Cruces, N. Mex., New Mexico Water Resources Research Institute, Technical Completion Report 332, 105 p., with 2005 addendum extending model into Rincon Valley and adjacent areas, accessed December 20, 2016, at https://nmwrri.nmsu.edu/tr332/.

Hawley, J.W., and Lozinsky, R.P., 1992, Hydrogeologic framework of the Mesilla Basin in New Mexico and western Texas: New Mexico Bureau of Mines and Mineral Resources, Open-File Report 323, 55 p., https://geoinfo.nmt.edu/publications/openfile/ downloads/300-399/323/ofr_323.pdf.

Hawley, J.W., Kennedy, J.F., and Creel, B.J., 2001, The Mesilla Basin aquifer system of New Mexico, West Texas and Chihuahua-An overview of its hydrogeologic framework and related aspects of groundwater flow and chemistry, in Mace, R.E., Mullican, W.F., III, and Angle, E.S., eds., Aquifers of West Texas: Texas Water Development Board Report 356, chap. 7, p. 76-99, accessed December 20, 2016, at http://www.twdb.texas.gov/ publications/reports/numbered_reports/doc/R356/ Report356.asp.

Hawley, J.W., Kennedy, J.F., Granados-Olivas, A., and Ortiz, M.A., 2009, Hydro-geologic framework of the binational western Hueco Bolson-Paso del Norte area, Texas, New Mexico, and Chihuahua-Overview and progress report on digital-model development: New Mexico Water Resources Research Institute Technical Report 349, 45 p., 2 pls., accessed December 20, 2016, at https://nmwrri.nmsu.edu/tr349/.

Hayes, S., 2015, OSE Wells May 2015: Santa Fe, N. Mex., New Mexico Office of the State Engineer Information Technology Systems Bureau Geographic Information System, originally accessed September 23, 2015, at http://gisdata.ose.opendata.arcgis.com/ datasets/b30d79d634674aa5bebee0b2f5a4425c_0. This website is no longer available and an equivalent data set accessed May 21, 2018, can be obtained at https:/geospatialdata-ose.opendata.arcgis.com/.

Heywood, C.E., and Yager, R.M., 2003, Simulated groundwater flow in the Hueco Bolson, an alluvial-basin aquifer system near El Paso, Texas: U.S. Geological Survey Water-Resources Investigation Report 2002-4108, 73 p., https://doi.org/10.3133/wri024108.
Hill, M.C., 1990, Preconditioned conjugate-gradient 2 (PCG2), a computer program for solving groundwater flow equations: U.S. Geological Survey WaterResources Investigations Report 90-4048, 43 p., https://doi.org/10.3133/wri904048.

Hill, M.C., and Tiedeman, C.R., 2007, Effective groundwater model calibration - With analysis of data, sensitivities, predictions, and uncertainty: New York, N.Y., Wiley and Sons, 480 p., https://doi.org/10.1002/9780470041086.index.

Hill, M.C., Banta, E.R, Harbaugh, A.W., and Anderman, E.R., 2000, MODFLOW-2000, the U.S Geological Survey modular ground-water model-User guide to the observation, sensitivity, and parameter-estimation processes and three post-processing programs: U.S. Geological Survey Open-File Report 2000-184, 209 p., https://doi.org/10.3133/ofr00184.

Hsieh, P.A., and Freckelton, J.R., 1993, Documentation of a computer program to simulate horizontal-flow barriers using the U.S. Geological Survey's modular threedimensional finite-difference ground-water-flow model: U.S. Geological Survey Open-File Report 92-477, 32 p., https://doi.org/10.3133/ofr92477.

Hurd, B.H., 2006, Water conservation and residential landscapes-Household preferences, household choices: Journal of Agricultural and Resource Economics, v. 31, no. 2, p. 173-192, https://aggie-horticulture.tamu.edu/ faculty/hall/EllisonChair/Water/Water\%20conservation $\% 20$ and $\% 20$ residential\%20landscapes.pdf.

Hutchison, W.R., 2008, Conceptual evaluation of surface water storage in El Paso County-Final report: El Paso Water Utilities Hydrogeology Report 08-02, 49 p., https:/www.twdb.texas.gov/publications/ reports/contracted_reports/doc/0704830690_RegionE/ SurfaceWaterStorage-EPCounty-revisedfinal.pdf.

International Boundary and Water Commission, 2011, Hydrogeological activities in the ConejosMedanos/Mesilla Basin Aquifer, Chihuahua, Phase I, Volume I: 104 p., accessed December 13, 2019, at https://www.ibwc.gov/Water_Data/Mesillabasin.html.

International Boundary and Water Commission, 2015, 1-meter resolution bare-earth LiDAR grids delivered through ftp, referenced in Tetra Tech/Watershed Sciences, Inc. Team, 2011, International Boundary and Water Commission LiDAR data report, $77 \mathrm{p}$.

International Boundary and Water Commission, 2016, Rio Grande historical mean daily discharge data: accessed June 1, 2016, at https://www.ibwc.gov/Water_Data/histflo1.htm. 
International Boundary and Water Commission, 2017a, Diversion dams and related structures: accessed March 21, 2017, at https://www.ibwc.gov/Mission_Operations/ Diversion_Dams.html\#.

International Boundary and Water Commission, 2017b, Upper Rio Grande flood control project: accessed March 21, 2017, at https://www.ibwc.gov/Organization/Operations/Field_ Offices/URGFCP.html.

Jacob, C.E., 1940, On the flow of water in an elastic artesian aquifer: EOS, Transactions of the American Geophysical Union, v. 21, no. 2, p. 574-586, https://doi.org/10.1029/TR021i002p00574.

Kallestad, J.C., Mexal, J.G., Sammis, T.W., and Heerema, R., 2008, Development of a simple irrigation scheduling calendar for Mesilla Valley pecan growersExtension education methods: HortTechnology, v. 18, no. 4, p. 714-725, accessed December 13, 2019, at https://doi.org/10.21273/HORTTECH.18.4.714.

Kambhammettu, B.V.N.P., Schmid, W., King, J.P., and Creel, B.J., 2012, Effect of elevation resolution on evapotranspiration simulations using MODFLOW: Ground Water, v. 50, no. 3, p. 367-375, https://doi.org/10.1111/j.1745-6584.2011.00852.x.

Knight, J., 2015, Use of an integrated hydrologic model to assess the effects of pumping on streamflow in the Lower Rio Grande: Tucson, Ariz., University of Arizona, Masters of Science Thesis, 117 p., http://hdl.handle.net/10150/556878.

Konikow, L.F., Hornberger, G.Z., Halford, K.J., Hanson, R.T., and Harbaugh, A.W., 2009, Revised multi-node well (MNW2) package for MODFLOW ground-water flow model: U.S. Geological Survey Techniques and Methods 6A30, 67 p., https://doi.org/10.3133/tm6A30.

Laudon, J., and Belitz, K., 1991, Texture and depositional history of late Pleistocene-Holocene alluvium in the central part of the western San Joaquin Valley, California: Environmental and Enginnering Geoscience, v. 28, no. 1, p. 73-88, https://doi.org/10.2113/gseegeosci.xxviii.1.73.

Leighton, D.A., Fio, J.L., and Metzger, L.F., 1995, Database of well and areal data, South San Francisco Bay and Peninsula area, California: U.S. Geological Survey Water-Resources Investigations Report 94-4151, 47 p., https://doi.org/10.3133/wri944151.

Longworth, J.W., Valdez, J.M., Magnuson, M.L., Albury Sims, E., and Keller, J., 2008, New Mexico water use by categories 2005: New Mexico Office of the State Engineer Technical Report 52, 111 p., https://www.ose.state.nm.us/WUC/wucTechReports/2005/ PDF/TechReport-052.pdf.
Longworth, J.W., Valdez, J.M., Magnuson, M.L., and Richard, K., 2013, New Mexico water use by categories 2010: New Mexico Office of the State Engineer Technical Report 54, 128 p., https://www.ose.state.nm.us/WUC/wucTechReports/2010/ PDF/2010WaterUseByCategories.pdf.

Maddock, T., III, and Wright Water Engineers, Inc., 1987, An investigation of the effects of proposed pumping in the Lower Rio Grande Declared Basin: Tucson, Ariz., University of Arizona, variously paginated.

Maddock, T., III, Baird, K.J., Hanson, R.T., Schmid, W., and Ajami, H., 2012, RIP-ET-A riparian evapotranspiration package for MODFLOW-2005: U.S. Geological Survey Techniques and Methods 6-A39, 76 p., https://doi.org/10.3133/tm6A39.

McCabe, G.J., Palecki, M.A., and Betancourt, J.L., 2004, Pacific and Atlantic Ocean influences on multidecadal drought frequency in the United States: Proceedings of the National Academy of Sciences of the United States of America, v. 101, no. 12, p. 4136-4141, https://doi.org/10.1073/pnas.0306738101.

McCoy, A.M., and Peery, R.L., 2008, City of Las Cruces 40-year water development plan: John Shomaker and Associates, Inc., 515 p.

McDonald, M.G., and Harbaugh, A.W., 1984, A modular three-dimensional finite-difference ground-water flow model: U.S. Geological Survey Open-File Report 83-875, 528 p., https://doi.org/10.3133/ofr83875.

McDonald, M.G., and Harbaugh, A.W., 1988, A modular three-dimensional finite-difference ground-water flow model: U.S. Geological Survey Techniques of Water-Resources Investigations 06-A1, 586 p., https://doi.org/10.3133/twri06A1.

Miller, L.K., and Stiles, J.A., 2006, Water resources data, New Mexico, water year 2005: U.S. Geological Survey Water Data Report NM-05-1, 500 p., https://doi.org/10.3133/wdrNM051.

Molz, F., Hanson, R.T., and Riley, F., 1996, Discussion of papers: Ground Water, v. 34, no. 5, p. 770-771, https://doi.org/10.1111/j.1745-6584.1996.tb02068.x.

Muehlberger, W.R., 1980, Texas lineament revisited, in Dickerson, P.W., Hoffer, J.M., and Callender, J.F., eds., The Trans-Pecos Region: New Mexico Geological Society 31st Annual Fall Field Conference Guidebook, p. 113-121.

Naff, R.L., and Banta, E.R., 2008, The U.S. Geological Survey modular ground-water model-PCGN-A preconditioned conjugate gradient solver with improved nonlinear control: U.S. Geological Survey Open-File Report 2008-1331, 35 p., https://doi.org/10.3133/ofr20081331. 
National Climatic Data Center, 2016a, Monthly summaries station details, CABALLO DAM, NM US, GHCND:USC00291286, 1936-09-01 to 2016-01-01, accessed February 11, 2016, at https://www.ncdc.noaa.gov/cdo-web/datasets/GHCNDMS/ stations/GHCND:USC00291286/detail.

National Climatic Data Center, 2016b, Monthly summaries station details, STATE UNIVERSITY, NM US, GHCND: USC00290131, 1892-01-01 to 1959-03-01, accessed February 11, 2016, at https:/www.ncdc.noaa.gov/cdo-web/ datasets/GHCNDMS/stations/GHCND:USC00290131/ detail.

National Climatic Data Center, 2016c, Monthly summaries station details, STATE UNIVERSITY, NM US, GHCND: USC00298535, 1959-04-01 to 2016-01-01, accessed February 11, 2016, at https:/www.ncdc.noaa.gov/cdo-web/ datasets/GHCNDMS/stations/GHCND:USC00298535/ detail.

National Climatic Data Center, 2016d, Monthly summaries station details, HILLSBORO, NM US, GHCND: USC00294009, 1893-01-01 to 2016-01-01, accessed February 11, 2016, at https://www.ncdc.noaa.gov/cdo-web/ datasets/GHCNDMS/stations/GHCND:USC00294009/ detail.

National Renewable Energy Laboratory, 2014, Measurement and instrumentation data center (MODC): Golden, Colo., U.S. Department of Energy, accessed June 15, 2014, at http://www.nrel.gov/midc/.

Natural Resources Conservation Service, 2005, Soil survey geographic (SSURGO) database: U.S. Department of Agriculture Natural Resources Conservation Service database, accessed September 12, 2005, at http:/www.ncgc.nrcs.usda.gov/products/datasets/ssurgo/.

Natural Resources Conservation Service, 2006, State soil survey map (SSURGO): U.S. Department of Agriculture, accessed July 1, 2010, at https://www.nrcs.usda.gov/wps/ portal/nrcs/soilsurvey/soils/survey/state/.

Natural Resources Conservation Service, 2008, Soil survey geographic database for Sierra County area, New Mexico: U.S. Department of Agriculture Natural Resources Conservation Service database, accessed October 1, 2010, at https://sdmdataaccess.sc.egov.usda.gov.

Natural Resources Conservation Service, 2009a, Soil survey geographic (SSURGO) database for Doña Ana County area, New Mexico: U.S. Department of Agriculture Natural Resources Conservation Service database, accessed October 1, 2010, at https://sdmdataaccess.sc.egov.usda.gov.
Natural Resources Conservation Service, 2009b, Soil survey geographic (SSURGO) database for El Paso County, Texas (main part): U.S. Department of Agriculture Natural Resources Conservation Service database, accessed October 1, 2010, at https://sdmdataaccess.sc.egov.usda.gov.

Natural Resources Conservation Service, 2009c, Soil survey geographic (SSURGO) database for Fort Bliss Military Reservation, New Mexico and Texas: U.S. Department of Agriculture Natural Resources Conservation Service database, accessed October 1, 2010, at https://sdmdataaccess.sc.egov.usda.gov.

Newhouse, M.W., Hanson, R.T., Wentworth, C.M., Everett, R.R., Williams, C.F., Tinsley J.C., Noce, T.E., and Carkin, B.A., 2004, Geologic, water-chemistry, and hydrologic data from multiple-well monitoring sites and selected water-supply wells in the Santa Clara Valley, California, 1999-2003: U.S. Geological Survey Scientific Investigations Report 2004-5250, 142 p., https://doi.org/10.3133/sir20045250.

New Mexico Office of the State Engineer, 2015, New Mexico water rights reporting system: New Mexico Office of the State Engineer, accessed June 1, 2016, at http://nmwrrs.ose.state.nm.us/nmwrrs/index.html.

New Mexico Office of the State Engineer, 2016, Lower Rio Grande hydrographic survey (1999-2000): New Mexico Office of the State Engineer, accessed June 1, 2016, at http://www.ose.state.nm.us/HydroSurvey/legal_ose_hydro_ LRG.php.

New Mexico Office of the State Engineer, 2017, Lower Rio Grande Regional Water Plan: New Mexico Office of the State Engineer, 175 p., accessed June 1, 2017, at http://www.ose.state.nm.us/Planning/RWP/documents/ Reg11_LowerRioGrande_RegionalWaterPlan2017.pdf.

New Mexico State University, 2015, New Mexico

State University Turfgrass weather station daily data, accessed December 13, 2019, at https://weather.nmsu.edu/turf/station/turf-da-1.

Niswonger, R.G., and Prudic, D.E., 2005, Documentation of the streamflow-routing (SFR2) package to include unsaturated flow beneath streams-A modification to SFR1: U.S. Geological Survey Techniques and Methods 6-A13, 50 p., https://doi.org/10.3133/tm6A13.

Ortiz, D., and Lange, K.M., 1996, Water resources data, New Mexico, water year 1995: U.S. Geological Survey Water Data Report NM-95-1, 644 p., accessed May 22, 2017, at https://doi.org/10.3133/wdrNM951. 
Ortiz, D., Lange, K., and Beal, L., 2000, Water resources data, New Mexico, water year 1999, Volume 1, The Rio Grande Basin; the Mimbres River Basin; and the Tularosa Valley Basin: U.S. Geological Survey Water Data Report NM-99-1, 424 p., accessed May 23, 2017, at https://doi.org/10.3133/wdrNM991.

Ortiz, D., Lange, K., and Beal, L., 2001, Water resources data, New Mexico, water year 2000: U.S. Geological Survey Water Data Report NM-00-1, 442 p., accessed May 23, 2017, at https://doi.org/10.3133/wdrNM001.

Peterson, D.M., Khaleel, R., and Hawley, J.W., 1984, Quasi three-dimensional modeling of groundwater flow in the Mesilla Bolson, New Mexico and Texas: Las Cruces, N. Mex., New Mexico Water Resources Research Institute Technical Report no. 178, 185 p., http://nmwrri.nmsu.edu/?page_id=1108.

Petronis, L.H., Finch, S.T., Jr., and Shomaker, J.W., 2006, Ground-water flow and solute transport model for the Griggs and Walnut Superfund Site, Las Cruces, New Mexico: Albuquerque, N. Mex., John Shomaker and Associates, Inc., 53 p., https://donaanacounty.org/sites/ default/files/pages/FSRappendixA.pdf.

Phillips, S.P., and Belitz, K., 1991, Calibration of a textured-based model of a ground-water flow system, western San Joaquin Valley, California: Groundwater, v. 29, no. 5, p. 702-715, https://doi.org/10.1111/j.1745-6584.1991.tb00562.x.

Phillips, S.P, Green, C.T., Burow, K.R., Shelton, J.L., and Rewis, D.L., 2007, Simulation of multiscale ground-water flow in part of the northeastern San Joaquin Valley, California: U.S. Geological Survey Scientific Investigations Report 2007-5009, 43 p., https://doi.org/10.3133/sir20075009.

Reilly, T.E., and Harbaugh, A.W., 2004, Guidelines for evaluating ground-water flow models: U.S. Geological Survey Scientific Investigations Report 2004-5038, 37 p., https://doi.org/10.3133/sir20045038.

Reitz, M., Sanford, W.E., Senay, G.B., and Cazenas, J., 2017, Annual estimates of recharge, quick-flow runoff, and evapotranspiration for the contiguous U.S. using empirical regression equations: Journal of the American Water Resources Association, v. 53, no. 4, p. 961-983, https://doi.org/10.1111/1752-1688.12546.

Ritchie, A.B., Hanson, R.T., Galanter, A.E., Boyce, S.E., Damar, N.A., Shephard, Z.M., and Tillman, F.D., 2018, Digital hydrologic and geospatial data for the Rio Grande transboundary integrated hydrologic model and wateravailability analysis, New Mexico and Texas, United States, and Northern Chihuahua, Mexico: U.S. Geological Survey data release, https://doi.org/10.5066/P9J9NYND.
Sanford, A.R., Lin, K., Tsai, I., and Jaksha, L.H., 2002, Earthquake catalogs for New Mexico and bordering areas1869-1998: New Mexico Bureau of Geology and Mineral Resources Circular 210, 9 p., https://geoinfo.nmt.edu/ publications/monographs/circulars/210/circ210.pdf.

Sanford, A.R., Mayeau, T.M., Schlue, J.W., Aster, R.C., and Jaksha, L.H., 2006, Earthquake catalogs for New Mexico and bordering areas II-1999-2004: New Mexico Geology, v. 28, no. 4, p. 99-109, https://geoinfo.nmt.edu/publications/ periodicals/nmg/28/n4/nmg_v28_n4_p99.pdf.

Saxton, K.E., and Rawls, W.J., 2006, Soil water characteristic estimates by texture and organic matter for hydrologic solutions: Soil Science Society of America Journal, v. 70, no. 5, p. 1569-1578, https://doi.org/10.2136/sssaj2005.0117.

Schmid, W., 2004, A farm package for MODFLOW-2000Simulation of irrigation demand and conjunctively managed surface-water and ground-water supply: Tucson, Ariz., The University of Arizona, Ph.D. dissertation, 278 p.

Schmid, W., and Hanson, R.T., 2009, The farm process version 2 (FMP2) for MODFLOW-2005Modifications and upgrades to FMP1: U.S. Geological Survey Techniques and Methods 6-A32, 102 p., https://doi.org/10.3133/tm6A32.

Schmid, W., Hanson, R.T., Maddock, T., III, and Leake, S.A., 2006a, User's guide for the farm process (FMP) for the U.S. Geological Survey's modular three-dimensional finitedifference ground-water flow model, MODFLOW-2000: U.S. Geological Survey Techniques and Methods 6-A17, 127 p., https://doi.org/10.3133/tm6A17.

Schmid, W., Hanson, R.T., and Maddock, T., III, 2006b, Overview and advancements of the farm process for MODFLOW-2000: Managing groundwater systems: Conference Proceedings of the International Groundwater Modeling Center, Golden, Colo., May 21-24, 2006, p. 23-27.

Schmid, W., King, J.P., and Maddock, T., III, 2009, Conjunctive surface-water/groundwater model in the southern Rincon Valley using MODFLOW-2005 with the farm process: Las Cruces, N. Mex., New Mexico Water Resources Research Institute Technical Report, no. 350., 53 p., http://nmwrri.nmsu.edu/?page_id=754.

Serrano, R.J., 2014, Lower Rio Grande water master annual report 2013 accounting period: Las Cruces, N. Mex., State of New Mexico Office of the State Engineer, 9 p., https://www.ose.state.nm.us/WM/LRG/Reports/2013\%20 -\%20LRG\%20WM\%20REPORT.pdf. 
Serrano, R.J., 2015, Lower Rio Grande water master annual report 2014 accounting year: Las Cruces, N. Mex., State of New Mexico Office of the State Engineer, 25 p., https:/www.ose.state.nm.us/WM/LRG/Reports/2014\%20 LRG\%20Water\%20Master\%20Report.pdf.

Sheng, Z., Darr, M., King, J.P., Bumgarner, J., and Michelsen, A., 2013, Mesilla Basin/Conejos-Médanos section of the Transboundary Aquifer Assessment Program, in Alley, W.M., ed., Five-year interim report of the United States-Mexico transboundary aquifer assessment program-2007-2012: U.S. Geological Survey Open-File Report 2013-1059, 31 p., https://doi.org/10.3133/ofr20131059.

Sorensen, E.F., 1977, Water use by categories in New Mexico counties and river basins, and irrigated and dry cropland acreage in 1975: Santa Fe, N. Mex., New Mexico State Engineer Technical Report 41, 34 p.

Sorensen, E.F., 1982, Water use by categories in New Mexico counties and river basins, and irrigated acreage in 1980: Santa Fe, N. Mex., New Mexico State Engineer Technical Report 44, 51 p.

S.S. Papadopulos and Associates, Inc., 1987, Hydrogeologic evaluation of proposed appropriation of ground water from the Lower Rio Grande Underground Basin by the City of El Paso: S.S. Papadopulos and Associates, Inc., main report prepared for the State of New Mexico, variously paginated.

S.S. Papadopulos and Associates, Inc., 2007, DraftGroundwater flow model for administration and management in the Lower Rio Grande Basin: S.S. Papadopulos and Associates, Inc., draft reports for the New Mexico Office of the State Engineer, 380 p.

S.S. Papadopulos and Associates, Inc., 2016, Spreadsheets of M\&I pumping data compiled for the LRG_2007 groundwater model: S.S. Papadopulos and Associates, Inc.

Stangl, K., 2010, State Engineer's lower Rio Grande metering initiative is successful: New Mexico Office of the State Engineer Interstate Stream Commission, 3 p., accessed November 4, 2015, at http://www.ose.state.nm.us/PIO/ News/2010/pr-2010-04-02-MeteringInLRG.pdf.

Stewart, I.T., 2009, Changes in snowpack and snowmelt runoff for key mountain regions: Hydrological Processes, v. 23, no. 1, p. 78-94, https://doi.org/10.1002/hyp.7128.

Sweetkind, D.S., 2017, Three-dimensional hydrogeologic framework model of the Rio Grande transboundary region of New Mexico and Texas, USA, and northern Chihuahua, Mexico: U.S. Geological Survey Scientific Investigations Report 2017-5060, 49 p., https://doi.org/10.3133/sir20175060.
Sweetkind, D.S., Hanson, R.T., Ritchie, A.B., and Hawley, J.W., 2017, Data release of three-dimensional hydrogeologic framework model of the Rio Grande transboundary region of New Mexico and Texas, USA and northern Chihuahua, Mexico: U.S. Geological Survey data release, https://doi.org/10.5066/F7JM27T6.

Szynkiewicz, A., Witcher, J.C., Modelska, M., Borrok, D.M., and Pratt, L.M., 2011, Anthropogenic sulfate loads in the Rio Grande, New Mexico (USA): Chemical Geology, v. 283, no. 3-4, p. 194-209, https://doi.org/10.1016/j.chemgeo.2011.01.017.

Talbot, W.R., 2003, El Paso Water Utilities, Canutillo underflow evaluation; Revised estimates of underflow capture; 1995 to 2002: Denver, Colo., Bureau of Reclamation Technical Services Center, Water Resources Services Division, Groundwater and Drainage Group, Technical Memorandum D-8550, 25 p.

Tectonic, 2013, Doña Ana County, City of Anthony, City of Las Cruces, Elephant Butte Irrigation District, Village of Hatch, Town of Mesilla, New Mexico State University, and City of Sunland Park-All hazard mitigation planFinal: October 2013: Tectonic, 469 p., accessed March 21, 2017, at https://donaanacounty.org/sites/default/files/pages/ AHMP_Final_Oct\%202013.pdf.

Teeple, A.P., 2017, Geophysics- and geochemistrybased assessment of the geochemical characteristics and groundwater-flow system of the U.S. part of the Mesilla Basin/Conejos-Médanos aquifer system in Doña Ana County, New Mexico, and El Paso County, Texas, 2010-12: U.S. Geological Survey Scientific Investigations Report 2017-5028, 183 p., https://doi.org/10.3133/sir20175028.

Terracon Consultants, Inc., 2003, The New Mexico lower Rio Grande regional water plan-Consultants report for The Lower Rio Grande Water Users Organization: Terracon Consultants, Inc., 216 p., accessed January 1, 2017, at http://www.ose.state.nm.us/Planning/RWP/Regions/11 LRG/1999/LOWER-RIO-GRANDE-REGIONAL-WATERPLAN.pdf.

Tetra Tech EM, Inc., 2004, Report of surveying activities conducted within the Rincon and Mesilla Valleys, New Mexico: Prepared for New Mexico Interstate Stream Commission: Albuquerque, N. Mex., Tetra Tech EM, Inc.

Texas Water Development Board, 2015a, Groundwater database $(\mathrm{GWDB})$ reports - Well locations (shapefile) and entire groundwater database: Texas Water Development Board database, p. 185-186, accessed September 23, 2015, at http://www.twdb.texas.gov/groundwater/data/gwdbrpt.asp. 
Texas Water Development Board, 2015b, Submitted drillers reports (SDR) database-Well location (shapefiles): Texas Water Development Board database, accessed September 23, 2015, at http://www.twdb.texas.gov/ groundwater/data/drillersdb.asp.

Texas Water Development Board, 2015c, Water data interactive (WDI) groundwater data viewer: Texas Water Development Board, September 23, 2015, at http://www2.twdb.texas.gov/apps/WaterDataInteractive/ GroundWaterDataViewer.

Thorne, J., Boynton, R., Flint, L., Flint, A., and Le, T., 2012, Development and application of downscaled hydroclimatic predictor variables for use in climate vulnerability and assessment studies: California Energy Commission, no. CEC-500-2012-010, 86 p., http://uc-ciee.org/climate-change/3/667/101/nested.

Tillery, S., and King, J.P., 2006, MODFLOW-2000 farm package case study: Southern Rincon Valley, New Mexico: Technical Report prepared for the Las Cruces, N. Mex., U.S. Army Corps of Engineers, New Mexico State University, Department of Civil and Geological Engineering.

Tillery, S., Sheng, Z., King, J.P., Creel, B., Brown, C., Michelsen, A., Srinivasan, R., and Olivas, A.G., 2009, The development of a coordinated database for water resources and flow model in the Paso Del Norte watershed (phase III): New Mexico Water Resources Research Institute Technical Completion Report no. 348, Part II, and Texas Water Resources Institute Technical Report 359, Part II, 14 p., accessed September 25, 2017, at https://nmwrri.nmsu.edu/ wp-content/uploads/2015/technical-reports/tr348ii.pdf.

United States of America and Republic of Mexico, 1906, Convention between the United States and Mexico, equitable distribution of the waters of the Rio Grande: Signed at Washington, May 21, 1906; Ratification advised by the Senate June 26, 1906; Ratified by the President December 26, 1906; Ratified by Mexico January 5, 1907; Ratifications exchanged at Washington January 16, 1907; Proclaimed January 16, 1907, by the President of the United States, Theodore Roosevelt: Washington, D.C., United States of America, $3 \mathrm{p}$.

University of Arizona, 2012, The Arizona meteorological network: Arizona Cooperative Extension, College of Agriculture and Life Sciences, accessed May 1, 2013, at http://ag.arizona.edu/azmet/.

U.S. Census Bureau, 2017a, American factfinder-Annual estimates of the resident population April 1, 2010, to July 1, 2015, New Mexico: U.S. Bureau of the Census, accessed March 20, 2017, at https://factfinder.census.gov/faces/nav/ jsf/pages/index.xhtml.
U.S. Census Bureau, 2017b, American factfinderProfile of general demographic characteristics: 2000, Doña Ana County, New Mexico, total population: U.S. Bureau of the Census, accessed February 10, 2017, at http://factfinder.census.gov/bkmk/table/1.0/en/DEC/00_ SF1/DP1/0500000US35013.

U.S. Environmental Protection Agency, 2016a, Enforcement and compliance history online (ECHO): U.S. Environmental Protection Agency, accessed December 2, 2016, at https://echo.epa.gov/.

U.S. Environmental Protection Agency, 2016b, Envirofacts, Permit Compliance System-Integrated Compliance Information System (PCS-ICIS) search: U.S. Environmental Protection Agency, accessed December 2, 2016, at https://www3.epa.gov/enviro/facts/pcs-icis/search.html.

U.S. Environmental Protection Agency, 2016c, Permit Compliance System-Integrated Compliance Information System (PCS-ICIS) customized search: U.S. Environmental Protection Agency, accessed December 2, 2016, at https://www.epa.gov/enviro/pcs-icis-customized-search.

U.S. Geological Survey, 2013a, U.S. Geological Survey National Elevation Dataset n32w107 1/3 arc-second 2013 1 x 1 degree ArcGrid: U.S. Geological Survey National Elevation Dataset, http://ned.usgs.gov.

U.S. Geological Survey, 2013b, U.S. Geological Survey National Elevation Dataset n32w108 1/3 arc-second 2013 1 x 1 degree ArcGrid: U.S. Geological Survey National Elevation Dataset, http://ned.usgs.gov.

U.S. Geological Survey, 2013c, U.S. Geological Survey National Elevation Dataset n33w107 1/3 arc-second 2013 1 x 1 degree ArcGrid: U.S. Geological Survey National Elevation Dataset, http://ned.usgs.gov.

U.S. Geological Survey, 2013d, U.S. Geological Survey National Elevation Dataset n33w108 1/3 arc-second 2013 1 x 1 degree ArcGrid: U.S. Geological Survey National Elevation Dataset, http://ned.usgs.gov.

U.S. Geological Survey, 2013e, U.S. Geological Survey National Elevation Dataset n34w107 1/3 arc-second 2013 $1 \times 1$ degree ArcGrid: U.S. Geological Survey National Elevation Dataset, http://ned.usgs.gov.

U.S. Geological Survey, 2013f, U.S. Geological Survey National Elevation Dataset n34w108 1/3 arc-second 2013 1 x 1 degree ArcGrid: U.S. Geological Survey National Elevation Dataset, http://ned.usgs.gov.

U.S. Geological Survey, 2015, Federal Emergency Management Agency Region 6 Texas-Rio Grande and Fort Whitman watershed QL2 LiDAR, in Quantum Spatial, Inc., Airborne topographic LiDAR report: U.S. Geological Survey, $31 \mathrm{p}$. 
U.S. Geological Survey, 2016a, National Geospatial Program, National Hydrography Dataset (NHD) best resolution for New Mexico 20160226 state or territory File GDB 10.1: Reston, Va., U.S. Geological Survey, accessed May 21, 2018, at http://prd-tnm.s3-website-us-west-2.amazonaws. com/?prefix=StagedProducts/Hydrography/NHD/State/ HighResolution/GDB/.

U.S. Geological Survey, 2016b, National Water Information System: Web interface-Water data for the nation: U.S. Geological Survey database, accessed December 2, 2016, at https://waterdata.usgs.gov/nwis/.

Valdes, J.B., and Maddock, T., III, 2010, Conjunctive water management in the US Southwest, in Schneier-Madanes, G., and Courel, M.-F., eds., Water and sustainability in arid regions-Bridging the gap between physical and social sciences: Dordrecht, Netherlands, Springer, p. 221-244.

Westenbroek, S.M., Kelson, V.A., Dripps, W.R., Hunt, R.J., and Bradbury, K.R., 2010, SWB-A modified Thornthwaite-Mather soil-moisture-balance code for estimating groundwater recharge: U.S. Geological Survey Techniques and Methods Report 6-A31, 60 p., https://doi.org/10.3133/tm6A31.

White, D.E., 1983, Summary of hydrologic information in the El Paso, Texas area, with emphasis on ground-water studies, 1903-80: U.S. Geological Survey Open-File Report 83-775, 77 p., accessed November 6, 2015, at https://doi.org/10.3133/ofr83775.

Wilson, B., 1986, Water use in New Mexico in 1985: New Mexico State Engineer Office Technical Report 46, 84 p.

Wilson, B.C., 1992, Water use by categories in New Mexico counties and river basins, and irrigated acreage in 1990: New Mexico State Engineer Office Technical Report 47, $141 \mathrm{p}$.
Wilson, B.C., and Lucero, A.A., 1997, Water use by categories in New Mexico counties and river basins, and irrigated acreage in 1995: New Mexico State Engineer Office Technical Report 49, 149 p., https:/www.ose.state.nm.us/ Library/TechnicalReports/TechReport-049.PDF.

Wilson, B.C., and Lucero, A.A., 1998, Irrigated agriculture water use and acreage in New Mexico counties and river basins, 1993-1995: New Mexico State Engineer Office Technical Report 50, 108 p., https:/www.ose.state.nm.us/ Library/TechnicalReports/TechReport-050.PDF.

Wilson, B.C., Lucero, A.A., Romero, J.T., and Romero, P.J., 2003, Water use by categories in New Mexico counties and river basins, and irrigated acreage in 2000: New Mexico Office of the State Engineer Technical Report 51, 164 p., https://wipp.energy.gov/information_repository/cra/2009 cra/references/Others/Wilson_et_al_2003_Water_Use_by_ Categories_in_NM_Counties_in_2000.pdf.

Wilson, C.A., and White, R.R., 1984, Geohydrology of the central Mesilla Valley, Doña Ana County, New Mexico: U.S. Geological Survey Open-File Report 82-555, 144 p., https://doi.org/10.3133/ofr82555.

Wilson, C.A, White, R.R., Orr, B.R., and Roybal, R.G., 1981, Water resources of the Rincon and Mesilla Valleys and adjacent areas, New Mexico: U.S. Geological Survey Technical Report 43, 514 p., accessed October 23, 2015, at https://pubs.er.usgs.gov/publication/70042517.

Witcher, J.C., King, J.P., Hawley, J.W., Kennedy, J.F., Williams, J., Cleary, M., and Bothern, L.R., 2004, Sources of salinity in the Rio Grande and Mesilla Basin groundwater: New Mexico Water Resources Research Institute Technical Report no. 330, 168 p. 
For more information concerning the research in this report, contact the Director, California Water Science Center

U.S. Geological Survey

6000 J Street, Placer Hall

Sacramento, California 95819

https://ca.water.usgs.gov

Publishing support provided by the U.S. Geological Survey Science Publishing Network, Sacramento Publishing Service Center 


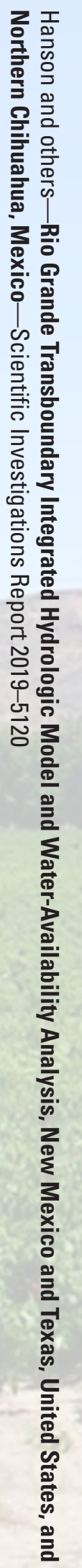

